\title{
THERMO-TECTONIC STUDIES OF MESOZOIC BASEMENT ROCKS, NORTH ISLAND, NEW ZEALAND
}

\author{
by \\ Ruohong Jiao
}

\author{
A thesis \\ submitted to Victoria University of Wellington \\ in fulfilment of the requirements for the degree of \\ Doctor of Philosophy
}

Victoria University of Wellington 



\section{Abstract}

The basement rocks of North Island, New Zealand, comprise metasedimentary terranes that were accreted onto the eastern Gondwana margin during Mesozoic subduction. Since the Oligocene, these terranes have been sitting at the leading edge of the Australian Plate, as the hanging wall of the Hikurangi subduction margin, overriding the subducting Pacific Plate. This thesis examines the thermo-tectonic histories of the basement rocks in North Island, using fission-track and (U-Th-Sm)/He thermochronology.

In eastern North Island, thermochronological data from the basement rocks record the exhumation histories since the latest Jurassic, related to two subduction cycles. Zircon fission-track analysis yields detrital or slightly reset ages (264-102 Ma); apatite fission-track ages range from 122 to $7.9 \mathrm{Ma}$ and (U-Th-Sm)/He from 33.3 to $6.0 \mathrm{Ma}$.

In central North Island, modelled thermal histories suggest that the basement rocks were exhumed to shallow levels $(<2 \mathrm{~km})$ of the crust in the Early Cretaceous $(\sim 150$ $135 \mathrm{Ma}$ ). This was followed by a period of reheating until 100 Ma, which is interpreted to be the result of burial by sedimentation above the accretionary wedge. From $100 \mathrm{Ma}$, models indicate thermo-tectonic quiescence until the Late Oligocene.

During the late Cenozoic, exhumation of the basement rocks accelerated at $27 \mathrm{Ma}$ in the western margin of the axial ranges (Kaimanawa Mountains). This acceleration in exhumation rate is interpreted to reflect the initiation of the subduction of the Pacific Plate beneath central North Island. Since the Late Oligocene, basement exhumation in the axial ranges migrated towards the trough. Modelled thermal histories indicate significant eastwards reverse faulting on the margin-parallel Ngamatea Fault between $\sim 27$ and $20 \mathrm{Ma}$ and on the Wellington-Mohaka Fault between 20 and $10 \mathrm{Ma}$.

In contrast to the activity in the axial ranges, in western North Island, the exhumational response of the basement rocks to the Cenozoic subduction was less significant and not revealed from the present thermochronological data. 
Since the Late Miocene, the exhumation rate in the axial ranges has varied significantly along-strike, lower in the centre and higher to the north and south. During the last $10 \mathrm{Myr}$, the total magnitude of exhumation has been $\sim 4 \mathrm{~km}$ in the Wellington region in the south, $>1 \mathrm{~km}$ in the Raukumara Range in the north and negligible (less than a few hundred metres) in the central axial ranges in the Hawke's Bay region. Although the accumulation of underplated material at the basal upper plate may have contributed to the localised rock uplift and exhumation (e.g. in the Raukumara Range), margin-normal shortening of the upper plate in the forearc of the Hikurangi Margin has most likely dominated the unroofing process of the axial ranges.

In northwestern North Island, the Northland Allochthon, an assemblage of Cretaceous-Oligocene sedimentary rocks, was emplaced during the Late Oligoceneearliest Miocene, onto in situ Mesozoic and early Cenozoic rocks. Detrital zircon and apatite fission-track ages reveal that the basal Northland Allochthon sequences and the underlying Miocene autochthonous sedimentary rocks were predominantly derived from the local Jurassic terrane (Waipapa Supergrop) and perhaps the Late Cretaceous volcanics. In addition, the Early Miocene autochthon contains significant sedimentary influx from the Late Oligocene volcanics related to the subduction initiation in northern New Zealand.

Zircon and apatite fission-track data from the in situ Mesozoic basement were inverted using thermo-kinematic models coupled with an inversion algorithm. The results suggest that during the Late Oligocene, $4-6 \mathrm{~km}$ thick nappes were emplaced onto the in situ rocks in the northernmost Northland region. Prior to basement unroofing in the Early Miocene, the nappes thinned towards the south. Following allochthon emplacement, eastern Northland was uplifted and unroofed rapidly over a period of $\sim 1-6 \mathrm{Myr}$, leading to $\sim 0.4-1.5 \mathrm{~km}$ erosion of the allochthon. Since the midMiocene, due to the decline in tectonic activity in this region, the Northland Allochthon and the underlying rocks have been eroded slowly.

This thesis has documented variable exhumation and burial processes that occurred in the upper plates of both the Mesozoic Gondwana and late Cenozoic Hikurangi subduction margins. The results provide the foundation for future studies to investigate the kinematics and mechanism of the crustal exhumation and deformation of the North Island basement in further detail. 


\section{Acknowledgement}

I would like to thank Diane Seward and Tim Little, my supervisors in VUW. Diane initiated this study, helped me secure funding and provided limitless support throughout my thesis. Tim's constructive comments and proficient editing improved my written work significantly. Both Diane and Tim are good friends.

I thank Barry Kohn, who also advised my thesis and helped me in the helium dating and writing. Barry and the colleagues in his group assisted me in the fission-track and (U-Th-Sm)/He work at the University of Melbourne. I thank Frédéric Herman and his group for hosting my visit in Université de Lausanne and providing codes and guidance for the modelling task. Thanks to Aleksandr Beliaev for helping me compile the codes on the server in VUW.

Thanks to Kevin Norton, Ben Hines, Joseph Kelly and Terry Seward for the invaluable help and memorable times in the field. Thanks to Bruce Mountain, Nellie Olsen, Sarah Milicich, Marc-Alban Millet, George Cooper, Kirsten Henden and John Collen for collecting additional samples.

I thank my friends and colleagues from SGEES: Alexa Van Eaton, Aidan Allan, Simon Barker, Melissa Rotella, Chris Conway, Katy Chamberlain, Calum Chamberlain, Loretta Corcoran, Jenni Hopkins, Shaun Eaves, Richard Jones, Emily Warren-Smith, John Creech, Matt Ryan, Ignacio Jara, Denise Tang, Elliot Swallow, Celine Mandon, Shane Rooyakkers, Colin Wilson, John Gamble, Joe Hiess, Kate King, Ningsheng Wang, Rewi Newnham, the administration team and technical staff, for giving me many good times and making my study and life easy in Wellington.

I am grateful to Mum and Dad for supporting my study continuously. To my wife Liqin Zhao, many thanks for helping and looking after me every day; I have been fortunate to share my life with you. Thank our daughter Ruby for joining the journey and bringing lots of fun. 



\section{Contents}

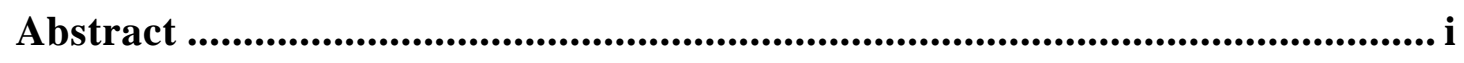

Acknowledgement ................................................................................................ii

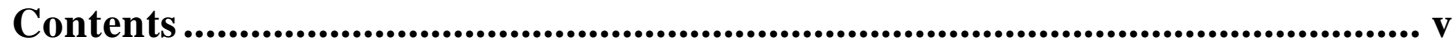

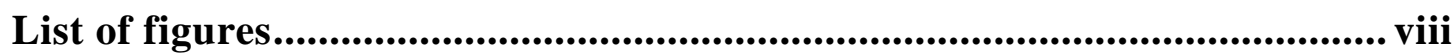

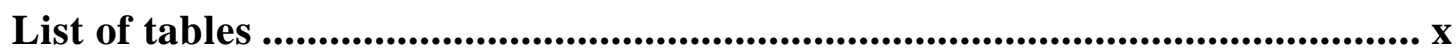

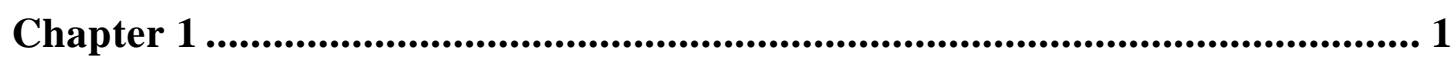

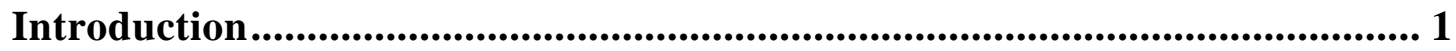

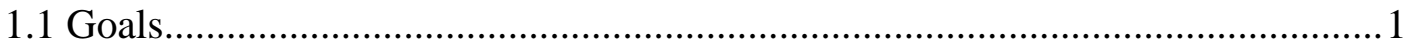

1.2 Rock uplift, surface uplift and exhumation ........................................................

1.3 Low-temperature thermochronology ................................................................

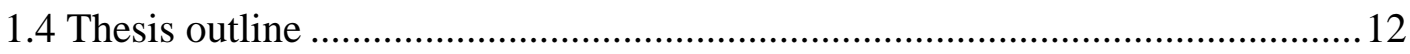

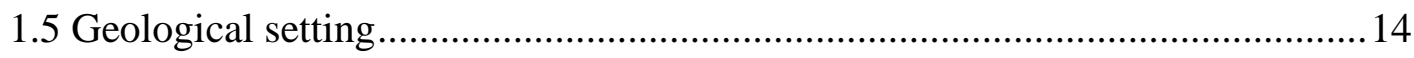

1.5.1 Basement terranes................................................................................ 14

1.5.2 Unconformity between basement terranes and overlying rocks...................18

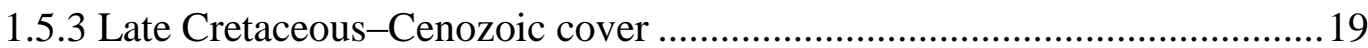

1.6 Low-temperature thermochronology studies ..................................................20

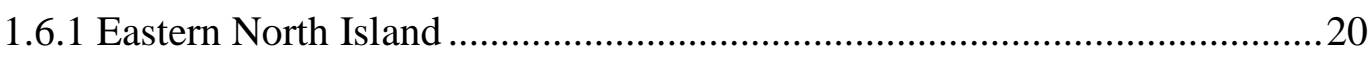

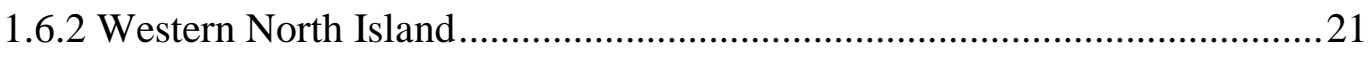

Chapter 2 ......................................................................................................... 23

Thermal history and exhumation of basement rocks from Mesozoic to Cenozoic subduction cycles, central North Island ............................................... 23

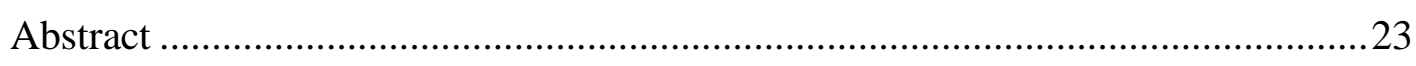

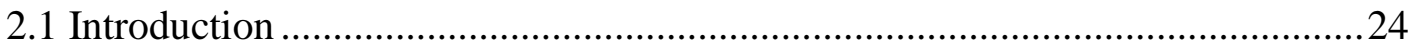

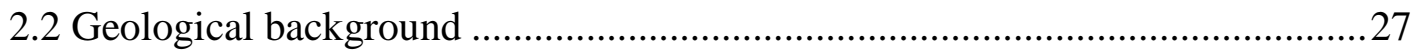

2.3 Thermochronological data............................................................................ 30

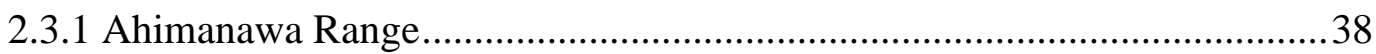

2.3.2 Kaimanawa Mountains and Kaweka Range .................................................38

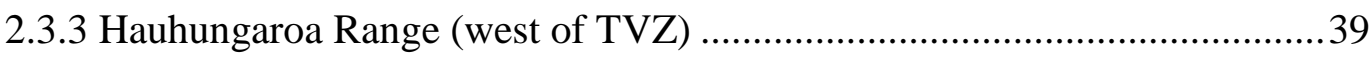

2.4 Apatite Fission-track and (U-Th-Sm)/He modelling ..........................................39 


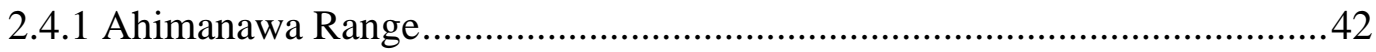

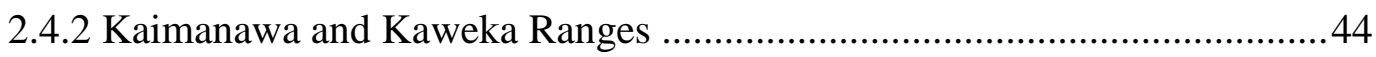

2.4.3 Hauhungaroa Range (west of TVZ) ......................................................46

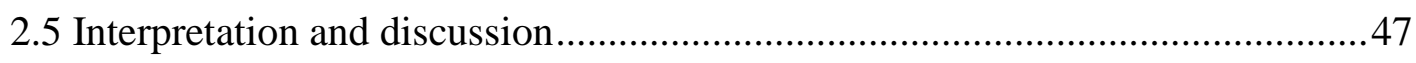

2.5.1 Thermal and exhumation history of the eastern Gondwana margin............47

2.5.2 Cenozoic exhumation in the hanging wall of the Hikurangi Margin ..........51

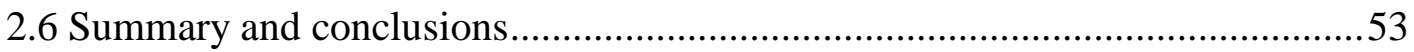

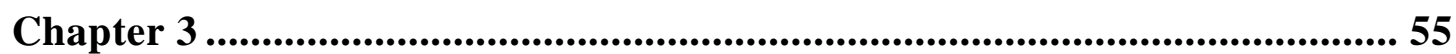

Unroofing of frontal ridges at the Hikurangi Margin, New Zealand: constraints from low-temperature thermochronology .................................. 55

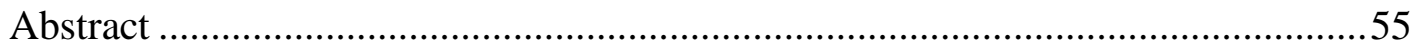

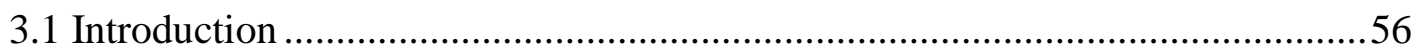

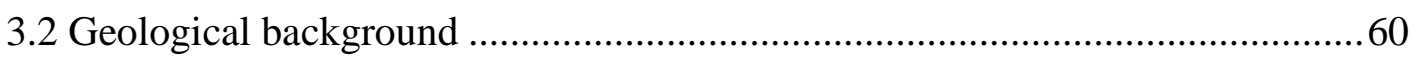

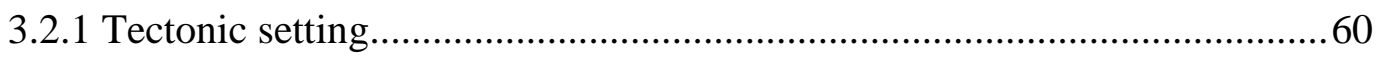

3.2.2 Axial ranges and North Island Fault System ...........................................61

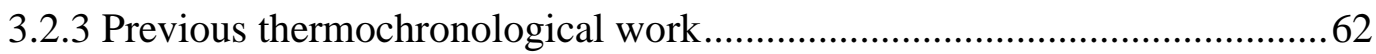

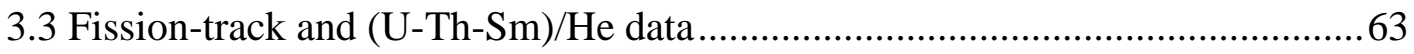

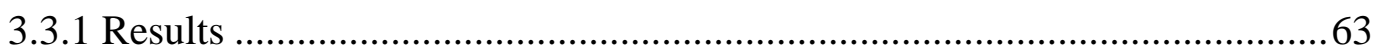

3.3.2 Distribution of AFT and AHe ages in the axial ranges ............................66

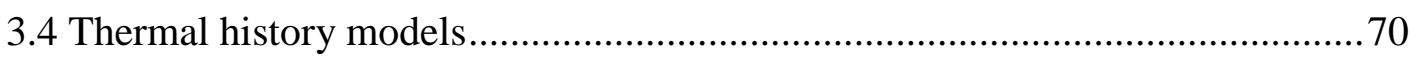

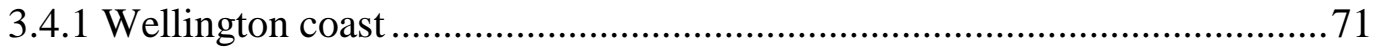

3.4.2 Tararua Range (Mount Holdsworth) ..................................................... 72

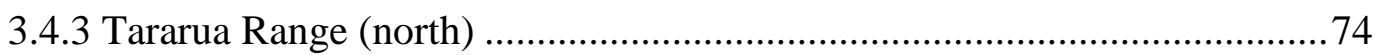

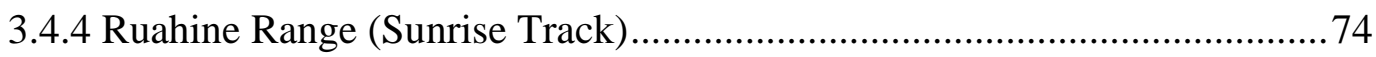

3.4.5 Ikawhenua and Huiarau Ranges (Waikaremoana) ....................................74

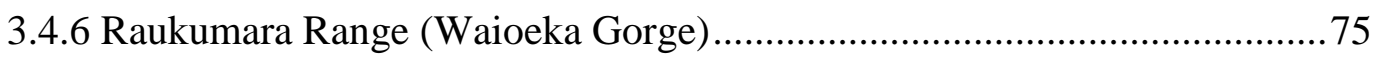

3.5 Inferred history of unroofing in the axial ranges............................................. 75

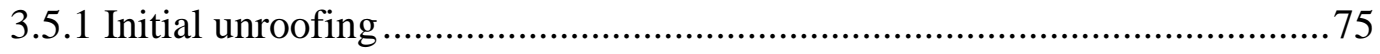

3.5.2 Change of exhumation rates in the Late Miocene .......................................78

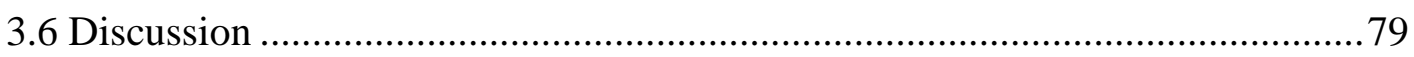

3.6.1 Thrust faulting, crustal shortening and plate coupling ............................79

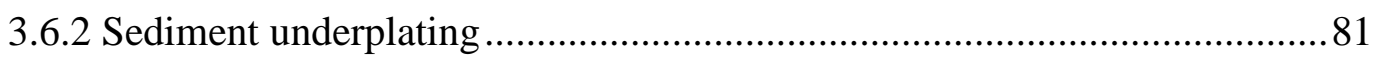

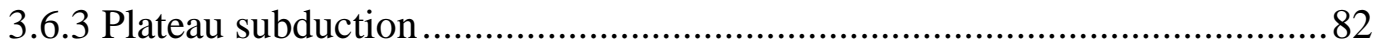

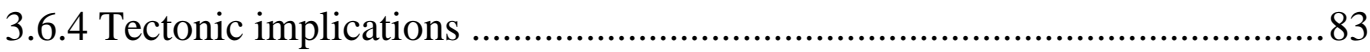


3.7 Conclusions

Chapter 4

Constraining provenance, thickness and erosion of the Northland Allochthon, New Zealand, using low-temperature thermochronology ............................ 87

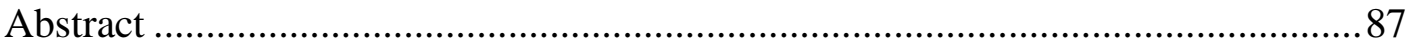

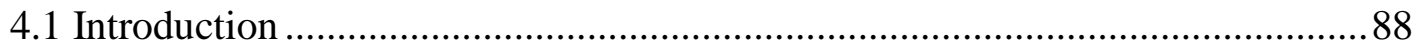

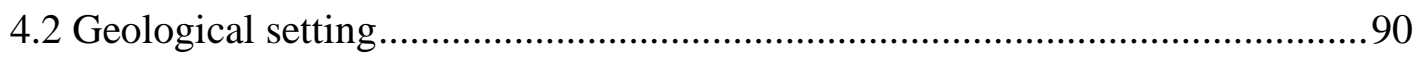

4.3 Thermochronological age models of the allochthon and autochthon ................94

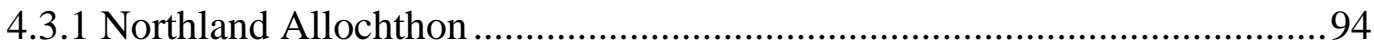

4.3.2 Early Miocene Autochthon....................................................................94

4.4 Thermal history models of the allochthon and autochthon ..............................95

4.4.1 Method and model set-up .......................................................................... 96

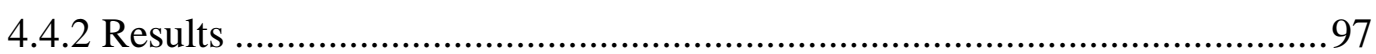

4.5 Thermo-kinematic modelling of the basement (Waipapa Supergroup) .............99

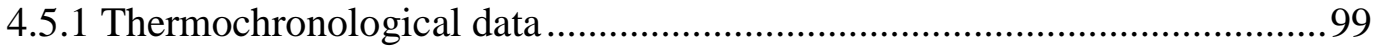

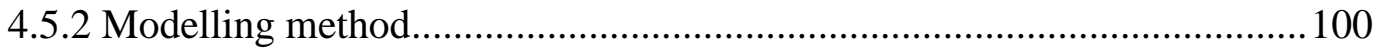

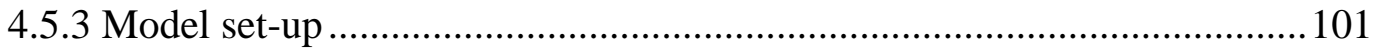

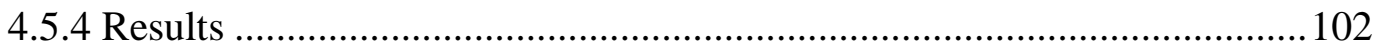

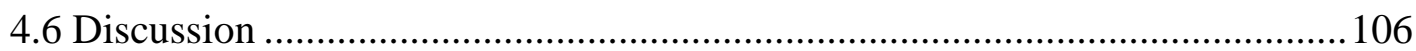

4.6.1 Detrital provenance of allochthon and autochthon ...................................106

4.6.2 Thickness of the allochthon during its emplacement ...............................107

4.6.3 Post-emplacement erosion of the allochthon ........................................... 107

4.6.4 Dependence of the model results on prescribed boundary temperatures ..109

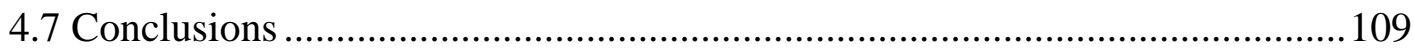

Chapter 5 ..........................................................................................111

Conclusions and recommendations .......................................................111

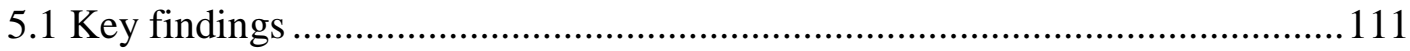

5.2 Exhumation histories of North Island basement ...........................................113

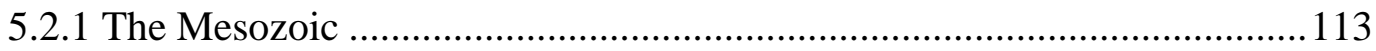

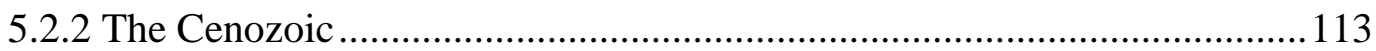

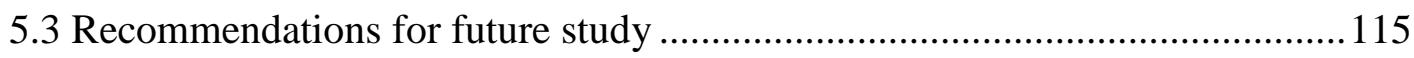

Bibliography ...............................................................................................117

Appendix I .................................................................................................143 
Large-scale temporal and spatial variations in the exhumation of New Zealand basement since 40 Ma: inversion of thermochronological agesfuture work

6.1 Introduction 143

6.2 Methods.... 144

6.2.1 Data selection 144

6.2.2 Closure temperature and annealing/diffusion models 145

6.2.3 Inversion of thermochronological data 148

6.3 Preliminary results: an example 150

Supplementary references of thermochronological data.

Appendix II.

Sample preparation and analytical methods

7.1 Mineral preparation

7.2 Zircon and apatite fission-track 173

7.3 Apatite (U-Th-Sm)/He 176

\section{List of figures}

Fig. 1.1 Topography and bathymetry of the Australian-Pacific Plate boundary zone.. 4 Fig. 1.2 The concept of an exhumed apatite partial annealing zone (PAZ) .................5

Fig. 1.3 The concept of closure temperature

Fig. 1.4 Effective closure temperatures for different thermochronometers as a function of cooling rate. .9

Fig. 1.5 Closure isotherms of different thermochronometers in a crustal block .........12

Fig. 1.6 Simplified distributions of metasedimentary rocks of North Island ..............15

Fig. 1.7 Simplified geological map of North Island and sample sites.......................17

Fig. 1.8 Topographic map of the basement-cored ranges in North Island ..................18

Fig. 2.1 Key tectonic elements in Hikurangi Margin .26 
Fig. 2.2 Study area in central North Island, New Zealand .....................................28

Fig. 2.3 Thermochronological ages along profiles across central North Island ...........30

Fig. 2.4 Inverse modelling results in the Ahimanawa Range ...................................41

Fig. 2.5 Expected thermal histories in the Ahimanawa Range ..................................43

Fig. 2.6 Inverse modelling results in the Kaimanawa Mountains .............................45

Fig. 2.7 Thermal history modelling results for the Kaweka Range ............................46

Fig. 2.8 AFT modelling result in the Hauhungaroa Range .......................................47

Fig. 2.9 Summary of inferred thermal histories for basement rocks in central North

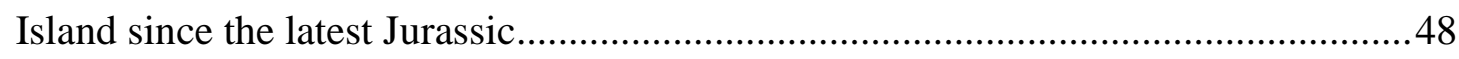

Fig. 2.10 Exhumation histories of the basement rocks of central North Island...........50

Fig. 3.1 Tectonic setting of the Hikurangi Margin .................................................57

Fig. 3.2 Reconstructions of New Zealand Plate boundary zone at 25, 10 and $0 \mathrm{Ma}$...58

Fig. 3.3 Geological map of North Island and thermochronological ages ...................60

Fig. 3.4 Variation of AFT and AHe ages along the strike of axial ranges .................69

Fig. 3.5 Boomerang plot of AFT age versus mean track length...............................70

Fig. 3.6 Schematic unroofing pattern of the axial ranges ......................................... 72

Fig. 3.7 Composite transect along the Hikurangi Margin ........................................ 80

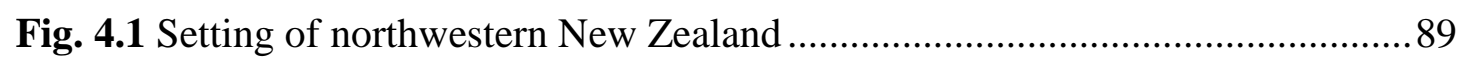

Fig. 4.2 Lower hemisphere equal-area projections of poles to beddings in the in situ

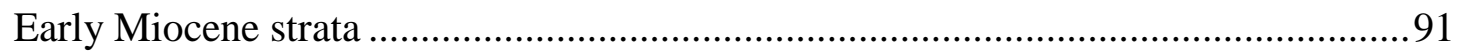

Fig. 4.3 ZFT and AFT ages of the allochthon and autochthon at Parua Bay .............95

Fig. 4.4 Thermal history modelling results from Parua Bay .....................................98

Fig. 4.5 Radial plots of the ZFT and AFT ages from the Waipapa Supergroup .........99

Fig. 4.6 2D thermo-kinematic model of the eastern Northland basement ................. 101

Fig. 4.7 Inversion results of the thermo-kinematic model in eastern Northland...... 103

Fig. 4.8 Prediction of the 2D thermo-kinematic model .......................................... 105

Fig. 4.9 Isopachs of the Northland Allochthon at 27 Ma, 20 Ma and $10 \mathrm{Ma}$............ 108

Fig. 4.10 Variation of the inversion results in relationship with the prescribed........110

Fig. 6.1 Apatite and zircon (U-Th)/He and fission-track ages in New Zealand ........146 
Fig. 6.2 Biotite, muscovite and total-rock ${ }^{40} \mathrm{Ar} /{ }^{39} \mathrm{Ar}$ or K-Ar ages in New Zealand. 147

Fig. 6.3 Change in residual of the model during the inversion 150

Fig. 6.4 Exhumation model of New Zealand for the time interval 40-38 Ma ..........151

Fig. 6.5 Exhumation model of New Zealand for the time interval 38-36 Ma ..........152

Fig. 6.6 Exhumation model of New Zealand for the time interval 36-34 Ma ..........153

Fig. 6.7 Exhumation model of New Zealand for the time interval 34-32 Ma ..........154

Fig. 6.8 Exhumation model of New Zealand for the time interval 32-30 Ma ..........155

Fig. 6.9 Exhumation model of New Zealand for the time interval 30-28 Ma ..........156

Fig. 6.10 Exhumation model of New Zealand for the time interval 28-26 Ma ........157

Fig. 6.11 Exhumation model of New Zealand for the time interval 26-24 Ma. .......158

Fig. 6.12 Exhumation model of New Zealand for the time interval 24-22 Ma ........159

Fig. 6.13 Exhumation model of New Zealand for the time interval 22-20 Ma ........160

Fig. 6.14 Exhumation model of New Zealand for the time interval 20-18 Ma ........161

Fig. 6.15 Exhumation model of New Zealand for the time interval 18-16 Ma ........162

Fig. 6.16 Exhumation model of New Zealand for the time interval 16-14 Ma ........163

Fig. 6.17 Exhumation model of New Zealand for the time interval 14-12 Ma ........164

Fig. 6.18 Exhumation model of New Zealand for the time interval 12-10 Ma ........165

Fig. 6.19 Exhumation model of New Zealand for the time interval 10-8 Ma ..........166

Fig. 6.20 Exhumation model of New Zealand for the time interval 8-6 Ma ............167

Fig. 6.21 Exhumation model of New Zealand for the time interval 6-4 Ma ............168

Fig. 6.22 Exhumation model of New Zealand for the time interval 4-2 Ma ............169

Fig. 6.23 Exhumation model of New Zealand for the time interval 2-0 Ma ............170

Fig. 7.1 Zeta values evaluated by R. Jiao for apatite (CN5) and zircon (CN1)........176

\section{List of tables}

Table 2.1 Zircon fission-track results in central North Island.....................................32

Table 2.2 Apatite fission-track results in central North Island ....................................33

Table 2.3 Apatite (U-Th-Sm)/He results in central North Island.................................35 
Table 3.1 Zircon and apatite fission-track results in the axial ranges ........................64

Table 3.2 Apatite (U-Th-Sm)/He results in the axial ranges....................................66

Table 4.1 Zircon and apatite fission-track results in northwestern New Zealand.......93

Table 4.2 Apatite (U-Th-Sm)/He results in northwestern New Zealand .....................93

Table 4.3 Fixed thermo-kinematic model parameters............................................... 102

Table 4.4 Free thermo-kinematic model parameters and inversion results............... 104

Table 7.1 Zeta values evaluated by R. Jiao for apatite and zircon..........................175 



\section{Chapter 1}

\section{Introduction}

\subsection{Goals}

New Zealand is the subaerial, emergent portion of the continent of Zealandia (Fig. 1.1) (Mortimer, 2006). It represents only about $10 \%$ of the area of Zealandia, a fragment of Gondwana that, before Late Cretaceous was contiguous with both Australia and Antarctica. The Waipapa and Torlesse Supergroups are two major units of the basement rocks of North Island, New Zealand. Both are Mesozoic sedimentary sequences that were deposited, deformed and later exhumed in the accretionary wedge of the Gondwana Margin. During the Late Cretaceous, Zealandia was separated from the other continental fragments of Gondwana (Bradshaw, 1989). The related passive margin setting changed to a compressional or transpressional regime during the Middle Eocene-Late Oligocene such that the present land area of New Zealand straddles the boundary between the modern converging Australia and Pacific Plates. During this plate convergence, the basement rocks of North Island experienced a period of deformation and exhumation in the hanging wall position of the new margin (the Hikurangi Margin).

Deformation causes the advection and uplift of the crustal material, and is expressed by both surface uplift and exhumation. Dating and quantifying the magnitudes and rates of exhumation of crustal basement rocks in North Island, New Zealand, has the potential to contribute important new understanding to the geodynamics of this Andean-type margin and its subduction zone.

From the Mesozoic Gondwana to the modern Hikurangi subduction margins, this thesis aims to resolve how the subduction cycles have impacted the thermal and 
exhumation histories of the basement rocks in North Island, New Zealand. Within this broad topic, key questions addressed include:

- The Mesozoic Gondwana Margin,

What were the thermal and exhumation histories of the accretionary terranes?

- The late Cenozoic Hikurangi Margin,

How did the subduction initiation in North Island impact the crustal rocks in the upper plate?

- Impact of emplacement of the Northland Allochthon,

During the Late Oligocene-earliest Miocene, how did the emplacement and subsequent erosion of the Northland Allochthon overprint the thermal histories of the in situ basement rocks?

\subsection{Rock uplift, surface uplift and exhumation}

Vertical movement of the crustal mass in a convergent plate boundary is generally associated with horizontal plate motions. Accurate estimates of the rates and magnitude of the upward motion may in turn provide important constraints on the kinematic and geodynamic evolution of a subduction margin.

For quantification of the upward motion of the crust, England and Molnar (1990) clarified three types of measurements that are widely used in orogenic studies, which are related as:

$$
\text { Rock uplift }=\text { surface uplift }+ \text { exhumation }
$$

a) Rock uplift is the vertical displacement of an individual rock particle relative to the geoid or sea level, i.e. the change in elevation of a rock. Records of continuous GPS stations provide direct measurements of short-term (tens of years) rock uplift relative to sea level (e.g. Beavan et al., 2004; Beavan et al., 2010). Over a longer time scale (thousands of years), average rock uplift rates can be estimated using well-constrained ages and the present-day altitudes of uplifted marine and fluvial terraces and palaeoshoreline markers (e.g. Bull and Cooper, 1986; Litchfield and Berryman, 2006; Litchfield et al., 2010; Litchfield, 2008; Simpson et al., 1994). 
b) Surface uplift is the vertical displacement of the land surface with respect to the geoid. England and Molnar (1990) noted the difficulties in providing reliable and quantitative constraints on surface uplift due to the lack of appropriate protocols. In the past two decades, many efforts have been made to reconstruct the palaeotopography of mountain belts, using different approaches (e.g. Chamberlain et al., 2012; Chase et al., 1998; Sahagian and Proussevitch, 2007). Particularly, Rowley et al. (2001) and Rowley and Garzione (2007) introduced a protocol to estimate the local palaeo-altitude based on the relationship between stable isotopes and elevation, and demonstrated its application in the Himalayas and the Andes.

c) Exhumation, or unroofing, is the upward motion of a rock towards the earth surface, representing the difference between rock and surface uplift. Exhumation is the result of denudation, which refers to the removal of rocks or sediments from a point at the earth surface, during erosional or tectonic processes. Erosional denudation occurs at the surface and is driven by the both mechanical and chemical weathering. Denudation may also be tectonic. For example during extension, normal faulting allows rapid exhumation of rocks in the footwall, often well illustrated in the evolution of metamorphic core complexes (e.g. Schulte et al., 2014; Seward et al., 2009; Spell et al., 2000).

For different time scales erosion can be constrained using various methods. Over the $10^{3}$ to $10^{5}$ years scale, bedrock erosion rates can be determined by measuring the concentration of in situ-produced cosmogenic nuclides (e.g. ${ }^{10} \mathrm{Be},{ }^{26} \mathrm{Al}$; Bennett et al., 2005; Granger et al., 1996; Nishiizumi et al., 1993; Norton et al., 2010; von Blanckenburg, 2005). Over longer time scales (millions of years), the rock exhumation rate can be constrained by low temperature thermochronology, which is the approach used in this thesis. 


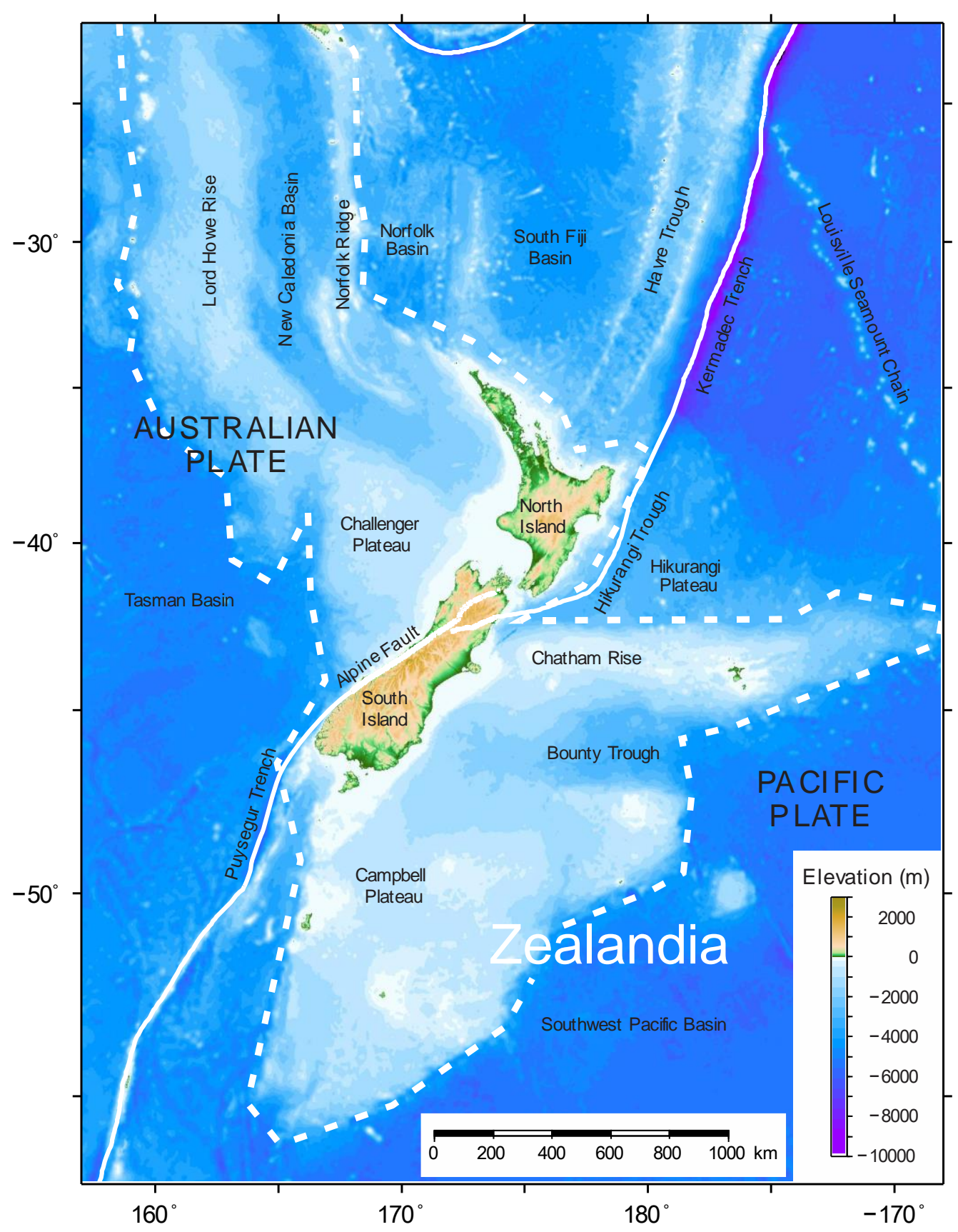

Fig. 1.1 Topography and bathymetry (ETOPO1, NOAA) of the Australian-Pacific Plate boundary zone. The plate boundary is emphasised (solid line) and the region of Zealandia is indicated (dashed line) (Mortimer, 2006).

\subsection{Low-temperature thermochronology}

The ability to constrain time-temperature paths makes this technique a powerful tool for constraining thermal events, especially in the upper crust. This thermal information related to cooling and heating of rocks is usually interpreted in terms of the causative processes of exhumation and burial, which in turn are interpreted in 
terms of tectonic and geomorphological/landscape evolution. The spatial and temporal patterns of exhumation and landscape evolution may also provide constraints on the kinematics and mechanism of orogenesis and other earth surface processes in response to tectonic forces and climatic controls.

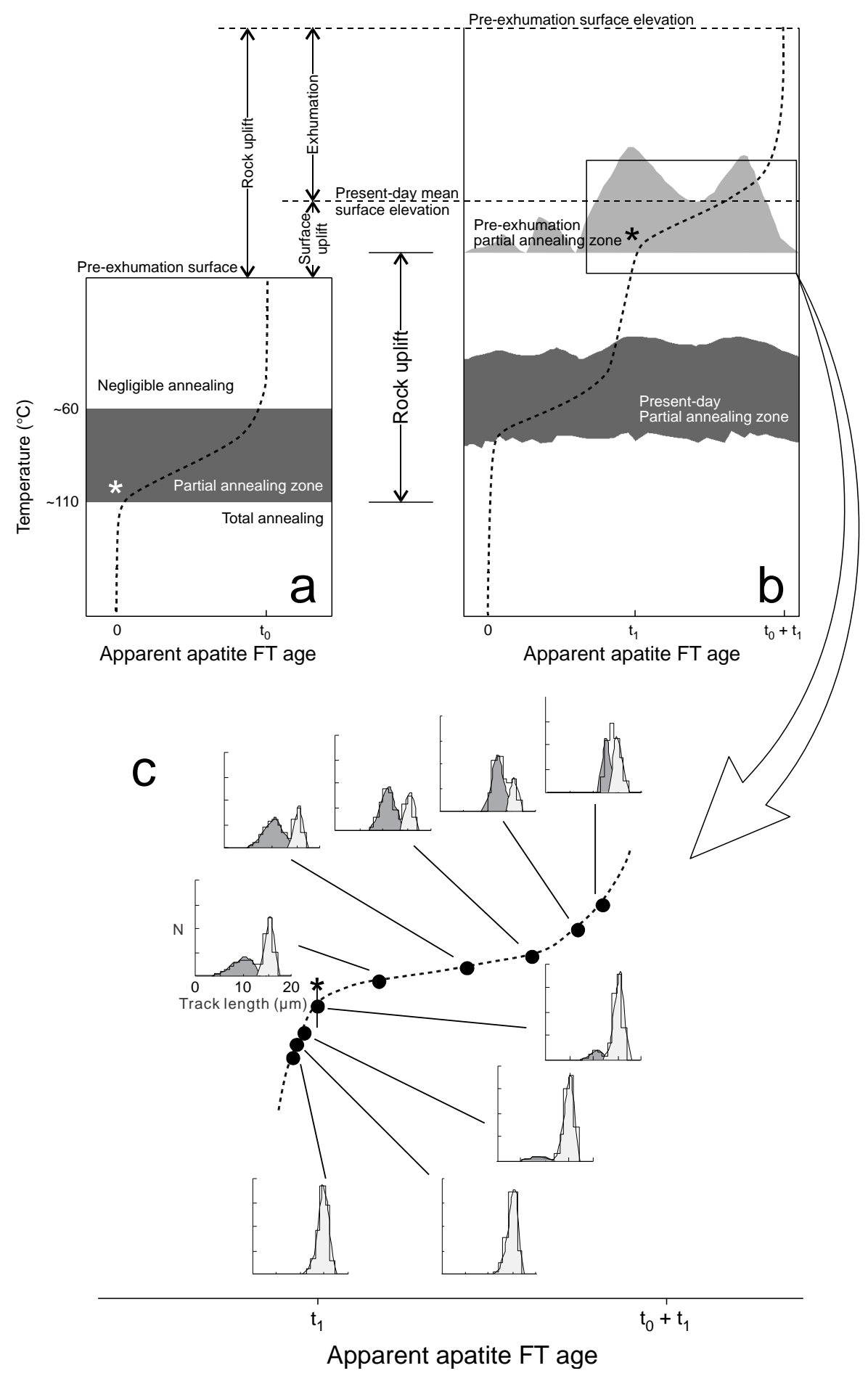

Fig. 1.2 The concept of an exhumed apatite partial annealing zone (PAZ), modified from Fitzgerald et al. (1995) and Gallagher et al. (1998). (a) The initial apatite age-profile, established under conditions of relative thermotectonic stability over a period $t_{0}$. The apatite 
fission-track age decreases rapidly downwards in the PAZ. (b) The present-day age-elevation profile. Rapid exhumation since $t 1$ exposes part of pre-exhumation profile. A sample from the base of the palaeo-PAZ (marked by an asterisk) indicates the age of the onset of rapid exhumation. (c) The expected trend in fission-track age and length with respect to elevation. The length distribution has two components: tracks formed prior to rapid exhumation (dark) and those formed after exhumation (white).

Low temperature thermochronology is a term generally applied to isotopic geochronological methods that yield information on thermal histories of rocks below about $350{ }^{\circ} \mathrm{C}$. In this section, I briefly summarise some fundamental concepts relevant to my thesis while more detailed reviews of the methods are given by Wagner and Van den Haute (1992), McDougall and Harrison (1999), Farley (2002) and Reiners and Ehlers (2005).

In low-temperature thermochronology, the three main methods in use today are (UTh-Sm)/He, fission-track (FT) and ${ }^{40} \mathrm{Ar} /{ }^{39} \mathrm{Ar}$. A combination of these methods on different minerals potentially allows for the investigation of thermal histories in a temperature range from $\sim 350{ }^{\circ} \mathrm{C}$ to $\sim 50{ }^{\circ} \mathrm{C}$. The $(\mathrm{U}-\mathrm{Th}-\mathrm{Sm}) / \mathrm{He}$ dating, is based on the alpha decay of ${ }^{238} \mathrm{U},{ }^{235} \mathrm{U},{ }^{232} \mathrm{Th}$ and ${ }^{147} \mathrm{Sm}$ to ${ }^{4} \mathrm{He}$ in a U-bearing mineral. The radiogenic ${ }^{4} \mathrm{He}$ accumulates in, but may also progressively diffuse out of the mineral at rates controlled by temperature and the helium diffusivity, which may vary with the mineral being analysed. For the fission-track method, a fission track is the ionization damage produced by spontaneous fission decay of ${ }^{238} \mathrm{U}$, whereby ${ }^{238} \mathrm{U}$ splits into two smaller atoms. This high energy event leaves a linear damage trail in the crystal that can be revealed by chemical etching. The etched length of a newly formed fission track is $\sim 16 \mu \mathrm{m}$ for apatite (Gleadow et al., 1986) and $\sim 11 \mu \mathrm{m}$ for zircon (Hasebe et al., 1994). Naturally formed fission tracks anneal due to thermally activated diffusion, represented as shortening of the track length and consequent decrease of the track density. In the ${ }^{40} \mathrm{Ar} /{ }^{39} \mathrm{Ar}$ (or K-Ar) system, ${ }^{40} \mathrm{Ar}$ is generated by electron capture from ${ }^{40} \mathrm{~K}$. The retention of ${ }^{40} \mathrm{Ar}$ in a mineral is dependent on the thermally activated diffusion, in a similar manner but slower than that of He, perhaps due to its larger atomic radius. Traditional minerals used for the (U-Th-Sm)/He and fission-track methods are zircon and apatite, whereas hornblende, K-feldspar, biotite and muscovite are commonly used for ${ }^{40} \mathrm{Ar} /{ }^{39} \mathrm{Ar}$ (or K-Ar) dating.

Many laboratory and field-based studies indicate that annealing of fission tracks and diffusion of $\mathrm{He}$ and Ar occur predominantly over specific temperature ranges, which 
are termed the partial annealing zone (PAZ) for fission-track (Fig. 1.2) (Gleadow and Fitzgerald, 1987) and partial retention zone (PRZ) for the $\mathrm{He}$ and $\mathrm{Ar}$ systems (Baldwin and Lister, 1998; Wolf et al., 1998). The temperature dependent diffusive loss of daughter products can be described by the Arrhenius equation,

$$
D=D_{0} \exp \left(\frac{-E_{a}}{R T}\right)
$$

where $D$ is the diffusivity at temperature $T, R$ is the gas constant, $E_{\mathrm{a}}$ is the activation energy and $D_{0}$, known as the diffusion constant, represents the diffusion coefficient at infinitely high temperature,. Note that this equation does not account for the effect of pressure on the retention of daughter products, which is negligible in most cases because most thermochronometers are retentive only at relatively shallow crustal depths. However, exceptions exist and pressure could be important for Ar thermochronometers under low-temperature, high-pressure conditions (Lister and Baldwin, 1996). Laboratory experiments provided the estimates for the constant in equation 1.2 for different thermochronometers, and these estimates have been correlated and tested with field-based studies in boreholes (Coyle and Wagner, 1996; Gleadow and Duddy, 1981) or exhumed normal faults (Bernet, 2009; Reiners et al., 2000; Stockli et al., 2000).

A major contribution of thermochronology is the generation of cooling paths of rocks through the PAZ or PRZ. In the (U-Th-Sm)/He system, the variation of the closure temperature with grain size and cooling rate allows the reconstruction of the thermal history through the age-grain size relationship (Farley, 2002; Farley and Stockli, 2002; Reiners, 2005). In addition, the natural spatial distribution of ${ }^{4} \mathrm{He}$ can be explored by stepwise degassing ${ }^{4} \mathrm{He} /{ }^{3} \mathrm{He}$ analysis $\left({ }^{4} \mathrm{He} /{ }^{3} \mathrm{He}\right.$ thermochronometry), and the results can be used to constrain the sample's temperature-time path (Shuster et al., 2004; Shuster and Farley, 2005). In the fission-track system, track lengths are used to investigate the thermal evolution of a rock within the PAZ (Fig. 1.2c) (Gallagher, 1995; Gallagher, 2012; Gleadow et al., 1986; Ketcham, 2005; Tagami and Murakami, 2007). The ability to infer complex thermal histories from thermochronological data is particularly useful in cases where cooling rates are slow and the rocks reside for a long period in the PAZ or PRZ. 
Although a thermochronometer closes over a temperature range, under ideal conditions a measured cooling age indicates a single temperature on the thermal path. Dodson (1973) defined the effective closure temperature $\left(T_{\mathrm{c}}\right)$ as the temperature at the time indicated by a thermochronometer, providing a practical solution for interpretation of the measured age (Fig. 1.3). The concept of $T_{\mathrm{c}}$ is only meaningful in the case where a rock cools through the PAZ or PRZ at a constant rate. Dodson (1973) demonstrated that for a given thermochronometer, $T_{\mathrm{c}}$ is positively dependent on the cooling rate, using the equation

$$
T_{\mathrm{c}}=\frac{E_{\mathrm{a}}}{R \ln \left(A \tau D_{0} / a^{2}\right)}
$$

where $\tau$ is the time taken for the diffusivity to decrease, $a$ is the dimension of the diffusion domain and $A$ is a constant dependent on the geometry and decay constant of parent ( $A=25$ for a sphere, 27 for a cylinder and 8.7 for a plane sheet); other variables are the same as in Equation 1.2. In helium dating systems, the diffusion domain usually scales with the natural size of the dated grain (Farley, 2000; Reiners and Farley, 1999; Reiners et al., 2004), and in practise it can be modelled as an equivalent spherical radius of a prismatic grain. For the ${ }^{40} \mathrm{Ar} /{ }^{39} \mathrm{Ar}$ methods, the sizes of Ar diffusion domains in biotite, muscovite and hornblende appear to be equivalent to the physical size of the dated grain. In contrast, Ar diffusion domain in a K-feldspar can be some sub-grain structure with a smaller size than the dated grain (McDougall and Harrison, 1999). 


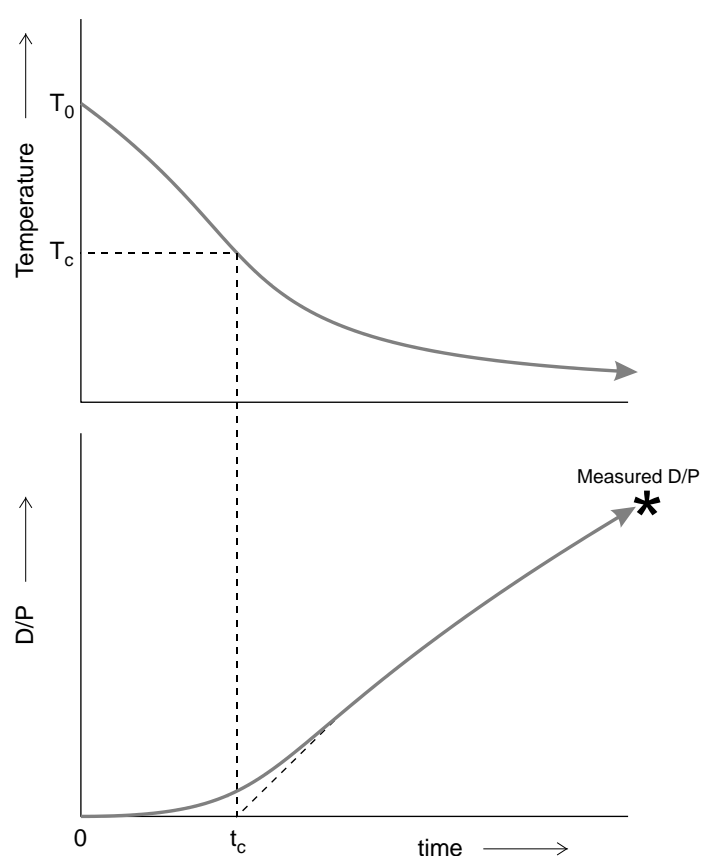

Fig. 1.3 The concept of closure temperature, defined by Dodson (1973). The upper panel represents the cooling path of a sample. The lower panel shows the accumulation of the daughter products (D) divided by the production ratio $(P)$ as a function of time. Time $t_{c}$ indicated by the apparent age records the cooling at the closure temperature $\mathrm{T}_{\mathrm{c}}$.

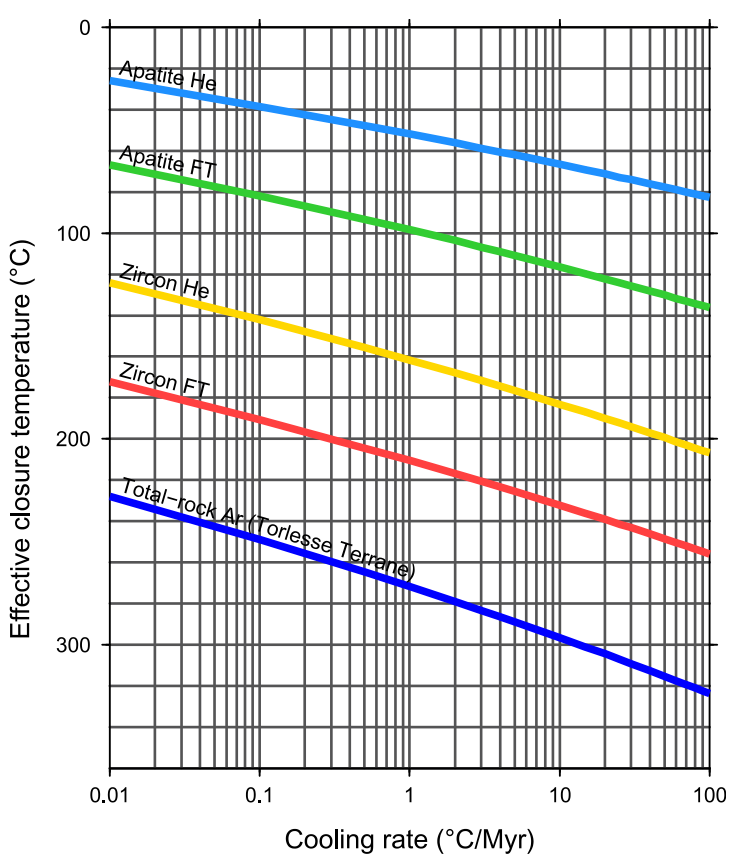

Fig. 1.4 Effective closure temperatures for different thermochronometers as a function of cooling rate, calculated using the method of Reiners and Brandon (2006). Fission-track annealing and helium diffusion parameters are from Reiners and Brandon (2006) and the references within; the closure temperature of total-rock ${ }^{40} \mathrm{Ar} /{ }^{39} \mathrm{Ar}$ (K-Ar) method in the Torlesse Supergroup rocks is calculated after Adams (2003) and Kirschner et al. (1996).

Based on equation 1.3, Reiners and Brandon (2006) calculated and summarised the effective closure temperature of the commonly used thermochronometers for standard mineral composition in steady cooling situations at different rates (Fig. 1.4), using available fission-track annealing and $\mathrm{He}$ and $\mathrm{Ar}$ retention models. The closure temperature of apatite and zircon (U-Th-Sm)/He systems are typically $50-80{ }^{\circ} \mathrm{C}$ and 140-200 ${ }^{\circ} \mathrm{C}$, respectively. For the fission-track system, the closure temperatures are typically $60-120{ }^{\circ} \mathrm{C}$ for apatite and $240 \pm 40{ }^{\circ} \mathrm{C}$ for zircon with natural radiation damage. For the three minerals commonly used for ${ }^{40} \mathrm{Ar} /{ }^{39} \mathrm{Ar}$ dating, K-feldspar, biotite and muscovite, their closure temperatures are $180-260{ }^{\circ} \mathrm{C}, 280-360{ }^{\circ} \mathrm{C}$ and $300-400{ }^{\circ} \mathrm{C}$, respectively. In addition to the factors mentioned above, it is noticeable that the thermal sensitivity of a thermochronometer may also depend on the variations in mineral composition (Carlson et al., 1999; Donelick et al., 2005; Ketcham et al., 1999) and the radiation damage of a crystal (Shuster et al., 2006; Shuster and Farley, 
2009). For the apatite (U-Th-Sm)/He system, potential factors that may affect the $\mathrm{He}$ diffusion/retention are discussed in more detail in Appendix II.

Assuming cooling at a constant rate, dividing the temperature difference between the closure temperature and that at the earth's surface by a thermochronological age yields the time-averaged cooling rate. Furthermore, combining ages of thermochronometers with different closure temperature may provide constraints on longer term temporal variations in the cooling rate. A simplistic estimate of the exhumation rate can then be made by dividing the cooling rate by the geothermal gradient, which is difficult to ascertain accurately and must often be assumed. Complication occurs, for example when the upward motion of the crustal mass compresses the isotherms towards the surface and thus increases the geothermal gradient, especially at shallow depths (Moore and England, 2001). Thus, when dealing with paleotopography, estimates may be inaccurate. When rock uplift and exhumation rates have been constant for a period that is sufficiently long to establish a steady-steady thermal structure (Willett and Brandon, 2002), the perturbation of isotherms by exhumation can be approximated by assuming the geothermal gradient as a function of depth (Brandon et al., 1998). However, if the thermal structure is yet to reach a steady-state, the variation of geothermal gradient through time will add more complexity to the interpretation of exhumation rates (Moore and England, 2001).

To avoid some of the uncertainty caused by assuming a geothermal gradient, another approach to interpret the exhumation rate is to explore the cooling ages from the same thermochronological system as a function of their elevation or depth. In mountainous regions, cooling ages from a given thermochronometer usually yield positive correlations with elevation (Fig. 1.2c), because the rock that is now located at higher elevation would have exhumed through the closure temperature earlier than that lower down. On a plot of the cooling age against the sample elevation, the slope of the ageelevation relationship (AER) yields a direct estimate of the exhumation rate for the time span indicated by the range of ages; a "break in slope" is traditionally interpreted as a change in the exhumation rate (Fig. 1.2) (Fitzgerald and Gleadow, 1988; Fitzgerald et al., 1995; Gleadow and Fitzgerald, 1987). Interpretation of the exhumation rate from the AER is based on three assumptions: (1) the closure isotherm was flat when the samples were exhumed through it; (2) the exhumation rates were 
identical for all samples, i.e. the exhumation was uniform in time and space; (3) the closure temperature depth did not change over that time. Therefore in practise, the application of the AER method requires sampling in a nearly vertical transect to minimise the influence of spatial variation in exhumation rate and to avoid perturbation of the closure temperature isotherm by the undulating topography. However, a "break in slope" on the AER is only valid as a qualitative marker for the change in exhumation rate, and its shape is determined by various factors including the thermal history prior to the break, maximum reheating temperature, cooling rate and geothermal gradient (Prenzel et al., 2013).

Many studies have reported the bending of subsurface isotherms associated with topography and some also demonstrated its importance on the interpretation of the bedrock cooling ages, especially for the apatite FT and (U-Th-Sm)/He methods (Fig. 1.5) (e.g. Braun, 2002a; Braun, 2002b; Braun and Robert, 2005; Ehlers et al., 2001; Ehlers and Farley, 2003; Ehlers, 2005; House et al., 1998; House et al., 2001; Kohl, 1999; Mancktelow and Grasemann, 1997; Stüwe et al., 1994; Stüwe and Hintermüller, 2000; Turcotte and Schubert, 2014). A typical treatment of this problem (e.g. Braun, 2003; Mancktelow and Grasemann, 1997) is to solve the temperature equation as a function of depth in a 2D or 3D lithospheric model with fixed thickness, surface and basal temperatures, thermal diffusivity, density, heat production rate and surface lapse rate, complemented by topography of fixed or changing wavelength and amplitude. 


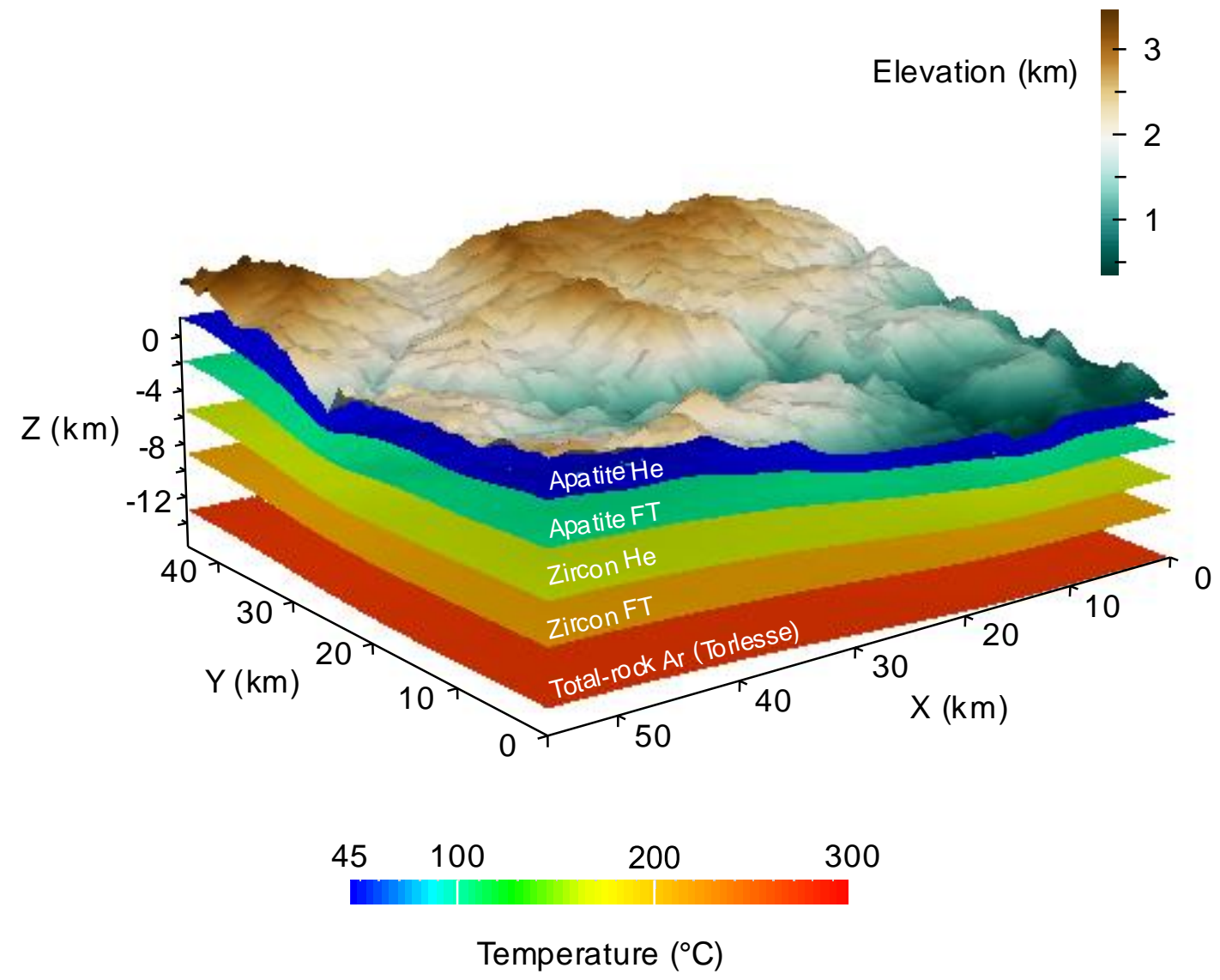

Fig. 1.5 Closure isotherms of different thermochronometers in a crustal block. The results are calculated using Pecube (Braun, 2003; Braun et al., 2012), for a 3D thermal model of the Kings Canyon region in the Sierra Nevada, USA. Refer to Braun (2003) for model settings and parameters of the example.

\subsection{Thesis outline}

This chapter (Chapter 1) of the thesis introduces the objectives, methods and structure of the thesis. Thermochronology and its application in the study of orogenic exhumation are briefly reviewed. The geological background of the North Island and previous thermochronological studies on the basement rocks are reviewed.

Chapter 2 presents new basement fission-track and (U-Th-Sm)/He data obtained across the central North Island, in a transect normal to the hanging wall of the Hikurangi margin. Samples extend from the central axial ranges in the fore-arc to the west of Lake Taupo in a present back-arc position. Inverse modelling of the data using a transdimensional method (Gallagher, 2012) reveals thermal histories of the meta-sedimentary basement during two subduction cycles: Mesozoic subduction on 
the Gondwana margin and the "modern" subduction that was initiated in the late Cenozoic.

Chapter 3 investigates the unroofing pattern and kinematics of basement rocks in the present axial ranges of North Island in transects parallel to the subduction margin, using new and published apatite fission-track and (U-Th-Sm)/He data from the Raukumara Range in the northeast to the Wellington region in the south. The results suggest a trough-ward migration of the rock exhumation histories in the frontal ridges during evolution of the Hikurangi Margin. Based on the temporal and spatial correlations of the basement unroofing history to other tectonic processes/measurements, potential drivers for fore-arc rock uplift and exhumation are also discussed.

Chapter 4 presents a thermochronological study on the Northland Allochthon, which was obducted onto the in situ basement and Paleocene-earliest Miocene rocks in northwestern New Zealand, during plate convergence in the Southwest Pacific region in the latest Oligocene-Early Miocene. New data are reported from the Mesozoic basement and the in situ Early Miocene sequences in the footwall position, as well as from the overlying nappes with sedimentary ages of latest Cretaceous-Paleocene. Data from the allochthon and the underlying Early Miocene autochthon are used to interpret their sedimentary provenance and to model their burial histories. Data from the Mesozoic basement are inverted using thermo-kinematic models (PECUBE) coupled with an inversion algorithm. The kinematic models simulate the emplacement and erosion of the Northland Allochthon. The results provide constraints on the extent, timing and magnitude of the allochthon emplacement as well as on its subsequent erosion.

Chapter 5 summarises the key findings drawn from the previous chapters and synthesises the exhumation histories of the North Island basemetn. This chapter also addresses the remaining gaps in the present research, as well as suggests some directions for future studies.

During my $\mathrm{PhD}$ study, Chapters 2 to 4 were written as stand-alone papers for publication in international scientific journals. As such, each consists of the standard components of a manuscript, i.e. an abstract, introduction, geological setting, 
methodology, data, interpretation, discussion and conclusions. Therefore, it is inevitable that there may be some partial overlap in material presented in the different sections between some of the chapters. To avoid repetition, references cited in this thesis are compiled in one bibliography section following Chapter 5.

At the time of thesis submission (March 2015), Chapter 2 has been published in the journal Tectonics, Chapter 3 has been submitted for publication to the journal Tectonophysics and Chapter 4 will be submitted later. I am the lead author on all three of these papers. My co-authors include my supervisors (Diane Seward, Timothy Little and Barry Kohn). Their contributions to each of the papers and manuscripts are similar to those normally provided by supervisors to a Ph.D student, such as logistical and financial support, assistance during data acquisition and interpretation, guidance and discussion on my research strategy, and editing and commenting on my written work. The project conception, research designs, fieldwork, laboratory data collection, interpretation of results and writing of the manuscripts have all been the work of the candidate.

Appendix I presents the preliminary results of a study that attempts to resolve the larger-scale exhumation pattern of the meta-sedimentary basement rocks of New Zealand, using the present thermochronology data. This work was not an initial objective of my thesis and will be finalised later for publication. Appendix II contains details of the analytical methods used in this study. Appendix III archives the singlegrain data of the apatite and zircon fission-track analysis.

\subsection{Geological setting}

\subsubsection{Basement terranes}

The basement rocks of New Zealand were formed along the boundary of the Gondwana supercontinent as an amalgamation of several constituent tectonic units (Fig. 1.6). In North Island, these rocks include mainly Permian to Early Cretaceous metasedimentary terranes (Fig. 1.7) that are categorised from west to east as, Murihiku, Waipapa and Torlesse Supergroups (Adams et al., 2009; Mortimer, 2004; Mortimer et al., 2014). 
The Murihiku Terrane of North Island is distributed along the central west coast (Fig. 1.6), generally consisting of Permian to Jurassic volcaniclastic sandstone-dominated marine successions, as well as conglomerates, mudstones and tuffs (Adams et al., 2007; Campbell et al., 2001). Campbell and Grant-Mackie (2000) inferred that the terrane was formed in a long-lived basin in the Mesozoic subduction margin, and that sedimentation in either a forearc or backarc position was possible.

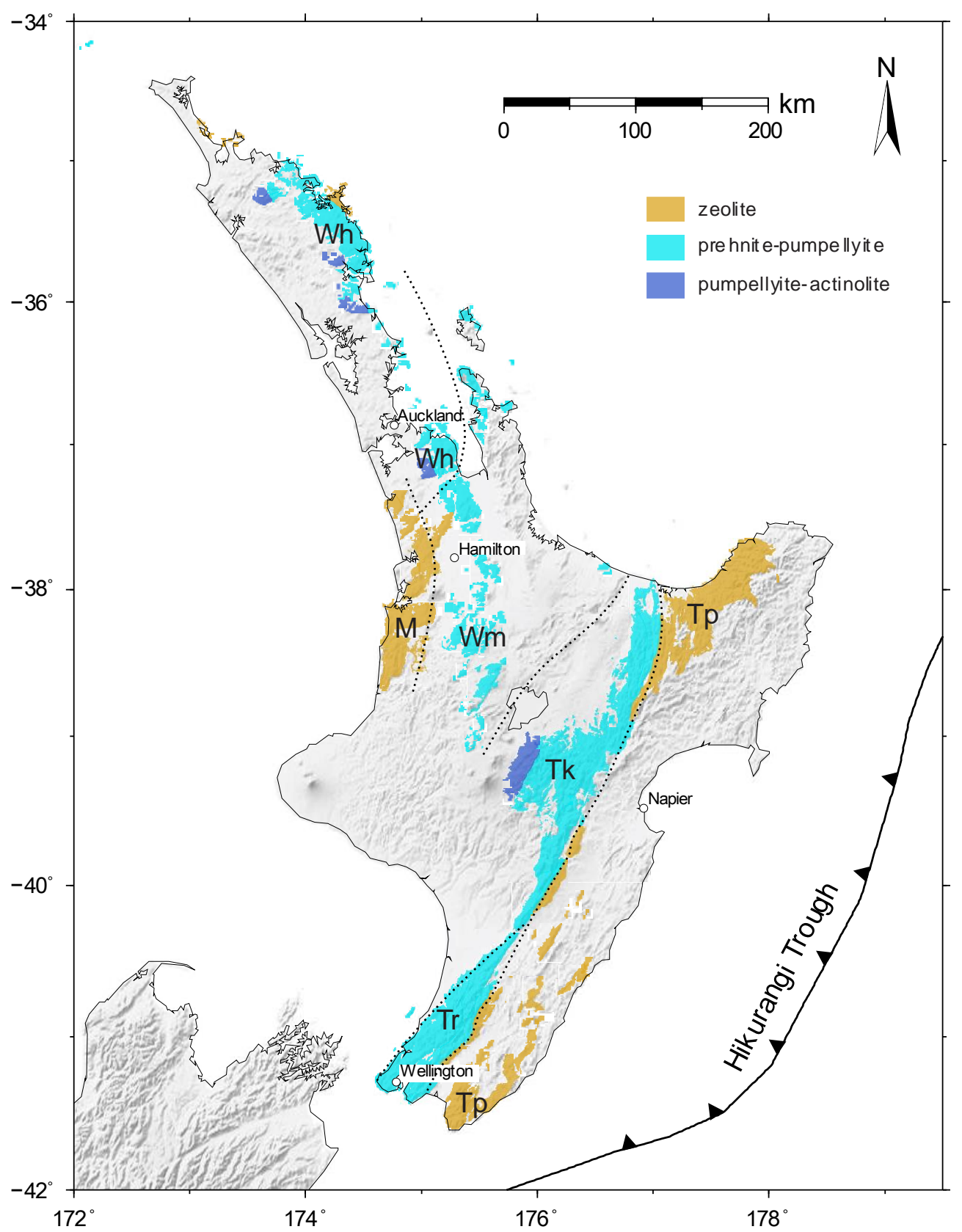

Fig. 1.6 Simplified distributions of metasedimentary rocks of North Island. Data is from the 1:250 000 geological map project of New Zealand (QMAP, GNS Science). Dotted lines indicate boundaries between the metasedimentary terranes, after Mortimer (2004), Adams et al. (2007) and Leonard et al. (2010). M, Murihiku Terrane; Wh, Waipapa Supergroup 
(Hunua); Wm, Waipapa Supergroup (Morrinsville); Tr, Torlesse Supergroup (Rakaia); Tk, Torlesse Supergroup (Kaweka); Tp, Torlesse Supergroup (Pahau).

The Waipapa and Torlesse Supergroups are interpreted as Mesozoic accretionary complexes associated with the subduction beneath the eastern Gondwana margin (Bradshaw, 1989; Mortimer, 2004). The Waipapa Supergroup rocks are largely represented by sandstone-dominated recycled (mainly turbiditic) sedimentary rocks, which accumulated in a complex accretionary environment. The older part of the terrane (Hunua Facies), of Permian to Jurassic age, occurs mainly in the Auckland and Northland regions (Fig. 1.6). The younger part (Morrinsville Facies) is chiefly exposed south of Auckland and in the western-central North Island (Fig. 1.6). The Hunua Facies consists of volcaniclastic successions of sandstone and siltstone with melange and chert horizons (Edbrooke, 2001; Edbrooke and Brook, 2009), whereas the Morrinsville Facies contains more massive, coarser successions of sandstone-fine conglomerate with no intercalated melange and chert (Leonard et al., 2010). The contact between the Waipapa and Torlesse Supergroups is buried by the deposits in the Taupo Volcanic Zone (Leonard et al., 2010).

The Torlesse Supergroup crops out extensively in the east of North and South Islands (Fig. 1.6). Rocks in the Torlesse Supergroup are similar to those in the Waipapa Supergroup, dominated by turbiditic submarine Permian to Early Cretaceous sandstone-mudstone successions. The older part of the composite terrane (Rakaia and Kaweka Terranes) is generally of Permian to Late Jurassic age, and the younger part (Pahau Terrane) was deposited during the Jurassic to Early Cretaceous (Adams et al., 2009; Adams et al., 2012; Leonard et al., 2010).

The basement terranes of North Island have been extensively affected by low-grade metamorphism, with the highest grade in central North Island and decreasing towards the west and east (Fig. 1.6). In central North Island, schistose rocks of pumpellyiteactinolite facies occur within the Torlesse Supergroup on the western flank of the Kaimanawa Mountains. In the rest of the Kaweka and Rakaia Terranes (older Torlesse Supergroup) and in the Waipapa Supergroup of North Island, metamorphism has generally reached prehnite-pumpellyite facies (Adams et al., 2009; Black et al., 1993; Edbrooke, 2001; Lee et al., 2011). In the Pahau Terrane (younger Torlesse Supergroup) and in the Murihiku Terrane, the metamorphism generally only reaches zeolite grade (Begg and Johnston, 2000; Leonard et al., 2010). 


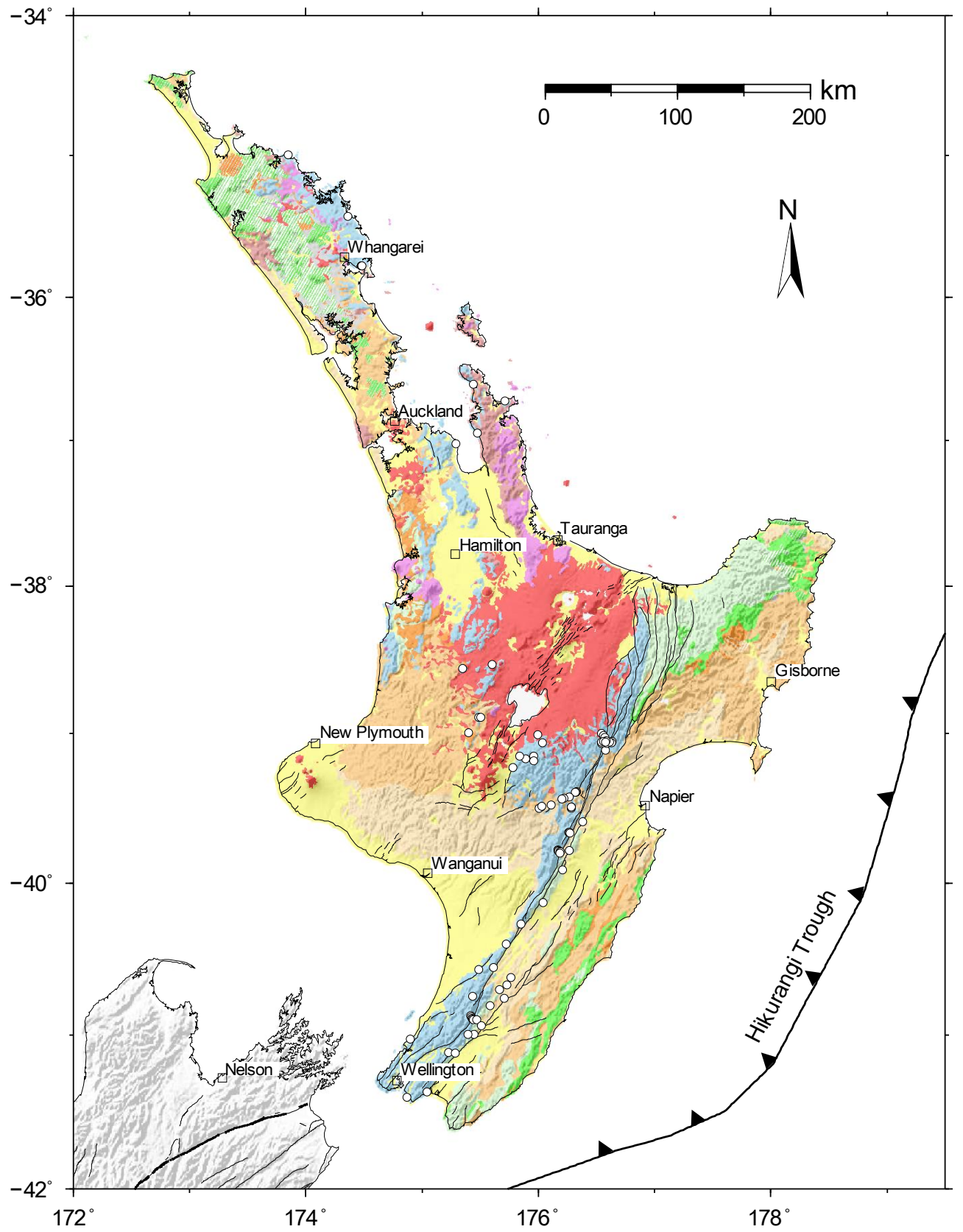

Basement and sedimentary rocks
Quaternary
Pliocene to Pleistocene
Miocene
Eocene to Oligocene
Paleocene
Late Cretaceous
Early Cretaceous
Late Triassic to Late Jurassic

$$
\begin{aligned}
& \text { Igneous rocks } \\
& \text { Quaternary } \\
& \text { Early Miocene to Middle Miocene } \\
& \text { Late Miocene to Pliocene } \\
& \text { Northland and East Cape Allochthon } \\
& \text { 2yardin Miocene } \\
& \text { Ww:Ih Eocene to Oligocene } \\
& \text { Wumbia Cretaceous }
\end{aligned}
$$

Fig. 1.7 Simplified geological map of North Island and sample sites. Geology is from the 1:250 000 geological map project of New Zealand (QMAP, GNS Science). Active faults are depicted by solid lines. Open circles mark sample sites in this study. 


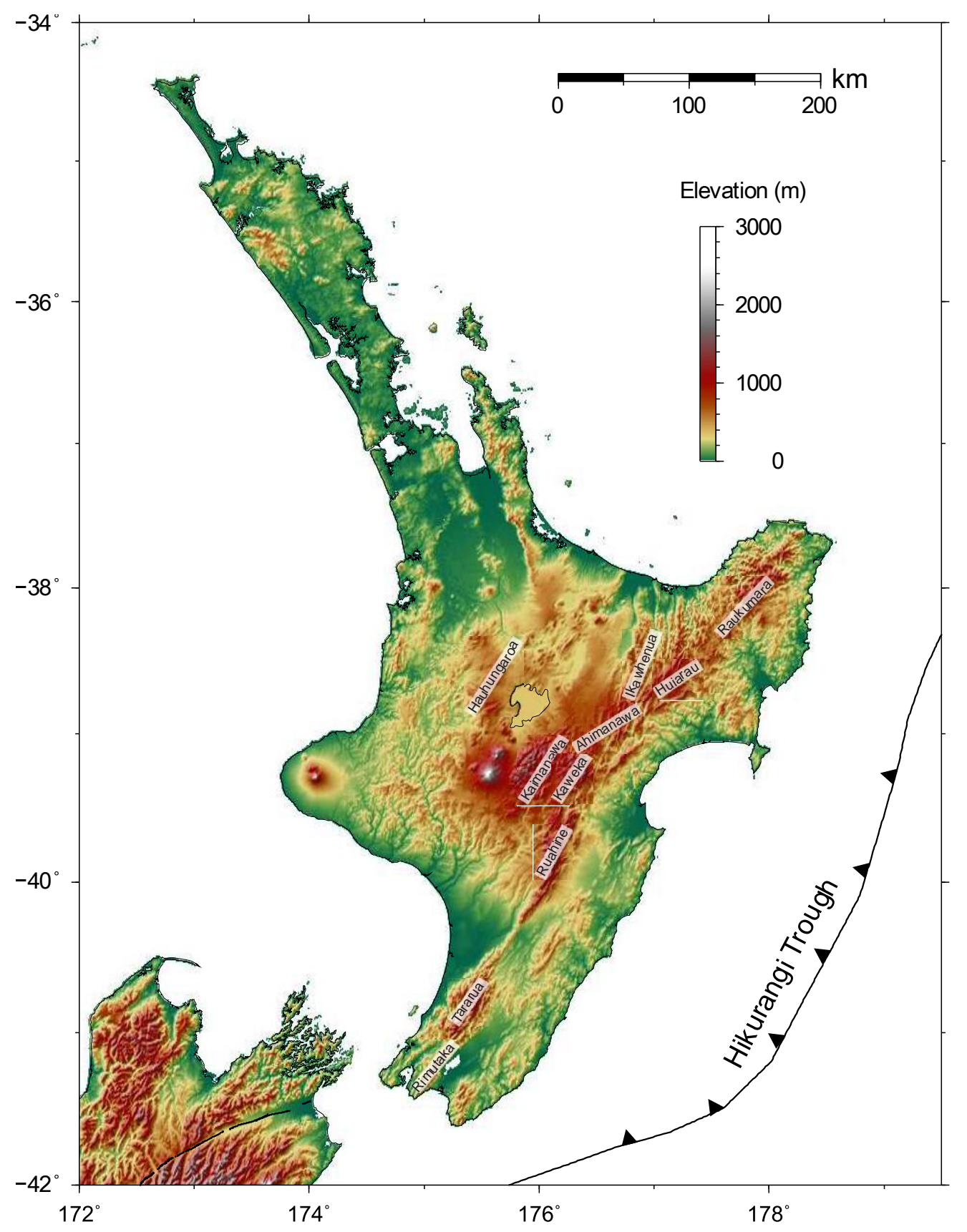

Fig. 1.8 Topographic map and locations of the basement-cored ranges in North Island. Topography is from the Shuttle Radar Topography Mission (SRTM), 3 arc-second resolution.

\subsubsection{Unconformity between basement terranes and overlying rocks}

In eastern North Island, the intensely deformed subduction-related basement rocks are in general separated from the overlying younger, less deformed sedimentary rocks by a regional unconformity. In northeastern North Island, this unconformity is well preserved. It is estimated to have formed at approximately 115-100 Ma (Laird and Bradshaw, 2004; Leonard et al., 2010) and represents a major change in the tectonics of New Zealand region during the mid-Cretaceous. The unconformity marks the 
cessation of Mesozoic subduction and the onset of a passive margin setting as Zealandia began drifting away from the eastern margin of Gondwana. During the evolution of the Cenozoic subduction margin, this regional unconformity has been eroded in most places during uplift and exhumation of eastern North Island.

\subsubsection{Late Cretaceous-Cenozoic cover}

From Late Cretaceous to Oligocene time, when the continent of Zealandia was separating from the Australian section of Gondwana, passive margin sedimentary rocks accumulated throughout North Island (Fig. 1.7) (Ballance, 1993; Mazengarb and Speden, 2000). Until the Late Oligocene, tectonic quiescence dominated. During the Eocene and Oligocene, localised deformation occurred in western North Island (Edbrooke, 2005).

The rate of convergence along the plate boundary of New Zealand increased during the Late Oligocene, leading to an abrupt change in the tectonism, which is revealed in the sedimentary record. During this time, widespread carbonate deposition changed to marine siliciclastic and volcanogenic sedimentation (e.g. Lee et al., 2011; Leonard et al., 2010). Between 25 and $21 \mathrm{Ma}$, nappes comprising Cretaceous-early Cenozoic deep marine sequences and ophiolite slabs, were emplaced to their present position in Northland and the East Coast from the northeast of northern Zealandia (Fig. 1.7) (Ballance and Spörli, 1979; Hayward et al., 1989; Isaac et al., 1994; Rait, 2000). In western North Island, large scale thrust faulting occurred on the Taranaki Fault throughout the Oligocene and Miocene. Arc volcanism began at 25-23 $\mathrm{Ma}$ in Northland (Hayward et al., 2001; Kear, 2004; Mortimer et al., 2010). In eastern North Island, the Early Miocene initiation of subduction of the Pacific Plate was accompanied by a short ( $\sim 5 \mathrm{Myr})$ period of deformation of the Late CretaceousPaleogene passive margin sequence and the older greywacke basement (Pettinga, 1982; Rait et al., 1991).

From the Miocene to Pliocene, in western New Zealand, basement downwarping and the depocentre of sedimentary basins on the upper plate migrated gradually southwestwards (Furlong and Kamp, 2006; Kamp et al., 2004; Stern et al., 2006). From Late Miocene to Pliocene, in eastern North Island, widespread subsidence and marine transgression occurred, and forearc basins developed to the east of the 
basement-cored ranges in eastern North Island (Fig. 1.8) (Lee et al., 2011). From the Pliocene to Pleistocene, temporal changes in sedimentation in eastern North Island reflect the oscillation between marine transgression and regression, with a general increase in the proportion of terrestrial material resulting from the uplift and erosion of the Mesozoic basement (Bland, 2001; Kelsey et al., 1995; Lee et al., 2011). Since the Pleistocene, the forearc basins of the eastern North Island (Fig. 1.7) have been uplifted becoming emergent, with lacustrine and estuarine deposition followed by fluvial sedimentation that contains volcanic detritus derived from the Taupo Volcanic Zone (Begg and Johnston, 2000; Lee et al., 2011; Shane et al., 1996).

\subsection{Low-temperature thermochronology studies}

This section provides a brief review of previous studies in western and eastern North Island, which focused on the Mesozoic or late Cenozoic exhumation histories of the basement rocks.

\subsubsection{Eastern North Island}

From the Torlesse Supergroup rocks in northeastern North Island, Kamp (1999) reported zircon (252-108 Ma) and apatite (112-4.4 Ma) fission-track (ZFT and AFT, respectively) ages on samples along two transects across the northern axial ranges. Forward modelling of the data led the author to propose an Early Miocene phase of rapid crustal downwarping during the initiation of subduction of the Pacific Plate, followed by basin formation and subsequent uplift and erosion; this series of processes was inferred to migrate on a margin-parallel orientation towards the southwest. In the Wellington region in southern North Island, Kamp (2000) interpreted 10-12 km exhumation of the basement rocks since $200 \mathrm{Ma}$ based on (partially) annealed ZFT ages and $>4 \mathrm{~km}$ exhumation since $\sim 10 \mathrm{Ma}$ based on fully reset AFT ages.

In the central axial ranges, total-rock Rb-Sr studies (145-205 Ma) (Adams et al., 2009) generally yielded ages older than the stratigraphic ages, and the total-rock K-Ar ages (typically > $155 \mathrm{Ma}$ ) (Adams et al., 2009) of the Torlesse greywacke rocks also overlap with the detrital U-Pb ages. Only the Kaimanawa Schist yielded K-Ar ages between 150 and $125 \mathrm{Ma}$ (Adams et al., 2009), clearly younger than both the sedimentary age and K-Ar ages measured in other parts of the Torlesse Supergroup 
with lower grade metamorphic grade. In southern North Island, the $\mathrm{Rb}-\mathrm{Sr}$ and $\mathrm{K}-\mathrm{Ar}$ ages of the older Torlesse rocks were inferred to represent metamorphism of 225-200 Ma and post-metamorphic cooling until 170 Ma (Adams and Graham, 1996).

\subsubsection{Western North Island}

In northwestern North Island, Raza et al. (1999) reported a set of ZFT and AFT data in the Auckland region, including ZFT (190-138 Ma) and AFT (119-84 Ma) results of three samples collected from the Waipapa Supergroup. The authors inferred the ZFT ages to be detrital and interpreted the AFT ages to represent two phases of accelerated cooling of the basement, during the Early ( 117 Ma) and Late ( 84 Ma) Cretaceous, respectively. In western North Island, Kamp and Liddell (2000) carried out an AFT analysis (ages of 144-87 Ma) on the Murihiku Terrane, in which the authors inferred differential sedimentation across the region during the Cretaceous accompanied by an increase in geothermal gradient and an eastward tilting of the terrane during the latest Cretaceous-Paleocene.

In the Waipapa Supergroup in the Northland and Auckland region, Adams and Maas (2004) reported two components of total-rock Rb-Sr ages (217-209 Ma and 174-164 Ma, respectively) and two peaks of total-rock K-Ar ages (175-165 Ma and 160-150 Ma, respectively). The authors inferred Late Triassic-Middle Jurassic deformation and metamorphism in the accretionary wedge of the Gondwana margin based on $\mathrm{Rb}$ Sr ages, and suggested two Jurassic episodes of rock exhumation and cooling based on the K-Ar ages. However, these ages overlap with the youngest component of the detrital zircon $\mathrm{U}-\mathrm{Pb}$ ages (Adams et al., 2013), and thus may retain inheritance from detrital sources. In western-central North Island, total-rock $\mathrm{Rb}-\mathrm{Sr}$ ages range between 205 and $149 \mathrm{Ma}$ and K-Ar ages between 169 and $126 \mathrm{Ma}$ (Adams et al., 2009). These ages were again inferred by the authors to represent latest Triassic to Early Cretaceous metamorphism and post-metamorphism cooling in the accretionary wedge of the Gondwana margin. 



\title{
Chapter 2
}

\section{Thermal history and exhumation of basement rocks from Mesozoic to}

\section{Cenozoic subduction cycles, central}

\section{North Island ${ }^{1}$}

\begin{abstract}
A new thermochronological study of the basement rocks of the central North Island, New Zealand, records thermal and exhumation histories related to two subduction cycles since the latest Jurassic. The basement comprises metasedimentary terranes accreted onto eastern Gondwana during Mesozoic subduction. Since the Oligocene, these terranes have been located on the hanging wall of the Hikurangi subduction margin, overriding the Pacific Plate. Results of zircon fission-track (264-121 Ma) analysis yield detrital or slightly reset ages; apatite fission-track (122-19.8 Ma) and (U-Th-Sm)/He (95.2-10.3 Ma) ages are fully reset. Results from inverse thermal history modelling of the data of individual and stacked samples imply that: (1) after their accretion, the basement rocks were cooled and exhumed to shallow depths of the crust in the Early Cretaceous (by $\sim 150-135 \mathrm{Ma}$ ). This was followed by an episode of reheating until $\sim 100 \mathrm{Ma}$, which we interpret to be the result of burial by sedimentation above the accretionary wedge during extensional deformation caused
\end{abstract}

\footnotetext{
${ }^{1}$ Published as Jiao, R., Seward, D., Little, T.A. and Kohn, B.P., 2014. Thermal history and exhumation of basement rocks from Mesozoic to Cenozoic subduction cycles, central North Island, New Zealand. Tectonics, 33(10): 2014TC003653.
} 
by continued underplating and thickening of the wedge from beneath; (2) from 100 $\mathrm{Ma}$, our data indicate thermo-tectonic quiescence until the Oligocene ( 27 Ma); (3) during initiation of the Hikurangi Margin, the fore-arc proto-axial ranges began to exhume during the Late Oligocene-Early Miocene ( 27-20 Ma). Subductiontriggered unroofing removed $\sim 1.2-2.8 \mathrm{~km}$ of overburden, most of which was probably the less lithified passive margin sedimentary rocks; (4) along the western-central North Island, the exhumational response to the Hikurangi subduction was limited, with a total magnitude of erosion $<1.5 \mathrm{~km}$ in the Cenozoic.

\subsection{Introduction}

Basement rocks of North Island, New Zealand were formed by deposition and accretion onto the eastern Gondwana margin in the Mesozoic. These rocks now sit at the leading edge of the upper plate of the modern Hikurangi subduction margin with respect to the westward-subducting Pacific Plate (Figs. 2.1a and 2.1b). The basement of central North Island has thus been modified and deformed during two major subduction events, the late Mesozoic and the Oligocene-Neogene (King, 2000; Mortimer, 2004), separated by a long period associated with drift from the eastern margin of Gondwana. In this paper we strive to quantify patterns of crustal thermal evolution during these events in order to obtain an improved understanding of 1) the timing of the extension and break-up of the eastern Gondwana and 2) subduction initiation and hanging wall uplift and erosion along the Hikurangi margin. These data provide insights into the long-term evolution and dynamics of an Andean subduction zone.

Previous studies (Kamp et al., 2004; Litchfield and Berryman, 2006; Pulford and Stern, 2004) in the North Island have revealed variations in uplift and exhumation rates with distance inland from the modern trough. Nearest to the subduction zone, in the east, stratigraphic mapping of Neogene paleoshorelines and analysis of mudstone porosity suggested a mean rock uplift rate in the fore-arc of up to $1 \mathrm{~mm} / \mathrm{yr}$ over the last $~ 5$ Myr (Litchfield and Berryman, 2006). Farther west in the back-arc in the western and central parts of the North Island, a study of mudstone porosity (Pulford and Stern, 2004) indicated that the rock uplift there since $~ 5$ Ma has exhumed a broad dome that has a maximum erosional amplitude of over $2 \mathrm{~km}$ in the centre of the dome just south of Lake Taupo (Fig. 2.1a). These previous studies have not provided any 
insight into exhumation or uplift magnitudes or rates across this margin for the period prior to $\sim 5 \mathrm{Ma}$. Consequently, there is currently a large gap in our knowledge about the tectonics and long-term vertical motion of this margin since the Late Oligocene to Early Miocene onset of subduction.

We investigate the long-term (post Late Jurassic) thermal events interpreted in terms of uplift and exhumation of basement rocks along an east-west section in central North Island, New Zealand, using a combination of zircon and apatite fission-track (ZFT and AFT, respectively) and apatite (U-Th-Sm)/He (AHe) methods. In previous fission-track studies on the basement rocks of eastern North Island, Kamp (1999) collected samples along several transects across the northern axial ranges. Forward modelling of the data led the author to propose an Early Miocene phase of rapid crustal downwarping during the initiation of subduction of the Pacific Plate, followed by basin formation and subsequent uplift and erosion; this series of processes was inferred to migrate towards the southwest. In another study in the Wellington region (Kamp, 2000), (partially) annealed ZFT ages indicated maximum burial depths of 10$12 \mathrm{~km}$ for the presently exposed greywacke rocks, and the fully reset AFT ages of $\sim 10$ Ma suggested at least $4 \mathrm{~km}$ of exhumation since the Late Miocene. These earlier data provided first-order constraints on the exhumation magnitude related to the evolution of subduction, but were limited to the most northern and southern ends of the island.

This paper focuses on the basement rocks of central North Island, where we determined the first set of thermochronological data and modelled the AFT and AHe data using a transdimensional approach (Gallagher et al., 2009; Gallagher, 2012). Firstly, we provide timing, rates and magnitude constraints on thermal evolution of the accretionary terranes preceding break-up of the eastern Gondwana margin in the Cretaceous. Secondly, we are able to document the diverse impact of subduction processes on the upper continental crust at varying distances from the subduction trough of the modern evolving Hikurangi Margin through the uplifted fore-arc to the present back-arc region. 

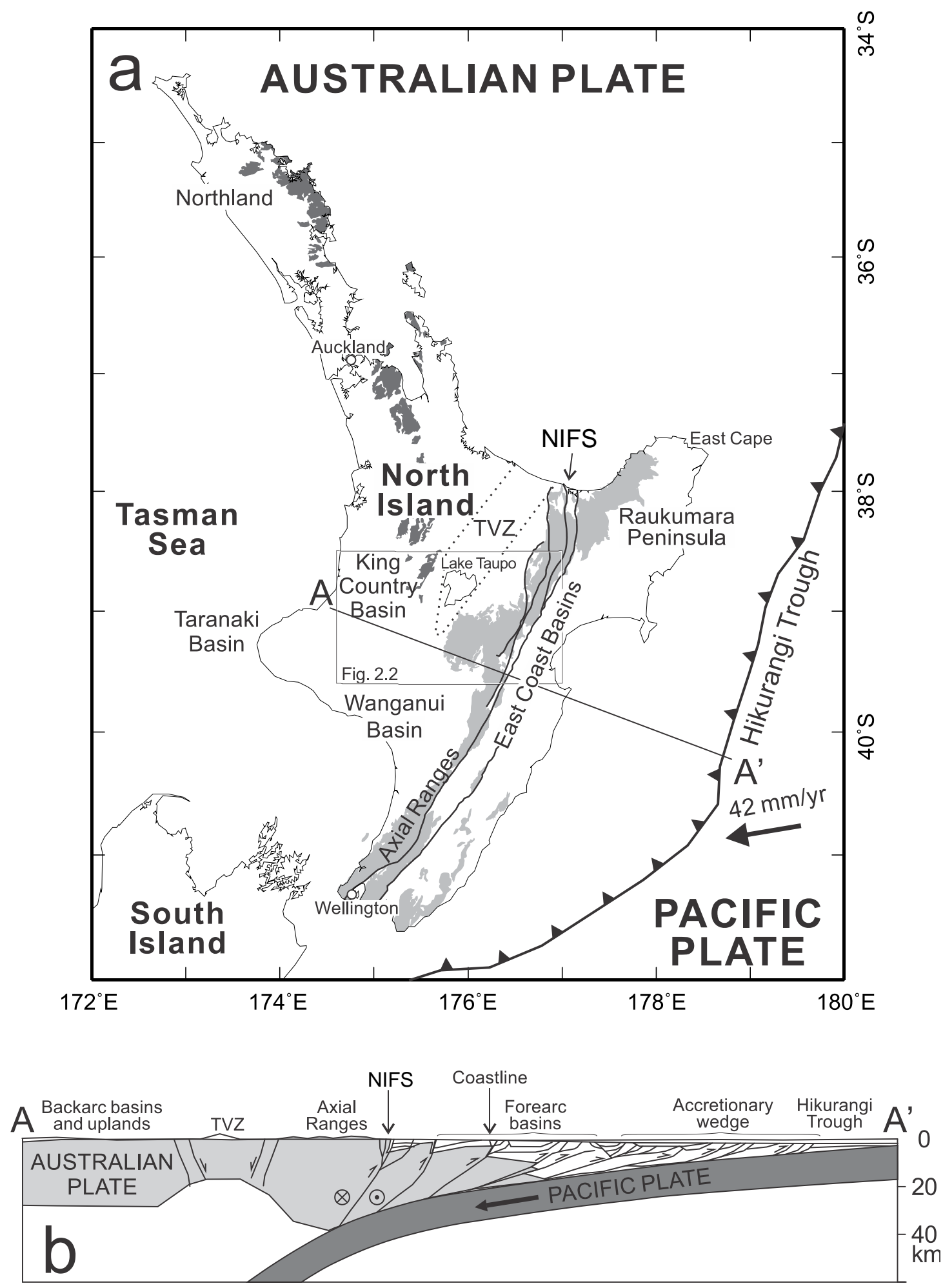

Fig. 2.1 Key tectonic elements in Hikurangi Margin. (a) Locations of key tectonic elements onshore. Grey areas are the exposed basement rocks of Torlesse (light) and Waipapa (dark) Terranes. Black arrow shows the motion of Pacific Plate relative to Australian Plate Beavan et al. (2002). TVZ, Taupo Volcanic Zone; NIFS, North Island Fault System. Box corresponds to the region of Fig 2.2. (b) Crustal cross-section, modified from Barnes et al. (2002). 


\subsection{Geological background}

The continent of Zealandia (Mortimer, 2006) was once located on the outermost margin of Gondwana until its extensional fragmentation and separation in the Cretaceous. The present landmass of New Zealand represents the subaerial portion of this continent. The North Island is underlain by a series of basement rocks that represent Mesozoic accretionary terranes consisting chiefly of sandstone ("greywacke"), argillite and schist (Kaimanawa Schist; Fig. 2.2a). Here we focus on the low-temperature thermochronology of Triassic to Early Cretaceous rocks of the Torlesse Supergroup (in the axial ranges) and Waipapa Supergroup (west of Taupo Volcanic Zone, TVZ) of central North Island (Figs. 2.1a and 2.2a).

Based on different lines of evidence, many authors have proposed the timing of initiation of the break-up of Zealandia from eastern Gondwana and the cessation of the Mesozoic subduction. This was well summarised by Laird and Bradshaw (2004). Estimates of the timing of the cessation of Mesozoic subduction range from $105 \mathrm{Ma}$ (Bradshaw, 1989) to about 85 Ma (Kamp, 1999; Mazengarb and Harris, 1994). Laird and Bradshaw (2004) concluded that the subduction ceased and extension started at about $100 \mathrm{Ma}$, based on tectonic, geochronological and stratigraphic evidence along the east coast of North Island and north-western South Island. Based on U-Pb and ${ }^{40} \mathrm{Ar} /{ }^{39} \mathrm{Ar}$ ages of volcanic rocks from across Zealandia, Tulloch et al. (2009) suggested that the crustal extension within Gondwana may have started at about 112 $\mathrm{Ma}$ and that thinning by normal faulting continued until $82 \mathrm{Ma}$. The range in age estimates may well be due to the fact that such a major event was probably diachronous both in time and space.

Inception of Cenozoic subduction of the Pacific Plate along the Hikurangi Trough beneath the eastern margin of the Australian Plate caused thickening and uplift of the hanging wall of that juvenile subduction zone, leading to subaerial exposure of what are now the islands of New Zealand (King, 2000; Sutherland et al., 2009). The forearc of this margin includes, on its eastern side, Neogene-Recent accretionary wedges that young eastward into the still actively deforming belt of the offshore region (Fig. 2.1b); a discontinuously preserved cover of Neogene sedimentary basins (Figs. 2.1 and 2.2a); and, farther west, the axial ranges, which consist of the uplifted Mesozoic basement. Today, the axial ranges are cut by the active North Island Fault System 
(NIFS; Figs. 2.1 and 2.2a)(Beanland, 1995; Nicol et al., 2007)(New Zealand Active Faults Database, GNS). Farther west is the actively extending TVZ (Wilson et al., 2010), with uplands and basins along the western margin of that rift (Figs. 2.1 and 2.2a).
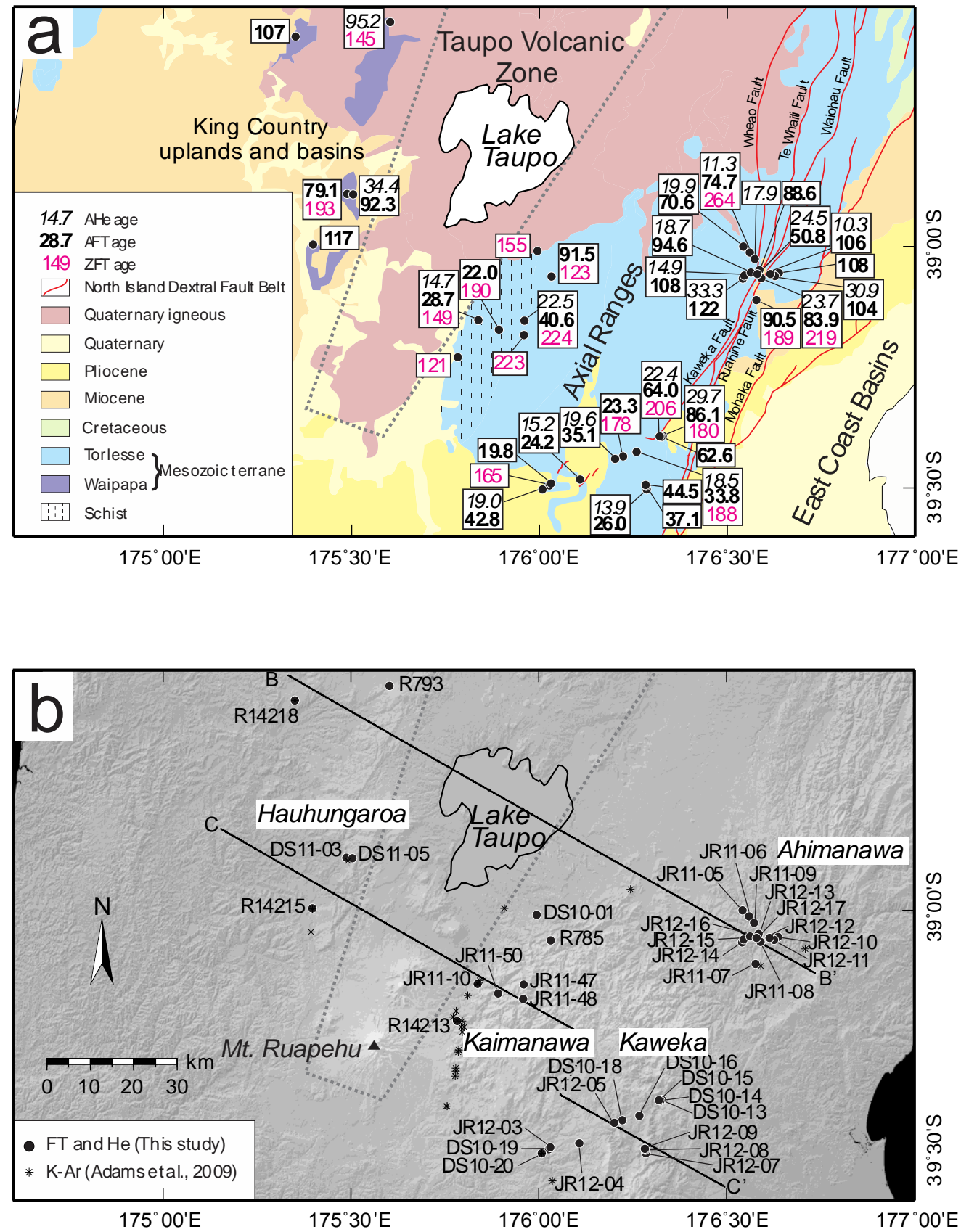

Fig. 2.2 Study area in central North Island, New Zealand. (a) Simplified geological map, modified from the Geologicla map of New Zealand 1:10 ${ }^{6}$ project, produced by GNS Science, New Zealand. Major faults in the North Island Fault System (NIFS) are named. Numbers depict AFT (bold), AHe (italic) and ZFT (magenta) ages (Ma). (b) Shaded relief and sample locations. Topography is from the Shuttle Radar Topography Mission (SRTM), 3 arc-second resolution. Locations of whole-rock K-Ar ages (Adams et al., 2009) cited in this study are shown. Lines B-B' and C-C' correspond to margin-normal cross sections in Figs. 2.3a and $2.3 \mathrm{~b}$, respectively. 
The axial ranges trend northeast-southwest subparallel to the Hikurangi subduction trough. They include the Kaimanawa, Kaweka and Ahimanawa Ranges in central North Island (Fig. 2.2b). These narrow (about $60 \mathrm{~km}$ at the widest segment), elongate ranges reaching heights over $1.6 \mathrm{~km}$ (Fig. 2.2b) are chiefly composed of low-grade (prehnite-pumpellyite facies) metamorphosed greywackes of the Torlesse Supergroup (here mostly of Jurassic stratigraphic age, (Adams et al., 1998; Adams et al., 2009)). Higher grade, pumpellyite-actinolite facies occurs on the western flank of the Kaimanawa Mountains (Fig. 2.2a) (Adams et al., 2009; Beetham and Watters, 1985), immediately to the east of the TVZ. Remnants of a pre-Pliocene erosional surface (Lee et al., 2011) are inferred to control the elevation of aligned summit tops in the Kaimanawa Mountains. From these uplifted deposits, a mean surface uplift rate has been calculated for the axial ranges of $\sim 1.0-1.3 \mathrm{~mm} / \mathrm{yr}$ over the last $\sim 1-5 \mathrm{Myr}$ (Beu et al., 1981; Litchfield and Berryman, 2006).

Previous geochronological studies on the basement terranes provided some constraints on the timing of their low-grade metamorphism during their accretion to Gondwana in the Mesozoic (Adams and Maas, 2004; Adams et al., 2009; Mortimer, 1994; Mortimer, 2004). Whole-rock K-Ar slate ages (Figs. 2.3a and 2.3b), which vary inversely with metamorphic grade, have been interpreted as estimates for the timing of cooling of the terranes from their maximum metamorphism (Adams, 2003; Adams et al., 2009). The Kaimanawa Schist yielded K-Ar ages between 150 and $125 \mathrm{Ma}$ (Fig. $2.3 \mathrm{~b}$ ), distinctly younger than such ages measured in other parts of the Torlesse (and Waipapa) Terranes with lower grade metamorphic grade, which are typically 175-155 Ma (Figs. 2.3a and 2.3b) (Adams et al., 2009). Torlesse rocks in the Ahimanawa Range in the northeast of the study area yielded K-Ar ages of 220-180Ma (Fig. 2.3a). These ages overlap with those of detrital zircons as measured by U-Pb methods and are older than the age of deposition of the strata in which they occur (Adams et al., 2009). This observation implies that rocks in the Ahimanawa Ranges were never heated to K-Ar closure temperature subsequent to their deposition.

West of TVZ, the basement rocks of the Waipapa Supergroup (Late Triassic-Late Jurassic age, (Adams et al., 2009)) crop out in the rolling and relatively low-relief uplands including the Hauhungaroa Range (Figs. 2.2a and 2.2b). Here, Cenozoic sedimentary sequences unconformably overlying the Mesozoic basement in the adjacent King Country basin have been extensively preserved. Sedimentation in the 
basin was continuous between the Late Oligocene and Early Pliocene (Fig. 2.2a) (Kamp et al., 2004).
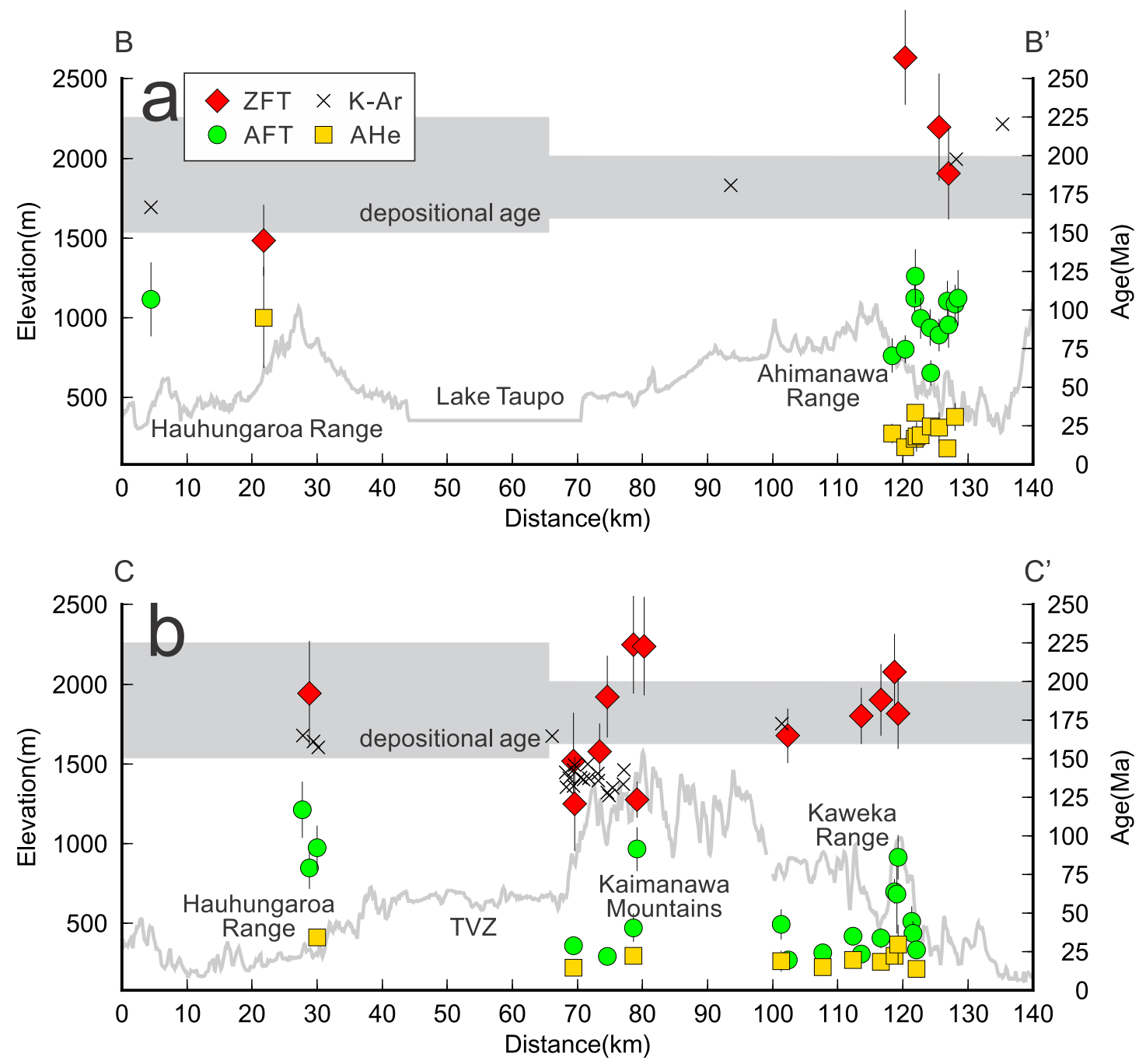

Fig. 2.3 Thermochronological ages along profiles across central North Island (see Fig. 2.2b for locations). Terrane depositional age and K-Ar whole-rock slate ages are taken from Adams et al. (2009).

\subsection{Thermochronological data}

We analysed 38 samples, from which we obtained 32 AFT ages (18 with track-length data), 18 ZFT ages and 22 AHe ages (62 single-grain ages). Appendix II describes the methods used for fission-track and (U-Th-Sm)/He analyses. Detailed results are given in Tables 2.1, 2.2 and 2.3. We report all the FT ages as central ages (Galbraith and Laslett, 1993) that include a $\pm 2 \sigma$ uncertainty. For AHe data, a central age ( $\alpha$-ejection corrected) (Vermeesch, 2010) was calculated for samples that contained 3 or more single-grain ages; for samples with only two single-grain ages, an error-weighted arithmetic mean was calculated. Fig. 2.2a summarises ages for all samples in map 
form. These data are projected onto the two transects across the central North Island in Fig. 2.3.

ZFT ages vary between $264 \pm 31$ and $121 \pm 30 \mathrm{Ma}$ (Table 2.1). All ages except those in the Kaimanawa Schist overlap with, or predate, the sedimentary age of the rock as previously constrained by $\mathrm{U} / \mathrm{Pb}$ dating of detrital zircons (Adams et al., 2009). The overall ZFT age pattern is comparable to that of whole-rock K-Ar ages (Adams et al., 2009) for the same region (Fig. 2.3).

AFT ages range from $122 \pm 17$ to $19.8 \pm 3.6 \mathrm{Ma}$ (Table 2.2), and all are younger than the corresponding sedimentation ages (Fig 2.3). Single-grain AFT age distributions are mostly consistent within a unique population with $\mathrm{P}\left(\chi^{2}\right)>70 \%$. Low P $\left(\chi^{2}\right)$ values $(<50 \%)$ exist for 7 samples, indicating variability in apatite composition and/or complicated thermal histories. The mean length of confined tracks ranges between $10.47 \pm 2.06$ and $13.81 \pm 1.47 \mu \mathrm{m}$.

We excluded the AHe data of one sample (JR12-13) in our interpretation, due to its over-dispersed (120\%) single-grain ages. For all other samples, the AHe grain age dispersions (range of the grain ages divided by the mean, as used by Brown et al. (2013)) yield 0.7-80\%, which are typical for samples that experienced complex thermal histories (see discussion in Appendix II). The accepted AHe sample ages range from $95.2 \pm 32.6$ to $10.3 \pm 4.8 \mathrm{Ma}$, with the $\mathrm{F}_{T}$-corrected single-grain ages between $119.7 \pm 17.6$ and $6.9 \pm 1.0 \mathrm{Ma}$ (Table 2.3).

In the following sections, we describe the data in more systematic detail for each region across the study area. 


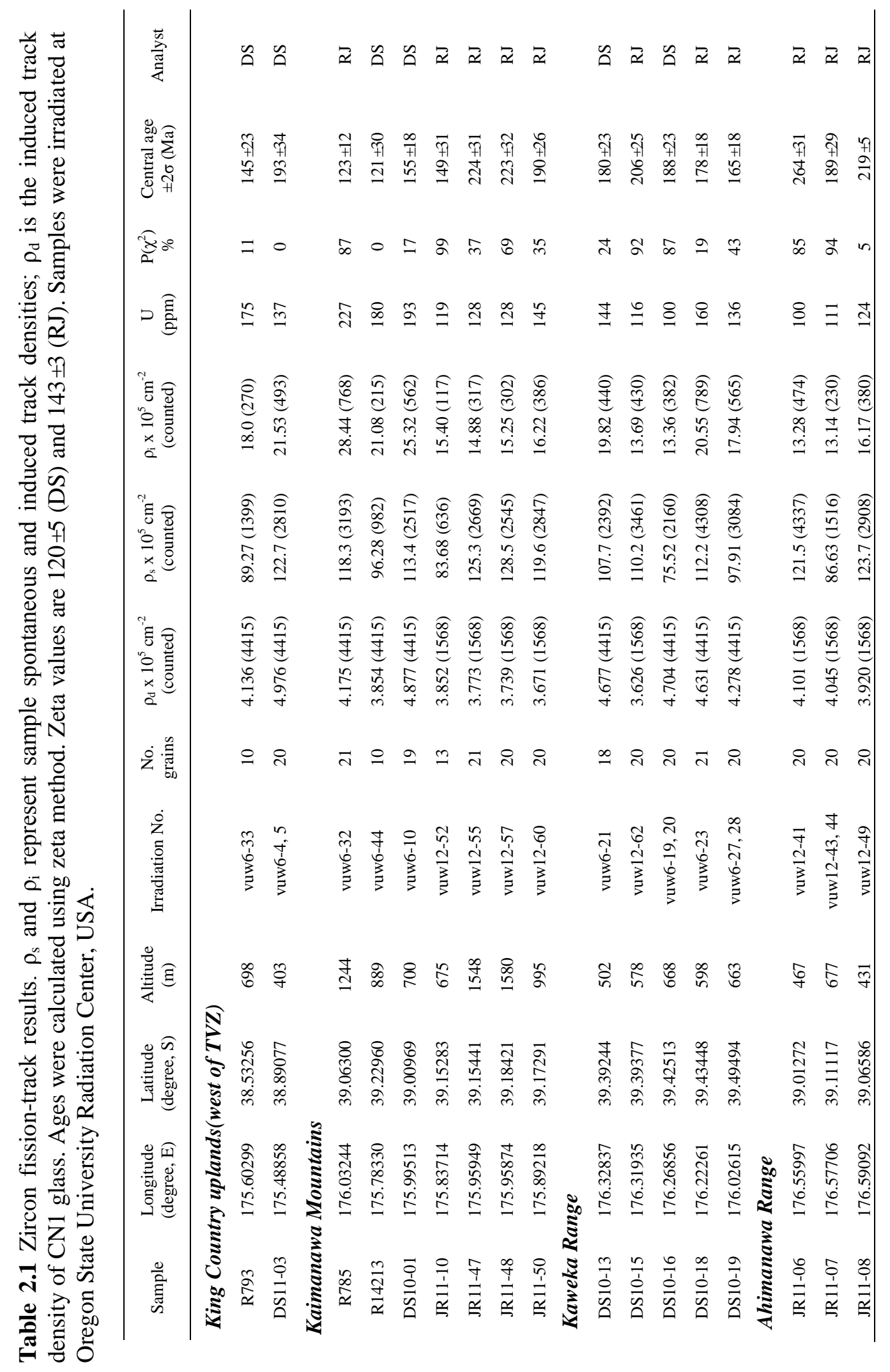




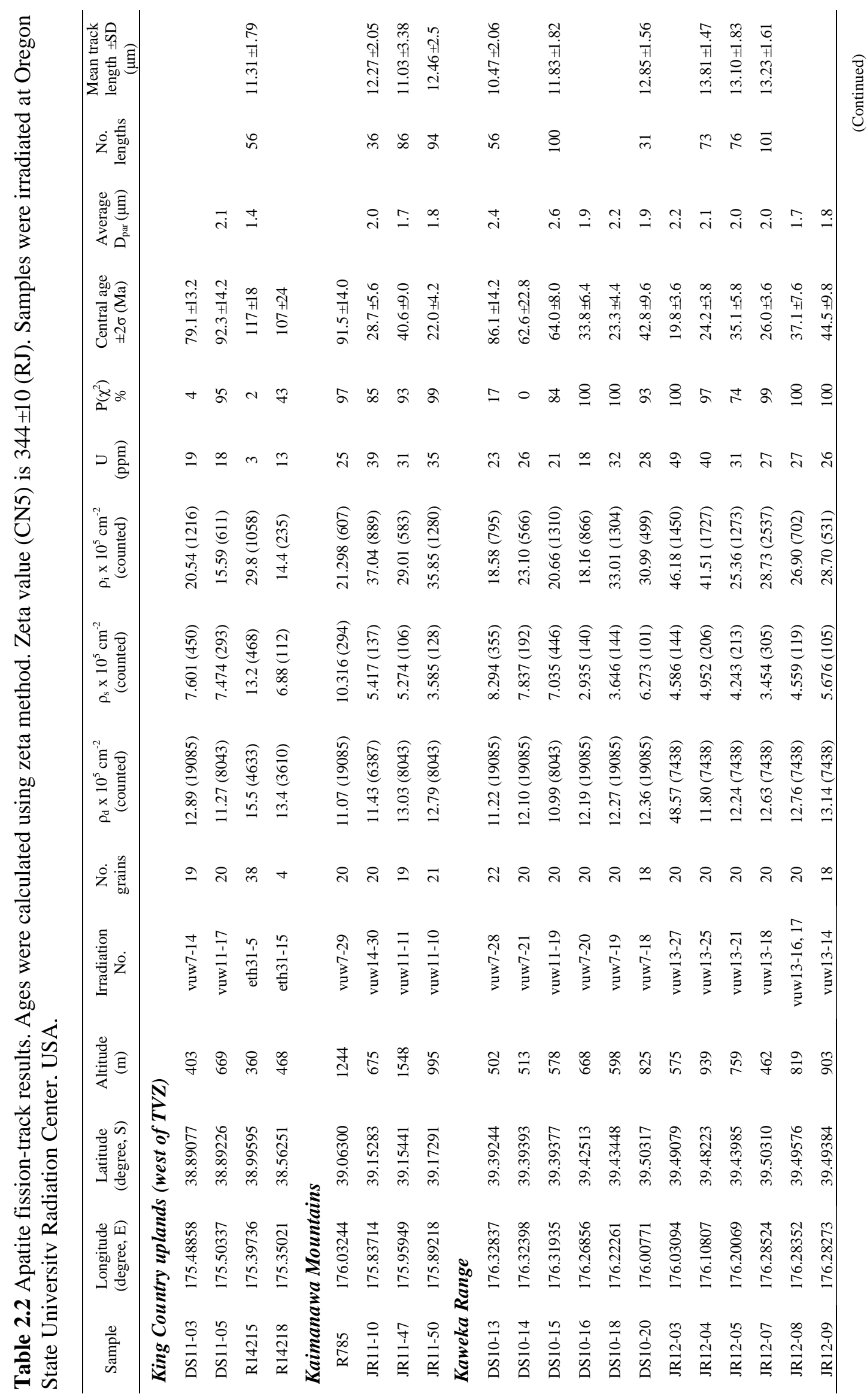




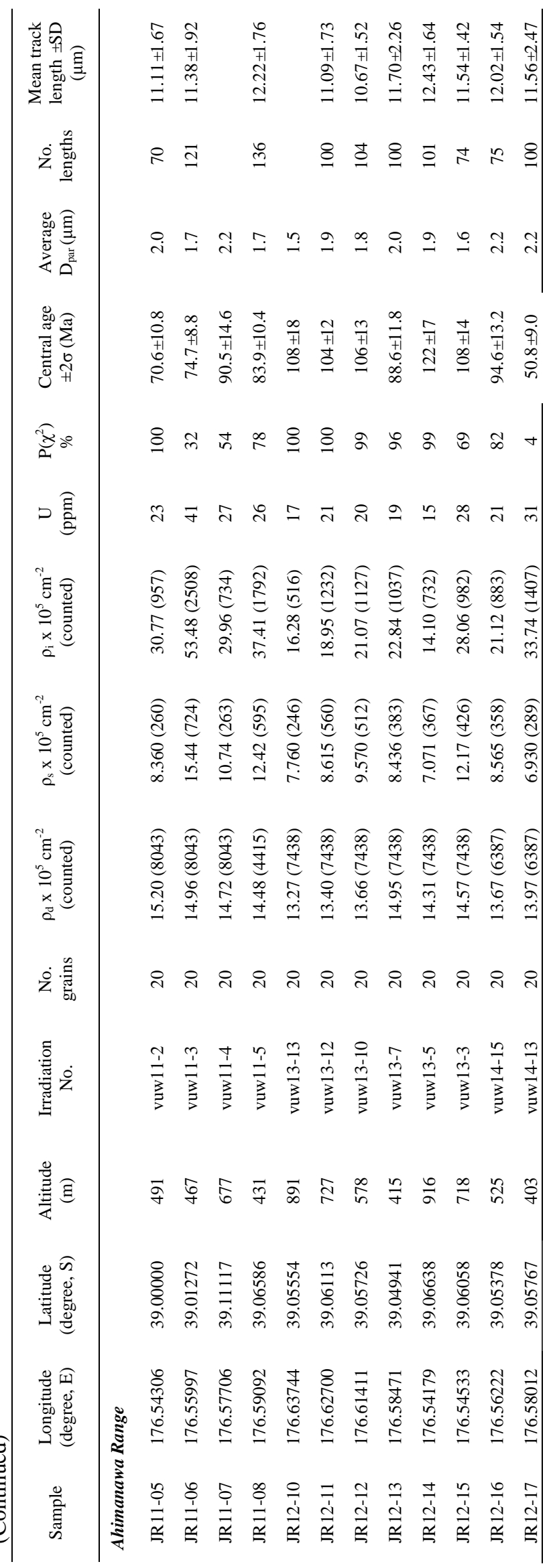




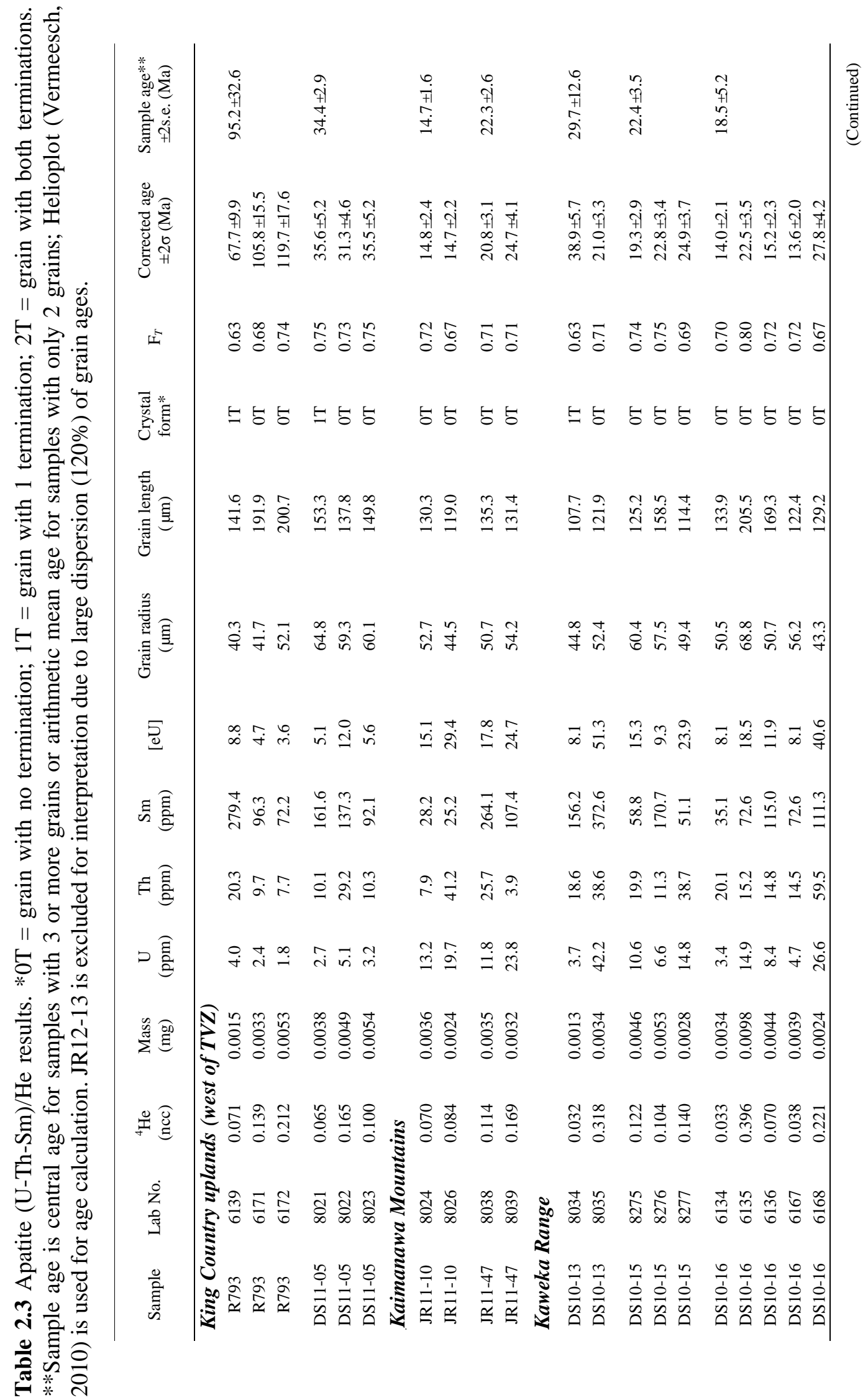




\begin{tabular}{|c|c|c|c|c|c|c|c|c|}
\hline 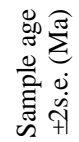 & $\mid$ & 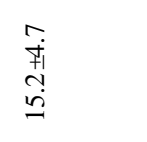 & 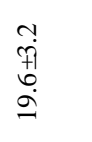 & 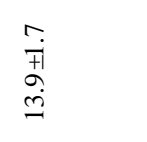 & 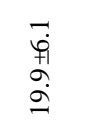 & 焉 & 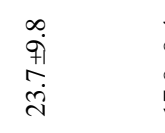 & 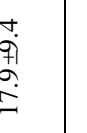 \\
\hline 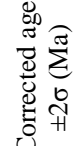 & 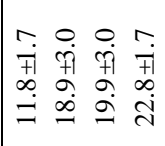 & 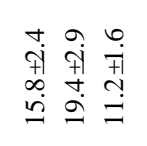 & 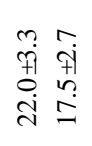 & 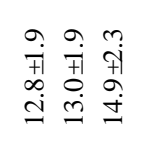 & 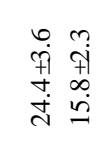 & 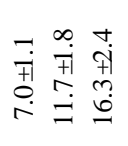 & 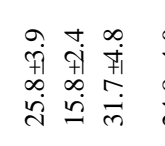 & 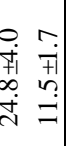 \\
\hline 幽 & 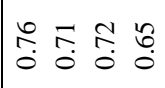 & : & 蓆 & 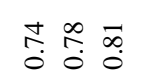 & 要: & $\begin{array}{lll}\infty & 0 \\
0 & 0 & 0 \\
0 & 0 & 0 \\
0\end{array}$ & 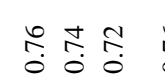 & $\begin{array}{lll}2 & 0 \\
0 & 0 & 0 \\
0\end{array}$ \\
\hline 喽言 & $\Xi 5 \Xi E$ & 555 & $\Xi 5$ & 555 & \pm 5 & 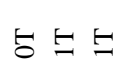 & $\Xi t 5$ & 55 \\
\hline 童高 & 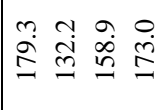 & 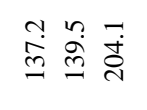 & $\vec{q}$ & 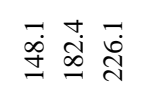 & 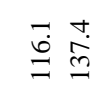 & $\begin{array}{l}\infty \\
\dot{\leftrightarrow} \\
\stackrel{\leftrightarrow}{\circ}\end{array}$ & 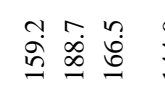 & \\
\hline 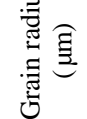 & 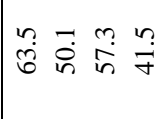 & 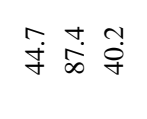 & $\begin{array}{l}\infty \\
\substack{\infty \\
\infty \\
\infty} \\
\end{array}$ & 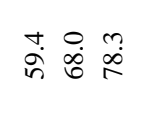 & $\vec{g} \dot{q}$ & ठี वें & 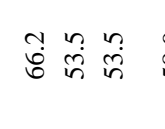 & \\
\hline క్ర & 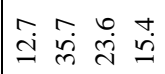 & 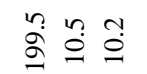 & $\stackrel{\infty}{\infty}$ in & $\stackrel{\mathscr{P}}{=} \ddot{m} \stackrel{\sim}{m}$ & 里 & 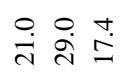 & 官号 & جे \\
\hline ह & 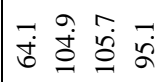 & 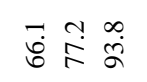 & 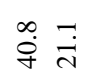 & 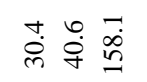 & 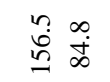 & 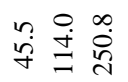 & 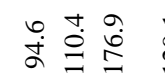 & \\
\hline$F \overline{\bar{y}}$ & 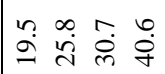 & 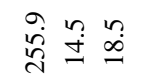 & 恶 & તેંi & $\ddot{i} \dot{\vec{j}}$ & 我学总品 & 守总导 & 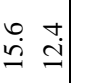 \\
\hline D & 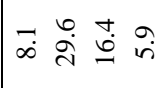 & 莒: & $\stackrel{\infty}{\stackrel{9}{=}} \stackrel{?}{+}$ & $\stackrel{\infty}{\infty} \stackrel{\infty}{-\infty}$ & $\overrightarrow{\dot{m}} \overrightarrow{\mathrm{i}}$ & ूㅡㅁ & 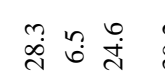 & \\
\hline 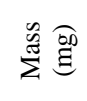 & 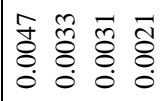 & 홍 흥 영 & 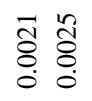 & 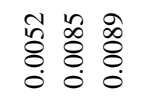 & 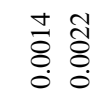 & $\begin{array}{l}0 \\
0 \\
0 \\
0 \\
0\end{array}$ & 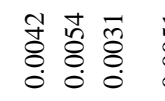 & 蒿 \\
\hline 邑预 & {$\left[\begin{array}{ll}0 \\
0 \\
0\end{array}\right.$} & $\begin{array}{l}\overrightarrow{0} \\
\substack{0 \\
0} \vec{d} \\
0\end{array}$ & : & $\begin{array}{l}\stackrel{0}{0} \\
0 \\
0\end{array}$ & 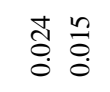 & $\begin{array}{lll}0 & 0 \\
0 & 0\end{array}$ & 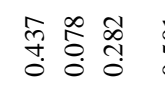 & $\begin{array}{l}\overrightarrow{0} \\
\text { no } \\
0\end{array}$ \\
\hline$\stackrel{\dot{s}}{\frac{\pi}{\pi}}$ & $\frac{\tilde{D}}{0} \frac{\pi}{0} \frac{8}{0} \frac{8}{0}$ & 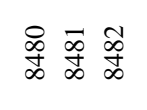 & 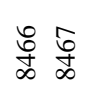 & 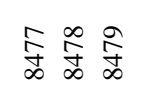 & : & 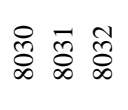 & 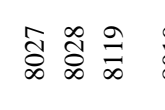 & 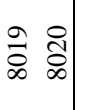 \\
\hline 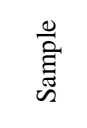 & 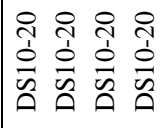 & 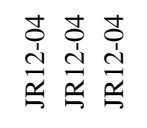 & 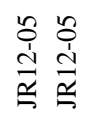 & & & 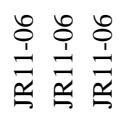 & 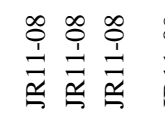 & \\
\hline
\end{tabular}




\begin{tabular}{|c|c|c|c|c|c|c|c|}
\hline 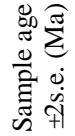 & $\begin{array}{l}a \\
0 \\
o \\
+1 \\
\hat{d} \\
\dot{\rho}\end{array}$ & 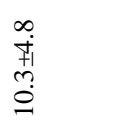 & & $\begin{array}{l}\stackrel{1}{+} \\
\stackrel{+}{+} \\
\stackrel{m}{m}\end{array}$ & 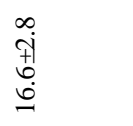 & $\begin{array}{l}\stackrel{+}{+} \\
+1 \\
\stackrel{+}{\infty} \\
\infty\end{array}$ & 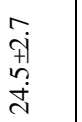 \\
\hline 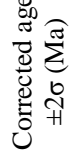 & 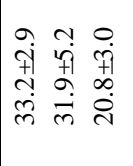 & 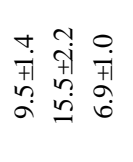 & 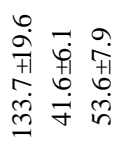 & 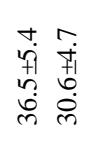 & 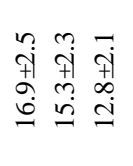 & 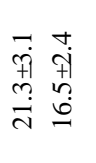 & 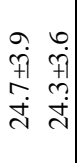 \\
\hline 斗 & 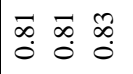 & 중 & $\begin{array}{lll}0 & n \\
0 & 0 & 0 \\
0 & 0 & 0\end{array}$ & $\overrightarrow{0}: \overrightarrow{0}$ & 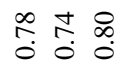 & 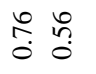 & 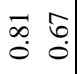 \\
\hline 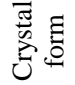 & เร เ & 555 & 555 & $\Xi 5$ & 555 & 55 & $\Xi \vec{\sim}$ \\
\hline 离 & 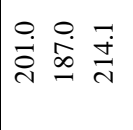 & $\stackrel{\infty}{\stackrel{\Xi}{\Xi} \stackrel{ }{\Xi}}$ & 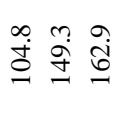 & 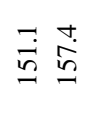 & 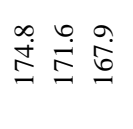 & 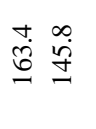 & 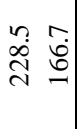 \\
\hline 丞 & 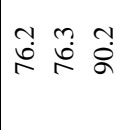 & 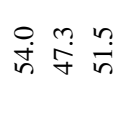 & $\begin{array}{l}\stackrel{m}{g} \vec{~} \vec{j} \\
\dot{y}\end{array}$ & 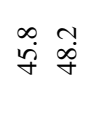 & 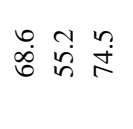 & 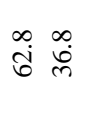 & 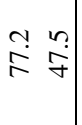 \\
\hline 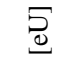 & $\stackrel{a}{r} \overrightarrow{0} \stackrel{0}{i}$ & $a_{0} \cdot \overrightarrow{0}$ & 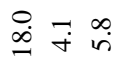 & $\overrightarrow{\dot{g}}$ & $\stackrel{\infty}{\sim} \underset{\dot{m}}{\bar{m}}$ & $\stackrel{\vec{c}}{\infty} \underset{\infty}{\infty}$ & 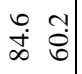 \\
\hline ह & 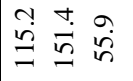 & ڤू & 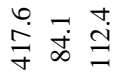 & 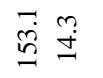 & $\begin{array}{l}\infty \\
\infty \\
i \\
i\end{array}$ & बेे & 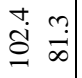 \\
\hline$F$ & 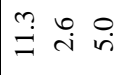 & $n=\hat{i}$ & 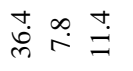 & iे & 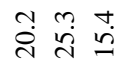 & 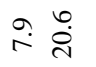 & \begin{tabular}{ll}
+ & $\infty$ \\
\hdashline & 0 \\
\hdashline
\end{tabular} \\
\hline$\supset$ 高 & in & 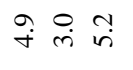 & $\stackrel{+}{\circ} \stackrel{m}{\vec{i}}$ & $\stackrel{\infty}{\circ} \stackrel{\circ}{\circ} \stackrel{0}{i}$ & $\vec{m} \stackrel{\infty}{\sigma} \stackrel{n}{\sim}$ & $\because \stackrel{\infty}{\sim}$ & 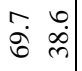 \\
\hline 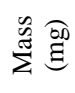 & 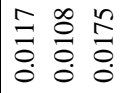 & 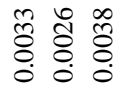 & 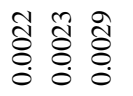 & 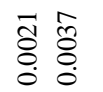 & 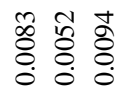 & 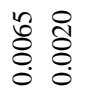 & $\left.\begin{array}{ll}\infty & \overline{0} \\
0 & 0 \\
0 & 0 \\
0 & 0 \\
0\end{array}\right]$ \\
\hline 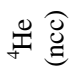 & 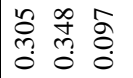 & 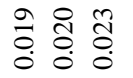 & 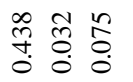 & $\begin{array}{l}\overline{0} \\
\bar{o} \\
0 \\
0\end{array}$ & 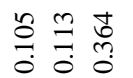 & 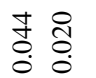 & 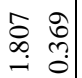 \\
\hline & 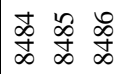 & 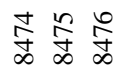 & 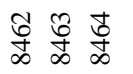 & 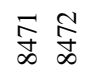 & 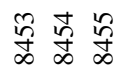 & 象 & $\left.\begin{array}{ll}0 & 0 \\
0 \\
0 \\
\infty\end{array}\right)$ \\
\hline & 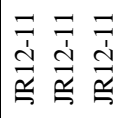 & 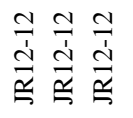 & 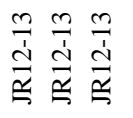 & $\begin{array}{l}\frac{ \pm}{\Delta} \\
\stackrel{\Delta}{\cong} \\
\cong \cong\end{array}$ & 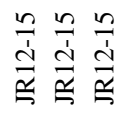 & 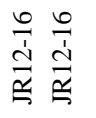 & 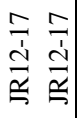 \\
\hline
\end{tabular}




\subsubsection{Ahimanawa Range}

The Ahimanawa Range (Fig. 2.2b) is the most northerly and easterly part of the axial ranges in the study area. Three ZFT ages (264-189 Ma; Table 2.1) are older than the sedimentary age, 200-160 Ma (Fig. 2.3a) (Adams et al., 2009), suggesting that the ZFT system has not been fully reset. The AFT ages (122-50.8 Ma; Table 2.2) are younger than the sedimentation age and yield tight grain age distributions $\left(\mathrm{P}\left(\chi^{2}\right)>30 \%\right)$; these ages have been reset during the burial and low-grade metamorphism, recording post-burial exhumation leaving little information related to their original sources. Sampling across the Wheao and Ruahine Faults (Fig. 2.2a), part of the North Island Fault System (NIFS, Fig. 2.1), reveals no significant age difference over those structures, indicating that little differential vertical displacement has accumulated on these faults over the last $100 \mathrm{Myr}$.

AHe ages in the Ahimanawa Range are between $33.3 \pm 4.2$ and $10.3 \pm 4.8 \mathrm{Ma}$ (Table 2.3). The difference of AHe ages over faults is also negligible. Thus no differential vertical displacement over these structures could be identified using the present thermochronological datasets. Here age-elevation relationships of AFT and AHe ages are not used for inference of exhumation history, as we acknowledge that the shape of age-elevation curves could result from various factors in addition to cooling rates and onsets of accelerated cooling (Prenzel et al., 2013).

\subsubsection{Kaimanawa Mountains and Kaweka Range}

Four schist samples from the Kaimanawa Mountains yield ZFT ages (155-121 Ma; Table 2.1) that are consistently younger than the corresponding sedimentary age ( 200-160 Ma, Figs. 2.2a and 2.3b), suggesting full or almost-full resetting at higher temperatures when the rocks were in a deeper position in the crust in comparison with similar aged greywackes exposed in other parts central North Island. The relationship is not unexpected, because the metamorphic grade of the Kaimanawa Schist (pumpellyite-actinolite facies; $220-350{ }^{\circ} \mathrm{C}$ ) (Adams, 2003; Frey et al., 1991) is higher than other Torlesse and Waipapa Supergroups (prehnite-pumpellyite facies; 180$280{ }^{\circ} \mathrm{C}$ ) (Adams, 2003; Frey et al., 1991) in central North Island. This relationship is further supported by the unusually young whole-rock K-Ar slate ages reported for the same rocks (Adams et al., 2009). At higher peaks of the Kaimanawa Mountains and in the Kaweka Range, samples yield detrital ZFT ages (224-165 Ma; Table 2.1) similar 
to or older than the corresponding stratigraphic age (Fig. 2.3b). These have clearly not been heated to the ZFT total annealing temperature $\left(\sim 240{ }^{\circ} \mathrm{C}\right)$.

AFT ages in the Kaimanawa and the Kaweka Ranges are between $91.5 \pm 14.0$ and $22.0 \pm 4.2 \mathrm{Ma}$ (Table 2.2; Figs. 2.2a and 2.3b). Most are Miocene, but some relict Cretaceous ages are locally preserved, e.g. $91.5 \pm 14.0 \mathrm{Ma}(\mathrm{R} 785)$ on the northern flank of the Kaimanawa Mountains, and 86.1 \pm 14.2 Ma (DS10-13) in the southeast of the Kaweka Range. Although the average altitude is higher in the Kaimanawa than in the Kaweka Range, the AFT age distributions across both ranges are similar.

Spatial trends in the AHe ages resemble those for AFT data. The AHe ages from the Kaimanawa and Kaweka Ranges vary between $29.7 \pm 12.6$ and $13.9 \pm 1.7$ Ma. The single pre-Miocene age $(29.7 \pm 12.6 \mathrm{Ma})$ was measured on a sample located on the eastern flank of the Kaweka Range (DS10-13; Fig. 2.2a).

\subsubsection{Hauhungaroa Range (west of TVZ)}

Waipapa Supergroup greywacke outcrops are scattered in the Hauhungaroa Range to the west of Lake Taupo. Two samples yield ZFT ages of $193 \pm 34$ and $145 \pm 23 \mathrm{Ma}$ (Table 2.1; Fig. 2.2a), which are within the depositional age range for the rocks (Fig. 2.3). Four AFT ages are between $117 \pm 18$ and 79.1 $\pm 13.2 \mathrm{Ma}$ (Table 2.2), within the same range as those from the Ahimanawa Range. Two AHe samples yield ages of $95.2 \pm 32.6$ and $34.4 \pm 2.9$ Ma (Table 2.3), both older than those from east of TVZ. No vertical-profile sampling was made in the Hauhungaroa Range due to the low local relief.

\subsection{Apatite Fission-track and (U-Th-Sm)/He modelling}

We used the QTQt software (Gallagher, 2012; Gallagher, 2013) to model thermal histories from the AFT and AHe data. Figs. 2.4-2.8 show the inverse modelling results. Fig. 2.9 summarises all inferred thermal history paths.

The inversion sampler (Gallagher et al., 2009) uses a Bayesian Markov chain Monte Carlo (MCMC) method, which favours simpler solutions and thus minimises problems of over-interpretation. The inverse modelling process starts from a random Temperature-time (T-t) path with a set of kinetic parameters, which are used to make predictions to compare with the observed data (using likelihood functions). Then the thermal history and parameters are perturbed, and the likelihood between model 
predictions and observations are recalculated and compared to the initial model. If the data fit of the posterior model is better, it is accepted and contributes to the overall posterior collection of models; otherwise it is rejected. Such a process is repeated for many iterations (as specified by the user) to reproduce the posterior distribution of the thermal histories. For "stacked" samples on a vertical profile, an iteration simulates a thermal history for the uppermost sample and the temperature offset between the uppermost and lowermost samples, and then applies a linear interpolation to derive T$\mathrm{t}$ paths for intermediate samples. Given a fixed vertical distance between the highest and lowest samples, a geothermal gradient and its variation through time can also be estimated, based on the assumption that the gradient was linear in the shallow level of the crust (from the surface to the maximum depth of apatite PAZ). Gallagher et al. (2009) and Gallagher (2012) provided detailed introduction and demonstration of the inversion approach.

We modelled thermal histories of the basement rocks between the time of their initial cooling after the peak of their low-grade metamorphism and their present exposure at the surface. For setting up the modelling, we constrained the starting time, using the K-Ar ages (Adams et al., 2009), i.e. 155-125 Ma for schist and 175-155 Ma for greywacke samples. Because the ZFT system has only been reset in the schist but not in greywacke samples, the starting temperature range was set at $200-300{ }^{\circ} \mathrm{C}$ for schist and lower at $150-250^{\circ} \mathrm{C}$ for greywacke models. In the end, all models were forced to the surface temperature $\left(20 \pm 10^{\circ} \mathrm{C}\right)$ at $0 \mathrm{Ma}$.

To model the AFT ages, we used the multi-kinetic annealing model of Ketcham et al. (2007) with measured Dpar (etch pit diameter parallel to the c-axis of crystal)(Donelick, 1993) values to constrain the apatite compositional parameters; and for the AHe ages, we used the radiation damage accumulation model of Flowers et al. (2009). In each inversion, a sum of 200000 iterations was run to ensure consistent sampling from the stationary posterior distribution (see discussion in Gallagher (2012)). To model the data of vertically stacked samples, we allowed the thermal gradient to vary between 10 and $50{ }^{\circ} \mathrm{C} / \mathrm{km}$ over the modelled span of geological time. 

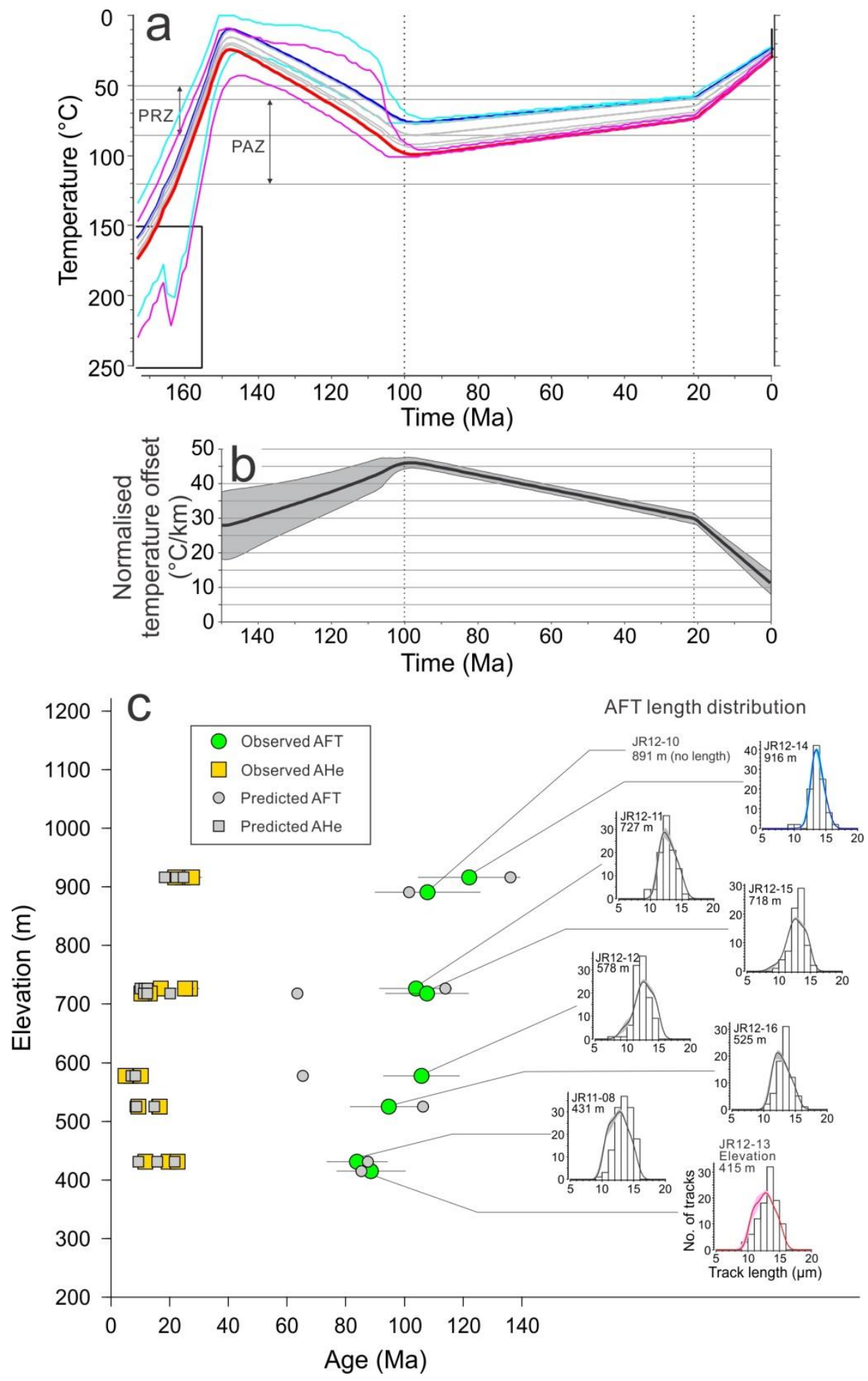

Fig. 2.4 Inverse modelling results for eight samples on the vertical profile in the Ahimanawa Range. (a) Expected (weighted mean) thermal histories. T-t paths of the uppermost (blue) and lowermost (red) samples are shown in heavy lines, with their 95\% credible intervals. AFT PAZ and AHe PRZ are approximate for standard Durango apatites. Black box is the constraint on the modelling. (b) Predicted normalised temperature offset over time with the 95\% credible interval. (c) Predicted versus observed data. AFT data are shown as central ages $( \pm 2 \sigma$ errors) and $\mathrm{AHe}$ are uncorrected single-grain ages. Predicted track-length distributions (solid curves) are plotted with 95\% credible intervals in comparison with observed tracklength data (histograms). 


\subsubsection{Ahimanawa Range}

A thermal history inversion of the Ahimanawa Range data was made using a vertical profile. This profile stretching across strike-slip faults of the NIFS, yielded no difference in the AFT or AHe data across the structures. Thus we argue that there is no identifiable vertical component along the faults, and the samples can be treated as in a single structural block. The modelling combined data from 8 samples (JR12-10 to JR12-16 and JR11-08), including 8 AFT ages, 7 with track-length data and 18 AHe grain ages (Fig. 2.4). The successful models predict cooling and exhumation of the rocks towards the surface soon after their peak burial and metamorphism in the Jurassic (Fig. 2.4a). Subsequently, the models suggest reheating of samples to $\sim 75-$ $100{ }^{\circ} \mathrm{C}$ by $\sim 100 \mathrm{Ma}$. However, the accurate magnitude and beginning of reheating cannot be effectively constrained as this part of the T-t paths lies at temperatures outside the apatite fission-track PAZ and helium PRZ. After $100 \mathrm{Ma}$, the samples were subject to very slow cooling throughout the Late Cretaceous and Paleogene, continuing into the Neogene until just before $20 \mathrm{Ma}$. At this point, the cooling rates of the models accelerated; the average rate for this final cooling episode is $1-2{ }^{\circ} \mathrm{C} / \mathrm{Myr}$.

The fluctuation in geothermal gradient (Fig. 2.4b) was inferred from the modelled temperature offsets between the uppermost and lowermost samples on the modelled profile. The models predict an increase of geothermal gradient during the Early Cretaceous (prior to $100 \mathrm{Ma}$ ) reaching over $45^{\circ} \mathrm{C} / \mathrm{km}$ at $100 \mathrm{Ma}$; the uncertainty for this period is large due to the large uncertainties in the modelled T-t paths. Subsequently, the gradient is inferred to decrease gradually from $100 \mathrm{Ma}$ to $20 \mathrm{Ma}$. During the final cooling stage, the thermal gradient decreased quickly as all samples are required to be at the surface temperature at the present. The modelled geothermal gradient just prior to the Miocene acceleration of cooling is estimated to be $30 \pm$ $2{ }^{\circ} \mathrm{C} / \mathrm{km}$. This value is similar to that at present in the Taranaki Basin on western North Island $\left(29^{\circ} \mathrm{C} / \mathrm{km}\right.$ (Funnell et al., 1996)) and the gradient $\left(27.5 \pm 2.5^{\circ} \mathrm{C} / \mathrm{km}\right)$ adopted by Tippett and Kamp (1993) to calculate the exhumation of the Torlesse greywacke rocks in South Island. Therefore this geothermal gradient $\left(30 \pm 2{ }^{\circ} \mathrm{C} / \mathrm{km}\right)$ is used in this study to estimate the Neogene exhumation and its rates for the basement samples in central North Island. 

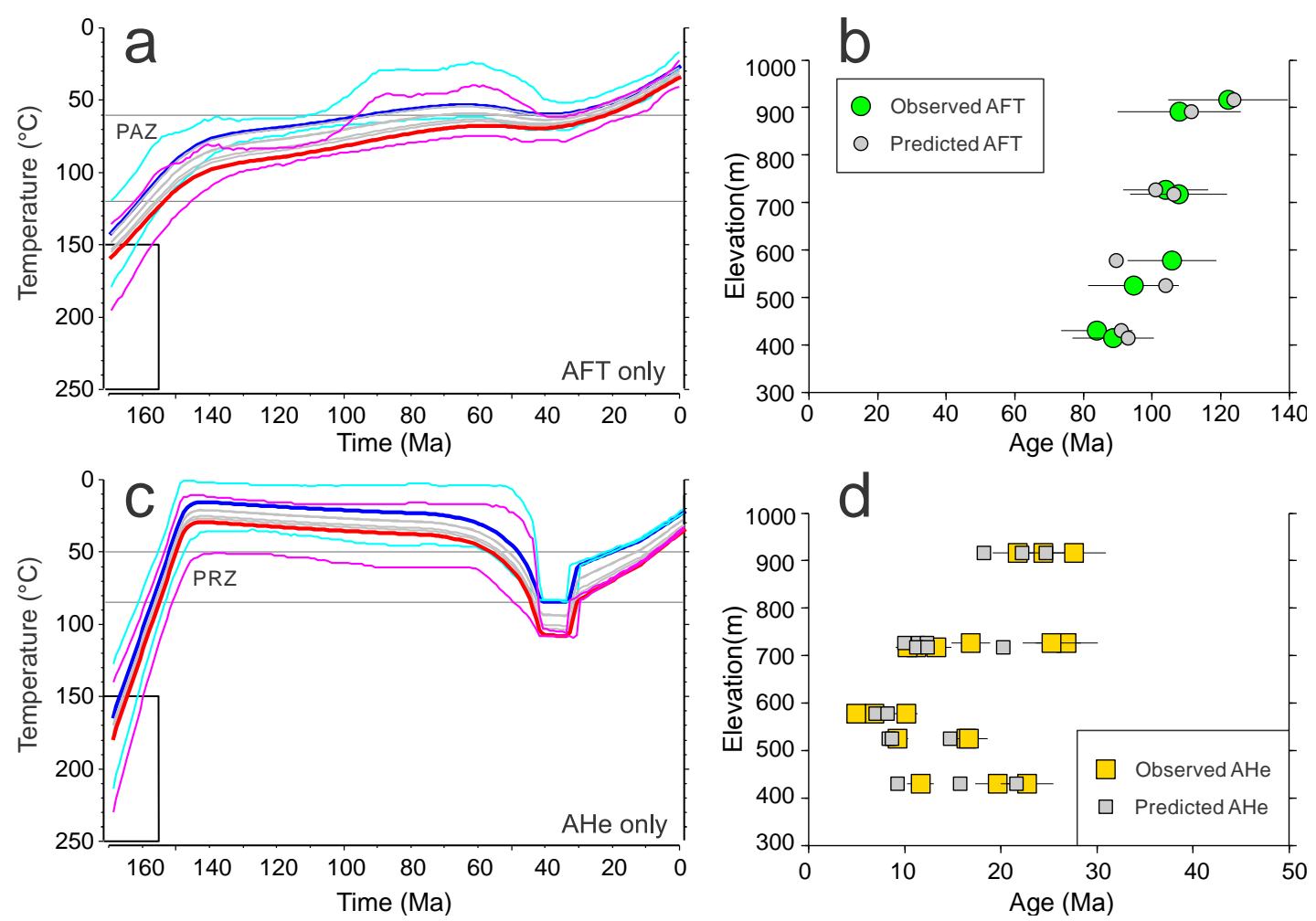

Fig. 2.5 Expected thermal histories of the vertical profile in the Ahimanawa Range, modelled with (a) AFT and (c) AHe data alone, respectively. Age predictions from expected models are shown in (b) and (d). See Fig. 2.4 caption for further explanation.

We also modelled the AFT and AHe data separately to compare with the integrated modelling results, using the same model parameters and constraints. The T-t paths simulated with AFT data alone (Fig. 2.5a) reveals less detail. The models predict a decrease of cooling rates at $\sim 140 \mathrm{Ma}$ after the initial rapid cooling. After $100 \mathrm{Ma}$, the modelled T-t paths passed to the temperature range near the upper boundary of PAZ $\left(60{ }^{\circ} \mathrm{C}\right)$ and the uncertainties became large. Finally, models imply that all samples cooled monotonically to temperatures $<60{ }^{\circ} \mathrm{C}$ between 40 and $20 \mathrm{Ma}$. The predicted AFT ages (Fig. 2.5b) fit the observed data better than when both AFT and AHe are used. On the other hand, the AHe data modelling (Fig. 2.5c) predict that, between 40 and $30 \mathrm{Ma}$, all samples were below the base of the helium PRZ $\left(85^{\circ} \mathrm{C}\right)$. This temperature would reset the AHe ages (on a geological timescale). In summary, modelling of AFT data alone provided little information regarding the samples' final cooling phase in the last 30 million years, whereas the AHe data alone were unable to provide reliable information related to thermal histories prior to $\sim 30 \mathrm{Ma}$. Therefore, the modelling of a combination of AFT and AHe data from multiple samples provided more reliability and details on the thermal histories than that using one chronometer. Furthermore, the integrated modelling could help avoid artefacts that might be 
introduced by modelling data from individual samples (Gallagher et al., 2005). Thus our interpretation of thermal and exhumation histories will be based on the results of integrated modelling of AFT and AHe data from multiple samples where applicable.

\subsubsection{Kaimanawa and Kaweka Ranges}

Along the western flank of the Kaimanawa Mountains AFT and AHe data of three schist samples (JR11-10, JR11-50 and JR11-47), including 3 AFT ages and tracklength data and 4 AHe single-grain ages, were modelled together (Fig. 2.6). Tracklength data of the uppermost sample (JR11-47) yield a bimodal distribution, while the lower two retain a small hint of the bimodality in their negatively skewed distributions (Fig. 2.6b). Unlike the models of greywacke samples in the Ahimanawa Range (Fig. 2.4a), the simulation of schist samples implies no reheating events in the Early Cretaceous before $100 \mathrm{Ma}$. Following the initial cooling from the low-grade metamorphism, the models (Fig 2.6) predict long residence of the samples within the AFT PAZ throughout the Late Cretaceous and Paleogene. These samples passed into a Miocene phase of accelerated cooling at rates $>5{ }^{\circ} \mathrm{C} / \mathrm{Myr}$, starting at $\sim 26 \mathrm{Ma}$. This cooling event ended at $\sim 17 \mathrm{Ma}$, when the uppermost sample on the profile was cooled to the surface temperature.

Five thermal models from different locations in the Kaweka Range were obtained (Fig. 2.7). Four models were simulated with single-site AFT and AHe data, and one other used 3 AFT ages (JR12-07, 8 and 9) on a vertical profile but with only track-lengths and AHe data from one sample (JR12-07). The models suggest similar thermal histories: all invoke a prolonged period within or deeper than the apatite PAZ for 100-80 Myr since mid- Cretaceous, until the cooling accelerated at $\sim 27-20 \mathrm{Ma}$. In regard to the final cooling stage, two samples (Fig. 2.7) are predicted to cool rapidly (up to $>10{ }^{\circ} \mathrm{C} / \mathrm{Myr}$ ) and to be exhumed to depths shallower than the PAZ before 15 $\mathrm{Ma}$; these are comparable with the thermal history model of the Kaimanawa samples. The other models (Fig. 2.7) reveal average cooling rates $>2{ }^{\circ} \mathrm{C} / \mathrm{Myr}$ until the presentday. 


\section{Kaimanawa Range}
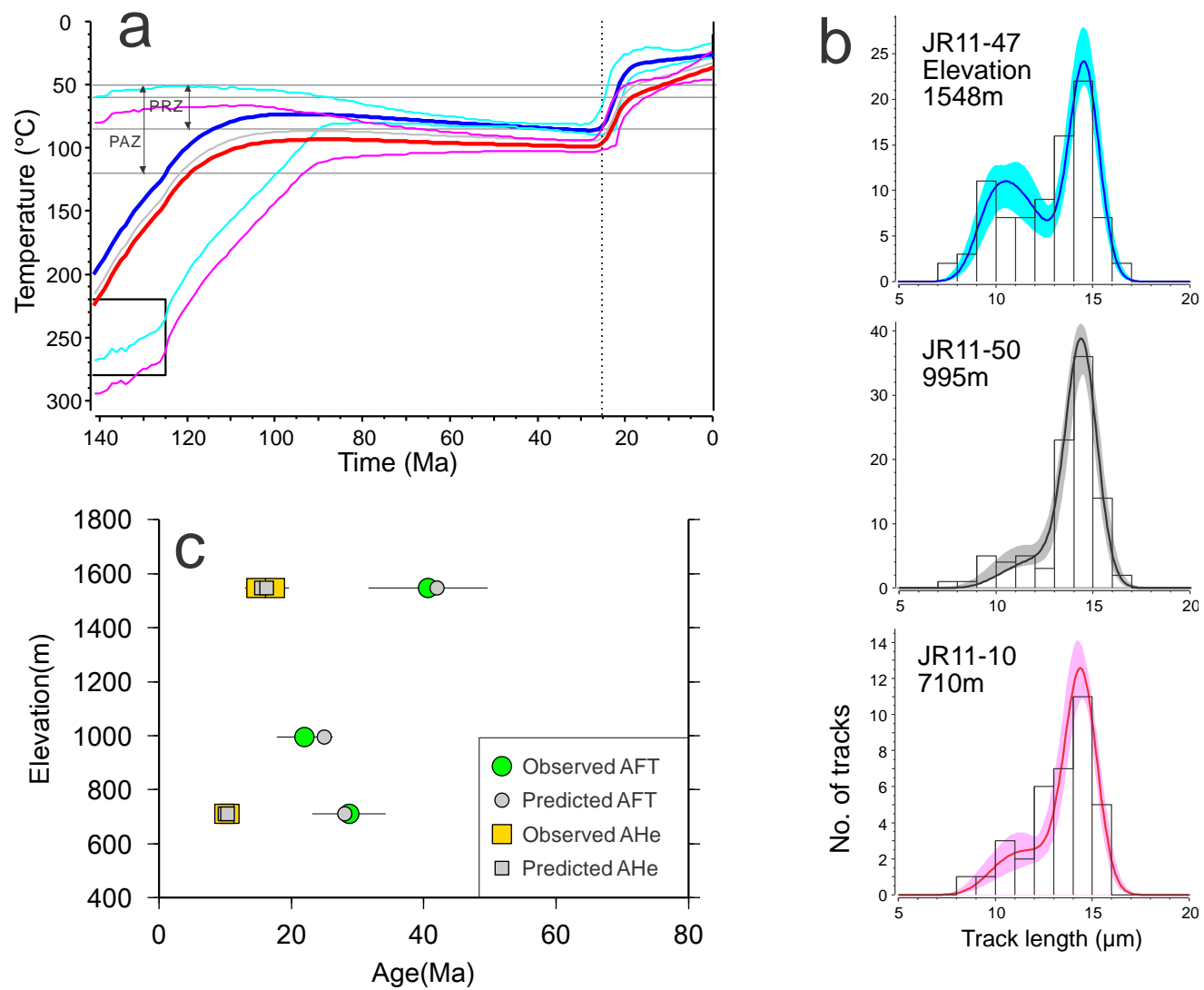

Fig. 2.6 Inverse modelling results for three samples on a vertical profile in the Kaimanawa Mountains. (a) Expected (weighted mean) thermal histories. Heavy lines show the uppermost (blue) and lowermost (red) sample histories with the 95\% credible intervals. AFT PAZ and AHe PRZ are approximate for standard Durango apatites. Black box is the input constraint. (b) Predicted versus observed AFT track-length distributions. Expected track-length distributions (solid curves) are plotted with $95 \%$ credible intervals in comparison with observed tracklength data (histograms). (c) Predicted versus observed ( $\pm 2 \sigma$ errors) AFT and AHe ages. AHe age is uncorrected single-grain age. 


\section{Kaweka Range}
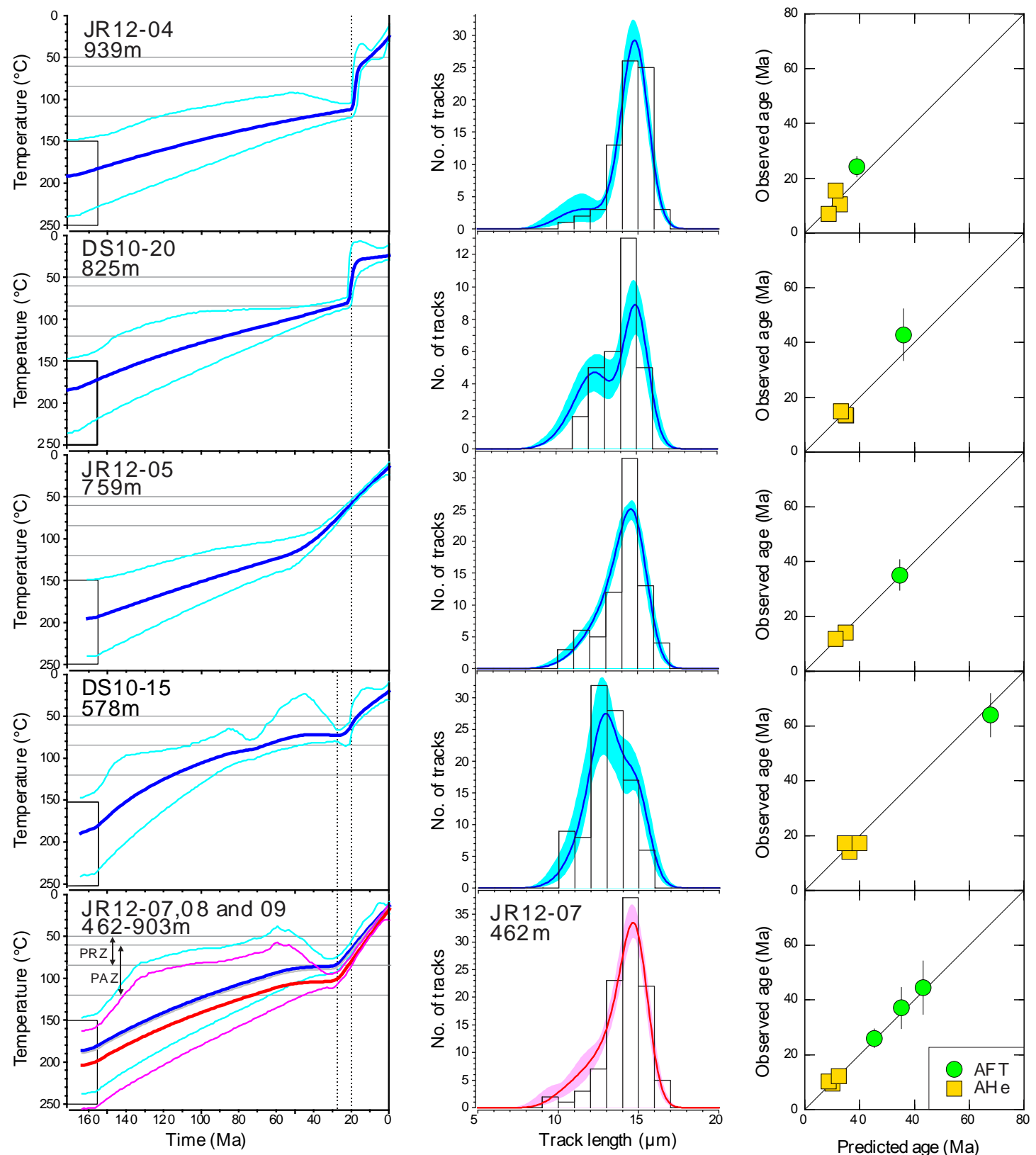

Fig. 2.7 Thermal history modelling results for the Kaweka Range. The lowest model (JR1207, 08 and 09) is simulated with AFT ages of three stacked samples, track-length and AHe data from one; the others are simulated with individual sample data. Left panel: Temperaturetime history for modelled sample(s). Central panel: Predicted and observed track-length distribution. Right panel: Predicted versus observed ages for each model. 1:1 line is plotted for reference. See Fig. 2.8 caption for further explanation.

\subsubsection{Hauhungaroa Range (west of TVZ)}

Thermal history of the Hauhungaroa Range (Fig. 2.8) was modelled using AFT data of only one Waipapa Supergroup greywacke sample (R14215). The results predict the initial cooling of samples before $135 \mathrm{Ma}$, similar to that implied by the Ahimanawa samples (Fig. 2.4a). From then the sample resided at a shallow depth in the upper 
crust (temperature $<70{ }^{\circ} \mathrm{C}$ ) for a very long period until the Oligocene. After $\sim 30 \mathrm{Ma}$, this sample was cooled to the temperature $<60{ }^{\circ} \mathrm{C}$, and thus the AFT data provide no constraints for its later thermal history.

\section{Hauhungaroa Range (west of TVZ)}
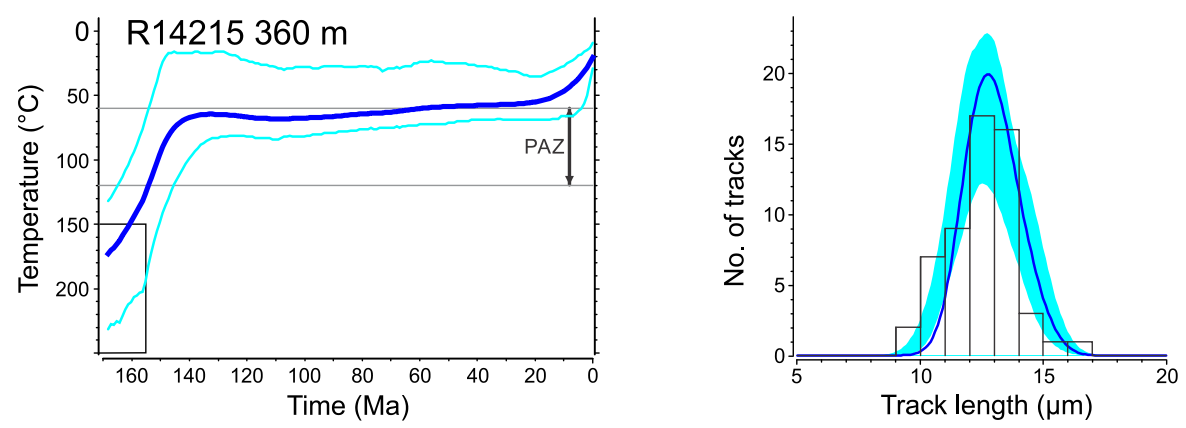

Fig. 2.8 AFT modelling result in the Hauhungaroa Range, west of TVZ. See captions of Figs. 2.6 and 2.7 for explanation.

\subsection{Interpretation and discussion}

Data and thermal history modelling in this work document the long-term thermal history of the basement rocks of central North Island (Fig. 2.6). This history ranges from a major phase of Jurassic-Early Cretaceous cooling of accreted terranes on the eastern Gondwana margin to a passive margin setting in the Late Cretacous and Paleogene, and finally to initiation of the Hikurangi subduction zone between the Pacific and Australian Plates during the Late Oligocene-Early Miocene.

\subsubsection{Thermal and exhumation history of the eastern Gondwana margin}

After deposition during the Triassic to Early Cretaceous, the rocks of the present basement of North Island were deformed in the accretionary wedge on the eastern Gondwana margin (Fig. 2.10a). Exhumation of these Mesozoic accretionary terranes has been previously studied in the Otago Schist at South Island (Mortimer et al., 2012; Nishimura et al., 2000). Little et al. (1999), based on mica ${ }^{40} \mathrm{Ar} /{ }^{39} \mathrm{Ar}$ ages, suggested that the schist was unroofed after $135 \pm 5$ Ma from mid- to lower crust. Nishimura et al. (2000) interpreted a period of cooling of the schist at 155-135 Ma following its peak metamorphism, based on K-Ar ages. On the other hand, Little et al. (1999) inferred that the $\mathrm{K}-\mathrm{Ar}$ and ${ }^{40} \mathrm{Ar} /{ }^{39} \mathrm{Ar}$ methods were unsuitable for determining the timing of cooling or unroofing of the lower-grade parts of Otago greywacke rocks, due to their partially retained detrital signature. In the North Island, using AFT and 
AHe analyses and associated modelling, we have been able to infer an episode of unroofing of the greywacke rocks in the Ahimanawa and Hauhungaroa Ranges that occurred prior to $150-135 \mathrm{Ma}$ (Fig. 2.9). This exhumation event brought the rocks from their peak metamorphic temperatures/depths in the accretionary prism and carried them to the near surface ( $<2 \mathrm{~km}$ depth). Due to the restrictions in setting up the modelling, we cannot refine the onsets of this cooling, but we suggest that the models reflect the same unroofing event for rocks in the Mesozoic accretionary wedge as that recorded in the Otago Schist. The end timing of this exhumation estimated by our T-t models is in general agreement with the inferences of Little et al. (1999) and Nishimura et al. (2000).

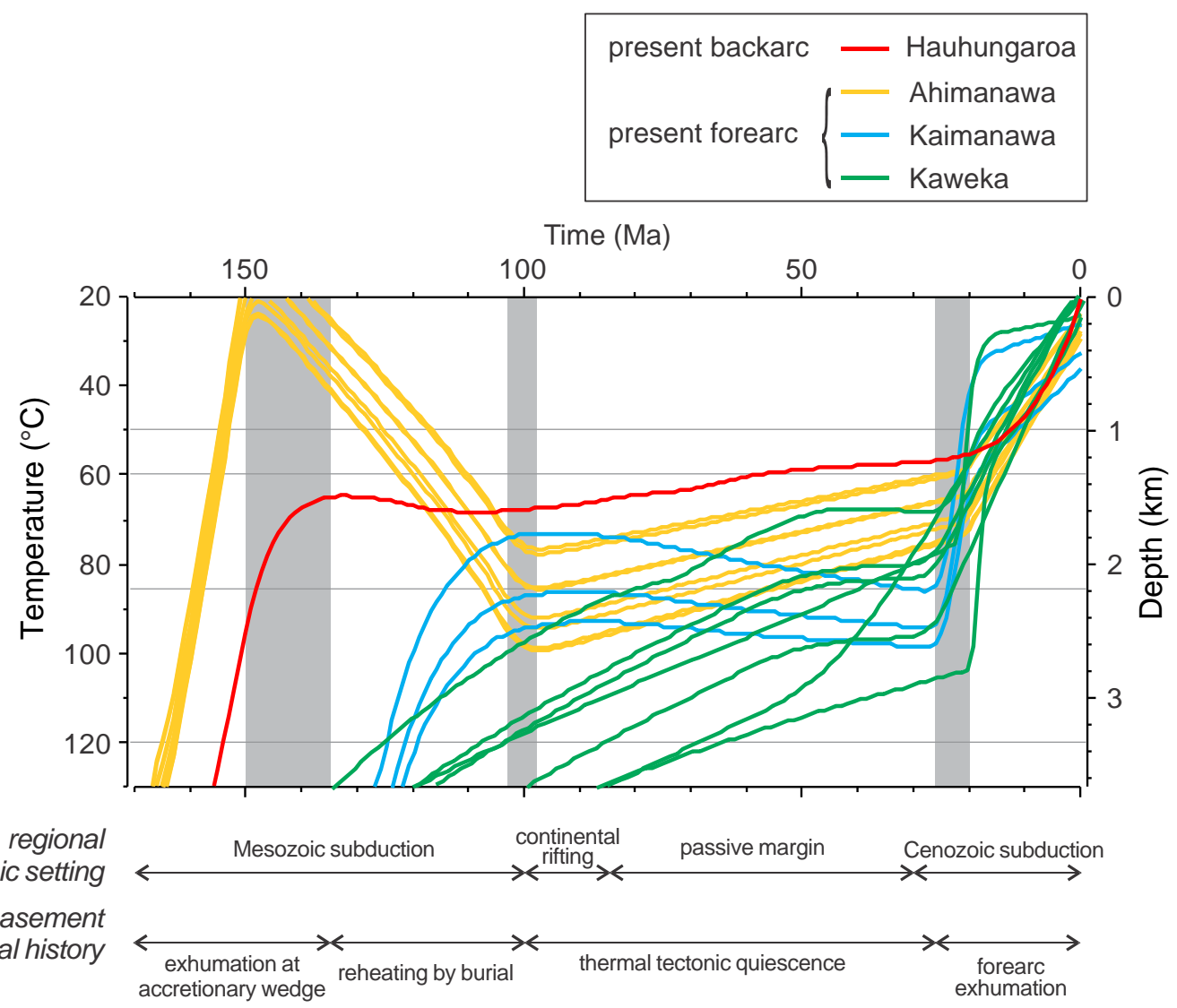

Fig. 2.9 Summary of inferred thermal histories for basement rocks at central North Island since the latest Jurassic. Regional tectonic settings indicated are according to Gaina et al. (1998), King (2000) and Laird and Bradshaw (2004). Grey bars highlight changes of cooling rates.

The magnitude of the Mesozoic exhumation and cooling is difficult to quantify precisely. Thermal history models of the Ahimanawa Range samples (Fig. 2.4a) imply an unroofing to the surface, but this might be a simplified solution from the inversion process. However, it is clear from the models that after the initial cooling event, the 
samples experienced some reheating (up to $100{ }^{\circ} \mathrm{C}$ ) prior to $100 \mathrm{Ma}$. This reheating process, albeit potentially simplified by the inversion, perhaps reflects thermal events that were indicated by periods of argon loss in the Otago Schist (Little et al., 1999). We suggest it was the result of one or more phases of extension that deformed the top of the now very large accretionary wedge during its waning stages (Fig. 2.10b). For example, Platt (1986) demonstrated that sediment underplating at the subduction interface thickens the wedge and thus may cause it to extend internally to regain stable geometry. The development of normal faults and related basins at the upper part of the accretionary wedge allowed sediments to accumulate, covering and reheating the previously exhumed terrane rocks. Evidence of underplating beneath the Mesozoic accretionary wedge of the North Island was reported by Charlier et al. (2010), who interpreted a package of zircon ages of 110-140 Ma from the xenolith in the TVZ as underplated and partially melted complexes at the base of the Torlesse and Waipapa Supergroups in the Early Cretaceous.

This period of reheating coincided with the depositional range of the Pahau Terrane (140-100 Ma) (Adams et al., 2007; Adams et al., 2009) which was possibly formed in a syn-subduction non- to shallow-marine depositional setting (Bassett and Orlowski, 2004). Therefore, subduction, associated accretion and underplating were still active when the reheating and inferred extension occurred at the upper accretionary wedge. Evidence related to progressive crustal thinning and extension of eastern Gondwana basement terranes in the Early and Late Cretaceous have been suggested elsewhere in the greater New Zealand region. For example, Tulloch et al. (2009) reported 112-82 Ma volcanism across Zealandia and suggested a phase of progressive crustal thinning over a time span of $\sim 30$ Myr preceding the final break-up of the eastern Gondwana margin. Additionally, based on dating of the lower plate rocks by ${ }^{40} \mathrm{Ar} /{ }^{39} \mathrm{Ar}$ geochronology in the Paparoa metamorphic core complex of South Island, Spell et al. (2000) suggested that continental extension in eastern Gondwana covered an interval of 110-90 Ma. 

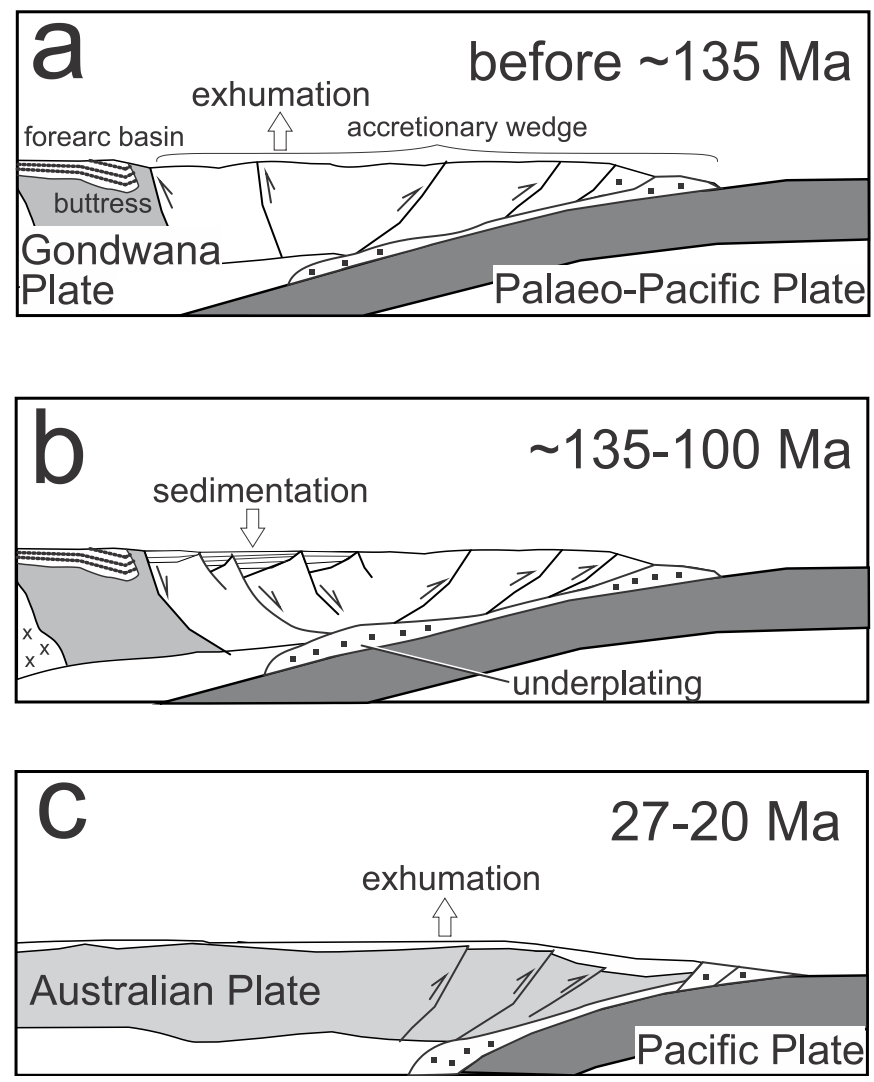

Fig. 2.10 Exhumation histories of the basement rocks of central North Island. (a) Rapid exhumation of the terrane rocks in the accretionary wedge during the active subduction. Cross-section is adapted from Mortimer et al. (2012) (not to scale). (b) Sedimentation and burial on top of the accretionary wedge due to extension in the wedge, as the result of continued underplating and thickening. (c) Accelerated exhumation of basement rocks at the upper Australian Plate, in response to the initiation of subduction of the Pacific Plate beneath North Island.

Although we attribute the reheating of accretionary terranes to the extension at the upper accretionary wedge, other subduction-related processes cannot yet be completely ruled out as potential causes. For example, Mortensen et al. (2010) in an ${ }^{40} \mathrm{Ar} /{ }^{39} \mathrm{Ar}$ study, identified two pulses of gold mineralization in the Otago Schist in the Early Cretaceous (142-135 and 106-101 Ma), which led the authors to propose the subduction of an actively spreading ridge in order to reconcile short-lived thermal events.

From $\sim 100 \mathrm{Ma}$, the thermal histories of the Torlesse and Waipapa Supergroups in central North Island imply this region was very stable until the Late Oligocene (Fig. 2.9), with no significant cooling or reheating (average rates $<1{ }^{\circ} \mathrm{C} / \mathrm{Myr}$ ). The modelled geothermal gradient for the North Island basement terranes during this period is a slowly decreasing one (Fig. 2.4b). We interpret this period of thermaltectonic quiescence to be the prolonged passive margin setting, as evidenced by many 
geological studies (Ballance, 1993) (Field et al., 1997; Moore, 1988) and references within). The onset of the thermal-tectonic quiescence at $\sim 100 \mathrm{Ma}$ is in agreement with previous estimates of the termination of Mesozoic subduction, which were mainly interpreted from sedimentary observations: the stratigraphic ages of the oldest undeformed cover rocks overlying the deformed Torlesse Supergroup (on the Raukumara Peninsula) are between late Early Cretaceous and mid- Late Cretaceous (Bradshaw, 1989; Crampton, 1997; Isaac, 1977; Lee et al., 2011; Leonard et al., 2010; Mazengarb and Speden, 2000; Moore and Speden, 1984).

Nowhere in our models do we see any evidence for a thermal event at $\sim 85 \mathrm{Ma}$ associated with the onset of seafloor spreading as reported by Gaina et al. (1998) and Sutherland (1999). This indicates that opening of Tasman Sea at $~ 85 \mathrm{Ma}$ had no significant impact on either the sedimentation rate or geothermal structure of the passive basins in eastern North Island. This inference supports the study of Adams et al. (2012), who suggested that, based on detrital zircon U-Pb age patterns in the sedimentary terranes, by $\sim 100 \mathrm{Ma}$ sediment transport from western Zealandia to eastern New Zealand has been cut off, perhaps due to continuous rifting/displacement across Zealandia.

\subsubsection{Cenozoic exhumation in the hanging wall of the Hikurangi Margin}

Modelling of the thermochronological data has been able to reflect the end of the passive margin setting at North Island, when the active tectonics started in the late Cenozoic. For this episode, modelled thermal histories from the present fore-arc (axial ranges) to back-arc (Hauhungaroa Range) regions are interpreted to represent differential exhumational responses of the upper crust to the renewed convergence between the Australian and Pacific Plates (Fig. 2.10c), including development of the Hikurangi subduction margin (Ballance, 1976; Nicol et al., 2007; Rait et al., 1991; Stagpoole and Nicol, 2008).

In the axial ranges in the fore-arc of the Hikurangi subduction margin, accelerated exhumation started at $\sim 20 \mathrm{Ma}$ in the Ahimanawa, at $\sim 26 \mathrm{Ma}$ in the Kaimanawa and between 27 and $20 \mathrm{Ma}$ in the Kaweka Range (Fig. 2.6). Thermal history models suggest the accelerated cooling rates were up to $10{ }^{\circ} \mathrm{C} / \mathrm{Myr}$ (in the Kaweka Range), corresponding to exhumation rates $>0.3 \mathrm{~km} / \mathrm{Myr}$, using a pre-orogenic geothermal gradient of $30 \pm 2{ }^{\circ} \mathrm{C} / \mathrm{km}$ (Fig. 2.4b). According to the samples' paleo-positions in the 
crust prior to the accelerated exhumation, the total eroded thickness from top of the basement was $\sim 1.2-1.8 \mathrm{~km}$ in the Ahimanawa, $\sim 2.1-2.5 \mathrm{~km}$ in the Kaimanawa and $\sim 1.6-2.8 \mathrm{~km}$ in the Kaweka Range. In general, the magnitude of post-subduction exhumation increased towards the southwest in the central axial ranges, and this trend appears to extend to the entire length of the axial ranges in North Island. For example, the Raukumara Range in the northeast of North Island has undergone the least exhumation, without yet even having removed the overlying Cretaceous sedimentary rocks; the Wellington Belt at the southernmost part of North Island has been eroded more and yields fully syn-orogenic AFT ages (Kamp, 2000).

Our estimates of the accelerated cooling phase in the hanging wall of the subduction zone concur with the period of increased crustal deformation during the Late Oligocene-Early Miocene, e.g. the development of thrust belts ( 25-20 Ma) in eastern North Island (Chanier and Ferriere, 1991; Rait et al., 1991) and allochthon obduction in Northland and the East Cape ( 25-21 Ma) (Ballance and Spörli, 1979; Spörli, 1989). The accelerated basement unroofing increased the sediment flux into the adjacent basins, depositing mudstone dominated sequences, including flysch facies, into the East Coast Basins to the east of the proto- axial ranges (Delteil et al., 2006; Lee et al., 2011). In north-eastern North Island, terrestrial conglomerates (in the Early Miocene-earliest Pliocene Tolaga Group) were suggested to derive from local emergent landmass, which had been uplifted during the subduction initiation (Marsaglia et al., 2014).

For the basement rocks of eastern North Island, the first period of unroofing triggered by the Hikurangi subduction, we suggest, was the removal of the passive margin cover sequences (up to $2.8 \mathrm{~km}$ ). Consequently, crustal exhumation at this stage did not result in extensive denudation of the basement rocks per se. This explains why the greywacke gravels only became prevalent since the early-Late Miocene age in the western Hawke's Bay area (Bland, 2001; Bland et al., 2007; Graafhuis, 2001; Lee et al., 2011). Thus the well-lithified greywacke basement rocks were only exhumed to the surface at low elevations, with insignificant relief by about 2.5 Ma. Rare outcrops of Late Miocene to Early Pliocene beach and marine sedimentary rocks overlying the greywacke mountains confirm their low altitude at that time (Beu et al., 1981; Litchfield and Berryman, 2006), and the formation of the ranges themselves was later. This interpretation is in agreement with work by Sobel et al. (2006), who proposed 
that in a basement-cored orogen (Kyrgyz Range), surface uplift accelerated and created high local relief only after the erosion-resistant bedrocks had been extensively exposed. Additionally, the lack of high topography in the region of the Ahimanawa Range was probably even until $1 \mathrm{Ma}$, supported by the eastward flow of the Kidnappers ignimbrite ( 1 Ma age) (Wilson et al., 1995) from the TVZ to the East Coast at Hawke's Bay.

In the present back-arc region, western North Island, the thermal history model in the Hauhungaroa Range (Fig. 2.8) represents no pulse of cooling/exhumation related to the initiation of Hikurangi subduction. However, according to the sample's present exposure at the surface and its cooling rates within the PAZ (prior to $30 \mathrm{Ma}$ ), we speculate that there was at least one period of accelerated cooling for this region. The magnitude of the basement unroofing was much lower in central-western North Island (generally $<1.5 \mathrm{~km}$ ) than that in the axial ranges. Thus the exhumational response to the initiation of Hikurangi subduction was insignificant in the present back-arc region.

Holt and Stern (1994) and Stern and Holt (1994) proposed a platform subsidence ( $200 \mathrm{~km}$ wavelength and $\sim 1.5 \mathrm{~km}$ magnitude) in the western North Island during the initiation of the Hikurangi subduction. Pulford and Stern (2004) and Kamp et al. (2004) in their study of rock and surface uplift in western-central North Island, inferred $\sim 1.6$ to $>1.8 \mathrm{~km}$ exhumation in this region since $\sim 5 \mathrm{Ma}$. Unfortunately, our thermochronological data are unable to test these previous estimates due to the low magnitudes of subsidence and later unroofing, which only exhumed scattered outcrops of the Waipapa Supergroup rocks in the relative low-relief rolling hills.

\subsection{Summary and conclusions}

In this study, we report apatite and zircon fission-track and apatite (U-Th-Sm)/He data in central North Island, New Zealand, providing constraints on the timing, rates and magnitudes of the exhumation of the Mesozoic accretionary basement. Our findings provide new insights into the large-scale evolution of North Island, New Zealand since the latest Jurassic.

Following their accretion onto the active eastern Gondwana margin, the deformed basement rocks, except the Kaimanawa Schist, in present-day central North Island were never heated to temperatures greater than ZFT closure temperature $\left(\sim 240{ }^{\circ} \mathrm{C}\right)$. 
These rocks were cooled and exhumed to shallow depths of the crust (corresponding to temperatures $<70{ }^{\circ} \mathrm{C}$ ) at some time between 150 and $135 \mathrm{Ma}$.

The central North Island basement experienced some reheating prior to $100 \mathrm{Ma}$. This might have been the result of burial by sedimentation above the accretionary wedge. We interpret this period to have included a phase of extensional deformation affecting the upper levels of the accretionary wedge due to the continued underplating and thickening of wedge from beneath, although other subduction-related thermal events cannot yet be ruled out.

From $100 \mathrm{Ma}$, our thermal history models reveal little change in temperature until the Late Oligocene. This was a period of slow crustal extension and extremely slow cooling, which represents a time of passive margin history as Zealandia retreated from Gondwana.

In the late Cenozoic, tectonic activity was renewed along the eastern margin of Zealandia with the Pacific Plate subducting underneath the Australian Plate. This is indicated by accelerated cooling (up to $10{ }^{\circ} \mathrm{C} / \mathrm{Myr}$ ) and exhumation (up to $>0.3$ $\mathrm{km} / \mathrm{Myr}$ ) commencing at $\sim 27-20 \mathrm{Ma}$ in the axial ranges of the eastern-central North Island. We suggest the initial unroofing of axial ranges was chiefly expressed by the removal of the cover sequences. In western-central North Island, the exhumational response to the Hikurangi subduction was less significant, with a total magnitude of erosion $<1.5 \mathrm{~km}$. 


\title{
Chapter 3
}

\section{Unroofing of frontal ridges at the}

\section{Hikurangi Margin, New Zealand:}

\section{constraints from low-temperature}

thermochronology ${ }^{1}$

\begin{abstract}
The axial ranges of North Island, New Zealand, parallel the Hikurangi subduction margin. They consist of uplifted and exhumed Mesozoic meta-sedimentary basement rocks of the overriding Australian Plate, beneath which the Pacific Plate has been subducting since the Late Oligocene. We investigate the unroofing histories of these fore-arc mountains during the evolution of the Hikurangi Margin, based on new and previous apatite fission-track, and (U-Th-Sm)/He data which we interpret based on inverse modelling. The results suggest that the exhumation of rocks in the axial ranges initiated in the west and migrated trough-wards towards the east. Onsets of accelerated exhumation in different parts of the ranges indicate significant eastwards reverse faulting on the margin-parallel Ngamatea Fault before $\sim 20 \mathrm{Ma}$ and on the Wellington-Mohaka Fault before $\sim 10$ Ma. The exhumation rate has varied significantly along-strike since the Late Miocene ( 10 Ma), lower in the central part of the axial ranges and higher to the north and south. Since $\sim 10 \mathrm{Ma}$, the increasing
\end{abstract}

\footnotetext{
${ }^{1}$ Accepted manuscript as Jiao, R., Seward, D., Little, T.A. and Kohn, B.P.. Unroofing of forearc ranges at the Hikurangi Margin, New Zealand: constraints from low-temperature thermochronology. Tectonophysics (2015), in press.
} 
exhumation rate from the central to southern axial ranges is consistent with the clockwise vertical-axis rotation of eastern North Island relative to the Australian Plate. In the Hikurangi Margin, although underplating of subducted material at the basal upper plate may have contributed to localised rock uplift (e.g. in the Raukumara Range), we suggest that the shortening of the fore-arc upper plate was a chief driver of unroofing of the (proto-) axial ranges.

\subsection{Introduction}

The oceanic crust of the Pacific Plate is obliquely subducting beneath the continental Australian Plate along the Hikurangi Trough, off the east coast of the North Island, New Zealand (Figs. 3.1 and 3.2). In the fore-arc of the present Hikurangi Margin, major along-strike changes in tectonic properties and rates are known to exist (e.g. Barker et al., 2009; Collot et al., 1996; Wallace et al., 2009). For example, the accretionary wedges are well developed (up to $\sim 160 \mathrm{~km}$ wide) in the centre and south of the margin (Fig. 3.1b), whereas the northern margin (off Raukumara Peninsula) is relatively sediment-starved and dominated by tectonic erosion (Collot et al., 1996; Joanne et al., 2013; Lamarche et al., 2008). Inversion of the onshore GPS velocity fields (Wallace and Beavan, 2004) indicates a slip rate deficit at the subduction interface that is high $(20-30 \mathrm{~mm} / \mathrm{yr})$ beneath the southern North Island, but that decreases northwards along the margin. Similarly, earthquake seismicity patterns indicate that coupling between subducted and overriding plates is strong beneath the Wellington and Wairarapa regions to the south, and weak beneath northern Raukumara Peninsula to the north (Henrys et al., 2013; Reyners, 1998; Wallace and Beavan, 2010).

Previous workers have attributed these along-strike changes in the geological characteristics of the Hikurangi Margin to a diversity of causes: for example, southward propagation of the edge of the subducted slab of the Pacific Plate (Furlong and Kamp, 2009; Walcott, 1978; Walcott, 1984); southward reduction in plate convergence rates (Fig. 3.1b) (Barker et al., 2009); and along-strike changes in the thickness and other physical properties of the subducting Pacific Plate (Barker et al., 2009; Wallace and Beavan, 2004; Wallace et al., 2005). 


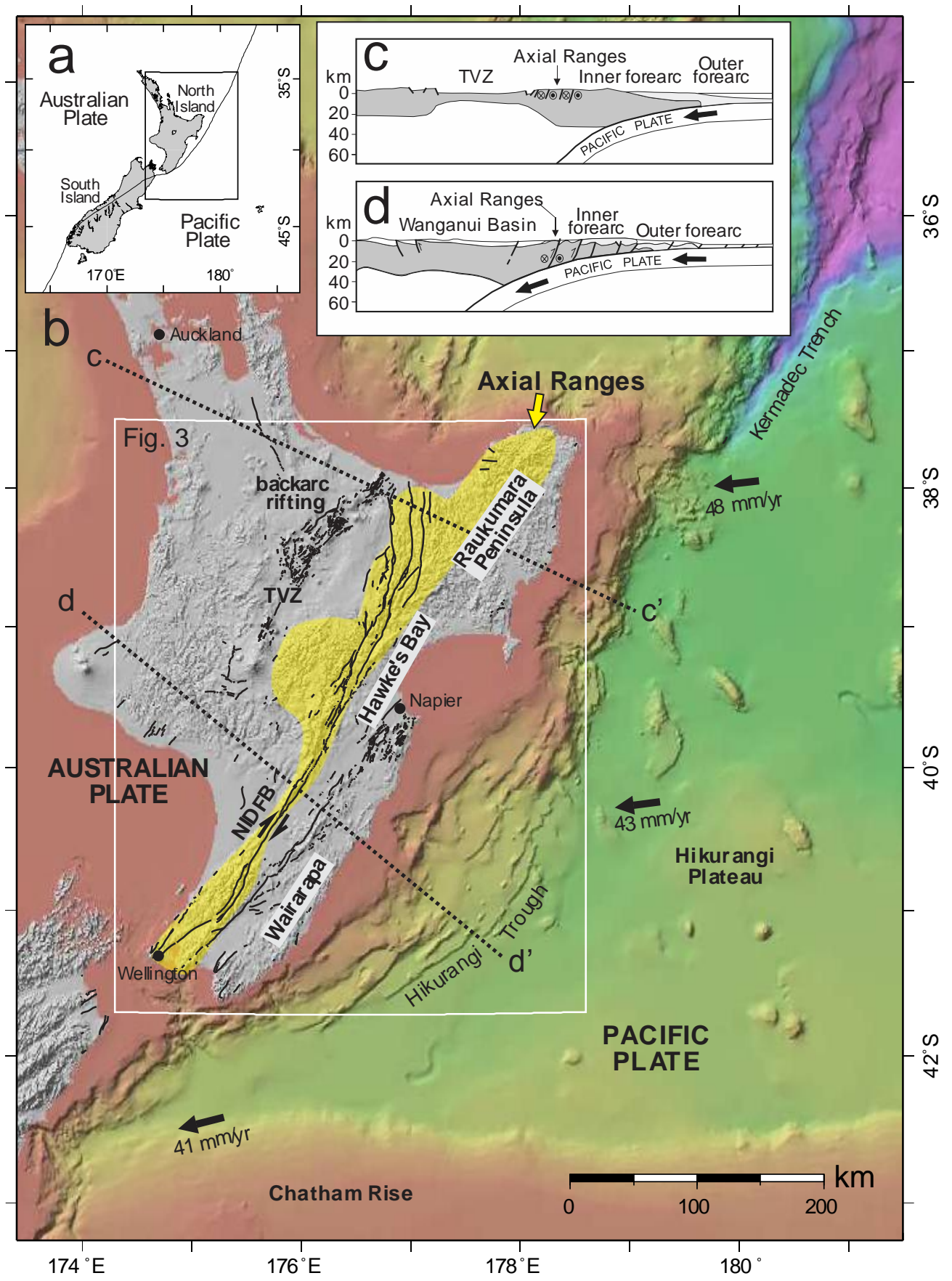

Fig. 3.1 Tectonic setting of the Hikurangi Margin. (a) Australian-Pacific Plate boundary in the New Zealand region. The box is region of Fig. 3.1b. (b) Bathymetry and topography (NIWA) and active onshore faults (New Zealand Active Faults Database, GNS Science) of the subduction margin. Yellow shading depicts the axial ranges, comprising Mesozoic Torlesse basement rocks. Relative plate motion vectors (black arrows) are from Beavan et al. (2002). Lines c-c' and d-d' denote the cross-section locations in Figs. 3.1c and 3.1d. White box corresponds to the region of Fig. 3.3. TVZ, Taupo Volcanic Zone; NIFS, North Island Fault System. (c) Cross-section through the northern Hikurangi Margin. (d) Cross-section through the southern margin. Both (c) and (d) are taken from Litchfield et al. (2007). 


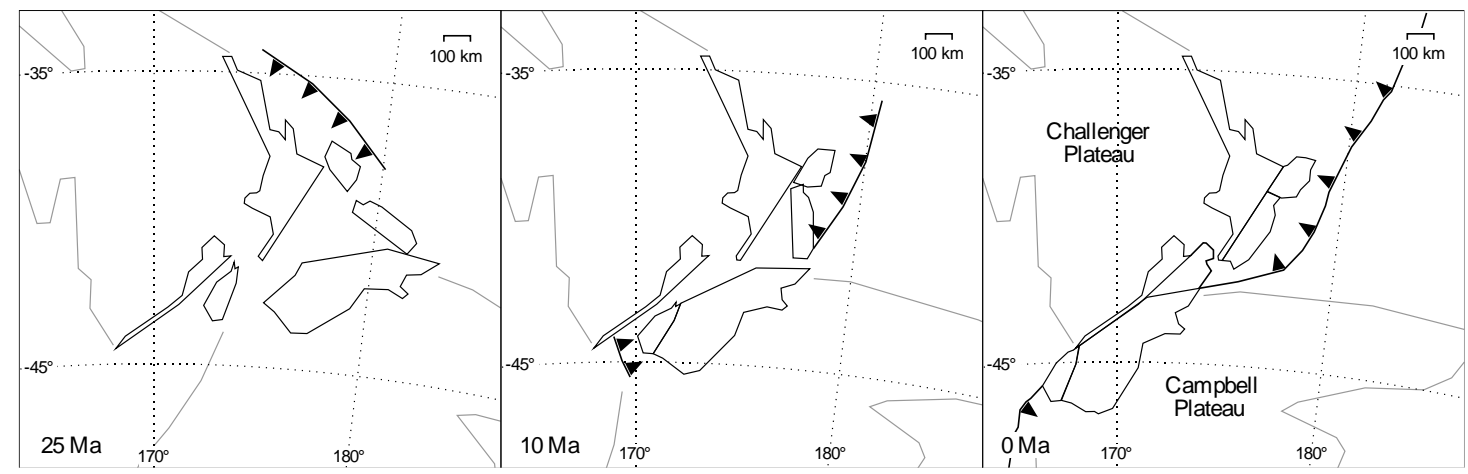

Fig. 3.2 Reconstructions of New Zealand Plate boundary zone at 25, 10 and $0 \mathrm{Ma}$, after Furlong and Kamp (2009). Extent of continental material is outlined (including the Campbell and Challenger Plateaus).

In this paper we use thermochronology to examine timing, rates, magnitudes and patterns of basement exhumation in the fore-arc in the upper plate of the Hikurangi Margin subduction zone since the Late Oligocene-Early Miocene. By comparing the history of basement exhumation in time and space against the key geological properties that vary along the strike of the margin, we strive to better understand the causes and tectonic significance of this variability, and the tectonic processes that have driven the uplift and exhumation of the upper plate. This study focuses on the NNE-SSW-striking axial ranges of North Island (Fig. 3.1b), which comprise chiefly the Mesozoic terrane rocks that have been uplifted and unroofed during the evolution of the Hikurangi Margin. This narrow (up to $60 \mathrm{~km}$ wide) mountain chain extends over $500 \mathrm{~km}$ from East Cape in the northeast to Wellington in the south of the island (Fig. 3.1b), approximately parallel to the East Coast shoreline and the subduction trough.

The significant topography and geomorphology of the present axial ranges are inferred to have grown since the Early Pliocene. In the centre and northeast of North Island, palaeogeographic reconstruction based on geological and biogeographic observations (Trewick and Bland, 2011) suggests that the landmass of the proto-axial ranges has been elevated only since the Early Pliocene. In the Hawke's Bay region, the significant influx of basement-derived conglomerates into the East Coast basins occurred since the early-Late Miocene age in the western Hawke's Bay area (Bland et al., 2007; Bland et al., 2013; Cutten and Heron, 1994; Graafhuis, 2001; Lee et al., 2011), which may reflect extensive exposure and erosion of the basement rocks in the adjacent ranges. In the southern North Island, during the early Quaternary, volcaniclastics from the TVZ had been transported by the palaeodrainage routes 
through the site of present axial ranges to the forearc lowlands in the south and southeast, suggesting that the Ruahine and Tararua Ranges had not attained high altitude until $1 \mathrm{Ma}$ (Lee and Begg, 2002; Shane et al., 1996; Trewick and Bland, 2011; Wilson et al., 1995). However, the thermochronology of basement rocks exposed today in the modern axial ranges preserves evidence for an older unroofing history that can be traced back to the Late Oligocene (Jiao et al., 2014; Kamp, 1999; Kamp, 2000), when the subduction of the Pacific Plate was initiated at the Hikurangi Margin, prior to the evolution of the modern mountain geomorphology. Much of this exhumation prior to the relatively recent surface uplift of the currently expressed ranges could have involved shedding of the Late Cretaceous-Paleogene cover successions off of the basement (Kamp et al., 2004; Pulford and Stern, 2004). Therefore, by the application of thermochronology, this paper focuses on the longterm, emphasising Late Oligocene and younger exhumation history of the basement rocks that today are exposed as the much younger, topographical, modern axial ranges. We are tracking the impact of subduction on the exhumation history of the proto-axial ranges predating the evolution of the current topography.

We determine and interpret the thermal and exhumation histories of the axial ranges using data from multiple thermochronometers, i.e. zircon and apatite fission-track (ZFT and AFT, respectively) and apatite (U-Th-Sm)/He (AHe) in the Ruahine, Tararua and Rimutaka Ranges (Fig. 3.3), spatially extending previous studies. Furthermore, an advanced modelling approach (Gallagher, 2012) is used to retrieve thermal histories from the thermochronological data of samples from vertical profiles. The compilation of new and published datasets provides a new coverage for the entire axial ranges, and allows better constraint of the comprehensive unroofing pattern of the basement-cored axial ranges. This pattern will contribute to the understanding of the subduction-related processes that have driven the uplift of the fore-arc of the upper plate. 


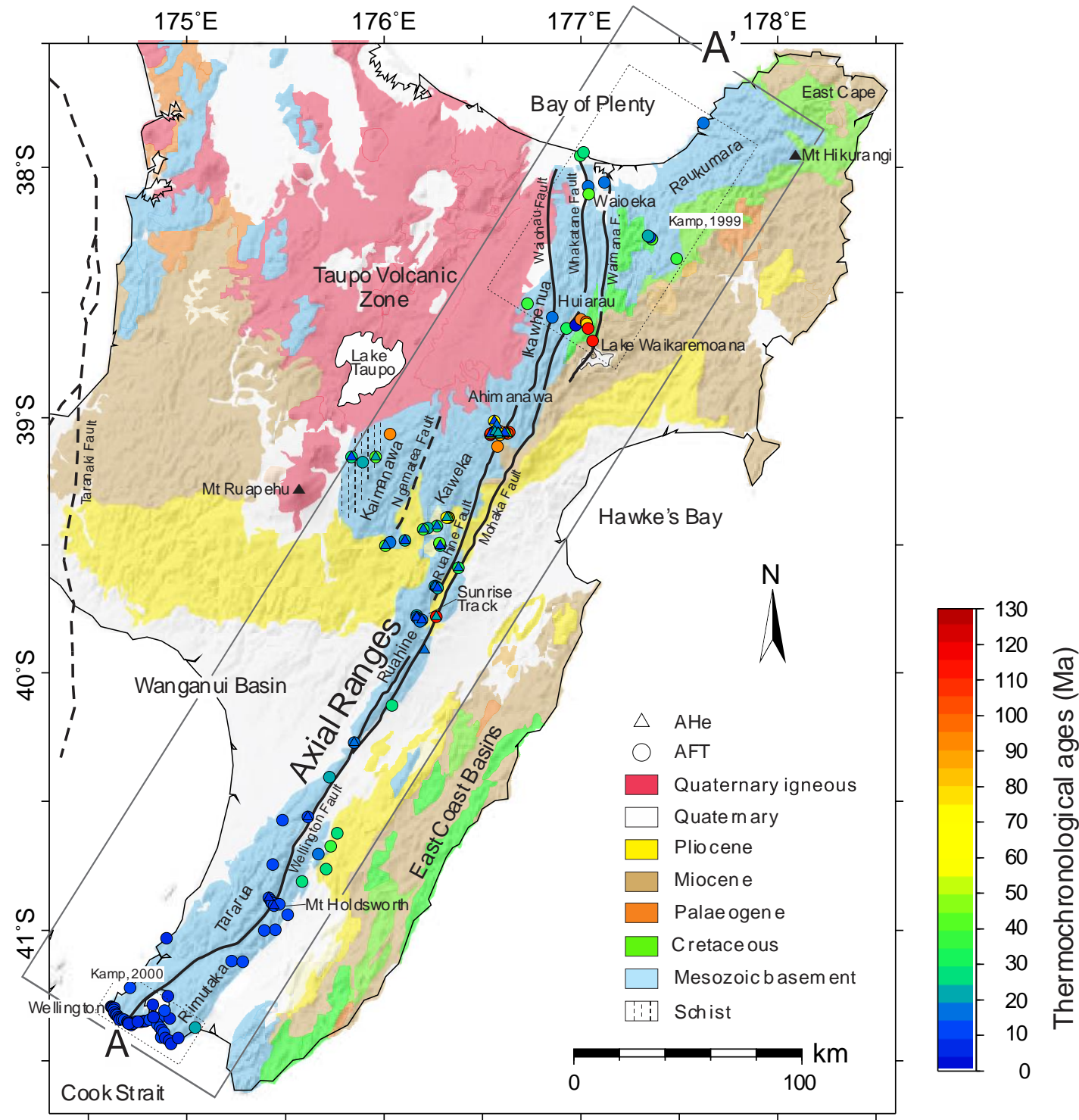

Fig. 3.3 Geological map of study area, simplified from the Geological Map of New Zealand 1: 1000 000, produced by GNS Science, New Zealand. Solid (active) and dashed (inactive) black lines depict major margin-parallel faults in the axial ranges. AFT and AHe age data from different localities, which are colour coded according to age are sourced from Kamp (1999), Kamp (2000) (enclosed by dotted boxes) and this study. Rectangle (A-A') depicts the location of transects in Fig. 3.4.

\subsection{Geological background}

\subsubsection{Tectonic setting}

The Hikurangi Margin of North Island of New Zealand, has been evolving since the Late Oligocene as a consequence of the south-westward subduction of the oceanic Pacific Plate beneath the continental Australian Plate (Fig. 3.2) (Ballance, 1976; Nicol et al., 2007; Rait et al., 1991; Stern et al., 2006). The margin represents a transitional segment of the larger Pacific-Australia plate boundary zone that interconnects the 
ocean-ocean subduction at the Kermadec Trench (Fig. 3.1b), to the north of North Island, to the continent-continent transpressive regime deforming the South Island, farther to the south (Fig. 3.1a). Along the modern Hikurangi Margin, the obliquity of plate convergence increases, and the rate of this convergence decreases southwards along the margin (Fig. 3.1b) (Beavan et al., 2002). The Pacific Plate that is entering the trough off the east coast of North Island is part of the Hikurangi Plateau, a portion of which has already been subducted. This plateau consists of anomalous oceanic crust that is higher and thicker than the more normal oceanic crust subducting along the margin farther north (e.g., at the Kermadec Trench; Fig. 3.1b). Using the current seismically resolved shape of the subducted slab (Reyners et al., 2011) and the finite rotation poles for Pacific-Australian motion (Schellart et al., 2006), Reyners (2013) estimated that the western edge of the Hikurangi Plateau first entered the trough at $\sim 10 \mathrm{Ma}$.

\subsubsection{Axial ranges and North Island Fault System}

In North Island, the axial ranges represent the primary frontal ridges on the hanging wall of the Hikurangi Margin. These mountains consist of the uplifted metasedimentary terrane rocks, predominantly greywacke, argillite and schists, which were accreted and intensely deformed in the accretionary wedge on the eastern Gondwana during the Mesozoic (Mortimer, 2004). Throughout the Late Cretaceous-Paleogene, the continent of North Island had been residing in a passive margin setting (e.g. Ballance, 1993). The sedimentary rocks that accumulated on the basement during this period are inferred to have been over $2 \mathrm{~km}$ thick in the region of the present central axial ranges (Jiao et al., 2014). Most of these cover sedimentary rocks were eroded during unroofing of basement rocks since the Late Oligocene. Only sparse erosional remnants of the cover are preserved atop the ranges in the northern part of the Hawke's Bay region (Fig. 3.3). In addition, some post-Oligocene sedimentary rocks outcrop in the axial ranges. In the Raukumara Range and the Ikawhenua and Huiarau Ranges in the north (Fig. 3.3), these include erosional remnants of OligoceneMiocene cover sequences exposed in the eastern side of the mountains, gently folded and generally dipping south-eastwards (Leonard et al., 2010; Mazengarb and Speden, 2000). In the central axial ranges, they consist of thin Late Miocene-Pliocene strata that overlie the Mesozoic accretionary basement in the south and east of the Kaimanawa and Kaweka Ranges (Beu et al., 1980; Beu et al., 1981; Beu, 1995; Lee et 
al., 2011). Farther south, in the Ruahine Range, uplifted Pliocene sequences occur sparsely on the western flank, gently dipping towards the northwest (Lee et al., 2011). These late Cenozoic dominantly marine sedimentary rocks indicate that the proto ranges resided at or about sea level in Oligocene to Miocene time, and have since been uplifted into the modern ranges.

The modern axial ranges are currently cut and bounded by a series of dextral strikeslip faults referred to as the North Island Fault System (NIFS; Fig. 3.1b) (Beanland, 1995; Beanland and Haines, 1998; Langridge et al., 2005; Mouslopoulou et al., 2007). Along the southern $350 \mathrm{~km}$ length of the NIFS, the faults strike NNE-SSW, generally parallel with the strike of the axial ranges (Fig. 3.3). Near the northern termination of the NIFS (in the Ikawhenua and Huiarau Ranges), the strikes of these faults change to N-S (Fig. 3.3). Among the active strike-slip faults in the NIFS, the WellingtonMohaka-Whakatane Fault is the most prominent and perhaps longest structure in the NIFS, traversing approximately $500 \mathrm{~km}$ from Wellington to the Bay of Plenty (Fig. 3.3). To the west of the major strands of the NIFS, the Ngamatea Fault (Fig. 3.3) separates the Kaimanawa Mountains to the west from the rest of the axial ranges to the east, but the history of its activity is little known (Spörli, 1987) and it is considered inactive at present (New Zealand Active Faults Database, GNS).

\subsubsection{Previous thermochronological work}

Previous thermochronological studies reported data in the axial ranges along several cross-strike transects (Fig. 3.3), comprising those on the Raukumara Peninsula (Kamp, 1999), along the Wellington coast (Kamp, 2000) and in the central region of the axial ranges (Jiao et al., 2014). ZFT ages in these studies, except those from the Kaimanawa Schist (Fig. 3.3), are usually detrital (or partially reset), indicating maximum burial temperatures of $<\sim 300{ }^{\circ} \mathrm{C}$ (the highest temperature of closure of the ZFT system). The previously published AFT ages (Figs. 3.3 and 3.4) generally decrease southwards from central to southern parts of the mountain chain, and also include some young ages near its northern tip (on the Raukumara Peninsula). The wide range of the reported AFT (122-4.4 Ma) and AHe (33.3-10.3 Ma) ages suggest various magnitudes of exhumation affecting different parts of the axial ranges. These results suggest variable depths of exposure of the basement, with structural levels spanning from within the pre-Late Oligocene AFT and AHe partial 
annealing/retention zones, to in some cases, tapping from below them. We seek to resolve this pattern in more detail and to understand its tectonic significance.

\subsection{Fission-track and (U-Th-Sm)/He data}

\subsubsection{Results}

AFT and AHe sample preparation and analyses follow the procedure as described in Appendix II.

New data for this study include 6 ZFT, 35 AFT (Table 3.1) and 11 accepted AHe (Table 3.2) ages from samples collected in the central and southern axial ranges. The ZFT ages range from $262 \pm 18$ to $102 \pm 21 \mathrm{Ma}$ (Table 3.1). In all but one case, the ZFT ages are older than, or overlap with, the stratigraphic ages (Middle JurassicEarly Cretaceous (Adams et al., 2007; Adams et al., 2009; Adams et al., 2012)) of the sampled basement rocks. This suggests that the rocks have not been fully reset since deposition and that they preserve at least partial detrital signatures. These ages are comparable with those reported from the northern (Kamp, 1999) and central axial ranges, excluding those in the Kaimanawa Schist (Jiao et al., 2014). Thus the ZFT ages only provide a maximum limit on the magnitude of the Cenozoic exhumation of the axial ranges of $\sim 7-11 \mathrm{~km}$, assuming a pre-orogenic geothermal gradient of $30{ }^{\circ} \mathrm{C} / \mathrm{km}$ (Jiao et al., 2014).

The AFT ages range between $112 \pm 18$ and $7.9 \pm 2.4$ Ma (Table 3.1), with a predominance of Oligocene-Miocene ages, recording thermal histories temporally associated with the evolution of the Hikurangi Margin. Only one Early Cretaceous age (112 Ma; JR12-27) was measured; this was from the northeast Ruahine Range, east of the Mohaka Fault. Due to the low densities of spontaneous tracks (age and uranium dependency), confined tracks are very rare in most samples; the mean track lengths of 7 measured samples range between $12.08 \pm 2.03$ and $14.42 \pm 1.10 \mu \mathrm{m}$ (Table 3.1).

The AHe data yield ages between $23.1 \pm 6.5$ and $6.0 \pm 0.7$ Ma with intra-sample dispersions of $2-68 \%$. The dispersion quoted here equals the range of the single-grain ages divided by the arithmetic mean (Brown et al., 2013). Generally, ages young southwards, with older ages in the Ruahine Range (23.1-11.3 Ma) compared to the Tararua Range (13.5-6.0 Ma). 


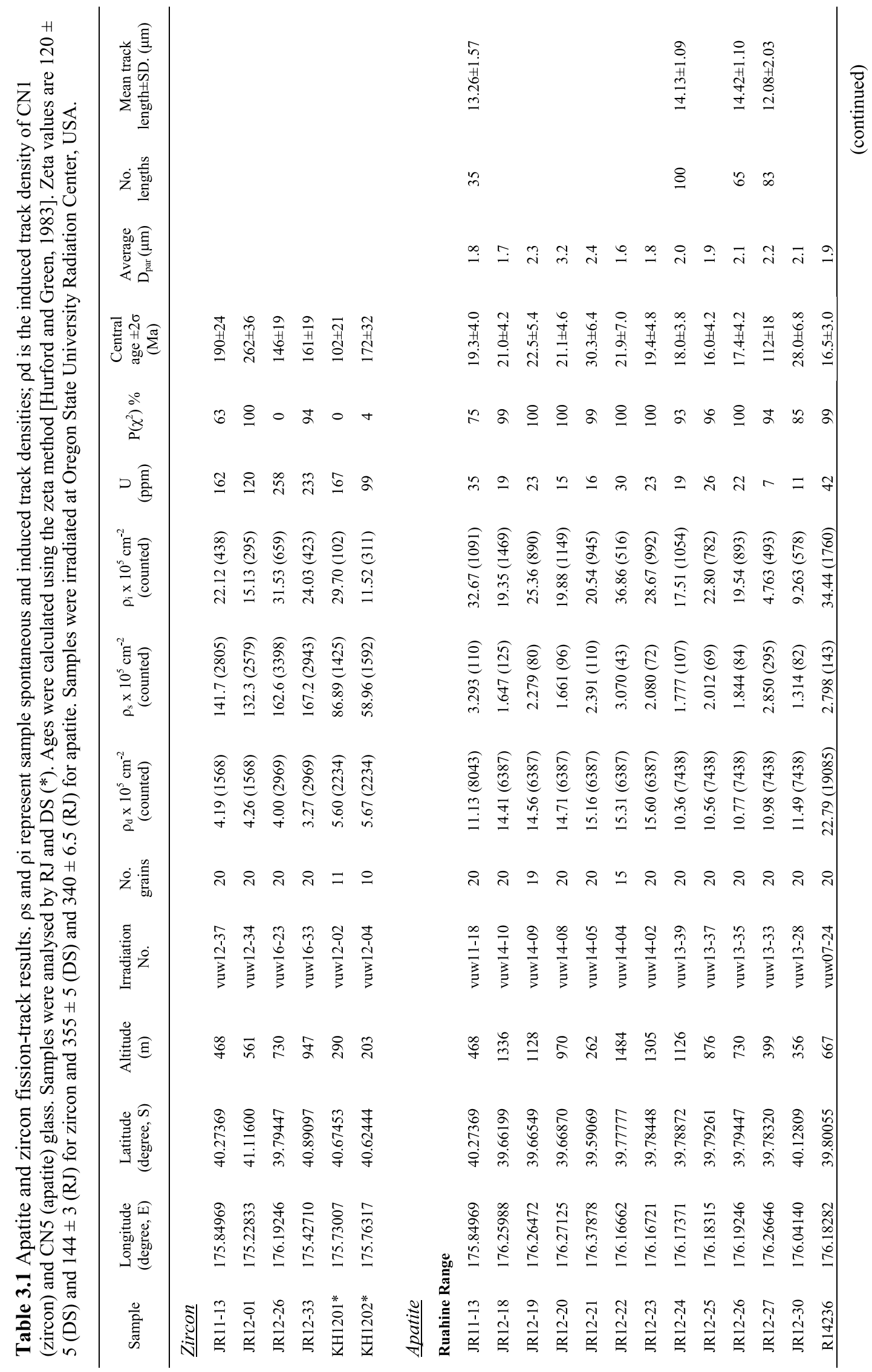




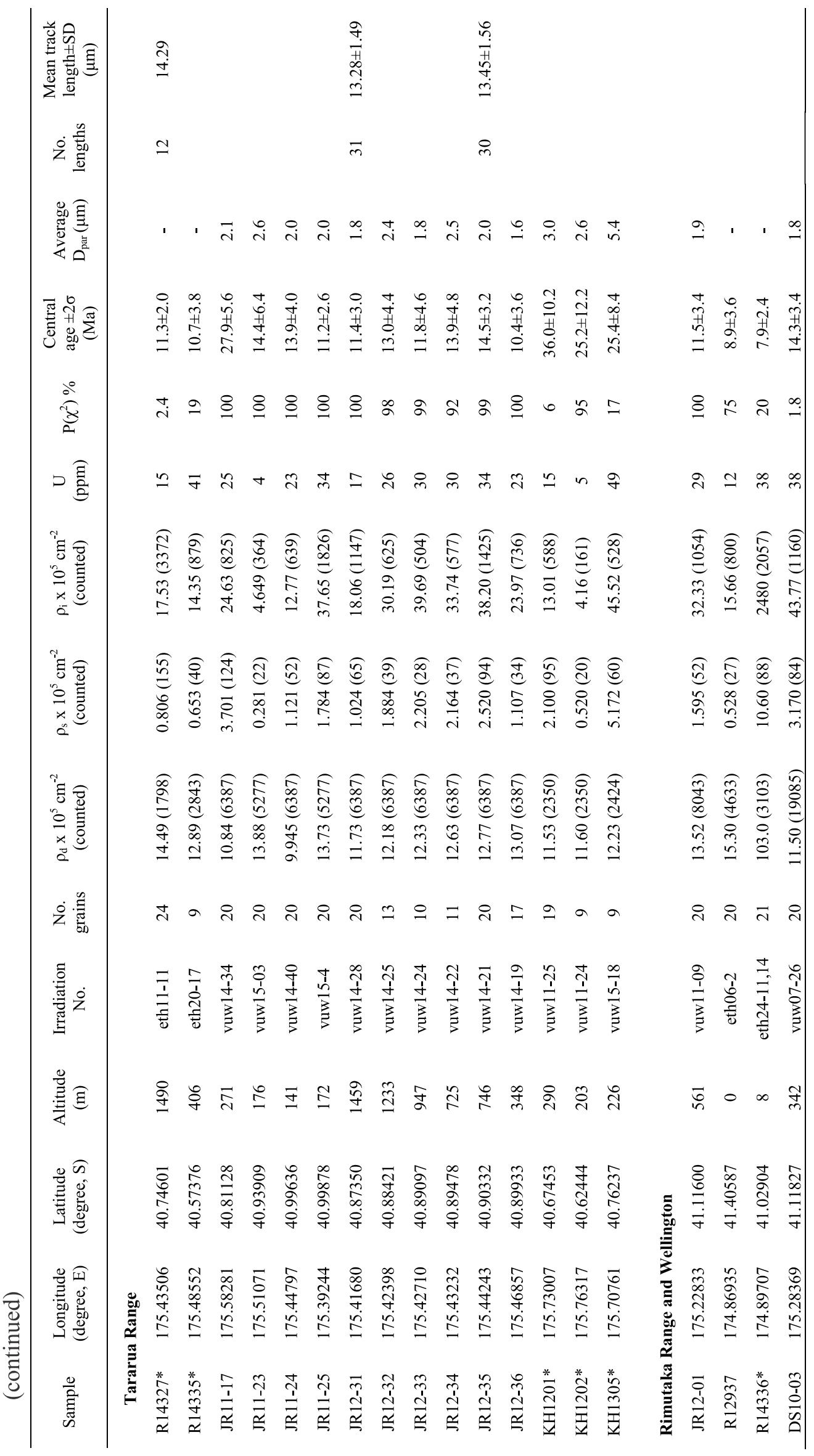




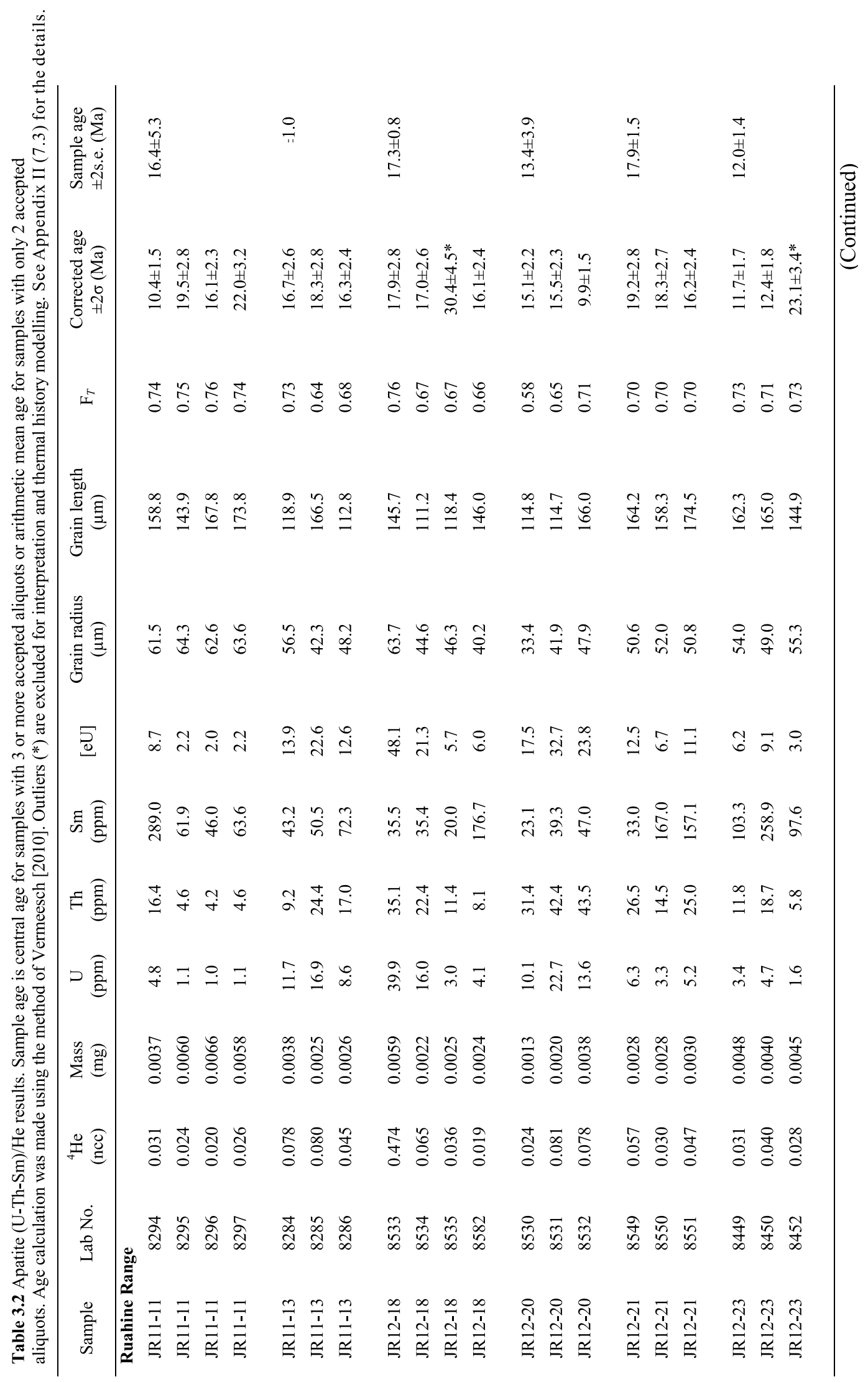




\begin{tabular}{|c|c|c|c|c|c|}
\hline 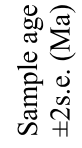 & & 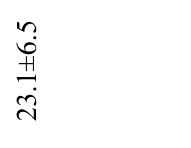 & $\begin{array}{l}\stackrel{0}{1} \\
\text { in } \\
\stackrel{\omega}{2} \\
\end{array}$ & 仓े & $\begin{array}{l}\stackrel{0}{0} \\
\text { 苗 } \\
\text {. }\end{array}$ \\
\hline 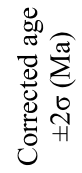 & 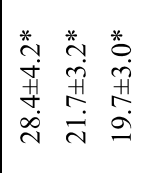 & 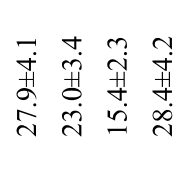 & 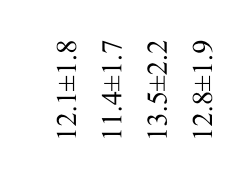 & 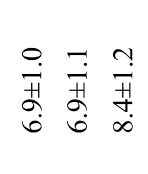 & 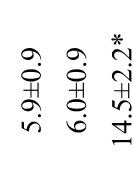 \\
\hline 庄 & \begin{tabular}{lll}
$n$ & \multirow{2}{*}{} & $R$ \\
0 & 0 \\
0
\end{tabular} & \begin{tabular}{llll}
$\infty$ & $\infty$ & $n$ & $\infty$ \\
\hdashline & $\infty$ & 0 & 0 \\
0 & 0 & 0 & 0
\end{tabular} & 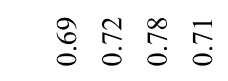 & $\begin{array}{lll}n & 0 & \infty \\
0 & 0 & 0 \\
0 & 0\end{array}$ & 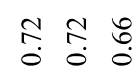 \\
\hline 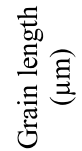 & 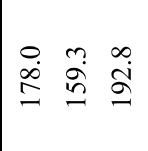 & 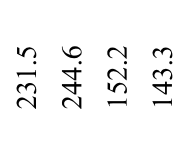 & 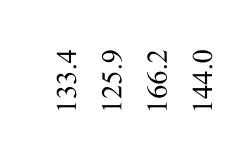 & 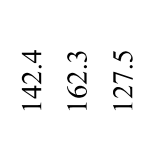 & 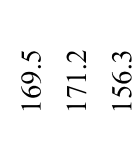 \\
\hline 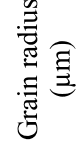 & 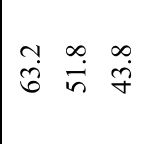 & 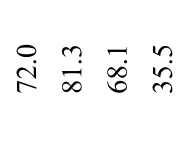 & 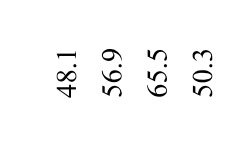 & $\overrightarrow{i ் ~} \frac{n}{b}$ ò & 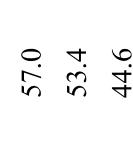 \\
\hline S & $\begin{array}{lll}m & \infty & \infty \\
\infty & \stackrel{n}{r} & \stackrel{+}{+}\end{array}$ & $\stackrel{\circ}{\dot{ \pm}} \stackrel{\sim}{i} \stackrel{\sim}{+} \stackrel{?}{r}$ & 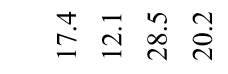 & $\stackrel{r}{\stackrel{0}{ \pm}} \stackrel{m}{=}$ & $\begin{array}{lll}\vec{i} & \stackrel{n}{n} \\
m & \stackrel{n}{n} & n\end{array}$ \\
\hline 호흥 & $\begin{array}{lll}0 & \infty & \infty \\
\dot{\delta} & \stackrel{0}{0} & \infty \\
0 & \infty & \infty \\
+\end{array}$ & 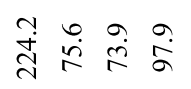 & 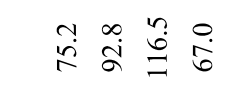 & گृ & 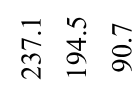 \\
\hline ت & 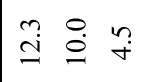 & $\vec{\infty} \stackrel{\sim}{\sim} \stackrel{\infty}{\sim} \stackrel{m}{0} \stackrel{m}{=}$ & $\stackrel{m}{m} \stackrel{m}{=} \stackrel{n}{=} \stackrel{m}{n}$ & $\underset{n}{n} \stackrel{0}{m} \underset{m}{m} \stackrel{+}{\infty}$ & 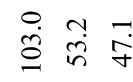 \\
\hline$\supset$ हू영 & $\ddot{n} \stackrel{\dot{n}}{\dot{m}}$ & 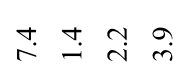 & 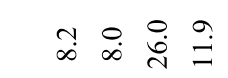 & $\stackrel{m}{\rightarrow} \underset{\infty}{+} \stackrel{0}{b}$ & 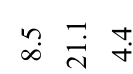 \\
\hline 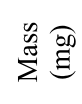 & 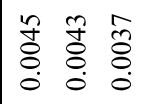 & 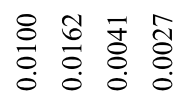 & 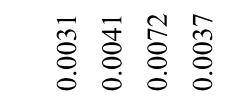 & 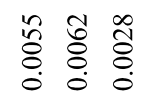 & 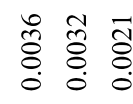 \\
\hline 串 & $\mid \begin{array}{lll}\infty & \overline{0} & 0 \\
0 & 0 \\
0 & 0 & 0 \\
0 & 0 & 0\end{array}$ & $\begin{array}{llll}n & n & \infty & \infty \\
\hat{n} & 0 & 0 & 0 \\
0 & 0 & 0 & 0 \\
0 & 0 & 0\end{array}$ & 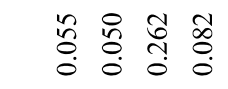 & $\begin{array}{lll}\bar{n} & 0 & 0 \\
0 & 0 & 0 \\
0 & 0 & 0 \\
0\end{array}$ & $\begin{array}{lll}\overrightarrow{0} & \tilde{n} & \infty \\
0 & 0 \\
0 & 0 \\
0 & 0\end{array}$ \\
\hline$\dot{z}$ & 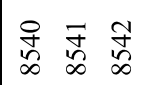 & 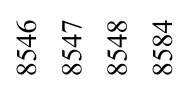 & 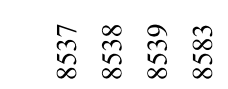 & 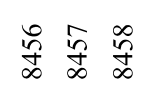 & 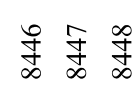 \\
\hline 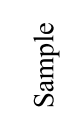 & 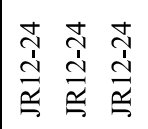 & 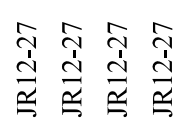 & 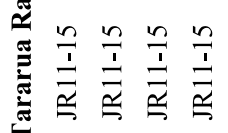 & 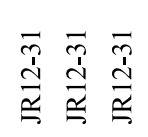 & 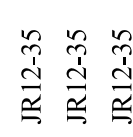 \\
\hline
\end{tabular}




\subsubsection{Distribution of AFT and AHe ages in the axial ranges}

All existing (Jiao et al., 2014; Kamp, 1999; Kamp, 2000) and new AFT and AHe ages of the basement rocks in the axial ranges are presented in Fig. 3.3 and are also projected onto an along-strike transect in Figs. 3.4a and 3.4b. Fig. 3.5 summarises the relationship between AFT age and mean track length of all samples. These data stretch nearly $500 \mathrm{~km}$ along strike and sample the full width and relief of the axial ranges, while crossing the Wellington, Mohaka, Ngamatea and several other marginparallel faults (Fig. 3.3). The age variation of these samples reflects a combination of sample elevation differences, varying palaeo-geothermal gradient, displacement on faults, and spatial change in exhumation processes. The first-order features of the age pattern emerging from this data set can be described as follows (Figs. 3.3 and 3.4):

(1) In the south (from 0 to $200 \mathrm{~km}$ on the transect; Fig. 3.4), all AHe and all but one AFT ages are younger than $\sim 30 \mathrm{Ma}$. Where both were measured, paired AFT and AHe sample ages yield small age differences (0.3-12 Myr). These ages increase gradually northwards from Wellington into the southern Ruahine Range. AFT ages west of the Wellington-Mohaka Fault (Fig. 3.3) are generally younger than those to the east of that fault for samples at the same distance along the transect (Fig. 3.4b), even though the eastern ages are often from lower elevations where without structural perturbation the thermochronometers should reveal younger ages. This difference in the apparent AFT ages across the fault increases northwards from <5 Myr along the Wellington coast to 10-20 Ma in the Tararua Range.

(2) In the central axial ranges (from 200 to $350 \mathrm{~km}$; Fig. 3.4), both AHe and AFT ages increase more rapidly northwards (Fig. 3.4b) albeit at different rates. Some of the oldest (Early Cretaceous) AFT and AHe ages in the axial ranges occur in the Ahimanawa Range (Figs. 3.3 and 3.4). No data is available to the east of the Mohaka Fault in this sector, because the basement rocks are not extensively exposed. 

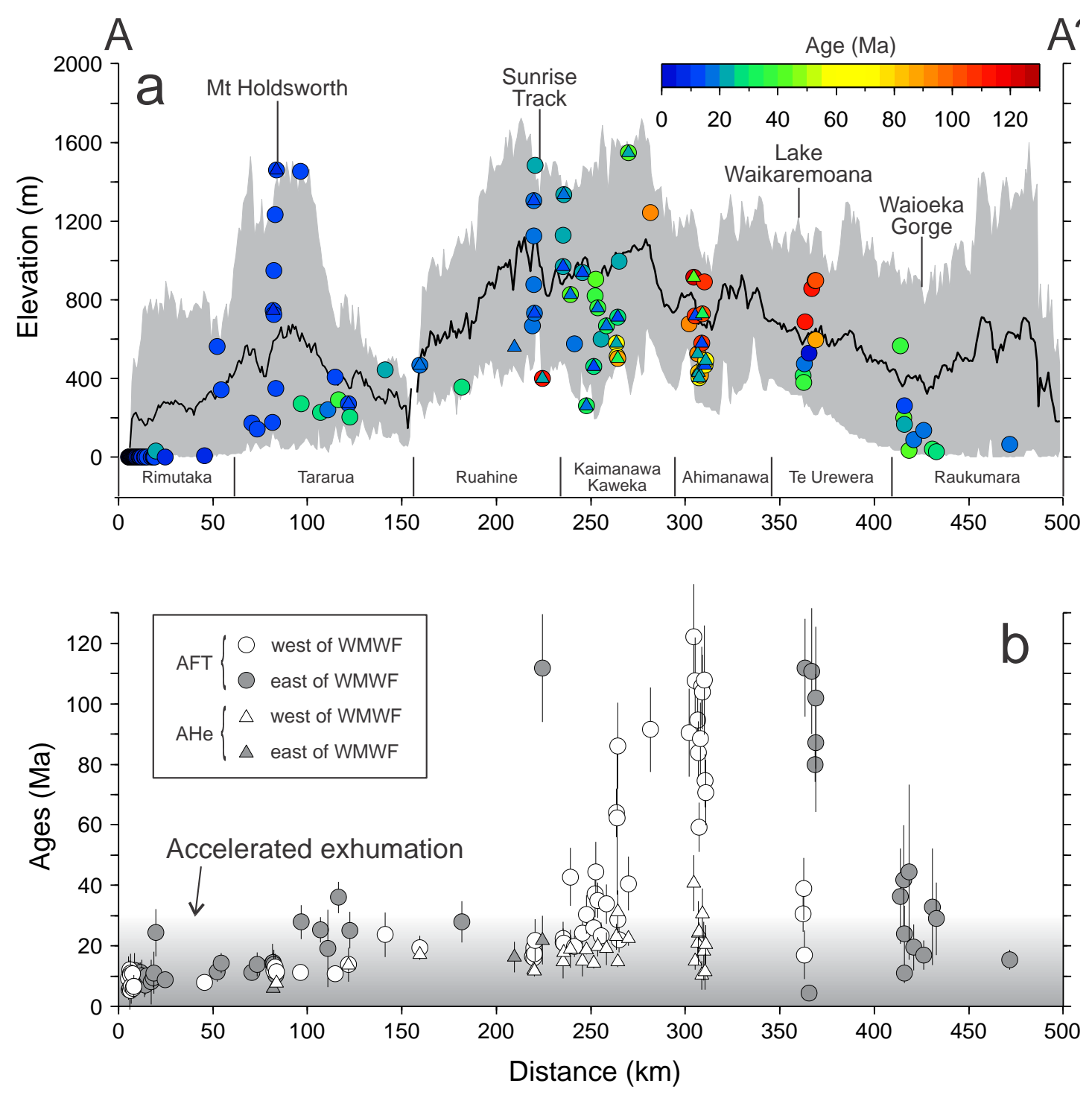

Fig. 3.4 Variation of AFT and AHe ages along the strike of axial ranges. (a) Topographic profile along the strike of the axial ranges showing AFT and AHe ages (coded by colour). Location of the transect is shown in Fig. 3.3. Grey region indicates elevations of the axial ranges; black line is the mean elevation. AFT and AHe ages and sample elevations are shown. (b) Variation in thermochronology ages along the range strike of axial ranges. Data are differentiated according to their positions with respect to the Wellington-Mohaka-Whakatane Fault (WMWF). Grey shade indicates ages related to the accelerated exhumation at the Hikurangi Margin.

(3) In the northern axial ranges (north of $350 \mathrm{~km}$; Fig. 3.4), AFT ages decrease northwards. In this region, the NIFS embraces several major faults, including the Waiohau, Whakatane and Waimana Faults (Fig. 3.3), and intersects the eastern Taupo rift system-Taupo Volcanic Zone (Figs. 3.1b and 3.3) (Mouslopoulou et al., 2007). Near Lake Waikaremoana (Figs. 3.3 and 3.4a), AFT ages to the west of the Whakatane Fault (except one age of 4.4 Ma near 
the fault scarp) are younger than those to the east of the fault. The competing effects of slip on these rift-associated Quaternary faults may contribute to the relatively large variation (>100 Myr) of the AFT ages in this sector. In the Raukumara Range (north of $400 \mathrm{~km}$; Fig. 3.4), data are only available to the east of the NIFS, where the basement rocks are exposed onshore.

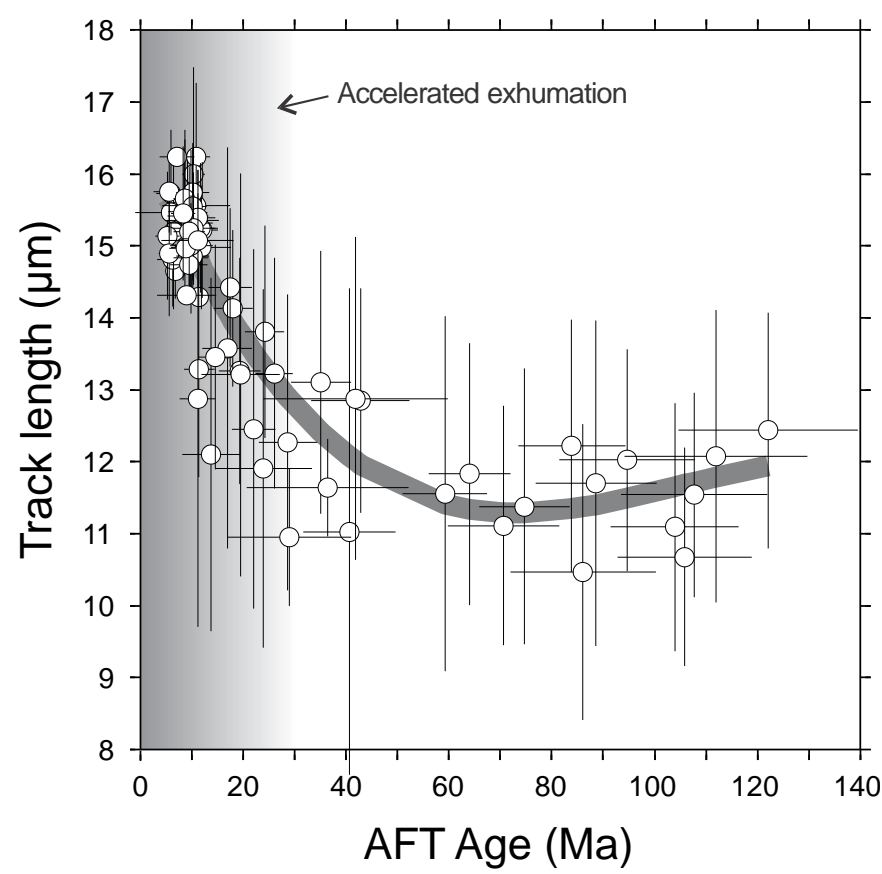

Fig. 3.5 Boomerang plot of AFT age versus mean track length, indicating a general phase of accelerated cooling and exhumation since the Late Oligocene.

\subsection{Thermal history models}

The age-elevation relationship is a conventional method for the inference of exhumation rates and timing of cooling acceleration, (e.g. Blythe et al., 2007; Fitzgerald et al., 1995). However, Sobel et al. (2006) demonstrated that apatites with various resistances to annealing could yield very different ages under the same cooling paths, and on a vertical profile, these ages may represent age-elevation relationships that are more complicated than linear curves. Furthermore, the shape of an age-elevation plot is dependent on several factors (e.g. thermal history prior to final cooling, maximum temperature of reheating, cooling rate and geothermal gradient) (Prenzel et al., 2013), so the break in slope of an age-elevation curve may be unreliable for accurately determining the acceleration/change in cooling rates. Therefore, rather than employing an interpretation directly from apparent ageelevation relationships, we derive the thermal histories by modelling of the AFT and 
AHe data on vertical profiles. Inverse modelling is applied to data of "stacked" or individual samples from the Tararua, Ruahine, Ikawhenua and Huiarau Ranges and Raukumara Ranges.

We use the programme QTQt (Gallagher, 2012) for thermal history modelling, with the multi-kinetic annealing model of Ketcham et al. (2007) for the simulation of AFT data and radiation damage accumulation and annealing model of Flowers et al. (2009) for AHe data. The inversion sampler (Gallagher et al., 2009) uses a Bayesian Markov chain Monte Carlo (MCMC) method, which favours simpler solutions and thus minimises problems of over-interpretation. Detailed introduction and demonstration of the inverse modelling approach are given by Gallagher et al. (2009) and Gallagher (2012). For new data obtained from the Tararua and Ruahine Ranges, we use the mean Dpar (etch pit diameter parallel to the c-axis of crystal)(Donelick, 1993) measurement on each grain as a proxy for the apatite compositional parameter; for data from the Ikawhenua and Huiarau Ranges and Raukumara Range (Kamp, 1999), the average chlorine content of all samples is used. Inverse modelling has been conducted for a time span from 150 to $0 \mathrm{Ma}$ in the temperature range between $150^{\circ}$ and $0{ }^{\circ} \mathrm{C}$. In order to derive an unbiased inference of the thermal history from the thermochronological data, we employ no pre-defined constraints on the inverse models except for the present surface temperature of $20 \pm 10^{\circ} \mathrm{C}$. For thermal histories represented in this paper, each inversion comprises at least 100000 burn-in and 100 000 post-burn-in iterations to ensure consistent sampling from a stationary probability distribution (see discussion in Gallagher (2012)). Fig. 3.6 represents the expected thermal histories since 100 Ma predicted by the inverse modelling.

\subsubsection{Wellington coast}

We did not inverse model the data from the Rimutaka Range (This study) and Wellington region (Kamp, 2000), due to the lack of suitable apatite crystals for AHe analysis, low spontaneous fission-track densities and hence insufficient confined tracks that can be measured in the apatites. However, the young AFT ages (12.7-5.3 Ma) and long AFT mean track lengths $(14.3-16.2 \mu \mathrm{m})$ along the Wellington coast (Kamp, 2000) imply rapid cooling since at least the Late Miocene. For samples to the west of the Wellington Fault, partially rest ZFT ages (232-143 Ma) (Kamp, 2000) provide an upper limit for the pre-orogenic temperature of $\sim 210-260{ }^{\circ} \mathrm{C}$. 


\subsubsection{Tararua Range (Mount Holdsworth)}

Along the eastern flank of the central Tararua Range, the Mount Holdsworth (Figs. 3.3 and 3.4) profile comprises three samples (JR12-31 to -33) to the west of the Wellington Fault and four to the east (JR12-34 to -36 and JR11-23). The sample sites represent $\sim 1.3 \mathrm{~km}$ difference in elevation within $\sim 8 \mathrm{~km}$ horizontal distance, and samples to the west of Wellington Fault were collected from higher elevations than to the east (Table 3.1). All samples yield similar AFT ages (14.5-10.4 Ma; Table 3.1); AHe ages of two samples (7.5-6.7 Ma; Table 3.2) also overlap within error.

To the west of the Wellington Fault, the modelling results (Fig. 3.6a) suggest an accelerated cooling phase since at least Early Miocene (prior to $15 \mathrm{Ma}$ ), continuing to the present day. The onset of this cooling phase cannot be further constrained independently from the present data set, because prior to $15 \mathrm{Ma}$, the samples were at temperatures $>120{ }^{\circ} \mathrm{C}$, beyond the scope of the AFT and AHe thermochronology.

Thermal histories for samples to the east of the Wellington Fault (Fig. 3.6b) are constrained since 40 Ma. During the Oligocene and Early Miocene, it is clear that these rocks were at lower paleotemperatures $\left(80-120^{\circ} \mathrm{C}\right)$, at shallower levels in the crust, compared to those to the west (at temperatures $>120{ }^{\circ} \mathrm{C}$ ), despite the latter being collected from higher elevations in the present mountain range. Since Late Miocene ( $10 \mathrm{Ma})$, our thermal history models suggest a phase of accelerated cooling at rates up to $10{ }^{\circ} \mathrm{C} / \mathrm{Myr}$, continuing into the present.

Fig. 3.6 Schematic unroofing pattern of the axial ranges. Map shows principal tectonic features that are inferred to contribute to the uplift and unroofing of the axial ranges. Regions of crustal shortening and extension since $5 \mathrm{Ma}$ are according to Nicol et al. (2007). Thick dotted lines depict approximate zones where underplated material has been imaged on geophysical transects. Distribution of underplating beneath the northern and central axial ranges is taken from Litchfield et al. (2007). Underplating beneath the southern axial ranges is sketched according to Henrys et al. (2013). Black dots indicate sample sites of modelled data. (a-i) Temperature-time (T-t) models of the basement rocks from different regions. T-t paths of the uppermost (blue) and lowermost (red) samples are shown in heavy lines, with their $95 \%$ credible intervals. Grey bars highlight the timing of active cooling/exhumation. AFT PAZ and AHe PRZ are approximate for standard Durango apatites. Panel of (f) the Kaweka Range summarises five weighted-mean inverse models (Fig. 2.7) with no credible intervals shown. Thermal histories of (h) the Ikawhenua and Huiarau Ranges and (i) the Raukumara Range are modelled based on the data of Kamp (1999). 


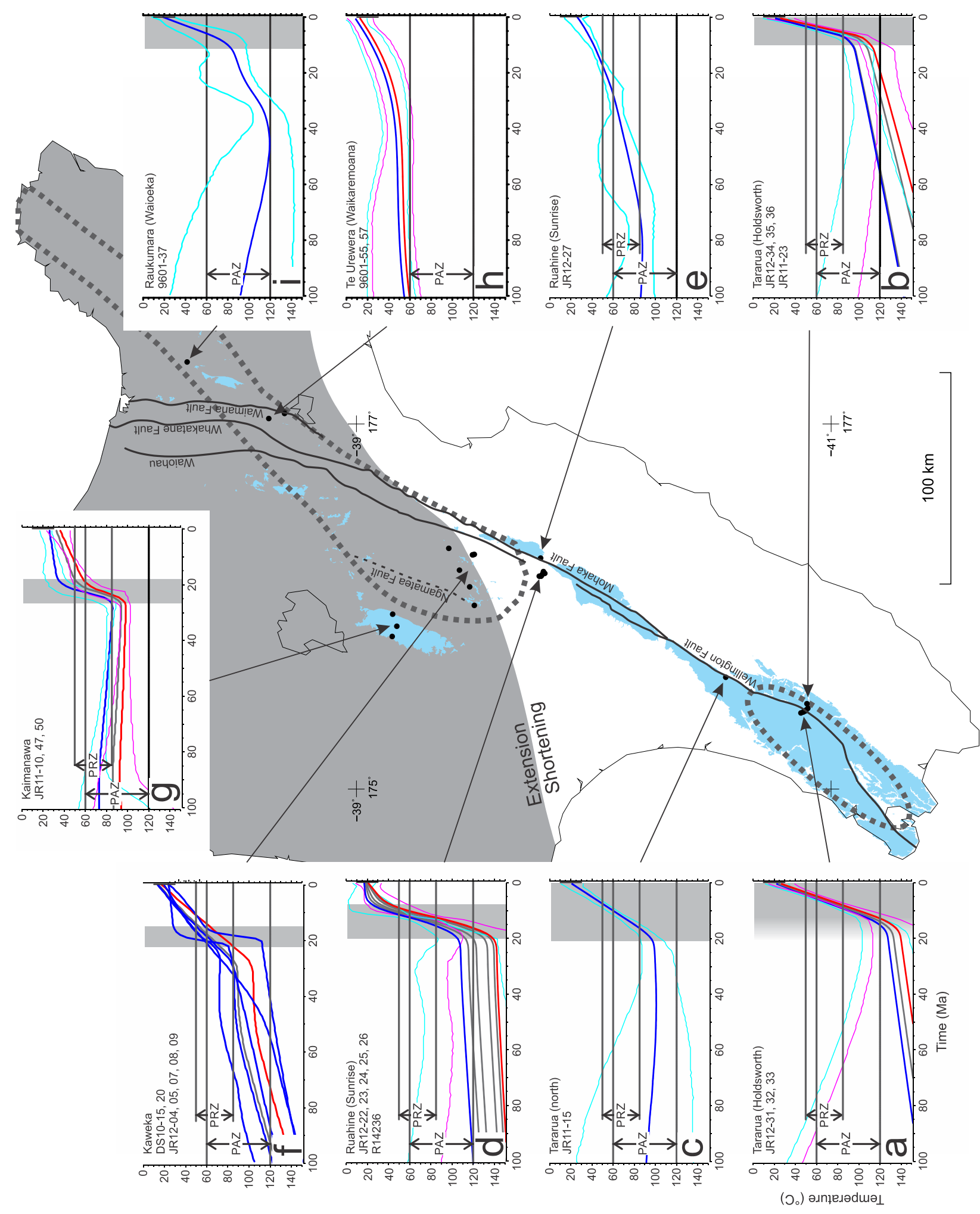




\subsubsection{Tararua Range (north)}

In the north of the Tararua Range (Fig. 3.3), we model the thermal history of an individual sample (JR11-15) using its AFT age, track length and AHe data. Similar to thermal history models from the Mount Holdsworth section, the modelling results of this sample (Fig. 3.6c) provide little constraint on the thermal history prior to $40 \mathrm{Ma}$. During the Oligocene, the sample is inferred to have resided at temperatures between 85 and $120{ }^{\circ} \mathrm{C}$. From $\sim 21 \mathrm{Ma}$, the expected thermal history shows a phase of accelerated cooling at rates up to $5-6{ }^{\circ} \mathrm{C} / \mathrm{Myr}$, continuing to the present.

\subsubsection{Ruahine Range (Sunrise Track)}

In the Ruahine Range, thermal history modelling was carried out for samples along the Sunrise Track (Figs. 3.3 and 3.4) on both sides the Mohaka Fault. To the west of the Mohaka Fault, modelling incorporates data of six samples (JR12-22 to -26 and R14236), including AFT ages from all six samples, AFT track-length data from two (Table 3.1) and AHe ages from two (Table 3.2). The modelling results (Fig. 3.6d) suggest that samples were within the lower part of, or below, the apatite partial annealing zone (PAZ) prior to the Early Miocene. Cooling rates of these samples are inferred to increase at around $20 \mathrm{Ma}$ and the accelerated $\left(>6^{\circ} \mathrm{C} / \mathrm{Myr}\right)$ cooling phase continued until the Late Miocene.

To the east of the Mohaka Fault, we simulate the thermal history from AFT and AHe data of a single sample (JR12-27). The results (Fig. 3.6e) suggest that this sample had cooled to $<100{ }^{\circ} \mathrm{C}$ by the Late Cretaceous, followed by a long period of slow $\left(<2{ }^{\circ} \mathrm{C} / \mathrm{Myr}\right)$ and monotonic cooling, reaching the upper boundary of the partial retention zone (PRZ) between 20 and $15 \mathrm{Ma}$.

\subsubsection{Ikawhenua and Huiarau Ranges (Waikaremoana)}

For many samples of Kamp (1999) in this region, the number of track lengths is less than optimal (<30 measurements) for thermal history modelling and some of the forward models were over complicated with fluctuations of T-t paths outside the apatite PAZ, a result that may have led to over-interpretation of the data. To further investigate the resolution of this data set, we apply inverse modelling to two samples 9601-55 and -57 (Kamp, 1999) on which 99 and 78 AFT lengths were measured, respectively. These samples are located between the Whakatane and Waimana Faults. 
The modelling results (Fig. 3.6h) suggest that the samples have resided at near-surface temperatures of $<60{ }^{\circ} \mathrm{C}$ since the Late Cretaceous, without any subsequent reheating into the PAZ. This is a similar cooling pattern, albeit at a lower temperature and perhaps a shallower structural position, to the thermal history inferred from the sample to the east of Mohaka Fault in the Ruahine Range (Fig. 3.6e). In comparison with the forward modelling results of Kamp (1999), who imposed a Late OligoceneEarly Miocene ( 26-12 Ma) phase of reheating to $\sim 85^{\circ} \mathrm{C}$ in the thermal models due to inferred basement downwarping and sedimentation, our results suggest that such a reheating event is not necessary to reconcile the AFT data.

\subsubsection{Raukumara Range (Waioeka Gorge)}

In the Raukumara Range, we chose to model sample 9601-37 (Kamp, 1999), which has the most measured track lengths (46 measurements) from the Waioeka Gorge (Figs. 3.3 and 3.4). The modelled thermal history (Fig. 3.6i) suggests large uncertainties on the thermal history prior to $40 \mathrm{Ma}$, when the sample was possibly in or below the PAZ for a long period. Our modelling results predict slow cooling $\left(<2{ }^{\circ} \mathrm{C} / \mathrm{Myr}\right)$ during the late Paleogene to Early Miocene. Accelerated cooling is inferred to start in the Middle Miocene ( 12 Ma) and to continue to the present, at rates up to $\sim 7^{\circ} \mathrm{C} / \mathrm{Myr}$. Our inverse modelling does not simulate that of Kamp (1999), who predefined an event of burial and reheating to $\sim 110{ }^{\circ} \mathrm{C}$ between 26 and $12 \mathrm{Ma}$ on his thermal model.

\subsection{Inferred history of unroofing in the axial ranges}

We here interpret the pattern of basement cooling and unroofing of the eastern North Island during the evolution of the Hikurangi Margin in the late Cenozoic, based on our inverse modelling of the AFT and AHe data from the axial ranges.

\subsubsection{Initial unroofing}

All thermal history models (Fig. 3.6) of the basement rocks in the axial ranges suggest insignificant temperature change $\left(<2{ }^{\circ} \mathrm{C} / \mathrm{Myr}\right)$ throughout the Late Cretaceous and Paleogene, until the Late Oligocene-Early Miocene when an acceleration in cooling rates are noted in most models. The pre-Oligocene phase of thermal quiescence is related to the passive margin setting of the continental fragment of New Zealand, as it drifted away from the Gondwana margin (Ballance, 1993). During this period, the 
Mesozoic basement terranes of North Island, including the proto-axial ranges, were possibly overlain by Cretaceous and younger sedimentary sequences. These Late Cretaceous-Paleogene sedimentary rocks are now only preserved in the ranges north of Hawke's Bay (Fig. 3.3) and have been eroded from elsewhere in the axial ranges. In the central part of axial ranges, the burial (1-2 km thick) of the basement rocks in the passive margin setting has been identified by integrated modelling of AFT and AHe that were sampled on high relief profiles (Fig. 3.6g) (Jiao et al., 2014). In the other parts of the ranges, we do not observe thermal records related to the reheating from the present data set, due to the high magnitude of later cooling (from temperatures $>100{ }^{\circ} \mathrm{C}$ ) during the late Cenozoic; more AFT and AHe ages along high relief profiles may help reveal more details in the thermal histories.

In a large scale view, the AFT age vs. mean track length plot of all samples (Fig. 3.5) clearly indicates a general phase of accelerated cooling and exhumation of the forearc basement since the Late Oligocene-Early Miocene (30-20 Ma). We suggest that this cooling/exhumation is related to the initiation of subduction of the Pacific Plate beneath the North Island, in agreement with the timing inferred from dating of the arc magmatism in northern New Zealand (Ballance, 1976) and the intense fore-arc deformation documented in the onshore sector of the margin (Rait et al., 1991).

In the centre and south of the axial ranges, the initial unroofing of the basement also presents differences in thermal histories across the margin-parallel Ngamatea and Wellington-Mohaka Faults.

(1) Based on thermal history modelling, the earliest basement unroofing of the axial ranges occurred at $\sim 27 \mathrm{Ma}$ in the Kaimanawa Mountains (Fig. 3.6g)(Jiao et al., 2014), which is located to the west of the Ngamatea Fault and is the westernmost structural block of the present frontal ridges. Between the Ngamatea and Wellington-Mohaka Faults, the onsets of accelerated cooling and exhumation are estimated to have occurred just prior to or at $\sim 20 \mathrm{Ma}$ (Figs. $3.5 \mathrm{c}, 3.5 \mathrm{~d}$ and $3.5 \mathrm{f})$.

(2) For basement rocks to the east of Wellington and Waimana Faults, our thermal history models suggest that the basement cooling and exhumation accelerated around $\sim 12-10 \mathrm{Ma}$ in the Tararua (Fig. 3.6b) and Raukumara (Fig. 3.6i) Ranges. In the Ruahine Range (Fig. 3.6e) and the Ikawhenua and Huiarau 
Ranges (Fig. 3.6h), we identify no significant change in the cooling/exhumation rates over the last 100 million years for rocks to the east of Mohaka and Whakatane Faults.

Kamp (1999), in a fission-track study in the northern axial ranges, proposed a phase of basement downwarping and subsequent uplift in the fore-arc of the Hikurangi Margin associated with the initiation of Pacific subduction beneath the northeastern North Island, and suggested that this localised vertical tectonics propagated southwards along the margin. When considering the entire length of the axial ranges however, we suggest that the unroofing of the basement rocks did not propagate along the ranges towards the south or southwest. This inference is based on the onsets of the exhumation phases since the Late Oligocene indicated by our inverse modelling. We further propose that propagation of post-Oligocene crustal unroofing of the eastern North Island has instead been transverse and towards the trough.

In the central and southern axial ranges, a trough-ward migration of basement unroofing is evident from the thermal history models. The exhumation of the Kaimanawa Mountains was possibly achieved through eastward reverse faulting on the Ngamatea Fault prior to 20 Ma. In the Ruahine and Tararua Ranges, differential exhumation prior to $\sim 10 \mathrm{Ma}$ implies significant eastward reverse faulting on the Wellington-Mohaka Fault in the Early Miocene. Assuming a pre-orogenic geothermal gradient of $30{ }^{\circ} \mathrm{C} / \mathrm{km}$ (Jiao et al., 2014), the total thickness of denuded rocks (since the Late Oligocene) to the west of the Wellington-Mohaka Fault has been approximately $1-2 \mathrm{~km}$ more than that to the east. This inference supports the deformation history of the Wellington-Mohaka Fault interpreted by Beanland (1995), who suggested that this active strike-slip fault was inherited from an older reverse fault that was active in the Miocene.

In the northern axial ranges, we do not have thermal history models to the west of the Whakatane Fault, and the distribution of the AFT ages related to the early episode of the basement unroofing may be disturbed by displacement and reheating related to the Quaternary back-arc rifting in the TVZ (Fig. 3.1b) (Mouslopoulou et al., 2007). However, in the Ikawhenua and Huiarau Ranges (Waikaremoana), the AFT ages also generally increase towards the southeast across the faults in the NIFS (Kamp, 1999), representing a comparable age pattern with that in the northern Ruahine Range (Fig. $3.4 b)$. 


\subsubsection{Change of exhumation rates in the Late Miocene}

Since the Late Miocene, there has been a significant along-strike change in exhumation rate in the eastern North Island. We infer that the change of exhumation rate in the trough-normal orientation across the present axial ranges has become less significant over time.

The exhumation of the Kaimanawa (Fig. 3.6g) and Kaweka Ranges (Fig. 3.6f) in the central North Island slowed down around 17 and $15 \mathrm{Ma}$, respectively. Farther to the south in the Ruahine Range, west of the Mohaka Fault, the predicted cooling rates also decreased in the Late Miocene ( 7 Ma). By then, most samples from the central part of the axial ranges had cooled to $<50{ }^{\circ} \mathrm{C}$ and had been exhumed to the near surface $(<2 \mathrm{~km}$ depth). These predictions are in general agreement with the Neogene sedimentary histories in these regions. In the Kaimanawa and northern Ruahine Range, long-term erosion of the Torlesse Supergroup basement rocks is implied by an extensive erosion surface, which is inferred to have developed since the MiocenePliocene (Lee et al., 2011). On the southern and eastern flanks of the Kaimanawa, Kaweka and Ahimanawa Ranges a thin cover of Late Miocene and Pliocene shallow marine rocks directly overlie the Mesozoic basement (Fig. 3.3), indicating marine transgression of the central-eastern North Island (Browne, 2004; Lee et al., 2011). Early Pliocene marine sedimentary rocks also perch on the ridges in the north of the Ruahine Range (Fig. 3.3) (Beu et al., 1980; Beu et al., 1981; Beu, 1995) and exist in the lowlands in the Ikawhenua and Huiarau Ranges (Leonard et al., 2010). These remnants of marine deposits in the axial ranges reflect episodic subsidence followed by surface uplift (Lee et al., 2011), but with only small magnitudes $(<1 \mathrm{~km})$ of burial and erosion of the basement rocks leading to little impact on the thermal history models.

In contrast, the basement exhumation continued in the northern and southern axial ranges subsequent to the Late Miocene. In the Raukumara and Tararua Ranges, we infer active and relatively constant basement denudation during the last $\sim 10 \mathrm{Myr}$, leading to cooling of the basement at an average rate of $>6{ }^{\circ} \mathrm{C} / \mathrm{Myr}$ (Fig. 3.6). Maximum basement exhumation occurred near the south coast of Wellington, where $>4 \mathrm{~km}$ of overburden has been eroded in a period of less than 10 million years (Kamp, 2000). 


\subsection{Discussion}

The long-term exhumation histories of the axial ranges provide an opportunity to evaluate the tectonic causes that have driven the regional uplift of the hanging wall of the Hikurangi Margin. In addition, we also discuss previously proposed tectonic models that may have shaped the unroofing pattern of the fore-arc basement inferred in this study.

\subsubsection{Thrust faulting, crustal shortening and plate coupling}

Along the entire length of the fore-arc of the modern Hikurangi Margin, previous studies (Little et al., 2009; Mountjoy and Barnes, 2011; Ota and Yamaguchi, 2004; Schermer et al., 2009; Wilson et al., 2006; Wilson et al., 2007) have documented ongoing vertical displacements of the onshore and offshore landscape resulting from slip on reverse (and oblique reverse) faults attributed to horizontal compression in the upper plate. These displacements (mostly coseismic) have been aggregating to the long-term uplift of the basement rocks of the eastern North Island. As mentioned above, we identify significant eastwards reverse faulting on the Ngamatea Fault prior to $20 \mathrm{Ma}$ and on the (precursors to) Wellington-Mohaka Fault between 20 and $10 \mathrm{Ma}$, based on the differential exhumation histories across the fault (Fig. 3.6).

In most parts of the axial ranges, due to the general absence of the Neogene strata above the Mesozoic basement, absolute measurements of crustal shortening driven by the late Cenozoic Pacific subduction are unavailable. In the adjacent fore-arc basins to the east of the ranges, using cross sections of the upper crust compiled from seismic reflection, drill hole and outcrop data, Nicol et al. (2007) estimated finite horizontal shortening of the upper plate due to reverse faulting and folding during the evolution of Hikurangi Margin. They noted that since the Late Oligocene, crustal shortening has been dominant in the inner fore-arc of the upper plate from approximately Hawke's Bay to Wairarapa (Fig. 3.7a), with the average shortening rate increasing southwards, reaching a maximum of 3-8 $\mathrm{mm} /$ year in the southern North Island. We estimate the total basement exhumation in the axial ranges has also increased southwestwards since the Late Oligocene (Fig. 3.7b). Our inferred highest magnitude of exhumation since 30 Ma occurred in the southernmost part of the North Island (Fig. 3.7b), at a latitude similar to where the most crustal shortening has been observed in fore-arc basins (Fig. 3.7a) (Nicol et al., 2007). This spatial correlation suggests that crustal 
shortening in the fore-arc of the margin was a driver of the regional uplift and unroofing of eastern North Island.

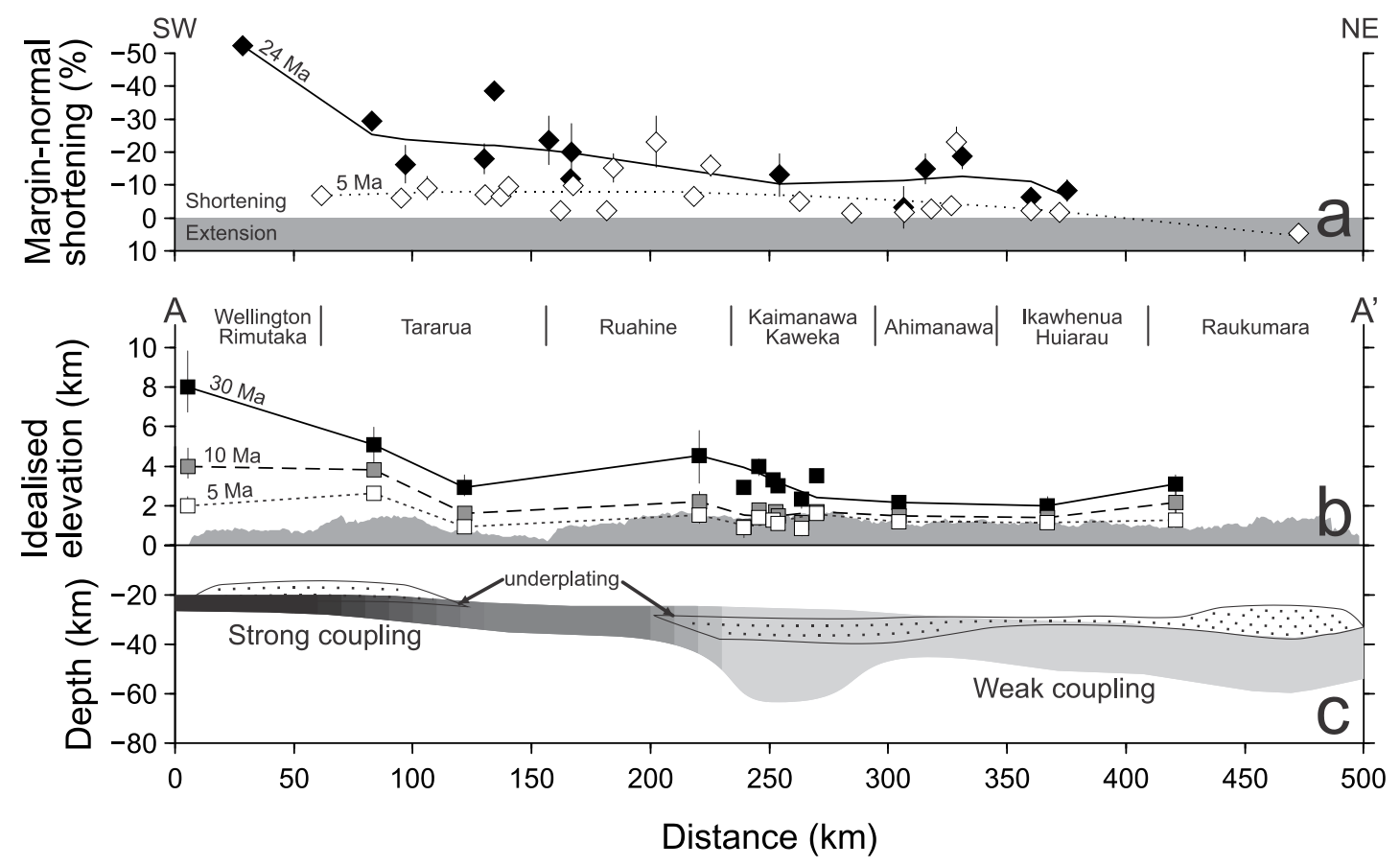

Fig. 3.7 Composite transect along the Hikurangi Margin. Location of the transect is shown in Fig. 3.3. (a) Margin-normal horizontal shortening strain in the fore-arc of the upper plate since the Miocene and Pliocene, based on estimates of Nicol et al. (2007). (b) Elevation of inferred paleo-surfaces based on thermal history models. Exhumation is calculated using a passive-margin geothermal gradient of $30^{\circ} \mathrm{C} / \mathrm{km}$ (Jiao et al., 2014; Kamp and Liddell, 2000). Grey region indicates the present crest of the axial ranges. (c) Schematic figure showing the modern subduction interface beneath the axial ranges. The shaded region depicts the depth of the subduction interface (Williams et al., 2013) and the degree of coupling (strong coupling in black and weak in grey) between the overriding and subducting plates (Wallace et al., 2012). Zones of underplating are approximate (Henrys et al., 2013; Reyners et al., 1999; Reyners et al., 2006).

In a laboratory setting, physical analogue models of the lithospheric deformation of the Andean margin (Iaffaldano et al., 2012) suggests that the high degree of coupling (shear resistance) between the subducting and overriding plates is important for the efficient transfer of shortening strain into the overriding plate. At the Hikurangi Margin, Wallace and Beavan (2004) estimated the interseismic coupling on the subduction interface beneath North Island based on horizontal velocity fields. Although the velocity fields are estimated using contemporary GPS data collected over a period of 10-15 years, they agree well with long-term geological deformation rates on a million-year time scale (Nicol and Wallace, 2007). Furthermore, our data and interpretation indicate that the present inter-plate coupling distributions modelled by Wallace and Beavan (2004) (Fig. 3.7c) are spatially correlated to the magnitude of 
basement exhumation in central and southern axial ranges since $10 \mathrm{Ma}$ (Fig. 3.7b). For example, the plate interface is strongly coupled (down to $\sim 40 \mathrm{~km}$ depth) beneath the Tararua Range and Wellington region, where since $10 \mathrm{Ma}$ the crust of the upper plate has been extensively exhumed (3-4 km unroofing). On the other hand, plate interface coupling is weak beneath central axial ranges, where the amount of exhumation has been less than $1 \mathrm{~km}$ since $10 \mathrm{Ma}$.

The distribution of finite horizontal shortening strain does not explain the exhumation pattern in the Raukumara Range (Fig. 3.6i). We infer that the Raukumara Range has been actively exhuming since $\sim 12 \mathrm{Ma}$, at a time when the region was not considerably shortened-rather it was extended in the margin-normal direction in the last $5 \mathrm{Myr}$ (Figs. 3.6 and 3.7a) (Nicol et al., 2007). This contrast suggests that, during the evolution of the Hikurangi Margin, uplift of the axial ranges was not solely driven by crustal shortening.

\subsubsection{Sediment underplating}

Based on an estimate of the volume of sediments that entered the Hikurangi subduction zone, Walcott (1987) proposed the underplating of subducted sediments at the base of Australian Plate to be an important driver for rock uplift in the axial ranges of North Island. Some authors (Henrys et al., 2013; Scherwath et al., 2010) further suggested that the underplated complexes possibly consist of both subducted fine sediments covering the slab as well as debris eroded from the hanging wall.

Along the Hikurangi Margin, underplated material has been recognised at the subduction interface as low-velocity zones on seismic transects, and has been inferred to be responsible for some of the rock uplift in the upper plate, (e.g. Eberhart-Phillips et al., 2008; Henrys et al., 2013; Reyners et al., 1999; Reyners et al., 2006). For example, Reyners et al. (1999) interpreted an up to $20 \mathrm{~km}$-thick pond of underplated sediments beneath Raukumara Peninsula as supporting the rapid rock uplift (up to 3 mm/yr since $125 \mathrm{ka}$ ) (Yoshikawa et al., 1980) of the Raukumara Range. Underplated sediments were also suggested to have accumulated beneath the Kaimanawa (Eberhart-Phillips et al., 2008; Reyners et al., 2006) and Tararua Ranges (Henrys et al., 2013). The accumulation of underplated material beneath the frontal ridges supports the contribution of underplating to the thickening of the upper crust and growth of the mountains. During the last $\sim 10 \mathrm{Myr}$, we identify active exhumation of bedrock in the 
Raukumara, Tararua and Rimutaka Ranges, which are regions where rock uplift and exhumation can be (partially) attributed to continuous underplating of sediments at the base of upper plate (Henrys et al., 2013; Reyners et al., 1999).

Models for Kaimanawa Mountainss indicate subdued exhumation rates over the last 17 Myr (Fig. 3.6). If sediments also accumulated beneath the central axial ranges as interpreted (for a high $\mathrm{Vp} / \mathrm{Vs}$ zone at up to $\sim 40 \mathrm{~km}$ depth) from seismic sections (Figs. 3.6 and 3.7c) (Reyners et al., 2006), this underplated body is no longer coupled to rapid rock uplift and exhumation at the earth surface. Underplated material has not been identified beneath the Ruahine Range (Eberhart-Phillips et al., 2005), the narrowest ridge in this mountain chain (Fig. 3.3). The lack of sediment accumulation beneath the Ruahine Range is coupled with the negligible exhumation rate since Late Miocene.

\subsubsection{Plateau subduction}

The subducting Pacific Plate beneath North Island is capped by the Hikurangi Plateau, which is a triangular-shaped block of elevated (3-4 km) oceanic crust of Early Cretaceous age (Davy and Wood, 1994; Davy et al., 2008; Hoernle et al., 2005; Mortimer and Parkinson, 1996). The positive buoyancy and extra thickness of this plateau, compared to normal oceanic crust farther north, were suggested as being responsible for the crustal uplift of the eastern North Island (Davy, 1992; Kelsey et al., 1995).

Based on our thermal history models, there has been a decrease of exhumation rates in the central axial ranges since the subduction of Hikurangi Plateau ( 10 Ma) (Reyners, 2013). We therefore discount the thickness or buoyancy of Hikurangi Plateau as being the chief driver of rock uplift and exhumation in the axial ranges. This is in agreement with the interpretation from numerical models (Litchfield et al., 2007), which demonstrated that plateau subduction is most likely to imprint on the surface uplift of the entire fore-arc region, and is therefore unlikely responsible for the uplift of the axial ranges, which stretches over a relatively short wavelength on the margin-normal direction. 


\subsubsection{Tectonic implications}

Furlong and Kamp (2009) hypothesised an unconventional collision-to-subduction model to describe the Neogene convergence between the Australian and Pacific Plates at the Hikurangi Margin. The model is based on the paleogeographic reconstruction of the basement terranes (Mortimer, 2004) using the finite Euler rotation poles that were determined by Cande and Stock (2004) for the relative Australian-Pacific motion. In the model, Cenozoic plate convergence in the vicinity of North Island initiated as continental transpression that significantly shortened and thickened the lithosphere resulting in a Southern Alps, New Zealand style orogeny. This inferred orogeny preceded delamination of the lower Australian lithosphere leading to subduction of the oceanic Pacific Plate beneath the North Island. Furlong and Kamp (2009) also suggest that this distinctive tectonism has migrated southwestwards since $\sim 23 \mathrm{Ma}$ and as a result the leading edge of the subducting Pacific slab was swept southwestwards systematically, from beneath the northeast of North Island to beneath the northernmost South Island.

However, our data and thermal history models do not support a model of monotonically southward migrating vertical deformation for the North Island. In the early stage (25-10 Ma) of plate convergence in the North Island boundary zone, the observed exhumation rates in the northern and central axial ranges (generally $<0.4$ $\mathrm{km} / \mathrm{Myr}$, assuming a pre-Oligocene geothermal gradient of $30^{\circ} \mathrm{C} / \mathrm{km}$ (Jiao et al., 2014)) were much lower than that in the modern Southern Alps, which are generally 1-3 km/Myr (Tippett and Kamp, 1993) and up to $\sim 6-9 \mathrm{~km} / \mathrm{Myr}$ in the central Southern Alps near the Alpine Fault (Little et al., 2005). This difference does not support the existence of a Southern Alps-like orogen in the northeast and centre of North Island, resulting from continental collision/transpression during the initiation of the Hikurangi Margin. Moreover, we do not identify any southward propagation in the timing of onset or rate of rock exhumation during evolution of the axial ranges in the Hikurangi Margin, which would be predicted from the southward advance of the tectonic transition from collision to subduction (Furlong and Kamp, 2009).

Based on the inversion of GPS velocities of the modern North Island, Wallace et al. (2005) proposed a rotation model of fore-arc blocks to accommodate the along-strike variation of geology at the Hikurangi Margin. In this model, roll-back of the oceanic 
slab at the Kermadec Trench and the "collisional resistance" near the Chatham Rise (Fig. 3.1b) exerted a torque, which forced the clockwise vertical-axis rotation of the eastern North Island (relative to the Australian Plate) and led to rifting in the TVZ. Following this proposed mechanism for the fore-arc rotation (Wallace and Beavan, 2004; Wallace et al., 2005) we use it to explain the along-strike increase in exhumation rate from central to southern axial ranges. Moreover, we propose that rotation of fore-arc blocks commenced as early as in the Late Miocene ( 10 Ma), when rock exhumation decreased in the central North Island. Since the Late Miocene, in the southern North Island (Wellington region), both the margin-normal shortening rate $(3-8 \mathrm{~mm} / \mathrm{yr})(\mathrm{Nicol}$ et al., 2007) and basement exhumation rate $(>0.4 \mathrm{~km} / \mathrm{Myr}$, assuming a constant geothermal gradient of $30^{\circ} \mathrm{C} / \mathrm{km}$ ) are high, due to the locking of plate convergence adjacent to the region where the Chatham Rise collides with the Australian Plate. Farther north in the central North Island (Hawke's Bay region), the continuous subduction of the oceanic Pacific Plate pulled the upper plate trenchwards (resulting from subduction-induced mantle flow) (Conrad and Lithgow-Bertelloni, 2004; Wallace et al., 2005), so both the margin-normal shortening of the upper plate and exhumation of the basement rocks in the central axial ranges have been insignificant since the Late Miocene.

\subsection{Conclusions}

The long-term unroofing process of the basement-cored axial ranges of North Island, New Zealand began in the Late Oligocene-Early Miocene, as a consequence of the subduction of the Pacific Plate beneath the Australian Plate. Our thermochronology study provides independent time constraints on the evolution of the Hikurangi Margin, through the estimation of the time- and space variable exhumation histories of the basement rocks in the hanging wall of the subduction zone.

Since subduction commenced along the Hikurangi Margin, basement unroofing initiated in the west and migrated trench-wards towards the east. The unroofing of the Kaimanawa Mountains ( 27-17 Ma) was accommodated by eastwards reverse faulting on the margin-parallel Ngamatea Fault. During the Early-Late Miocene ( 20-10 Ma), eastwards reverse faulting was evident at the site of the current Wellington-Mohaka Fault, where accelerated exhumation of basement rocks started prior to or at $20 \mathrm{Ma}$ to its west and around $10 \mathrm{Ma}$ to its east. 
Since the Late Miocene ( $\sim 10 \mathrm{Ma})$, the rate of rock exhumation in the axial ranges has varied along strike, lower in the central part and higher to the north and south. In the Raukumara Range in the north, localised rock uplift may have been caused by significant underplating at the basal upper plate. From the central to southern axial ranges, the increase of exhumation rate is in accordance with the increase in the margin-normal shortening in the forearc of the upper plate, which is interpreted to be a chief driver for the regional uplift and unroofing of this section of axial ranges of North Island. 



\title{
Chapter 4
}

\section{Constraining provenance, thickness}

\author{
and erosion of the Northland
}

\section{Allochthon, New Zealand, using}

low-temperature thermochronology ${ }^{1}$

\begin{abstract}
The Northland Allochthon, an assemblage of Cretaceous-Oligocene sedimentary rocks, was emplaced during the Late Oligocene-earliest Miocene, onto the in situ Mesozoic and early Cenozoic rocks (predominantly Late Eocene-earliest Miocene) in northwestern New Zealand. Using low-temperature thermochronology, we investigate the sedimentary provenance, burial and erosion histories of the rocks from both the hanging and footwalls of the allochthon. In central Northland (Parua Bay), both the overlying allochthon and underlying Early Miocene autochthon yield detrital zircon and partially reset apatite fission-track ages that were sourced from the local Jurassic terrane and perhaps Late Cretaceous volcanics; the autochthon contains, additionally, material sourced from Oligocene volcanics. Thermal history modelling indicates that the lower part of the allochthon together with the autochthon was heated to $\sim 55-$ $100{ }^{\circ} \mathrm{C}$ during the Late Oligocene and Early Miocene, most likely due to the burial beneath the overlying nappe sequences. From the Mesozoic basement exposed in eastern Northland, we obtained zircon fission-track ages tightly bracketed between
\end{abstract}

\footnotetext{
${ }^{1}$ Manuscript submitted to Basin Research as Jiao, R., Seward, D., Little, T.A., Herman, F. and Kohn, B.P.. Constraining provenance, thickness and erosion of the Northland Allochthon, New Zealand, using low-temperature thermochronology.
} 
153 and $149 \mathrm{Ma}$; the apatite fission-track ages on the other hand, generally young towards the northwest, from 129 to 20.9 Ma. Basement thermochronological ages are inverted to simulate the emplacement and later erosion of the Northland Allochthon, using a thermo-kinematic model coupled with an inversion algorithm. The results suggest that during the Late Oligocene, the nappes in eastern Northland ranged from 4-6 km thick in the north to zero in the Auckland region (over a distance $>200 \mathrm{~km}$ ). Following the allochthon emplacement, eastern Northland was uplifted and unroofed during the Early Miocene for a period of $\sim 1-6 \mathrm{Myr}$ at the rate of $0.1-0.8 \mathrm{~km} / \mathrm{Myr}$, leading to rapid erosion of the nappes. Since Middle Miocene, the basement uplift ceased and the erosion of the nappes and the region as a whole slowed down $(\sim 0-0.2$ $\mathrm{km} / \mathrm{Myr}$ ), implying a decay in tectonic activity in this region.

\subsection{Introduction}

In northern New Zealand, as a result of the active convergence between the Australian and Pacific Plates, a series of nappes known as the Northland Allochthon comprising an assemblage of Cretaceous-Oligocene deep marine sediments and igneous rocks (Ballance and Spörli, 1979), were thrust onto the in situ continental crust of the present Northland Peninsula during the Late Oligocene and earliest Miocene (Hayward et al., 1989; Rait, 2000). In eastern Northland, a significant portion of the nappes has been eroded, leading to difficulties in interpreting their emplacement history and the potential implications for understanding the regional tectonic evolution in northern New Zealand and the SW Pacific (Fig. 4.1a).

The main goal of this paper is to provide quantitative constraints on the original extent and thickness of the Northland Allochthon, as well as its subsequent erosion history. To reach this goal, we employ zircon fission-track (ZFT), apatite fission-track (AFT) and apatite (U-Th-Sm)/He (AHe) thermochronometers. These systems are sensitive to the thermal evolution of rocks at different temperatures within a range from approximately 240 to $50{ }^{\circ} \mathrm{C}$. Under the assumption that depth (and associated geothermal gradients) is the first order control on temperature, the thermal history of a rock is often interpreted in terms of exhumation and burial processes in the upper crust within a few kilometres of the Earth's surface. 


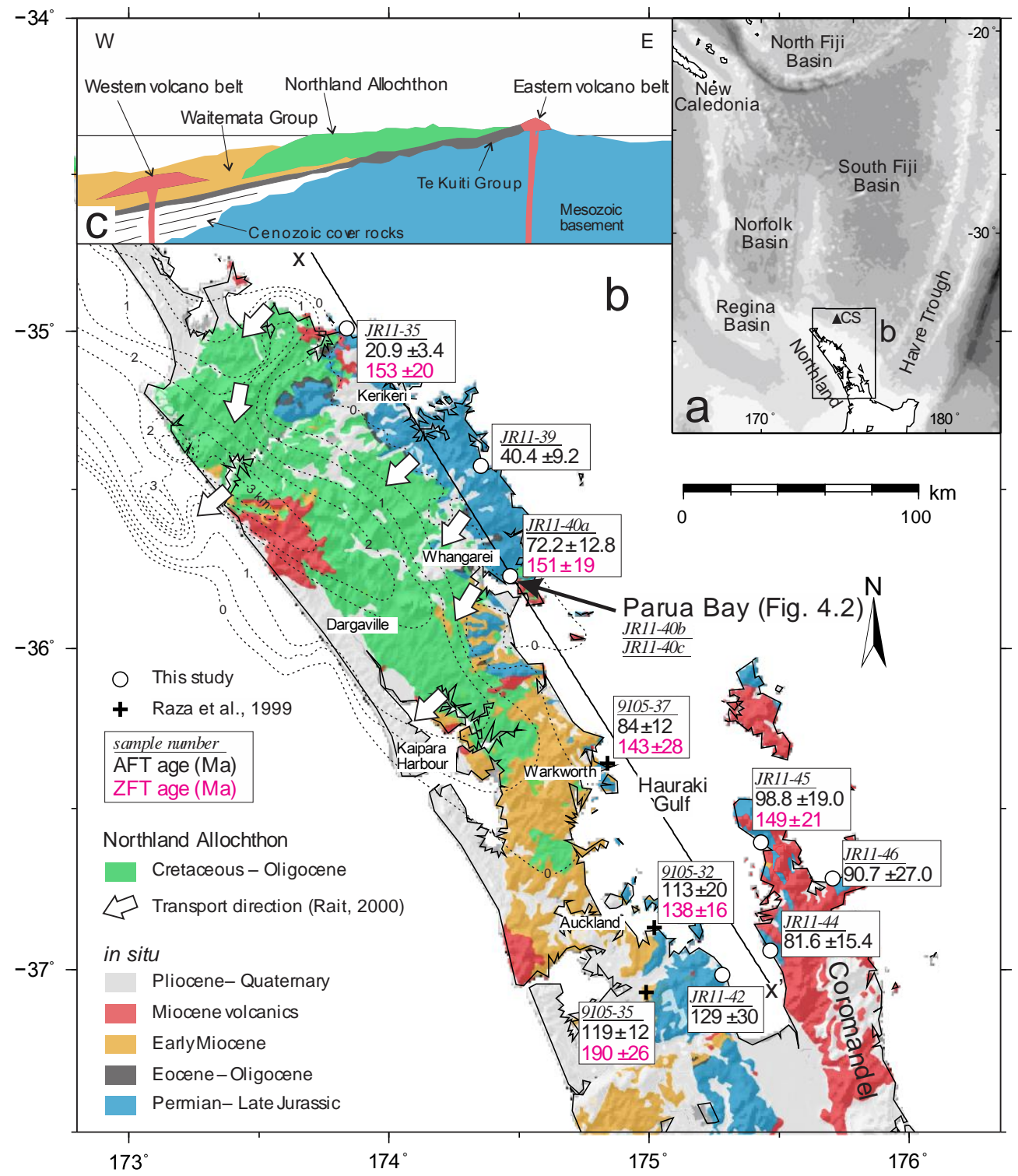

Fig. 4.1 Setting of northwestern New Zealand and the study area. (a) Geographic setting of SW Pacific and location of Northland Peninsula. CS, Cavalli Seamount. (b) Geology of northwestern New Zealand, simplified from the 1: 1000000 Geological Map of New Zealand, produced by GNS Science (2014). White arrows indicate transport directions of the Northland Allochthon during the Late Oligocene-earliest Miocene (Rait, 2000). Contours (dotted lines) represent the mapped current thickness $(\mathrm{km})$ of the allochthon (Isaac et al., 1994). Basement fission-track ages are from this study and Raza et al. (1999). Line $\mathrm{x}-\mathrm{x}$ ' depicts the location of profiles in Figs. 4.4 and 4.6. (c) Structural section through the northern part of (b), after Hayward (1993) and Spörli and Rowland (2007).

The preserved parts of the allochthon outcrop extensively on the Northland Peninsula (Figs. 4.1b and 4.1c) and have been recognized on seismic sections, up to a maximum thickness of over $3.5 \mathrm{~km}$ off the west coast (Isaac et al., 1994). At one locality in Parua Bay (Fig. 4.1b), we obtained ZFT, AFT and AHe data from samples within the allochthon and also from the Early Miocene autochthon, where the contact and relationship between nappes and the footwall are well exposed (Spörli and Harrison, 
2004). Data are modelled to determine their sources (Section 4.3) and possible heating during the deposition and emplacement (Section 4.4). From the underlying in situ Mesozoic basement, new and published (Raza et al., 1999) data are predicted by a thermo-kinematic model that simulates the allochthon emplacement and subsequent erosion (Section 4.5). The results of different modelling approaches provide constraints on the provenances, maximum thickness and the post-emplacement erosion history of the Northland Allochthon (Section 4.6).

In this chapter, we use the term "basement" to refer to the Mesozoic terrane of Northland, whereas the term "autochthon" refers to the early Cenozoic successions between this terrane and the allochthon.

\subsection{Geological setting}

The Oligocene-earliest Miocene emplacement of the Northland Allochthon marks a short period of intensive crustal deformation during the onset of the westerly directed subduction of the Pacific Plate beneath North Island, accompanied and followed by widespread volcanism during the Early and Middle Miocene (25-11 Ma) (Hayward et al., 2001; Mortimer et al., 2010). Following the allochthon emplacement, the basement of eastern Northland is inferred to have undergone regional uplift, leading to extensive erosion of the overlying allochthonous sequences (Edbrooke and Brook, 2009; Evans, 1992). During this period, the basement of western and southern Northland was tilted towards the southwest or west, as evidenced by the mean bedding of the syn- and post-obduction Early Miocene sediments (Fig. 4.2). In eastern Northland (Whangarei and Warkworth; Fig. 4.2), the Early Miocene sequences were folded on NW-trending axes. By the Middle-Late Miocene, subduction-associated volcanism and compressional crustal deformation had declined in Northland (Evans, 1992; Hayward et al., 2001), due possibly to a southeastwards migration of the subduction zone (King, 2000; Mortimer et al., 2007). 


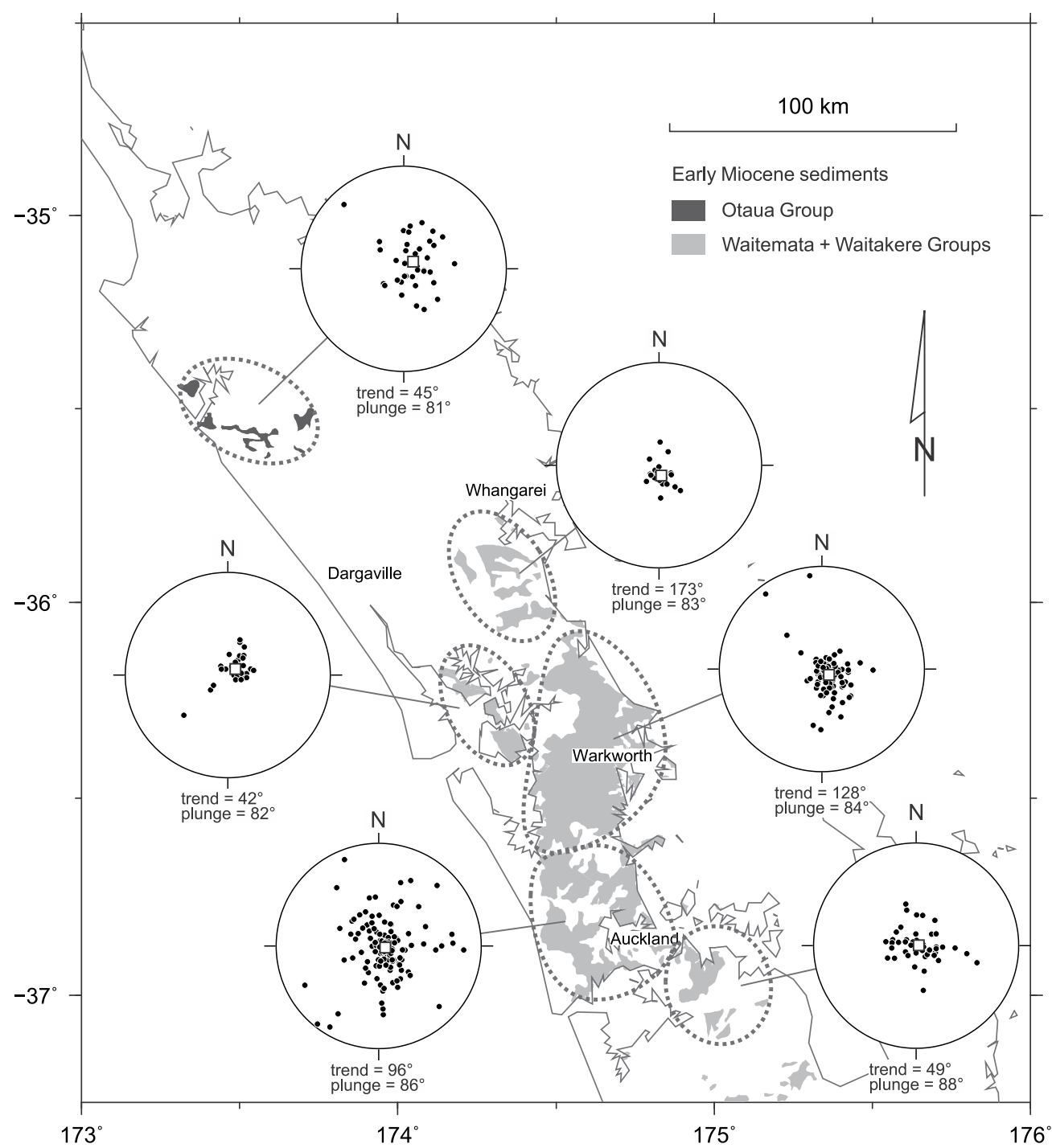

Fig. 4.2 Lower hemisphere equal-area projections of poles to beddings in the in situ Early Miocene strata. White squares depict the mean vectors. Trends and plunges of the mean vector are also indicated. Measurements are taken from the 1: 250000 Geological Map of New Zealand (QMAP), produced by GNS Science (2013).

The allochthonous sequences originally accumulated in a deep marine basin, which most authors believe was located on the Pacific Plate to the northeast of Northland (Edbrooke and Brook, 2009; Hayward et al., 1989). These sequences were intensively deformed during their transport to the present location (Evans, 1992; Rait, 2000). Emplacement is inferred to have occurred during the Late Oligocene to earliest Miocene, based on the stratigraphic relationships between the deformed footwall and hanging wall rocks, and from the overlapping cover sequences (Hayward et al., 1989). Whattam et al. (2005) and Whattam et al. (2006) reported zircon U-Pb and wholerock ${ }^{40} \mathrm{Ar} /{ }^{39} \mathrm{Ar}$ ages of $32-26 \mathrm{Ma}$ for an ophiolite in the uppermost sheets of the 
nappes, and suggested that the youngest suite of the nappes was formed in a subduction-zone setting during the Oligocene.

The current extent and thickness of the allochthon have been estimated previously from field mapping, drill hole data and geophysical studies (Hayward et al., 1989; Isaac et al., 1994) and references within). The exposed allochthon generally thickens northwestwards, reaching a maximum of over $3 \mathrm{~km}$ off the northwest coast and perhaps as much as $4 \mathrm{~km}$ north off northernmost New Zealand (Fig. 4.1b) (Edbrooke and Brook, 2009; Isaac et al., 1994). The western edge, i.e. emplacement front, of the nappes strikes northwest-southeast, subparallel to the west coast of Northland. The allochthon is not currently preserved to the south of Auckland, nor on the Coromandel Peninsula, and may never have covered these regions.

Structurally beneath the allochthon, autochthonous Eocene to earliest Miocene sequences unconformably overlie the Mesozoic basement (Fig. 4.1c). The upper, Neogene part of the autochthonous sequences is marked by a transition of depositional environment from shallow marine to mid-bathyal depth, implying rapid subsidence during the Oligocene (Hayward et al., 1989). Although the thickness of the autochthonous Cenozoic rocks is over $1 \mathrm{~km}$ off the west coast of Northland (Isaac et al., 1994), field observations and drill hole data (Hayward et al., 1989; Isaac et al., 1994) indicate that they are generally $<400 \mathrm{~m}$ thick, and usually $<200 \mathrm{~m}$ thick where exposed on land.

Underlying the Cenozoic autochthonous sequence, the older, in situ basement of northern New Zealand consists of Permian-Jurassic metasedimentary units, which were formed and intensively deformed in the accretionary wedge of eastern Gondwana before break-up in the Late Cretaceous (Laird and Bradshaw, 2004). In the study area of eastern Northland and Coromandel Peninsula, the basement is part of the Waipapa Supergroup, comprising massive greywacke and argillite sequences with minor volcanics and cherts (Edbrooke and Brook, 2009). Detrital zircon U-Pb dating results (Adams et al., 2013) place the stratigraphic age of the Waipapa Supergroup basement at $159-152 \mathrm{Ma}$. 


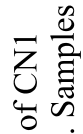

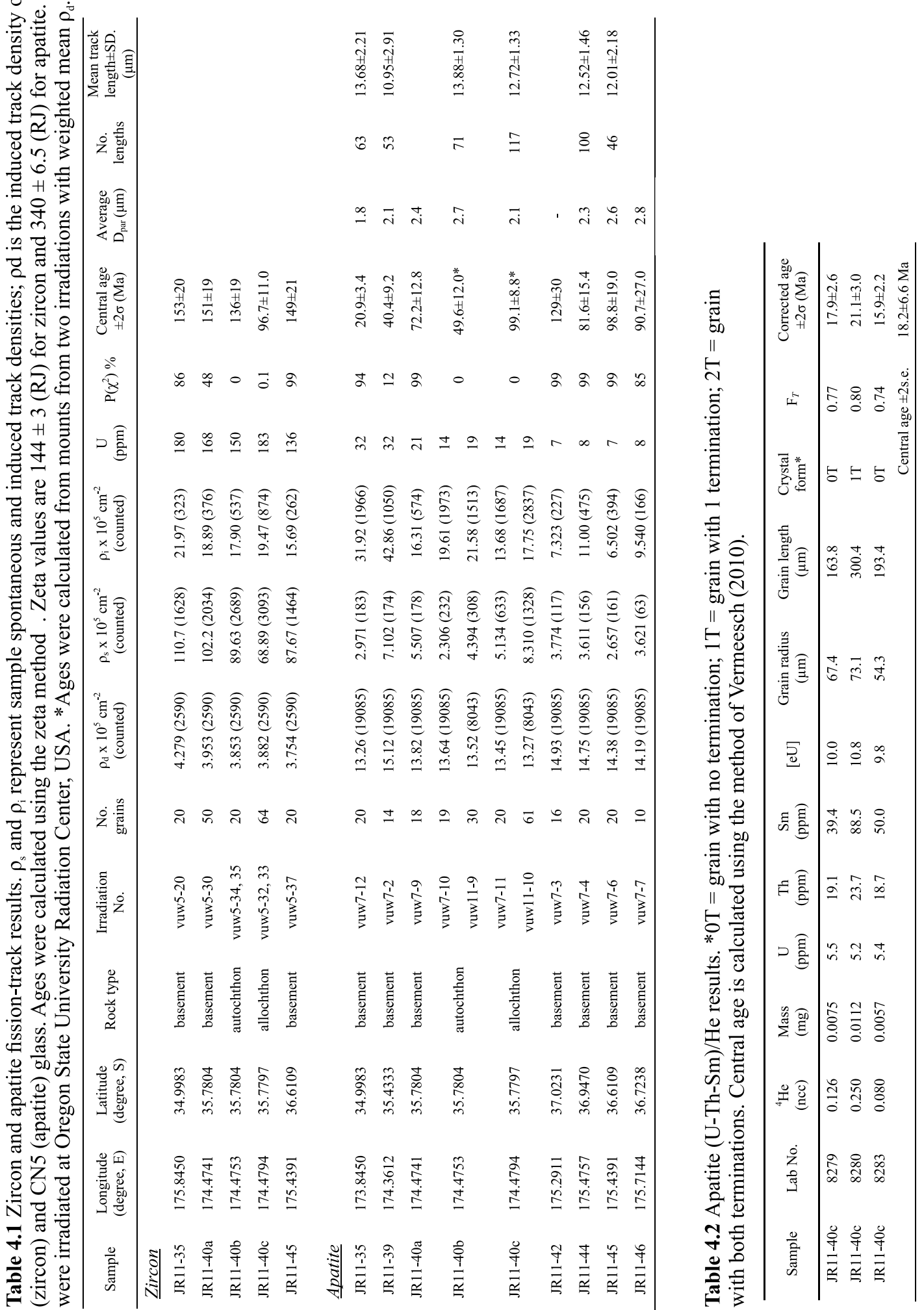




\subsection{Thermochronological age models of the allochthon and autochthon}

Fission-track and (U-Th-Sm)/He sample preparation and analysis follow the procedure described in the Appendix II. Data are presented in Tables 4.1 and 4.2 and on map in Fig. 4.1b. For the fission-track ages, we use the programme DensityPlotter (Vermeesch, 2012) to model the detrital age mixture, based on the algorithm of Galbraith and Green (1990). The number of age populations is determined by minimising the Bayes Information Criterion (Galbraith, 2005). Mixture models of subsets of the samples associated with different irradiations always yield similar age populations. Thus in this chapter, a weighted mean $\rho_{d}$ (the induced track density of a dosimeter glass) is used to combine the different sets of data from one sample but with different irradiations, for the age calibration and mixture modelling.

\subsubsection{Northland Allochthon}

At Parua Bay (Fig. 4.1b), a sample (JR11-40c) was collected from the sandstones at the base of the Northland Allochthon, which is inferred by Spörli and Harrison (2004) to be correlated with units within the Late Cretaceous-Paleocene complex (Isaac et al., 1994) (Fig. 4.3a). The ZFT ages yield $P\left(\chi^{2}\right)$ at almost zero and therefore most likely contain inherited signatures from different detrital sources. In the mixture model, the ZFT ages fall into two components of $84 \pm 10$ and $143 \pm 38$ Ma, respectively (Fig. 4.3b). The single-grain AFT ages of the allochthon sample yield two peaks of $67.5 \pm$ 5.8 and $110.7 \pm 5.0 \mathrm{Ma}$ (Fig. 4.3b), younger than the two ZFT age components, respectively. Three single-grain AHe ages (21.1-15.9 Ma) yield a central age of 18.2 $\pm 6.6 \mathrm{Ma}$ (Table 4.2), which is considerably younger than the depositional age. Thus we infer that the AHe ages are thermally fully reset.

\subsubsection{Early Miocene Autochthon}

Data were obtained from the Early Miocene autochthon directly underlying the nappes at Parua Bay (Fig. 4.3a). Mixture modelling of the ZFT ages suggests two peaks of $80 \pm 11$ and $164 \pm 12 \mathrm{Ma}$ (Fig. 4.3c), similar to the age pattern of the allochthon (Fig. 4.3b). AFT ages fall into three groups (Fig. 4.3c): a major component of $26.2 \pm 1.7 \mathrm{Ma}$ includes $65.9 \%$ of the grain ages, while the two other age peaks are $72 \pm 11$ Ma and $223 \pm 42 \mathrm{Ma}$, respectively. 


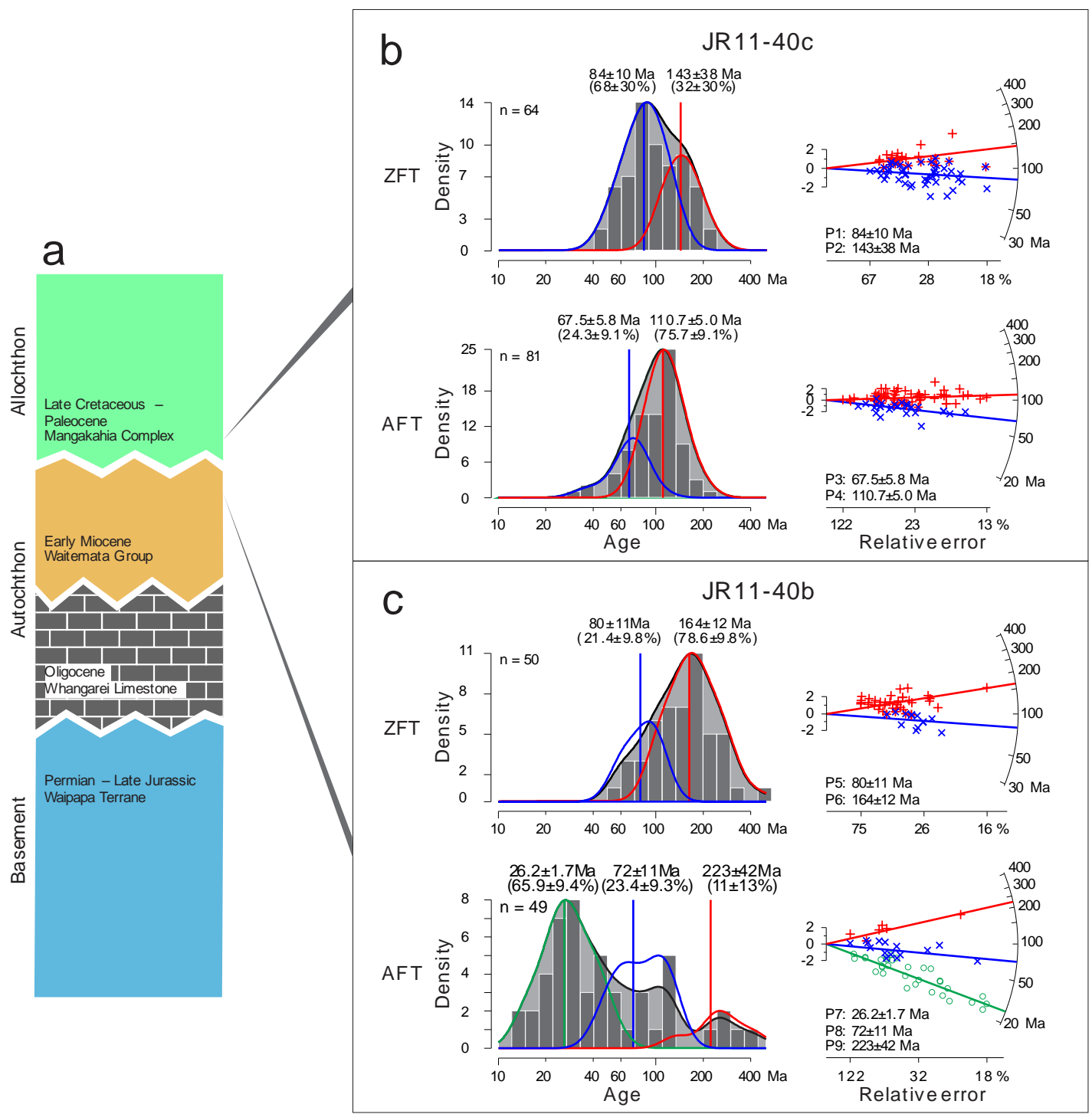

Fig. 4.3 ZFT and AFT ages of the allochthon and autochthon at Parua Bay. (a) Structural positions of the stratigraphic units at Parua Bay (not to scale). (b and c) Distribution and radial plots of the single-grain ZFT and AFT ages from (b) the allochthon and (c) the autochthon. Single-grain ages are statistically split into populations (P1-P9) using DensityPlotter (Vermeesch, 2012). The shading on the density plots represent the kernel density estimates (KDE); coloured curves represent modelled age components. The KDE bandwidth is 0.2 ; the bin width of the histograms is 0.2 .

\subsection{Thermal history models of the allochthon and autochthon}

Inverse modelling of the ZFT, AFT and AHe data is applied to elucidate the thermal histories of the allochthon and autochthon. 


\subsubsection{Method and model set-up}

The modelling is carried out using the programme QTQt (Gallagher, 2012), which allows the integrated simulation of the thermal histories of multiple samples. The inversion sampler (Gallagher et al., 2009) uses a transdimensional Bayesian Markov chain Monte Carlo (MCMC) method, which favours simpler solutions and thus reduces the potential for over-interpretation. Detailed introduction and demonstration of the inverse modelling approach are given by Gallagher et al. (2009) and Gallagher (2012). Inverse modelling has been conducted for a time span from 250 to $0 \mathrm{Ma}$ in the temperature range between 250 and $0{ }^{\circ} \mathrm{C}$. The modelled thermal history represents the results from 100000 burn-in and 100000 post-burn-in iterations.

To sample the pre-depositional thermal histories, the sedimentary ages are prescribed as temperature-time (T-t) constraints on the model: $0-30{ }^{\circ} \mathrm{C}$ between 100 and $55 \mathrm{Ma}$ for the allochthon and $0-30{ }^{\circ} \mathrm{C}$ between 33 and $21 \mathrm{Ma}$ for the autochthon. Vermeesch and Tian (2014) argued that imposing T-t constraints (bounding boxes) on QTQt models increases the risk of misinterpretation, and the "most likely" thermal histories may not reasonably reproduce the data set. Therefore we also tested the modelling without any T-t constraints. The results are inconsistent with geological observations and are thus not adopted for interpretation in this paper.

For modelling the detrital fission-track ages, we split the data set based on the mixture models (Section 4.3; Fig. 4.3), i.e. each population is simulated as an individual sample. Eight fission-track age populations (P1-P8; Fig. 4.3) are modelled; P9 is excluded from modelling as it contains only six single-grain ages (Fig. 4.3c). For the allochthon, AFT lengths were not all measured on the grains on which the ages were determined, and therefore they are not used in the modelling. For the autochthon, the AFT lengths measured on large, euhedral apatites are incorporated with the age component of P7 (26.2 Ma; Fig 2c). These apatites were most likely sourced from local and contemporaneous volcanics. The annealing model of Tagami et al. (1998) and Ketcham et al. (1999) are used to simulate the ZFT and AFT data, respectively. The mean Dpar measurement of each AFT age component is used as a proxy for the apatite composition.

For the AHe data, we use the models of Gautheron et al. (2009) and Flowers et al. (2009), both of which predict increasing helium rententivity in apatite with the 
increasing amount of alpha-recoil damage in either a linear (Gautheron et al., 2009) or a non-linear (Flowers et al., 2009) manner. Despite the different AHe retention algorithm used, our simulations yield similar results. Thus here we only present the results using the model of Gautheron et al. (2009) (Fig. 4.4). The apatite grains used in $\mathrm{AHe}$ analysis have one or no terminations. We consider the apatites as either fragments, using the method proposed by Brown et al. (2013), or as intact crystals. This choice does not change the predicted thermal history models significantly. Here again we only present the models based on broken grains.

\subsubsection{Results}

The pre-Cenozoic part of the models includes enormous uncertainties and thus is not presented. During the Cenozoic, the results (Fig. 4.4a) suggest that the allochthon was at temperatures $<50{ }^{\circ} \mathrm{C}$ prior to the Late Oligocene, whereas pre-depositional thermal histories of the components (P5-P8) in the autochthon were markedly variable. Since the Oligocene, the allochthon and autochthon had both undergone a period of heating until the Early Miocene ( $20 \mathrm{Ma})$. During this time, the maximum temperature is modelled to be between 55 and $100{ }^{\circ} \mathrm{C}$, which would have had no impact on the ZFT ages but has fully reset the AHe and partially reset the AFT ages. This maximum heating temperature, assuming a geothermal gradient of $30-40{ }^{\circ} \mathrm{C} / \mathrm{km}$ and a surface temperature of $5-15{ }^{\circ} \mathrm{C}$, corresponds to a burial depth of $\sim 1-3 \mathrm{~km}$, which we infer to be an approximation of the thickness of nappes at Parua Bay during their emplacement. Following the heating, the samples experienced gradual cooling until the present (Fig. 4.4a), which we infer to represent the final cooling due to erosion of the nappes. 

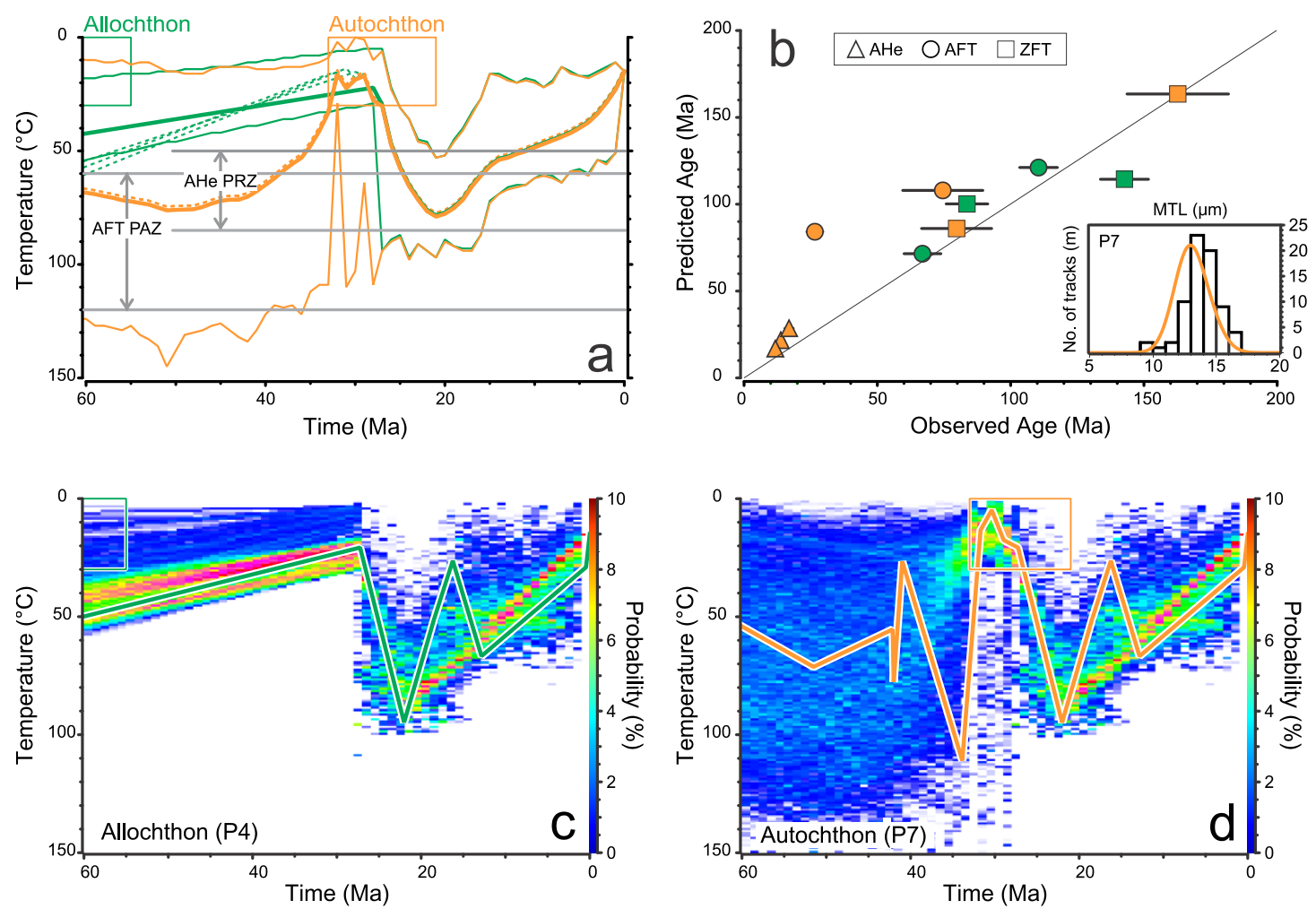

Fig. 4.4 Thermal history modelling results from Parua Bay using QTQt (Gallagher, 2012). (a) Thermal history models of the allochthon (green) and autochthon (orange). Solid lines represent the expected (weighted mean) temperature-time (T-t) paths of P4 (allochthon) and P7 (autochthon) with $95 \%$ credible intervals. Dotted lines represent the expected T-t paths of other components. Boxes depict prescribed constraints from sedimentary ages of the allochthon and autochthon, respectively. AFT partial annealing zone (PAZ) and AHe partial retention zone (PRZ) are approximate for standard Durango apatites. (b) Predicted versus observed thermochronological data. AHe are uncorrected single-grain ages, while AFT and ZFT are age populations (P1-P8) in mixture models (Fig. 4.3). Inset presents the predicted AFT length distribution (curve) in comparison with the track lengths measured from the autochthon (histogram). (c) Expected thermal history of the allochthon (P4) with probability distribution. (d) Expected thermal history of the autochthon (P7) with probability distribution.

In general, the predicted thermal history models reconcile the observed data reasonably well (Fig. 4.4b). However, the youngest component (P7) in the autochthon cannot be reproduced by the weighted mean model. The possible reason is that the post-burn-in T-t paths include a variety of pre-depositional thermal histories, which are not consistent with the observed young age component (26.2 Ma), which we have inferred to represent penecontemporaneous volcanic crystals. 


\subsection{Thermo-kinematic modelling of the basement (Waipapa Supergroup)}

\subsubsection{Thermochronological data}

Three new ZFT samples from the Waipapa Supergroup yield a single group of ages at 153-149 Ma (Table 4.1), overlapping the whole-rock K-Ar ages (200-100Ma) of Adams and Maas (2004), and the youngest (159-152 Ma) detrital zircon U-Pb ages obtained from the same units (Adams et al., 2013). For each sample, the single-grain ZFT ages represent a single population (Fig. 4.5), implying derivation from a single source.
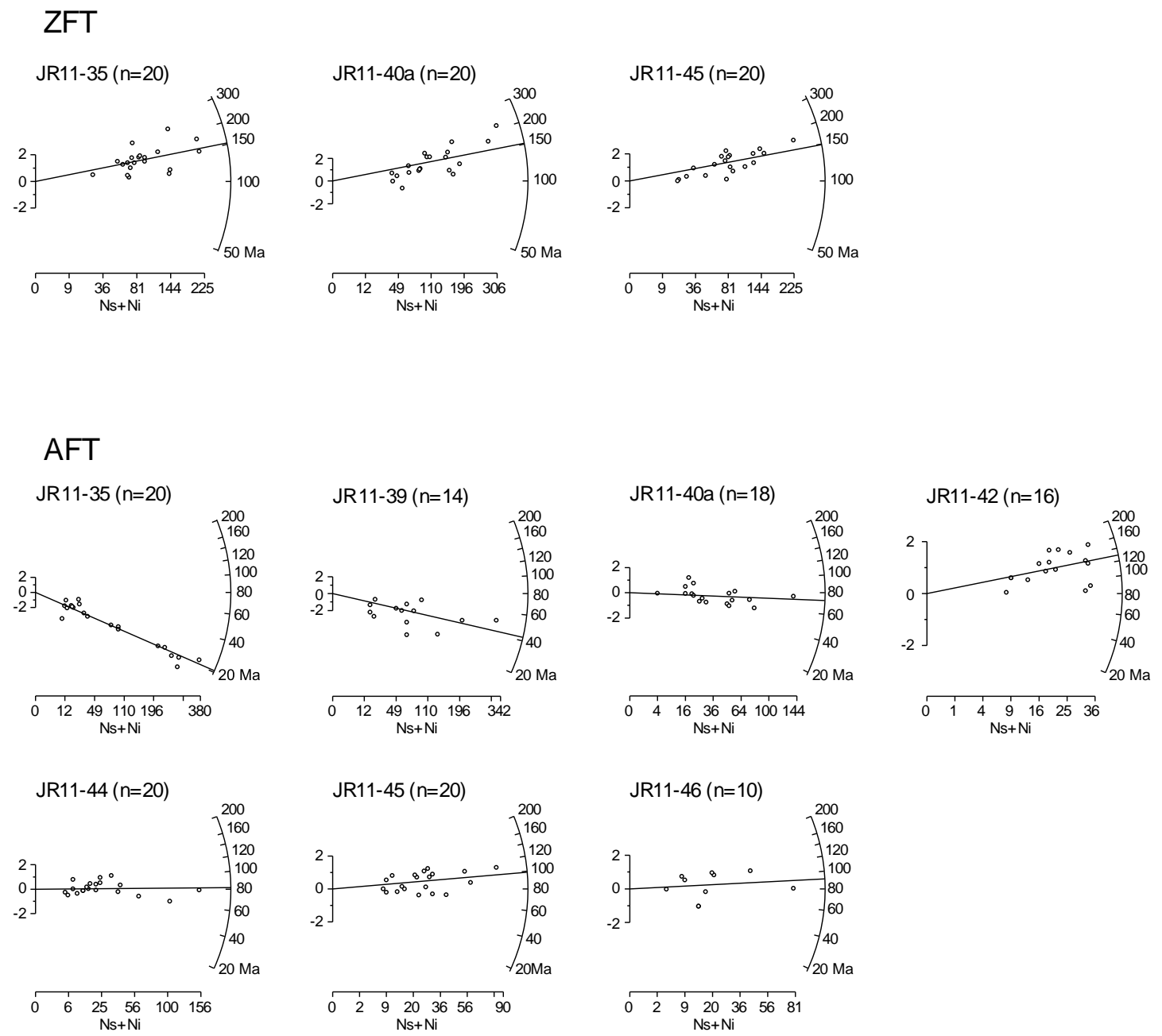

Fig. 4.5 Radial plots of the ZFT and AFT ages from the Waipapa Supergroup, using DensityPlotter (Vermeesch, 2012).

AFT ages from the basement rocks generally young from $129 \mathrm{Ma}$ in the southeast to 20.9 Ma in northern Northland (Fig. 4.1b); each sample yields a single age group 
$\left(\mathrm{P}\left(\chi^{2}\right)>12 \%\right)$ (Fig. 4.5). Mean AFT lengths of four basement samples vary between 10.95 and $13.68 \mu \mathrm{m}$ (Table 4.1).

\subsubsection{Modelling method}

We use 2D thermo-kinematic modelling to constrain the emplacement and subsequent erosion history of the Northland Allochthon, using fission-track data from the Mesozoic basement rocks.

The data are inverted using the thermo-kinematic model Pecube (Braun, 2003; Braun et al., 2012) coupled with the neighbourhood algorithm (Sambridge, 1999a; Sambridge, 1999b). Pecube is a finite-element code that solves the heat transfer equation in the crust under prescribed kinematic and topographic histories. The neighbourhood algorithm is a two-stage inversion approach. In the first stage, the model parameters are optimized through an iterative process. For each iteration, a set of forward models is solved using Pecube to predict thermochronological data of the rocks exposed at the surface. The ages are computed by extracting the T-t paths from the model, using the annealing models of Tagami et al. (1998) for ZFT and Ketcham et al. (1999) for AFT. For each model run, the fit to the data is assessed through a misfit function:

$$
\varphi=\sum_{i=1}^{N}\left(\frac{m_{i}-o_{i}}{\sigma_{i}}\right)^{2}
$$

where $\mathrm{N}$ is the number of data points, $m_{i}$ are the modelled ages, $o_{i}$ the observed ages, and $\sigma_{i}$ is their analytical uncertainty. In this work, we conduct the inversion with 100 forward models for the initial and every other iteration, with a re-sampling ratio of 0.9 . A sum of 100 iterations is run for the inversion.

In the second stage, the neighbourhood algorithm enables the derivation of Bayesian estimates of the constrained parameters. The ensemble of all forward models produced in the first stage is re-sampled to calculate the posterior probability distributions of parameter values, i.e. a marginal probability density function (PDF) for each parameter or for a pair of two parameters. Details of the neighbourhood algorithm are provided by Sambridge (1999a); (1999b ). 


\subsubsection{Model set-up}

We project the data points onto a transect $\mathrm{x}-\mathrm{x}$ ' along the east coast of the Northland Peninsula (Fig. 4.1b) and conduct the modelling in 2 dimensions to reduce the complexity and increase the inversion efficiency. This is a reasonable simplification as our data points strike approximately $300 \mathrm{~km}$ within a relative narrow width $(<80$ $\mathrm{km})$ and the topographic relief is insignificant in the modelled region. As the trend of the $2 \mathrm{D}$ model is generally perpendicular to the proposed direction of allochthon (Rait, 2000) (Fig. 4.1b), the thermochronological data from the footwall basement are more sensitive to heating from the burial of the overlying nappes rather than the true transport direction of the allochthon movement. Thus, here we simulate the emplacement and subsequent erosion of the allochthon as the burial and exhumation of the basement.

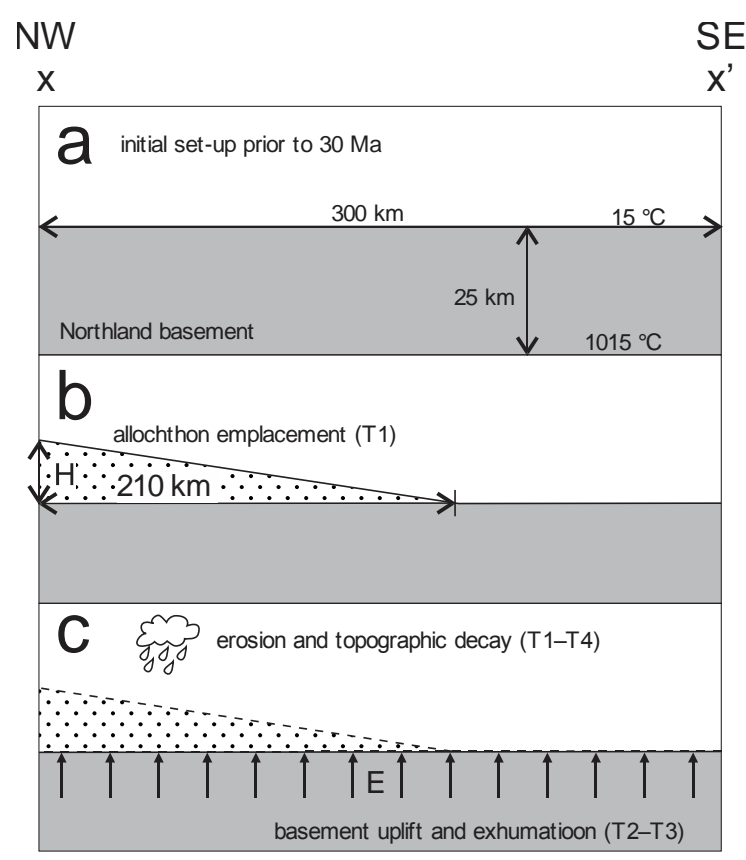

Fig. 4.6 2D thermo-kinematic model of the eastern Northland basement, involving the emplacement and erosion of the Northland Allochthon. (a) Initial model setting prior to 30 Ma. (b) Allochthon emplacement. (c) Post-emplacement uplift of the basement and erosion of the allochthon. See section 4.5.3 for more details. Location of the profile is shown in Fig.4.1b.

In the model set-up, the crustal thickness is set to $\sim 25 \mathrm{~km}$ (Fig. 4.6a), according to Salmon et al. (2013). The initial thermal structure is set to approximate the presentday geothermal gradient of $40{ }^{\circ} \mathrm{C} / \mathrm{km}$ (Reyes, 2007). Other thermo-kinematic parameters are as typical in Pecube models (Braun et al., 2012), listed in Table 4.3. For simplicity no flexural isostasy is considered. The allochthon in eastern Northland 
is simulated to be emplaced at the time T1 (Fig. 4.6b), which is allowed to vary in the range of 30-15 Ma. The basement AFT ages young towards the northwest, implying an increase, in this same direction, in the original thickness of the allochthon; this must be satisfied in the $2 \mathrm{D}$ model. To this end, we set the maximum thickness of allochthon to $\mathrm{H}$ in the northwestern boundary of the transect thinning towards the southeast (Fig. 4.6b); while $\mathrm{H}$ is allowed to vary from 0 to $10 \mathrm{~km}$. The original extent of the allochthon along the model transect is prescribed to $210 \mathrm{~km}$ (Fig. 4.6b), corresponding to the present outcrop of the allochthon in western Northland. Following allochthon emplacement, the basement of eastern Northland is set to be uplifted and exhumed at rate E during a period from time T2 to T3 (Fig. 4.6c). T2 and $\mathrm{T} 3$ are searched in time ranges of 30-0 Ma and T2-0 Ma, respectively, whereas E is allowed to vary between 0.01 and $5 \mathrm{~km} / \mathrm{Myr}$ and is sampled in a logarithmic space. Above the basement, the surface relief is set to reduce gradually due to erosion of the allochthon, over a period from T1 to T4 (Fig. 4.6c); T4 is searched between 15 and 0 Ma.

We prescribe a Mesozoic basement exhumation from 150 to $100 \mathrm{Ma}$ at the rate of $0.15 \mathrm{~km} / \mathrm{Myr}$, in order to reproduce the oldest ZFT and AFT ages south of Auckland, where no allochthon emplacement has been documented.

Table 4.3 Fixed thermo-kinematic model parameters

\begin{tabular}{lc}
\hline Parameter (unit) & Value \\
\hline Crustal density $\left(\mathrm{kg} / \mathrm{m}^{3}\right)$ & 2700 \\
Mantle density $\left(\mathrm{kg} / \mathrm{m}^{3}\right)$ & 3200 \\
Crustal thickness $(\mathrm{km})$ & 25 \\
Thermal diffusivity $\left(\mathrm{km}^{2} / \mathrm{Myr}\right)$ & 30 \\
Basal crustal temperature $\left({ }^{\circ} \mathrm{C}\right)$ & 1015 \\
Sea-level temperature $\left({ }^{\circ} \mathrm{C}\right)$ & 15 \\
Atmospheric lapse rate $\left({ }^{\circ} \mathrm{C} / \mathrm{km}\right)$ & 6 \\
Crustal heat production $\left({ }^{\circ} / \mathrm{Myr}\right)$ & 0 \\
\hline
\end{tabular}

\subsubsection{Results}

The inversion results are presented in Fig. 4.7, as scatter plots in the parameter space projected onto a surface each defined by two parameters. Each dot represents a forward model, and its colour depicts the model misfit between prediction and 
observation. 1D and 2D posterior marginal PDFs are computed for each parameter and for parameter combinations, respectively. Predictions by the expected (weighted mean) and "best-fit" models are summarised in Table 4.4.
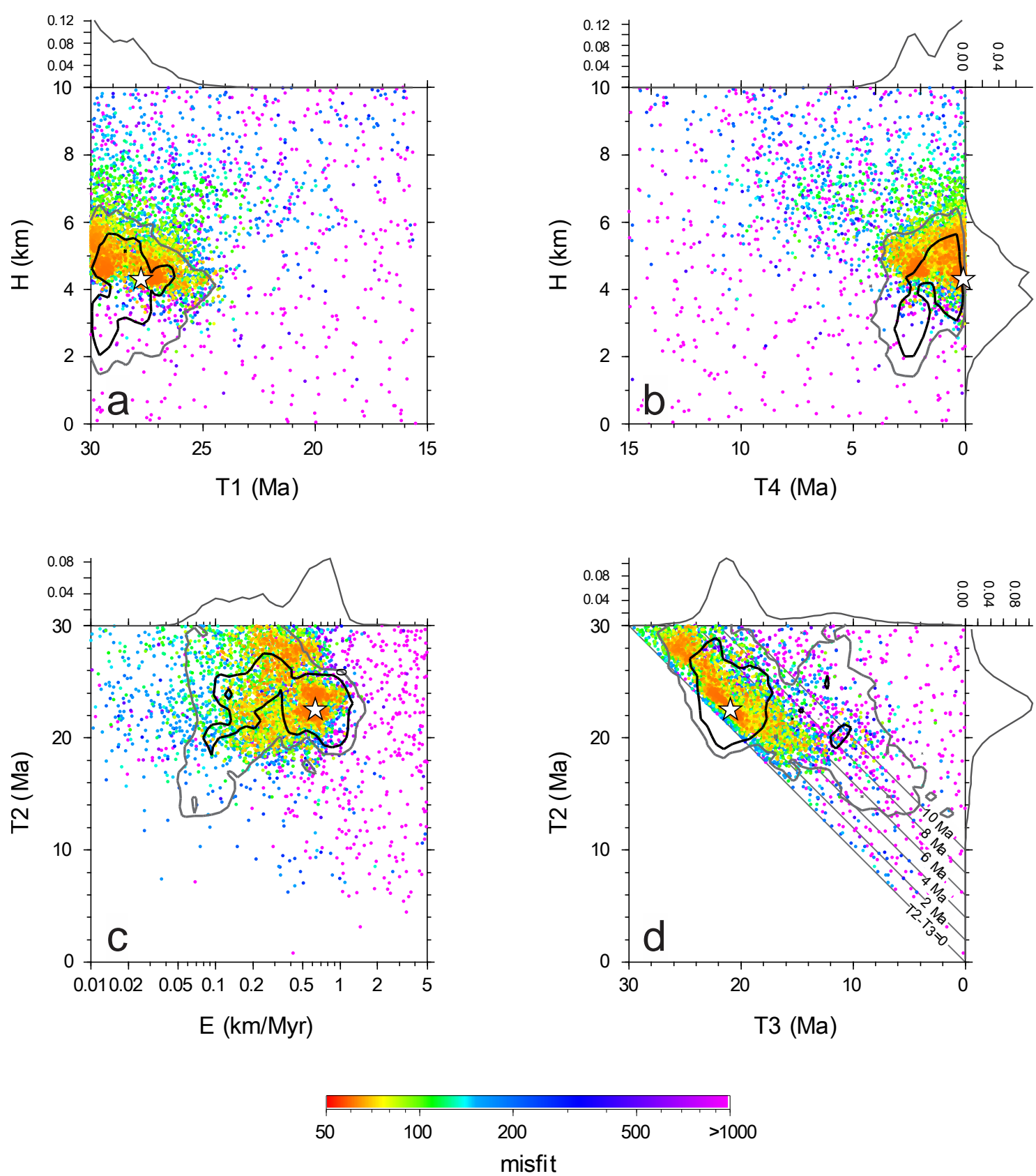

Fig. 4.7 Inversion results of the thermo-kinematic model in eastern Northland. Scatter plots present the parameter space projected onto planes defined by pairs of parameters. Each dot depicts a forward model colour coded according to its misfit value. 1D posterior marginal probability density functions (PDFs) are plotted along axes. 2D posterior marginal PDFs are plotted as $67 \%$ (black) and $95 \%$ (grey) confidence contours. Stars represent the "best-fit" forward model (lowest misfit).

Results suggest that the emplacement of Northland Allochthon occurred since the mid-Oligocene ( 30-27 Ma) (T1; Fig. 4.7a), and its maximum thickness was up to 4-6 km (H; Fig. 4.7a) in northern Northland. Following allochthon emplacement, 
the model predicts a short ( 1-6 Myr; Fig. 4.7d) period of basement uplift at the rate of $\sim 0.1-0.8 \mathrm{~km} / \mathrm{Myr}$ (E; Fig. 4.7c). Finally, the results suggest that the emplaced allochthon has been eroded slowly over a long period until 3-0 Ma (T4; Fig. 4.7b).

Table 4.4 Free model parameters.

\begin{tabular}{|c|c|c|c|c|}
\hline Parameter & Code & Range & Unit & $\begin{array}{c}\text { Mean } \pm \text { standard error } \\
\text { (best-fit) }\end{array}$ \\
\hline Allochthon emplacement & $\mathrm{T} 1$ & $30-15$ & Ma & $28.3 \pm 1.3(27.7)$ \\
\hline $\begin{array}{l}\text { Maximum thickness of } \\
\text { allochthon at } \mathrm{T} 1\end{array}$ & $\mathrm{H}$ & $0-10$ & $\mathrm{~km}$ & $3.9 \pm 1.0(4.3)$ \\
\hline Onset of basement uplift & $\mathrm{T} 2$ & $30-0$ & $\mathrm{Ma}$ & $22.7 \pm 3.0(22.6)$ \\
\hline End of basement uplift & $\mathrm{T} 3$ & $\mathrm{~T} 2-0$ & Ma & $18.5 \pm 4.9(21.0)$ \\
\hline $\begin{array}{l}\text { Logarithm of basement uplift } \\
\text { rate during } \mathrm{T} 2-\mathrm{T} 3\end{array}$ & $\log (E)$ & $-2-0.7$ & $\begin{array}{c}\log \\
(\mathrm{km} / \mathrm{Myr})\end{array}$ & $-0.46 \pm 0.37(-0.19)$ \\
\hline End of allochthon erosion & $\mathrm{T} 4$ & $15-0$ & $\mathrm{Ma}$ & $1.6 \pm 1.1(0.09)$ \\
\hline Lowest misfit & & & & 63 \\
\hline
\end{tabular}

In general, both the mean and the "best-fit" models reproduce the observed data well (Fig. 4.8b), except for the oldest ZFT age in the southeast of the model, which most likely represents a mixed age inherited from multiple detrital sources (Raza et al., 1999). During the Late Oligocene-Early Miocene, the basement rocks in northern Northland are predicted to have undergone heating to over $\sim 120{ }^{\circ} \mathrm{C}$ (Fig. 4.8a), interpreted as the result of burial beneath the allochthon (and autochthon) sequences. The magnitude of heating decreased towards the southeast (Fig. 4.8a), due to the thinning of the allochthon in that direction (Fig. 4.8c). 

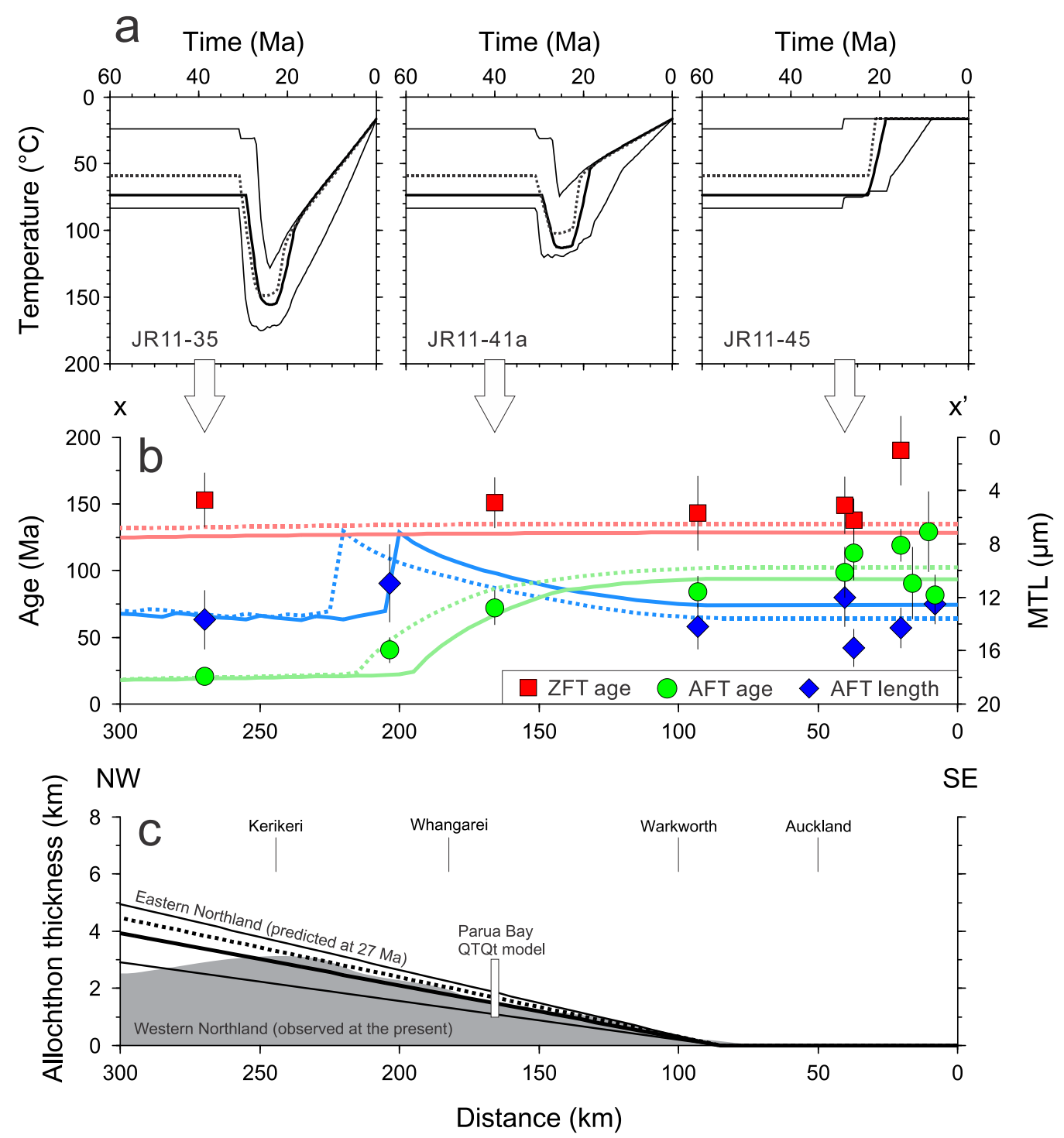

Fig. 4.8 Prediction of the 2D thermo-kinematic model. (a) Predicted thermal histories of representative samples. Heavy lines represent the mean T-t paths; light lines represent the envelopes of "good-fit" models (misfit $<100$ ); dotted lines represent the "best-fit" models (lowest misfit). (b) Observed (symbols) versus the predicted data by the mean (solid lines) and the "best-fit" models (dotted lines). (c) The current allochthon thickness in western Northland (grey shade) (Isaac et al., 1994) versus the predicted maximum allochthon thickness (at $\sim 27 \mathrm{Ma}$ ) in eastern Northland. Solid lines represent the thickness predicted by the mean model with the envelope of "good-fit" models (misfit $<100$ ), whereas the dotted line is thickness predicted by the "best-fit" model (lowest misfit). Box represents the thickness of the allochthon at Parua Bay, predicted by the thermal models (QTQt) of the allochthon (JR11-40c) and autochthon (JR11-40b), assuming 30-40 ${ }^{\circ} \mathrm{C} / \mathrm{km}$ geothermal gradient and $5-15{ }^{\circ} \mathrm{C}$ surface temperature at time of emplacement. 


\subsection{Discussion}

\subsubsection{Detrital provenance of allochthon and autochthon}

At Parua Bay, the new ZFT single-grain age patterns from the allochthon and Early Miocene autochthon are similar to each other (Figs. 4.3b and 4.3c). The old ZFT age components $(143 \pm 38 \mathrm{Ma}$ in the allochthon and $164 \pm 12 \mathrm{Ma}$ in the autochthon, respectively) are consistent with (1) the youngest zircon U-Pb age component obtained from the older Waipapa Supergroup (Adams et al., 2013) and (2) the ZFT ages from Waipapa Supergroup reported in this study. Thus we interpret the Waipapa Supergroup as one of the main sedimentary sources for the Late CretaceousPaleocene allochthon and Early Miocene autochthon in the Northland region. This concurs with the provenance of the allochthon sediments as inferred by Adams et al. (2013), who determined predominant U-Pb zircon detrital components of 130-110 Ma for five Cretaceous allochthon samples and suggested that the sedimentary sources of the allochthon included the local Mesozoic terranes and the Median Batholith (Mortimer et al., 1999). A similar provenance, based on zircon U-Pb dating, was identified by Mortimer et al. (2003) for the Late Cretaceous (or younger) metasedimentary samples dredged from the Cavalli Seamount (Fig. 4.1a) to the northeast of Northland Peninsula. This accordance in the detrital provenance for sediments deposited over different periods in northern New Zealand implies continuous erosion of the Waipapa Supergroup from the Late Cretaceous to Early Miocene, supplying sediments to the adjacent basins.

The younger ZFT age peaks in the allochthon $(84 \pm 10 \mathrm{Ma})$ and autochthon $(80 \pm 11$ Ma) are again similar to one another. These ages are consistent with the Late Cretaceous felsic volcanism in New Zealand (Tulloch et al., 2009), associated with the final break-up of eastern Gondwana.

In addition to the two older provenances, the autochthon sample contains a significant population of large, euhedral apatites that yield Late Oligocene-Early Miocene (26.2 $\pm 1.7 \mathrm{Ma}$ ) ages (Fig. 4.3c). Although these ages may have been partially reset (Fig. 4.4d) during allochthon emplacement, their modelled rapid cooling time in the Oligocene (Fig. 4.4a) is just prior to and perhaps associated with the oldest currently 
identified ages (27-26 Ma) of the andesite in the western volcano belt in Northland (Fig. 4.1c) (Isaac et al., 1994; Stern et al., 2006).

\subsubsection{Thickness of the allochthon during its emplacement}

During the Late Oligocene and Early Miocene, the 2D thermo-kinematic model provides constraints on the burial depth of the Waipapa basement, which we interpret as dominantly the thickness of the Northland Allochthon during its emplacement. It is worth noting that this estimation is based on an assumption that the surface and basal temperatures of the crust have been relatively consistent since $\sim 30 \mathrm{Ma}$.

The thermo-kinematic model suggests that the emplaced allochthon was up to $4-6$ $\mathrm{km}$ thick in the northernmost part of Northland, thinning to zero near Auckland (Fig. 4.8c). At Parua Bay, the model predicts $\sim 1-2 \mathrm{~km}$ thick allochthonous overburden during Late Oligocene, within the range of that inferred from the single-site thermal history models of the detrital samples (Fig. 4.8c).

\subsubsection{Post-emplacement erosion of the allochthon}

Combining the model prediction in eastern Northland and the current thickness estimated by Isaac et al. (1994) along the west coast, we have determined the distribution of the Northland Allochthon over different time periods (Fig. 4.9). This estimation is based on an assumption that along the west coast (offshore and onshore), the allochthonous rocks have not been eroded, as they have been beneath sea level and/or covered by younger sediments, respectively (Fig. 4.1b). The inferred palaeoisopach maps (Fig. 4.9) of the allochthon indicate that, in the Late Oligocene, the thickest part of the allochthon was located in northern Northland and thinned southwards (Fig. 4.9a). This distribution of thickness supports the proposal that the allochthon originated northnortheast of its present location in Northland (Bradshaw, 2004; Hayward et al., 1989) and was transported generally towards the southwest (Rait, 2000).

During the Early Miocene, the eastern Northland basement was uplifted, leading to rapid erosion of the allochthon in northern and eastern Northland (Fig. 4.9b) and sedimentation in the basins to the west and south (Edbrooke and Brook, 2009; Hayward et al., 1989). The thermo-kinematic model predicts $\sim 0.4-1.5 \mathrm{~km}$ basement unroofing in a relatively short period ( 1-6 Myr), although the onset (T2) and end 
timing (T3) of the exhumation are not tightly constrained (Fig. 4.7d). The uplift and unroofing of eastern Northland basement had ceased in mid-Miocene, since when the erosion of the allochthon has been very slow ( 0-0.2 km/Myr) (Fig. 4.9c). The end of basement unroofing predated or coincided with the decline of most subduction-related volcanism in western and northern Northland (Hayward et al., 2001; Herzer, 1995), reflecting the cessation of the active plate boundary in northwestern New Zealand (Mortimer et al., 2007).
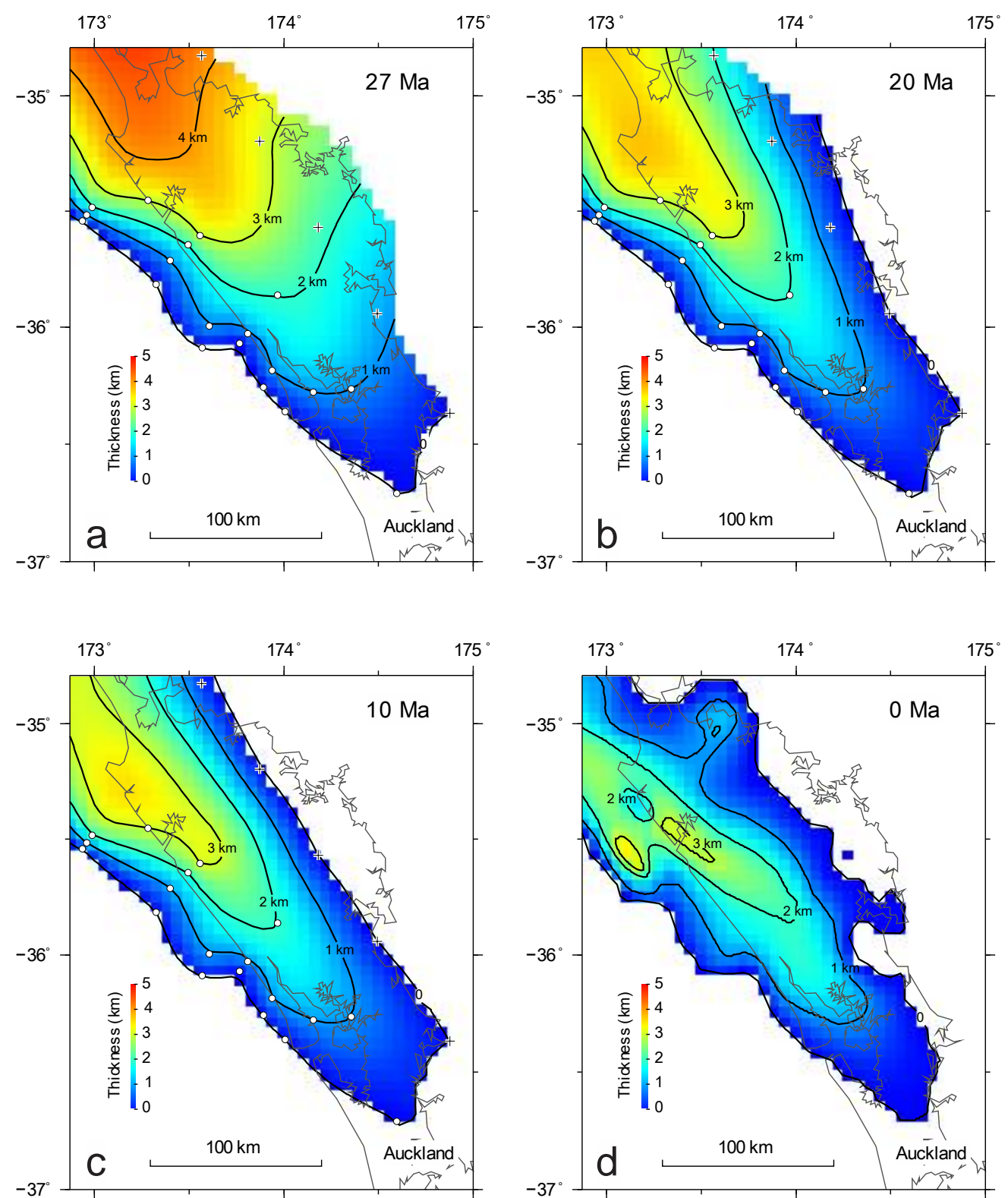

Fig. 4.9 Isopachs of the Northland Allochthon at (a) $27 \mathrm{Ma}$, (b) $20 \mathrm{Ma}$ and (c) $10 \mathrm{Ma}$. Contours are interpolated using Generic Mapping Tools (Wessel and Smith, 1998). Allochthon thickness is estimated from the results of the thermo-kinematic model in eastern Northland incorporating the current allochthon thickness along the west coast. Control points used for interpolation are shown as circles (Isaac et al., 1994) and pluses (this study). (d) The current thickness of Northland Allochthon, after (Isaac et al., 1994). 


\subsubsection{Dependence of the model results on prescribed boundary temperatures}

We assumed constant thermal parameters throughout the thermo-kinematic model, in order to concentrate on the emplacement and erosion history of the allochthon. These parameters were prescribed to approximate the present thermal state of crust in the region (Reyes, 2007), but any potential variability of the crustal thermal structure may have had an influence on the modelling results. Using the model presented above as a reference, we tested the sensitivity of the inversion results to the prescribed surface and basal temperatures of the model. The results (Fig. 4.10) suggest that the basal temperature has considerable impact on the predicted allochthon thickness $(\mathrm{H})$, which decreases with an increasing basal temperature. For other searched parameters, the influence of the surface and basal temperatures are less significant and generally within the predicted uncertainties of the reference model (Fig. 4.10).

\subsection{Conclusions}

We provide constraints on the provenance, original thickness and subsequent erosion history of a thrust sheet that has been mostly eroded, in eastern Northland, New Zealand. At Parua Bay, mixture models of the detrital ZFT and partially annealed AFT ages from the overlying Northland Allochthon and underlying Early Miocene autochthon yield similar age components. Both the allochthon and autochthon indicate sedimentary sources from the Waipapa Supergroup and perhaps from Late Cretaceous volcanics. In addition, the Early Miocene autochthon contains a major sedimentary component from Oligocene subduction-related volcanism.

At Parua Bay, thermal histories of the allochthon and autochthon have been modelled using the ZFT, AFT and AHe data. The results confirm a period of heating during the Late Oligocene and Early Miocene, which we interpret as the result of burial by the thrust sheets. The maximum temperature of the heating is modelled to be $\sim 55-100{ }^{\circ} \mathrm{C}$.

Along the east coast of Northland, ZFT and AFT data from the Waipapa Supergroup have been inverted using a 2D thermo-kinematic model. During the allochthon emplacement, the model suggests that the nappes were up to $\sim-6 \mathrm{~km}$ thick in the northernmost Northland, thinning to zero near Auckland and on the Coromandel Peninsula. Following the allochthon emplacement, eastern Northland was uplifted and unroofed during a short period (1-6 Myr), leading to $\sim 0.4-1.5 \mathrm{~km}$ erosion. The 
basement uplift ended before mid-Miocene in Northland, and since then the erosion of the allochthon and underlying rocks has been very slow ( 0-0.2 km/Myr).

a
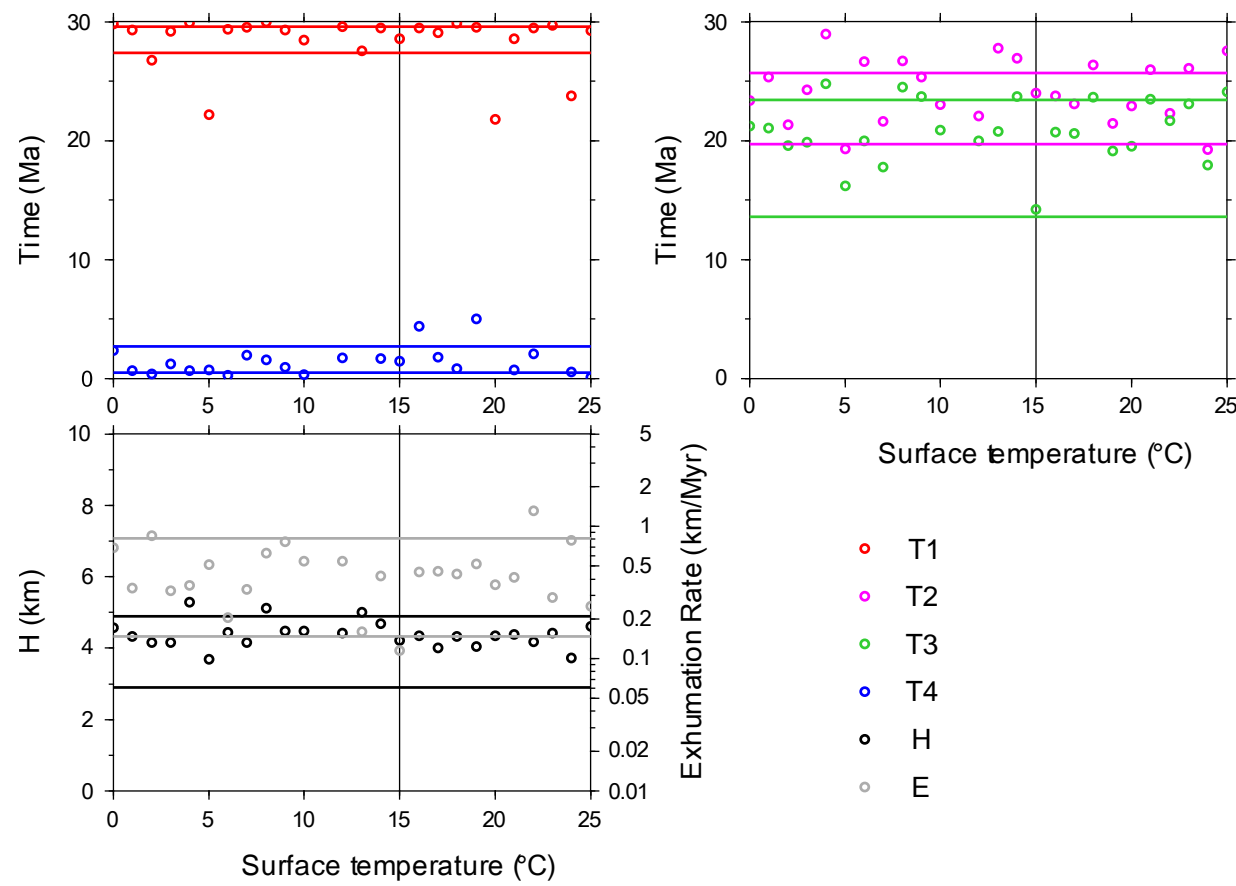

b
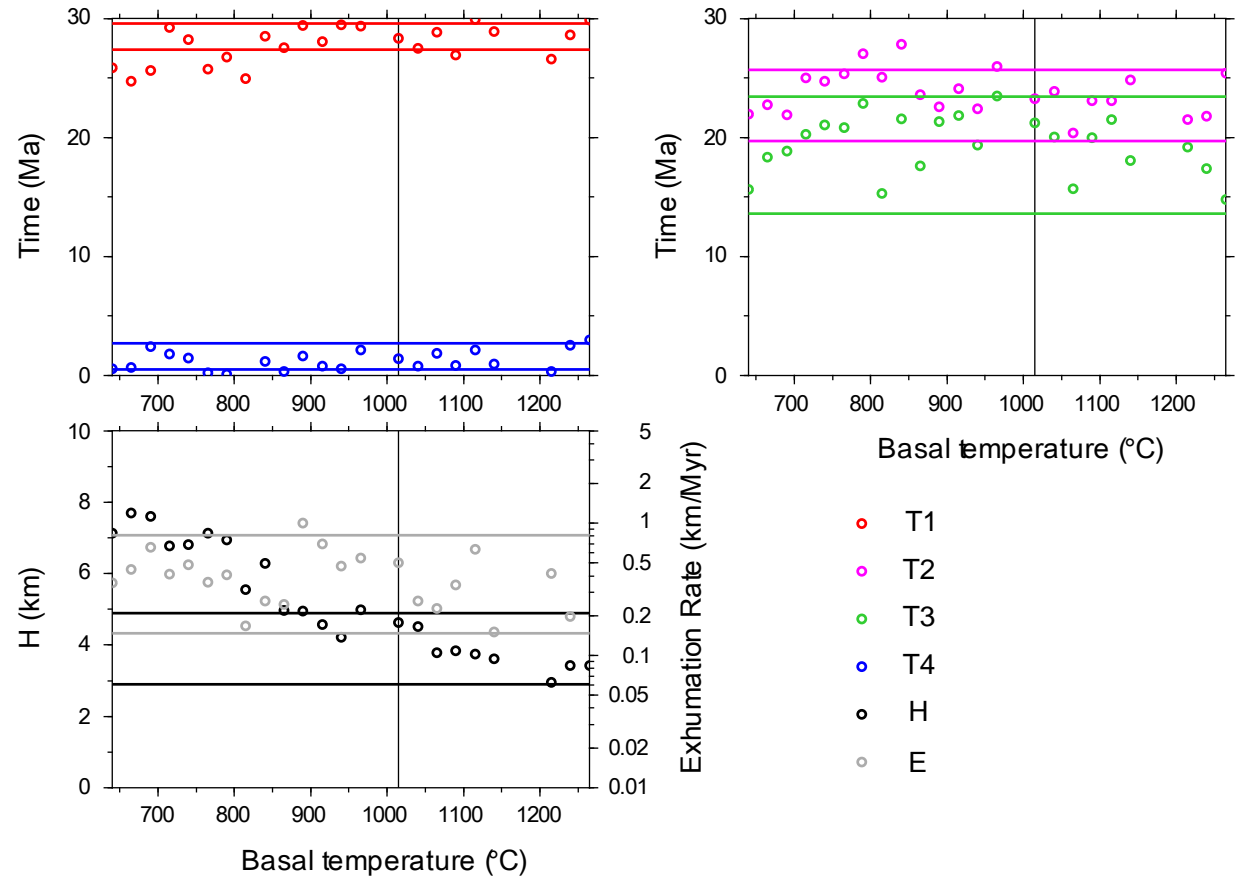

Fig. 4.10 Variation of the inversion results in relationship with the prescribed (a) surface and (b) basal temperatures in the thermo-kinematic (Pecube) model. Each circle depicts the "bestfit" model of an inversion. All other parameters and settings are the same as the reference model (Fig. 4.6 and Table 4.3) 


\section{Chapter 5}

\section{Conclusions and recommendations}

This thesis provides a comprehensive understanding of the exhumation histories of the Mesozoic basement rocks (Waipapa and Torlesse Supergroups) of North Island, New Zealand, using new and published thermochronological data covering a large geographical extent. I have demonstrated that a diversity of exhumation and burial processes occurred in the upper plates of both the Mesozoic Gondwana and late Cenozoic Hikurangi margins. This study also forms the foundation for some future projects, to investigate the kinematics and mechanism of the crustal exhumation and deformation of the North Island basement through thermochronology. This chapter summarises the key points from the thesis and synthesises the thermal and exhumation histories of the basement rocks of North Island.

\subsection{Key findings}

\section{Throughout North Island}

- The zircon fission-track (ZFT) ages from the North Island basement (except those from the Kaimanawa Schist) are mostly detrital, indicating a maximum postdepositional heating temperature lower than $\sim 240{ }^{\circ} \mathrm{C}$.

- The apatite fission-track (AFT) and apatite (U-Th-Sm)/He ages (AHe) were thermally reset during burial in the Mesozoic Gondwana margin. They provide important constraints on the thermal and related exhumation histories of the basement rocks.

$\underline{\text { In central North Island }}$

- Inverse modelling of AFT and AHe reveals thermal and exhumation histories in the both the Mesozoic and late Cenozoic margins. 
- Following the burial and maximum metamorphism, the basement rocks were exhumed to shallow depths of the crust and cooled to $<70{ }^{\circ} \mathrm{C}$ between 150 and $135 \mathrm{Ma}$.

- The basement experienced some reheating (up to $100^{\circ} \mathrm{C}$ ) prior to $100 \mathrm{Ma}$.

- From $100 \mathrm{Ma}$ to the Late Oligocene, thermal history models of the basement rocks reveal little change in temperature.

- Since the Late Oligocene, the exhumation magnitude was much higher in the axial ranges in the eastern North Island than that in the western central North Island.

In the axial ranges in eastern North Island

- Unroofing of the axial ranges began in the Late Oligocene, associated with the subduction of the Pacific Plate beneath North Island.

- During the evolution of the Hikurangi Margin, basement exhumation in the axial ranges migrated towards the trough.

- During the Early Miocene, basement exhumation in the axial ranges was accommodated by eastwards reverse faulting on the margin-parallel Ngamatea Fault ( 27-17 Ma) and Wellington-Mohaka Fault ( 20-7 Ma).

- Since the Late Miocene from the central to southern axial ranges, the increase in exhumation rate is in accordance with the margin-normal crustal shortening in the forearc of the upper plate, which is suggested as the dominant driver for the uplift and exhumation of this section of the axial ranges.

$\underline{\text { In northwestern North Island }}$

- At Parua Bay on the east coast of central Northland, the single-grain ZFT and AFT age distributions of the Northland Allochthon and underlying Early Miocene autochthon indicate sedimentary sources from the Mesozoic Waipapa Supergroup and perhaps from the Late Cretaceous volcanics. In addition, the autochthon contains a major sedimentary component from the Oligocene volcanics.

- Inverse modelling of the ZFT, AFT and AHe data from the allochthon and autochthon suggests a period of heating (at $\sim 55-100{ }^{\circ} \mathrm{C}$ ) during the Late Oligocene and Early Miocene, interpreted to be the result of burial by the nappes.

- Thermo-kinematic modelling of the ZFT and AFT data from the basement rocks (Waipapa Supergroup) suggests up to $\sim 4-6 \mathrm{~km}$ thick nappes in the northernmost Northland during the emplacement, thinning to zero near Auckland. 
- Following the allochthon emplacement, the thermo-kinematic model suggests that eastern Northland was uplifted and unroofed during a short period ( 1-6 Myr) in the Early Miocene, leading to $\sim 0.4-1.5 \mathrm{~km}$ of erosion of the allochthon.

- The basement uplift ended before mid-Miocene in Northland, and since then the erosion of the allochthon and underlying rocks has been slow ( $\sim-0.2 \mathrm{~km} / \mathrm{Myr})$.

\subsection{Exhumation histories of North Island basement}

\subsubsection{The Mesozoic}

After deposition, partial subduction and amalgamation in the accretionary wedge of the eastern Gondwana margin, the Waipapa and Torlesse Supergroups of North Island experienced significant exhumation during latest Jurassic-Early Cretaceous. In central North Island, the basement rocks were cooled rapidly (at $>10{ }^{\circ} \mathrm{C} / \mathrm{Myr}$ ) and were exhumed to shallow levels of the crust between $\sim 150$ and $\sim 135$ Ma. A similar period of cooling was documented in the Otago Schist (Torlesse Supergroup) of South Island in previous studies (Little et al., 1999; Mortimer et al., 2012; Nishimura et al., 2000).

During the late Early Cretaceous, some of the basement rocks in central North Island were reheated to up to $\sim 100{ }^{\circ} \mathrm{C}$, perhaps correlated with the argon-loss events observed in the Otago Schist (Little et al., 1999; Mortensen et al., 2010). I speculated the reheating to be the result of burial by sedimentation above the accretionary wedge during its waning stage, reflecting a phase of extensional deformation, as part of the progressive crustal thinning and extension across the margin (Tulloch et al., 2009) preceding the final breakup of eastern Gondwana.

Since $100 \mathrm{Ma}$, all thermal history models in North Island reveal little change in temperature until the Late Oligocene. During this period, the continent of New Zealand was retreating from the rest of Gondwana.

\subsubsection{The Cenozoic}

A renewed convergent plate boundary was initiated during the Middle Eocene-Late Oligocene, leading to a diverse thermal impact on the basement rocks of North Island.

During the Late Oligocene-earliest Miocene in northwestern New Zealand, the initiation of subduction was marked by the emplacement of the Northland Allochthon, which partially or totally overprinted the apatite fission-track ages from the Mesozoic 
basement (Waipapa Supergroup). During about the same period in eastern North Island, the frontal ridges started to exhume at $\sim 27 \mathrm{Ma}$ in the west of the central axial ranges (Kaimanawa Mountains), which I infer to be a direct response in the upper plate to the initiation of subduction of the Pacific Plate. In contrast, the renewed plate convergence had little impact on the rocks in western North Island (Waipapa Supergroup to the west of Lake Taupo) that can be identified through thermochronology.

Following the allochthon emplacement, eastern Northland was uplifted and unroofed during the Early Miocene, leading to extensive erosion of the nappes, as predicted by the thermo-kinematic model. At this time, the accelerated exhumation of basement rocks became more widespread, observed in most parts of the axial ranges to the west of the Wellington-Mohaka Fault. During this period, the intensive crustal deformation of the upper plate was also evidenced by the development of thrust belts in eastern North Island (Chanier and Ferriere, 1991; Rait et al., 1991).

Basement uplift ended before mid-Miocene in Northland. The end of basement unroofing is inferred to reflect the cessation of the active plate boundary in northwestern New Zealand (Hayward et al., 2001; Herzer, 1995; Mortimer et al., 2010), perhaps as a result of the southeastwards migration of subduction (King, 2000; Mortimer et al., 2007).

Throughout the Miocene, the exhumation of basement rocks in the axial ranges continued and migrated eastwards towards the Hikurangi Trough. The exhumation pattern indicates considerable eastwards reverse faulting on the Wellington-Mohaka Fault during the Early Miocene; this supports previous speculations (Beanland, 1995; Beanland et al., 1998) that the active strike-slip structure was inherited from an older reverse fault that was active in the Miocene.

During the last $10 \mathrm{Myr}$, the exhumation rate in the axial ranges has varied significantly along strike, lower in the central region and higher to the north and south. From the Hawke's Bay to the Wellington region, the increase in the magnitude of exhumation is very consistent with the increase in the magnitude of the marginnormal shortening strains that were measured from the forearc (Nicol et al., 2007). Thus I suggest the unroofing of the axial ranges was predominantly driven by the crustal shortening of the upper plate in the margin-normal direction. 


\subsection{Recommendations for future study}

This study indicates the importance of the margin-parallel faults in eastern North Island for the uplift and exhumation of the basement-cored ranges during the Hikurangi subduction. However, the understanding of the Miocene deformation history of eastern North Island remains preliminary. More thermochronological data, with closer spatial collections, especially employing apatite (U-Th-Sm)/He, from the Mesozoic basement across the North Island Fault System will contribute to further investigation of the past activities of these structures. This work would also benefit with integration and balancing the erosion/exhumation data sets with the stratigraphy of the Cenozoic basins in the east coast.

A large number of thermochronological data available from the basement rocks throughout New Zealand, is now available. These are useful for constraining the exhumation histories in various geological/geomorphic settings. A compilation and review of these data have the potential to provide further useful information related to the Cenozoic evolution of the plate boundary. The Appendix I of this thesis is an attempt, albeit unfinished, of such a study. 



\section{Bibliography}

Adams, C.J. and Graham, I.J., 1993. K-Ar and Rb-Sr age studies of the metamorphism and quartz vein $\mathrm{Au}$ mineralisation on Terawhiti Hill, near Wellington, New Zealand. Chemical Geology, 103(1-4): 235-249.

Adams, C.J. and Graham, I.J., 1996. Metamorphic and tectonic geochronology of the Torlesse Terrane, Wellington, New Zealand. New Zealand Journal of Geology and Geophysics, 39(2): 157-180.

Adams, C.J., Campbell, H.J., Graham, I.J. and Mortimer, N., 1998. Torlesse, Waipapa and Caples suspect terranes of New Zealand: Integrated studies of their geological history in relation to neighbouring terranes. Episodes, 21(4): 235240.

Adams, C.J., Graham, I.J. and Johnston, M.R., 1999. Age and isotopic characterisation of geological terranes in Marlborough Schist, Nelson/Marlborough, New Zealand. New Zealand Journal of Geology and Geophysics, 42(1): 33-55.

Adams, C.J., 2003. K-Ar geochronology of Torlesse Supergroup metasedimentary rocks in Canterbury, New Zealand. Journal of the Royal Society of New Zealand, 33(1): 165-187.

Adams, C.J. and Maas, R., 2004. Age/isotopic characterisation of the Waipapa Group in Northland and Auckland, New Zealand, and implications for the status of the Waipapa Terrane. New Zealand Journal of Geology and Geophysics, 47(2): 173-187.

Adams, C.J., Campbell, H.J. and Griffin, W.L., 2007. Provenance comparisons of Permian to Jurassic tectonostratigraphic terranes in New Zealand: perspectives from detrital zircon age patterns. Geological Magazine, 144(4): 701-729.

Adams, C.J., Mortimer, N., Campbell, H.J. and Griffin, W.L., 2009. Age and isotopic characterisation of metasedimentary rocks from the Torlesse Supergroup and Waipapa Group in the central North Island, New Zealand. New Zealand Journal of Geology and Geophysics, 52(2): 149-170.

Adams, C.J., Mortimer, N., Campbell, H.J. and Griffin, W.L., 2012. The midCretaceous transition from basement to cover within sedimentary rocks in eastern New Zealand: evidence from detrital zircon age patterns. Geological Magazine, 150(03): 455-478. 
Adams, C.J., Mortimer, N., Campbell, H.J. and Griffin, W.L., 2013. Detrital zircon geochronology and sandstone provenance of basement Waipapa Terrane (Triassic-Cretaceous) and Cretaceous cover rocks (Northland Allochthon and Houhora Complex) in northern North Island, New Zealand. Geological Magazine, 150(1): 89-109.

Ault, A.K. and Flowers, R.M., 2012. Is apatite U-Th zonation information necessary for accurate interpretation of apatite $(\mathrm{U}-\mathrm{Th}) / \mathrm{He}$ thermochronometry data? Geochimica et Cosmochimica Acta, 79(0): 60-78.

Baker, J. and Seward, D., 1996. Timing of Cretaceous extension and Miocene compression in northeast South Island, New Zealand: Constraints from $\mathrm{Rb}-\mathrm{Sr}$ and fission-track dating of an igneous pluton. Tectonics, 15(5): 976-983.

Baldwin, S.L. and Lister, G.S., 1998. Thermochronology of the South Cyclades Shear Zone, Ios, Greece: Effects of ductile shear in the argon partial retention zone. Journal of Geophysical Research: Solid Earth, 103(B4): 7315-7336.

Ballance, P.F., 1976. Evolution of the Upper Cenozoic Magmatic Arc and plate boundary in northern New Zealand. Earth and Planetary Science Letters, 28(3): 356-370.

Ballance, P.F. and Spörli, K.B., 1979. Northland Allochthon. Journal of the Royal Society of New Zealand, 9(2): 259-275.

Ballance, P.F., 1993. The Paleo-Pacific, post-subduction, passive margin thermal relaxation sequence (Late Cretaceous-Paleogene) of the drifting New Zealand continent. In: P.F. Ballance (Editor), South Pacific sedimentary Basins. Sedimentary Basins of the World. Elsevier, Amsterdam, The Netherlands, pp. 93-110.

Barker, D.H.N., Sutherland, R., Henrys, S. and Bannister, S., 2009. Geometry of the Hikurangi subduction thrust and upper plate, North Island, New Zealand. Geochemistry, Geophysics, Geosystems, 10(2): Q02007.

Barnes, P.M., Nicol, A. and Harrison, T., 2002. Late Cenozoic evolution and earthquake potential of an active listric thrust complex above the Hikurangi subduction zone, New Zealand. Geological Society of America Bulletin, 114(11): 1379-1405.

Bassett, K.N. and Orlowski, R., 2004. Pahau Terrane type locality: Fan delta in an accretionary prism trench-slope basin. New Zealand Journal of Geology and Geophysics, 47(4): 603-623.

Beanland, S., 1995. The North Island Dextral Fault Belt, Hikurangi Subduction Margin, New Zealand, Victoria University of Wellington. 
Beanland, S. and Haines, J., 1998. The kinematics of active deformation in the North Island, New Zealand, determined from geological strain rates. New Zealand Journal of Geology and Geophysics, 41(4): 311-323.

Beanland, S., Melhuish, A., Nicol, A. and Ravens, J., 1998. Structure and deformational history of the inner forearc region, Hikurangi subduction margin, New Zealand. New Zealand Journal of Geology and Geophysics, 41(4): 325-342.

Beavan, J., Tregoning, P., Bevis, M., Kato, T. and Meertens, C., 2002. Motion and rigidity of the Pacific Plate and implications for plate boundary deformation. Journal of Geophysical Research: Solid Earth, 107(B10): 2261.

Beavan, J., Matheson, D., Denys, P., Denham, M., Herring, T., Hager, B. and Molnar, P., 2004. A vertical deformation profile across the Southern Alps, New Zealand, from 3.5 years of continuous GPS data, Proceedings of the Cahiers du Centre Européen de Géodynamique et de Séismologie workshop: The State of GPS Vertical Positioning Precision: Separation of Earth Processes by Space Geodesy, Luxembourg, pp. 111-123.

Beavan, J., Denys, P., Denham, M., Hager, B., Herring, T. and Molnar, P., 2010. Distribution of present-day vertical deformation across the Southern Alps, New Zealand, from 10 years of GPS data. Geophysical Research Letters, 37(16): L16305.

Beetham, R.D. and Watters, W.A., 1985. Geology of Torlesse and Waipapa terrane basement rocks encountered during the Tongariro Power Development project, North Island, New Zealand. New Zealand Journal of Geology and Geophysics, 28(4): 575-594.

Begg, J.G. and Johnston, M.R., 2000. Geology of the Wellington area. Institute of Geological \& Nuclear Sciences, Lower Hutt.

Bennett, E.R., Youngson, J.H., Jackson, J.A., Norris, R.J., Raisbeck, G.M., Yiou, F. and Fielding, E., 2005. Growth of South Rough Ridge, Central Otago, New Zealand: Using in situ cosmogenic isotopes and geomorphology to study an active, blind reverse fault. Journal of Geophysical Research: Solid Earth, 110(B2): B02404.

Bernet, M., 2009. A field-based estimate of the zircon fission-track closure temperature. Chemical Geology, 259(3-4): 181-189.

Beu, A., Grant-Taylor, T.L. and Hornibrook, N.d.B., 1980. The Te Aute Limestone Facies: Poverty Bay to Northern Wairarapa. New Zealand Geological Survey, Department of Scientific and Industrial Research. 
Beu, A.G., Browne, G.H. and Grant-Taylor, T.L., 1981. New Chlamys delicatula localities in the central North Island and uplift of the Ruahine Range. New Zealand Journal of Geology and Geophysics, 24(1): 127-132.

Beu, A.G., 1995. Pliocene limestones and their scallops: lithostratigraphy, pectinid biostratigraphy, and paleogeography of eastern North Island late Neogene limestone. Institute of Geological \& Nuclear Sciences Limited.

Black, P.M., Clark, A.S.B. and Hawke, A.A., 1993. Diagenesis and very low-grade metamorphism of volcaniclastic sandstones from contrasting geodynamic environments, North Island, New Zealand: the Murihiku and Waipapa terranes. Journal of Metamorphic Geology, 11(3): 429-435.

Bland, K.J., 2001. Analysis of the Pliocene forearc basin succession Esk River catchment, Hawke's Bay, University of Waikato, Hamilton, New Zealand.

Bland, K.J., Kamp, P.J. and Nelson, C.S., 2007. Systematic lithostratigraphy of the Neogene succession exposed in central parts of Hawke's Bay Basin, eastern North Island, New Zealand.

Bland, K.J., Hendy, A.J.W., Kamp, P.J.J. and Nelson, C.S., 2013. Macrofossil biofacies in the late Neogene of central Hawke's Bay: applications to palaeogeography. New Zealand Journal of Geology and Geophysics, 56(4): 200-222.

Blythe, A.E., Burbank, D.W., Carter, A., Schmidt, K. and Putkonen, J., 2007. PlioQuaternary exhumation history of the central Nepalese Himalaya: 1. Apatite and zircon fission track and apatite [U-Th]/He analyses. Tectonics, 26(3): TC3002.

Bradshaw, J.D., 1989. Cretaceous geotectonic patterns in the New Zealand Region. Tectonics, 8(4): 803-820.

Bradshaw, J.D., 2004. Northland Allochthon: An alternative hypothesis of origin. New Zealand Journal of Geology and Geophysics, 47(3): 375-382.

Brandon, M.T., Roden-Tice, M.K. and Garver, J.I., 1998. Late Cenozoic exhumation of the Cascadia accretionary wedge in the Olympic Mountains, northwest Washington State. Geological Society of America Bulletin, 110(8): 985-1009.

Braun, J., 2002a. Quantifying the effect of recent relief changes on age-elevation relationships. Earth and Planetary Science Letters, 200(3-4): 331-343.

Braun, J., 2002b. Estimating exhumation rate and relief evolution by spectral analysis of age-elevation datasets. Terra Nova, 14(3): 210-214. 
Braun, J., 2003. Pecube: a new finite-element code to solve the 3D heat transport equation including the effects of a time-varying, finite amplitude surface topography. Computers \& Geosciences, 29(6): 787-794.

Braun, J. and Robert, X., 2005. Constraints on the rate of post-orogenic erosional decay from low-temperature thermochronological data: application to the Dabie Shan, China. Earth Surface Processes and Landforms, 30(9): 1203-1225.

Braun, J., van der Beek, P., Valla, P., Robert, X., Herman, F., Glotzbach, C., Pedersen, V., Perry, C., Simon-Labric, T. and Prigent, C., 2012. Quantifying rates of landscape evolution and tectonic processes by thermochronology and numerical modeling of crustal heat transport using PECUBE. Tectonophysics, 524-525(0): 1-28.

Brown, R.W., Beucher, R., Roper, S., Persano, C., Stuart, F. and Fitzgerald, P., 2013. Natural age dispersion arising from the analysis of broken crystals. Part I: Theoretical basis and implications for the apatite (U-Th)/He thermochronometer. Geochimica et Cosmochimica Acta, 122(0): 478-497.

Browne, G.H., 2004. Late Neogene sedimentation adjacent to the tectonically evolving North Island axial ranges: Insights from Kuripapango, western Hawke's Bay. New Zealand Journal of Geology and Geophysics, 47(4): 663674.

Bull, W.B. and Cooper, A.F., 1986. Uplifted Marine Terraces Along the Alpine Fault, New Zealand. Science, 234(4781): 1225-1228.

Campbell, H.J. and Grant-Mackie, J.A., 2000. The Marine Triassic of Australasian and its interregional correlation. In: J.M.D.G.R.S. Hongfu Yin and T. Jinnan (Editors), Developments in Palaeontology and Stratigraphy. Elsevier, pp. 235255.

Campbell, H.J., Mortimer, N. and Raine, J.I., 2001. Geology of the Permian Kuriwao Group, Murihiku Terrane, Southland, New Zealand. New Zealand Journal of Geology and Geophysics, 44(4): 485-500.

Cande, S.C. and Stock, J.M., 2004. Pacific-Antarctic-Australia motion and the formation of the Macquarie Plate. Geophysical Journal International, 157(1): 399-414.

Carlson, W.D., Donelick, R.A. and Ketcham, R.A., 1999. Variability of apatite fission-track annealing kinetics; I, Experimental results. American Mineralogist, 84(9): 1213-1223.

Chamberlain, C.P., Mix, H.T., Mulch, A., Hren, M.T., Kent-Corson, M.L., Davis, S.J., Horton, T.W. and Graham, S.A., 2012. The Cenozoic climatic and topographic 
evolution of the western North American Cordillera. American Journal of Science, 312(2): 213-262.

Chanier, F. and Ferriere, J., 1991. From a passive to an active margin; tectonic and sedimentary processes linked to the birth of an accretionary prism (Hikurangi Margin, New Zealand). Bulletin de la Societe Geologique de France, 162(4): 649-660.

Charlier, B.L.A., Wilson, C.J.N. and Mortimer, N., 2010. Evidence from zircon U-Pb age spectra for crustal structure and felsic magma genesis at Taupo volcano, New Zealand. Geology, 38(10): 915-918.

Chase, C.G., Gregory-Wodzicki, K.M., Parrish, J.T. and DeCelles, P.G., 1998. Topographic history of the western Cordillera of North America and controls on climate. Oxford Monographs on Geology and Geophysics, 39: 73-99.

Cogné, N., Gallagher, K. and Cobbold, P.R., 2011. Post-rift reactivation of the onshore margin of southeast Brazil: Evidence from apatite (U-Th)/He and fission-track data. Earth and Planetary Science Letters, 309(1-2): 118-130.

Cogné, N., Gallagher, K., Cobbold, P.R., Riccomini, C. and Gautheron, C., 2012. Post-breakup tectonics in southeast Brazil from thermochronological data and combined inverse-forward thermal history modeling. Journal of Geophysical Research: Solid Earth, 117(B11): B11413.

Collot, J.-Y., Delteil, J., Lewis, K., Davy, B., Lamarche, G., Audru, J.-C., Barnes, P., Chanier, F., Chaumillon, E., Lallemand, S., Lepinay, B., Orpin, A., Pelletier, B., Sosson, M., Toussaint, B. and Uruski, C., 1996. From oblique subduction to intra-continental transpression: Structures of the southern KermadecHikurangi margin from multibeam bathymetry, side-scan sonar and seismic reflection. Marine Geophysical Researches, 18(2-4): 357-381.

Conrad, C.P. and Lithgow-Bertelloni, C., 2004. The temporal evolution of plate driving forces: Importance of "slab suction" versus "slab pull" during the Cenozoic. Journal of Geophysical Research: Solid Earth, 109(B10): B10407.

Coyle, D.A. and Wagner, G.A., 1996. Fission-track dating of zircon and titanite from the $9101 \mathrm{~m}$ deep KTB: observed fundamentals of track stability and thermal history reconstruction, International Workshop on Fission Track Dating, University of Ghent, Ghent, pp. 22.

Crampton, J.S., 1997. The Cretaceous stratigraphy of the southern Hawke's BayWairarapa region. 0478095740, Institute of Geological \& Nuclear Sciences Limited, Lower Hutt, New Zealand.

Cutten, H.N.C. and Heron, D.W., 1994. Geology of the middle reaches of the Mohaka River. Institute of Geological and Nuclear Sciences. 
Danišík, M., Pfaff, K., Evans, N.J., Manoloukos, C., Staude, S., McDonald, B.J. and Markl, G., 2010. Tectonothermal history of the Schwarzwald Ore District (Germany): An apatite triple dating approach. Chemical Geology, 278(1-2): 58-69.

Davy, B., 1992. The Influence of Subducting Plate Buoyancy on Subduction of the Hikurangi-Chatham Plateau beneath the North Island, New Zealand. In: J.S. Watkins, Z. Feng and K.J. McMillen (Editors), Geology and Geophysics of Continental Margins (AAPG Memoir), pp. 75-91.

Davy, B. and Wood, R., 1994. Gravity and magnetic modelling of the Hikurangi Plateau. Marine Geology, 118(1-2): 139-151.

Davy, B., Hoernle, K. and Werner, R., 2008. Hikurangi Plateau: Crustal structure, rifted formation, and Gondwana subduction history. Geochemistry Geophysics Geosystems, 9(7): Q07004.

Delteil, J., de Lepinay, B.M., Morgans, H.E.G. and Field, B.D., 2006. Olistostromes marking tectonic events, East Coast, New Zealand. New Zealand Journal of Geology and Geophysics, 49(4): 517-531.

Dodson, M.H., 1973. Closure temperature in cooling geochronological and petrological systems. Contributions to Mineralogy and Petrology, 40(3): 259274.

Donelick, R.A. and Miller, D.S., 1991. Enhanced TINT fission track densities in low spontaneous track density apatites using 252Cf-derived fission fragment tracks: A model and experimental observations. International Journal of Radiation Applications and Instrumentation. Part D. Nuclear Tracks and Radiation Measurements, 18(3): 301-307.

Donelick, R.A., 1993. Method of fission track analysis utilizing bulk chemical etching of apatite. Google Patents.

Donelick, R.A., O’Sullivan, P.B. and Ketcham, R.A., 2005. Apatite Fission-Track Analysis. Reviews in Mineralogy and Geochemistry, 58(1): 49-94.

Dunkl, I., 2002. Trackkey: a Windows program for calculation and graphical presentation of fission track data. Computers \& Geosciences, 28(1): 3-12.

Eberhart-Phillips, D., Reyners, M., Chadwick, M. and Chiu, J.-M., 2005. Crustal heterogeneity and subduction processes: 3-D Vp, Vp/Vs and Q in the southern North Island, New Zealand. Geophysical Journal International, 162(1): 270288.

Eberhart-Phillips, D., Reyners, M., Chadwick, M. and Stuart, G., 2008. Threedimensional attenuation structure of the Hikurangi subduction zone in the 
central North Island, New Zealand. Geophysical Journal International, 174(1): 418-434.

Edbrooke, S.W., 2001. Geology of the Auckland area. Institute of Geological \& Nuclear Sciences, Lower Hutt.

Edbrooke, S.W., 2005. Geology of the Waikato area. Institute of Geological \& Nuclear Sciences, Lower Hutt.

Edbrooke, S.W. and Brook, F.J., 2009. Geology of the Whangarei area. Institute of Geological \& Nuclear Sciences, Lower Hutt.

Ehlers, T.A., Armstrong, P.A. and Chapman, D.S., 2001. Normal fault thermal regimes and the interpretation of low-temperature thermochronometers. Physics of the Earth and Planetary Interiors, 126(3-4): 179-194.

Ehlers, T.A. and Farley, K.A., 2003. Apatite (U-Th)/He thermochronometry: methods and applications to problems in tectonic and surface processes. Earth and Planetary Science Letters, 206(1-2): 1-14.

Ehlers, T.A., 2005. Crustal Thermal Processes and the Interpretation of Thermochronometer Data. Reviews in Mineralogy and Geochemistry, 58(1): 315-350.

England, P. and Molnar, P., 1990. Surface uplift, uplift of rocks, and exhumation of rocks. Geology, 18(12): 1173-1177.

Evans, R.B., 1992. Tertiary tectonic development of Whangaroa district, northeastern Northland, New Zealand. New Zealand Journal of Geology and Geophysics, 35(4): 549-559.

Farley, K.A., Wolf, R.A. and Silver, L.T., 1996. The effects of long alpha-stopping distances on (U-Th)/He ages. Geochimica et Cosmochimica Acta, 60(21): 4223-4229.

Farley, K.A., 2000. Helium diffusion from apatite: General behavior as illustrated by Durango fluorapatite. Journal of Geophysical Research-Solid Earth, 105(B2): 2903-2914.

Farley, K.A., 2002. (U-Th)/He Dating: Techniques, Calibrations, and Applications. Reviews in Mineralogy and Geochemistry, 47(1): 819-844.

Farley, K.A. and Stockli, D.F., 2002. (U-Th)/He Dating of Phosphates: Apatite, Monazite, and Xenotime. Reviews in Mineralogy and Geochemistry, 48(1): 559-577. 
Field, B.D., Uruski, C.I., Beu, A.G., Browne, G.H., Crampton, J.S., Funnell, R.H., Killops, S.D., Laird, M., Mazengarb, C., Morgans, H.E.G., Rait, G.J., Smale, D. and Strong, C.P., 1997. Cretaceous - Cenozoic geology and petroleum systems of the East Coast region, New Zealand. Institute of Geological \& Nuclear Sciences Monograph 19. Institute of Geological \& Nuclear Sciences, Lower Hutt, 301 pp.

Fitzgerald, P.G. and Gleadow, A.J.W., 1988. Fission-track geochronology, tectonics and structure of the transantarctic mountains in Northern Victoria land, antarctica. Chemical Geology: Isotope Geoscience section, 73(2): 169-198.

Fitzgerald, P.G., Sorkhabi, R.B., Redfield, T.F. and Stump, E., 1995. Uplift and denudation of the central Alaska Range: A case study in the use of apatite fission track thermochronology to determine absolute uplift parameters. Journal of Geophysical Research, 100(B10): 20175-20191.

Fitzgerald, P.G., Baldwin, S.L., Webb, L.E. and O'Sullivan, P.B., 2006. Interpretation of (U-Th)/He single grain ages from slowly cooled crustal terranes: A case study from the Transantarctic Mountains of southern Victoria Land. Chemical Geology, 225(1-2): 91-120.

Flowers, R.M., Ketcham, R.A., Shuster, D.L. and Farley, K.A., 2009. Apatite (U$\mathrm{Th} / \mathrm{He}$ thermochronometry using a radiation damage accumulation and annealing model. Geochimica et Cosmochimica Acta, 73(8): 2347-2365.

Flowers, R.M. and Kelley, S.A., 2011. Interpreting data dispersion and "inverted" dates in apatite (U-Th)/He and fission-track datasets: An example from the US midcontinent. Geochimica et Cosmochimica Acta, 75(18): 5169-5186.

Fox, M., Herman, F., Willett, S.D. and May, D.A., 2014. A linear inversion method to infer exhumation rates in space and time from thermochronometric data. Earth Surf. Dynam., 2(1): 47-65.

Frey, M., Capitani, C.D. and Liou, J.G., 1991. A new petrogenetic grid for low-grade metabasites. Journal of Metamorphic Geology, 9(4): 497-509.

Funnell, R., Chapman, D., Allis, R. and Armstrong, P., 1996. Thermal state of the Taranaki Basin, New Zealand. Journal of Geophysical Research: Solid Earth, 101(B11): 25197-25215.

Furlong, K.P. and Kamp, P.J.J., 2006. Neogene plate tectonic reconstructions and geodynamics of North Island sedimentary basins: Implications for the petroleum systems, New Zealand Petroleum Conference.

Furlong, K.P. and Kamp, P.J.J., 2009. The lithospheric geodynamics of plate boundary transpression in New Zealand: Initiating and emplacing subduction 
along the Hikurangi margin, and the tectonic evolution of the Alpine Fault system. Tectonophysics, 474(3-4): 449-462.

Gaina, C., Müller, D.R., Royer, J.-Y., Stock, J., Hardebeck, J. and Symonds, P., 1998. The tectonic history of the Tasman Sea: A puzzle with 13 pieces. Journal of Geophysical Research: Solid Earth, 103(B6): 12413-12433.

Galbraith, R.F., 1990. The radial plot: Graphical assessment of spread in ages. International Journal of Radiation Applications and Instrumentation. Part D. Nuclear Tracks and Radiation Measurements, 17(3): 207-214.

Galbraith, R.F. and Green, P.F., 1990. Estimating the component ages in a finite mixture. International Journal of Radiation Applications and Instrumentation. Part D. Nuclear Tracks and Radiation Measurements, 17(3): 197-206.

Galbraith, R.F. and Laslett, G.M., 1993. Statistical models for mixed fission track ages. Nuclear Tracks and Radiation Measurements, 21(4): 459-470.

Galbraith, R.F., 2005. Statistics for fission track analysis. Chapman and Hall/CRC Press.

Gallagher, K., 1995. Evolving temperature histories from apatite fission-track data. Earth and Planetary Science Letters, 136(3-4): 421-435.

Gallagher, K., Brown, R. and Johnson, C., 1998. Fission track analysis and its applications to geological problems. Annual Review of Earth and Planetary Sciences, 26(1): 519-572.

Gallagher, K., Stephenson, J., Brown, R., Holmes, C. and Fitzgerald, P., 2005. Low temperature thermochronology and modeling strategies for multiple samples 1: Vertical profiles. Earth and Planetary Science Letters, 237(1-2): 193-208.

Gallagher, K., Charvin, K., Nielsen, S., Sambridge, M. and Stephenson, J., 2009. Markov chain Monte Carlo (MCMC) sampling methods to determine optimal models, model resolution and model choice for Earth Science problems. Marine and Petroleum Geology, 26(4): 525-535.

Gallagher, K., 2012. Transdimensional inverse thermal history modeling for quantitative thermochronology. Journal of Geophysical Research: Solid Earth, 117(B2): B02408.

Gallagher, K., 2013. QTQt User Guide v.5, pp. 1-47.

Gautheron, C., Tassan-Got, L., Barbarand, J. and Pagel, M., 2009. Effect of alphadamage annealing on apatite (U-Th)/He thermochronology. Chemical Geology, 266(3-4): 157-170. 
Gautheron, C., Barbarand, J., Ketcham, R.A., Tassan-Got, L., van der Beek, P., Pagel, M., Pinna-Jamme, R., Couffignal, F. and Fialin, M., 2013. Chemical influence on $\alpha$-recoil damage annealing in apatite: Implications for $(\mathrm{U}-\mathrm{Th}) / \mathrm{He}$ dating. Chemical Geology, 351(0): 257-267.

Gleadow, A.J.W., Hurford, A.J. and Quaife, R.D., 1976. Fission track dating of zircon: Improved etching techniques. Earth and Planetary Science Letters, 33(2): 273276.

Gleadow, A.J.W. and Duddy, I.R., 1981. A natural long-term track annealing experiment for apatite. Nuclear Tracks, 5(1-2): 169-174.

Gleadow, A.J.W., Duddy, I.R., Green, P.F. and Lovering, J.F., 1986. Confined fission track lengths in apatite: a diagnostic tool for thermal history analysis. Contributions to Mineralogy and Petrology, 94(4): 405-415.

Gleadow, A.J.W. and Fitzgerald, P.G., 1987. Uplift history and structure of the Transantarctic Mountains: new evidence from fission track dating of basement apatites in the Dry Valleys area, southern Victoria Land. Earth and Planetary Science Letters, 82(1-2): 1-14.

Graafhuis, R.B., 2001. Stratigraphy and sedimentology of Pliocene strata in the forearc basin (Waikoau and Waikari River catchments), northern Hawke's Bay, University of Waikato, Hamilton, New Zealand.

Granger, D.E., Kirchner, J.W. and Finkel, R., 1996. Spatially averaged long-term erosion rates measured from in situ-produced cosmogenic nuclides in alluvial sediment. The Journal of Geology: 249-257.

Green, P.F., 1981. A new look at statistics in fission-track dating. Nuclear Tracks, 5(1-2): 77-86.

Grove, M. and Harrison, T.M., 1996. ${ }^{40} \mathrm{Ar} *$ diffusion in Fe-rich biotite. American Mineralogist, 81(7-8): 940-951.

Hames, W.E. and Bowring, S.A., 1994. An empirical evaluation of the argon diffusion geometry in muscovite. Earth and Planetary Science Letters, 124(14): 161-169.

Hasebe, N., Tagami, T. and Nishimura, S., 1994. Towards zircon fission-track thermochronology: Reference framework for confined track length measurements. Chemical Geology, 112(1-2): 169-178.

Hayward, B., 1993. The tempestuous 10 million year life of a double arc and intra-arc basin-New Zealand's Northland Basin in the Early Miocene. In: P.F. Ballance (Editor), South Pacific sedimentary basins. Elsevier, Amsterdam, The Netherlands, pp. 113-142. 
Hayward, B.W., Brook, F.J. and Isaac, M.J., 1989. Cretaceous to middle Tertiary stratigraphy, paleogeography and tectonic history of Northland, New Zealand. In: K.B. Spörli and D. Kear (Editors), Geology of Northland: accretion, allochthouns and arcs at the edge of the New Zealand micro-continent. Royal Society of New Zealand Bulletin, pp. 47-64.

Hayward, B.W., Black, P.M., Smith, I.E.M., Ballance, P.F., Itaya, T., Doi, M., Takagi, M., Bergman, S., Adams, C.J., Herzer, R.H. and Robertson, D.J., 2001. K-Ar ages of early Miocene arc-type volcanoes in northern New Zealand. New Zealand Journal of Geology and Geophysics, 44(2): 285-311.

Henrys, S., Wech, A., Sutherland, R., Stern, T., Savage, M., Sato, H., Mochizuki, K., Iwasaki, T., Okaya, D., Seward, A., Tozer, B., Townend, J., Kurashimo, E., Iidaka, T. and Ishiyama, T., 2013. SAHKE geophysical transect reveals crustal and subduction zone structure at the southern Hikurangi margin, New Zealand. Geochemistry Geophysics Geosystems, 14(7): 2063-2083.

Herman, F., Seward, D., Valla, P.G., Carter, A., Kohn, B., Willett, S.D. and Ehlers, T.A., 2013. Worldwide acceleration of mountain erosion under a cooling climate. Nature, 504(7480): 423-426.

Herzer, R.H., 1995. Seismic stratigraphy of a buried volcanic arc, Northland, New Zealand and implications for Neogene subduction. Marine and Petroleum Geology, 12(5): 511-531.

Hoernle, K., Hauff, F., van den Bogaard, P., Werner, R. and Mortimer, N., 2005. The Hikurangi oceanic plateau: another large piece of the largest volcanic event on earth.

Holt, W.E. and Stern, T.A., 1994. Subduction, platform subsidence, and foreland thrust loading: The late Tertiary development of Taranaki Basin, New Zealand. Tectonics, 13(5): 1068-1092.

House, M.A., Wernicke, B.P. and Farley, K.A., 1998. Dating topography of the Sierra Nevada, California, using apatite (U-Th)/He ages. Nature, 396(6706): 66-69.

House, M.A., Farley, K.A. and Stockli, D., 2000. Helium chronometry of apatite and titanite using Nd-YAG laser heating. Earth and Planetary Science Letters, 183(3-4): 365-368.

House, M.A., Wernicke, B.P. and Farley, K.A., 2001. Paleo-Geomorphology of the Sierra Nevada, California, from (U-TH) /He Ages in Apatite. American Journal of Science, 301(2): 77-102.

Hunziker, J.C., Frey, M., Clauer, N., Dallmeyer, R.D., Friedrichsen, H., Flehmig, W., Hochstrasser, K., Roggwiler, P. and Schwander, H., 1986. The evolution of 
illite to muscovite: mineralogical and isotopic data from the Glarus Alps, Switzerland. Contributions to Mineralogy and Petrology, 92(2): 157-180.

Hurford, A.J. and Green, P.F., 1983. The zeta age calibration of fission-track dating. Chemical Geology, 41(0): 285-317.

Hurford, A.J. and Carter, A., 1991. The role of fission track dating in discrimination of provenance. Geological Society, London, Special Publications, 57(1): 67-78.

Iaffaldano, G., Di Giuseppe, E., Corbi, F., Funiciello, F., Faccenna, C. and Bunge, H.P., 2012. Varying mechanical coupling along the Andean margin: Implications for trench curvature, shortening and topography. Tectonophysics, 526-529(0): 16-23.

Isaac, M.J., 1977. Mesozoic geology of the Matawai district, Raukumara Peninsula, The University of Auckland.

Isaac, M.J., Herzer, R.H., Brook, F.J. and Hayward, B.W., 1994. Cretaceous and Cenozoic sedimentary basins of Northland, New Zealand. Institute of Geological \& Nuclear Sciences monograph 8. Institute of Geological \& Nuclear Sciences, Lower Hutt, 230 pp.

Jiao, R., Seward, D., Little, T.A. and Kohn, B.P., 2014. Thermal history and exhumation of basement rocks from Mesozoic to Cenozoic subduction cycles, central North Island, New Zealand. Tectonics, 33(10): 2014 TC003653.

Joanne, C., Lamarche, G. and Collot, J.Y., 2013. Dynamics of giant mass transport in deep submarine environments: the Matakaoa Debris Flow, New Zealand. Basin Research, 25(4): 471-488.

Kamp, P.J.J., 1999. Tracking crustal processes by FT thermochronology in a forearc high (Hikurangi margin, New Zealand) involving Cretaceous subduction termination and mid-Cenozoic subduction initiation. Tectonophysics, 307(34): 313-343.

Kamp, P.J.J., 2000. Thermochronology of the Torlesse accretionary complex, Wellington region, New Zealand. Journal of Geophysical Research-Solid Earth, 105(B8): 19253-19272.

Kamp, P.J.J. and Liddell, I.J., 2000. Thermochronology of northern Murihiku Terrane, New Zealand, derived from apatite FT analysis. Journal of the Geological Society, 157(2): 345-354.

Kamp, P.J.J., Vonk, A.J., Bland, K.J., Hansen, R.J., Hendy, A.J.W., McIntyre, A.P., Ngatai, M., Cartwright, S.J., Hayton, S. and Nelson, C.S., 2004. Neogene stratigraphic architecture and tectonic evolution of Wanganui, King Country, 
and eastern Taranaki Basins, New Zealand. New Zealand Journal of Geology and Geophysics, 47(4): 625-644.

Kear, D., 2004. Reassessment of Neogene tectonism and volcanism in North Island, New Zealand. New Zealand Journal of Geology and Geophysics, 47(3): 361374.

Kelsey, H.M., Cashman, S.M., Beanland, S. and Berryman, K.R., 1995. Structural evolution along the inner forearc of the obliquely convergent Hikurangi margin, New Zealand. Tectonics, 14(1): 1-18.

Ketcham, R.A., Donelick, R.A. and Carlson, W.D., 1999. Variability of apatite fission-track annealing kinetics; III, Extrapolation to geological time scales. American Mineralogist, 84(9): 1235-1255.

Ketcham, R.A., 2005. Forward and Inverse Modeling of Low-Temperature Thermochronometry Data. Reviews in Mineralogy and Geochemistry, 58(1): 275-314.

Ketcham, R.A., Carter, A., Donelick, R.A., Barbarand, J. and Hurford, A.J., 2007. Improved modeling of fission-track annealing in apatite. American Mineralogist, 92(5-6): 799-810.

King, P.R., 2000. Tectonic reconstructions of New Zealand: $40 \mathrm{Ma}$ to the Present. New Zealand Journal of Geology and Geophysics, 43(4): 611-638.

Kirschner, D.L., Cosca, M.A., Masson, H. and Hunziker, J.C., 1996. Staircase ${ }^{40} \mathrm{Ar} /{ }^{39} \mathrm{Ar}$ spectra of fine-grained white mica: Timing and duration of deformation and empirical constraints on argon diffusion. Geology, 24(8): 747-750.

Kohl, T., 1999. Transient thermal effects below complex topographies. Tectonophysics, 306(3-4): 311-324.

Laird, M.G. and Bradshaw, J.D., 2004. The Break-up of a Long-term Relationship: the Cretaceous Separation of New Zealand from Gondwana. Gondwana Research, 7(1): 273-286.

Lamarche, G., Joanne, C. and Collot, J.-Y., 2008. Successive, large mass-transport deposits in the south Kermadec fore-arc basin, New Zealand: The Matakaoa Submarine Instability Complex. Geochemistry, Geophysics, Geosystems, 9(4): Q04001.

Langridge, R.M., Berryman, K.R. and Van Dissen, R.J., 2005. Defining the geometric segmentation and Holocene slip rate of the Wellington Fault, New Zealand: The Pahiatua section. New Zealand Journal of Geology and Geophysics, 48(4): 591-607. 
Lee, J.M. and Begg, J.G., 2002. Geology of the Wairarapa area. Institute of Geological \& Nuclear Sciences, Lower Hutt.

Lee, J.M., Bland, K.J., Townsend, D.B. and Kamp, P.J.J., 2011. Geology of the Hawke's Bay area. Institute of Geological and Nuclear Sciences, Lower Hutt.

Leonard, G.S., Begg, J.G. and Wilson, C.J.N., 2010. Geology of the Rotorua area. Institute of Geological \& Nuclear Sciences, Lower Hutt.

Lippolt, H.J., Leitz, M., Wernicke, R.S. and Hagedorn, B., 1994. (Uranium + thorium)/helium dating of apatite: experience with samples from different geochemical environments. Chemical Geology, 112(1-2): 179-191.

Lister, G.S. and Baldwin, S.L., 1996. Modelling the effect of arbitrary P-T-t histories on argon diffusion in minerals using the MacArgon program for the Apple Macintosh. Tectonophysics, 253(1-2): 83-109.

Litchfield, N. and Berryman, K., 2006. Relations between postglacial fluvial incision rates and uplift rates in the North Island, New Zealand. Journal of Geophysical Research, 111(F2): F02007.

Litchfield, N., Ellis, S., Berryman, K. and Nicol, A., 2007. Insights into subductionrelated uplift along the Hikurangi Margin, New Zealand, using numerical modeling. Journal of Geophysical Research, 112(F2): F02021.

Litchfield, N., Wilson, K., Berryman, K. and Wallace, L., 2010. Coastal uplift mechanisms at Pakarae River mouth: Constraints from a combined Holocene fluvial and marine terrace dataset. Marine Geology, 270(1-4): 72-83.

Litchfield, N.J., 2008. Using fluvial terraces to determine Holocene coastal erosion and Late Pleistocene uplift rates: An example from northwestern Hawke Bay, New Zealand. Geomorphology, 99(1-4): 369-386.

Little, T.A., Mortimer, N. and McWilliams, M., 1999. An episodic Cretaceous cooling model for the Otago-Marlborough Schist, New Zealand, based on 40Ar/39Ar white mica ages. New Zealand Journal of Geology and Geophysics, 42(3): 305-325.

Little, T.A., Cox, S., Vry, J.K. and Batt, G., 2005. Variations in exhumation level and uplift rate along the obliqu-slip Alpine fault, central Southern Alps, New Zealand. Geological Society of America Bulletin, 117(5-6): 707-723.

Little, T.A., Van Dissen, R., Schermer, E. and Carne, R., 2009. Late Holocene surface ruptures on the southern Wairarapa fault, New Zealand: Link between earthquakes and the uplifting of beach ridges on a rocky coast. Lithosphere, 1(1): 4-28. 
Mancktelow, N.S. and Grasemann, B., 1997. Time-dependent effects of heat advection and topography on cooling histories during erosion. Tectonophysics, 270(3-4): 167-195.

Marsaglia, K.M., Mortimer, N., Bender-Whitaker, C., Marden, M. and Mazengarb, C., 2014. Ophioliticlastic Ihungia igneous conglomerate (Early Miocene), North Island, New Zealand: evidence for an island source related to subduction initiation and deposition within a slump-generated submarine slope re-entrant. New Zealand Journal of Geology and Geophysics, 57(2): 219-235.

Mazengarb, C. and Harris, D.H.M., 1994. Cretaceous stratigraphic and structural relationships of Raukumara Peninsula, New Zealand; stratigraphic patterns associated with the migration of a thrust system. Annales Tectonicae, 8(2): 100-118.

Mazengarb, C. and Speden, I.G., 2000. Geology of the Raukumara area. Institute of Geological \& Nuclear Sciences, Lower Hutt.

McDougall, I. and Harrison, T.M., 1999. Geochronology and Thermochronology by the ${ }^{40} \mathrm{Ar} /{ }^{39} \mathrm{Ar}$ Method. Oxford University Press.

McDowell, F.W., McIntosh, W.C. and Farley, K.A., 2005. A precise 40Ar-39Ar reference age for the Durango apatite (U-Th)/He and fission-track dating standard. Chemical Geology, 214(3-4): 249-263.

Meesters, A.G.C.A. and Dunai, T.J., 2002. Solving the production-diffusion equation for finite diffusion domains of various shapes: Part II. Application to cases with $\alpha$-ejection and nonhomogeneous distribution of the source. Chemical Geology, 186(3-4): 347-363.

Moore, M.A. and England, P.C., 2001. On the inference of denudation rates from cooling ages of minerals. Earth and Planetary Science Letters, 185(3-4): 265284.

Moore, P., 1988. Stratigraphy, composition and environment of deposition of the Whangai Formation and associated Late Cretaceous-Paleocene rocks, eastern North Island, New Zealand, 100. New Zealand Geological Survey.

Moore, P.R. and Speden, I.G., 1984. The Early Cretaceous (Albian) sequence of eastern Wairarapa, New Zealand. New Zealand Geological Survey, Lower Hutt, New Zealand.

Mortensen, J.K., Craw, D., MacKenzie, D.J., Gabites, J.E. and Ullrich, T., 2010. Age and Origin of Orogenic Gold Mineralization in the Otago Schist Belt, South Island, New Zealand: Constraints from Lead Isotope and 40Ar/39Ar Dating Studies. Economic Geology, 105(4): 777-793. 
Mortimer, N., 1994. Origin of the Torlesse Terrane and Coeval Rocks, North Island, New Zealand. International Geology Review, 36(10): 891-910.

Mortimer, N. and Parkinson, D., 1996. Hikurangi Plateau: A Cretaceous large igneous province in the southwest Pacific Ocean. Journal of Geophysical Research: Solid Earth, 101(B1): 687-696.

Mortimer, N., Tulloch, A.J., Spark, R.N., Walker, N.W., Ladley, E., Allibone, A. and Kimbrough, D.L., 1999. Overview of the Median Batholith, New Zealand: a new interpretation of the geology of the Median Tectonic Zone and adjacent rocks. Journal of African Earth Sciences, 29(1): 257-268.

Mortimer, N., Herzer, R.H., Walker, N.W., Calvert, A.T., Seward, D. and Chaproniere, G.C.H., 2003. Cavalli Seamount, Northland Plateau, SW Pacific Ocean: a Miocene metamorphic core complex? Journal of the Geological Society, 160(6): 971-983.

Mortimer, N., 2004. New Zealand's Geological Foundations. Gondwana Research, 7(1): 261-272.

Mortimer, N., 2006. Zealandia. ASEG Extended Abstracts, 2006(1): 1-4.

Mortimer, N., Herzer, R.H., Gans, P.B., Laporte-Magoni, C., Calvert, A.T. and Bosch, D., 2007. Oligocene-Miocene tectonic evolution of the South Fiji Basin and Northland Plateau, SW Pacific Ocean: Evidence from petrology and dating of dredged rocks. Marine Geology, 237(1-2): 1-24.

Mortimer, N., Gans, P.B., Palin, J.M., Meffre, S., Herzer, R.H. and Skinner, D.N.B., 2010. Location and migration of Miocene-Quaternary volcanic arcs in the SW Pacific region. Journal of Volcanology and Geothermal Research, 190(1-2): $1-10$.

Mortimer, N., McLaren, S. and Dunlap, W.J., 2012. Ar-Ar dating of K-feldspar in low grade metamorphic rocks: Example of an exhumed Mesozoic accretionary wedge and forearc, South Island, New Zealand. Tectonics, 31(3): TC3020.

Mortimer, N., Rattenbury, M.S., King, P.R., Bland, K.J., Barrell, D.J.A., Bache, F., Begg, J.G., Campbell, H.J., Cox, S.C., Crampton, J.S., Edbrooke, S.W., Forsyth, P.J., Johnston, M.R., Jongens, R., Lee, J.M., Leonard, G.S., Raine, J.I., Skinner, D.N.B., Timm, C., Townsend, D.B., Tulloch, A.J., Turnbull, I.M. and Turnbull, R.E., 2014. High-level stratigraphic scheme for New Zealand rocks. New Zealand Journal of Geology and Geophysics: 1-18.

Mountjoy, J.J. and Barnes, P.M., 2011. Active upper plate thrust faulting in regions of low plate interface coupling, repeated slow slip events, and coastal uplift: Example from the Hikurangi Margin, New Zealand. Geochemistry, Geophysics, Geosystems, 12(1): Q01005. 
Mouslopoulou, V., Nicol, A., Little, T.A. and Walsh, J.J., 2007. Terminations of large strike-slip faults: an alternative model from New Zealand. Geological Society, London, Special Publications, 290(1): 387-415.

Nathan, S., Thurlow, C., Warnes, P. and Zucchetto, R., 2000. Geochronology database for New Zealand rocks (2nd edition): 1961-1999, Institute of Geological \& Nuclear Sciences, Lower Hutt.

Nicol, A., Mazengarb, C., Chanier, F., Rait, G., Uruski, C. and Wallace, L., 2007. Tectonic evolution of the active Hikurangi subduction margin, New Zealand, since the Oligocene. Tectonics, 26(4): TC4002.

Nicol, A. and Wallace, L.M., 2007. Temporal stability of deformation rates: Comparison of geological and geodetic observations, Hikurangi subduction margin, New Zealand. Earth and Planetary Science Letters, 258(3-4): 397-413.

Nishiizumi, K., Kohl, C.P., Arnold, J.R., Dorn, R., Klein, I., Fink, D., Middleton, R. and Lal, D., 1993. Role of in situ cosmogenic nuclides 10be and 26al in the study of diverse geomorphic processes. Earth Surface Processes and Landforms, 18(5): 407-425.

Nishimura, Y., Coombs, D.S., Landis, C.A. and Itaya, T., 2000. Continuous metamorphic gradient documented by graphitization and $\mathrm{K}-\mathrm{Ar}$ age, southeast Otago, New Zealand. American Mineralogist, 85(11-12): 1625-1636.

Norton, K.P., von Blanckenburg, F. and Kubik, P.W., 2010. Cosmogenic nuclidederived rates of diffusive and episodic erosion in the glacially sculpted upper Rhone Valley, Swiss Alps. Earth Surface Processes and Landforms, 35(6): 651-662.

Ota, Y. and Yamaguchi, M., 2004. Holocene coastal uplift in the western Pacific Rim in the context of late Quaternary uplift. Quaternary International, 120(1): 105117.

Pettinga, J.R., 1982. Upper Cenozoic structural history, coastal Southern Hawke's Bay, New Zealand. New Zealand Journal of Geology and Geophysics, 25(2): 149191.

Platt, J.P., 1986. Dynamics of orogenic wedges and the uplift of high-pressure metamorphic rocks. Geological Society of America Bulletin, 97(9): 1037-1053.

Prenzel, J., Lisker, F., Balestrieri, M.L., Läufer, A. and Spiegel, C., 2013. The Eisenhower Range, Transantarctic Mountains: Evaluation of qualitative interpretation concepts of thermochronological data. Chemical Geology, 352(0): 176-187. 
Pulford, A. and Stern, T., 2004. Pliocene exhumation and landscape evolution of central North Island, New Zealand: The role of the upper mantle. Journal of Geophysical Research-Earth Surface, 109(F1): F01016.

Rait, G., Chanier, F. and Waters, D.W., 1991. Landward- and seaward-directed thrusting accompanying the onset of subduction beneath New Zealand. Geology, 19(3): 230-233.

Rait, G.J., 2000. Thrust transport directions in the Northland Allochthon, New Zealand. New Zealand Journal of Geology and Geophysics, 43(2): 271-288.

Raza, A., Brown, R.W., Ballance, P.F., Hill, K.C. and Kamp, P.J.J., 1999. Thermal history of the early Miocene Waitemata Basin and adjacent Waipapa Group, North Island, New Zealand. New Zealand Journal of Geology and Geophysics, 42(3): 469-488.

Reiners, P.W. and Farley, K.A., 1999. Helium diffusion and (U-Th)/He thermochronometry of titanite. Geochimica et Cosmochimica Acta, 63(22): 3845-3859.

Reiners, P.W., Brady, R., Farley, K.A., Fryxell, J.E., Wernicke, B. and Lux, D., 2000. Helium and argon thermochronometry of the Gold Butte block, south Virgin Mountains, Nevada. Earth and Planetary Science Letters, 178(3-4): 315-326.

Reiners, P.W. and Farley, K.A., 2001. Influence of crystal size on apatite (U-Th)/He thermochronology: an example from the Bighorn Mountains, Wyoming. Earth and Planetary Science Letters, 188(3-4): 413-420.

Reiners, P.W., Spell, T.L., Nicolescu, S. and Zanetti, K.A., 2004. Zircon (U-Th)/He thermochronometry: He diffusion and comparisons with ${ }^{40} \mathrm{Ar} /{ }^{39} \mathrm{Ar}$ dating. Geochimica et Cosmochimica Acta, 68(8): 1857-1887.

Reiners, P.W., 2005. Zircon (U-Th)/He Thermochronometry. Reviews in Mineralogy and Geochemistry, 58(1): 151-179.

Reiners, P.W. and Ehlers, T.A., 2005. Low-temperature thermochronology: Techniques, interpretations, and applications. Mineralogical Society of America, Washington, D. C.

Reiners, P.W. and Brandon, M.T., 2006. Using Thermochronology to Understand Orogenic Erosion. Annual Review of Earth and Planetary Sciences, 34(1): 419-466.

Reyes, A.G., 2007. Abondoned oil and gas wells - a reconnaissance study of an unconventional geothermal resource. 
Reyners, M., 1998. Plate coupling and the hazard of large subduction thrust earthquakes at the Hikurangi subduction zone, New Zealand. New Zealand Journal of Geology and Geophysics, 41(4): 343-354.

Reyners, M., Eberhart-Phillips, D. and Stuart, G., 1999. A three-dimensional image of shallow subduction: crustal structure of the Raukumara Peninsula, New Zealand. Geophysical Journal International, 137(3): 873-890.

Reyners, M., Eberhart-Phillips, D., Stuart, G. and Nishimura, Y., 2006. Imaging subduction from the trench to $300 \mathrm{~km}$ depth beneath the central North Island, New Zealand, with Vp and Vp/Vs. Geophysical Journal International, 165(2): 565-583.

Reyners, M., Eberhart-Phillips, D. and Bannister, S., 2011. Tracking repeated subduction of the Hikurangi Plateau beneath New Zealand. Earth and Planetary Science Letters, 311(1-2): 165-171.

Reyners, M., 2013. The central role of the Hikurangi Plateau in the Cenozoic tectonics of New Zealand and the Southwest Pacific. Earth and Planetary Science Letters, 361(0): 460-468.

Rowley, D.B., Pierrehumbert, R.T. and Currie, B.S., 2001. A new approach to stable isotope-based paleoaltimetry: implications for paleoaltimetry and paleohypsometry of the High Himalaya since the Late Miocene. Earth and Planetary Science Letters, 188(1-2): 253-268.

Rowley, D.B. and Garzione, C.N., 2007. Stable Isotope-Based Paleoaltimetry. Annual Review of Earth and Planetary Sciences, 35(1): 463-508.

Sahagian, D. and Proussevitch, A., 2007. Paleoelevation Measurement on the Basis of Vesicular Basalts. Reviews in Mineralogy and Geochemistry, 66(1): 195-213.

Salmon, M., Kennett, B.L.N., Stern, T. and Aitken, A.R.A., 2013. The Moho in Australia and New Zealand. Tectonophysics, 609(0): 288-298.

Sambridge, M., 1999a. Geophysical inversion with a neighbourhood algorithm-I. Searching a parameter space. Geophysical Journal International, 138(2): 479494.

Sambridge, M., 1999b. Geophysical inversion with a neighbourhood algorithm-II. Appraising the ensemble. Geophysical Journal International, 138(3): 727-746.

Schellart, W.P., Lister, G.S. and Toy, V.G., 2006. A Late Cretaceous and Cenozoic reconstruction of the Southwest Pacific region: Tectonics controlled by subduction and slab rollback processes. Earth-Science Reviews, 76(3-4): 191233. 
Schermer, E.R., Little, T.A. and Rieser, U., 2009. Quaternary deformation along the Wharekauhau fault system, North Island, New Zealand: Implications for an unstable linkage between active strike-slip and thrust faults. Tectonics, 28(6): TC6008.

Scherwath, M., Kopp, H., Flueh, E.R., Henrys, S.A., Sutherland, R., Stagpoole, V.M., Barker, D.H.N., Reyners, M.E., Bassett, D.G., Planert, L. and Dannowski, A., 2010. Fore-arc deformation and underplating at the northern Hikurangi margin, New Zealand. Journal of Geophysical Research, 115(B6): B06408.

Schulte, D.O., Ring, U., Thomson, S.N., Glodny, J. and Carrad, H., 2014. Two-stage development of the Paparoa Metamorphic Core Complex, West Coast, South Island, New Zealand: Hot continental extension precedes sea-floor spreading by 25 m.y. Lithosphere, 6(3): 177-194.

Seward, D., Vanderhaeghe, O., Siebenaller, L., Thomson, S., Hibsch, C., Zingg, A., Holzner, P., Ring, U. and Duchene, S., 2009. Cenozoic tectonic evolution of Naxos Island through a multi-faceted approach of fission-track analysis. Geological Society, London, Special Publications, 321(1): 179-196.

Shane, P.A.R., Black, T.M., Alloway, B.V. and Westgate, J.A., 1996. Early to middle Pleistocene tephrochronology of North Island, New Zealand: Implications for volcanism, tectonism, and paleoenvironments. Geological Society of America Bulletin, 108(8): 915-925.

Shuster, D.L., Farley, K.A., Sisterson, J.M. and Burnett, D.S., 2004. Quantifying the diffusion kinetics and spatial distributions of radiogenic $4 \mathrm{He}$ in minerals containing proton-induced 3He. Earth and Planetary Science Letters, 217(1-2): $19-32$.

Shuster, D.L. and Farley, K.A., 2005. 4He/3He Thermochronometry: Theory, Practice, and Potential Complications. Reviews in Mineralogy and Geochemistry, 58(1): 181-203.

Shuster, D.L., Flowers, R.M. and Farley, K.A., 2006. The influence of natural radiation damage on helium diffusion kinetics in apatite. Earth and Planetary Science Letters, 249(3-4): 148-161.

Shuster, D.L. and Farley, K.A., 2009. The influence of artificial radiation damage and thermal annealing on helium diffusion kinetics in apatite. Geochimica et Cosmochimica Acta, 73(1): 183-196.

Simpson, G.D.H., Cooper, A.F. and Norris, R.J., 1994. Late Quaternary evolution of the Alpine Fault Zone at Paringa, South Westland, New Zealand. New Zealand Journal of Geology and Geophysics, 37(1): 49-58. 
Sobel, E.R., Oskin, M., Burbank, D. and Mikolaichuk, A., 2006. Exhumation of basement-cored uplifts: Example of the Kyrgyz Range quantified with apatite fission track thermochronology. Tectonics, 25(2): TC2008.

Spell, T.L., McDougall, I. and Tulloch, A.J., 2000. Thermochronologic constraints on the breakup of the Pacific Gondwana margin: The Paparoa metamorphic core complex, South Island, New Zealand. Tectonics, 19(3): 433-451.

Spencer, S., Kohn, B., Gleadow, A., Norman, M., Belton, D. and Carter, T., 2004. The importance of residing in a good neighbourhood: Rechecking the rules of the game for apatite (U-Th)/He thermochronometry, 10th International Conference on Fission Track Dating and Thermochronology, Amsterdam, pp. 20.

Spiegel, C., Kohn, B., Belton, D., Berner, Z. and Gleadow, A., 2009. Apatite (U-Th$\mathrm{Sm}) / \mathrm{He}$ thermochronology of rapidly cooled samples: The effect of $\mathrm{He}$ implantation. Earth and Planetary Science Letters, 285(1-2): 105-114.

Spörli, K.B., 1987. Airphoto lineaments and fracturing in the axial ranges of the central North Island, New Zealand. Journal of the Royal Society of New Zealand, 17(2): 139-156.

Spörli, K.B., 1989. Tectonic framework of Northland, New Zealand. In: K.B. Spörli and D. Kear (Editors), Geology of Northland: accretion, allochthouns and arcs at the edge of the New Zealand micro-continent. Royal Society of New Zealand Bulletin, pp. 3-14.

Spörli, K.B. and Harrison, R.E., 2004. Northland Allochthon infolded into basement, Whangarei area, northern New Zealand. New Zealand Journal of Geology and Geophysics, 47(3): 391-398.

Spörli, K.B. and Rowland, J.V., 2007. Superposed deformation in turbidites and synsedimentary slides of the tectonically active Miocene Waitemata Basin, northern New Zealand. Basin Research, 19(2): 199-216.

Stagpoole, V. and Nicol, A., 2008. Regional structure and kinematic history of a large subduction back thrust: Taranaki Fault, New Zealand. Journal of Geophysical Research, 113(B1): B01403.

Stern, T.A. and Holt, W.E., 1994. Platform subsidence behind an active subduction zone. Nature, 368(6468): 233-236.

Stern, T.A., Stratford, W.R. and Salmon, M.L., 2006. Subduction evolution and mantle dynamics at a continental margin: Central North Island, New Zealand. Reviews of Geophysics, 44(4): RG4002. 
Stockli, D.F., Farley, K.A. and Dumitru, T.A., 2000. Calibration of the apatite (U$\mathrm{Th}) / \mathrm{He}$ thermochronometer on an exhumed fault block, White Mountains, California. Geology, 28(11): 983-986.

Stüwe, K., White, L. and Brown, R., 1994. The influence of eroding topography on steady-state isotherms. Application to fission track analysis. Earth and Planetary Science Letters, 124(1-4): 63-74.

Stüwe, K. and Hintermüller, M., 2000. Topography and isotherms revisited: the influence of laterally migrating drainage divides. Earth and Planetary Science Letters, 184(1): 287-303.

Sutherland, R., 1999. Basement geology and tectonic development of the greater New Zealand region: an interpretation from regional magnetic data. Tectonophysics, 308(3): 341-362.

Sutherland, R., Stagpoole, V., Uruski, C., Kennedy, C., Bassett, D., Henrys, S., Scherwath, M., Kopp, H., Field, B., Toulmin, S., Barker, D., Bannister, S., Davey, F., Stern, T. and Flueh, E.R., 2009. Reactivation of tectonics, crustal underplating, and uplift after $60 \mathrm{Myr}$ of passive subsidence, Raukumara Basin, Hikurangi-Kermadec fore arc, New Zealand: Implications for global growth and recycling of continents. Tectonics, 28(5): TC5017.

Tagami, T., Galbraith, R.F., Yamada, R. and Laslett, G.M., 1998. Revised annealing kinetics of fission tracks in zircon and geological implications. In: P. Van Den Haute and F. De Corte (Editors), Advances in Fission-Track Geochronology. Kluwer academic publishers, Dordrecht, The Netherlands, pp. 99-112.

Tagami, T. and Murakami, M., 2007. Probing fault zone heterogeneity on the Nojima fault: Constraints from zircon fission-track analysis of borehole samples. Tectonophysics, 443(3-4): 139-152.

Tippett, J.M. and Kamp, P.J.J., 1993. Fission Track Analysis of the Late Cenozoic Vertical Kinematics of Continental Pacific Crust, South Island, New Zealand. Journal of Geophysical Research, 98(B9): 16119-16148.

Trewick, S.A. and Bland, K.J., 2011. Fire and slice: palaeogeography for biogeography at New Zealand's North Island/South Island juncture. Journal of the Royal Society of New Zealand, 42(3): 153-183.

Tulloch, A.J., Ramezani, J., Mortimer, N., Mortensen, J., van den Bogaard, P. and Maas, R., 2009. Cretaceous felsic volcanism in New Zealand and Lord Howe Rise (Zealandia) as a precursor to final Gondwana break-up. Geological Society, London, Special Publications, 321(1): 89-118.

Turcotte, D.L. and Schubert, G., 2014. Geodynamics. Cambridge University Press. 
Vermeesch, P., Seward, D., Latkoczy, C., Wipf, M., Günther, D. and Baur, H., 2007. $\alpha$-Emitting mineral inclusions in apatite, their effect on (U-Th)/He ages, and how to reduce it. Geochimica et Cosmochimica Acta, 71(7): 1737-1746.

Vermeesch, P., 2010. HelioPlot, and the treatment of overdispersed (U-Th-Sm)/He data. Chemical Geology, 271(3-4): 108-111.

Vermeesch, P., 2012. On the visualisation of detrital age distributions. Chemical Geology, 312-313(0): 190-194.

Vermeesch, P. and Tian, Y., 2014. Thermal history modelling: HeFTy vs. QTQt. Earth-Science Reviews, 139(0): 279-290.

von Blanckenburg, F., 2005. The control mechanisms of erosion and weathering at basin scale from cosmogenic nuclides in river sediment. Earth and Planetary Science Letters, 237(3-4): 462-479.

Wagner, G.A. and Van den Haute, P., 1992. Fission Track Dating. Kluwer Academic Pub, Dordrecht.

Walcott, R.I., 1978. Present tectonics and Late Cenozoic evolution of New Zealand. Geophysical Journal of the Royal Astronomical Society, 52(1): 137-164.

Walcott, R.I., 1984. The kinematics of the plate boundary zone through New Zealand: a comparison of short-and long-term deformations. Geophysical Journal of the Royal Astronomical Society, 79(2): 613-633.

Walcott, R.I., 1987. Geodetic Strain and the Deformational History of the North Island of New Zealand during the Late Cainozoic. Philosophical Transactions of the Royal Society of London. Series A, Mathematical and Physical Sciences, 321(1557): 163-181.

Wallace, L.M. and Beavan, J., 2004. Subduction zone coupling and tectonic block rotations in the North Island, New Zealand. Journal of Geophysical Research, 109(B12): B12406.

Wallace, L.M., McCaffrey, R., Beavan, J. and Ellis, S., 2005. Rapid microplate rotations and backarc rifting at the transition between collision and subduction. Geology, 33(11): 857-860.

Wallace, L.M., Reyners, M., Cochran, U., Bannister, S., Barnes, P.M., Berryman, K., Downes, G., Eberhart-Phillips, D., Fagereng, A., Ellis, S., Nicol, A., McCaffrey, R., Beavan, R.J., Henrys, S., Sutherland, R., Barker, D.H.N., Litchfield, N., Townend, J., Robinson, R., Bell, R., Wilson, K. and Power, W., 2009. Characterizing the seismogenic zone of a major plate boundary subduction thrust: Hikurangi Margin, New Zealand. Geochemistry, Geophysics, Geosystems, 10(10): Q10006. 
Wallace, L.M. and Beavan, J., 2010. Diverse slow slip behavior at the Hikurangi subduction margin, New Zealand. Journal of Geophysical Research: Solid Earth, 115(B12): B12402.

Wallace, L.M., Barnes, P., Beavan, J., Van Dissen, R., Litchfield, N., Mountjoy, J., Langridge, R., Lamarche, G. and Pondard, N., 2012. The kinematics of a transition from subduction to strike-slip: An example from the central New Zealand plate boundary. Journal of Geophysical Research, 117(B2): B02405.

Wessel, P. and Smith, W.H.F., 1998. New, improved version of generic mapping tools released. Eos, Transactions American Geophysical Union, 79(47): 579579.

Whattam, S.A., Malpas, J., Ali, J.R., Lo, C.-H. and Smith, I.E.M., 2005. Formation and emplacement of the Northland ophiolite, northern New Zealand: SW Pacific tectonic implications. Journal of the Geological Society, 162(2): 225241.

Whattam, S.A., Malpas, J., Smith, I.E.M. and Ali, J.R., 2006. Link between SSZ ophiolite formation, emplacement and arc inception, Northland, New Zealand: U-Pb SHRIMP constraints; Cenozoic SW Pacific tectonic implications. Earth and Planetary Science Letters, 250(3-4): 606-632.

Willett, S.D. and Brandon, M.T., 2002. On steady states in mountain belts. Geology, 30(2): 175-178.

Williams, C.A., Eberhart-Phillips, D., Bannister, S., Barker, D.H.N., Henrys, S., Reyners, M. and Sutherland, R., 2013. Revised Interface Geometry for the Hikurangi Subduction Zone, New Zealand. Seismological Research Letters, 84(6): 1066-1073.

Wilson, C.J.N., Houghton, B.F., Kampt, P.J.J. and McWilliamst, M.O., 1995. An exceptionally widespread ignimbrite with implications for pyroclastic flow emplacement. Nature, 378(6557): 605-607.

Wilson, C.J.N., Charlier, B.L.A., Rowland, J.V. and Browne, P.R.L., 2010. U-Pb dating of zircon in subsurface, hydrothermally altered pyroclastic deposits and implications for subsidence in a magmatically active rift: Taupo Volcanic Zone, New Zealand. Journal of Volcanology and Geothermal Research, 191(12): 69-78.

Wilson, K., Berryman, K., Litchfield, N. and Little, T., 2006. A revision of mid-late Holocene marine terrace distribution and chronology at the Pakarae River mouth, North Island, New Zealand. New Zealand Journal of Geology and Geophysics, 49(4): 477-489. 
Wilson, K., Berryman, K., Cochran, U. and Little, T., 2007. Holocene coastal evolution and uplift mechanisms of the northeastern Raukumara Peninsula, North Island, New Zealand. Quaternary Science Reviews, 26(7-8): 1106-1128.

Wolf, R.A., Farley, K.A. and Kass, D.M., 1998. Modeling of the temperature sensitivity of the apatite (U-Th)/He thermochronometer. Chemical Geology, 148(1-2): 105-114.

Yamada, R., Tagami, T., Nishimura, S. and Ito, H., 1995. Annealing kinetics of fission tracks in zircon: an experimental study. Chemical Geology, 122(1-4): 249-258.

Yoshikawa, T., Ota, Y., Yonekura, N., Okada, A. and Iso, N., 1980. Marine terraces and their tectonic deformation on the northeast coast of the North Island, New Zealand. Geographical Review of Japan, 53(4): 238-262. 


\section{Appendix I}

\section{Large-scale temporal and spatial}

variations in the exhumation of New

\section{Zealand basement since 40 Ma:}

\section{inversion of thermochronological}

\section{ages-future work}

\subsection{Introduction}

Tectonic evolution during the Cenozoic has intensively deformed the lithosphere in the vicinity of New Zealand, leading to episodic uplift and exhumation of the basement rocks. Focusing on the Cenozoic evolution of the plate boundary zone, this study strives to resolve the exhumation histories of the basement rocks of New Zealand since $40 \mathrm{Ma}$, based on inversion of an extensive thermochronological dataset.

In the past decades, different thermochronometers have been applied on the New Zealand basement in order to constrain the rock exhumation histories, reporting a large number of ages (Figs. 6.1 and 6.2). However, these studies were often focused on the rock exhumation processes at specific regions. This study will complement previous works and compile the thermochronological data obtained in the pre-Late Cretaceous rocks of New Zealand. This compilation of data represents clear variations in the cooling ages and thus implies variations in the rock exhumation processes of different regions. An inversion approach will be applied on this dataset, aiming to resolve the temporal and spatial variations in the exhumation rates. The inversion 
method is based on a one-dimensional thermal model that is used to predict each thermochronological age, and is combined with a spectral method to estimate the perturbation of the topography on the subsurface isotherms. This inversion approach allows us to emphasize the first-order variations of the exhumation rates in time and space, which could possibly be extracted from the thermochronological data. The second-order features that may require interpretation from $2 \mathrm{D} / 3 \mathrm{D}$ thermal models at particular regions are beyond the scope of this study.

\subsection{Methods}

\subsubsection{Data selection}

Numerous thermochronological studies have been performed in the basement rocks of New Zealand since 1960s. In order to investigate spatial and temporal variation of the exhumation of these rocks during the Cenozoic, we used a large dataset consisting of seven thermochronometers (Figs. 6.1 and 6.2), including apatite and zircon fissiontrack, apatite and zircon (U-Th)/He, muscovite and biotite ${ }^{40} \mathrm{Ar} /{ }^{39} \mathrm{Ar}$ (or K-Ar) and total rock K-Ar. Data reported before 2000 are taken from Nathan et al. (2000). A list of extra references that contain data used in this study is given after Section 6.3.

However, some reported ages were excluded from the analysis in order to get a relative consistent dataset and to improve the efficiency of inversion. Focusing on the late Cenozoic exhumation histories, we only used apparent ages that are younger than $40 \mathrm{Ma}$. As only the rock exhumation in the upper crust is considered, we did not use the ${ }^{40} \mathrm{Ar} /{ }^{39} \mathrm{Ar}$ ages of hornblende which correspond to a higher $\left(>500{ }^{\circ} \mathrm{C}\right)$ closure temperature. K-feldspar ${ }^{40} \mathrm{Ar} /{ }^{39} \mathrm{Ar}$ ages were not modelled, because the closure temperature of the method is similar to the ZFT system, the ages of which are more abundant across New Zealand. We did not model the total-rock Rb-Sr ages, which often yield a large range of ages that overlap with the sedimentary ages of the host rocks (Adams et al., 1999; Adams et al., 2009). Crystallization ages of mineral veins (Adams and Graham, 1993) or plutonic intrusions (Baker and Seward, 1996) were excluded for analysis, due to their irrelevance to the exhumation history. Tippett and Kamp (1993) reported several AFT ages with no spontaneous tracks; we excluded these ages from the calculation of the exhumation rates. We excluded the ages with significant detrital signatures which are older than the stratigraphic ages of the 
sampled strata; these include the many ZFT and total-rock K-Ar ages from the Torlesse Supergroup. Ages of ${ }^{40} \mathrm{Ar} /{ }^{39} \mathrm{Ar}$ or K-Ar methods were usually reported with very low analytical uncertainties, which however do not reflect the reproducibility of the ages, and thus instead we used an uncertainty of $15 \%$ for such ages.

\subsubsection{Closure temperature and annealing/diffusion models}

A thermochronometer closes over a temperature range, in which the radioactive decay products are partially retained in the crystal due to thermal diffusion (of ${ }^{40} \mathrm{Ar}$ or ${ }^{4} \mathrm{He}$ ) or annealing (of fission tracks). This temperature range is termed as the partial retention zone (PRZ) (Baldwin and Lister, 1998; Wolf et al., 1998) for the argon and helium dating systems or partial annealing zone (PAZ) (Gleadow and Duddy, 1981) for the fission-track systems. For the steady cooling of a mineral through the PRZ or PAZ, Dodson (1973) defined the effective closure temperature (Tc) as the temperature at the time indicated by a thermochronometer, providing a practical solution for interpretation of the measured age. The method of Dodson (1973) demonstrated the positive dependence of the Tc of any given thermochronometer on the cooling rate of the mineral.

In this study, we use the annealing model of Ketcham et al. (1999) to calculate the Tc of AFT system, assuming a uniform crystal composition as standard Durango apatite. For the ZFT system, we choose the field-based estimates of Brandon et al. (1998), which yield better consistence with the naturally cooled zircons than the annealing models derived from laboratory experiments (Tagami et al., 1998; Yamada et al., 1995) (see discussion in Bernet (2009)). We use the models of Farley (2000) and Reiners et al. (2004) for the helium retention in apatite and zircon, respectively, and those of Hames and Bowring (1994) and Grove and Harrison (1996) for the argon retention in muscovite and biotite, respectively. Based on the petrology, metamorphic facies and regional comparison with the biostratigraphic ages of the strata, Adams (2003) argued that total-rock K-Ar ages of the Torlesse greywacke rocks represent the timing of metamorphism or post-metamorphic cooling from $230-300{ }^{\circ} \mathrm{C}$, close to the closure temperature of illitic white mica $260 \pm 30{ }^{\circ} \mathrm{C}$ (Hunziker et al., 1986). Following Adams (2003), we used the revised parameters of argon retention in detrital white mica (Kirschner et al., 1996) to predict the total-rock K-Ar ages from the basement terranes. 

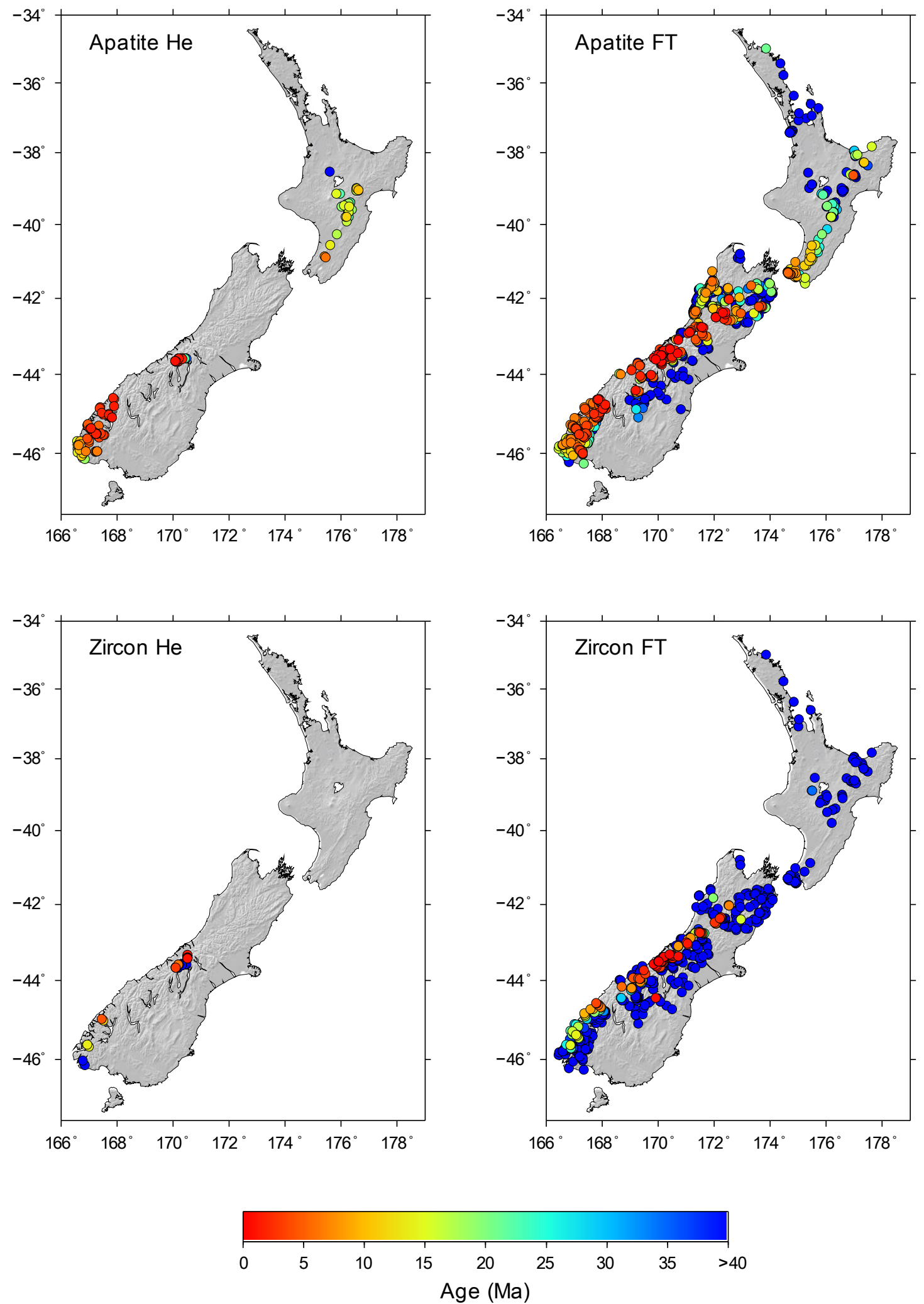

Fig. 6.1 Apatite and zircon (U-Th)/He and fission-track ages in New Zealand. Note that ages older than $40 \mathrm{Ma}$ are not used in the inversion. 

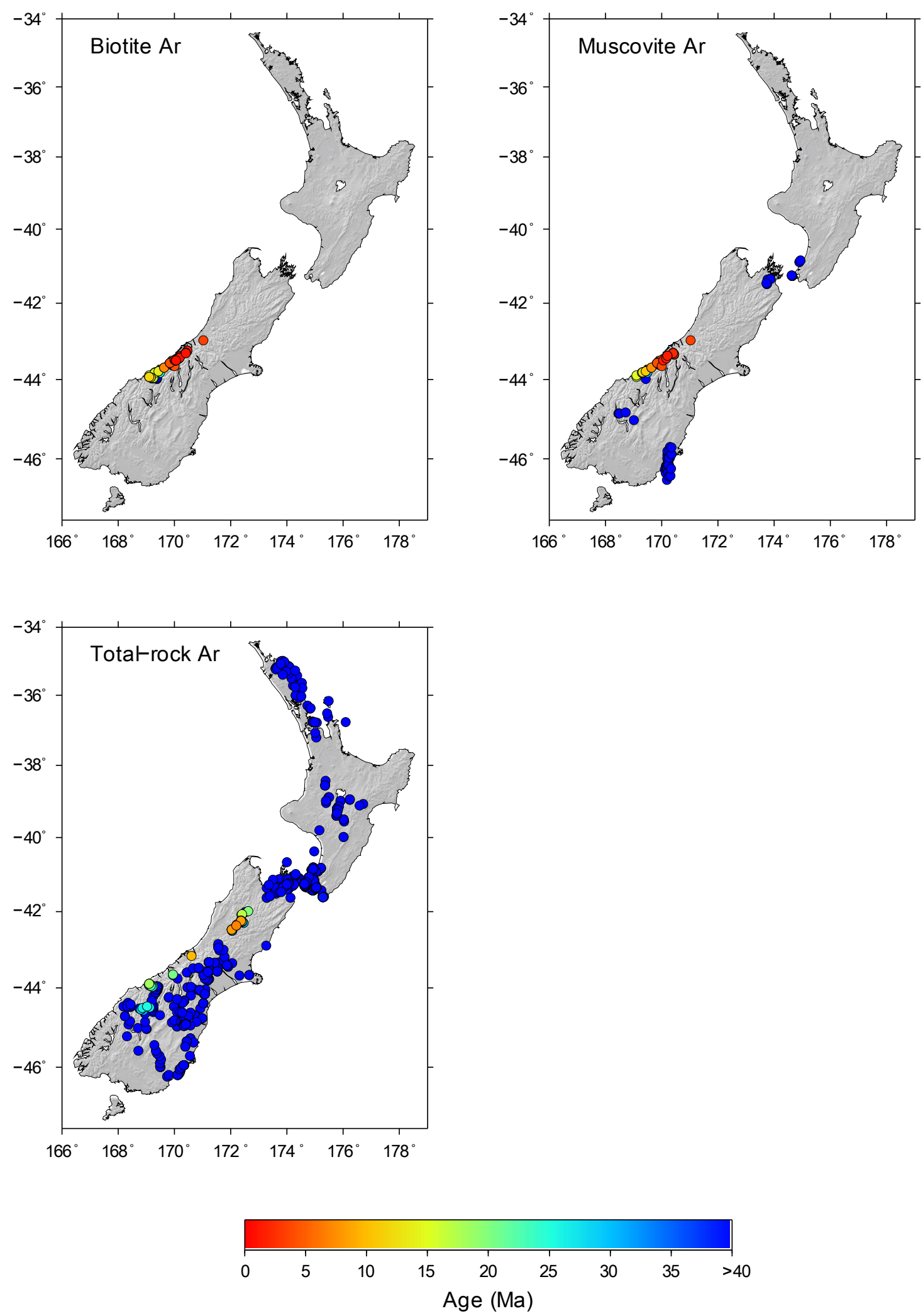

Fig. 6.2 Biotite, muscovite and total-rock ${ }^{40} \mathrm{Ar} /{ }^{39} \mathrm{Ar}$ or K-Ar ages in New Zealand. Note that ages older than $40 \mathrm{Ma}$ are not used in the inversion. 


\subsubsection{Inversion of thermochronological data}

We modified the approach developed by Fox et al. (2014) and used in Herman et al. (2013) to infer exhumation rates from thermochronological data. This approach is targeted to extract the information of rock exhumation archived in both age-elevation profiles and ages of multiple thermochronological systems. Fox et al. (2014) consider the depth to the effective closure temperature as the integral of exhumation rates from the measured thermochronological age to the present-day, using

$$
z_{c}=\int_{0}^{\tau} \dot{e} d t
$$

where $\mathrm{z}_{\mathrm{c}}$ is the closure depth $(\mathrm{km}), \tau$ is the measured thermochronological age (Ma) and $\dot{e}$ the erosion rate $(\mathrm{km} / \mathrm{Myr})$. Thus we can solve the average exhumation rate since the time $\tau$ given that the $z_{c}$ is estimated. Furthermore, we can examine the temporal variations in the exhumation rates through ages of multiple thermochronological methods. Here we impose a positivity constraint on the inverse problem by changing the variables to the logarithmic space, using

$$
\begin{aligned}
& \zeta=\ln \left(z_{c}\right) \\
& \varepsilon=\ln (\dot{e})
\end{aligned}
$$

Thus we can write Equation 6.1 as

$$
\zeta=\ln \left(\int_{0}^{\tau} \exp (\varepsilon) d t\right)
$$

which forms the inverse problem we want to solve, and $\varepsilon$ can be solved if $\zeta$ is estimated.

We compute $\mathrm{z}_{\mathrm{c}}$ using the same approach of Fox et al. (2014) and Herman et al. (2013) and then take the logarithm. This approach uses a transient one-dimensional thermal model to solve the heat transfer equation using the finite difference method, incorporated with a spectral solution which is used to evaluate the perturbation of the isotherms caused by topography (Mancktelow and Grasemann, 1997). The solution procedure initiates as an a priori condition with an unperturbed geotherm. Then the closure depth is computed by extracting a cooling history of each sample using Dodson (1973)'s method. Both the temperature structure and Dodson (1973)'s approximation depend on the solution (exhumation rate), so the problem is weakly 
nonlinear and can be solved using least-squares method. The final solution is achieved by the inverse approach as described below and convergence usually occurs after a few iterations.

We first discretize Equation 6.4, transforming it to a summation in which the erosion rate (i.e. exponential of $\varepsilon$ ) is parameterized as a piecewise constant function over fixed timesteps. We require that the exhumation rates are spatially correlated over each timestep; this is imposed by defining an a priori model covariance matrix, $\mathrm{C}_{\mathrm{M}}$. This matrix is constructed for all time intervals using the horizontal distance between the $i^{\text {th }}$ and $\mathrm{j}^{\text {th }}$ data points, $\mathrm{d}$, and a Gaussian correlation function,

$$
C_{M}(\mathrm{i}, \mathrm{j})=\sigma^{2} \exp \left(-\left(\frac{d}{L}\right)^{2}\right)
$$

where $\mathrm{L}$ is a specified correlation length, $d$ the distance between samples, and $\sigma^{2}$ is the a priori variance, which serves primarily as a weighing factor. This covariance matrix simply implies that the exhumation histories must be identical for samples close to each other and may be independent for those far apart. Finally, our non-linear problem for $\varepsilon$ is solved using the steepest descent algorithm,

$$
\varepsilon_{m+1}=\varepsilon_{m}+\mu\left(C_{M} G^{t} C_{D}^{-1}\left(\zeta_{m}-\zeta_{o b s}\right)+\left(\varepsilon_{m}-\varepsilon_{p r}\right)\right)
$$

where $m$ is the number of iterations, $C_{D}$ is the data covariance matrix (which is a diagonal matrix) and $\mu$ is an ad hoc parameter chosen by trial and errors. The model and data covariance are chosen to minimize tradeoff between model and data variance. We start the iterative process using the a priori expected value of $\varepsilon_{\mathrm{pr}}$, and $\mathrm{G}$ corresponds to:

$$
G(i, j)=\frac{\partial \ln \left(\sum \exp (\varepsilon) \Delta t\right)}{\partial \zeta_{j}}
$$

which can be computed analytically,

$$
G(i, j)=\frac{\exp (\varepsilon) \Delta t}{z_{c, j}}
$$

Ultimately, the exhumation rates are computed by taking the exponential of $\varepsilon$. The misfit function, $\mathrm{S}$, that we minimize corresponds to

$$
2 S(\varepsilon)=\left(\zeta_{m}-\zeta_{o b s}\right)^{t} C_{D}^{-1}\left(\zeta_{m}-\zeta_{o b s}\right)+\left(\varepsilon_{m}-\varepsilon_{p r}\right)^{t} C_{M}^{-1}\left(\varepsilon_{m}-\varepsilon_{p r}\right)
$$


and the a posteriori covariance, $\mathrm{R}$, corresponds to

$$
R=C_{M}-C_{M} G^{t}\left(G C_{M} G^{t}+C_{D}\right)^{-1} G C_{M}
$$

where the diagonal elements of $\mathrm{R}$ represent the a posteriori variance, $\sigma_{\mathrm{po}}{ }^{2}$.

\subsection{Preliminary results: an example}

I obtained a statistically acceptable solution for the exhumation model of the New Zealand since $40 \mathrm{Ma}$. This solution represents the result of inversion that uses 1) an a priori exhumation rate of $0.05 \mathrm{~km} / \mathrm{Myr}$ with a standard deviation of $2 \mathrm{~km} / \mathrm{Myr}$; 2) a 2-Myr length for each time interval; 3) a representative thermal model including crustal thickness of $30 \mathrm{~km}$, surface temperature of $15{ }^{\circ} \mathrm{C}$, a basal temperature of $750{ }^{\circ} \mathrm{C}$, thermal diffusivity of $30 \mathrm{~km}^{2} / \mathrm{Myr}$ and crustal heat production of $0.0001{ }^{\circ} \mathrm{C} / \mathrm{Myr}$; and 4) a specified correlation length of $20 \mathrm{~km}$. During the inversion process, the model residual has reduced significantly after several iterations (Fig. 6.3a). Predicted residuals for all data point are summarised in Fig. 6.3b, as the difference between the closure depth and the integral of exhumation rate over the period indicated by the apparent age.

Figs. 6.4-6.23 present maps of exhumation rates since $40 \mathrm{Ma}$ from the example exhumation model, based on the palaeogeographic reconstruction of New Zealand after (King, 2000). Note that this example represents only one of many solutions, as the solution is non-unique but dependent on several a priori settings.
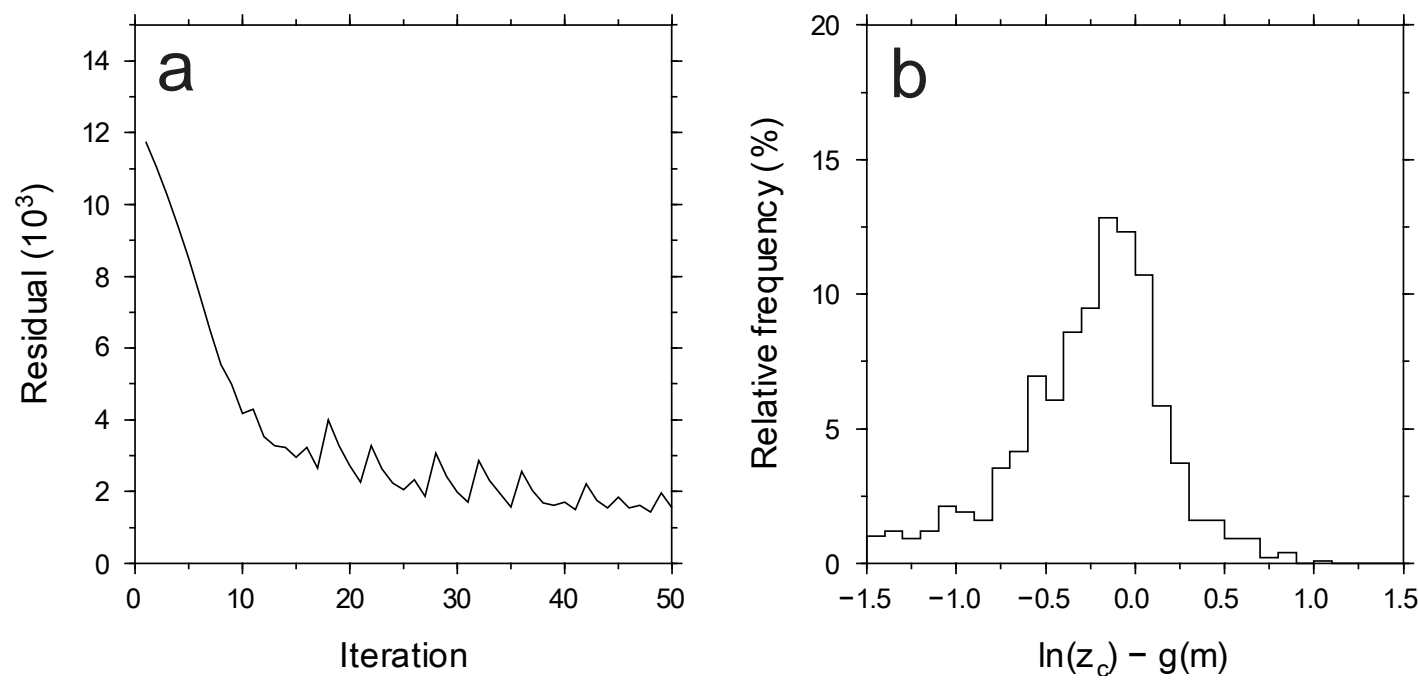

Fig. 6.3 (a) Change in residual of the model during the inversion. (b) Difference between the closure depth and the integral of exhumation rate over the period indicated by the apparent age. 

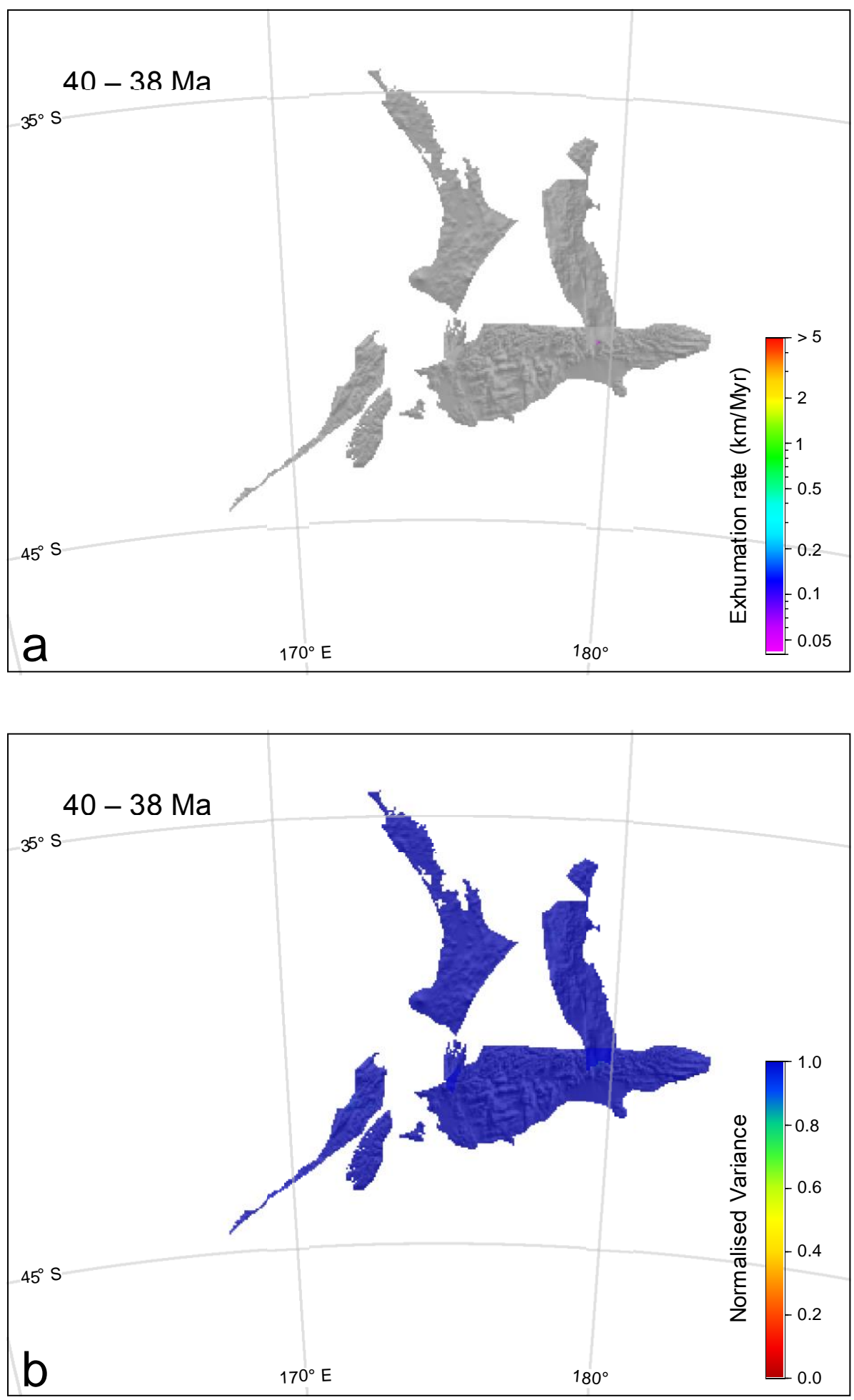

Fig. 6.4 Exhumation model of New Zealand for the time interval 40-38 Ma. (a) Inferred map of exhumation rates during the interval 40-38 Ma. (b) Temporal resolution of the exhumation model. 

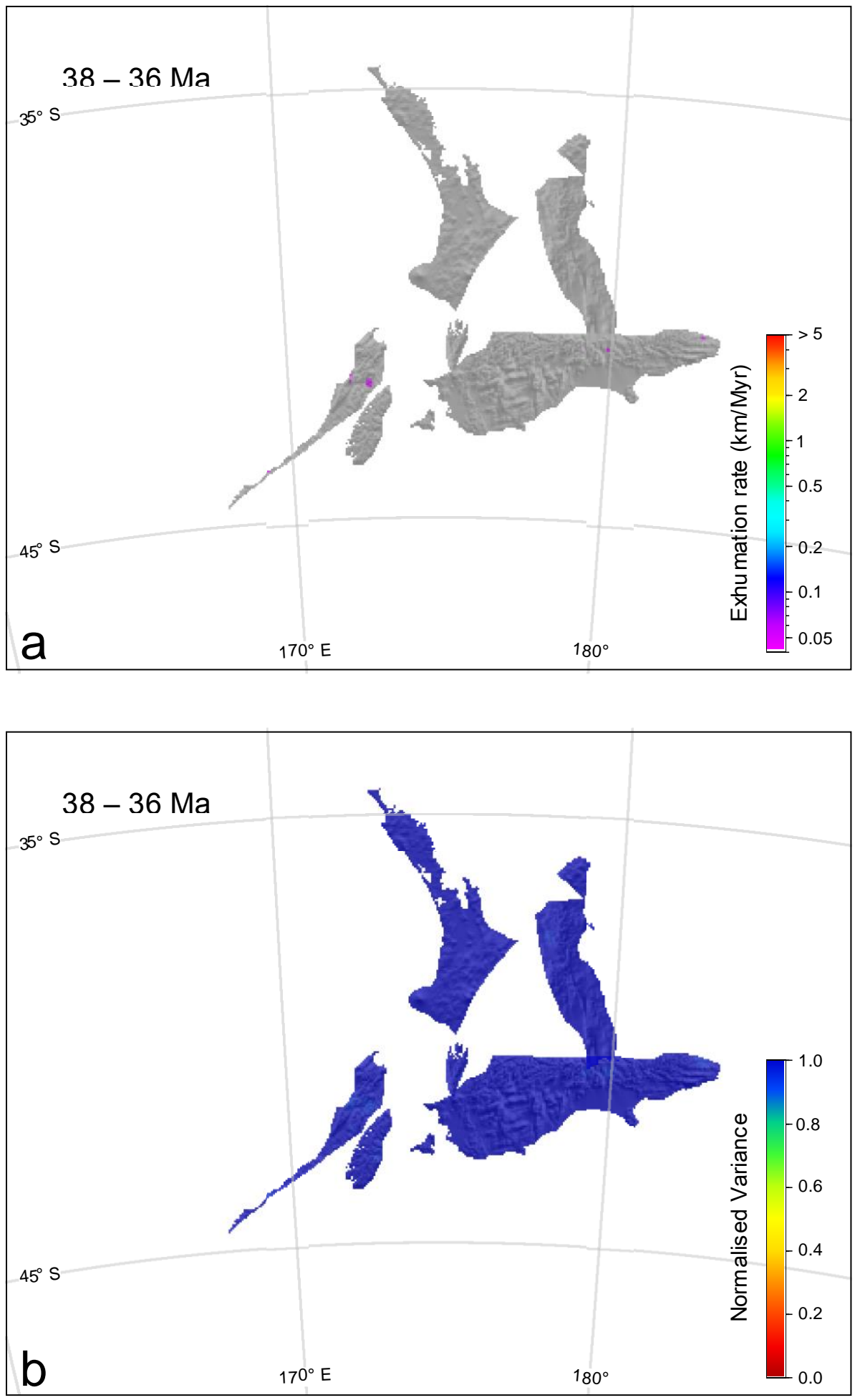

Fig. 6.5 Exhumation model of New Zealand for the time interval 38-36 Ma. 

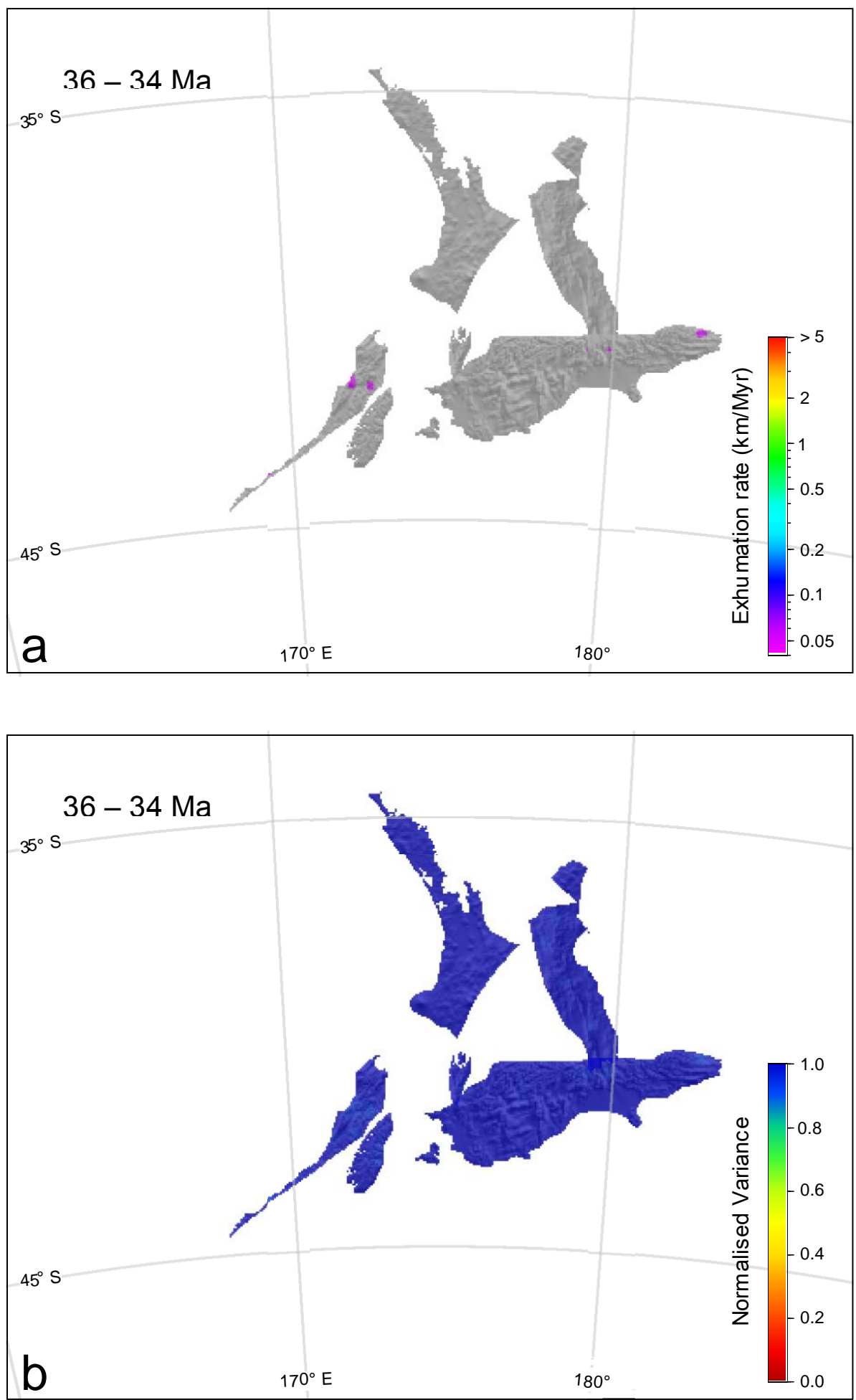

Fig. 6.6 Exhumation model of New Zealand for the time interval 36-34 Ma. 

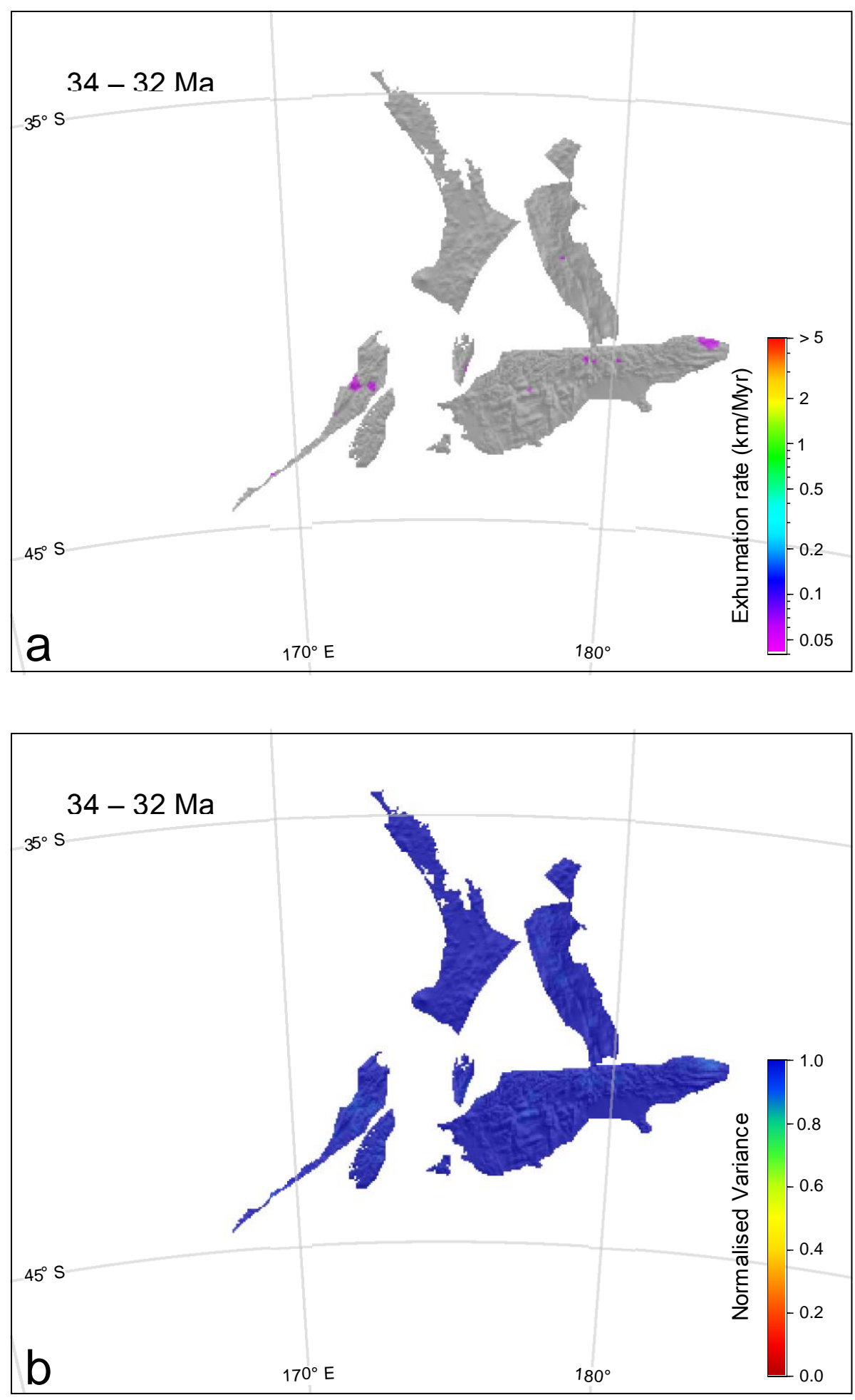

Fig. 6.7 Exhumation model of New Zealand for the time interval 34-32 Ma. 

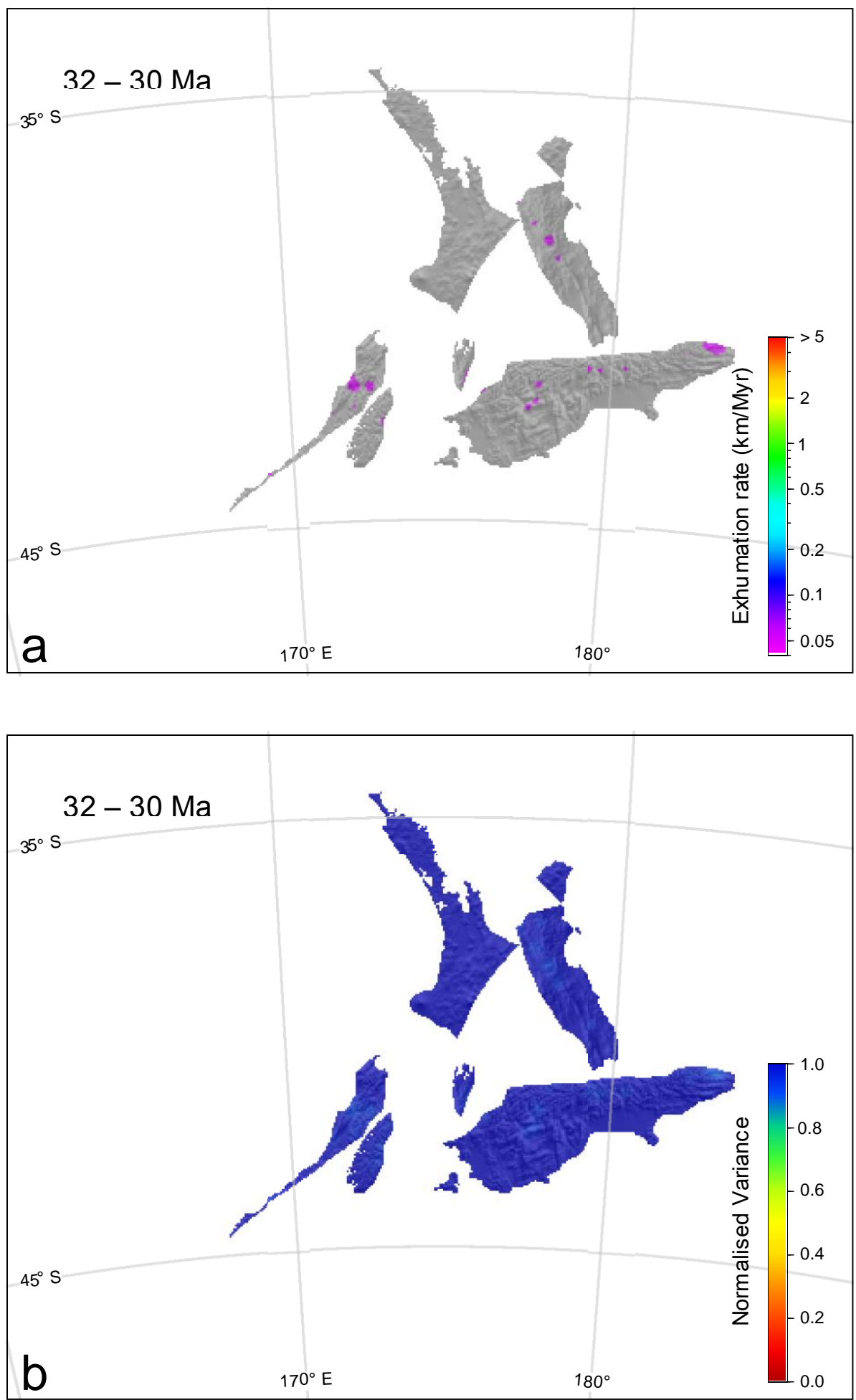

Fig. 6.8 Exhumation model of New Zealand for the time interval 32-30 Ma. 

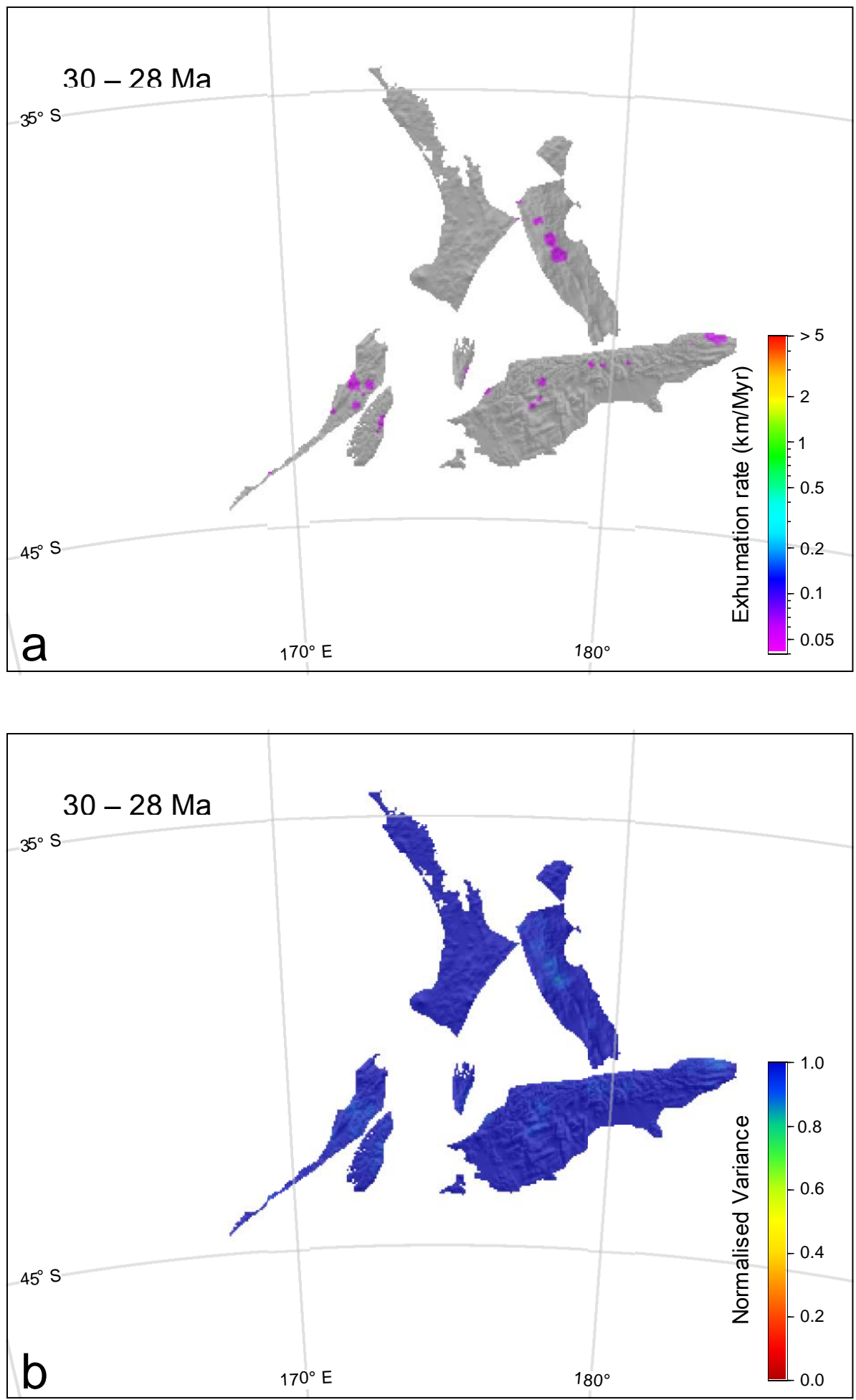

Fig. 6.9 Exhumation model of New Zealand for the time interval 30-28 Ma. 

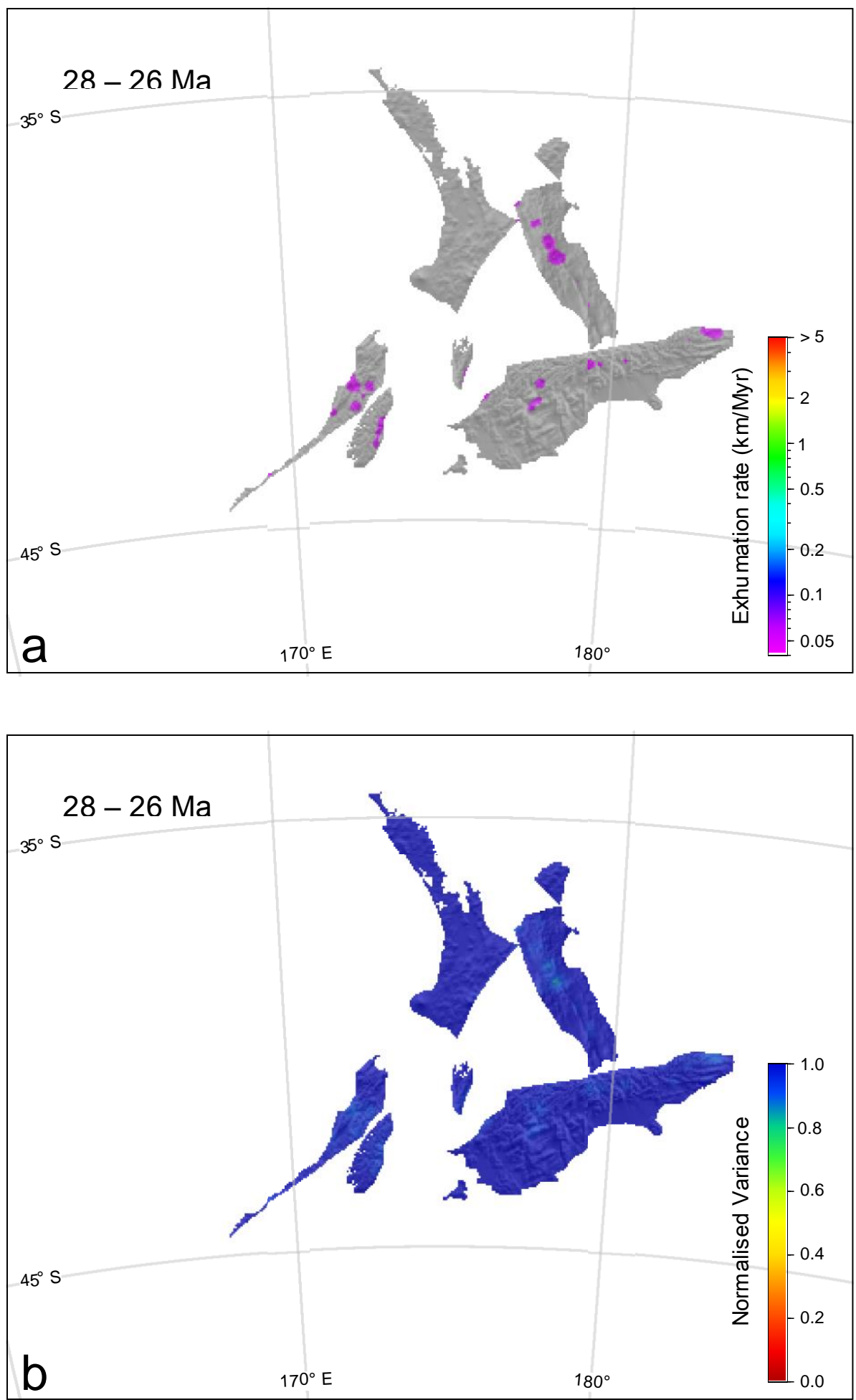

Fig. 6.10 Exhumation model of New Zealand for the time interval 28-26 Ma. 

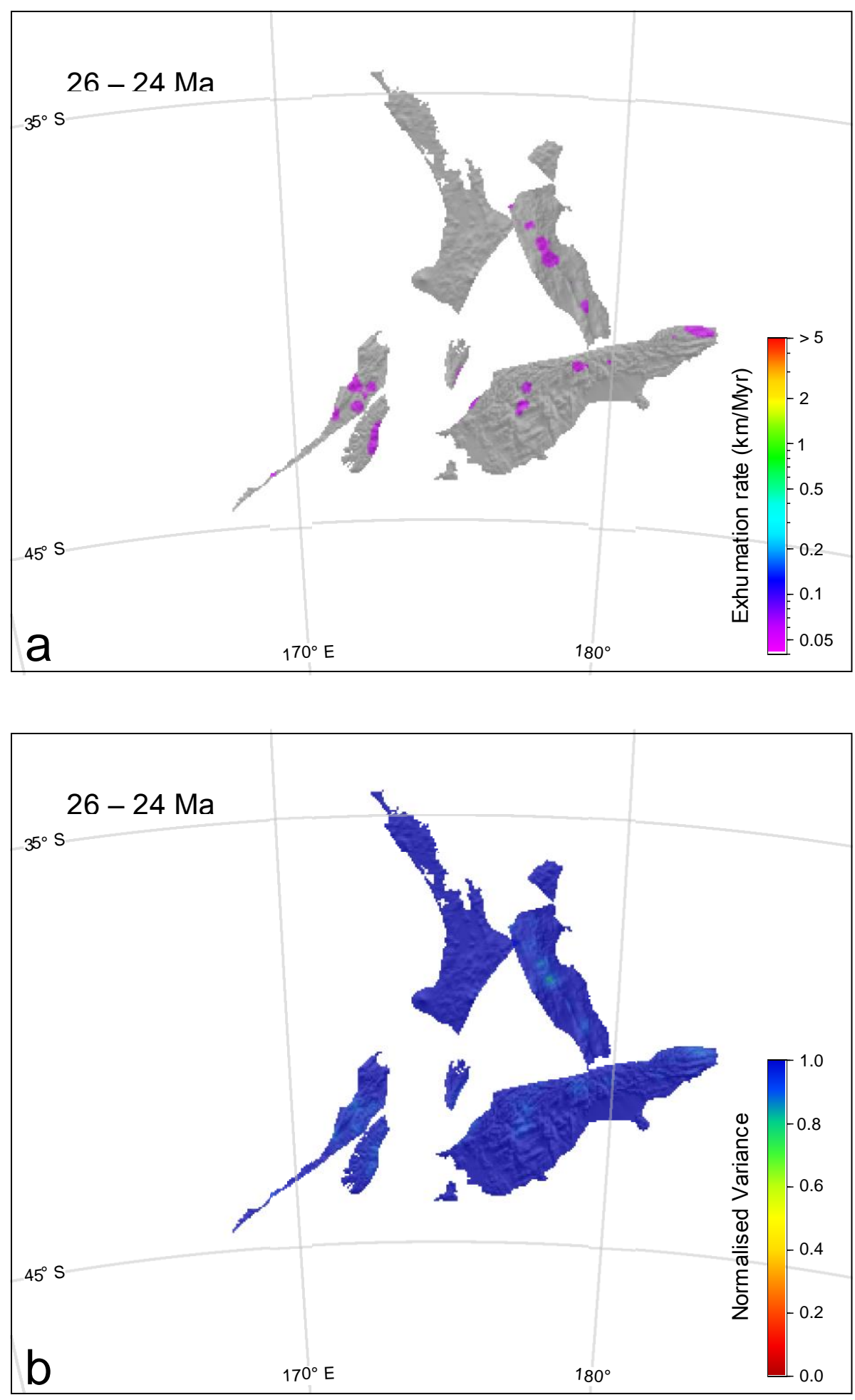

Fig. 6.11 Exhumation model of New Zealand for the time interval 26-24 Ma. 

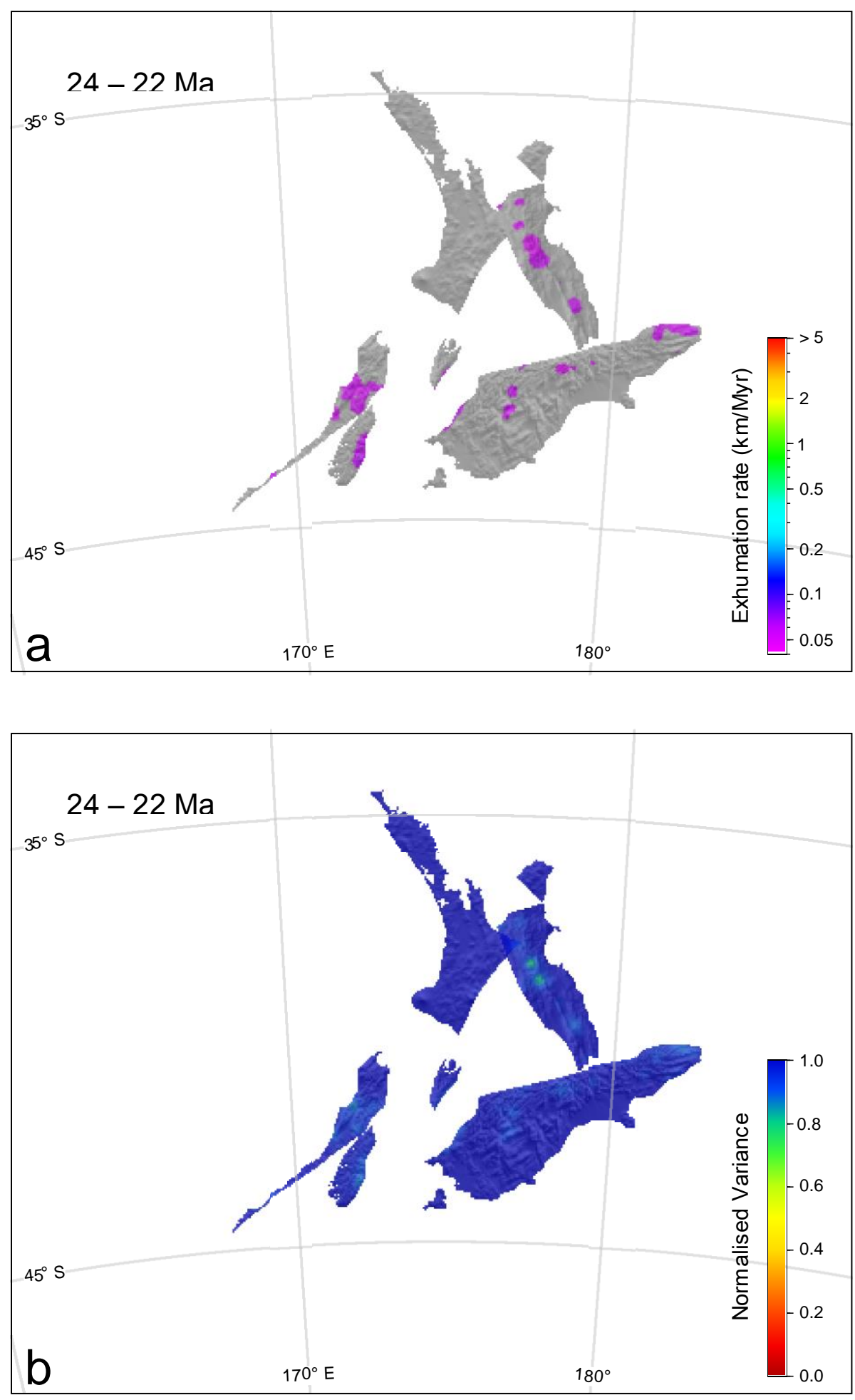

Fig. 6.12 Exhumation model of New Zealand for the time interval 24-22 Ma. 

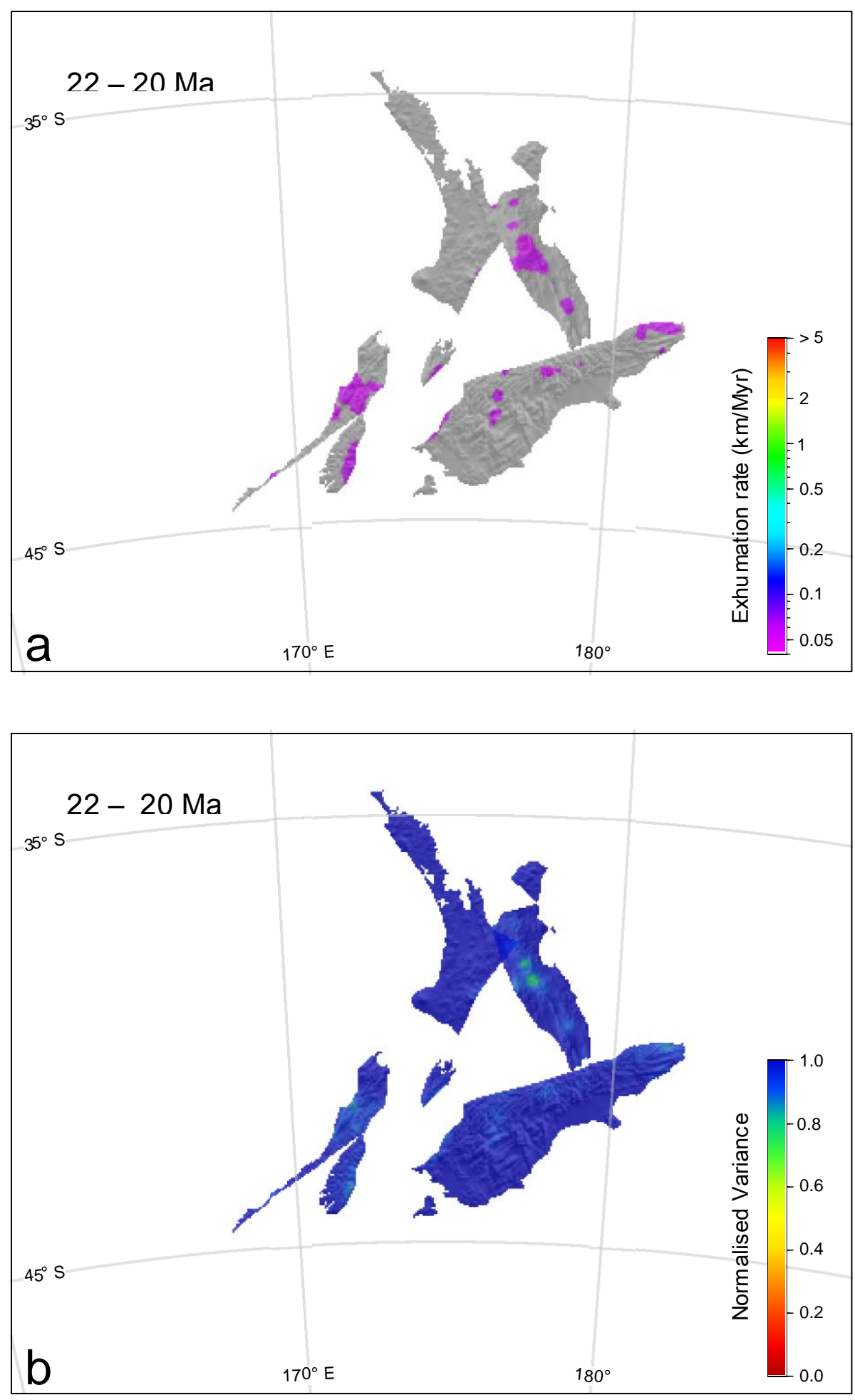

Fig. 6.13 Exhumation model of New Zealand for the time interval 22-20 Ma. 

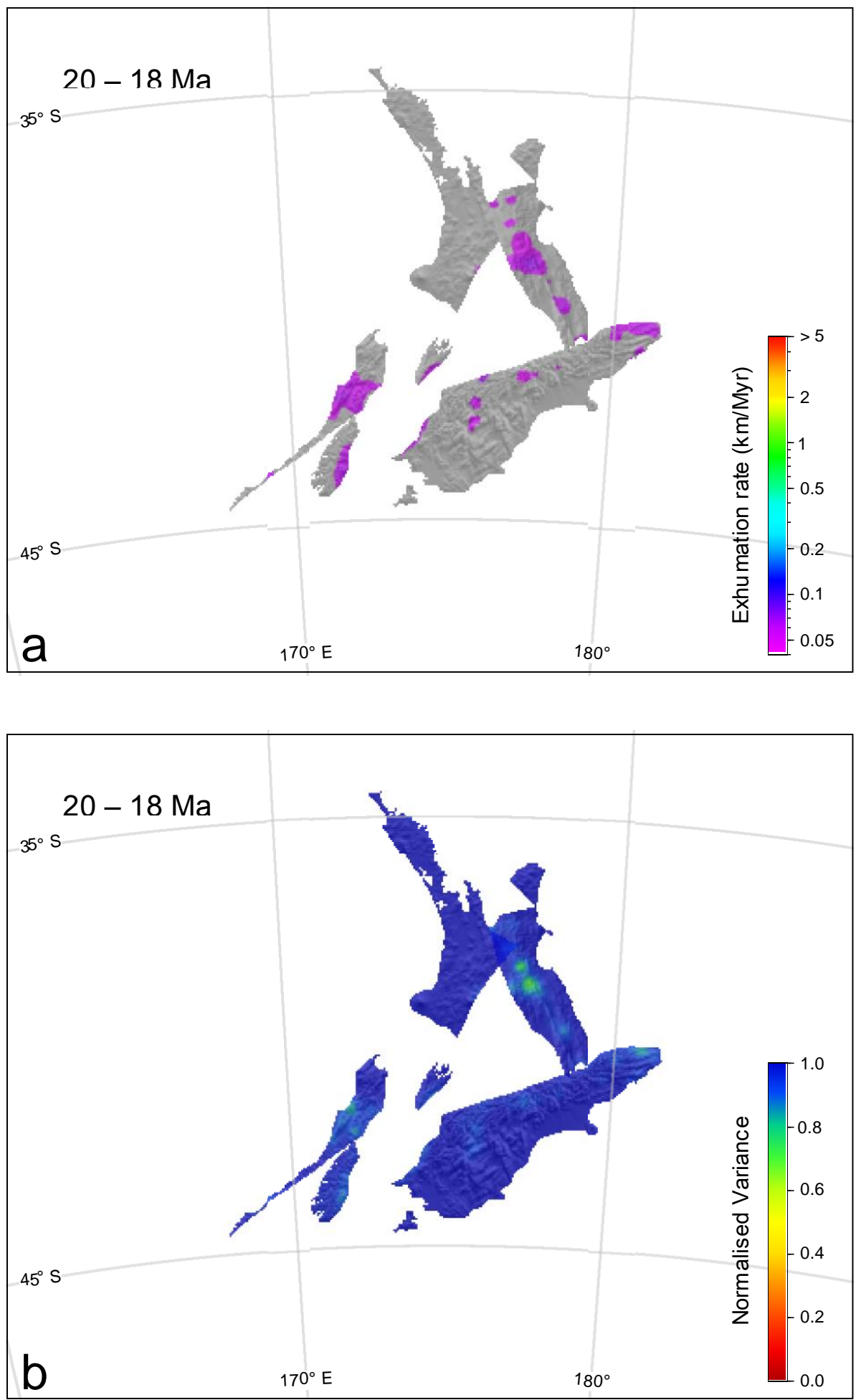

Fig. 6.14 Exhumation model of New Zealand for the time interval 20-18 Ma. 

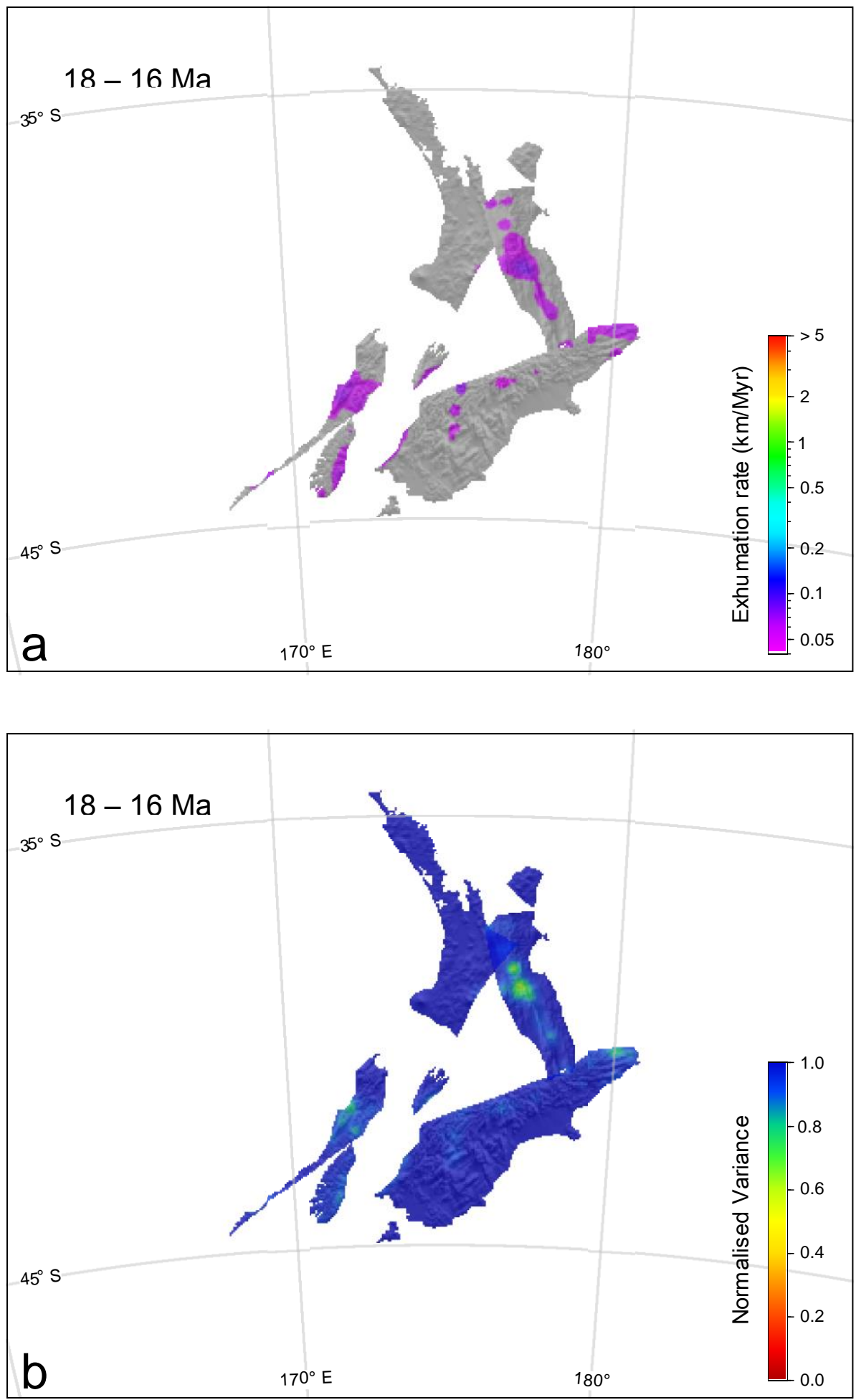

Fig. 6.15 Exhumation model of New Zealand for the time interval 18-16 Ma. 

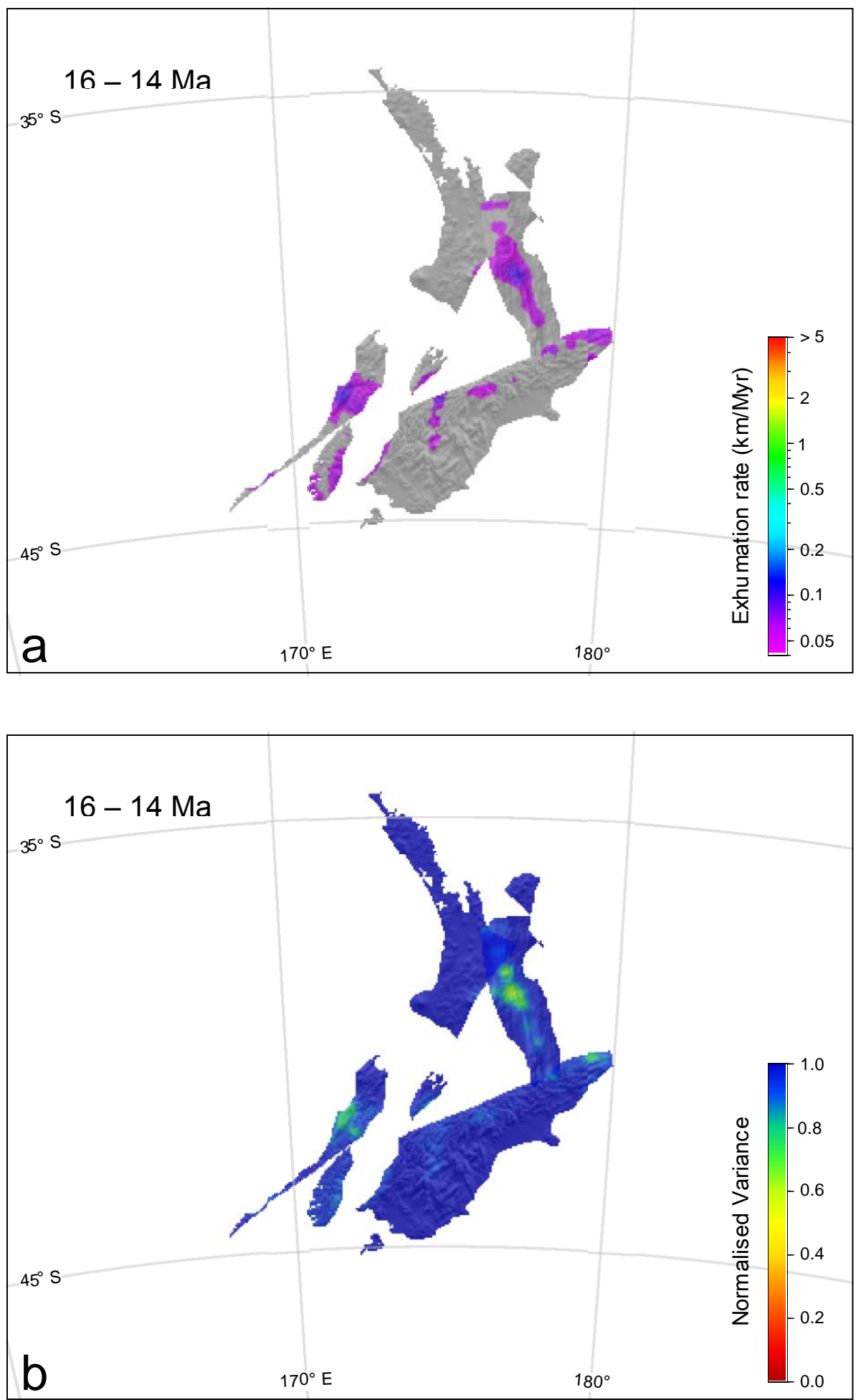

Fig. 6.16 Exhumation model of New Zealand for the time interval 16-14 Ma. 

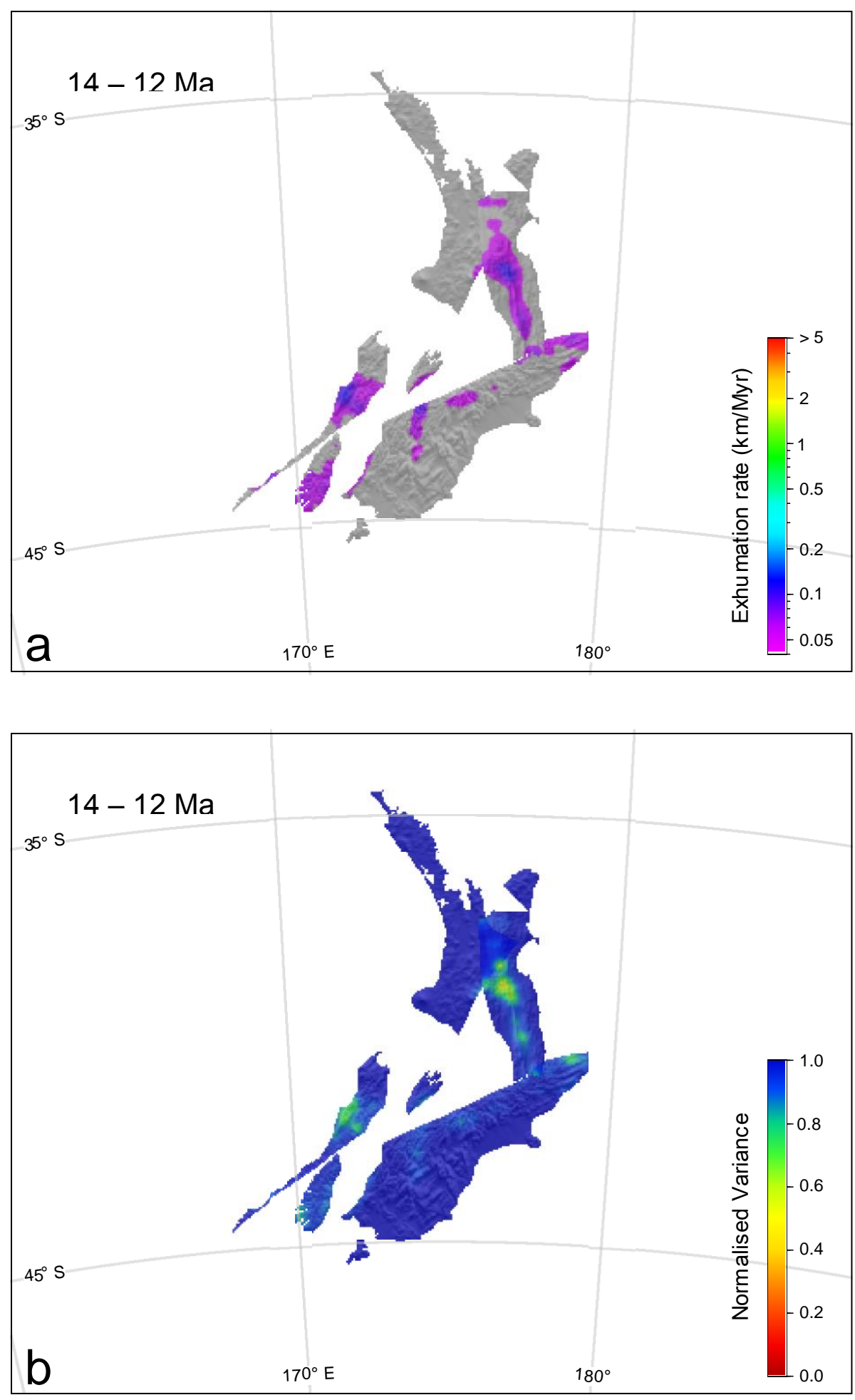

Fig. 6.17 Exhumation model of New Zealand for the time interval 14-12 Ma. 

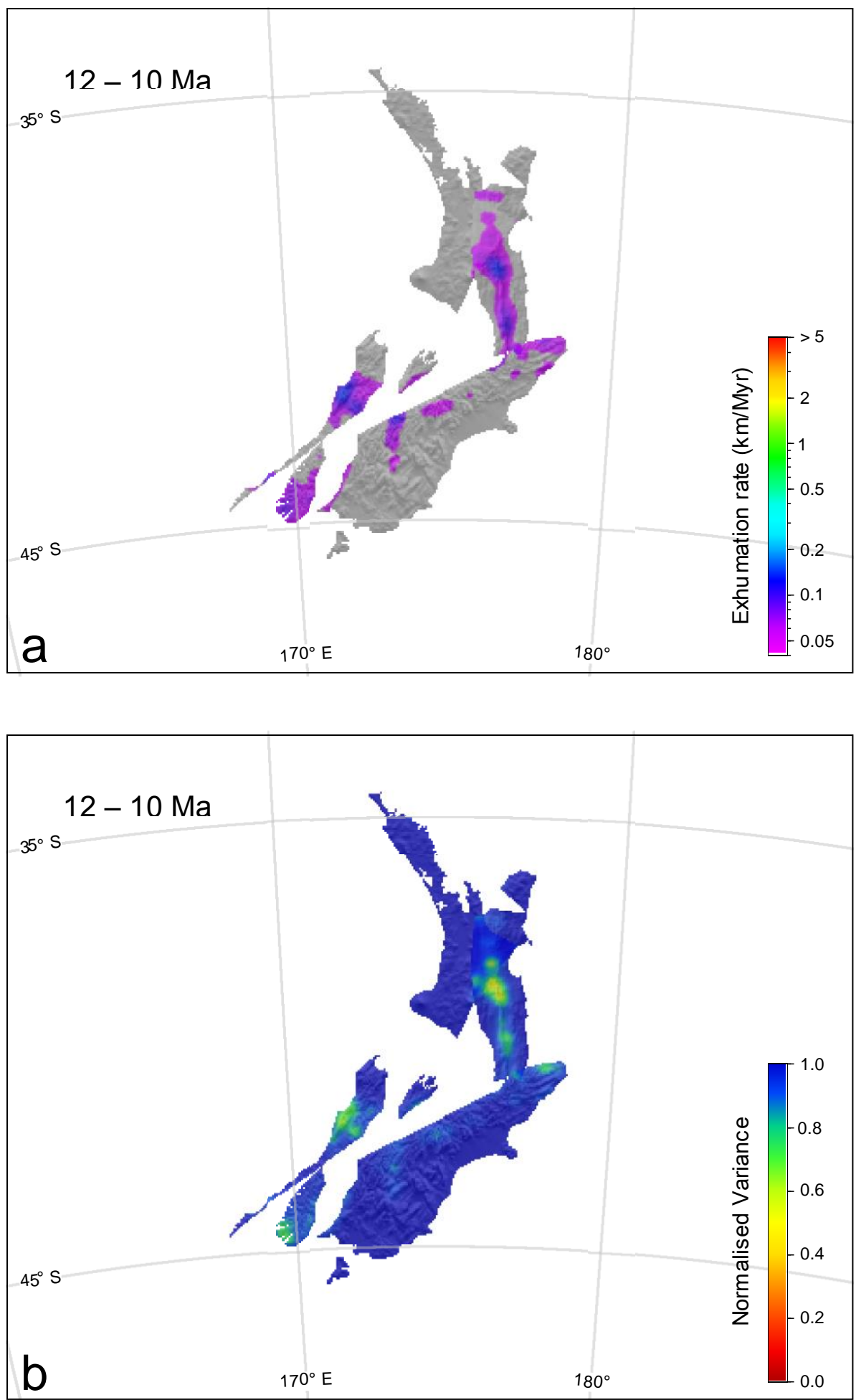

Fig. 6.18 Exhumation model of New Zealand for the time interval 12-10 Ma. 

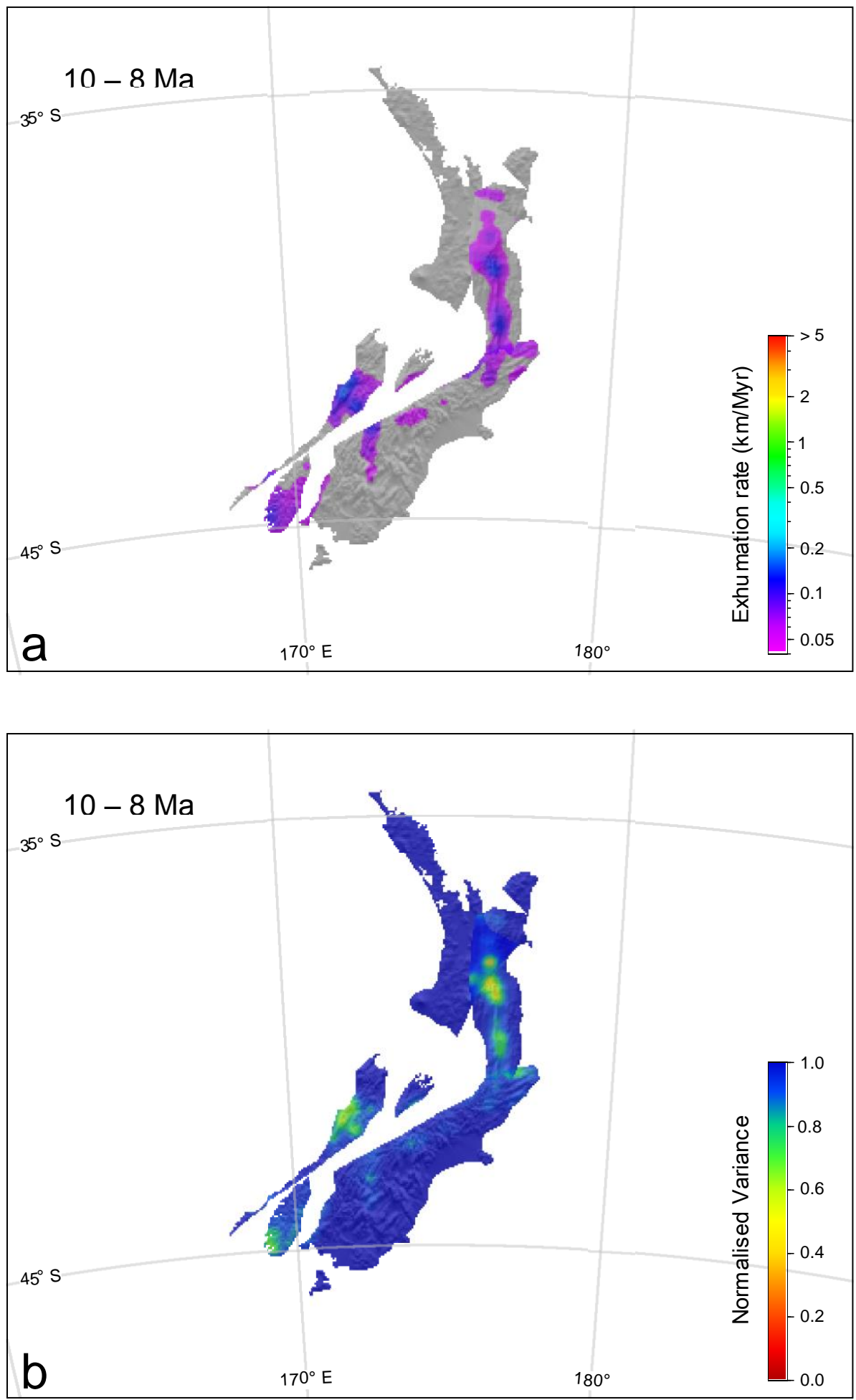

Fig. 6.19 Exhumation model of New Zealand for the time interval 10-8 Ma. 

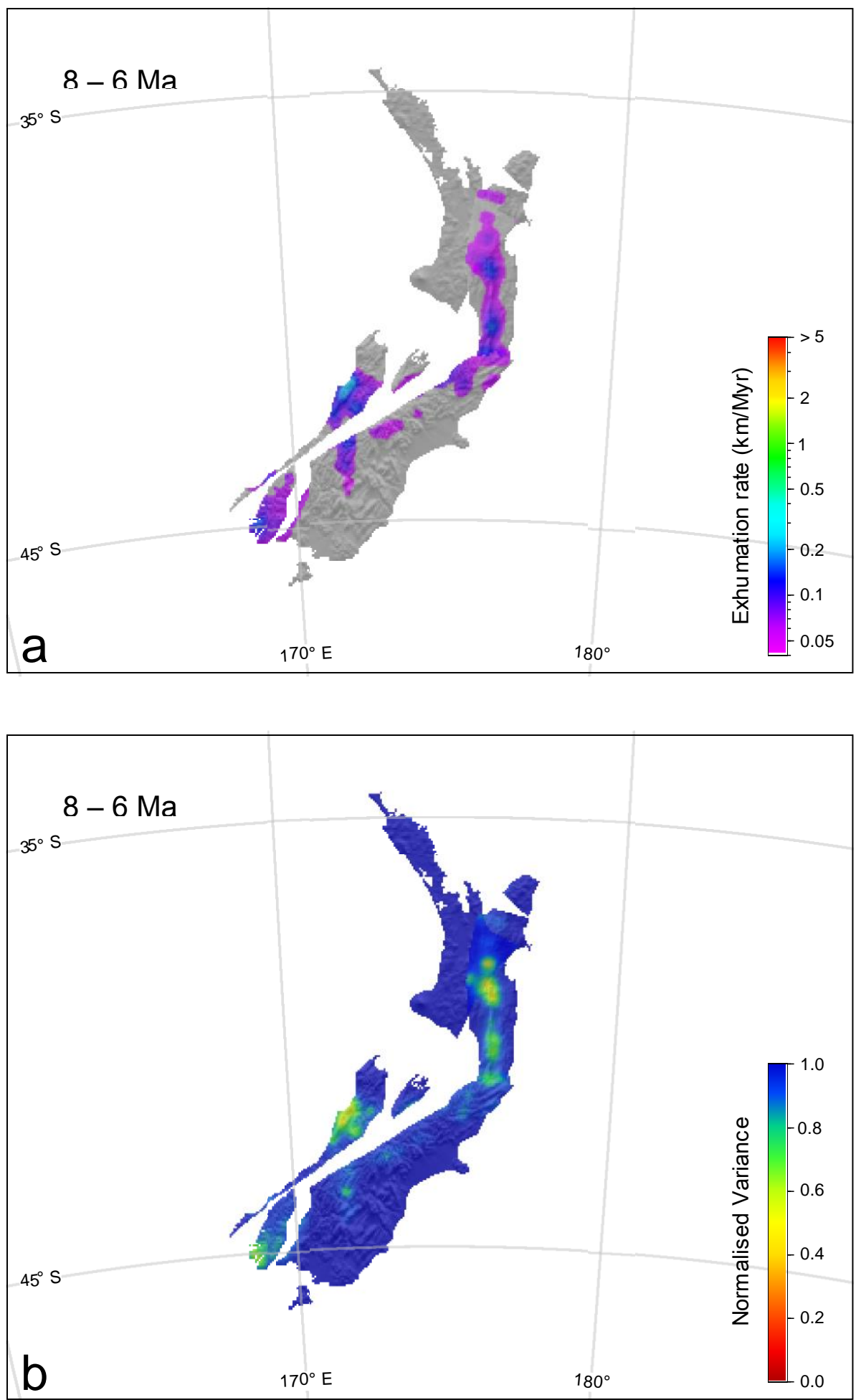

Fig. 6.20 Exhumation model of New Zealand for the time interval 8-6 Ma. 

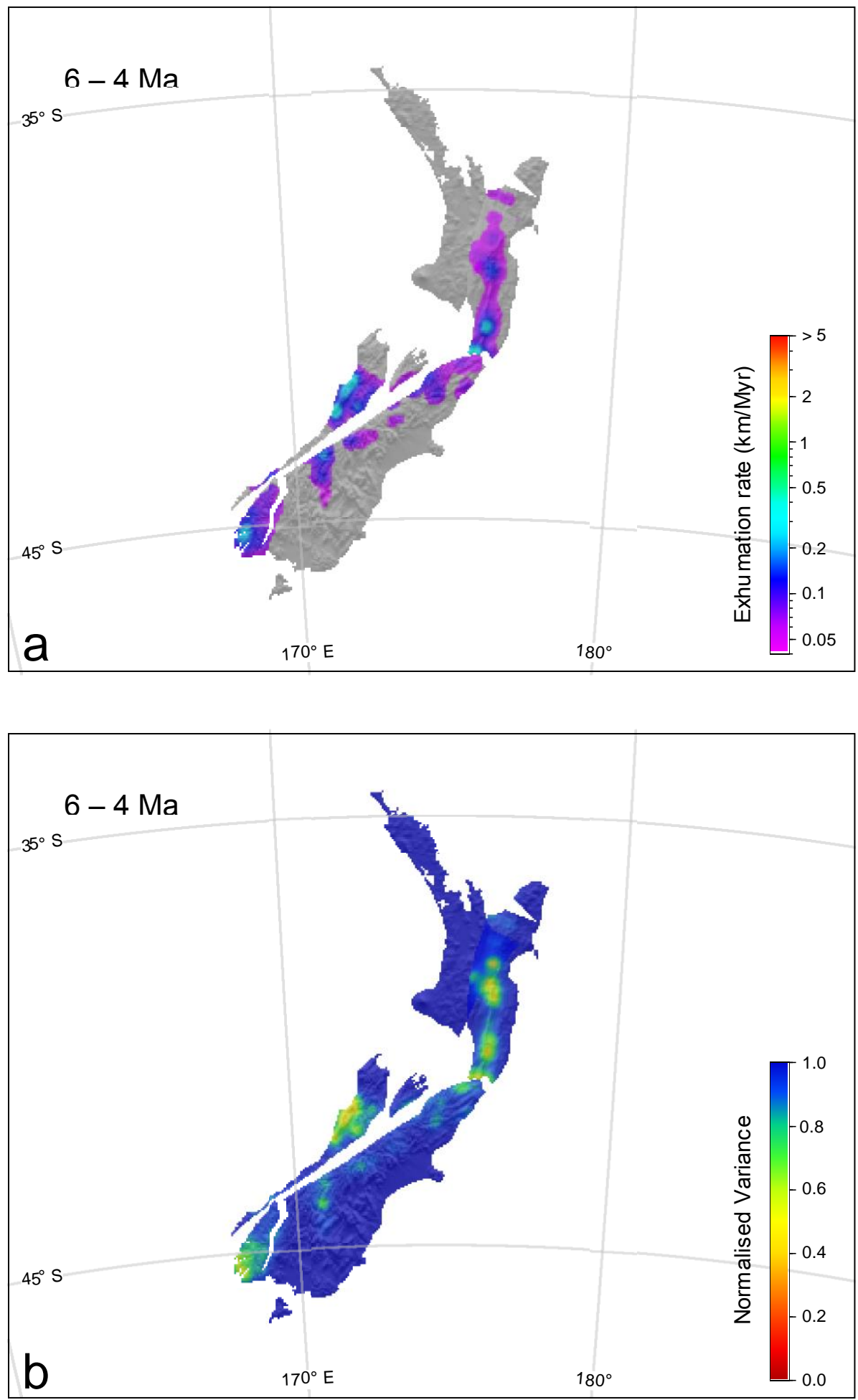

Fig. 6.21 Exhumation model of New Zealand for the time interval 6-4 Ma. 

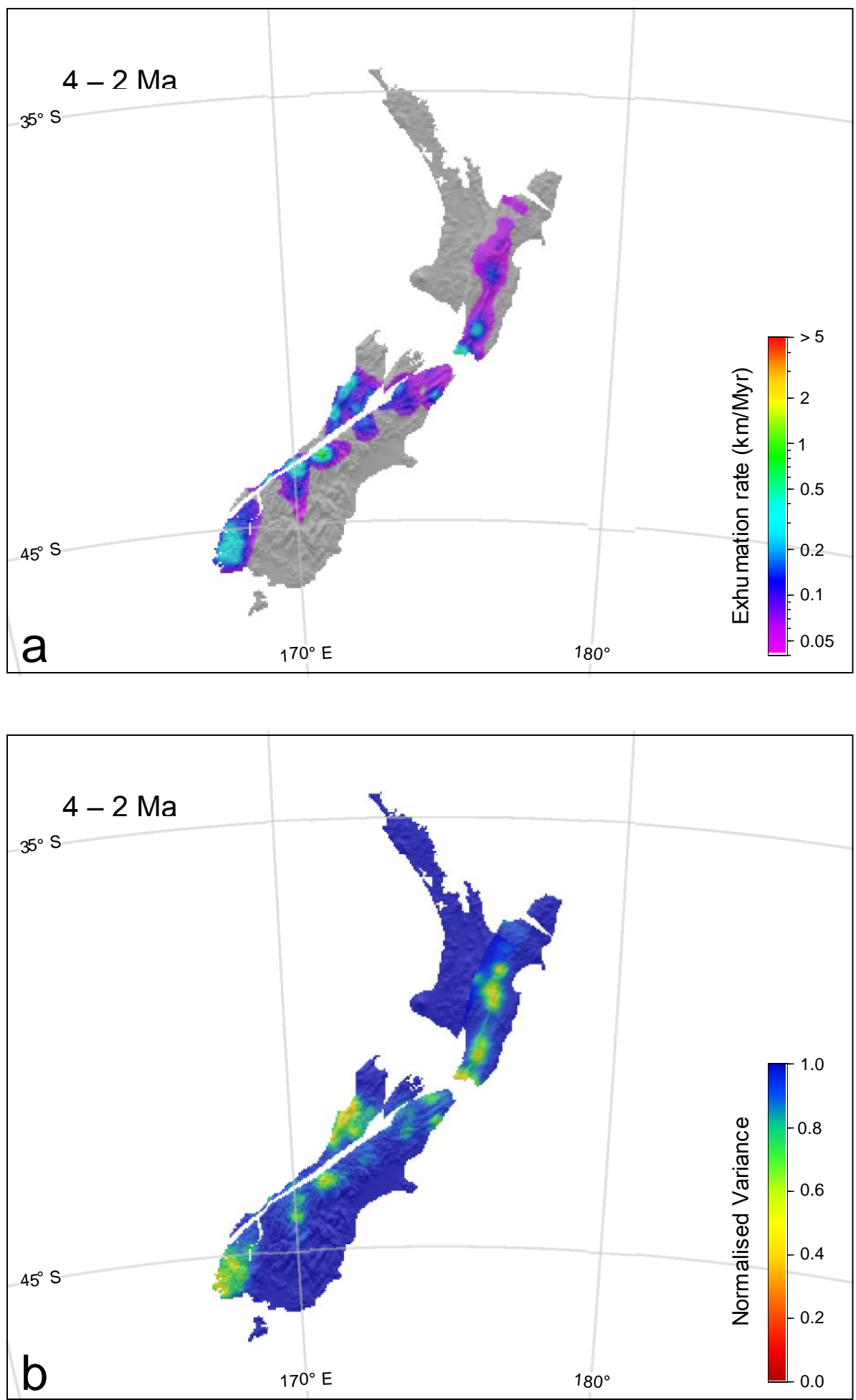

Fig. 6.22 Exhumation model of New Zealand for the time interval 4-2 Ma. 

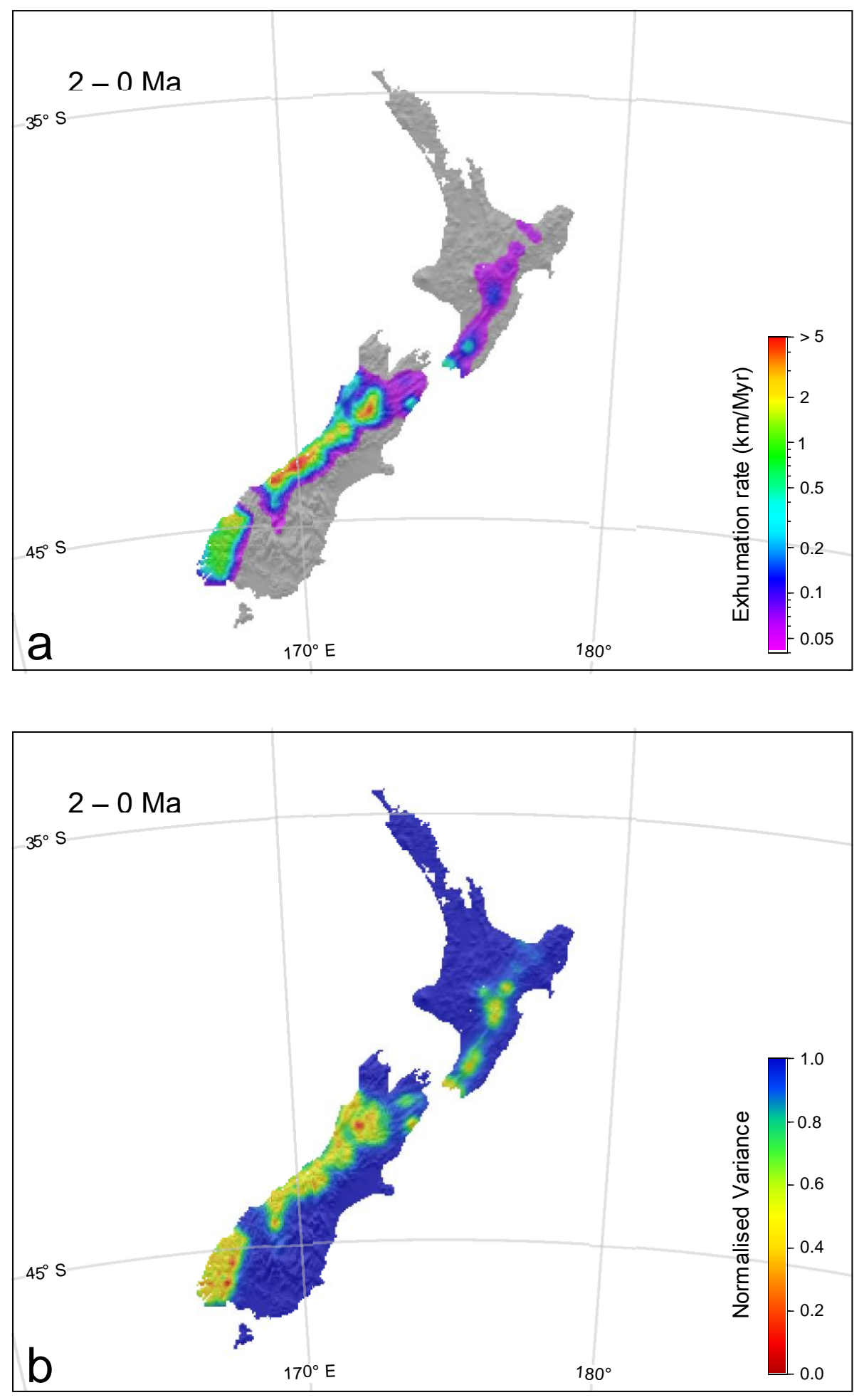

Fig. 6.23 Exhumation model of New Zealand for the time interval 2-0 Ma. 


\section{Supplementary references of thermochronological data}

Batt, G.E., Braun, J., Kohn, B.P. and McDougall, I., 2000. Thermochronological analysis of the dynamics of the Southern Alps, New Zealand. Geological Society of America Bulletin, 112(2): 250-266.

Herman, F., Braun, J. and Dunlap, W.J., 2007. Tectonomorphic scenarios in the Southern Alps of New Zealand. Journal of Geophysical Research, 112(B4): B04201.

Herman, F., Cox, S.C. and Kamp, P.J.J., 2009. Low-temperature thermochronology and thermokinematic modeling of deformation, exhumation, and development of topography in the central Southern Alps, New Zealand. Tectonics, 28(5): TC5011.

House, M.A., Gurnis, M., Kamp, P.J.J. and Sutherland, R., 2002. Uplift in the Fiordland Region, New Zealand: Implications for Incipient Subduction. Science, 297(5589): 2038-2041.

House, M.A., Gurnis, M., Sutherland, R. and Kamp, P.J.J., 2005. Patterns of Late Cenozoic exhumation deduced from apatite and zircon U-He ages from Fiordland, New Zealand. Geochemistry, Geophysics, Geosystems, 6(9): Q09013.

Kamp, P.J.J. and Liddell, I.J., 2000. Thermochronology of northern Murihiku Terrane, New Zealand, derived from apatite FT analysis. Journal of the Geological Society, 157(2): 345-354.

Kao, M.-h., 2001. Thermo-Tectonic History of the Marlborough Region, South Island, New Zealand. Terrestrial, Atmospheric and Oceanic Sciences, 12(3): 485-502.

Kao, M.-h., 2002. Thermo-Tectonic Implications of Zircon and Apatite FT Data of the Marlborough Region, South Island, New Zealand. Terrestrial, Atmospheric and Oceanic Sciences, 13(2): 109-124.

Little, T.A., Cox, S., Vry, J.K. and Batt, G., 2005. Variations in exhumation level and uplift rate along the obliqu-slip Alpine fault, central Southern Alps, New Zealand. Geological Society of America Bulletin, 117(5-6): 707-723.

Ring, U. and Bernet, M., 2010. Fission-track analysis unravels the denudation history of the Bonar Range in the footwall of the Alpine Fault, South Island, New Zealand. Geological Magazine, 147(06): 801-813.

Schulte, D.O., Ring, U., Thomson, S.N., Glodny, J. and Carrad, H., 2014. Two-stage development of the Paparoa Metamorphic Core Complex, West Coast, South Island, New Zealand: Hot continental extension precedes sea-floor spreading by 25 m.y. Lithosphere, 6(3): 177-194. 
Sutherland, R., Gurnis, M., Kamp, P.J.J. and House, M.A., 2009. Regional exhumation history of brittle crust during subduction initiation, Fiordland, southwest New Zealand, and implications for thermochronologic sampling and analysis strategies. Geosphere, 5(5): 409-425. 


\section{Appendix II}

\section{Sample preparation and analytical methods}

This appendix describes the laboratory routines for apatite and zircon fission-track analyses at VUW, and for apatite (U-Th-Sm)/He analysis at University of Melbourne.

\subsection{Mineral preparation}

For preparation of samples for fission-track and (U-Th-Sm)/He analyses, the zircon and apatite crystals were separated from greywacke rocks from North Island. Mineral separation was carried out at Victoria University of Wellington (VUW) and included the steps of sample crushing, sieving (to $<250 \mu \mathrm{m}$ grain size), Wifley table separation, magnetic and heavy liquid separation (various densities of methylene iodide). Following the above steps, hand-picking under binocular microscope was sometimes required to obtain purer mineral concentrates.

\subsection{Zircon and apatite fission-track}

The external detector method (EDM) (e.g. Hurford and Carter, 1991) was used fission-track analyses. Zircons were mounted on Teflon sheets on a hotplate at $250{ }^{\circ} \mathrm{C}$. Apatites were mounted in epoxy resin on glass plates.

Grinding and polishing were completed to expose the crystals and obtain $4 \pi$ geometry. This thickness corresponds to a half of the etchable track length, which is $\sim 6 \mu \mathrm{m}$ for zircon and $\sim 8 \mu \mathrm{m}$ for apatite. Zircon and apatite mounts were ground on wet sandpaper of 1200 grit $(\sim 9 \mu \mathrm{m})$ followed by polishing on nylon cloth with diamond suspension liquid of $3 \mu \mathrm{m}$ and $1 \mu \mathrm{m}$ grain size. 
Latent fission tracks are only $\sim 1 \mathrm{~nm}$ in width, invisible under optical microscopes, and thus require enlargement by chemical etching. Zircons were etched in eutectic $\mathrm{KOH}-$ $\mathrm{NaOH}\left(1: 1\right.$ mole ratio) melt at $\sim 215^{\circ} \mathrm{C}$ (Gleadow et al., 1976) for $24-60$ hours until the spontaneous tracks are fully revealed. The zircon etching process was done in a temperature-controlled furnace with the etchant in a Teflon or platinum crucible. The apatites were etched in $5.5 \mathrm{M} \mathrm{HNO}_{3}$ for 20 seconds at $21^{\circ} \mathrm{C}$ (Donelick et al., 2005).

After etching of spontaneous tracks in the zircon or apatite crystals, a muscovite sheet was attached to the etched sample mount for recording fission tracks induced by thermal neutron irradiation. The muscovite detector and the sample mount were tightly wrapped together with tape. A muscovite sheet was also attached to the dosimeter glasses (CN5 for apatite and $\mathrm{CN} 1$ for zircon) for monitoring thermal neutron fluence during irradiation. Samples and dosimeter glasses were stacked and packed in a "delron" tubes for irradiation at Oregon State University Radiation Center, USA.

After irradiation, the muscovites were etched in $40 \% \mathrm{HF}$ at room temperature for 45 minutes to reveal the induced fission tracks. After etching, the etched muscovite was washed with running water for at least 30 minutes. Finally, the sample and corresponding muscovite were aligned on a glass slide with super glue or resin, ready for analysis.

Track counting and length measurements were made using a Zeiss M1m microscope with a magnification of $\mathrm{x} 1000$ with the Autoscan system; oil immersion was applied only for counting zircons. Counting and measurement were performed only on crystals with exposed surfaces parallel to the $c$-axes. The zeta method (Hurford and Green, 1983) was used for age calibration, and all the FT ages reported in this thesis are central ages (Galbraith and Laslett, 1993) that include a $\pm 2 \sigma$ uncertainty (unless otherwise stated). Three-dimensional confined tracks were measured for track-length distribution, including their angles to the $c$-axis. The mean etch pit diameter (Dpar) was measured for each grain as a proxy for the compositional parameter to be used in annealing models (Ketcham et al., 2007).

To increase the number of measurable confined track lengths in apatites for thermal history modelling, ${ }^{252} \mathrm{Cf}$ irradiation (Donelick and Miller, 1991) was carried out on 
selected samples. The ${ }^{252} \mathrm{Cf}$ irradiation was performed at the University of Melbourne and each mount was irradiated for 3-4 hours.

Table 7.1 Zeta values evaluated by R. Jiao for apatite (CN5) and zircon (CN1).

\begin{tabular}{cccccc}
\hline & Apatite & \multicolumn{3}{c}{ Zircon } \\
\hline Irradiation code & Standard & Zeta $\pm 1 \sigma$ & Irradiation code & Standard & Zeta $\pm 1 \sigma$ \\
\hline eth-27 & Durango & $401 \pm 21$ & vuw2-37 & FCT & $135 \pm 7$ \\
eth-27-8 & Durango & $424 \pm 23$ & vuw12-45 & FCT & $146 \pm 8$ \\
eth5-10 & Durango & $358 \pm 35$ & vuw16-28 & FCT & $150 \pm 8$ \\
eth245-8 & FCT* & $327 \pm 28$ & vuw5-17 & FCT & $141 \pm 6$ \\
vuw7-8 & Durango & $293 \pm 16$ & vuw6-16 & FCT & $140 \pm 6$ \\
vuw7-22 & Durango & $313 \pm 19$ & vuw6-41 & FCT & $141 \pm 6$ \\
vuw13-23 & FCT & $269 \pm 45$ & vuw5-31 & FCT & $159 \pm 8$ \\
vuw13-2 & Durango & $352 \pm 21$ & vuw16-24 & FCT & $136 \pm 6$ \\
vuw14-17 & Durango & $329 \pm 20$ & & & \\
vuw9-17 & Durango & $349 \pm 22$ & & & \\
vuw9-6 & Durango & $323 \pm 20$ & & & \\
vuw8-14 & Durango & $342 \pm 22$ & & & \\
\hline
\end{tabular}

Weighted mean: $339 \pm 6.5$

Weighted mean: $143.6 \pm 2.4$

*Fish Canyon Tuff 

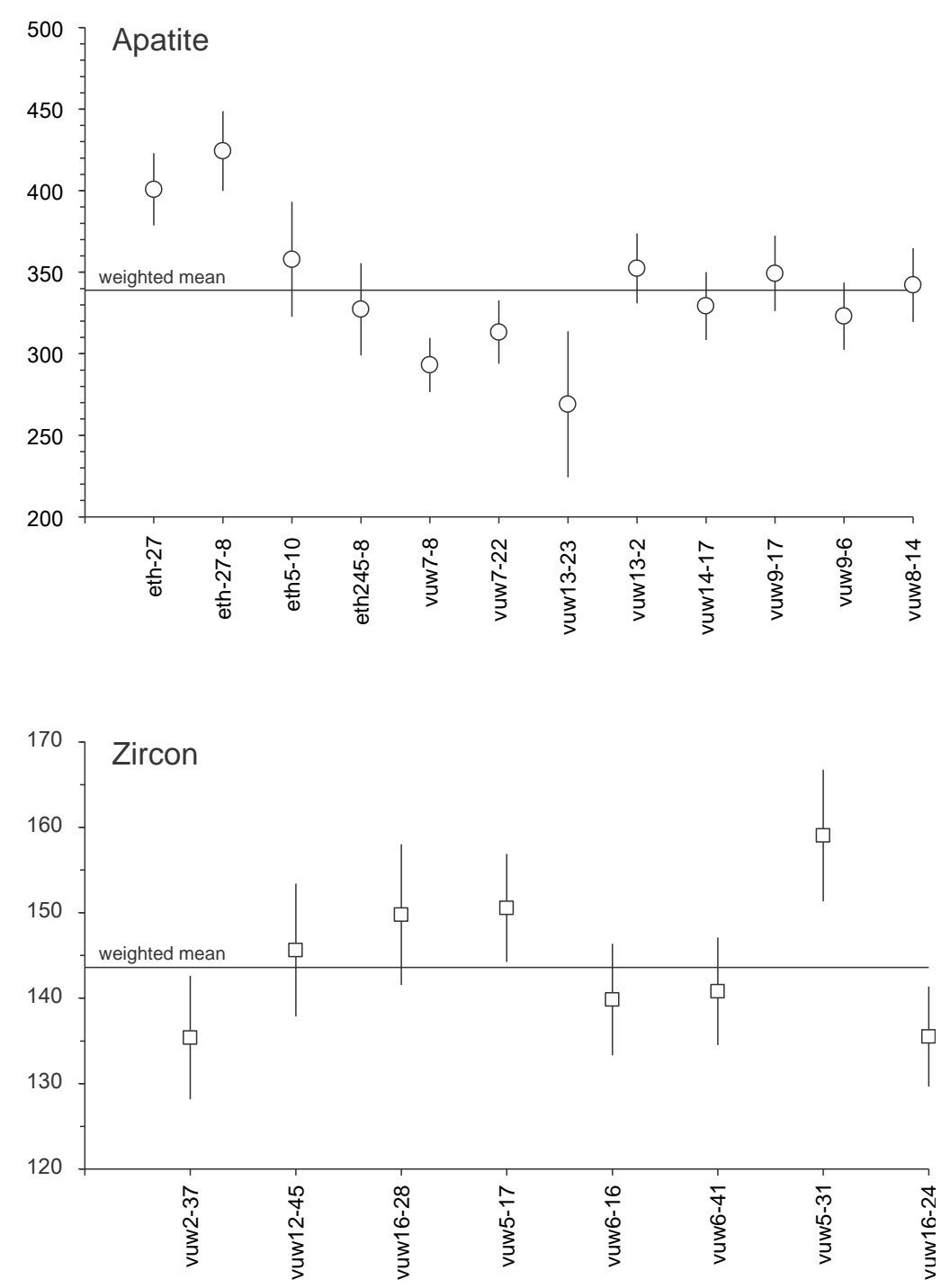

Fig. 7.1 Zeta values evaluated by R. Jiao for apatite (CN5) and zircon (CN1).

\subsection{Apatite (U-Th-Sm)/He}

Analyses followed a laboratory routine that was developed by House et al. (2000) for extracting $\mathrm{He}$ from single sample aliquots, i.e. single apatite crystals in this study. Euhedral grains with average grain radii in a close size range with each aliquot were handpicked under an Olympus SZX12 binocular microscope, and then were immersed in ethanol and checked under polarised light to exclude grains with visible mineral inclusions. Grain geometry was imaged, measured and recorded in order to apply a correction for $\alpha$-ejection (Farley et al., 1996). Then grains were placed into acidtreated platinum capsules. The grains in the capsules were outgassed at $\sim 900{ }^{\circ} \mathrm{C}$ for 5 minutes, using a semiconductor diode Coherent Quattro FAP laser, set on a wavelength of $820 \mathrm{~nm}$ with fibre-optic coupling to the sample chamber to provide optimal coupling with samples and heating without melting, ablation or fusion. $\mathrm{He}$ 
volume was determined by isotope dilution using a pure ${ }^{3} \mathrm{He}$ spike, calibrated against an independent ${ }^{4} \mathrm{He}$ standard and measured using a Balzers quadrupole (QMS $200-$ Prisma) mass spectrometer. A hot blank was run after each gas extraction to verify complete outgassing of the apatite grains. Most samples yielded negligible amounts of gas even after the first re-extract, and for all samples the second re-extract contributed less than $0.5 \%$ of the total measured ${ }^{4} \mathrm{He}$.

Table 7.2 Apatite (U-Th-Sm)/He age data for Durango apatite age standard.

\begin{tabular}{ccccccccc}
\hline Sample & $\begin{array}{c}\text { Lab. } \\
\text { No. }\end{array}$ & He\# & $\begin{array}{c}{ }^{4} \mathrm{He} \\
(\mathrm{ncc})\end{array}$ & $\begin{array}{c}\text { Mass } \\
(\mathrm{mg})\end{array}$ & ${ }^{*} \mathrm{~F}_{T}$ & $\begin{array}{c}\text { Th/U } \\
\text { ratio }\end{array}$ & $\begin{array}{c}\text { Corrected } \\
\text { age }(\mathrm{Ma})\end{array}$ & $\begin{array}{c}\text { Error } \\
( \pm 1 \sigma)\end{array}$ \\
\hline Durango & 5938 & 17218 & 7.210 & - & 1.00 & 20.96 & 31.6 & 2.0 \\
Durango & 5939 & 17298 & 11.661 & - & 1.00 & 19.88 & 32.0 & 2.0 \\
Durango & 6166 & 18089 & 17.624 & - & 1.00 & 21.05 & 30.6 & 1.9 \\
Durango & 6130 & 18104 & 3.910 & - & 1.00 & 21.22 & 32.8 & 2.0 \\
Durango & 7993 & 23637 & 5.033 & - & 1.00 & 20.18 & 31.4 & 1.9 \\
Durango & 8036 & 23751 & 4.653 & - & 1.00 & 20.61 & 28.2 & 1.8 \\
Durango & $8400-1$ & 25163 & 2.785 & - & 1.00 & 18.34 & 33.1 & 2.1 \\
Durango & $8400-2$ & 25166 & 2.817 & - & 1.00 & 20.77 & 32.7 & 2.0 \\
Durango & $8400-3$ & 25169 & 3.691 & - & 1.00 & 20.30 & 31.8 & 2.0 \\
Durango & $8400-4$ & 25172 & 3.791 & - & 1.00 & 19.81 & 32.5 & 2.0 \\
Durango & $8400-5$ & 25175 & 3.730 & - & 1.00 & 20.20 & 33.1 & 2.1 \\
Durango & 8483 & 25371 & 1.444 & - & 1.00 & 19.31 & 31.3 & 1.9 \\
Durango & 8505 & 25380 & 3.014 & - & 1.00 & 21.23 & 33.3 & 2.1 \\
Durango & 8517 & 25523 & 8.776 & - & 1.00 & 21.15 & 32.7 & 2.0 \\
Durango & 8536 & 25580 & 6.748 & - & 1.00 & 20.11 & 32.1 & 2.0 \\
Durango & 8587 & 25737 & 4.558 & - & 1.00 & 20.53 & 31.0 & 1.9 \\
\hline & & & & & & & & \\
\hline
\end{tabular}

Weighted mean: $31.79 \pm 0.97$ (95\% confidence)

$* \mathrm{~F}_{T}$ is the a-ejection correction, which is not required as only internal pieces are analysed.

No mass is calculated as dimensions on the crystal pieces are not measured and therefore only a $\mathrm{Th} / \mathrm{U}$ ratio is calculated rather than the $\mathrm{U}, \mathrm{Th}$ and $\mathrm{Sm}$ content.

Samples were removed from the laser chamber. The outgassed apatites (still in the platinum capsules) were then dissolved in $\mathrm{HNO}_{3}$, for determination of ${ }^{238} \mathrm{U},{ }^{235} \mathrm{U}$, ${ }^{232} \mathrm{Th}$ and ${ }^{147} \mathrm{Sm}$ using an Agilent $7700 \mathrm{x}$ inductively coupled plasma mass spectrometer (ICP-MS). The reference material BHVO-1 was used to calibrate the 
analyses. With each batch of samples, Mud Tank apatite and international rock standard BCR-2 were run and used as check standards. (U-Th-Sm)/He ages were calculated and corrected for $\alpha$-ejection (Farley et al., 1996). Analytical uncertainties for He line in the University of Melbourne are conservatively assessed to be $\sim 6.2 \%$ $( \pm 1 \sigma)$. This incorporates the $\alpha$-ejection-related constituent, an estimated $5 \mu \mathrm{m}$ uncertainty in grain dimension measurements, gas analysis (estimated as <1\%) and ICP-MS analytical uncertainties, but not those related to possible heterogeneous $U$ and Th distributions. Accuracy and precision of $\mathrm{U}, \mathrm{Th}$, and $\mathrm{Sm}$ content is typically lower than $1 \%$, ranging up to $2 \%( \pm 2 \sigma)$ for some aliquots. An internal piece of Durango apatite (McDowell et al., 2005) was also analysed within each batch of samples to check the analytical accuracy.

The intra-sample variation in the grain age is not unusual in apatite (U-Th-Sm)/He, and in some cases could be significant (> $100 \%$ ) (see Brown et al. (2013) and references within). AHe age dispersion may arise for diverse reasons (e.g. Brown et al., 2013; Cogné et al., 2011; Fitzgerald et al., 2006). These include:

(1) Undetected U-Th-rich inclusions (Lippolt et al., 1994). The crystal selection procedure excludes visible inclusions identified under polarized light. Those smaller than a few $\mu \mathrm{m}$ are unlikely to produce significant He age variation (Vermeesch et al., 2007).

(2) Helium implantation from external sources (Danišík et al., 2010; Spencer et al., 2004; Spiegel et al., 2009). This effect is important for very low U-Th $(<3$ ppm) grains surrounded by high $U$ rich minerals or matrix, but the eU (effective $U$ concentration, a parameter that weights the decay of the two isotopes for their alpha productivity, computed as $[\mathrm{U}]+0.235[\mathrm{Th}]$ ) of most apatite grains analysed is $>5$ ppm.

(3) Zonation in $\mathrm{U}$ and Th. U-Th zonation in crystals was reported as an issue in interpretation of a helium age (Meesters and Dunai, 2002). However, Ault and Flowers (2012) suggested that the U-Th zonation in apatite usually leads to less than $15 \%$ age dispersion, but it is usually safe to assume that most grains are unzoned. 
(4) Grain size variation (Reiners and Farley, 2001). Age and grain size are correlated in some (R793, JR12-04 and JR12-16; Table 2.3) but not all samples. The grain size is used as the diffusion domain in the thermal history modelling.

(5) Radiation damage. The accumulation of $\alpha$-recoil damage, traps helium in the apatite structure to produce old apparent ages (Flowers et al., 2009; Gautheron et al., 2009; Shuster et al., 2006; Shuster and Farley, 2009), especially for the high-eU samples that have slowly cooled through or have had prolonged residence in the helium PRZ. This effect is quantified by the radiation damage accumulation models (Flowers et al., 2009; Gautheron et al., 2009) using fission-track data and incorporated in the thermal history modelling programme (Gallagher, 2013).

(6) Crystal breakage. Most grains in this study are broken with one or no terminations (Table 2.3), which could yield either younger or older ages than the whole grain age (Brown et al., 2013).

(7) Chemical influence. (Gautheron et al., 2013) suggested that different grain chemistry ( $\mathrm{Cl}$ content) can cause up to $\sim 12-15 \%$ AHe age dispersion by changing the annealing rate of $\alpha$-recoil damage, but the true relation between $\mathrm{He}$ diffusion and $\mathrm{Cl}$ content in apatite has not yet been validated.

Among the reasons listed above, three have been comprehensively evaluated and considered in different He diffusion models proposed by different authors, i.e. variation in grain size (Farley, 2000), accumulation of $\alpha$-recoil damage (Flowers et al., 2009; Gautheron et al., 2009; Shuster et al., 2006) and crystal breakage (Brown et al., 2013). For samples that experienced complex thermal histories, each of the three causes could lead to intra-sample age dispersion over $50 \%$, and the combined effect could lead to dispersion over $100 \%$ (Brown et al., 2013). In order to obtain a consistent AHe data set for interpretation, each single-grain AHe age in this thesis is cross-checked using the corresponding AFT age, and those outliers that overlap, or are older than, the corresponding AFT ages are excluded for interpretation. Rejection of some results in this manner was suggested by several authors (e.g. Cogné et al., 2012; Fitzgerald et al., 2006; Flowers and Kelley, 2011) for the retrieval of a meaningful or representative AHe data set. 


\section{Appendix III}

\section{Single-grain fission-track data}

Age calculation and radial plot (Galbraith, 1990) of fission-track data were carried out with the program TrackKey (Dunkl, 2002). Age is calculated using the equation

$$
\text { Age }=\frac{1}{\lambda_{\mathrm{a}}} \ln \left(1+\lambda_{\mathrm{a}} \zeta \rho_{\text {ratio }} \rho_{d} g\right)
$$

where $\lambda_{\mathrm{a}}=1.55125, \mathrm{~g}=0.5, \mathrm{n}=$ number of counted grains; other parameters are listed as follows.

Ns: Number of spontaneous tracks counted

Ni: Number of induced tracks counted

Area: Number of microscope squares. One grid includes 100 squares.

RhoS: Density of spontaneous tracks $\left(10^{5} \mathrm{~cm}^{-2}\right)$

RhoI: Density of induced tracks $\left(10^{5} \mathrm{~cm}^{-2}\right)$

Pooled Age: $\quad$ Pooled age $\pm 1 \sigma(\mathrm{Ma})$, calculated with $\rho_{\text {ratio }}=\frac{\sum N s}{\sum N i}$

Mean Age: $\quad$ Mean age $\pm 1 \sigma(\mathrm{Ma})$, calculated with $\rho_{\text {ratio }}=\frac{\sum\left(\rho_{s} / \rho_{i}\right)}{n}$

Central Age: Central age $\pm 1 \sigma(\mathrm{Ma})$, according to Galbraith and Laslett (1993)

Chi-sq: $\chi^{2}$, according to Green (1981)

$\mathrm{P}(\%)$ : Probability of $\chi^{2}$ for $\mathrm{n}-1$ degrees of freedom

RhoD: Track density on a U standard $\left(10^{5} \mathrm{~cm}^{-2}\right)$

Nd: Number of induced tracks counted on a U standard

U standard: Standard glass used as an external detector

Zeta: $\zeta$ factor $\pm 1 \sigma$ 
Sample number: 12937

Mineral: Apatite Irradiation code: eth-6

$\begin{aligned} \text { Ns: } & 27 \\ \text { Ni: } & 800 \\ \text { Area: } & 511 \\ & \\ \text { RhoS: } & 0.528 \\ \text { RhoI: } & 15.66 \\ & \\ \text { Pooled Age: } & 8.7 \pm 1.7 \\ \text { Mean Age: } & 8.2 \pm 1.5 \\ \text { Central Age: } & 8.8 \pm 1.7 \\ \text { Chi-sq.: } & 14.59 \\ \text { P(\%) } & 74.85 \\ \text { Dispersion: } & 0.10 \\ \text { RhoD: } & 15.3 \\ \text { Nd: } & 4633 \\ \text { U standard } & \text { CN_5 } \\ \text { Zeta } \pm 1 \sigma & 339 \pm 6.5 \\ \text { counted by } & \text { RJ }\end{aligned}$

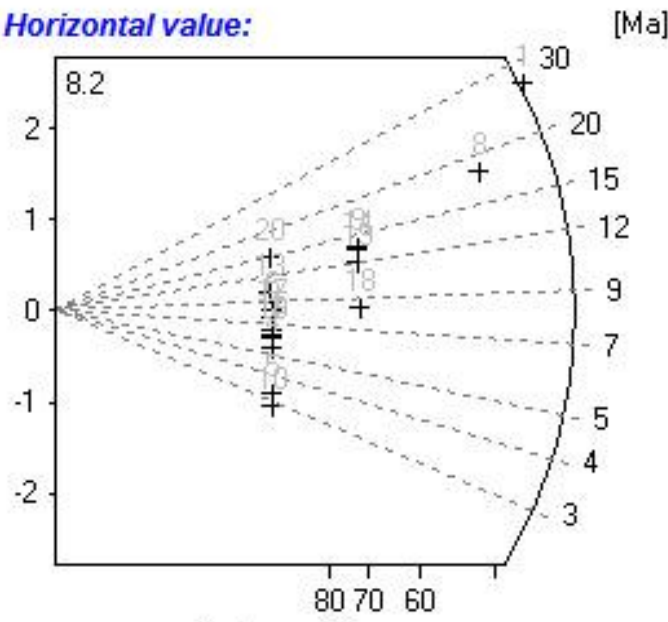

Rel. error [\%]

Ma] 
Sample number: 14236

Mineral: Apatite

Irradiation code: vuw007-24

Ns: 143

Ni: 1760

Area: 511

RhoS: 2.798

RhoI: 34.44

Pooled Age: $\quad 16.2 \pm 1.4$

Mean Age: $14.3 \pm 1.7$

Central Age: $16.2 \pm 1.4$

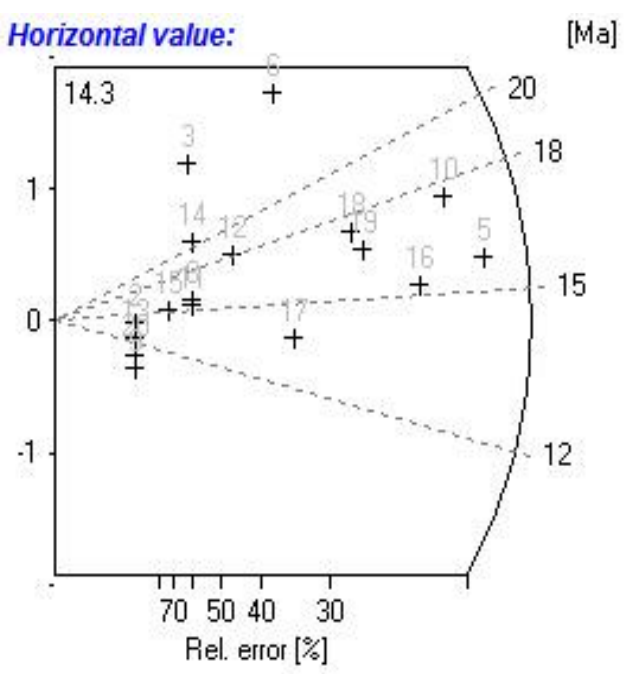

Chi-sq.: 7.42

$\mathrm{P}(\%) \quad 99.16$

Dispersion: $\quad 0.00$

RhoD: 11.79

Nd: 19085

U standard CN_5

Zeta $\pm 1 \sigma \quad 339 \pm 6.5$

counted by RJ

\begin{tabular}{ccccccccc} 
Crystal & $\mathrm{Ns}$ & $\mathrm{Ni}$ & Area & RhoS(e5) & RhoI(e5) & Age(Ma) & $+-1 \mathrm{~s}$ & $\mathrm{U}(\mathrm{ppm})$ \\
\hline 1 & 0 & 24 & 25 & 0.00 & 9.60 & 0.00 & 0.00 & 9.36 \\
2 & 1 & 14 & 25 & 0.40 & 5.60 & 14.26 & 14.77 & 5.46 \\
3 & 3 & 20 & 12 & 2.50 & 16.67 & 29.92 & 18.53 & 16.25 \\
4 & 0 & 7 & 16 & 0.00 & 4.38 & 0.00 & 0.00 & 4.27 \\
5 & 29 & 368 & 24 & 12.08 & 153.33 & 15.73 & 3.05 & 149.53 \\
6 & 8 & 58 & 10 & 8.00 & 58.00 & 27.51 & 10.39 & 56.56 \\
7 & 0 & 8 & 48 & 0.00 & 1.67 & 0.00 & 0.00 & 1.63 \\
8 & 3 & 38 & 21 & 1.43 & 18.10 & 15.76 & 9.46 & 17.65 \\
9 & 1 & 20 & 36 & 0.28 & 5.56 & 9.99 & 10.24 & 5.42 \\
10 & 24 & 273 & 15 & 16.00 & 182.00 & 17.55 & 3.75 & 177.48 \\
11 & 3 & 39 & 42 & 0.71 & 9.29 & 15.36 & 9.21 & 9.06 \\
12 & 5 & 55 & 30 & 1.67 & 18.33 & 18.15 & 8.48 & 17.88 \\
13 & 1 & 16 & 30 & 0.33 & 5.33 & 12.48 & 12.87 & 5.20 \\
14 & 3 & 29 & 32 & 0.94 & 9.06 & 20.65 & 12.53 & 8.84 \\
15 & 2 & 26 & 30 & 0.67 & 8.67 & 15.36 & 11.27 & 8.45 \\
16 & 21 & 275 & 25 & 8.40 & 110.00 & 15.25 & 3.47 & 107.27 \\
17 & 9 & 131 & 24 & 3.75 & 54.58 & 13.72 & 4.74 & 53.23 \\
18 & 14 & 161 & 16 & 8.75 & 100.63 & 17.36 & 4.85 & 98.13 \\
19 & 15 & 180 & 20 & 7.50 & 90.00 & 16.64 & 4.48 & 87.77 \\
20 & 1 & 18 & 30 & 0.33 & 6.00 & 11.10 & 11.40 & 5.85 \\
\hline
\end{tabular}


Sample number: DS10-03

Mineral: Apatite

Irradiation code: vuw007-26

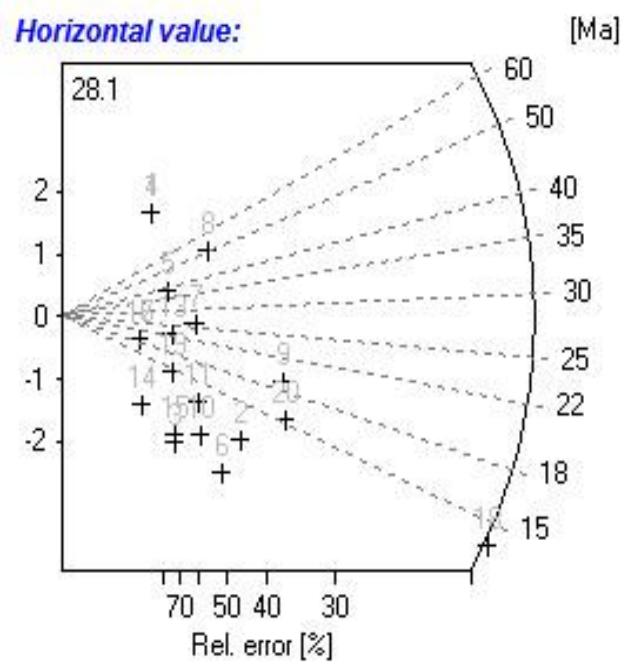

Chi-sq.: $\quad 34.16$

$\mathrm{P}(\%) \quad 1.76$

Dispersion: 0.00

RhoD: 11.5

Nd: 19085

U standard CN_5

Zeta $\pm 1 \sigma \quad 339 \pm 6.5$

counted by RJ

\begin{tabular}{ccccccccc} 
Crystal & $\mathrm{Ns}$ & $\mathrm{Ni}$ & Area & RhoS(e5) & Rhol(e5) & Age(Ma) & $+-1 \mathrm{~s}$ & $\mathrm{U}(\mathrm{ppm})$ \\
\hline 1 & 2 & 3 & 8 & 2.50 & 3.75 & 128.71 & 117.52 & 3.75 \\
2 & 5 & 86 & 16 & 3.13 & 53.75 & 11.33 & 5.22 & 53.73 \\
3 & 2 & 58 & 16 & 1.25 & 36.25 & 6.72 & 4.84 & 36.24 \\
4 & 2 & 3 & 6 & 3.33 & 5.00 & 128.71 & 117.52 & 5.00 \\
5 & 2 & 10 & 12 & 1.67 & 8.33 & 38.88 & 30.13 & 8.33 \\
6 & 4 & 99 & 16 & 2.50 & 61.88 & 7.87 & 4.02 & 61.86 \\
7 & 3 & 22 & 9 & 3.33 & 24.44 & 26.54 & 16.34 & 24.44 \\
8 & 4 & 15 & 12 & 3.33 & 12.50 & 51.79 & 29.16 & 12.50 \\
9 & 8 & 81 & 15 & 5.33 & 54.00 & 19.23 & 7.14 & 53.98 \\
10 & 3 & 63 & 20 & 1.50 & 31.50 & 9.28 & 5.49 & 31.49 \\
11 & 3 & 47 & 9 & 3.33 & 52.22 & 12.43 & 7.41 & 52.21 \\
12 & 0 & 19 & 20 & 0.00 & 9.50 & 0.00 & 0.00 & 9.50 \\
13 & 2 & 17 & 12 & 1.67 & 14.17 & 22.90 & 17.13 & 14.16 \\
14 & 1 & 29 & 16 & 0.63 & 18.13 & 6.72 & 6.84 & 18.12 \\
15 & 2 & 54 & 16 & 1.25 & 33.75 & 7.22 & 5.20 & 33.74 \\
16 & 1 & 10 & 12 & 0.83 & 8.33 & 19.47 & 20.42 & 8.33 \\
17 & 1 & 10 & 12 & 0.83 & 8.33 & 19.47 & 20.42 & 8.33 \\
18 & 29 & 406 & 20 & 14.50 & 203.00 & 13.91 & 2.69 & 202.94 \\
19 & 2 & 26 & 6 & 3.33 & 43.33 & 14.98 & 11.00 & 43.32 \\
20 & 8 & 102 & 12 & 6.67 & 85.00 & 15.28 & 5.62 & 84.97 \\
\hline
\end{tabular}


Sample number: DS10-06

Mineral: Apatite

Irradiation code: vuw007-7

Ns: 54

Ni: 554

Area: 250

RhoS: 2.16

RhoI: 22.16

Pooled Age: $\quad 23.4 \pm 3.4$

Mean Age: $\quad 28.4 \pm 4.7$

Central Age: $24.1 \pm 3.8$

Chi-sq.: $\quad 16.29$

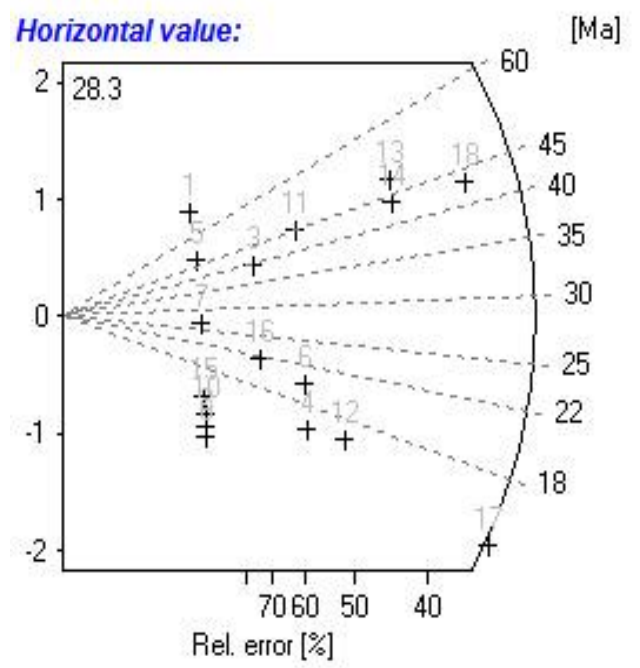

$\mathrm{P}(\%) \quad 50.34$

Dispersion: $\quad 0.20$

$\begin{aligned} \text { RhoD: } & 14.19 \\ \text { Nd: } & 19085 \\ \text { U standard } & \text { CN_5 } \\ & \\ \text { Zeta } \pm 1 \sigma & 339 \pm 6.5 \\ \text { counted by } & \text { RJ }\end{aligned}$

\begin{tabular}{ccccccccc} 
Crystal & $\mathrm{Ns}$ & $\mathrm{Ni}$ & Area & RhoS(e5) & RhoI(e5) & Age(Ma) & $+-1 \mathrm{~s}$ & $\mathrm{U}(\mathrm{ppm})$ \\
\hline 1 & 1 & 3 & 6 & 1.67 & 5.00 & 79.69 & 92.04 & 4.05 \\
2 & 1 & 22 & 9 & 1.11 & 24.44 & 10.93 & 11.17 & 19.81 \\
3 & 2 & 12 & 12 & 1.67 & 10.00 & 39.97 & 30.54 & 8.10 \\
4 & 3 & 45 & 9 & 3.33 & 50.00 & 16.02 & 9.56 & 40.52 \\
5 & 1 & 5 & 25 & 0.40 & 2.00 & 47.93 & 52.52 & 1.62 \\
6 & 3 & 36 & 6 & 5.00 & 60.00 & 20.02 & 12.03 & 48.62 \\
7 & 1 & 9 & 12 & 0.83 & 7.50 & 26.67 & 28.12 & 6.08 \\
8 & 1 & 24 & 20 & 0.50 & 12.00 & 10.02 & 10.22 & 9.72 \\
9 & 0 & 3 & 20 & 0.00 & 1.50 & 0.00 & 0.00 & 1.22 \\
10 & 1 & 20 & 20 & 0.50 & 10.00 & 12.02 & 12.32 & 8.10 \\
11 & 3 & 16 & 4 & 7.50 & 40.00 & 44.95 & 28.29 & 32.41 \\
12 & 4 & 58 & 16 & 2.50 & 36.25 & 16.57 & 8.57 & 29.38 \\
13 & 6 & 30 & 9 & 6.67 & 33.33 & 47.93 & 21.46 & 27.01 \\
14 & 6 & 33 & 16 & 3.75 & 20.63 & 43.59 & 19.37 & 16.71 \\
15 & 1 & 17 & 12 & 0.83 & 14.17 & 14.14 & 14.55 & 11.48 \\
16 & 2 & 22 & 12 & 1.67 & 18.33 & 21.83 & 16.13 & 14.86 \\
17 & 9 & 149 & 30 & 3.00 & 49.67 & 14.51 & 4.99 & 40.25 \\
18 & 9 & 50 & 12 & 7.50 & 41.67 & 43.16 & 15.65 & 33.76 \\
\hline
\end{tabular}


Sample number: DS10-13

Mineral: Apatite

Irradiation code: vuw007-28

Ns: 355

Ni: 795

Area: 428

RhoS: 8.294

RhoI: 18.58

Pooled Age: $\quad 84.3 \pm 5.7$

Mean Age: $\quad 87.5 \pm 8.1$

Central Age: $\quad 84.9 \pm 6.8$

Chi-sq.: $\quad 27.02$

$\mathrm{P}(\%) \quad 17.03$

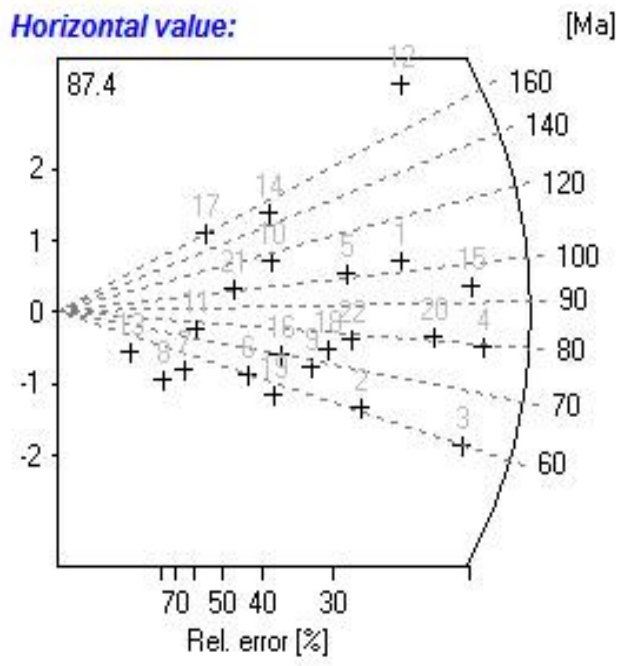

Dispersion: $\quad 0.17$

RhoD: 11.22

Nd: 19085

U standard CN_5

Zeta $\pm 1 \sigma \quad 339 \pm 6.5$

counted by RJ

\begin{tabular}{ccccccccc} 
Crystal & Ns & Ni & Area & RhoS(e5) & Rhol(e5) & Age(Ma) & $+-1 \mathrm{~s}$ & U(ppm) \\
\hline 1 & 27 & 49 & 12 & 22.50 & 40.83 & 103.91 & 24.99 & 41.87 \\
2 & 18 & 56 & 20 & 9.00 & 28.00 & 60.81 & 16.52 & 28.71 \\
3 & 32 & 101 & 12 & 26.67 & 84.17 & 59.95 & 12.22 & 86.31 \\
4 & 38 & 90 & 15 & 25.33 & 60.00 & 79.77 & 15.52 & 61.53 \\
5 & 19 & 35 & 30 & 6.33 & 11.67 & 102.38 & 29.25 & 11.96 \\
6 & 7 & 22 & 32 & 2.19 & 6.88 & 60.20 & 26.15 & 7.05 \\
7 & 3 & 11 & 20 & 1.50 & 5.50 & 51.64 & 33.65 & 5.64 \\
8 & 2 & 9 & 32 & 0.63 & 2.81 & 42.11 & 32.93 & 2.88 \\
9 & 13 & 36 & 15 & 8.67 & 24.00 & 68.28 & 22.14 & 24.61 \\
10 & 11 & 18 & 24 & 4.58 & 7.50 & 115.14 & 44.13 & 7.69 \\
11 & 4 & 10 & 9 & 4.44 & 11.11 & 75.59 & 44.75 & 11.39 \\
12 & 35 & 35 & 20 & 17.50 & 17.50 & 187.35 & 44.95 & 17.95 \\
13 & 1 & 4 & 15 & 0.67 & 2.67 & 47.35 & 52.95 & 2.74 \\
14 & 12 & 15 & 12 & 10.00 & 12.50 & 150.31 & 58.30 & 12.82 \\
15 & 38 & 76 & 15 & 25.33 & 50.67 & 94.35 & 18.85 & 51.96 \\
16 & 10 & 27 & 20 & 5.00 & 13.50 & 70.02 & 25.96 & 13.84 \\
17 & 6 & 7 & 20 & 3.00 & 3.50 & 160.91 & 89.59 & 3.59 \\
18 & 15 & 38 & 16 & 9.38 & 23.75 & 74.60 & 22.80 & 24.36 \\
19 & 9 & 30 & 20 & 4.50 & 15.00 & 56.78 & 21.61 & 15.38 \\
20 & 30 & 70 & 15 & 20.00 & 46.67 & 80.96 & 17.74 & 47.86 \\
21 & 7 & 13 & 24 & 2.92 & 5.42 & 101.56 & 47.66 & 5.56 \\
22 & 18 & 43 & 30 & 6.00 & 14.33 & 79.09 & 22.26 & 14.70 \\
\hline & & & & & & & &
\end{tabular}


Sample number: DS10-14

Mineral: Apatite

Irradiation code: vuw007-21

Ns: 192

Ni: 566

Area: 245

RhoS: $\quad 7.837$

RhoI: $\quad 23.1$

Pooled Age: $\quad 69.2 \pm 6.0$

Mean Age: $\quad 66.5 \pm 12.0$

Central Age: $\quad 61.7 \pm 11.2$

Chi-sq.: $\quad 68.97$

$\mathrm{P}(\%) \quad 0$

Dispersion: 0.66

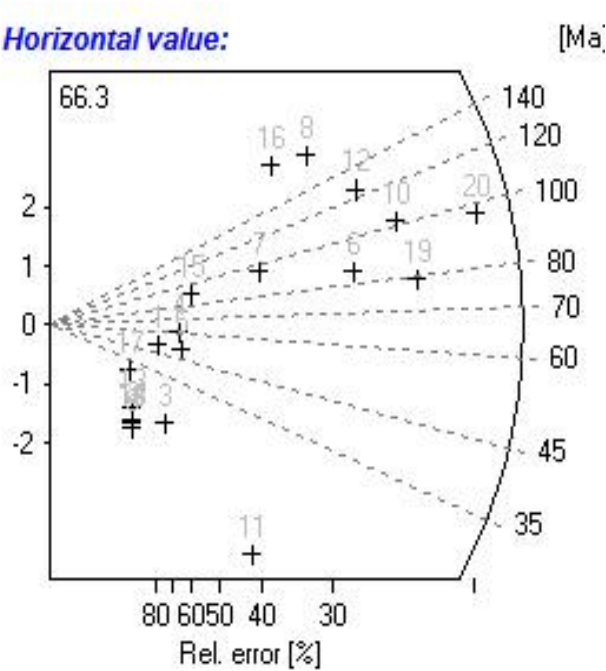

RhoD: 12.1

Nd: 19085

U standard CN_5

Zeta $\pm 1 \sigma \quad 339 \pm 6.5$

counted by RJ

\begin{tabular}{ccccccccc} 
Crystal & $\mathrm{Ns}$ & $\mathrm{Ni}$ & Area & RhoS(e5) & RhoI(e5) & Age(Ma) & $+-1 \mathrm{~s}$ & $\mathrm{U}(\mathrm{ppm})$ \\
\hline 1 & 2 & 8 & 9 & 2.22 & 8.89 & 51.09 & 40.40 & 8.45 \\
2 & 1 & 16 & 12 & 0.83 & 13.33 & 12.81 & 13.21 & 12.67 \\
3 & 2 & 21 & 28 & 0.71 & 7.50 & 19.51 & 14.44 & 7.13 \\
4 & 3 & 10 & 12 & 2.50 & 8.33 & 61.26 & 40.35 & 7.92 \\
5 & 3 & 12 & 10 & 3.00 & 12.00 & 51.09 & 33.00 & 11.40 \\
6 & 18 & 43 & 9 & 20.00 & 47.78 & 85.32 & 24.02 & 45.39 \\
7 & 9 & 19 & 9 & 10.00 & 21.11 & 96.46 & 39.08 & 20.06 \\
8 & 17 & 20 & 9 & 18.89 & 22.22 & 172.08 & 56.88 & 21.11 \\
9 & 1 & 18 & 15 & 0.67 & 12.00 & 11.39 & 11.70 & 11.40 \\
10 & 25 & 50 & 6 & 41.67 & 83.33 & 101.78 & 25.02 & 79.17 \\
11 & 6 & 94 & 9 & 6.67 & 104.44 & 13.08 & 5.52 & 99.23 \\
12 & 21 & 34 & 6 & 35.00 & 56.67 & 125.50 & 34.93 & 53.84 \\
13 & 1 & 13 & 12 & 0.83 & 10.83 & 15.76 & 16.36 & 10.29 \\
14 & 1 & 16 & 9 & 1.11 & 17.78 & 12.81 & 13.21 & 16.89 \\
15 & 4 & 9 & 15 & 2.67 & 6.00 & 90.55 & 54.45 & 5.70 \\
16 & 13 & 14 & 12 & 10.83 & 11.67 & 187.76 & 72.42 & 11.08 \\
17 & 1 & 7 & 12 & 0.83 & 5.83 & 29.24 & 31.27 & 5.54 \\
18 & 1 & 17 & 15 & 0.67 & 11.33 & 12.06 & 12.41 & 10.77 \\
19 & 26 & 67 & 12 & 21.67 & 55.83 & 79.13 & 18.36 & 53.05 \\
20 & 37 & 78 & 24 & 15.42 & 32.50 & 96.60 & 19.38 & 30.88 \\
\hline
\end{tabular}


Sample number: DS10-16

Mineral: Apatite

Irradiation code: vuw007-20

Ns: $\quad 140$

Ni: 866

Area: 477

RhoS: 2.935

RhoI: 18.16

Pooled Age: $\quad 33.3 \pm 3.1$

Mean Age: $\quad 34.0 \pm 1.9$

Central Age: $\quad 33.3 \pm 3.1$

Chi-sq.: $\quad 5.75$

$\mathrm{P}(\%) \quad 99.85$

Dispersion: $\quad 0.00$

RhoD: 12.19

Nd: 19085

U standard CN_5

Zeta $\pm 1 \sigma \quad 339 \pm 6.5$

counted by RJ

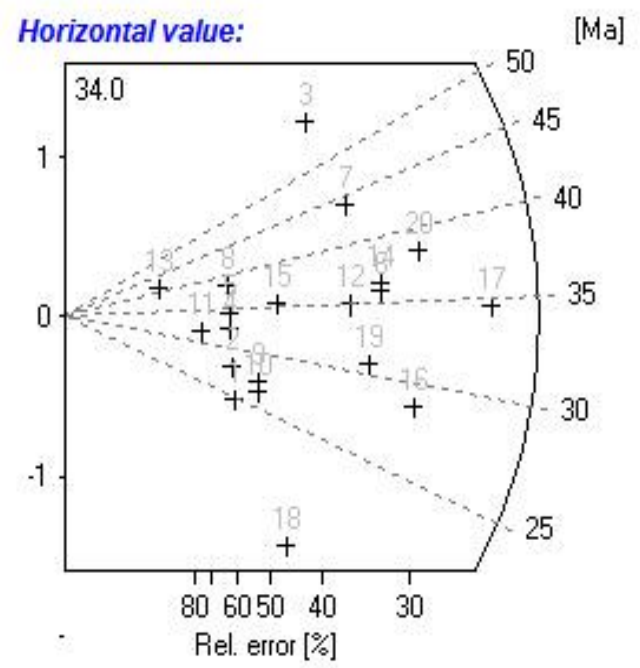

\begin{tabular}{ccccccccc} 
Crystal & Ns & Ni & Area & RhoS(e5) & RhoI(e5) & Age(Ma) & $+-1 \mathrm{~s}$ & $\mathrm{U}(\mathrm{ppm})$ \\
\hline 1 & 3 & 25 & 16 & 1.88 & 15.63 & 24.74 & 15.13 & 14.74 \\
2 & 3 & 22 & 9 & 3.33 & 24.44 & 28.11 & 17.31 & 23.07 \\
3 & 7 & 25 & 15 & 4.67 & 16.67 & 57.59 & 24.65 & 15.73 \\
4 & 3 & 19 & 18 & 1.67 & 10.56 & 32.54 & 20.23 & 9.96 \\
5 & 3 & 18 & 36 & 0.83 & 5.00 & 34.34 & 21.43 & 4.72 \\
6 & 11 & 63 & 36 & 3.06 & 17.50 & 35.97 & 11.78 & 16.51 \\
7 & 9 & 42 & 15 & 6.00 & 28.00 & 44.12 & 16.23 & 26.42 \\
8 & 3 & 16 & 25 & 1.20 & 6.40 & 38.62 & 24.31 & 6.04 \\
9 & 4 & 30 & 35 & 1.14 & 8.57 & 27.49 & 14.64 & 8.09 \\
10 & 4 & 31 & 12 & 3.33 & 25.83 & 26.60 & 14.14 & 24.38 \\
11 & 2 & 13 & 20 & 1.00 & 6.50 & 31.71 & 24.09 & 6.13 \\
12 & 9 & 53 & 35 & 2.57 & 15.14 & 34.99 & 12.63 & 14.29 \\
13 & 1 & 5 & 12 & 0.83 & 4.17 & 41.19 & 45.13 & 3.93 \\
14 & 11 & 62 & 24 & 4.58 & 25.83 & 36.55 & 11.98 & 24.38 \\
15 & 5 & 29 & 30 & 1.67 & 9.67 & 35.52 & 17.22 & 9.12 \\
16 & 13 & 93 & 20 & 6.50 & 46.50 & 28.81 & 8.55 & 43.88 \\
17 & 20 & 119 & 25 & 8.00 & 47.60 & 34.63 & 8.40 & 44.92 \\
18 & 5 & 59 & 36 & 1.39 & 16.39 & 17.48 & 8.15 & 15.46 \\
19 & 10 & 67 & 18 & 5.56 & 37.22 & 30.76 & 10.45 & 35.12 \\
20 & 14 & 75 & 40 & 3.50 & 18.75 & 38.45 & 11.22 & 17.69 \\
\hline
\end{tabular}


Sample number: DS10-18

Mineral: Apatite

Irradiation code: vuw007-19

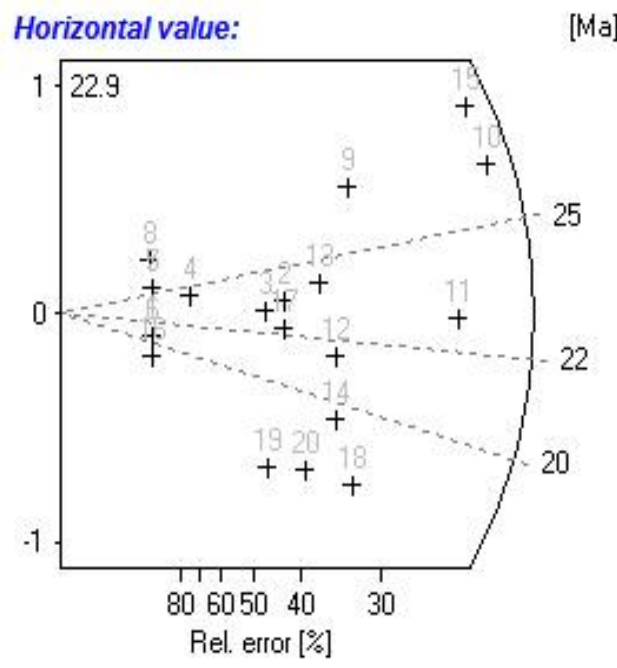

Chi-sq.: $\quad 3.48$

$\mathrm{P}(\%) \quad 100$

Dispersion: $\quad 0.00$

RhoD: 12.27

Nd: 19085

U standard CN_5

Zeta $\pm 1 \sigma \quad 339 \pm 6.5$

counted by RJ

\begin{tabular}{ccccccccc} 
Crystal & $\mathrm{Ns}$ & $\mathrm{Ni}$ & Area & RhoS(e5) & RhoI(e5) & Age(Ma) & $+-1 \mathrm{~s}$ & $\mathrm{U}(\mathrm{ppm})$ \\
\hline 1 & 1 & 10 & 30 & 0.33 & 3.33 & 20.77 & 21.78 & 3.12 \\
2 & 6 & 53 & 15 & 4.00 & 35.33 & 23.50 & 10.14 & 33.11 \\
3 & 5 & 45 & 12 & 4.17 & 37.50 & 23.07 & 10.89 & 35.14 \\
4 & 2 & 17 & 25 & 0.80 & 6.80 & 24.42 & 18.27 & 6.37 \\
5 & 1 & 8 & 16 & 0.63 & 5.00 & 25.95 & 27.53 & 4.69 \\
6 & 1 & 10 & 8 & 1.25 & 12.50 & 20.77 & 21.78 & 11.72 \\
7 & 1 & 8 & 6 & 1.67 & 13.33 & 25.95 & 27.53 & 12.50 \\
8 & 1 & 7 & 16 & 0.63 & 4.38 & 29.65 & 31.70 & 4.10 \\
9 & 10 & 75 & 35 & 2.86 & 21.43 & 27.67 & 9.33 & 20.08 \\
10 & 22 & 172 & 24 & 9.17 & 71.67 & 26.55 & 6.04 & 67.16 \\
11 & 19 & 173 & 25 & 7.60 & 69.20 & 22.80 & 5.53 & 64.85 \\
12 & 9 & 87 & 24 & 3.75 & 36.25 & 21.48 & 7.53 & 33.97 \\
13 & 8 & 69 & 30 & 2.67 & 23.00 & 24.07 & 9.00 & 21.56 \\
14 & 9 & 96 & 24 & 3.75 & 40.00 & 19.47 & 6.80 & 37.49 \\
15 & 20 & 146 & 25 & 8.00 & 58.40 & 28.43 & 6.80 & 54.73 \\
16 & 1 & 11 & 20 & 0.50 & 5.50 & 18.88 & 19.73 & 5.15 \\
17 & 6 & 56 & 6 & 10.00 & 93.33 & 22.25 & 9.57 & 87.47 \\
18 & 10 & 116 & 20 & 5.00 & 58.00 & 17.91 & 5.91 & 54.36 \\
19 & 5 & 62 & 18 & 2.78 & 34.44 & 16.75 & 7.80 & 32.28 \\
20 & 7 & 83 & 16 & 4.38 & 51.88 & 17.52 & 6.90 & 48.62 \\
\hline
\end{tabular}


Sample number: DS10-20

Mineral: Apatite

Irradiation code: vuw007-18

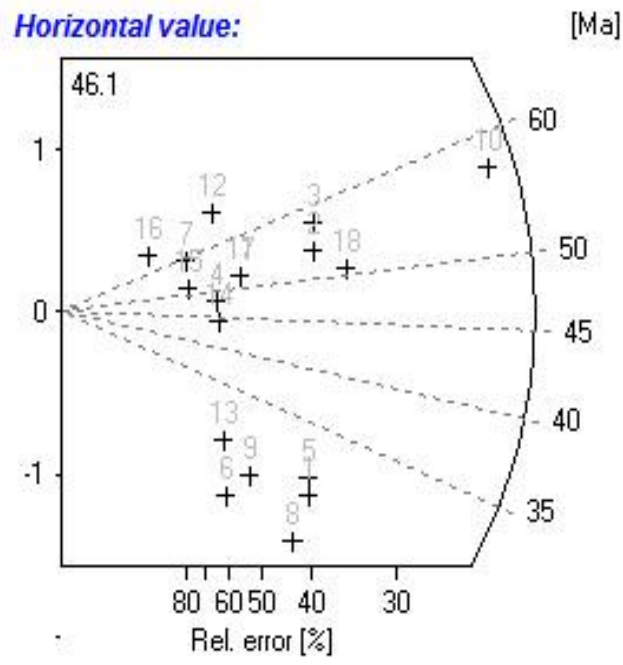

Chi-sq.: $\quad 9.43$

$\mathrm{P}(\%) \quad 92.57$

Dispersion: 0.01

RhoD: 12.36

Nd: 19085

U standard CN_5

Zeta $\pm 1 \sigma \quad 339 \pm 6.5$

counted by RJ

\begin{tabular}{ccccccccc} 
Crystal & Ns & Ni & Area & RhoS(e5) & RhoI(e5) & Age(Ma) & $+-1 \mathrm{~s}$ & U(ppm) \\
\hline 1 & 7 & 50 & 6 & 11.67 & 83.33 & 29.25 & 11.82 & 77.57 \\
2 & 8 & 31 & 6 & 13.33 & 51.67 & 53.82 & 21.37 & 48.09 \\
3 & 8 & 29 & 10 & 8.00 & 29.00 & 57.51 & 23.00 & 26.99 \\
4 & 3 & 13 & 9 & 3.33 & 14.44 & 48.15 & 30.85 & 13.45 \\
5 & 7 & 48 & 15 & 4.67 & 32.00 & 30.47 & 12.34 & 29.79 \\
6 & 3 & 27 & 9 & 3.33 & 30.00 & 23.23 & 14.14 & 27.93 \\
7 & 2 & 7 & 10 & 2.00 & 7.00 & 59.56 & 47.77 & 6.52 \\
8 & 6 & 50 & 12 & 5.00 & 41.67 & 25.08 & 10.85 & 38.79 \\
9 & 4 & 31 & 11 & 3.64 & 28.18 & 26.97 & 14.34 & 26.23 \\
10 & 23 & 84 & 15 & 15.33 & 56.00 & 57.09 & 13.49 & 52.13 \\
11 & 4 & 16 & 8 & 5.00 & 20.00 & 52.14 & 29.17 & 18.62 \\
12 & 3 & 9 & 9 & 3.33 & 10.00 & 69.43 & 46.31 & 9.31 \\
13 & 3 & 22 & 9 & 3.33 & 24.44 & 28.49 & 17.55 & 22.75 \\
14 & 3 & 14 & 4 & 7.50 & 35.00 & 44.72 & 28.47 & 32.58 \\
15 & 2 & 8 & 6 & 3.33 & 13.33 & 52.14 & 41.24 & 12.41 \\
16 & 1 & 3 & 4 & 2.50 & 7.50 & 69.43 & 80.18 & 6.98 \\
17 & 4 & 16 & 9 & 4.44 & 17.78 & 52.14 & 29.17 & 16.55 \\
18 & 10 & 41 & 9 & 11.11 & 45.56 & 50.88 & 17.97 & 42.41 \\
\hline
\end{tabular}


Sample number: DS11-03

Mineral: Apatite

Irradiation code: vuw007-14

Ns: 450

Ni: 1216

Area: 592

RhoS: 7.601

RhoI: 20.54

Pooled Age: $\quad 80.4 \pm 4.7$

Mean Age: $\quad 77.0 \pm 5.3$

Central Age: $\quad 78.0 \pm 6.3$

Chi-sq.: $\quad 29.76$

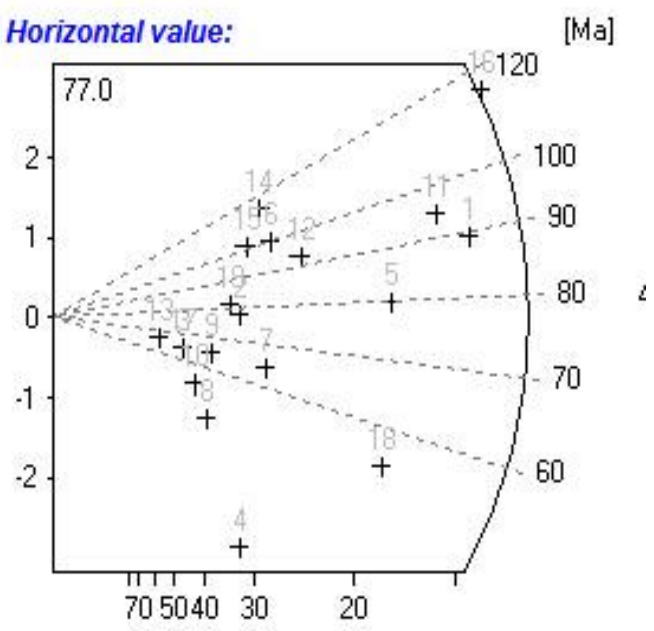

$\mathrm{P}(\%) \quad 3.98$

Dispersion: 0.21

RhoD: 12.89

Nd: 19085

U standard CN_5

Zeta $\pm 1 \sigma \quad 339 \pm 6.5$

counted by RJ

\begin{tabular}{ccccccccc} 
Crystal & Ns & Ni & Area & RhoS(e5) & RhoI(e5) & Age(Ma) & $+-1 \mathrm{~s}$ & $\mathrm{U}(\mathrm{ppm})$ \\
\hline 1 & 67 & 163 & 20 & 33.50 & 81.50 & 89.21 & 13.07 & 72.70 \\
2 & 13 & 36 & 24 & 5.42 & 15.00 & 78.44 & 25.43 & 13.38 \\
3 & 6 & 20 & 30 & 2.00 & 6.67 & 65.23 & 30.39 & 5.95 \\
4 & 11 & 78 & 50 & 2.20 & 15.60 & 30.75 & 9.92 & 13.92 \\
5 & 43 & 117 & 40 & 10.75 & 29.25 & 79.82 & 14.33 & 26.09 \\
6 & 19 & 41 & 35 & 5.43 & 11.71 & 100.49 & 27.96 & 10.45 \\
7 & 16 & 54 & 30 & 5.33 & 18.00 & 64.43 & 18.39 & 16.06 \\
8 & 8 & 37 & 30 & 2.67 & 12.33 & 47.08 & 18.38 & 11.00 \\
9 & 9 & 30 & 18 & 5.00 & 16.67 & 65.23 & 24.83 & 14.87 \\
10 & 7 & 28 & 16 & 4.38 & 17.50 & 54.40 & 23.02 & 15.61 \\
11 & 58 & 133 & 32 & 18.13 & 41.56 & 94.61 & 15.01 & 37.07 \\
12 & 24 & 56 & 32 & 7.50 & 17.50 & 92.99 & 22.77 & 15.61 \\
13 & 4 & 13 & 36 & 1.11 & 3.61 & 66.89 & 38.27 & 3.22 \\
14 & 18 & 34 & 20 & 9.00 & 17.00 & 114.67 & 33.51 & 15.16 \\
15 & 15 & 32 & 20 & 7.50 & 16.00 & 101.64 & 31.87 & 14.27 \\
16 & 77 & 145 & 42 & 18.33 & 34.52 & 115.02 & 16.39 & 30.80 \\
17 & 6 & 20 & 30 & 2.00 & 6.67 & 65.23 & 30.39 & 5.95 \\
18 & 37 & 147 & 72 & 5.14 & 20.42 & 54.77 & 10.14 & 18.21 \\
19 & 12 & 32 & 15 & 8.00 & 21.33 & 81.44 & 27.62 & 19.03 \\
\hline
\end{tabular}


Sample number: JR11-04

Mineral: Apatite

Irradiation code: vuw007-13

Ns: 314

Ni: 638

Area: 554

RhoS: 5.668

RhoI: 11.52

Pooled Age: $\quad 108.2 \pm 7.8$

Mean Age: $\quad 109.6 \pm 9.1$

Central Age: $\quad 108.1 \pm 8.0$

Chi-sq.: $\quad 17.82$

$\mathrm{P}(\%) \quad 59.96$

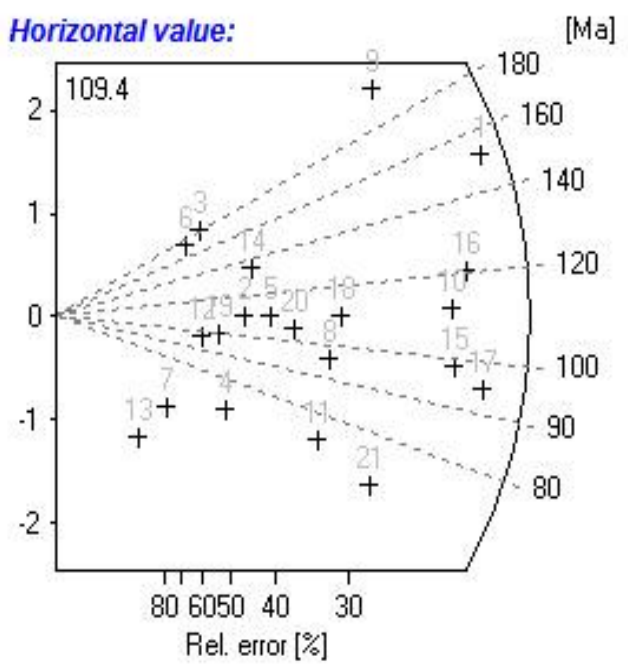

Dispersion: 0.06

$\begin{aligned} \text { RhoD: } & 13.08 \\ \text { Nd: } & 19085 \\ \text { U standard } & \text { CN_5 } \\ & \\ \text { Zeta } \pm 1 \sigma & 339 \pm 6.5 \\ \text { ounted by } & \text { RJ }\end{aligned}$

\begin{tabular}{ccccccccc} 
Crystal & Ns & Ni & Area & RhoS(e5) & RhoI(e5) & Age(Ma) & $+-1 \mathrm{~s}$ & U(ppm) \\
\hline 1 & 40 & 58 & 30 & 13.33 & 19.33 & 151.10 & 31.21 & 17.00 \\
2 & 7 & 14 & 36 & 1.94 & 3.89 & 109.90 & 50.92 & 3.42 \\
3 & 5 & 6 & 15 & 3.33 & 4.00 & 182.14 & 110.35 & 3.52 \\
4 & 5 & 16 & 15 & 3.33 & 10.67 & 68.91 & 35.33 & 9.38 \\
5 & 9 & 18 & 24 & 3.75 & 7.50 & 109.90 & 44.92 & 6.60 \\
6 & 4 & 5 & 18 & 2.22 & 2.78 & 174.95 & 117.42 & 2.44 \\
7 & 2 & 8 & 20 & 1.00 & 4.00 & 55.18 & 43.64 & 3.52 \\
8 & 14 & 32 & 25 & 5.60 & 12.80 & 96.27 & 30.91 & 11.26 \\
9 & 25 & 27 & 24 & 10.42 & 11.25 & 202.06 & 56.24 & 9.89 \\
10 & 31 & 61 & 28 & 11.07 & 21.79 & 111.69 & 24.74 & 19.16 \\
11 & 12 & 36 & 25 & 4.80 & 14.40 & 73.47 & 24.54 & 12.66 \\
12 & 4 & 9 & 12 & 3.33 & 7.50 & 97.78 & 58.79 & 6.60 \\
13 & 1 & 7 & 16 & 0.63 & 4.38 & 31.59 & 33.78 & 3.85 \\
14 & 8 & 13 & 35 & 2.29 & 3.71 & 135.00 & 60.73 & 3.27 \\
15 & 30 & 67 & 25 & 12.00 & 26.80 & 98.51 & 21.73 & 23.57 \\
16 & 34 & 62 & 36 & 9.44 & 17.22 & 120.44 & 25.82 & 15.14 \\
17 & 34 & 79 & 42 & 8.10 & 18.81 & 94.71 & 19.52 & 16.54 \\
18 & 16 & 32 & 20 & 8.00 & 16.00 & 109.90 & 33.73 & 14.07 \\
19 & 5 & 11 & 42 & 1.19 & 2.62 & 99.99 & 53.97 & 2.30 \\
20 & 11 & 23 & 12 & 9.17 & 19.17 & 105.16 & 38.61 & 16.85 \\
21 & 17 & 54 & 54 & 3.15 & 10.00 & 69.41 & 19.36 & 8.79 \\
\hline
\end{tabular}


Sample number: JR11-35

Mineral: Apatite

Irradiation code: vuw007-12

Ns: 183

Ni: 1966

Area: 616

RhoS: 2.971

RhoI: 31.92

Pooled Age: $\quad 20.9 \pm 1.7$

Mean Age: $23.8 \pm 2.4$

Central Age: $20.9 \pm 1.7$

Chi-sq.: $\quad 10.33$

$\mathrm{P}(\%) \quad 94.43$

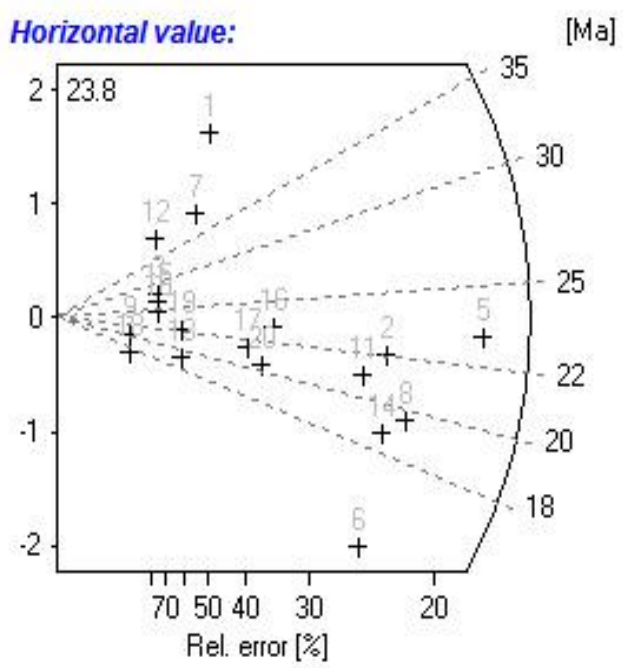

Dispersion: $\quad 0.00$

RhoD: 13.26

Nd: 19085

U standard CN_5

Zeta $\pm 1 \sigma \quad 339 \pm 6.5$

counted by RJ

\begin{tabular}{ccccccccc} 
Crystal & $\mathrm{Ns}$ & $\mathrm{Ni}$ & Area & RhoS(e5) & RhoI(e5) & Age(Ma) & $+-1 \mathrm{~s}$ & $\mathrm{U}(\mathrm{ppm})$ \\
\hline 1 & 5 & 21 & 25 & 2.00 & 8.40 & 53.31 & 26.55 & 7.28 \\
2 & 21 & 213 & 24 & 8.75 & 88.75 & 22.13 & 5.08 & 76.95 \\
3 & 2 & 16 & 30 & 0.67 & 5.33 & 28.04 & 21.04 & 4.62 \\
4 & 0 & 10 & 20 & 0.00 & 5.00 & 0.00 & 0.00 & 4.34 \\
5 & 35 & 340 & 30 & 11.67 & 113.33 & 23.10 & 4.13 & 98.26 \\
6 & 17 & 265 & 25 & 6.80 & 106.00 & 14.41 & 3.62 & 91.91 \\
7 & 4 & 23 & 36 & 1.11 & 6.39 & 38.98 & 21.13 & 5.54 \\
8 & 23 & 264 & 36 & 6.39 & 73.33 & 19.56 & 4.27 & 63.58 \\
9 & 1 & 11 & 35 & 0.29 & 3.14 & 20.41 & 21.32 & 2.73 \\
10 & 2 & 18 & 30 & 0.67 & 6.00 & 24.93 & 18.59 & 5.20 \\
11 & 18 & 192 & 36 & 5.00 & 53.33 & 21.04 & 5.21 & 46.24 \\
12 & 2 & 11 & 25 & 0.80 & 4.40 & 40.75 & 31.34 & 3.82 \\
13 & 3 & 35 & 42 & 0.71 & 8.33 & 19.24 & 11.58 & 7.23 \\
14 & 20 & 239 & 24 & 8.33 & 99.58 & 18.79 & 4.39 & 86.34 \\
15 & 2 & 17 & 42 & 0.48 & 4.05 & 26.40 & 19.74 & 3.51 \\
16 & 9 & 87 & 12 & 7.50 & 72.50 & 23.22 & 8.14 & 62.86 \\
17 & 7 & 73 & 30 & 2.33 & 24.33 & 21.52 & 8.53 & 21.10 \\
18 & 1 & 13 & 20 & 0.50 & 6.50 & 17.27 & 17.93 & 5.64 \\
19 & 3 & 30 & 70 & 0.43 & 4.29 & 22.44 & 13.60 & 3.72 \\
20 & 8 & 88 & 24 & 3.33 & 36.67 & 20.41 & 7.55 & 31.79 \\
\hline
\end{tabular}


Sample number: JR11-39

Mineral: Apatite

Irradiation code: vuw007-2

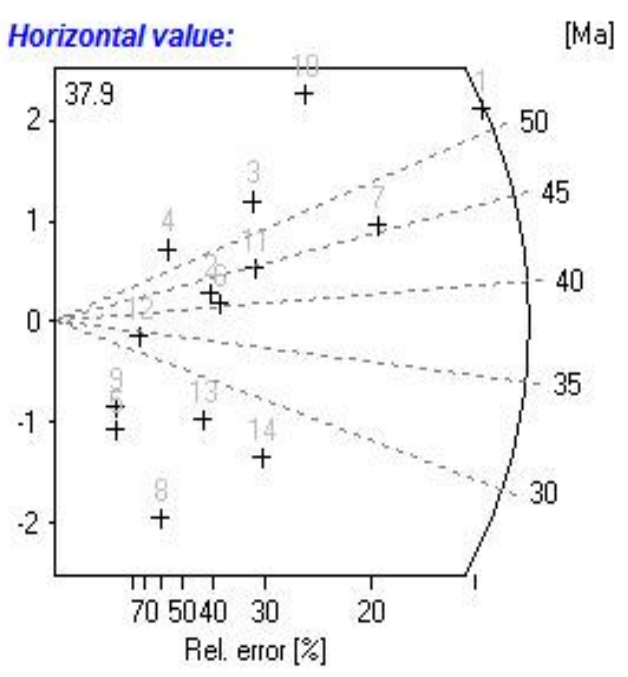

Pooled Age: $\quad 42.3 \pm 3.6$

Mean Age: $\quad 37.9 \pm 4.7$

Central Age: $\quad 40.4 \pm 4.6$

Chi-sq.: $\quad 19.01$

$\mathrm{P}(\%) \quad 12.29$

Dispersion: 0.23

RhoD: $\quad 15.12$

Nd: 19085

U standard CN_5

Zeta $\pm 1 \sigma \quad 339 \pm 6.5$

counted by RJ

\begin{tabular}{ccccccccc} 
Crystal & $\mathrm{Ns}$ & $\mathrm{Ni}$ & Area & RhoS(e5) & RhoI(e5) & Age(Ma) & $+-1 \mathrm{~s}$ & $\mathrm{U}(\mathrm{ppm})$ \\
\hline 1 & 55 & 270 & 20 & 27.50 & 135.00 & 52.00 & 7.77 & 102.68 \\
2 & 7 & 42 & 9 & 7.78 & 46.67 & 42.57 & 17.40 & 35.50 \\
3 & 12 & 55 & 18 & 6.67 & 30.56 & 55.68 & 17.78 & 23.24 \\
4 & 4 & 18 & 8 & 5.00 & 22.50 & 56.70 & 31.37 & 17.11 \\
5 & 1 & 20 & 16 & 0.63 & 12.50 & 12.80 & 13.12 & 9.51 \\
6 & 8 & 50 & 20 & 4.00 & 25.00 & 40.88 & 15.59 & 19.02 \\
7 & 31 & 173 & 21 & 14.76 & 82.38 & 45.76 & 8.97 & 62.66 \\
8 & 3 & 64 & 30 & 1.00 & 21.33 & 12.00 & 7.09 & 16.23 \\
9 & 1 & 16 & 9 & 1.11 & 17.78 & 16.00 & 16.49 & 13.52 \\
10 & 20 & 76 & 12 & 16.67 & 63.33 & 67.09 & 16.92 & 48.17 \\
11 & 12 & 68 & 15 & 8.00 & 45.33 & 45.07 & 14.14 & 34.48 \\
12 & 2 & 15 & 12 & 1.67 & 12.50 & 34.08 & 25.67 & 9.51 \\
13 & 6 & 61 & 20 & 3.00 & 30.50 & 25.16 & 10.78 & 23.20 \\
14 & 12 & 122 & 35 & 3.43 & 34.86 & 25.16 & 7.63 & 26.51 \\
\hline
\end{tabular}


Sample number: JR11-40a

Mineral: Apatite

Irradiation code: vuw007-9

Ns: 178

Ni: 574

Area: 352

RhoS: $\quad 5.057$

RhoI: 16.31

Pooled Age: $\quad 72.2 \pm 6.4$

Mean Age: $78.3 \pm 5.5$

Central Age: $\quad 72.2 \pm 6.4$

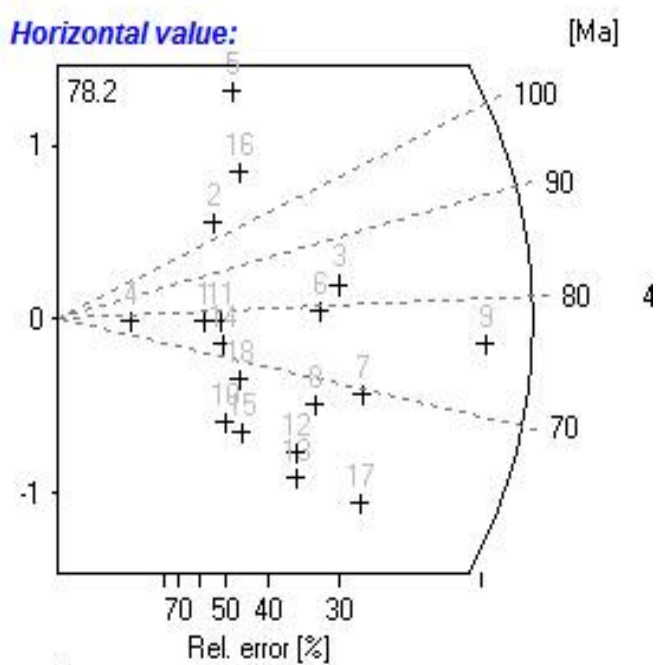

Chi-sq.: $\quad 6.2$

$\mathrm{P}(\%) \quad 99.17$

Dispersion: $\quad 0.00$

RhoD: 13.82

Nd: 19085

U standard CN_5

Zeta $\pm 1 \sigma \quad 339 \pm 6.5$

counted by RJ

\begin{tabular}{ccccccccc} 
Crystal & $\mathrm{Ns}$ & $\mathrm{Ni}$ & Area & RhoS(e5) & RhoI(e5) & Age(Ma) & $+-1 \mathrm{~s}$ & $\mathrm{U}(\mathrm{ppm})$ \\
\hline 1 & 4 & 12 & 15 & 2.67 & 8.00 & 77.62 & 44.84 & 6.66 \\
2 & 5 & 11 & 12 & 4.17 & 9.17 & 105.62 & 57.01 & 7.63 \\
3 & 15 & 42 & 6 & 25.00 & 70.00 & 83.13 & 25.06 & 58.25 \\
4 & 1 & 3 & 15 & 0.67 & 2.00 & 77.62 & 89.64 & 1.66 \\
5 & 7 & 11 & 6 & 11.67 & 18.33 & 147.38 & 71.32 & 15.26 \\
6 & 13 & 38 & 10 & 13.00 & 38.00 & 79.65 & 25.64 & 31.62 \\
7 & 17 & 57 & 9 & 18.89 & 63.33 & 69.49 & 19.26 & 52.70 \\
8 & 12 & 42 & 30 & 4.00 & 14.00 & 66.59 & 21.84 & 11.65 \\
9 & 34 & 104 & 30 & 11.33 & 34.67 & 76.14 & 15.12 & 28.85 \\
10 & 5 & 20 & 6 & 8.33 & 33.33 & 58.30 & 29.18 & 27.74 \\
11 & 5 & 15 & 4 & 12.50 & 37.50 & 77.62 & 40.11 & 31.20 \\
12 & 10 & 39 & 9 & 11.11 & 43.33 & 59.79 & 21.23 & 36.06 \\
13 & 10 & 41 & 20 & 5.00 & 20.50 & 56.89 & 20.10 & 17.06 \\
14 & 5 & 16 & 20 & 2.50 & 8.00 & 72.80 & 37.33 & 6.66 \\
15 & 6 & 24 & 16 & 3.75 & 15.00 & 58.30 & 26.64 & 12.48 \\
16 & 7 & 14 & 32 & 2.19 & 4.38 & 116.08 & 53.79 & 3.64 \\
17 & 16 & 64 & 100 & 1.60 & 6.40 & 58.30 & 16.34 & 5.33 \\
18 & 6 & 21 & 12 & 5.00 & 17.50 & 66.59 & 30.85 & 14.56 \\
\hline
\end{tabular}


Sample number: JR11-40b

Mineral: Apatite

Irradiation code: vuw007-10

Ns: 232

Ni: 1973

Area: 1006

RhoS: 2.306

RhoI: 19.61

Pooled Age: $\quad 27.1 \pm 2.0$

Mean Age: $\quad 31.3 \pm 2.4$

Central Age: $27.2 \pm 2.0$

Chi-sq.: $\quad 18.9$

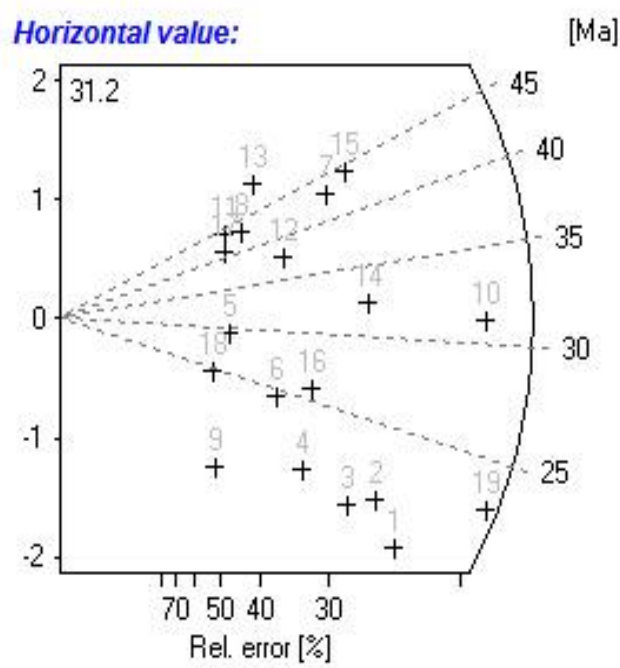

$\mathrm{P}(\%) \quad 39.82$

Dispersion: 0.06

RhoD: $\quad 13.64$

Nd: 19085

U standard CN_5

Zeta $\pm 1 \sigma \quad 339 \pm 6.5$

counted by RJ

\begin{tabular}{ccccccccc} 
Crystal & $\mathrm{Ns}$ & $\mathrm{Ni}$ & Area & RhoS(e5) & RhoI(e5) & Age(Ma) & $+-1 \mathrm{~s}$ & $\mathrm{U}(\mathrm{ppm})$ \\
\hline 1 & 19 & 222 & 100 & 1.90 & 22.20 & 19.75 & 4.74 & 18.72 \\
2 & 17 & 185 & 50 & 3.40 & 37.00 & 21.20 & 5.39 & 31.21 \\
3 & 14 & 160 & 25 & 5.60 & 64.00 & 20.19 & 5.64 & 53.98 \\
4 & 10 & 112 & 35 & 2.86 & 32.00 & 20.60 & 6.81 & 26.99 \\
5 & 5 & 39 & 80 & 0.63 & 4.88 & 29.56 & 14.06 & 4.11 \\
6 & 8 & 75 & 64 & 1.25 & 11.72 & 24.61 & 9.17 & 9.88 \\
7 & 13 & 70 & 49 & 2.65 & 14.29 & 42.78 & 12.95 & 12.05 \\
8 & 6 & 32 & 20 & 3.00 & 16.00 & 43.19 & 19.23 & 13.50 \\
9 & 4 & 56 & 18 & 2.22 & 31.11 & 16.49 & 8.54 & 26.24 \\
10 & 32 & 237 & 60 & 5.33 & 39.50 & 31.13 & 5.90 & 33.32 \\
11 & 5 & 26 & 56 & 0.89 & 4.64 & 44.29 & 21.65 & 3.92 \\
12 & 9 & 55 & 49 & 1.84 & 11.22 & 37.71 & 13.58 & 9.47 \\
13 & 7 & 32 & 48 & 1.46 & 6.67 & 50.36 & 21.04 & 5.62 \\
14 & 17 & 121 & 64 & 2.66 & 18.91 & 32.39 & 8.42 & 15.95 \\
15 & 15 & 78 & 100 & 1.50 & 7.80 & 44.29 & 12.52 & 6.58 \\
16 & 11 & 98 & 36 & 3.06 & 27.22 & 25.89 & 8.25 & 22.96 \\
17 & 5 & 28 & 60 & 0.83 & 4.67 & 41.14 & 19.99 & 3.94 \\
18 & 4 & 37 & 12 & 3.33 & 30.83 & 24.94 & 13.14 & 26.01 \\
19 & 31 & 310 & 80 & 3.88 & 38.75 & 23.07 & 4.37 & 32.68 \\
\hline
\end{tabular}


Sample number: JR11-40c

Mineral: Apatite

Irradiation code: vuw007-11

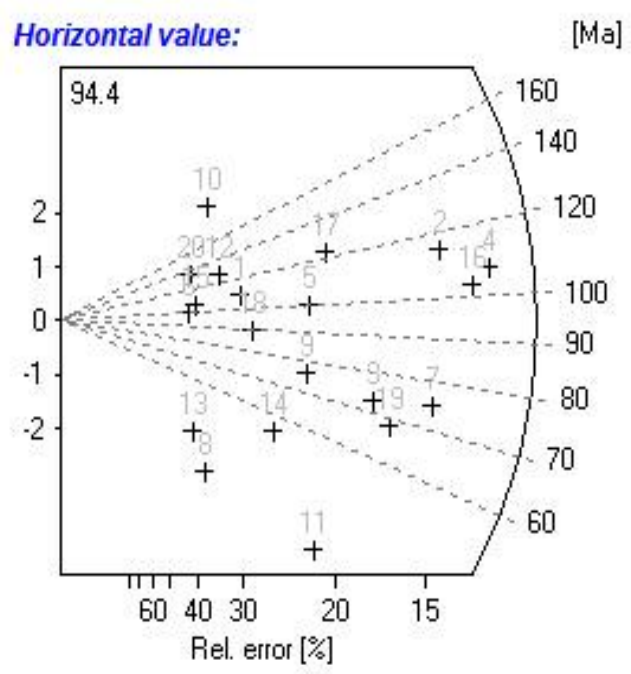

Chi-sq.: $\quad 55.41$

$\mathrm{P}(\%) \quad 0$

Dispersion: 0.29

RhoD: 13.45

Nd: 19085

U standard CN_5

Zeta $\pm 1 \sigma \quad 339 \pm 6.5$

counted by RJ

\begin{tabular}{ccccccccc} 
Crystal & Ns & Ni & Area & RhoS(e5) & RhoI(e5) & Age(Ma) & $+-1 \mathrm{~s}$ & U(ppm) \\
\hline 1 & 16 & 33 & 60 & 2.67 & 5.50 & 109.60 & 33.46 & 4.70 \\
2 & 72 & 142 & 100 & 7.20 & 14.20 & 114.57 & 16.74 & 12.14 \\
3 & 43 & 134 & 36 & 11.94 & 37.22 & 72.74 & 12.84 & 31.83 \\
4 & 90 & 190 & 36 & 25.00 & 52.78 & 107.09 & 13.88 & 45.13 \\
5 & 30 & 67 & 100 & 3.00 & 6.70 & 101.28 & 22.35 & 5.73 \\
6 & 8 & 18 & 100 & 0.80 & 1.80 & 100.54 & 42.77 & 1.54 \\
7 & 61 & 185 & 49 & 12.45 & 37.76 & 74.74 & 11.14 & 32.28 \\
8 & 8 & 55 & 70 & 1.14 & 7.86 & 33.08 & 12.53 & 6.72 \\
9 & 27 & 80 & 100 & 2.70 & 8.00 & 76.49 & 17.10 & 6.84 \\
10 & 14 & 15 & 30 & 4.67 & 5.00 & 209.34 & 77.91 & 4.28 \\
11 & 25 & 150 & 100 & 2.50 & 15.00 & 37.88 & 8.22 & 12.83 \\
12 & 13 & 23 & 9 & 14.44 & 25.56 & 127.59 & 44.35 & 21.85 \\
13 & 7 & 39 & 60 & 1.17 & 6.50 & 40.79 & 16.76 & 5.56 \\
14 & 19 & 77 & 64 & 2.97 & 12.03 & 56.01 & 14.39 & 10.29 \\
15 & 9 & 19 & 48 & 1.88 & 3.96 & 107.09 & 43.39 & 3.39 \\
16 & 82 & 180 & 100 & 8.20 & 18.00 & 103.03 & 13.89 & 15.39 \\
17 & 36 & 66 & 80 & 4.50 & 8.25 & 123.17 & 25.64 & 7.05 \\
18 & 17 & 43 & 18 & 9.44 & 23.89 & 89.51 & 25.71 & 20.43 \\
19 & 47 & 156 & 64 & 7.34 & 24.38 & 68.32 & 11.45 & 20.84 \\
20 & 9 & 15 & 9 & 10.00 & 16.67 & 135.36 & 57.14 & 14.25 \\
\hline
\end{tabular}


Sample number: JR11-42

Mineral: Apatite

Irradiation code: vuw007-3

Ns: 117

Ni: 227

Area: 310

RhoS: 3.774

RhoI: $\quad 7.323$

Pooled Age: $\quad 129.2 \pm 14.9$

Mean Age: $131.1 \pm 7.4$

Central Age: $\quad 129.2 \pm 14.9$

Chi-sq.: $\quad 4.22$

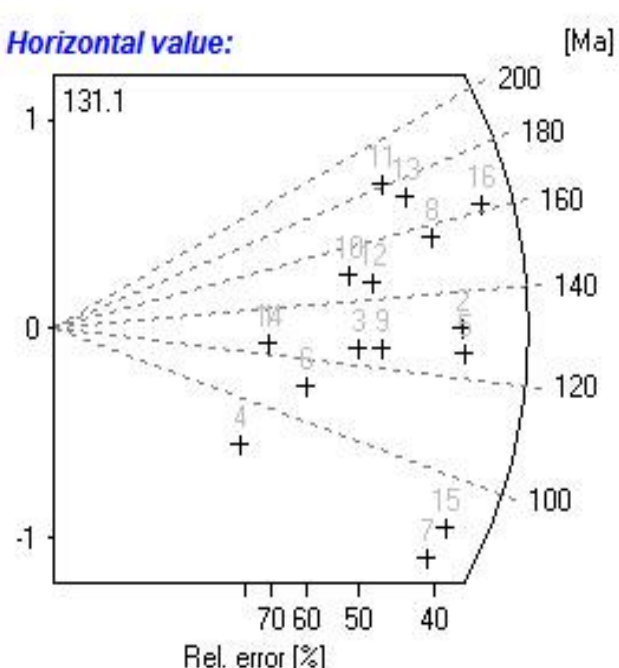

$\mathrm{P}(\%) \quad 99.69$

Dispersion: 0.00

RhoD: 14.93

Nd: 19085

U standard CN_5

Zeta $\pm 1 \sigma \quad 339 \pm 6.5$

counted by RJ

\begin{tabular}{ccccccccc} 
Crystal & Ns & Ni & Area & RhoS(e5) & Rhol(e5) & Age(Ma) & $+-1 \mathrm{~s}$ & U(ppm) \\
\hline 1 & 3 & 6 & 25 & 1.20 & 2.40 & 125.35 & 88.67 & 1.85 \\
2 & 11 & 21 & 9 & 12.22 & 23.33 & 131.25 & 48.93 & 17.97 \\
3 & 6 & 12 & 9 & 6.67 & 13.33 & 125.35 & 62.73 & 10.27 \\
4 & 2 & 6 & 12 & 1.67 & 5.00 & 83.83 & 68.47 & 3.85 \\
5 & 11 & 22 & 24 & 4.58 & 9.17 & 125.35 & 46.36 & 7.06 \\
6 & 4 & 9 & 8 & 5.00 & 11.25 & 111.54 & 67.07 & 8.66 \\
7 & 8 & 24 & 24 & 3.33 & 10.00 & 83.83 & 34.27 & 7.70 \\
8 & 10 & 16 & 54 & 1.85 & 2.96 & 156.31 & 63.09 & 2.28 \\
9 & 7 & 14 & 16 & 4.38 & 8.75 & 125.35 & 58.08 & 6.74 \\
10 & 6 & 10 & 15 & 4.00 & 6.67 & 150.13 & 77.59 & 5.13 \\
11 & 8 & 11 & 42 & 1.91 & 2.62 & 181.53 & 84.43 & 2.02 \\
12 & 7 & 12 & 12 & 5.83 & 10.00 & 146.00 & 69.50 & 7.70 \\
13 & 9 & 13 & 8 & 11.25 & 16.25 & 172.91 & 75.06 & 12.51 \\
14 & 3 & 6 & 16 & 1.88 & 3.75 & 125.35 & 88.67 & 2.89 \\
15 & 9 & 25 & 18 & 5.00 & 13.89 & 90.49 & 35.23 & 10.70 \\
16 & 13 & 20 & 18 & 7.22 & 11.11 & 162.48 & 57.98 & 8.56 \\
\hline
\end{tabular}


Sample number: JR11-44

Mineral: Apatite

Irradiation code: vuw007-4

Ns: 156

Ni: 475

Area: 432

RhoS: 3.611

RhoI: 11

Pooled Age: $\quad 81.6 \pm 7.7$

Mean Age: $\quad 86.7 \pm 5.5$

Central Age: $\quad 81.6 \pm 7.7$

Chi-sq.: $\quad 5.66$

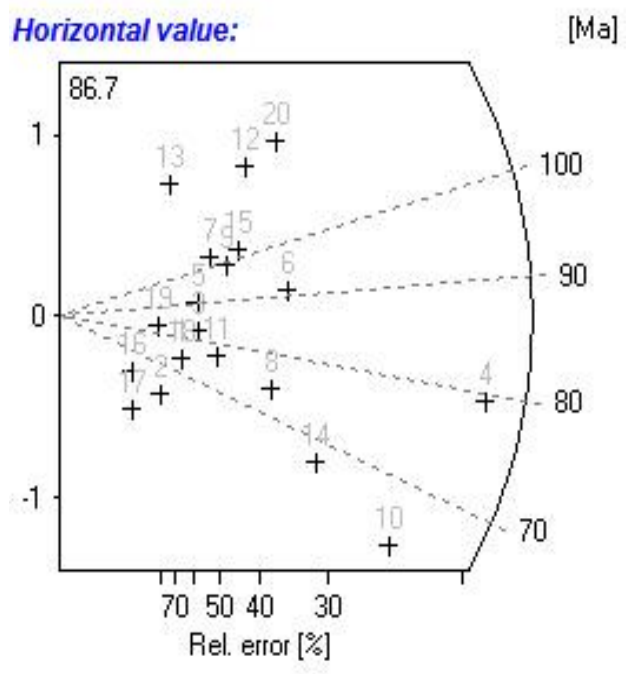

$\mathrm{P}(\%) \quad 99.86$

Dispersion: $\quad 0.00$

RhoD: 14.75

Nd: 19085

U standard CN_5

Zeta $\pm 1 \sigma \quad 339 \pm 6.5$

counted by RJ

\begin{tabular}{ccccccccc} 
Crystal & $\mathrm{Ns}$ & $\mathrm{Ni}$ & Area & RhoS(e5) & RhoI(e5) & Age(Ma) & $+-1 \mathrm{~s}$ & $\mathrm{U}(\mathrm{ppm})$ \\
\hline 1 & 3 & 10 & 20 & 1.50 & 5.00 & 74.57 & 49.11 & 3.90 \\
2 & 2 & 8 & 20 & 1.00 & 4.00 & 62.20 & 49.19 & 3.12 \\
3 & 4 & 12 & 28 & 1.43 & 4.29 & 82.80 & 47.83 & 3.34 \\
4 & 37 & 116 & 35 & 10.57 & 33.14 & 79.25 & 15.05 & 25.84 \\
5 & 4 & 11 & 9 & 4.44 & 12.22 & 90.27 & 52.74 & 9.53 \\
6 & 11 & 30 & 25 & 4.40 & 12.00 & 91.02 & 32.14 & 9.36 \\
7 & 5 & 12 & 20 & 2.50 & 6.00 & 103.33 & 55.04 & 4.68 \\
8 & 9 & 30 & 28 & 3.21 & 10.71 & 74.57 & 28.38 & 8.35 \\
9 & 6 & 15 & 12 & 5.00 & 12.50 & 99.23 & 47.98 & 9.75 \\
10 & 21 & 82 & 24 & 8.75 & 34.17 & 63.71 & 15.64 & 26.64 \\
11 & 5 & 16 & 8 & 6.25 & 20.00 & 77.66 & 39.82 & 15.60 \\
12 & 8 & 16 & 15 & 5.33 & 10.67 & 123.80 & 53.67 & 8.32 \\
13 & 3 & 5 & 15 & 2.00 & 3.33 & 148.28 & 108.33 & 2.60 \\
14 & 13 & 48 & 30 & 4.33 & 16.00 & 67.35 & 21.10 & 12.48 \\
15 & 7 & 17 & 28 & 2.50 & 6.07 & 102.13 & 45.91 & 4.73 \\
16 & 1 & 4 & 35 & 0.29 & 1.14 & 62.20 & 69.55 & 0.89 \\
17 & 1 & 5 & 25 & 0.40 & 2.00 & 49.81 & 54.57 & 1.56 \\
18 & 3 & 10 & 14 & 2.14 & 7.14 & 74.57 & 49.11 & 5.57 \\
19 & 2 & 6 & 9 & 2.22 & 6.67 & 82.80 & 67.63 & 5.20 \\
20 & 11 & 22 & 32 & 3.44 & 6.88 & 123.80 & 45.79 & 5.36 \\
\hline
\end{tabular}


Sample number: JR11-45

Mineral: Apatite

Irradiation code: vuw007-6

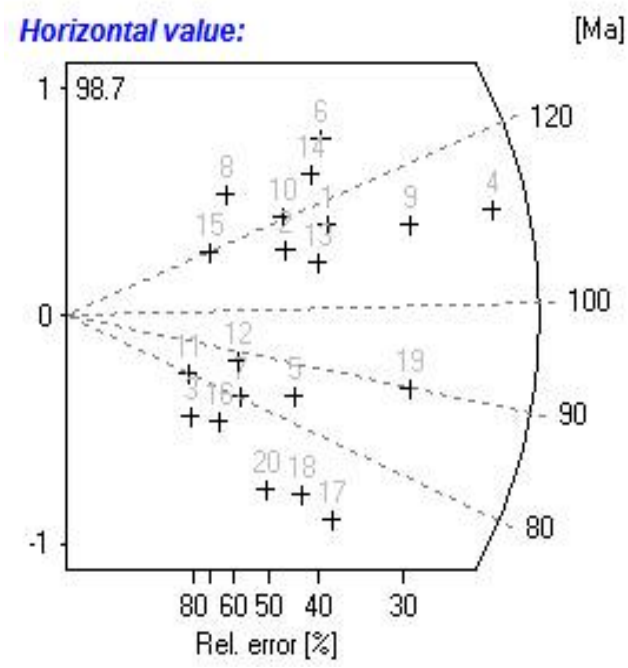

Chi-sq.: $\quad 5.16$

$\mathrm{P}(\%) \quad 99.93$

Dispersion: 0.00

RhoD: 14.38

Nd: 19085

U standard CN_5

Zeta $\pm 1 \sigma \quad 339 \pm 6.5$

counted by RJ

\begin{tabular}{ccccccccc} 
Crystal & Ns & Ni & Area & RhoS(e5) & Rhol(e5) & Age(Ma) & $+-1 \mathrm{~s}$ & U(ppm) \\
\hline 1 & 10 & 21 & 18 & 5.56 & 11.67 & 115.02 & 44.25 & 9.33 \\
2 & 7 & 15 & 9 & 7.78 & 16.67 & 112.74 & 51.66 & 13.33 \\
3 & 2 & 7 & 70 & 0.29 & 1.00 & 69.26 & 55.55 & 0.80 \\
4 & 26 & 57 & 48 & 5.42 & 11.88 & 110.22 & 26.18 & 9.50 \\
5 & 7 & 20 & 25 & 2.80 & 8.00 & 84.74 & 37.25 & 6.40 \\
6 & 10 & 18 & 12 & 8.33 & 15.00 & 133.99 & 52.92 & 12.00 \\
7 & 4 & 12 & 32 & 1.25 & 3.75 & 80.73 & 46.64 & 3.00 \\
8 & 4 & 7 & 36 & 1.11 & 1.94 & 137.78 & 86.40 & 1.56 \\
9 & 17 & 37 & 42 & 4.05 & 8.81 & 111.01 & 32.61 & 7.05 \\
10 & 7 & 14 & 35 & 2.00 & 4.00 & 120.72 & 55.94 & 3.20 \\
11 & 2 & 6 & 9 & 2.22 & 6.67 & 80.73 & 65.93 & 5.33 \\
12 & 4 & 11 & 24 & 1.67 & 4.58 & 88.02 & 51.42 & 3.67 \\
13 & 9 & 20 & 70 & 1.29 & 2.86 & 108.75 & 43.71 & 2.29 \\
14 & 9 & 17 & 35 & 2.57 & 4.86 & 127.75 & 52.73 & 3.89 \\
15 & 3 & 6 & 20 & 1.50 & 3.00 & 120.72 & 85.40 & 2.40 \\
16 & 3 & 10 & 12 & 2.50 & 8.33 & 72.70 & 47.88 & 6.67 \\
17 & 9 & 31 & 20 & 4.50 & 15.50 & 70.37 & 26.68 & 12.40 \\
18 & 7 & 24 & 20 & 3.50 & 12.00 & 70.69 & 30.40 & 9.60 \\
19 & 16 & 43 & 20 & 8.00 & 21.50 & 90.05 & 26.43 & 17.20 \\
20 & 5 & 18 & 49 & 1.02 & 3.67 & 67.34 & 34.07 & 2.94 \\
\hline
\end{tabular}


Sample number: JR11-46

Mineral: Apatite

Irradiation code: vuw007-7

Ns: 63

Ni: 166

Area: 174

RhoS: $\quad 3.621$

RhoI: 9.54

Pooled Age: $\quad 90.7 \pm 13.5$

Mean Age: $\quad 94.0 \pm 11.5$

Central Age: $90.7 \pm 13.5$

Chi-sq.: $\quad 4.82$

$\mathrm{P}(\%) \quad 85$

Dispersion: $\quad 0.00$

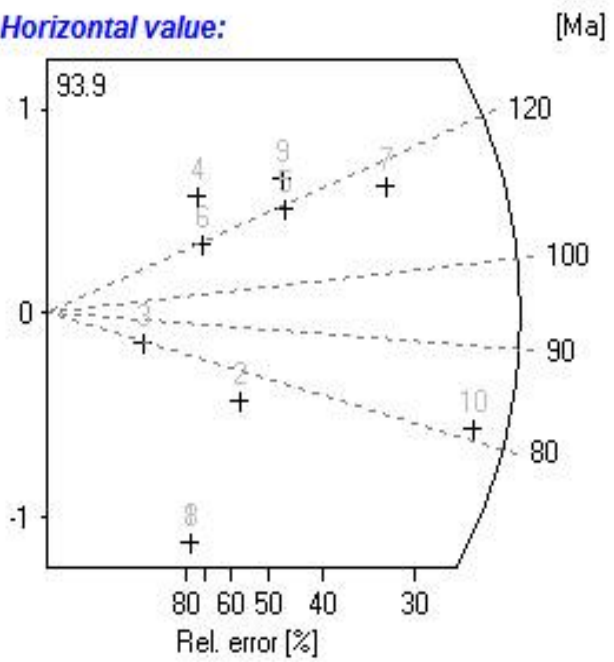

RhoD: 14.19

Nd: 19085

U standard CN_5

Zeta $\pm 1 \sigma \quad 339 \pm 6.5$

counted by RJ

\begin{tabular}{ccccccccc} 
Crystal & $\mathrm{Ns}$ & $\mathrm{Ni}$ & Area & RhoS(e5) & RhoI(e5) & Age(Ma) & $+-1 \mathrm{~s}$ & $\mathrm{U}(\mathrm{ppm})$ \\
\hline 1 & 2 & 12 & 15 & 1.33 & 8.00 & 39.97 & 30.54 & 6.48 \\
2 & 4 & 13 & 16 & 2.50 & 8.13 & 73.60 & 42.11 & 6.58 \\
3 & 1 & 3 & 20 & 0.50 & 1.50 & 79.69 & 92.04 & 1.22 \\
4 & 3 & 5 & 20 & 1.50 & 2.50 & 142.74 & 104.29 & 2.03 \\
5 & 7 & 14 & 20 & 3.50 & 7.00 & 119.17 & 55.22 & 5.67 \\
6 & 3 & 6 & 18 & 1.67 & 3.33 & 119.17 & 84.30 & 2.70 \\
7 & 14 & 29 & 20 & 7.00 & 14.50 & 115.10 & 37.53 & 11.75 \\
8 & 2 & 12 & 16 & 1.25 & 7.50 & 39.97 & 30.54 & 6.08 \\
9 & 7 & 13 & 9 & 7.78 & 14.44 & 128.25 & 60.18 & 11.71 \\
10 & 20 & 59 & 20 & 10.00 & 29.50 & 81.03 & 21.03 & 23.91 \\
\hline
\end{tabular}


Sample number: $\quad$ r785

Mineral: Apatite

Irradiation code: vuw007-29

Ns: 294

Ni: 607

Area: 285

RhoS: $\quad 10.32$

RhoI: 21.3

Pooled Age: $\quad 90.3 \pm 6.7$

Mean Age: $\quad 87.4 \pm 4.9$

Central Age: $\quad 90.3 \pm 6.7$

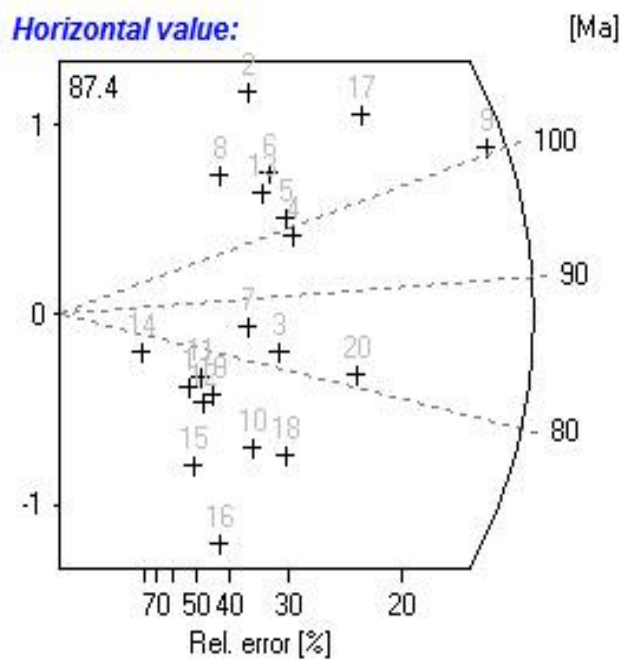

Chi-sq.: $\quad 9.01$

$\mathrm{P}(\%) \quad 97.33$

Dispersion: $\quad 0.00$

RhoD: 11.07

Nd: 19085

U standard CN_5

Zeta $\pm 1 \sigma \quad 339 \pm 6.5$

counted by RJ

\begin{tabular}{ccccccccc} 
Crystal & $\mathrm{Ns}$ & $\mathrm{Ni}$ & Area & RhoS(e5) & RhoI(e5) & Age(Ma) & $+-1 \mathrm{~s}$ & $\mathrm{U}(\mathrm{ppm})$ \\
\hline 1 & 5 & 13 & 15 & 3.33 & 8.67 & 71.77 & 37.80 & 9.00 \\
2 & 13 & 18 & 12 & 10.83 & 15.00 & 134.12 & 48.89 & 15.58 \\
3 & 15 & 34 & 10 & 15.00 & 34.00 & 82.26 & 25.55 & 35.32 \\
4 & 18 & 34 & 12 & 15.00 & 28.33 & 98.58 & 28.81 & 29.43 \\
5 & 17 & 31 & 16 & 10.63 & 19.38 & 102.09 & 30.88 & 20.13 \\
6 & 15 & 25 & 15 & 10.00 & 16.67 & 111.62 & 36.53 & 17.31 \\
7 & 11 & 24 & 20 & 5.50 & 12.00 & 85.44 & 31.16 & 12.47 \\
8 & 9 & 14 & 6 & 15.00 & 23.33 & 119.51 & 51.12 & 24.24 \\
9 & 60 & 111 & 21 & 28.57 & 52.86 & 100.64 & 16.26 & 54.91 \\
10 & 11 & 30 & 16 & 6.88 & 18.75 & 68.44 & 24.16 & 19.48 \\
11 & 6 & 15 & 16 & 3.75 & 9.38 & 74.62 & 36.08 & 9.74 \\
12 & 6 & 16 & 12 & 5.00 & 13.33 & 69.99 & 33.53 & 13.85 \\
13 & 14 & 24 & 6 & 23.33 & 40.00 & 108.54 & 36.57 & 41.55 \\
14 & 2 & 5 & 12 & 1.67 & 4.17 & 74.62 & 62.45 & 4.33 \\
15 & 5 & 16 & 30 & 1.67 & 5.33 & 58.37 & 29.93 & 5.54 \\
16 & 7 & 25 & 24 & 2.92 & 10.42 & 52.33 & 22.40 & 10.82 \\
17 & 31 & 52 & 12 & 25.83 & 43.33 & 110.91 & 25.27 & 45.02 \\
18 & 15 & 40 & 8 & 18.75 & 50.00 & 69.99 & 21.24 & 51.94 \\
19 & 7 & 18 & 6 & 11.67 & 30.00 & 72.56 & 32.36 & 31.17 \\
20 & 27 & 62 & 16 & 16.88 & 38.75 & 81.20 & 18.80 & 40.26 \\
\hline
\end{tabular}


Sample number: DS10-15

Mineral: Apatite

Irradiation code: vuw011-19

Ns: 446

Ni: 1310

Area: 634

RhoS: 7.035

RhoI: 20.66

Pooled Age: $\quad 63.1 \pm 3.7$

Mean Age: $\quad 64.0 \pm 3.1$

Central Age: $\quad 63.1 \pm 3.8$

Chi-sq.: $\quad 12.94$

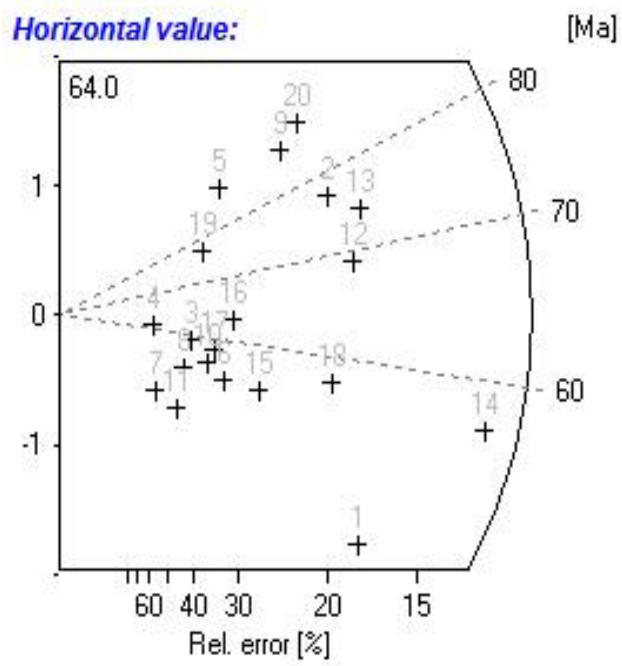

$\mathrm{P}(\%) \quad 84.15$

Dispersion: $\quad 0.02$

RhoD: 10.99

Nd: 8043

U standard CN_5

Zeta $\pm 1 \sigma \quad 339 \pm 6.5$

counted by RJ

\begin{tabular}{ccccccccc} 
Crystal & $\mathrm{Ns}$ & $\mathrm{Ni}$ & Area & RhoS(e5) & RhoI(e5) & Age(Ma) & $+-1 \mathrm{~s}$ & $\mathrm{U}(\mathrm{ppm})$ \\
\hline 1 & 39 & 155 & 55 & 7.09 & 28.18 & 46.70 & 8.43 & 29.49 \\
2 & 35 & 84 & 15 & 23.33 & 56.00 & 77.15 & 15.62 & 58.61 \\
3 & 8 & 25 & 20 & 4.00 & 12.50 & 59.33 & 24.14 & 13.08 \\
4 & 4 & 12 & 20 & 2.00 & 6.00 & 61.79 & 35.70 & 6.28 \\
5 & 13 & 27 & 24 & 5.42 & 11.25 & 89.07 & 30.13 & 11.77 \\
6 & 12 & 41 & 30 & 4.00 & 13.67 & 54.29 & 17.86 & 14.30 \\
7 & 4 & 16 & 42 & 0.95 & 3.81 & 46.40 & 25.96 & 3.99 \\
8 & 7 & 24 & 24 & 2.92 & 10.00 & 54.10 & 23.27 & 10.47 \\
9 & 25 & 53 & 25 & 10.00 & 21.20 & 87.27 & 21.26 & 22.19 \\
10 & 10 & 33 & 35 & 2.86 & 9.43 & 56.20 & 20.32 & 9.87 \\
11 & 6 & 24 & 36 & 1.67 & 6.67 & 46.40 & 21.20 & 6.98 \\
12 & 41 & 110 & 42 & 9.76 & 26.19 & 69.06 & 12.73 & 27.41 \\
13 & 44 & 110 & 30 & 14.67 & 36.67 & 74.08 & 13.32 & 38.37 \\
14 & 82 & 266 & 42 & 19.52 & 63.33 & 57.17 & 7.33 & 66.28 \\
15 & 18 & 61 & 40 & 4.50 & 15.25 & 54.73 & 14.73 & 15.96 \\
16 & 14 & 41 & 28 & 5.00 & 14.64 & 63.29 & 19.64 & 15.32 \\
17 & 11 & 35 & 25 & 4.40 & 14.00 & 58.28 & 20.19 & 14.65 \\
18 & 34 & 109 & 49 & 6.94 & 22.25 & 57.84 & 11.43 & 23.28 \\
19 & 10 & 24 & 28 & 3.57 & 8.57 & 77.15 & 29.09 & 8.97 \\
20 & 29 & 60 & 24 & 12.08 & 25.00 & 89.41 & 20.32 & 26.16 \\
\hline
\end{tabular}


Sample number: DS11-05

Mineral: Apatite

Irradiation code: vuw011-17

Ns: 293

Ni: 611

Area: 392

RhoS: 7.474

RhoI: 15.59

Pooled Age: $\quad 91.0 \pm 6.8$

Mean Age: $\quad 89.5 \pm 4.9$

Central Age: $\quad 91.0 \pm 6.8$

Chi-sq.: $\quad 9.44$

Horizontal value:

[Ma]

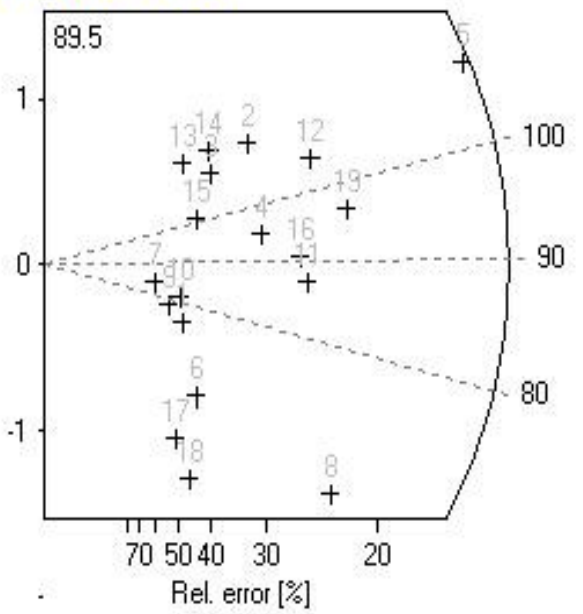

$\mathrm{P}(\%) \quad 94.85$

Dispersion: $\quad 0.00$

RhoD: 11.27

Nd: 8043

U standard CN_5

Zeta $\pm 1 \sigma \quad 339 \pm 6.5$

counted by RJ

\begin{tabular}{ccccccccc} 
Crystal & Ns & Ni & Area & RhoS(e5) & RhoI(e5) & Age(Ma) & $+-1 \mathrm{~s}$ & $\mathrm{U}(\mathrm{ppm})$ \\
\hline 1 & 6 & 15 & 9 & 6.67 & 16.67 & 75.99 & 36.75 & 17.00 \\
2 & 15 & 25 & 6 & 25.00 & 41.67 & 113.66 & 37.21 & 42.50 \\
3 & 10 & 17 & 32 & 3.13 & 5.31 & 111.45 & 44.48 & 5.42 \\
4 & 16 & 32 & 16 & 10.00 & 20.00 & 94.85 & 29.12 & 20.40 \\
5 & 62 & 108 & 30 & 20.67 & 36.00 & 108.79 & 17.50 & 36.72 \\
6 & 7 & 21 & 20 & 3.50 & 10.50 & 63.39 & 27.70 & 10.71 \\
7 & 4 & 9 & 20 & 2.00 & 4.50 & 84.38 & 50.74 & 4.59 \\
8 & 25 & 73 & 40 & 6.25 & 18.25 & 65.12 & 15.16 & 18.62 \\
9 & 5 & 12 & 8 & 6.25 & 15.00 & 79.14 & 42.16 & 15.30 \\
10 & 6 & 14 & 8 & 7.50 & 17.50 & 81.39 & 39.75 & 17.85 \\
11 & 23 & 50 & 12 & 19.17 & 41.67 & 87.31 & 22.08 & 42.50 \\
12 & 25 & 45 & 30 & 8.33 & 15.00 & 105.30 & 26.37 & 15.30 \\
13 & 7 & 11 & 14 & 5.00 & 7.86 & 120.48 & 58.31 & 8.02 \\
14 & 10 & 16 & 40 & 2.50 & 4.00 & 118.35 & 47.78 & 4.08 \\
15 & 8 & 15 & 24 & 3.33 & 6.25 & 101.13 & 44.33 & 6.38 \\
16 & 22 & 46 & 16 & 13.75 & 28.75 & 90.76 & 23.61 & 29.33 \\
17 & 5 & 18 & 12 & 4.17 & 15.00 & 52.87 & 26.75 & 15.30 \\
18 & 6 & 23 & 30 & 2.00 & 7.67 & 49.66 & 22.79 & 7.82 \\
19 & 31 & 61 & 25 & 12.40 & 24.40 & 96.39 & 21.37 & 24.89 \\
\hline
\end{tabular}


Sample number: JR11-05

Mineral: Apatite

Irradiation code: vuw011-2

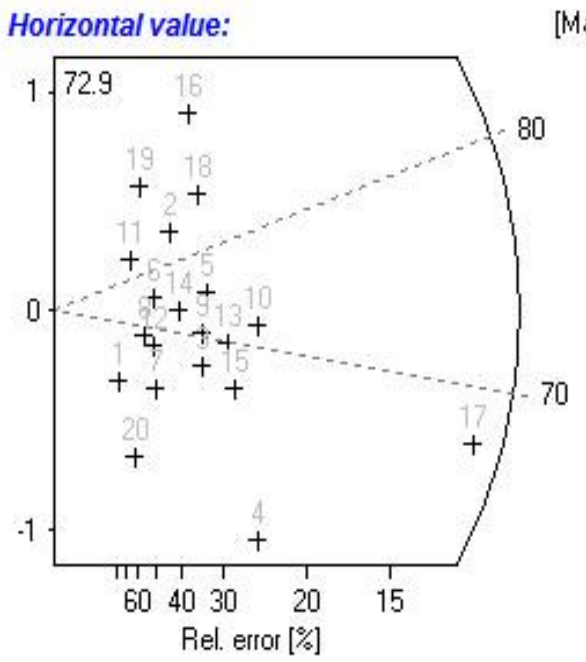

Chi-sq.: $\quad 3.72$

$\mathrm{P}(\%) \quad 99.99$

Dispersion: 0.00

RhoD: 15.2

Nd: 8043

U standard CN_5

Zeta $\pm 1 \sigma \quad 339 \pm 6.5$

counted by RJ

\begin{tabular}{ccccccccc} 
Crystal & $\mathrm{Ns}$ & $\mathrm{Ni}$ & Area & RhoS(e5) & RhoI(e5) & Age(Ma) & $+-1 \mathrm{~s}$ & $\mathrm{U}(\mathrm{ppm})$ \\
\hline 1 & 2 & 9 & 16 & 1.25 & 5.63 & 57.01 & 44.59 & 4.26 \\
2 & 7 & 21 & 6 & 11.67 & 35.00 & 85.33 & 37.29 & 26.48 \\
3 & 11 & 42 & 9 & 12.22 & 46.67 & 67.14 & 22.79 & 35.30 \\
4 & 20 & 91 & 20 & 10.00 & 45.50 & 56.39 & 13.98 & 34.42 \\
5 & 12 & 41 & 9 & 13.33 & 45.56 & 74.99 & 24.67 & 34.46 \\
6 & 5 & 17 & 6 & 8.33 & 28.33 & 75.35 & 38.37 & 21.43 \\
7 & 5 & 21 & 9 & 5.56 & 23.33 & 61.07 & 30.42 & 17.65 \\
8 & 4 & 15 & 16 & 2.50 & 9.38 & 68.36 & 38.50 & 7.09 \\
9 & 11 & 40 & 12 & 9.17 & 33.33 & 70.48 & 24.05 & 25.21 \\
10 & 21 & 75 & 16 & 13.13 & 46.88 & 71.76 & 17.79 & 35.46 \\
11 & 3 & 9 & 20 & 1.50 & 4.50 & 85.33 & 56.92 & 3.40 \\
12 & 5 & 19 & 20 & 2.50 & 9.50 & 67.46 & 33.94 & 7.19 \\
13 & 15 & 55 & 12 & 12.50 & 45.83 & 69.90 & 20.42 & 34.67 \\
14 & 8 & 28 & 9 & 8.89 & 31.11 & 73.21 & 29.40 & 23.53 \\
15 & 16 & 62 & 12 & 13.33 & 51.67 & 66.16 & 18.61 & 39.08 \\
16 & 10 & 25 & 32 & 3.13 & 7.81 & 102.27 & 38.33 & 5.91 \\
17 & 87 & 329 & 30 & 29.00 & 109.67 & 67.79 & 8.31 & 82.96 \\
18 & 11 & 32 & 30 & 3.67 & 10.67 & 87.98 & 30.81 & 8.07 \\
19 & 4 & 10 & 12 & 3.33 & 8.33 & 102.27 & 60.54 & 6.30 \\
20 & 3 & 16 & 15 & 2.00 & 10.67 & 48.14 & 30.31 & 8.07 \\
\hline
\end{tabular}


Sample number: JR11-06

Mineral: Apatite

Irradiation code: vuw011-3

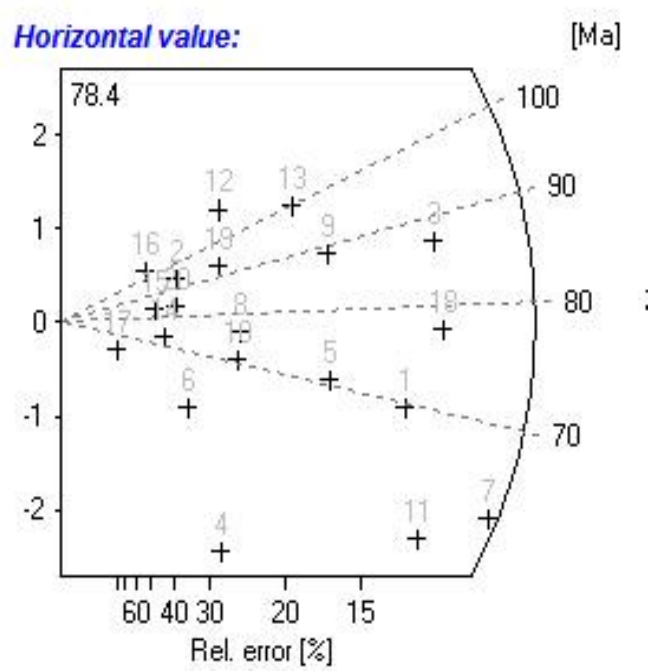

Chi-sq.: 21.33

$\mathrm{P}(\%) \quad 31.87$

Dispersion: 0.09

$\begin{aligned} \text { RhoD: } & 14.96 \\ \text { Nd: } & 8043 \\ \text { U standard } & \text { CN_5 } \\ \text { Zeta } \pm 1 \sigma & 339 \pm 6.5 \\ \text { counted by } & \text { RJ }\end{aligned}$

\begin{tabular}{ccccccccc} 
Crystal & $\mathrm{Ns}$ & $\mathrm{Ni}$ & Area & RhoS(e5) & RhoI(e5) & Age(Ma) & $+-1 \mathrm{~s}$ & $\mathrm{U}(\mathrm{ppm})$ \\
\hline 1 & 75 & 271 & 32 & 23.44 & 84.69 & 69.81 & 9.24 & 65.09 \\
2 & 9 & 24 & 12 & 7.50 & 20.00 & 94.41 & 36.96 & 15.37 \\
3 & 93 & 269 & 30 & 31.00 & 89.67 & 87.09 & 10.65 & 68.92 \\
4 & 15 & 95 & 15 & 10.00 & 63.33 & 39.92 & 11.13 & 48.68 \\
5 & 46 & 164 & 21 & 21.91 & 78.10 & 70.75 & 11.91 & 60.03 \\
6 & 10 & 44 & 50 & 2.00 & 8.80 & 57.38 & 20.14 & 6.76 \\
7 & 113 & 453 & 36 & 31.39 & 125.83 & 62.96 & 6.78 & 6.72 \\
8 & 21 & 69 & 24 & 8.75 & 28.75 & 76.73 & 19.20 & 22.10 \\
9 & 48 & 136 & 35 & 13.71 & 38.86 & 88.90 & 15.05 & 29.87 \\
10 & 20 & 71 & 9 & 22.22 & 78.89 & 71.05 & 18.05 & 60.64 \\
11 & 78 & 335 & 20 & 39.00 & 167.50 & 58.78 & 7.50 & 128.74 \\
12 & 18 & 41 & 35 & 5.14 & 11.71 & 110.39 & 31.31 & 9.00 \\
13 & 37 & 93 & 12 & 30.83 & 77.50 & 100.12 & 19.59 & 59.57 \\
14 & 7 & 24 & 30 & 2.33 & 8.00 & 73.55 & 31.64 & 6.15 \\
15 & 6 & 18 & 12 & 5.00 & 15.00 & 83.99 & 39.64 & 11.53 \\
16 & 5 & 12 & 12 & 4.17 & 10.00 & 104.82 & 55.84 & 7.69 \\
17 & 2 & 8 & 15 & 1.33 & 5.33 & 63.09 & 49.90 & 4.10 \\
18 & 95 & 308 & 28 & 33.93 & 110.00 & 77.76 & 9.29 & 84.55 \\
19 & 17 & 46 & 16 & 10.63 & 28.75 & 93.05 & 26.49 & 22.10 \\
20 & 9 & 27 & 25 & 3.60 & 10.80 & 83.99 & 32.38 & 8.30 \\
\hline
\end{tabular}


Sample number: JR11-07

Mineral: Apatite

Irradiation code: vuw011-4

Ns: 263

Ni: 734

Area: 245

RhoS: $\quad 10.74$

RhoI: 29.96

Pooled Age: $\quad 88.8 \pm 6.7$

Mean Age: $\quad 98.9 \pm 7.7$

Central Age: $\quad 89.2 \pm 7.0$

Chi-sq.: $\quad 17.69$

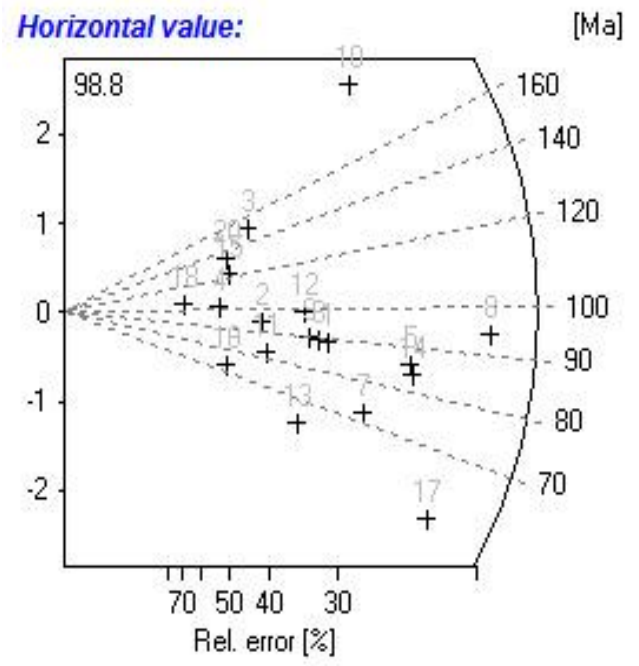

$\mathrm{P}(\%) \quad 54.3$

Dispersion: 0.08

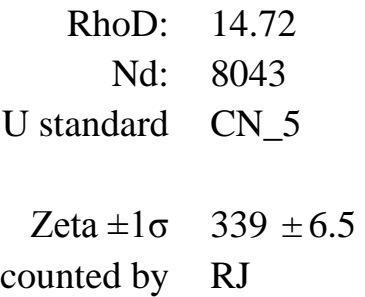

\begin{tabular}{ccccccccc} 
Crystal & $\mathrm{Ns}$ & $\mathrm{Ni}$ & Area & RhoS(e5) & RhoI(e5) & Age(Ma) & $+-1 \mathrm{~s}$ & $\mathrm{U}(\mathrm{ppm})$ \\
\hline 1 & 14 & 39 & 6 & 23.33 & 65.00 & 88.96 & 27.79 & 50.78 \\
2 & 8 & 21 & 6 & 13.33 & 35.00 & 94.37 & 39.26 & 27.34 \\
3 & 8 & 13 & 12 & 6.67 & 10.83 & 151.76 & 68.28 & 8.46 \\
4 & 5 & 12 & 12 & 4.17 & 10.00 & 103.14 & 54.95 & 7.81 \\
5 & 24 & 69 & 9 & 26.67 & 76.67 & 86.21 & 20.52 & 59.89 \\
6 & 13 & 36 & 16 & 8.13 & 22.50 & 89.48 & 29.02 & 17.58 \\
7 & 17 & 58 & 20 & 8.50 & 29.00 & 72.73 & 20.12 & 22.66 \\
8 & 37 & 97 & 15 & 24.67 & 64.67 & 94.49 & 18.38 & 50.52 \\
9 & 12 & 33 & 9 & 13.33 & 36.67 & 90.11 & 30.44 & 28.64 \\
10 & 22 & 26 & 12 & 18.33 & 21.67 & 207.76 & 60.36 & 16.93 \\
11 & 8 & 24 & 4 & 20.00 & 60.00 & 82.64 & 33.79 & 46.87 \\
12 & 12 & 30 & 14 & 8.57 & 21.43 & 99.05 & 33.90 & 16.74 \\
13 & 10 & 39 & 16 & 6.25 & 24.38 & 63.67 & 22.61 & 19.04 \\
14 & 24 & 71 & 8 & 30.00 & 88.75 & 83.80 & 19.87 & 69.33 \\
15 & 6 & 12 & 9 & 6.67 & 13.33 & 123.57 & 61.85 & 10.42 \\
16 & 5 & 17 & 9 & 5.56 & 18.89 & 72.98 & 37.16 & 14.76 \\
17 & 24 & 102 & 12 & 20.00 & 85.00 & 58.45 & 13.32 & 66.40 \\
18 & 3 & 7 & 20 & 1.50 & 3.50 & 106.06 & 73.23 & 2.73 \\
19 & 5 & 17 & 21 & 2.38 & 8.10 & 72.98 & 37.16 & 6.32 \\
20 & 6 & 11 & 15 & 4.00 & 7.33 & 134.69 & 68.42 & 5.73 \\
\hline
\end{tabular}


Sample number: JR11-08

Mineral: Apatite

Irradiation code: vuw006-5

Ns: 595

Ni: 1792

Area: 479

RhoS: $\quad 12.42$

RhoI: 37.41

Pooled Age: $\quad 81.0 \pm 4.3$

Mean Age: $\quad 91.0 \pm 4.4$

Central Age: $\quad 82.8 \pm 4.9$

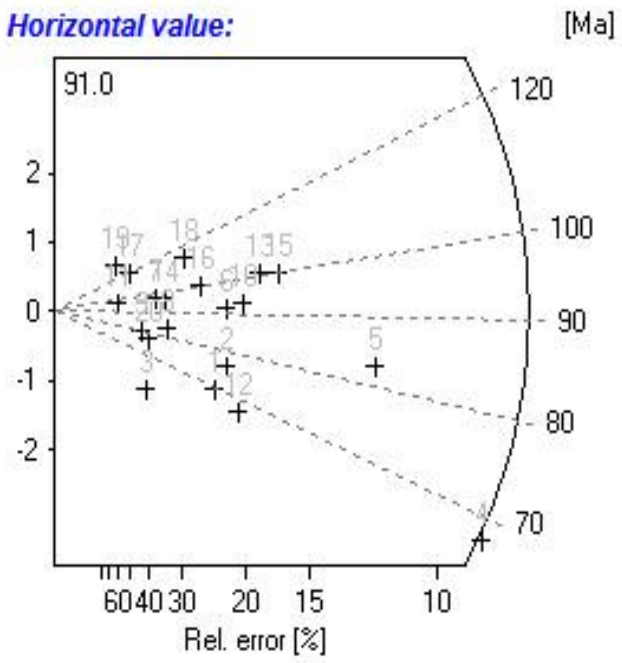

Chi-sq.: $\quad 14.06$

$\mathrm{P}(\%) \quad 78.03$

Dispersion: $\quad 0.07$

RhoD: 14.48

Nd: 4415

U standard CN_5

Zeta $\pm 1 \sigma \quad 339 \pm 6.5$

counted by RJ

\begin{tabular}{ccccccccc} 
Crystal & $\mathrm{Ns}$ & $\mathrm{Ni}$ & Area & RhoS(e5) & RhoI(e5) & Age(Ma) & $+-1 \mathrm{~s}$ & $\mathrm{U}(\mathrm{ppm})$ \\
\hline 1 & 23 & 80 & 12 & 19.17 & 66.67 & 70.18 & 16.69 & 52.95 \\
2 & 27 & 86 & 24 & 11.25 & 35.83 & 76.60 & 17.00 & 28.46 \\
3 & 7 & 30 & 12 & 5.83 & 25.00 & 57.02 & 23.97 & 19.86 \\
4 & 160 & 576 & 64 & 25.00 & 90.00 & 67.82 & 6.28 & 71.48 \\
5 & 95 & 279 & 39 & 24.36 & 71.54 & 83.04 & 10.07 & 56.82 \\
6 & 28 & 74 & 10 & 28.00 & 74.00 & 92.21 & 20.58 & 58.77 \\
7 & 10 & 25 & 20 & 5.00 & 12.50 & 97.44 & 36.53 & 9.93 \\
8 & 12 & 35 & 9 & 13.33 & 38.89 & 83.61 & 28.04 & 30.89 \\
9 & 7 & 21 & 15 & 4.67 & 14.00 & 81.30 & 35.54 & 11.12 \\
10 & 34 & 89 & 18 & 18.89 & 49.44 & 93.09 & 18.90 & 39.27 \\
11 & 4 & 10 & 16 & 2.50 & 6.25 & 97.44 & 57.69 & 4.96 \\
12 & 30 & 108 & 24 & 12.50 & 45.00 & 67.82 & 14.09 & 35.74 \\
13 & 41 & 99 & 45 & 9.11 & 22.00 & 100.85 & 18.89 & 17.47 \\
14 & 12 & 30 & 25 & 4.80 & 12.00 & 97.44 & 33.37 & 9.53 \\
15 & 49 & 119 & 25 & 19.60 & 47.60 & 100.28 & 17.20 & 37.81 \\
16 & 21 & 51 & 30 & 7.00 & 17.00 & 100.28 & 26.12 & 13.50 \\
17 & 6 & 12 & 24 & 2.50 & 5.00 & 121.57 & 60.86 & 3.97 \\
18 & 17 & 36 & 30 & 5.67 & 12.00 & 114.87 & 33.92 & 9.53 \\
19 & 4 & 7 & 16 & 2.50 & 4.38 & 138.75 & 87.03 & 3.48 \\
20 & 8 & 25 & 21 & 3.81 & 11.91 & 78.07 & 31.77 & 9.46 \\
\hline
\end{tabular}


Sample number: JR11-12

Mineral: Apatite

Irradiation code: vuw011-7

Ns: 181

Ni: 574

Area: 621

RhoS: 2.915

RhoI: 9.243

Pooled Age: $74.4 \pm 6.6$

Mean Age: $\quad 92.1 \pm 5.6$

Central Age: $\quad 77.0 \pm 7.4$

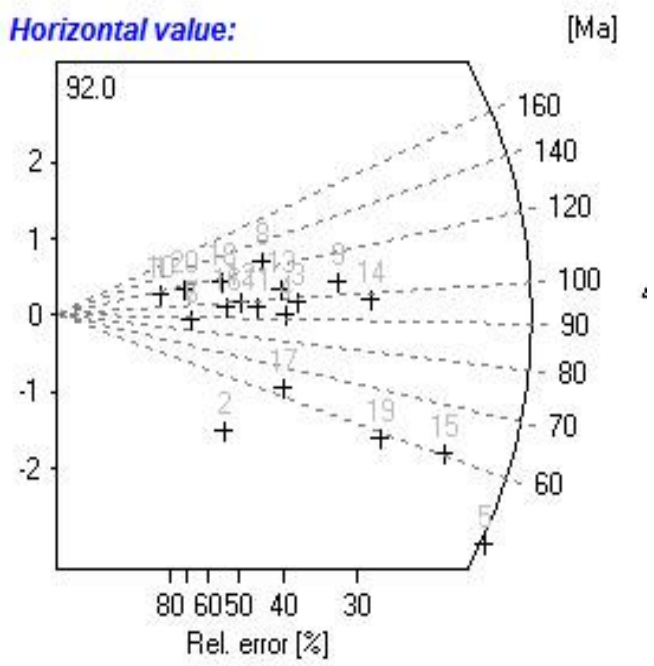

Chi-sq.: $\quad 15.06$

$\mathrm{P}(\%) \quad 71.89$

Dispersion: 0.13

RhoD: $\quad 14.00$

Nd: 8043

U standard CN_5

Zeta $\pm 1 \sigma \quad 339 \pm 6.5$

counted by RJ

\begin{tabular}{ccccccccc} 
Crystal & $\mathrm{Ns}$ & $\mathrm{Ni}$ & Area & RhoS(e5) & RhoI(e5) & Age(Ma) & $+-1 \mathrm{~s}$ & $\mathrm{U}(\mathrm{ppm})$ \\
\hline 1 & 2 & 4 & 12 & 1.67 & 3.33 & 117.56 & 101.84 & 2.74 \\
2 & 4 & 23 & 15 & 2.67 & 15.33 & 41.13 & 22.30 & 12.60 \\
3 & 10 & 24 & 42 & 2.38 & 5.71 & 98.11 & 36.99 & 4.70 \\
4 & 9 & 23 & 15 & 6.00 & 15.33 & 92.18 & 36.30 & 12.60 \\
5 & 27 & 130 & 30 & 9.00 & 43.33 & 49.09 & 10.44 & 35.60 \\
6 & 3 & 8 & 20 & 1.50 & 4.00 & 88.37 & 59.86 & 3.29 \\
7 & 3 & 8 & 32 & 0.94 & 2.50 & 88.37 & 59.86 & 2.05 \\
8 & 8 & 15 & 16 & 5.00 & 9.38 & 125.32 & 54.93 & 7.70 \\
9 & 14 & 31 & 30 & 4.67 & 10.33 & 106.27 & 34.30 & 8.49 \\
10 & 2 & 4 & 20 & 1.00 & 2.00 & 117.56 & 101.84 & 1.64 \\
11 & 7 & 17 & 25 & 2.80 & 6.80 & 96.97 & 43.60 & 5.59 \\
12 & 6 & 14 & 48 & 1.25 & 2.92 & 100.89 & 49.28 & 2.40 \\
13 & 9 & 20 & 60 & 1.50 & 3.33 & 105.90 & 42.57 & 2.74 \\
14 & 17 & 41 & 69 & 2.46 & 5.94 & 97.64 & 28.25 & 4.88 \\
15 & 23 & 90 & 24 & 9.58 & 37.50 & 60.35 & 14.16 & 30.81 \\
16 & 5 & 12 & 16 & 3.13 & 7.50 & 98.11 & 52.27 & 6.16 \\
17 & 8 & 30 & 24 & 3.33 & 12.50 & 62.96 & 25.09 & 10.27 \\
18 & 5 & 10 & 20 & 2.50 & 5.00 & 117.56 & 64.44 & 4.11 \\
19 & 16 & 64 & 63 & 2.54 & 10.16 & 59.05 & 16.56 & 8.35 \\
20 & 3 & 6 & 40 & 0.75 & 1.50 & 117.56 & 83.17 & 1.23 \\
\hline
\end{tabular}


Sample number: JR11-13

Mineral: Apatite

Irradiation code: vuw011-18

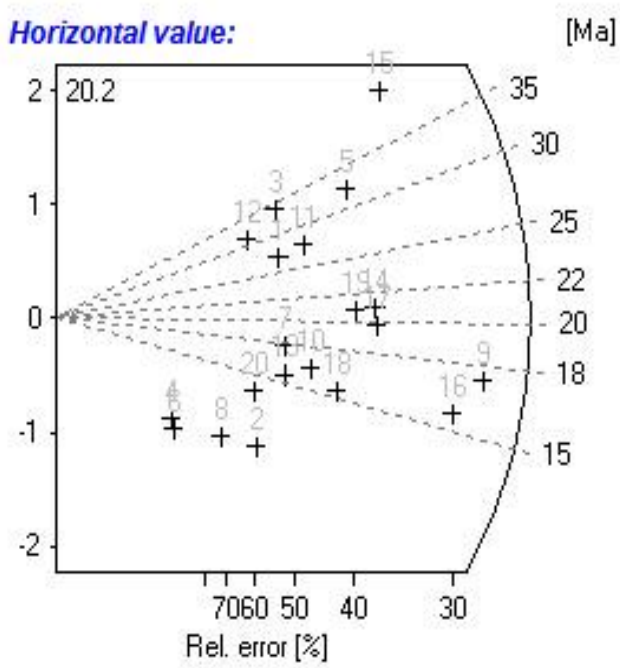

Chi-sq.: $\quad 14.55$

$\mathrm{P}(\%) \quad 75.1$

Dispersion: 0.00

RhoD: 11.13

Nd: 8043

U standard CN_5

Zeta $\pm 1 \sigma \quad 339 \pm 6.5$

counted by RJ

\begin{tabular}{ccccccccc} 
Crystal & $\mathrm{Ns}$ & $\mathrm{Ni}$ & Area & RhoS(e5) & RhoI(e5) & Age(Ma) & $+-1 \mathrm{~s}$ & $\mathrm{U}(\mathrm{ppm})$ \\
\hline 1 & 4 & 28 & 20 & 2.00 & 14.00 & 26.90 & 14.39 & 14.46 \\
2 & 3 & 54 & 20 & 1.50 & 27.00 & 10.47 & 6.22 & 27.89 \\
3 & 4 & 22 & 20 & 2.00 & 11.00 & 34.22 & 18.61 & 11.36 \\
4 & 1 & 23 & 20 & 0.50 & 11.50 & 8.20 & 8.38 & 11.88 \\
5 & 7 & 41 & 8 & 8.75 & 51.25 & 32.13 & 13.16 & 52.95 \\
6 & 1 & 25 & 20 & 0.50 & 12.50 & 7.54 & 7.69 & 12.91 \\
7 & 4 & 42 & 16 & 2.50 & 26.25 & 17.95 & 9.40 & 27.12 \\
8 & 2 & 39 & 12 & 1.67 & 32.50 & 9.67 & 7.01 & 33.58 \\
9 & 14 & 152 & 20 & 7.00 & 76.00 & 17.36 & 4.86 & 78.52 \\
10 & 5 & 57 & 15 & 3.33 & 38.00 & 16.53 & 7.72 & 39.26 \\
11 & 5 & 34 & 18 & 2.78 & 18.89 & 27.69 & 13.28 & 19.52 \\
12 & 3 & 18 & 6 & 5.00 & 30.00 & 31.37 & 19.58 & 30.99 \\
13 & 4 & 48 & 15 & 2.67 & 32.00 & 15.70 & 8.18 & 33.06 \\
14 & 8 & 72 & 20 & 4.00 & 36.00 & 20.93 & 7.81 & 37.19 \\
15 & 9 & 40 & 8 & 11.25 & 50.00 & 42.32 & 15.64 & 51.66 \\
16 & 12 & 143 & 25 & 4.80 & 57.20 & 15.81 & 4.77 & 59.10 \\
17 & 8 & 76 & 16 & 5.00 & 47.50 & 19.83 & 7.38 & 49.07 \\
18 & 6 & 73 & 12 & 5.00 & 60.83 & 15.49 & 6.59 & 62.85 \\
19 & 7 & 63 & 28 & 2.50 & 22.50 & 20.93 & 8.35 & 23.25 \\
20 & 3 & 41 & 15 & 2.00 & 27.33 & 13.79 & 8.25 & 28.24 \\
\hline
\end{tabular}


Sample number: JR11-14

Mineral: Apatite

Irradiation code: vuw011-8

Ns: 46

Ni: 459

Area: 178

RhoS: 2.584

RhoI: 25.79

Pooled Age: $\quad 23.3 \pm 3.6$

Mean Age: $\quad 23.0 \pm 2.0$

Central Age: $23.3 \pm 3.6$

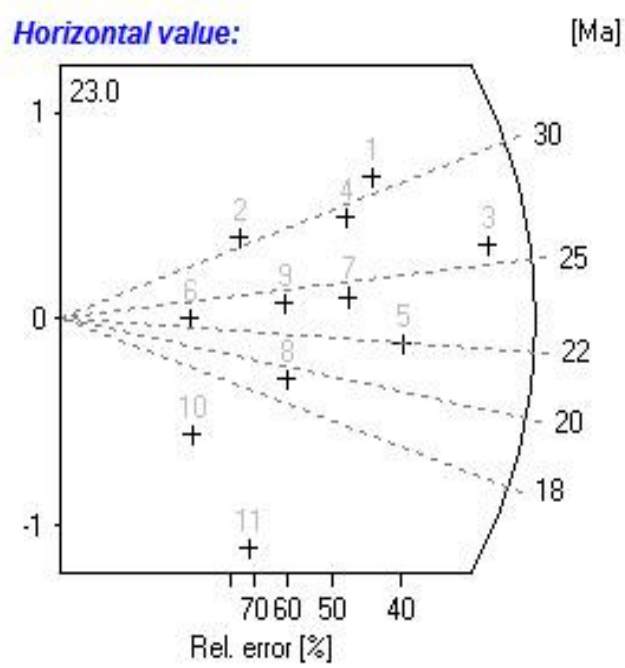

Chi-sq.: 2.7

$\mathrm{P}(\%) \quad 98.75$

Dispersion: $\quad 0.00$

RhoD: 13.76

Nd: 8043

U standard CN_5

Zeta $\pm 1 \sigma \quad 339 \pm 6.5$

counted by RJ

\begin{tabular}{ccccccccc} 
Crystal & Ns & Ni & Area & RhoS(e5) & RhoI(e5) & Age $(\mathrm{Ma})$ & $+-1 \mathrm{~s}$ & $\mathrm{U}(\mathrm{ppm})$ \\
\hline 1 & 6 & 45 & 20 & 3.00 & 22.50 & 31.02 & 13.50 & 18.81 \\
2 & 2 & 15 & 12 & 1.67 & 12.50 & 31.02 & 23.36 & 10.45 \\
3 & 11 & 99 & 12 & 9.17 & 82.50 & 25.86 & 8.24 & 68.97 \\
4 & 5 & 40 & 12 & 4.17 & 33.33 & 29.08 & 13.81 & 27.87 \\
5 & 7 & 74 & 6 & 11.67 & 123.33 & 22.02 & 8.72 & 103.11 \\
6 & 1 & 10 & 20 & 0.50 & 5.00 & 23.28 & 24.42 & 4.18 \\
7 & 5 & 48 & 16 & 3.13 & 30.00 & 24.24 & 11.41 & 25.08 \\
8 & 3 & 36 & 30 & 1.00 & 12.00 & 19.40 & 11.67 & 10.03 \\
9 & 3 & 29 & 16 & 1.88 & 18.13 & 24.08 & 14.61 & 15.15 \\
10 & 1 & 18 & 10 & 1.00 & 18.00 & 12.94 & 13.30 & 15.05 \\
11 & 2 & 45 & 24 & 0.83 & 18.75 & 10.36 & 7.49 & 15.68 \\
\hline
\end{tabular}


Sample number: JR11-40b

Mineral: Apatite

Irradiation code: vuw011-9

Ns: 308

Ni: 1513

Area: 701

RhoS: 4.394

RhoI: 21.58

Pooled Age: $\quad 46.5 \pm 3.1$

Mean Age: $\quad 101.1 \pm 19.0$

Central Age: $\quad 68.9 \pm 11.0$

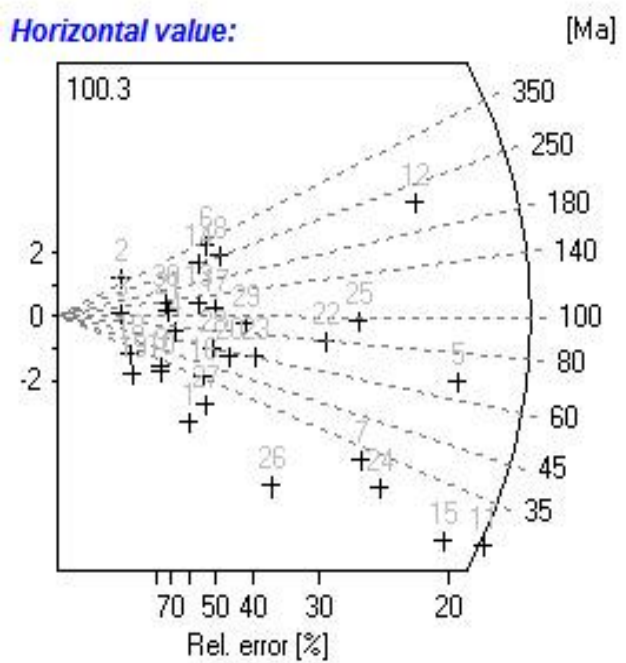

Chi-sq.: $\quad 194.5$

$\mathrm{P}(\%) \quad 0$

Dispersion: 0.73

RhoD: 13.52

Nd: 8043

U standard CN_5

Zeta $\pm 1 \sigma \quad 339 \pm 6.5$

counted by RJ

\begin{tabular}{ccccccccc} 
Crystal & Ns & Ni & Area & RhoS(e5) & RhoI(e5) & Age(Ma) & $+-1 \mathrm{~s}$ & $\mathrm{U}(\mathrm{ppm})$ \\
\hline 1 & 3 & 49 & 16 & 1.88 & 30.63 & 14.01 & 8.34 & 26.06 \\
2 & 2 & 1 & 16 & 1.25 & 0.63 & 442.63 & 542.20 & 0.53 \\
3 & 1 & 2 & 35 & 0.29 & 0.57 & 113.54 & 139.08 & 0.49 \\
4 & 3 & 9 & 9 & 3.33 & 10.00 & 75.92 & 50.64 & 8.51 \\
5 & 34 & 114 & 36 & 9.44 & 31.67 & 67.97 & 13.37 & 26.95 \\
6 & 9 & 6 & 16 & 5.63 & 3.75 & 334.79 & 176.61 & 3.19 \\
7 & 17 & 124 & 16 & 10.63 & 77.50 & 31.33 & 8.13 & 65.95 \\
8 & 9 & 8 & 20 & 4.50 & 4.00 & 252.71 & 122.92 & 3.40 \\
9 & 2 & 15 & 15 & 1.33 & 10.00 & 30.47 & 22.95 & 8.51 \\
10 & 2 & 16 & 30 & 0.67 & 5.33 & 28.76 & 21.44 & 4.54 \\
11 & 33 & 280 & 28 & 11.79 & 100.00 & 26.94 & 4.99 & 85.09 \\
12 & 41 & 42 & 35 & 11.71 & 12.00 & 219.85 & 48.51 & 10.21 \\
13 & 5 & 9 & 16 & 3.13 & 5.63 & 126.03 & 70.35 & 4.79 \\
14 & 7 & 6 & 28 & 2.50 & 2.14 & 261.88 & 145.81 & 1.82 \\
15 & 27 & 253 & 25 & 10.80 & 101.20 & 24.40 & 4.97 & 86.11 \\
16 & 4 & 25 & 15 & 2.67 & 16.67 & 36.55 & 19.70 & 14.18 \\
17 & 6 & 12 & 16 & 3.75 & 7.50 & 113.54 & 56.83 & 6.38 \\
18 & 1 & 8 & 16 & 0.63 & 5.00 & 28.57 & 30.31 & 4.26 \\
19 & 1 & 14 & 15 & 0.67 & 9.33 & 16.34 & 16.92 & 7.94 \\
20 & 6 & 24 & 30 & 2.00 & 8.00 & 57.02 & 26.06 & 6.81
\end{tabular}




\begin{tabular}{ccccccccc}
21 & 3 & 6 & 24 & 1.25 & 2.50 & 113.54 & 80.32 & 2.13 \\
22 & 16 & 45 & 35 & 4.57 & 12.86 & 80.94 & 23.63 & 10.94 \\
23 & 8 & 30 & 24 & 3.33 & 12.50 & 60.80 & 24.23 & 10.64 \\
24 & 19 & 157 & 50 & 3.80 & 31.40 & 27.67 & 6.75 & 26.72 \\
25 & 21 & 49 & 9 & 23.33 & 54.44 & 97.44 & 25.51 & 46.33 \\
26 & 8 & 126 & 20 & 4.00 & 63.00 & 14.53 & 5.31 & 53.61 \\
27 & 4 & 39 & 14 & 2.86 & 27.86 & 23.45 & 12.32 & 23.70 \\
28 & 5 & 19 & 20 & 2.50 & 9.50 & 60.01 & 30.19 & 8.08 \\
29 & 8 & 20 & 60 & 1.33 & 3.33 & 90.99 & 3.17 & 2.84 \\
30 & 3 & 5 & 12 & 2.50 & 4.17 & 136.01 & 99.37 & 3.55 \\
\hline
\end{tabular}


Sample number: JR11-40c

Mineral: Apatite

Irradiation code: vuw011-10

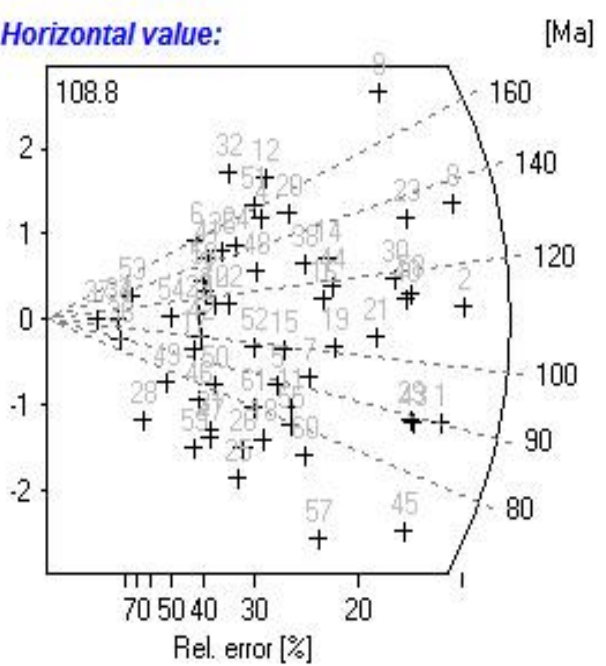

Chi-sq.: $\quad 68.93$

$\mathrm{P}(\%) \quad 20.1$

Dispersion: $\quad 0.14$

RhoD: 13.27

Nd: 8043

U standard CN_5

Zeta $\pm 1 \sigma \quad 339 \pm 6.5$

counted by RJ

\begin{tabular}{ccccccccc} 
Crystal & $\mathrm{Ns}$ & $\mathrm{Ni}$ & Area & RhoS(e5) & RhoI(e5) & Age(Ma) & $+-1 \mathrm{~s}$ & $\mathrm{U}(\mathrm{ppm})$ \\
\hline 1 & 56 & 139 & 50 & 11.20 & 27.80 & 90.02 & 14.39 & 24.09 \\
2 & 67 & 134 & 24 & 27.92 & 55.83 & 111.53 & 16.87 & 48.37 \\
3 & 10 & 18 & 20 & 5.00 & 9.00 & 123.81 & 48.91 & 7.80 \\
4 & 20 & 29 & 10 & 20.00 & 29.00 & 153.34 & 44.70 & 25.13 \\
5 & 19 & 48 & 6 & 31.67 & 80.00 & 88.45 & 24.06 & 69.31 \\
6 & 10 & 14 & 20 & 5.00 & 7.00 & 158.75 & 65.82 & 6.07 \\
7 & 25 & 60 & 15 & 16.67 & 40.00 & 93.08 & 22.25 & 34.66 \\
8 & 68 & 113 & 35 & 19.43 & 32.29 & 134.00 & 20.78 & 27.97 \\
9 & 51 & 63 & 40 & 12.75 & 15.75 & 179.62 & 34.07 & 13.65 \\
10 & 11 & 21 & 15 & 7.33 & 14.00 & 116.80 & 43.55 & 12.13 \\
11 & 21 & 56 & 30 & 7.00 & 18.67 & 83.83 & 21.53 & 16.17 \\
12 & 22 & 28 & 20 & 11.00 & 14.00 & 174.41 & 49.84 & 12.13 \\
13 & 10 & 17 & 9 & 11.11 & 18.89 & 131.02 & 52.29 & 16.37 \\
14 & 32 & 56 & 60 & 5.33 & 9.33 & 127.31 & 28.35 & 8.09 \\
15 & 21 & 47 & 30 & 7.00 & 15.67 & 99.76 & 26.28 & 13.57 \\
16 & 30 & 58 & 70 & 4.29 & 8.29 & 115.34 & 26.07 & 7.18 \\
17 & 8 & 19 & 40 & 2.00 & 4.75 & 94.05 & 39.69 & 4.12 \\
18 & 16 & 49 & 50 & 3.20 & 9.80 & 73.06 & 21.10 & 8.49 \\
19 & 31 & 68 & 18 & 17.22 & 37.78 & 101.77 & 22.17 & 32.73 \\
20 & 25 & 37 & 20 & 12.50 & 18.50 & 150.27 & 39.05 & 16.03
\end{tabular}




\begin{tabular}{|c|c|c|c|c|c|c|c|c|}
\hline 21 & 41 & 87 & 100 & 4.10 & 8.70 & 105.17 & 20.06 & 7.54 \\
\hline 22 & 13 & 25 & 8 & 16.25 & 31.25 & 115.95 & 39.73 & 27.07 \\
\hline 23 & 53 & 88 & 24 & 22.08 & 36.67 & 134.11 & 23.51 & 31.77 \\
\hline 24 & 15 & 23 & 30 & 5.00 & 7.67 & 145.10 & 48.26 & 6.64 \\
\hline 25 & 12 & 45 & 20 & 6.00 & 22.50 & 59.72 & 19.45 & 19.49 \\
\hline 26 & 13 & 43 & 15 & 8.67 & 28.67 & 67.67 & 21.47 & 24.84 \\
\hline 27 & 9 & 18 & 24 & 3.75 & 7.50 & 111.53 & 45.60 & 6.50 \\
\hline 28 & 3 & 13 & 12 & 2.50 & 10.83 & 51.72 & 33.14 & 9.39 \\
\hline 29 & 48 & 120 & 90 & 5.33 & 13.33 & 89.38 & 15.39 & 11.55 \\
\hline 30 & 48 & 90 & 70 & 6.86 & 12.86 & 118.90 & 21.41 & 11.14 \\
\hline 31 & 9 & 30 & 70 & 1.29 & 4.29 & 67.15 & 25.56 & 3.71 \\
\hline 32 & 16 & 18 & 21 & 7.62 & 8.57 & 196.96 & 67.82 & 7.43 \\
\hline 33 & 2 & 4 & 4 & 5.00 & 10.00 & 111.53 & 96.62 & 8.66 \\
\hline 34 & 2 & 4 & 15 & 1.33 & 2.67 & 111.53 & 96.62 & 2.31 \\
\hline 35 & 13 & 20 & 25 & 5.20 & 8.00 & 144.62 & 51.62 & 6.93 \\
\hline 36 & 2 & 5 & 2 & 10.00 & 25.00 & 89.38 & 74.81 & 21.66 \\
\hline 37 & 1 & 2 & 3 & 3.33 & 6.67 & 111.53 & 136.62 & 5.78 \\
\hline 38 & 27 & 47 & 16 & 16.88 & 29.38 & 127.98 & 31.03 & 25.45 \\
\hline 39 & 9 & 18 & 8 & 11.25 & 22.50 & 22.50 & 111.53 & 45.60 \\
\hline 40 & 50 & 98 & 24 & 20.83 & 40.83 & 113.79 & 19.94 & 35.38 \\
\hline 41 & 11 & 17 & 28 & 3.93 & 6.07 & 143.97 & 55.80 & 5.26 \\
\hline 42 & 9 & 20 & 20 & 4.50 & 10.00 & 100.47 & 40.39 & 8.66 \\
\hline 43 & 48 & 121 & 24 & 20.00 & 50.42 & 88.65 & 15.25 & 43.68 \\
\hline 44 & 32 & 60 & 6 & 53.33 & 100.00 & 118.90 & 26.16 & 86.64 \\
\hline 45 & 43 & 136 & 20 & 21.50 & 68.00 & 70.75 & 12.48 & 58.91 \\
\hline 46 & 8 & 24 & 16 & 5.00 & 15.00 & 74.57 & 30.49 & 13.00 \\
\hline 47 & 9 & 31 & 12 & 7.50 & 25.83 & 65.00 & 24.65 & 22.38 \\
\hline 48 & 18 & 31 & 25 & 7.20 & 12.40 & 129.34 & 38.44 & 10.74 \\
\hline 49 & 5 & 15 & 32 & 1.56 & 4.69 & 74.57 & 38.54 & 4.06 \\
\hline 50 & 10 & 27 & 16 & 6.25 & 16.88 & 82.80 & 30.71 & 14.62 \\
\hline 51 & 19 & 26 & 9 & 21.11 & 28.89 & 162.36 & 49.14 & 25.03 \\
\hline 52 & 16 & 36 & 24 & 6.67 & 15.00 & 99.23 & 29.90 & 13.00 \\
\hline 53 & 3 & 5 & 8 & 3.75 & 6.25 & 133.61 & 97.62 & 5.42 \\
\hline 54 & 6 & 12 & 9 & 6.67 & 13.33 & 111.53 & 55.82 & 11.55 \\
\hline 55 & 21 & 59 & 36 & 5.83 & 16.39 & 79.59 & 20.30 & 14.20 \\
\hline 56 & 10 & 17 & 24 & 4.17 & 7.08 & 131.02 & 52.29 & 6.14 \\
\hline 57 & 24 & 89 & 16 & 15.00 & 55.63 & 60.39 & 13.95 & 48.19 \\
\hline 58 & 52 & 101 & 20 & 26.00 & 50.50 & 114.82 & 19.76 & 43.75 \\
\hline 59 & 7 & 27 & 20 & 3.50 & 13.50 & 58.07 & 24.66 & 11.70 \\
\hline 60 & 23 & 69 & 20 & 11.50 & 34.50 & 74.57 & 18.03 & 29.89 \\
\hline 61 & 15 & 42 & 50 & 3.00 & 8.40 & 79.86 & 24.09 & 7.28 \\
\hline
\end{tabular}


Sample number: JR11-47

Mineral: Apatite

Irradiation code: vuw011-11

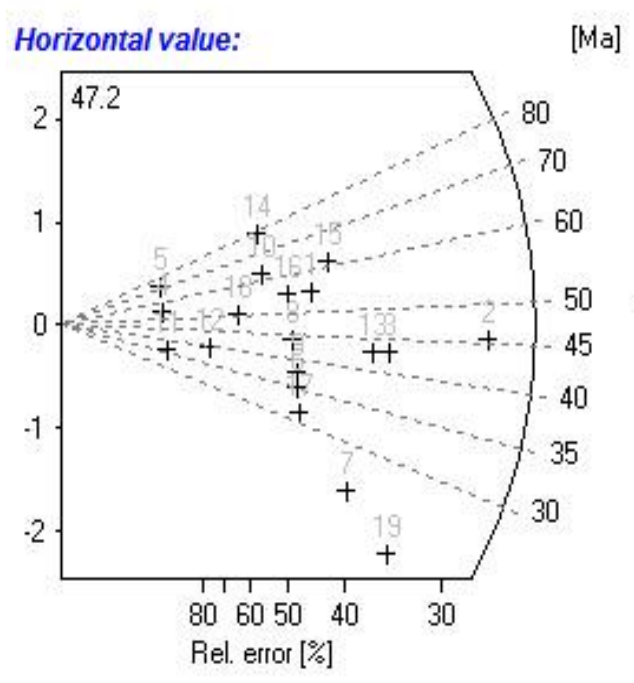

Chi-sq.: $\quad 9.85$

$\mathrm{P}(\%) \quad 93.68$

Dispersion: 0.01

RhoD: 13.03

Nd: 8043

U standard CN_5

Zeta $\pm 1 \sigma \quad 339 \pm 6.5$

counted by RJ

\begin{tabular}{ccccccccc} 
Crystal & Ns & Ni & Area & RhoS(e5) & RhoI(e5) & Age(Ma) & $+-1 \mathrm{~s}$ & $\mathrm{U}(\mathrm{ppm})$ \\
\hline 1 & 6 & 24 & 9 & 6.67 & 26.67 & 54.99 & 25.13 & 23.53 \\
2 & 17 & 82 & 6 & 28.33 & 136.67 & 45.64 & 12.20 & 120.59 \\
3 & 10 & 51 & 4 & 25.00 & 127.50 & 43.17 & 14.96 & 112.51 \\
4 & 1 & 4 & 9 & 1.11 & 4.44 & 54.99 & 61.50 & 3.92 \\
5 & 1 & 3 & 4 & 2.50 & 7.50 & 73.22 & 84.56 & 6.62 \\
6 & 5 & 31 & 8 & 6.25 & 38.75 & 35.53 & 17.14 & 34.19 \\
7 & 7 & 62 & 15 & 4.67 & 41.33 & 24.89 & 9.94 & 36.47 \\
8 & 5 & 25 & 9 & 5.56 & 27.78 & 44.03 & 21.59 & 24.51 \\
9 & 5 & 29 & 9 & 5.56 & 32.22 & 37.98 & 18.41 & 28.43 \\
10 & 4 & 14 & 20 & 2.00 & 7.00 & 62.81 & 35.64 & 6.18 \\
11 & 1 & 6 & 12 & 0.83 & 5.00 & 36.71 & 39.66 & 4.41 \\
12 & 2 & 11 & 10 & 2.00 & 11.00 & 40.04 & 30.79 & 9.71 \\
13 & 9 & 46 & 20 & 4.50 & 23.00 & 43.08 & 15.73 & 20.30 \\
14 & 4 & 11 & 9 & 4.44 & 12.22 & 79.84 & 46.65 & 10.79 \\
15 & 7 & 25 & 9 & 7.78 & 27.78 & 61.56 & 26.36 & 24.51 \\
16 & 5 & 20 & 18 & 2.78 & 11.11 & 54.99 & 27.52 & 9.80 \\
17 & 5 & 35 & 8 & 6.25 & 43.75 & 31.48 & 15.07 & 38.61 \\
18 & 3 & 13 & 10 & 3.00 & 13.00 & 50.78 & 32.54 & 11.47 \\
19 & 9 & 91 & 12 & 7.50 & 75.83 & 21.81 & 7.64 & 66.92 \\
\hline
\end{tabular}


Sample number: JR11-50

Mineral: Apatite

Irradiation code: vuw011-12

Ns: 128

Ni: 1280

Area: 357

RhoS: 3.585

RhoI: 35.85

Pooled Age: $\quad 21.6 \pm 2.1$

Mean Age: $23.5 \pm 1.8$

Central Age: $\quad 21.6 \pm 2.1$

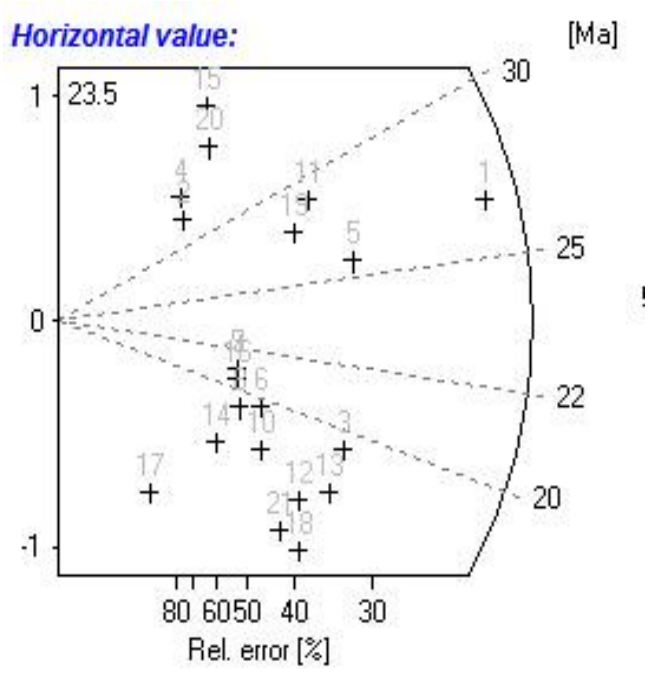

Chi-sq.: $\quad 7.76$

$\mathrm{P}(\%) \quad 99.33$

Dispersion: $\quad 0.00$

RhoD: 12.79

Nd: 8043

U standard CN_5

Zeta $\pm 1 \sigma \quad 339 \pm 6.5$

counted by RJ

\begin{tabular}{ccccccccc} 
Crystal & Ns & Ni & Area & RhoS(e5) & RhoI(e5) & Age(Ma) & $+-1 \mathrm{~s}$ & U(ppm) \\
\hline 1 & 23 & 188 & 20 & 11.50 & 94.00 & 26.47 & 5.88 & 84.51 \\
2 & 2 & 13 & 9 & 2.22 & 14.44 & 33.27 & 25.28 & 12.99 \\
3 & 10 & 111 & 12 & 8.33 & 92.50 & 19.50 & 6.45 & 83.16 \\
4 & 2 & 12 & 24 & 0.83 & 5.00 & 36.04 & 27.54 & 4.50 \\
5 & 11 & 93 & 21 & 5.24 & 44.29 & 25.60 & 8.18 & 39.81 \\
6 & 5 & 55 & 9 & 5.56 & 61.11 & 19.68 & 9.20 & 54.94 \\
7 & 4 & 41 & 12 & 3.33 & 34.17 & 21.12 & 11.07 & 30.72 \\
8 & 4 & 45 & 24 & 1.67 & 18.75 & 19.24 & 10.05 & 16.86 \\
9 & 4 & 41 & 9 & 4.44 & 45.56 & 21.12 & 11.07 & 40.96 \\
10 & 5 & 60 & 12 & 4.17 & 50.00 & 18.04 & 8.41 & 44.95 \\
11 & 8 & 60 & 20 & 4.00 & 30.00 & 28.85 & 10.88 & 26.97 \\
12 & 7 & 88 & 15 & 4.67 & 58.67 & 17.22 & 6.78 & 52.74 \\
13 & 9 & 108 & 36 & 2.50 & 30.00 & 18.04 & 6.27 & 26.97 \\
14 & 3 & 38 & 28 & 1.07 & 13.57 & 17.10 & 10.26 & 12.20 \\
15 & 3 & 15 & 16 & 1.88 & 9.38 & 43.22 & 27.35 & 8.43 \\
16 & 4 & 42 & 20 & 2.00 & 21.00 & 20.62 & 10.80 & 18.88 \\
17 & 1 & 20 & 16 & 0.63 & 12.50 & 10.83 & 11.10 & 11.24 \\
18 & 7 & 96 & 15 & 4.67 & 64.00 & 15.79 & 6.19 & 57.54 \\
19 & 7 & 55 & 12 & 5.83 & 45.83 & 27.54 & 11.07 & 41.21 \\
20 & 3 & 17 & 9 & 3.33 & 18.89 & 38.15 & 23.91 & 16.98 \\
21 & 6 & 82 & 18 & 3.33 & 45.56 & 15.85 & 6.71 & 40.96 \\
\hline
\end{tabular}


Sample number: JR12-01

Mineral: Apatite

Irradiation code: vuw011-9

Ns: 52

Ni: 1054

Area: 326

RhoS: 1.595

RhoI: 32.33

Pooled Age: $\quad 11.3 \pm 1.6$

Mean Age: $\quad 11.2 \pm 1.2$

Central Age: $11.3 \pm 1.6$

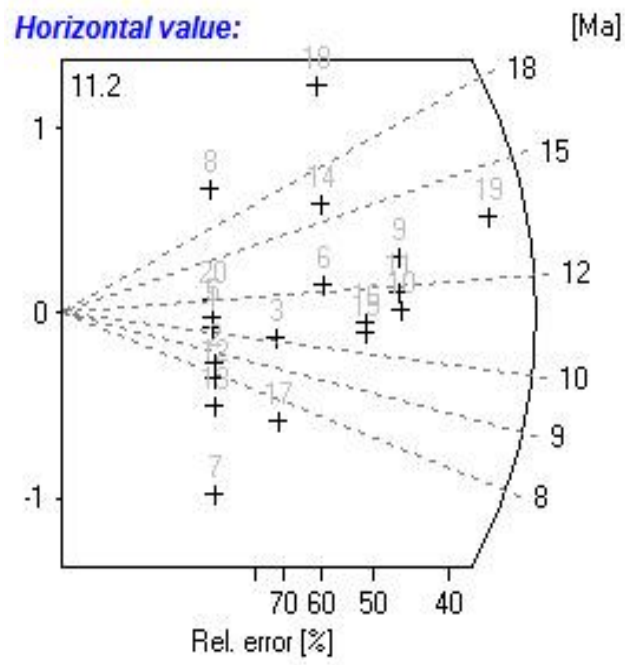

Chi-sq.: $\quad 5.17$

$\mathrm{P}(\%) \quad 99.93$

Dispersion: 0.00

RhoD: 13.52

Nd: 8043

U standard CN_5

Zeta $\pm 1 \sigma \quad 339 \pm 6.5$

counted by RJ

\begin{tabular}{ccccccccc} 
Crystal & Ns & Ni & Area & RhoS(e5) & Rhol(e5) & Age(Ma) & $+-1 \mathrm{~s}$ & U(ppm) \\
\hline 1 & 1 & 22 & 12 & 0.83 & 18.33 & 10.40 & 10.64 & 15.60 \\
2 & 1 & 27 & 16 & 0.63 & 16.88 & 8.48 & 8.64 & 14.36 \\
3 & 2 & 45 & 9 & 2.22 & 50.00 & 10.17 & 7.36 & 42.55 \\
4 & 0 & 10 & 12 & 0.00 & 8.33 & 0.00 & 0.00 & 7.09 \\
5 & 1 & 21 & 6 & 1.67 & 35.00 & 10.90 & 11.16 & 29.78 \\
6 & 3 & 56 & 20 & 1.50 & 28.00 & 12.26 & 7.27 & 23.83 \\
7 & 1 & 55 & 35 & 0.29 & 15.71 & 44.16 & 4.20 & 3.37 \\
8 & 1 & 10 & 9 & 1.11 & 11.11 & 22.87 & 23.99 & 9.46 \\
9 & 5 & 89 & 12 & 4.17 & 74.17 & 12.86 & 5.92 & 63.11 \\
10 & 5 & 101 & 12 & 4.17 & 84.17 & 11.33 & 5.20 & 71.62 \\
11 & 5 & 97 & 35 & 1.43 & 27.71 & 11.80 & 5.42 & 23.58 \\
12 & 1 & 29 & 25 & 0.40 & 11.60 & 7.89 & 8.03 & 9.87 \\
13 & 1 & 34 & 20 & 0.50 & 17.00 & 6.73 & 6.83 & 14.47 \\
14 & 3 & 43 & 16 & 1.88 & 26.88 & 15.96 & 9.54 & 22.87 \\
15 & 4 & 86 & 15 & 2.67 & 57.33 & 10.65 & 5.45 & 48.79 \\
16 & 4 & 84 & 16 & 2.50 & 52.50 & 10.90 & 5.58 & 44.67 \\
17 & 2 & 62 & 16 & 1.25 & 38.75 & 7.39 & 5.31 & 32.97 \\
18 & 3 & 29 & 12 & 2.50 & 24.17 & 23.66 & 14.36 & 20.56 \\
19 & 8 & 135 & 20 & 4.00 & 67.50 & 13.56 & 4.94 & 57.44 \\
20 & 1 & 19 & 8 & 1.25 & 23.75 & 12.05 & 12.36 & 20.21 \\
\hline
\end{tabular}


Sample number: JR12-03

Mineral: Apatite

Irradiation code: vuw013-27

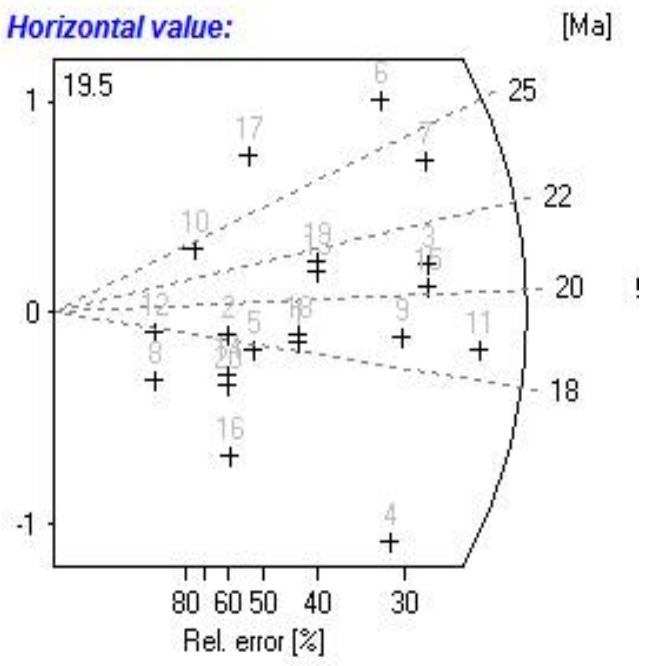

Chi-sq.: $\quad 4.42$

$\mathrm{P}(\%) \quad 99.98$

Dispersion: $\quad 0.00$

RhoD: 11.59

Nd: 7438

U standard CN_5

Zeta $\pm 1 \sigma \quad 339 \pm 6.5$

counted by RJ

\begin{tabular}{ccccccccc} 
Crystal & $\mathrm{Ns}$ & $\mathrm{Ni}$ & Area & RhoS(e5) & RhoI(e5) & Age(Ma) & $+-1 \mathrm{~s}$ & $\mathrm{U}(\mathrm{ppm})$ \\
\hline 1 & 6 & 64 & 12 & 5.00 & 53.33 & 18.40 & 7.87 & 52.90 \\
2 & 3 & 32 & 12 & 2.50 & 26.67 & 18.40 & 11.12 & 26.45 \\
3 & 14 & 132 & 15 & 9.33 & 88.00 & 20.81 & 5.87 & 87.29 \\
4 & 11 & 155 & 21 & 5.24 & 73.81 & 13.93 & 4.36 & 73.21 \\
5 & 4 & 44 & 16 & 2.50 & 27.50 & 17.84 & 9.33 & 27.28 \\
6 & 11 & 80 & 16 & 6.88 & 50.00 & 26.97 & 8.69 & 49.59 \\
7 & 14 & 115 & 15 & 9.33 & 76.67 & 23.88 & 6.78 & 76.05 \\
8 & 1 & 14 & 20 & 0.50 & 7.00 & 14.02 & 14.52 & 6.94 \\
9 & 12 & 125 & 20 & 6.00 & 62.50 & 18.84 & 5.71 & 61.99 \\
10 & 2 & 16 & 18 & 1.11 & 8.89 & 24.52 & 18.40 & 8.82 \\
11 & 18 & 189 & 24 & 7.50 & 78.75 & 18.69 & 4.63 & 78.11 \\
12 & 1 & 11 & 16 & 0.63 & 6.88 & 17.84 & 18.64 & 6.82 \\
13 & 7 & 65 & 20 & 3.50 & 32.50 & 21.13 & 8.42 & 32.24 \\
14 & 3 & 36 & 18 & 1.67 & 20.00 & 16.36 & 9.84 & 19.84 \\
15 & 14 & 136 & 9 & 15.56 & 151.11 & 20.20 & 5.69 & 149.89 \\
16 & 3 & 45 & 12 & 2.50 & 37.50 & 13.09 & 7.81 & 37.20 \\
17 & 4 & 27 & 20 & 2.00 & 13.50 & 29.05 & 15.58 & 13.39 \\
18 & 6 & 63 & 12 & 5.00 & 52.50 & 18.69 & 8.00 & 52.07 \\
19 & 7 & 64 & 9 & 7.78 & 71.11 & 21.46 & 8.56 & 70.53 \\
20 & 3 & 37 & 9 & 3.33 & 41.11 & 15.92 & 9.56 & 40.78 \\
\hline
\end{tabular}


Sample number: JR12-04

Mineral: Apatite

Irradiation code: vuw013-25

Ns: 206

Ni: 1727

Area: 416

RhoS: 4.952

RhoI: 41.51

Pooled Age: $\quad 23.8 \pm 1.8$

Mean Age: $\quad 23.4 \pm 1.3$

Central Age: $23.8 \pm 1.8$

Chi-sq.: $\quad 9.17$

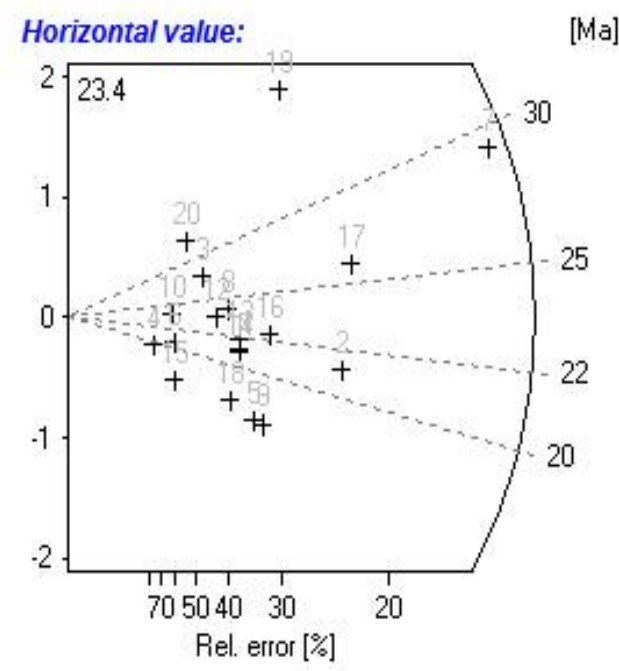

$\mathrm{P}(\%) \quad 97.05$

Dispersion: $\quad 0.00$

RhoD: 11.80

Nd: 7438

U standard CN_5

Zeta $\pm 1 \sigma \quad 339 \pm 6.5$

counted by RJ

\begin{tabular}{ccccccccc} 
Crystal & $\mathrm{Ns}$ & $\mathrm{Ni}$ & Area & RhoS(e5) & Rhol(e5) & Age(Ma) & $+-1 \mathrm{~s}$ & $\mathrm{U}(\mathrm{ppm})$ \\
\hline 1 & 8 & 76 & 24 & 3.33 & 31.67 & 21.02 & 7.83 & 30.86 \\
2 & 20 & 189 & 24 & 8.33 & 78.75 & 21.13 & 4.99 & 76.75 \\
3 & 5 & 36 & 12 & 4.17 & 30.00 & 27.72 & 13.24 & 29.24 \\
4 & 2 & 20 & 16 & 1.25 & 12.50 & 19.97 & 14.82 & 12.18 \\
5 & 9 & 103 & 30 & 3.00 & 34.33 & 17.45 & 6.08 & 33.46 \\
6 & 3 & 29 & 20 & 1.50 & 14.50 & 20.66 & 12.54 & 14.13 \\
7 & 49 & 336 & 24 & 20.42 & 140.00 & 29.10 & 4.50 & 136.44 \\
8 & 7 & 58 & 15 & 4.67 & 38.67 & 24.10 & 9.66 & 37.68 \\
9 & 10 & 114 & 16 & 6.25 & 71.25 & 17.52 & 5.79 & 69.44 \\
10 & 3 & 25 & 21 & 1.43 & 11.91 & 23.96 & 14.65 & 11.60 \\
11 & 8 & 75 & 16 & 5.00 & 46.88 & 21.30 & 7.94 & 45.68 \\
12 & 6 & 51 & 20 & 3.00 & 25.50 & 23.49 & 10.15 & 24.85 \\
13 & 8 & 73 & 36 & 2.22 & 20.28 & 21.88 & 8.16 & 19.76 \\
14 & 8 & 76 & 16 & 5.00 & 47.50 & 21.02 & 7.83 & 46.29 \\
15 & 3 & 35 & 15 & 2.00 & 23.33 & 17.12 & 10.31 & 22.74 \\
16 & 11 & 98 & 24 & 4.58 & 40.83 & 22.41 & 7.14 & 39.80 \\
17 & 22 & 169 & 25 & 8.80 & 67.60 & 25.99 & 5.92 & 65.88 \\
18 & 7 & 78 & 18 & 3.89 & 43.33 & 17.93 & 7.08 & 42.23 \\
19 & 13 & 62 & 20 & 6.50 & 31.00 & 41.80 & 12.79 & 30.21 \\
20 & 4 & 24 & 24 & 1.67 & 10.00 & 33.25 & 17.97 & 9.75 \\
\hline
\end{tabular}


Sample number: JR12-05

Mineral: Apatite

Irradiation code: vuw013-21

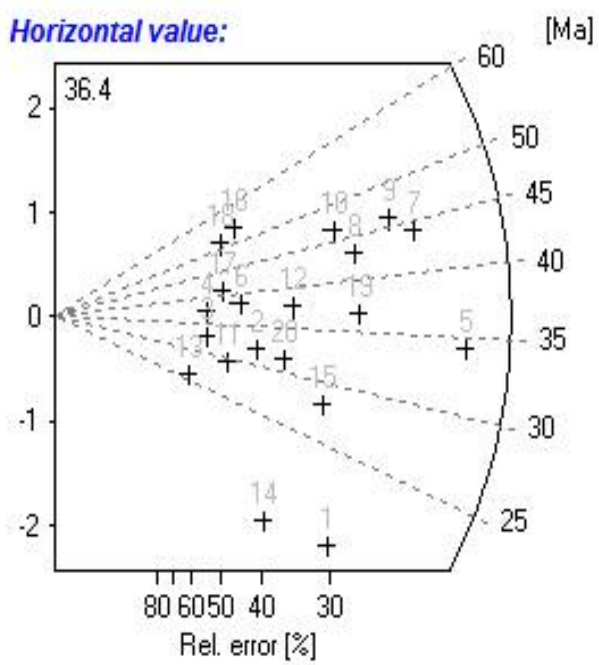

Chi-sq.: $\quad 14.65$

$\mathrm{P}(\%) \quad 74.44$

Dispersion: 0.06

RhoD: $\quad 12.24$

Nd: 7438

U standard CN_5

Zeta $\pm 1 \sigma \quad 339 \pm 6.5$

counted by RJ

\begin{tabular}{ccccccccc} 
Crystal & $\mathrm{Ns}$ & $\mathrm{Ni}$ & Area & RhoS(e5) & RhoI(e5) & Age(Ma) & $+-1 \mathrm{~s}$ & $\mathrm{U}(\mathrm{ppm})$ \\
\hline 1 & 2 & 132 & 25 & 4.80 & 52.80 & 18.83 & 5.69 & 49.61 \\
2 & 7 & 45 & 9 & 7.78 & 50.00 & 32.19 & 13.10 & 46.98 \\
3 & 4 & 25 & 16 & 2.50 & 15.63 & 33.11 & 17.84 & 14.68 \\
4 & 4 & 22 & 32 & 1.25 & 6.88 & 37.61 & 20.46 & 6.46 \\
5 & 29 & 175 & 30 & 9.67 & 58.33 & 34.29 & 6.92 & 54.81 \\
6 & 6 & 32 & 12 & 5.00 & 26.67 & 38.78 & 17.27 & 25.06 \\
7 & 23 & 108 & 9 & 25.56 & 120.00 & 44.03 & 10.16 & 12.76 \\
8 & 16 & 77 & 9 & 17.78 & 85.56 & 42.96 & 11.84 & 80.39 \\
9 & 20 & 90 & 24 & 8.33 & 37.50 & 45.94 & 11.40 & 35.24 \\
10 & 14 & 62 & 25 & 5.60 & 24.80 & 46.68 & 13.85 & 23.30 \\
11 & 5 & 35 & 24 & 2.08 & 14.58 & 29.57 & 14.15 & 13.70 \\
12 & 10 & 55 & 16 & 6.25 & 34.38 & 37.61 & 12.96 & 32.30 \\
13 & 3 & 24 & 35 & 0.86 & 6.86 & 25.88 & 15.86 & 6.44 \\
14 & 7 & 86 & 32 & 2.19 & 26.88 & 16.86 & 6.64 & 25.25 \\
15 & 12 & 88 & 40 & 3.00 & 22.00 & 28.23 & 8.71 & 20.67 \\
16 & 6 & 23 & 49 & 1.22 & 4.69 & 53.89 & 24.73 & 4.41 \\
17 & 5 & 25 & 24 & 2.08 & 10.42 & 41.36 & 20.28 & 9.79 \\
18 & 5 & 20 & 16 & 3.13 & 12.50 & 51.66 & 25.85 & 11.75 \\
19 & 16 & 90 & 40 & 4.00 & 22.50 & 36.78 & 10.01 & 21.14 \\
20 & 9 & 59 & 35 & 2.57 & 16.86 & 31.57 & 11.32 & 15.84 \\
\hline
\end{tabular}


Sample number: JR12-07

Mineral: Apatite

Irradiation code: vuw013-18

Ns: 305

Ni: 2537

Area: 883

RhoS: 3.454

RhoI: 28.73

Pooled Age: $\quad 25.7 \pm 1.7$

Mean Age: $25.8 \pm 1.1$

Central Age: $25.7 \pm 1.7$

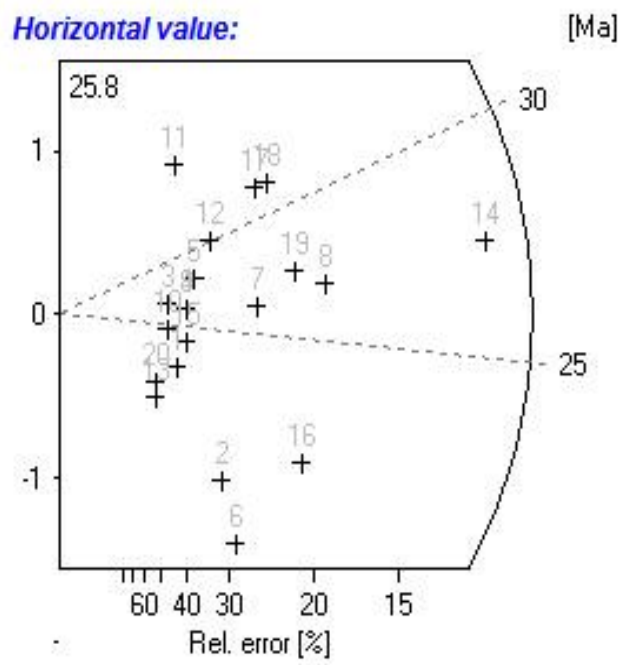

Chi-sq.: $\quad 7.11$

$\mathrm{P}(\%) \quad 99.36$

Dispersion: 0.00

RhoD: 12.63

Nd: 7438

U standard CN_5

Zeta $\pm 1 \sigma \quad 339 \pm 6.5$

counted by RJ

\begin{tabular}{ccccccccc} 
Crystal & $\mathrm{Ns}$ & $\mathrm{Ni}$ & Area & RhoS(e5) & Rhol(e5) & Age(Ma) & $+-1 \mathrm{~s}$ & $\mathrm{U}(\mathrm{ppm})$ \\
\hline 1 & 6 & 57 & 42 & 1.43 & 13.57 & 22.49 & 9.67 & 12.36 \\
2 & 11 & 125 & 28 & 3.93 & 44.64 & 18.81 & 5.93 & 40.66 \\
3 & 5 & 40 & 30 & 1.67 & 13.33 & 26.70 & 12.68 & 12.14 \\
4 & 7 & 57 & 50 & 1.40 & 11.40 & 26.23 & 10.52 & 10.38 \\
5 & 8 & 61 & 18 & 4.44 & 33.89 & 28.01 & 10.55 & 30.87 \\
6 & 13 & 161 & 70 & 1.86 & 23.00 & 17.26 & 4.99 & 20.95 \\
7 & 17 & 139 & 30 & 5.67 & 46.33 & 26.12 & 6.74 & 42.20 \\
8 & 31 & 247 & 25 & 12.40 & 98.80 & 26.81 & 5.14 & 89.99 \\
9 & 7 & 57 & 28 & 2.50 & 20.36 & 26.23 & 10.52 & 18.54 \\
10 & 5 & 43 & 30 & 1.67 & 14.33 & 24.84 & 11.75 & 13.06 \\
11 & 6 & 33 & 24 & 2.50 & 13.75 & 38.80 & 17.24 & 12.52 \\
12 & 10 & 71 & 70 & 1.43 & 10.14 & 30.07 & 10.18 & 9.24 \\
13 & 4 & 43 & 30 & 1.33 & 14.33 & 19.88 & 10.40 & 13.06 \\
14 & 79 & 619 & 100 & 7.90 & 61.90 & 27.26 & 3.31 & 56.38 \\
15 & 7 & 62 & 70 & 1.00 & 8.86 & 24.12 & 9.63 & 8.07 \\
16 & 25 & 250 & 36 & 6.94 & 69.44 & 21.37 & 4.51 & 63.25 \\
17 & 17 & 115 & 50 & 3.40 & 23.00 & 31.56 & 8.23 & 20.95 \\
18 & 19 & 129 & 50 & 3.80 & 25.80 & 31.45 & 7.76 & 23.50 \\
19 & 24 & 187 & 60 & 4.00 & 31.17 & 27.41 & 5.98 & 28.39 \\
20 & 4 & 41 & 42 & 0.95 & 9.76 & 20.85 & 10.93 & 8.89 \\
\hline
\end{tabular}


Sample number: JR12-08

Mineral: Apatite

Irradiation code: vuw013-17

Ns: 119

Ni: 702

Area: 261

RhoS: 4.559

RhoI: 26.9

Pooled Age: $\quad 36.5 \pm 3.7$

Mean Age: $\quad 37.5 \pm 1.8$

Central Age: $\quad 36.5 \pm 3.7$

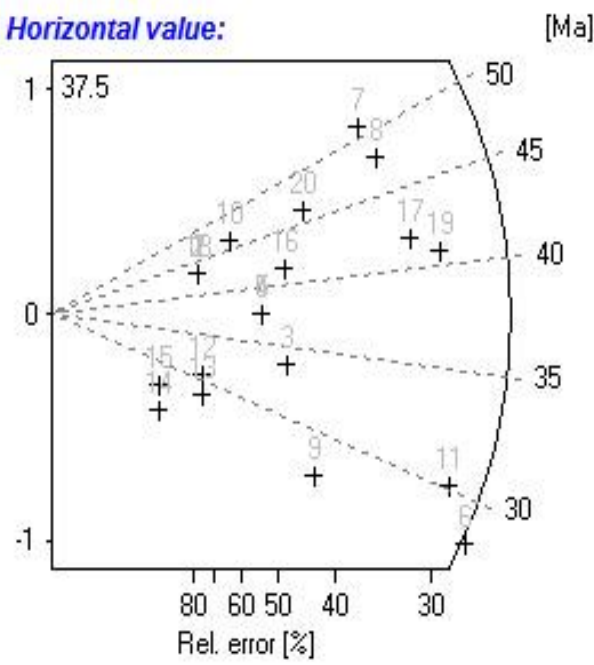

Chi-sq.: $\quad 4.53$

$\mathrm{P}(\%) \quad 99.97$

Dispersion: 0.00

RhoD: 12.76

Nd: 7438

U standard CN_5

Zeta $\pm 1 \sigma \quad 339 \pm 6.5$

counted by RJ

\begin{tabular}{ccccccccc} 
Crystal & $\mathrm{Ns}$ & $\mathrm{Ni}$ & Area & RhoS(e5) & RhoI(e5) & Age(Ma) & $+-1 \mathrm{~s}$ & $\mathrm{U}(\mathrm{ppm})$ \\
\hline 1 & 2 & 10 & 6 & 3.33 & 16.67 & 43.10 & 33.40 & 15.03 \\
2 & 2 & 10 & 12 & 1.67 & 8.33 & 43.10 & 33.40 & 7.51 \\
3 & 5 & 32 & 6 & 8.33 & 53.33 & 33.70 & 16.22 & 48.08 \\
4 & 4 & 23 & 12 & 3.33 & 19.17 & 37.49 & 20.33 & 17.28 \\
5 & 4 & 23 & 6 & 6.67 & 38.33 & 37.49 & 20.33 & 34.56 \\
6 & 15 & 114 & 12 & 12.50 & 95.00 & 28.39 & 7.82 & 85.65 \\
7 & 9 & 38 & 6 & 15.00 & 63.33 & 51.01 & 18.94 & 57.10 \\
8 & 10 & 45 & 12 & 8.33 & 37.50 & 47.87 & 16.77 & 33.81 \\
9 & 6 & 47 & 20 & 3.00 & 23.50 & 27.54 & 11.96 & 21.19 \\
10 & 3 & 14 & 9 & 3.33 & 15.56 & 46.17 & 29.39 & 14.02 \\
11 & 14 & 100 & 60 & 2.33 & 16.67 & 30.20 & 8.64 & 15.03 \\
12 & 2 & 14 & 9 & 2.22 & 15.56 & 30.82 & 23.30 & 14.02 \\
13 & 2 & 15 & 9 & 2.22 & 16.67 & 28.77 & 21.66 & 15.03 \\
14 & 1 & 9 & 12 & 0.83 & 7.50 & 23.98 & 25.28 & 6.76 \\
15 & 1 & 8 & 12 & 0.83 & 6.67 & 26.97 & 28.61 & 6.01 \\
16 & 5 & 26 & 12 & 4.17 & 21.67 & 41.45 & 20.26 & 19.53 \\
17 & 12 & 62 & 12 & 10.00 & 51.67 & 41.71 & 13.19 & 46.58 \\
18 & 2 & 10 & 9 & 2.22 & 11.11 & 43.10 & 33.40 & 10.02 \\
19 & 14 & 74 & 15 & 9.33 & 49.33 & 40.78 & 11.92 & 44.48 \\
20 & 6 & 28 & 10 & 6.00 & 28.00 & 46.17 & 20.79 & 25.24 \\
\hline
\end{tabular}


Sample number: JR12-09

Mineral: Apatite

Irradiation code: vuw013-14

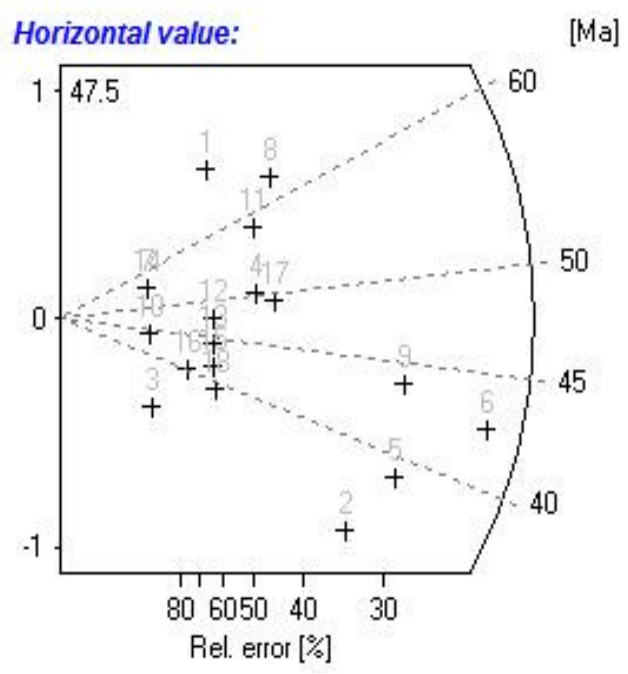

Chi-sq.: 2.67

$\mathrm{P}(\%) \quad 100$

Dispersion: $\quad 0.00$

RhoD: $\quad 13.14$

Nd: 7438

U standard CN_5

Zeta $\pm 1 \sigma \quad 339 \pm 6.5$

counted by RJ

\begin{tabular}{ccccccccc} 
Crystal & Ns & Ni & Area & RhoS(e5) & RhoI(e5) & Age(Ma) & $+-1 \mathrm{~s}$ & U(ppm) \\
\hline 1 & 3 & 9 & 9 & 3.33 & 10.00 & 73.84 & 49.25 & 8.75 \\
2 & 10 & 64 & 15 & 6.67 & 42.67 & 34.72 & 11.83 & 37.33 \\
3 & 1 & 7 & 9 & 1.11 & 7.78 & 31.75 & 33.95 & 6.81 \\
4 & 5 & 22 & 9 & 5.56 & 24.44 & 50.44 & 25.01 & 21.39 \\
5 & 14 & 80 & 10 & 14.00 & 80.00 & 38.87 & 11.29 & 70.00 \\
6 & 23 & 120 & 9 & 25.56 & 133.33 & 42.56 & 9.73 & 116.66 \\
7 & 1 & 4 & 9 & 1.11 & 4.44 & 55.46 & 62.02 & 3.89 \\
8 & 6 & 21 & 15 & 4.00 & 14.00 & 63.34 & 29.36 & 12.25 \\
9 & 15 & 76 & 9 & 16.67 & 84.44 & 43.82 & 12.42 & 73.89 \\
10 & 1 & 5 & 12 & 0.83 & 4.17 & 44.41 & 48.65 & 3.65 \\
11 & 5 & 19 & 9 & 5.56 & 21.11 & 58.37 & 29.37 & 18.47 \\
12 & 3 & 14 & 12 & 2.50 & 11.67 & 47.57 & 30.28 & 10.21 \\
13 & 3 & 15 & 12 & 2.50 & 12.50 & 44.41 & 28.10 & 10.94 \\
14 & 1 & 4 & 9 & 1.11 & 4.44 & 55.46 & 62.02 & 3.89 \\
15 & 3 & 16 & 16 & 1.88 & 10.00 & 41.64 & 26.21 & 8.75 \\
16 & 2 & 11 & 6 & 3.33 & 18.33 & 40.38 & 31.05 & 16.04 \\
17 & 6 & 27 & 9 & 6.67 & 30.00 & 49.32 & 22.29 & 26.25 \\
18 & 3 & 17 & 6 & 5.00 & 28.33 & 39.20 & 24.56 & 24.79 \\
\hline
\end{tabular}


Sample number: JR12-10

Mineral: Apatite

Irradiation code: vuw013-13

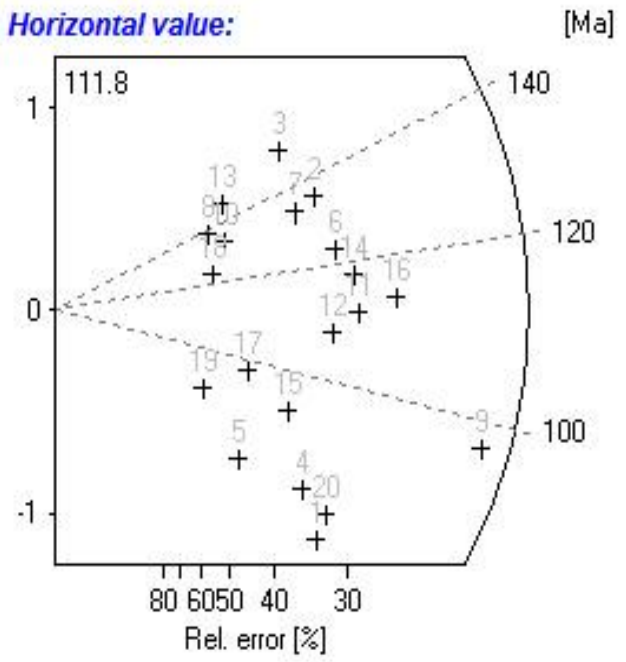

Chi-sq.: $\quad 6.29$

$\mathrm{P}(\%) \quad 99.71$

Dispersion: $\quad 0.00$

RhoD: 13.27

Nd: 7438

U standard CN_5

Zeta $\pm 1 \sigma \quad 339 \pm 6.5$

counted by RJ

\begin{tabular}{ccccccccc} 
Crystal & $\mathrm{Ns}$ & $\mathrm{Ni}$ & Area & RhoS(e5) & RhoI(e5) & Age(Ma) & $+-1 \mathrm{~s}$ & $\mathrm{U}(\mathrm{ppm})$ \\
\hline 1 & 12 & 35 & 12 & 10.00 & 29.17 & 76.68 & 25.71 & 25.27 \\
2 & 14 & 23 & 25 & 5.60 & 9.20 & 135.51 & 46.04 & 7.97 \\
3 & 11 & 16 & 25 & 4.40 & 6.40 & 152.85 & 59.97 & 5.55 \\
4 & 11 & 30 & 20 & 5.50 & 15.00 & 81.97 & 28.95 & 13.00 \\
5 & 6 & 17 & 9 & 6.67 & 18.89 & 78.92 & 37.52 & 16.37 \\
6 & 16 & 29 & 16 & 10.00 & 18.13 & 122.95 & 38.39 & 15.70 \\
7 & 12 & 20 & 12 & 10.00 & 16.67 & 133.60 & 48.87 & 14.44 \\
8 & 5 & 8 & 12 & 4.17 & 6.67 & 139.11 & 79.36 & 5.78 \\
9 & 34 & 78 & 12 & 28.33 & 65.00 & 97.33 & 20.12 & 56.32 \\
10 & 6 & 10 & 16 & 3.75 & 6.25 & 133.60 & 69.05 & 5.42 \\
11 & 18 & 36 & 6 & 30.00 & 60.00 & 111.52 & 32.29 & 51.99 \\
12 & 15 & 31 & 16 & 9.38 & 19.38 & 107.96 & 34.04 & 16.79 \\
13 & 6 & 9 & 20 & 3.00 & 4.50 & 148.27 & 78.22 & 3.90 \\
14 & 18 & 34 & 12 & 15.00 & 28.33 & 118.02 & 34.50 & 24.55 \\
15 & 10 & 24 & 25 & 4.00 & 9.60 & 93.07 & 35.09 & 8.32 \\
16 & 23 & 45 & 16 & 14.38 & 28.13 & 113.98 & 29.33 & 24.37 \\
17 & 7 & 16 & 18 & 3.89 & 8.89 & 97.69 & 44.32 & 7.70 \\
18 & 5 & 9 & 9 & 5.56 & 10.00 & 123.80 & 69.11 & 8.66 \\
19 & 4 & 10 & 24 & 1.67 & 4.17 & 89.37 & 52.91 & 3.61 \\
20 & 13 & 36 & 12 & 10.83 & 30.00 & 80.74 & 26.19 & 25.99 \\
\hline
\end{tabular}


Sample number: JR12-11

Mineral: Apatite

Irradiation code: vuw013-12

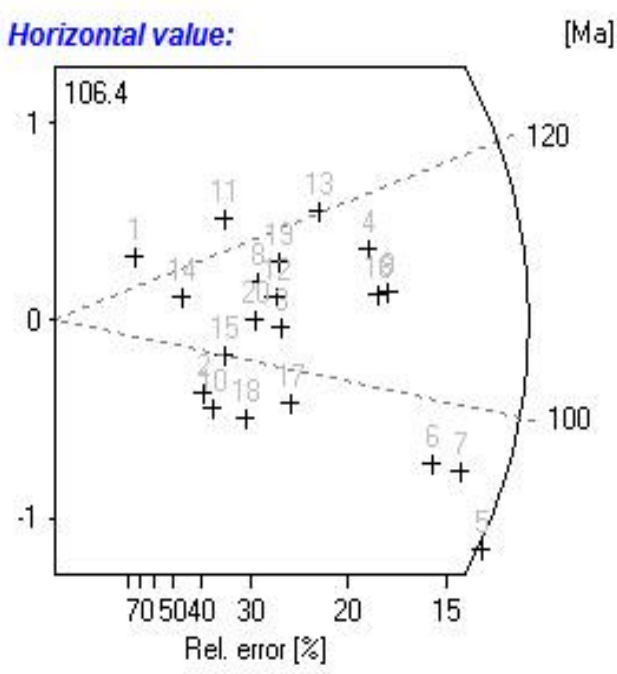

Chi-sq.: $\quad 3.8$

$\mathrm{P}(\%) \quad 99.99$

Dispersion: 0.00

RhoD: $\quad 13.40$

Nd: 7438

U standard CN_5

Zeta $\pm 1 \sigma \quad 339 \pm 6.5$

counted by RJ

\begin{tabular}{ccccccccc} 
Crystal & $\mathrm{Ns}$ & $\mathrm{Ni}$ & Area & RhoS(e5) & Rhol(e5) & Age(Ma) & $+-1 \mathrm{~s}$ & $\mathrm{U}(\mathrm{ppm})$ \\
\hline 1 & 3 & 5 & 15 & 2.00 & 3.33 & 134.89 & 98.55 & 2.86 \\
2 & 9 & 22 & 16 & 5.63 & 13.75 & 92.27 & 36.57 & 11.80 \\
3 & 22 & 47 & 12 & 18.33 & 39.17 & 105.47 & 27.35 & 33.61 \\
4 & 43 & 85 & 25 & 17.20 & 34.00 & 113.91 & 21.47 & 29.18 \\
5 & 74 & 184 & 32 & 23.13 & 57.50 & 90.72 & 12.65 & 49.34 \\
6 & 59 & 140 & 20 & 29.50 & 70.00 & 95.04 & 14.90 & 60.07 \\
7 & 68 & 161 & 161 & 4.22 & 10.00 & 95.24 & 13.94 & 8.58 \\
8 & 18 & 36 & 36 & 5.00 & 10.00 & 112.60 & 32.60 & 8.58 \\
9 & 48 & 99 & 99 & 4.85 & 10.00 & 109.22 & 19.36 & 8.58 \\
10 & 10 & 25 & 25 & 4.00 & 10.00 & 90.24 & 33.82 & 8.58 \\
11 & 13 & 23 & 15 & 8.67 & 15.33 & 127.14 & 44.21 & 13.16 \\
12 & 21 & 43 & 30 & 7.00 & 14.33 & 110.00 & 29.39 & 12.30 \\
13 & 31 & 58 & 30 & 10.33 & 19.33 & 120.29 & 26.90 & 16.59 \\
14 & 7 & 14 & 24 & 2.92 & 5.83 & 112.60 & 52.18 & 5.01 \\
15 & 12 & 27 & 9 & 13.33 & 30.00 & 100.19 & 34.83 & 25.74 \\
16 & 45 & 93 & 20 & 22.50 & 46.50 & 109.00 & 19.94 & 39.90 \\
17 & 23 & 54 & 16 & 14.38 & 33.75 & 96.04 & 24.01 & 28.96 \\
18 & 15 & 37 & 15 & 10.00 & 24.67 & 91.45 & 28.07 & 21.17 \\
19 & 22 & 43 & 20 & 11.00 & 21.50 & 115.20 & 30.31 & 18.45 \\
20 & 17 & 36 & 30 & 5.67 & 12.00 & 106.40 & 31.40 & 10.30 \\
\hline
\end{tabular}


Sample number: JR12-12

Mineral: Apatite

Irradiation code: vuw013-10

Ns: 512

Ni: 1127

Area: 535

RhoS: $\quad 9.57$

RhoI: 21.07

Pooled Age: $\quad 104.3 \pm 6.0$

Mean Age: $\quad 103.8 \pm 4.6$

Central Age: $\quad 104.3 \pm 6.0$

Chi-sq.: $\quad 8.13$

$\mathrm{P}(\%) \quad 98.53$

Dispersion: 0.00

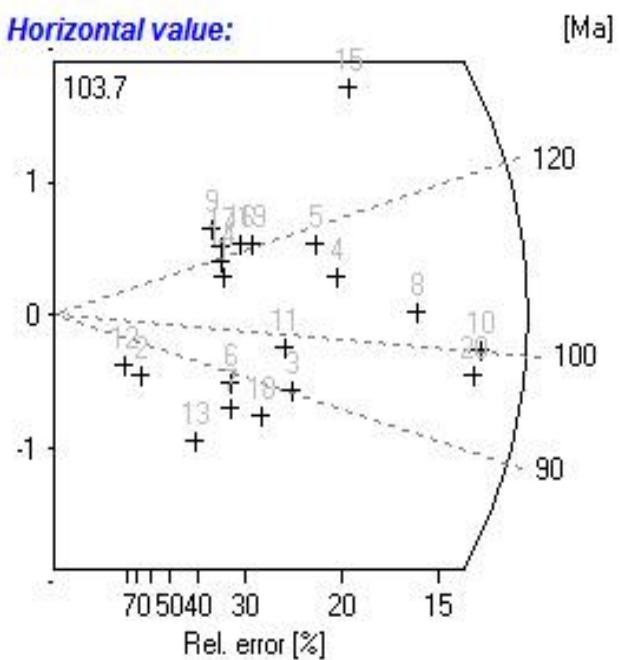

RhoD: 13.66

Nd: 7438

U standard CN_5

Zeta $\pm 1 \sigma \quad 339 \pm 6.5$

counted by RJ

\begin{tabular}{ccccccccc} 
Crystal & $\mathrm{Ns}$ & $\mathrm{Ni}$ & Area & RhoS(e5) & RhoI(e5) & Age(Ma) & $+-1 \mathrm{~s}$ & $\mathrm{U}(\mathrm{ppm})$ \\
\hline 1 & 13 & 26 & 15 & 8.67 & 17.33 & 114.75 & 39.06 & 14.59 \\
2 & 3 & 9 & 16 & 1.88 & 5.63 & 76.73 & 51.18 & 4.74 \\
3 & 24 & 61 & 49 & 4.90 & 12.45 & 90.47 & 21.89 & 10.48 \\
4 & 36 & 75 & 25 & 14.40 & 30.00 & 110.20 & 22.48 & 25.26 \\
5 & 31 & 61 & 40 & 7.75 & 15.25 & 116.62 & 25.85 & 12.84 \\
6 & 13 & 34 & 20 & 6.50 & 17.00 & 87.94 & 28.74 & 14.31 \\
7 & 13 & 36 & 20 & 6.50 & 18.00 & 83.08 & 26.95 & 15.15 \\
8 & 58 & 128 & 30 & 19.33 & 42.67 & 104.08 & 16.64 & 35.92 \\
9 & 12 & 21 & 9 & 13.33 & 23.33 & 130.98 & 47.49 & 19.64 \\
10 & 79 & 181 & 18 & 43.89 & 100.56 & 100.28 & 13.71 & 84.65 \\
11 & 23 & 54 & 12 & 19.17 & 45.00 & 97.88 & 24.47 & 37.88 \\
12 & 2 & 6 & 12 & 1.67 & 5.00 & 76.73 & 62.67 & 4.21 \\
13 & 8 & 26 & 54 & 1.48 & 4.82 & 70.86 & 28.69 & 4.05 \\
14 & 13 & 25 & 18 & 7.22 & 13.89 & 119.30 & 40.88 & 11.69 \\
15 & 43 & 68 & 20 & 21.50 & 34.00 & 144.79 & 28.40 & 28.62 \\
16 & 16 & 30 & 35 & 4.57 & 8.57 & 122.33 & 37.97 & 7.22 \\
17 & 13 & 24 & 42 & 3.10 & 5.71 & 124.22 & 42.87 & 4.81 \\
18 & 18 & 49 & 40 & 4.50 & 12.25 & 84.51 & 23.37 & 10.31 \\
19 & 18 & 34 & 25 & 7.20 & 13.60 & 121.44 & 35.50 & 11.45 \\
20 & 76 & 179 & 35 & 21.71 & 51.14 & 97.57 & 13.54 & 43.05 \\
\hline
\end{tabular}


Sample number: JR12-13

Mineral: Apatite

Irradiation code: vuw013-7

Ns: 383

Ni: 1037

Area: 454

RhoS: 8.436

RhoI: 22.84

Pooled Age: $\quad 87.4 \pm 5.6$

Mean Age: $\quad 92.3 \pm 5.2$

Central Age: $87.4 \pm 5.6$

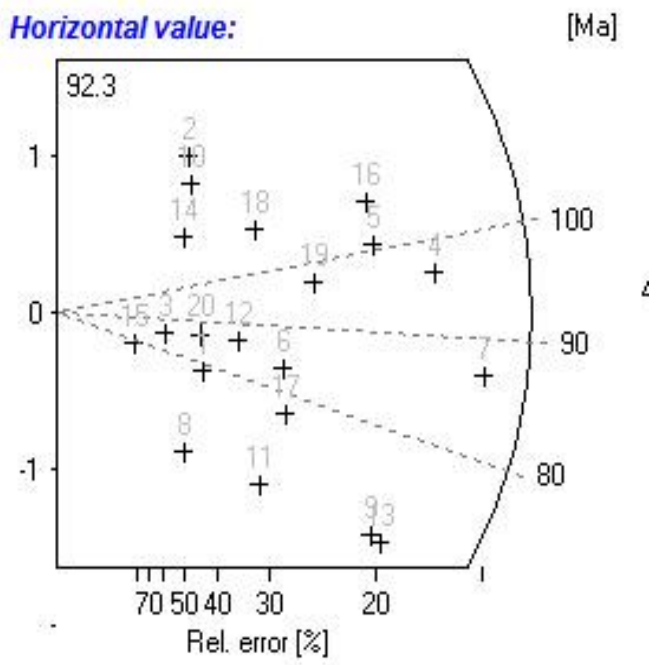

Chi-sq.: $\quad 9.66$

$\mathrm{P}(\%) \quad 96.09$

Dispersion: $\quad 0.00$

RhoD: $\quad 14.05$

Nd: 7438

U standard CN_5

Zeta $\pm 1 \sigma \quad 339 \pm 6.5$

counted by RJ

\begin{tabular}{ccccccccc} 
Crystal & $\mathrm{Ns}$ & $\mathrm{Ni}$ & Area & RhoS(e5) & Rhol(e5) & Age(Ma) & $+-1 \mathrm{~s}$ & $\mathrm{U}(\mathrm{ppm})$ \\
\hline 1 & 7 & 21 & 12 & 5.83 & 17.50 & 78.89 & 34.48 & 14.33 \\
2 & 7 & 11 & 16 & 4.38 & 6.88 & 149.79 & 72.50 & 5.63 \\
3 & 4 & 11 & 9 & 4.44 & 12.22 & 86.02 & 50.26 & 10.01 \\
4 & 49 & 120 & 24 & 20.42 & 50.00 & 96.51 & 16.50 & 40.93 \\
5 & 35 & 82 & 25 & 14.00 & 32.80 & 100.85 & 20.49 & 26.85 \\
6 & 17 & 48 & 15 & 11.33 & 32.00 & 83.79 & 23.72 & 26.20 \\
7 & 61 & 166 & 25 & 24.40 & 66.40 & 86.92 & 13.16 & 54.36 \\
8 & 5 & 20 & 24 & 2.08 & 8.33 & 59.26 & 29.66 & 6.82 \\
9 & 31 & 106 & 40 & 7.75 & 26.50 & 69.27 & 14.23 & 21.69 \\
10 & 7 & 12 & 25 & 2.80 & 4.80 & 137.44 & 65.44 & 3.93 \\
11 & 13 & 47 & 20 & 6.50 & 23.50 & 65.53 & 20.59 & 19.24 \\
12 & 11 & 30 & 12 & 9.17 & 25.00 & 86.73 & 30.63 & 20.47 \\
13 & 33 & 113 & 36 & 9.17 & 31.39 & 69.17 & 13.77 & 25.70 \\
14 & 6 & 12 & 30 & 2.00 & 4.00 & 117.98 & 59.05 & 3.27 \\
15 & 2 & 6 & 20 & 1.00 & 3.00 & 78.89 & 64.44 & 2.46 \\
16 & 34 & 75 & 20 & 17.00 & 37.50 & 107.06 & 22.26 & 30.70 \\
17 & 17 & 52 & 49 & 3.47 & 10.61 & 77.39 & 21.69 & 8.69 \\
18 & 14 & 30 & 21 & 6.67 & 14.29 & 110.18 & 35.75 & 11.69 \\
19 & 23 & 56 & 16 & 14.38 & 35.00 & 97.07 & 24.14 & 28.65 \\
20 & 7 & 19 & 15 & 4.67 & 12.67 & 87.14 & 38.58 & 10.37 \\
\hline
\end{tabular}


Sample number: JR12-14

Mineral: Apatite

Irradiation code: vuw013-5

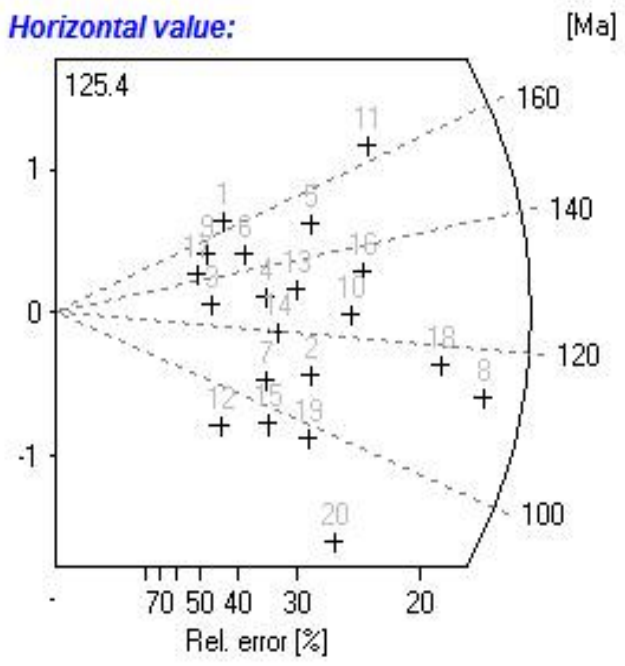

Chi-sq.: $\quad 8.01$

$\mathrm{P}(\%) \quad 98.66$

Dispersion: $\quad 0.00$

RhoD: 14.31

Nd: 7438

U standard CN_5

Zeta $\pm 1 \sigma \quad 339 \pm 6.5$

counted by RJ

\begin{tabular}{ccccccccc} 
Crystal & $\mathrm{Ns}$ & $\mathrm{Ni}$ & Area & RhoS(e5) & RhoI(e5) & Age(Ma) & $+-1 \mathrm{~s}$ & $\mathrm{U}(\mathrm{ppm})$ \\
\hline 1 & 9 & 13 & 30 & 3.00 & 4.33 & 165.75 & 71.97 & 3.48 \\
2 & 18 & 39 & 32 & 5.63 & 12.19 & 110.97 & 31.72 & 9.80 \\
3 & 7 & 13 & 36 & 1.94 & 3.61 & 129.28 & 60.68 & 2.90 \\
4 & 13 & 24 & 12 & 10.83 & 20.00 & 130.04 & 44.88 & 16.08 \\
5 & 20 & 32 & 9 & 22.22 & 35.56 & 149.82 & 42.84 & 28.58 \\
6 & 11 & 18 & 16 & 6.88 & 11.25 & 146.53 & 56.17 & 9.04 \\
7 & 12 & 27 & 20 & 6.00 & 13.50 & 106.89 & 37.16 & 10.85 \\
8 & 51 & 108 & 16 & 31.88 & 67.50 & 113.52 & 19.45 & 54.26 \\
9 & 7 & 11 & 12 & 5.83 & 9.17 & 152.51 & 73.82 & 7.37 \\
10 & 25 & 48 & 20 & 12.50 & 24.00 & 125.09 & 30.98 & 19.29 \\
11 & 31 & 45 & 36 & 8.61 & 12.50 & 164.94 & 38.68 & 10.05 \\
12 & 7 & 19 & 30 & 2.33 & 6.33 & 88.74 & 39.28 & 5.09 \\
13 & 17 & 31 & 30 & 5.67 & 10.33 & 131.64 & 39.84 & 8.31 \\
14 & 14 & 28 & 42 & 3.33 & 6.67 & 120.13 & 39.41 & 5.36 \\
15 & 12 & 30 & 48 & 2.50 & 6.25 & 96.28 & 32.96 & 5.02 \\
16 & 28 & 50 & 12 & 23.33 & 41.67 & 134.40 & 31.87 & 33.49 \\
17 & 6 & 10 & 25 & 2.40 & 4.00 & 143.89 & 74.38 & 3.22 \\
18 & 42 & 86 & 15 & 28.00 & 57.33 & 117.36 & 22.25 & 46.09 \\
19 & 17 & 42 & 36 & 4.72 & 11.67 & 97.42 & 28.09 & 9.38 \\
20 & 20 & 58 & 42 & 4.76 & 13.81 & 83.09 & 21.63 & 11.10 \\
\hline
\end{tabular}


Sample number: JR12-15

Mineral: Apatite

Irradiation code: vuw013-3

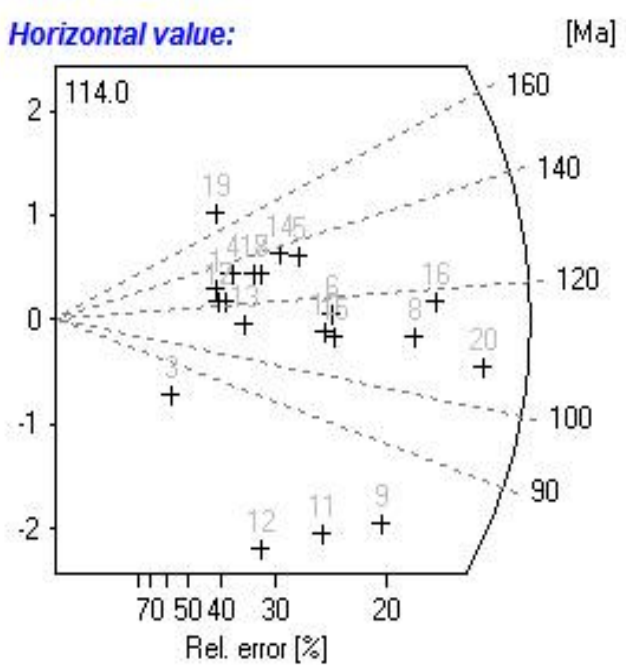

Chi-sq.: $\quad 15.58$

$\mathrm{P}(\%) \quad 68.51$

Dispersion: 0.02

RhoD: $\quad 14.57$

Nd: 7438

U standard CN_5

Zeta $\pm 1 \sigma \quad 339 \pm 6.5$

counted by RJ

\begin{tabular}{ccccccccc} 
Crystal & $\mathrm{Ns}$ & $\mathrm{Ni}$ & Area & RhoS(e5) & RhoI(e5) & Age(Ma) & $+-1 \mathrm{~s}$ & $\mathrm{U}(\mathrm{ppm})$ \\
\hline 1 & 9 & 17 & 6 & 15.00 & 28.33 & 129.40 & 53.42 & 22.37 \\
2 & 10 & 20 & 12 & 8.33 & 16.67 & 122.28 & 47.44 & 13.16 \\
3 & 4 & 13 & 42 & 0.95 & 3.10 & 75.53 & 43.22 & 2.44 \\
4 & 11 & 20 & 12 & 9.17 & 16.67 & 134.39 & 50.54 & 13.16 \\
5 & 21 & 38 & 12 & 17.50 & 31.67 & 135.02 & 36.84 & 25.00 \\
6 & 26 & 55 & 10 & 26.00 & 55.00 & 115.67 & 27.65 & 43.42 \\
7 & 15 & 28 & 15 & 10.00 & 18.67 & 130.93 & 42.00 & 14.74 \\
8 & 43 & 95 & 9 & 47.78 & 105.56 & 110.80 & 20.52 & 83.34 \\
9 & 32 & 102 & 28 & 11.43 & 36.43 & 77.00 & 15.70 & 28.76 \\
10 & 24 & 53 & 6 & 40.00 & 88.33 & 110.85 & 27.39 & 69.74 \\
11 & 21 & 75 & 15 & 14.00 & 50.00 & 68.76 & 17.05 & 39.48 \\
12 & 12 & 52 & 15 & 8.00 & 34.67 & 56.73 & 18.21 & 27.37 \\
13 & 12 & 26 & 16 & 7.50 & 16.25 & 112.96 & 39.50 & 12.83 \\
14 & 18 & 32 & 15 & 12.00 & 21.33 & 137.41 & 40.60 & 16.84 \\
15 & 26 & 58 & 35 & 7.43 & 16.57 & 109.74 & 26.02 & 13.08 \\
16 & 49 & 102 & 16 & 30.63 & 63.75 & 117.53 & 20.60 & 50.33 \\
17 & 9 & 18 & 12 & 7.50 & 15.00 & 122.28 & 50.00 & 11.84 \\
18 & 14 & 26 & 24 & 5.83 & 10.83 & 131.59 & 43.72 & 8.55 \\
19 & 10 & 14 & 30 & 3.33 & 4.67 & 173.99 & 72.14 & 3.68 \\
20 & 60 & 138 & 20 & 30.00 & 69.00 & 106.46 & 16.64 & 54.48 \\
\hline
\end{tabular}


Sample number: JR12-24

Mineral: Apatite

Irradiation code: vuw013-39

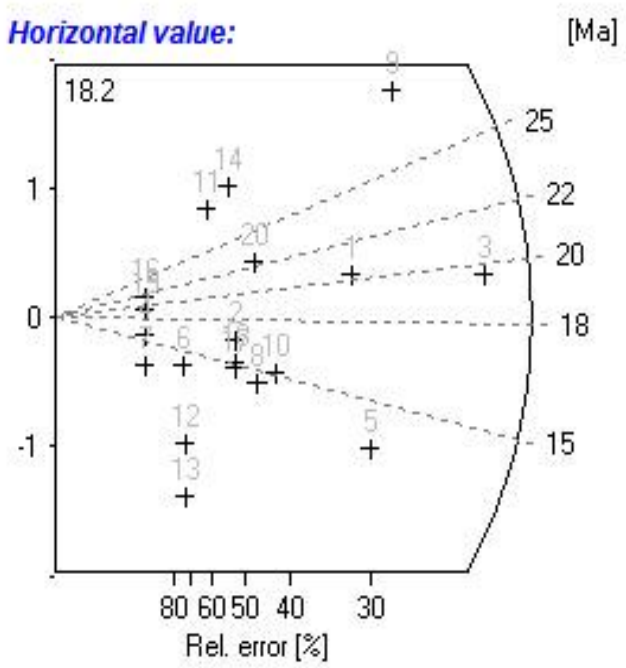

Chi-sq.: $\quad 10.72$

$\mathrm{P}(\%) \quad 93.3$

Dispersion: $\quad 0.01$

RhoD: $\quad 10.36$

Nd: 7438

U standard CN_5

Zeta $\pm 1 \sigma \quad 339 \pm 6.5$

counted by RJ

\begin{tabular}{ccccccccc} 
Crystal & $\mathrm{Ns}$ & $\mathrm{Ni}$ & Area & RhoS(e5) & RhoI(e5) & Age(Ma) & $+-1 \mathrm{~s}$ & $\mathrm{U}(\mathrm{ppm})$ \\
\hline 1 & 11 & 95 & 30 & 3.67 & 31.67 & 20.30 & 6.48 & 35.16 \\
2 & 4 & 42 & 30 & 1.33 & 14.00 & 16.70 & 8.75 & 15.54 \\
3 & 23 & 205 & 30 & 7.67 & 68.33 & 19.67 & 4.35 & 75.87 \\
4 & 1 & 11 & 24 & 0.42 & 4.58 & 15.94 & 16.65 & 5.09 \\
5 & 12 & 156 & 60 & 2.00 & 26.00 & 13.49 & 4.05 & 28.87 \\
6 & 2 & 25 & 20 & 1.00 & 12.50 & 14.03 & 10.31 & 13.88 \\
7 & 1 & 14 & 12 & 0.83 & 11.67 & 12.53 & 12.97 & 12.95 \\
8 & 5 & 61 & 60 & 0.83 & 10.17 & 14.37 & 6.69 & 11.29 \\
9 & 15 & 88 & 32 & 4.69 & 27.50 & 29.86 & 8.37 & 30.53 \\
10 & 6 & 69 & 23 & 2.61 & 30.00 & 15.25 & 6.50 & 33.31 \\
11 & 3 & 17 & 21 & 1.43 & 8.10 & 30.91 & 19.37 & 8.99 \\
12 & 2 & 39 & 35 & 0.57 & 11.14 & 9.00 & 6.53 & 12.37 \\
13 & 2 & 52 & 36 & 0.56 & 14.44 & 6.75 & 4.87 & 16.04 \\
14 & 4 & 22 & 25 & 1.60 & 8.80 & 31.84 & 17.32 & 9.77 \\
15 & 1 & 9 & 42 & 0.24 & 2.14 & 19.48 & 20.54 & 2.38 \\
16 & 1 & 8 & 25 & 0.40 & 3.20 & 21.91 & 23.24 & 3.55 \\
17 & 4 & 47 & 15 & 2.67 & 31.33 & 14.92 & 7.78 & 34.79 \\
18 & 4 & 46 & 42 & 0.95 & 10.95 & 15.25 & 7.96 & 12.16 \\
19 & 1 & 9 & 15 & 0.67 & 6.00 & 19.48 & 20.54 & 6.66 \\
20 & 5 & 39 & 25 & 2.00 & 15.60 & 22.47 & 10.69 & 17.32 \\
\hline
\end{tabular}


Sample number: JR12-25

Mineral: Apatite

Irradiation code: vuw013-37

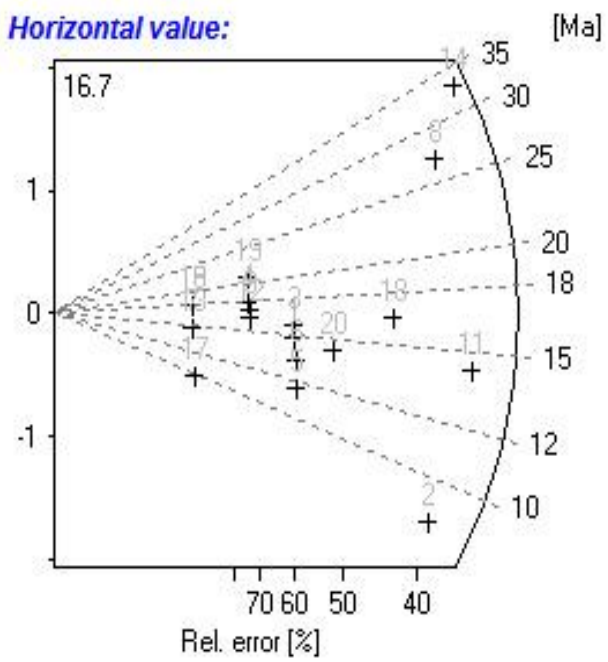

Chi-sq.: $\quad 9.69$

$\mathrm{P}(\%) \quad 96.02$

Dispersion: $\quad 0.04$

RhoD: 10.56

Nd: 7438

U standard CN_5

Zeta $\pm 1 \sigma \quad 339 \pm 6.5$

counted by RJ

\begin{tabular}{ccccccccc} 
Crystal & Ns & Ni & Area & RhoS(e5) & Rhol(e5) & Age(Ma) & $+-1 \mathrm{~s}$ & U(ppm) \\
\hline 1 & 3 & 36 & 8 & 3.75 & 45.00 & 14.90 & 8.96 & 48.99 \\
2 & 7 & 144 & 49 & 1.43 & 29.39 & 8.70 & 3.37 & 31.99 \\
3 & 3 & 34 & 12 & 2.50 & 28.33 & 15.78 & 9.51 & 30.85 \\
4 & 2 & 20 & 20 & 1.00 & 10.00 & 17.88 & 13.27 & 10.89 \\
5 & 3 & 46 & 16 & 1.88 & 28.75 & 11.67 & 6.96 & 31.30 \\
6 & 3 & 40 & 10 & 3.00 & 40.00 & 13.42 & 8.04 & 43.55 \\
7 & 1 & 12 & 15 & 0.67 & 8.00 & 14.90 & 15.52 & 8.71 \\
8 & 8 & 53 & 12 & 6.67 & 44.17 & 26.97 & 10.25 & 48.08 \\
9 & 2 & 21 & 9 & 2.22 & 23.33 & 17.03 & 12.61 & 25.40 \\
10 & 1 & 10 & 9 & 1.11 & 11.11 & 17.88 & 18.76 & 12.10 \\
11 & 9 & 113 & 16 & 5.63 & 70.63 & 14.25 & 4.94 & 76.89 \\
12 & 2 & 22 & 20 & 1.00 & 11.00 & 16.26 & 12.01 & 11.98 \\
13 & 1 & 12 & 8 & 1.25 & 15.00 & 14.90 & 15.52 & 16.33 \\
14 & 9 & 49 & 15 & 6.00 & 32.67 & 32.81 & 11.92 & 35.56 \\
15 & 1 & 10 & 24 & 0.42 & 4.17 & 17.88 & 18.76 & 4.54 \\
16 & 1 & 10 & 16 & 0.63 & 6.25 & 17.88 & 18.76 & 6.80 \\
17 & 1 & 18 & 28 & 0.36 & 6.43 & 9.94 & 10.22 & 7.00 \\
18 & 6 & 65 & 20 & 3.00 & 32.50 & 16.51 & 7.05 & 35.38 \\
19 & 2 & 17 & 16 & 1.25 & 10.63 & 21.03 & 15.73 & 11.57 \\
20 & 4 & 50 & 20 & 2.00 & 25.00 & 14.31 & 7.44 & 27.22 \\
\hline
\end{tabular}


Sample number: JR12-26

Mineral: Apatite

Irradiation code: vuw013-35

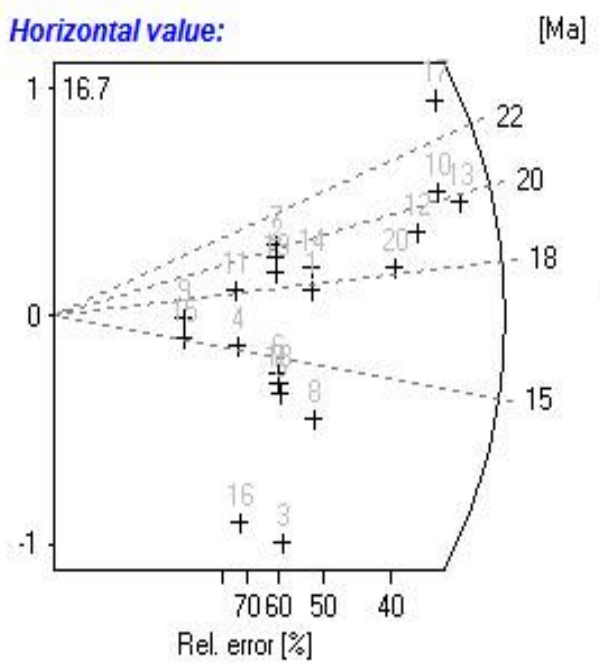

Chi-sq.: $\quad 4.17$

$\mathrm{P}(\%) \quad 99.99$

Dispersion: 0.00

RhoD: 10.77

Nd: 7438

U standard CN_5

Zeta $\pm 1 \sigma \quad 339 \pm 6.5$

counted by RJ

\begin{tabular}{ccccccccc} 
Crystal & Ns & Ni & Area & RhoS(e5) & Rhol(e5) & Age(Ma) & $+-1 \mathrm{~s}$ & U(ppm) \\
\hline 1 & 4 & 41 & 25 & 1.60 & 16.40 & 17.79 & 9.33 & 17.51 \\
2 & 3 & 28 & 15 & 2.00 & 18.67 & 19.53 & 11.87 & 19.93 \\
3 & 3 & 59 & 42 & 0.71 & 14.05 & 9.28 & 5.49 & 15.00 \\
4 & 2 & 24 & 36 & 0.56 & 6.67 & 15.20 & 11.19 & 7.12 \\
5 & 3 & 40 & 42 & 0.71 & 9.52 & 13.68 & 8.19 & 10.17 \\
6 & 3 & 38 & 20 & 1.50 & 19.00 & 14.40 & 8.64 & 20.29 \\
7 & 3 & 27 & 20 & 1.50 & 13.50 & 20.25 & 12.33 & 14.42 \\
8 & 4 & 55 & 15 & 2.67 & 36.67 & 13.26 & 6.87 & 39.15 \\
9 & 1 & 11 & 15 & 0.67 & 7.33 & 16.57 & 17.32 & 7.83 \\
10 & 9 & 81 & 25 & 3.60 & 32.40 & 20.25 & 7.13 & 34.60 \\
11 & 2 & 20 & 21 & 0.95 & 9.52 & 18.23 & 13.53 & 10.17 \\
12 & 8 & 76 & 16 & 5.00 & 47.50 & 19.19 & 7.14 & 50.72 \\
13 & 10 & 92 & 25 & 4.00 & 36.80 & 19.81 & 6.61 & 39.30 \\
14 & 4 & 39 & 24 & 1.67 & 16.25 & 18.70 & 9.82 & 17.35 \\
15 & 1 & 12 & 16 & 0.63 & 7.50 & 15.20 & 15.82 & 8.01 \\
16 & 2 & 42 & 15 & 1.33 & 28.00 & 8.69 & 6.29 & 29.90 \\
17 & 9 & 70 & 25 & 3.60 & 28.00 & 23.43 & 8.31 & 29.90 \\
18 & 3 & 39 & 25 & 1.20 & 15.60 & 14.03 & 8.41 & 16.66 \\
19 & 3 & 29 & 15 & 2.00 & 19.33 & 18.86 & 11.44 & 20.64 \\
20 & 7 & 70 & 20 & 3.50 & 35.00 & 18.23 & 7.24 & 37.37 \\
\hline
\end{tabular}


Sample number: JR12-27

Mineral: Apatite

Irradiation code: vuw013-33

Ns: 295

Ni: 493

Area: 1035

RhoS: 2.85

RhoI: 4.763

Pooled Age: $\quad 110.4 \pm 8.5$

Mean Age: $\quad 123.4 \pm 11.0$

Central Age: $\quad 110.4 \pm 8.5$

Chi-sq.: $\quad 10.47$

$\mathrm{P}(\%) \quad 94.04$

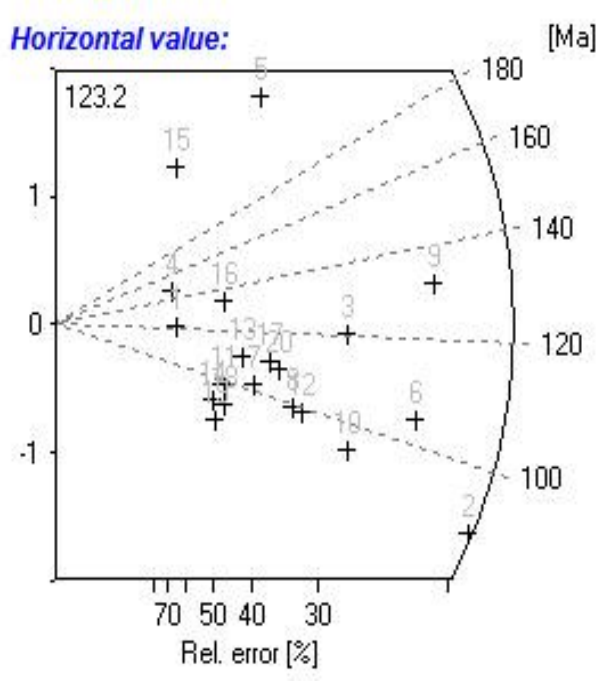

Dispersion: $\quad 0.00$

RhoD: 10.98

Nd: 7438

U standard CN_5

Zeta $\pm 1 \sigma \quad 339 \pm 6.5$

counted by RJ

\begin{tabular}{ccccccccc} 
Crystal & Ns & Ni & Area & RhoS(e5) & Rhol(e5) & Age(Ma) & $+-1 \mathrm{~s}$ & U(ppm) \\
\hline 1 & 4 & 6 & 25 & 1.60 & 2.40 & 122.86 & 79.35 & 2.52 \\
2 & 41 & 84 & 20 & 20.50 & 42.00 & 90.18 & 17.30 & 44.01 \\
3 & 23 & 35 & 42 & 5.48 & 8.33 & 121.12 & 32.62 & 8.73 \\
4 & 4 & 5 & 20 & 2.00 & 2.50 & 147.15 & 98.76 & 2.62 \\
5 & 16 & 12 & 25 & 6.40 & 4.80 & 243.41 & 93.11 & 5.03 \\
6 & 33 & 58 & 40 & 8.25 & 14.50 & 105.00 & 23.01 & 15.19 \\
7 & 10 & 18 & 24 & 4.17 & 7.50 & 102.54 & 40.51 & 7.86 \\
8 & 14 & 26 & 28 & 5.00 & 9.29 & 99.41 & 33.03 & 9.73 \\
9 & 40 & 56 & 70 & 5.71 & 48.00 & 131.54 & 27.39 & 8.38 \\
10 & 21 & 41 & 100 & 2.10 & 4.10 & 94.60 & 25.47 & 4.30 \\
11 & 7 & 13 & 32 & 2.19 & 4.06 & 99.41 & 46.66 & 4.26 \\
12 & 15 & 28 & 100 & 1.50 & 2.80 & 98.91 & 31.72 & 2.93 \\
13 & 9 & 15 & 80 & 1.13 & 1.88 & 110.67 & 46.73 & 1.97 \\
14 & 6 & 12 & 40 & 1.50 & 3.00 & 92.36 & 46.23 & 3.14 \\
15 & 6 & 4 & 24 & 2.50 & 1.67 & 273.20 & 76.46 & 1.75 \\
16 & 8 & 11 & 100 & 0.80 & 1.10 & 133.91 & 62.29 & 1.15 \\
17 & 12 & 20 & 63 & 1.90 & 53.18 & 110.67 & 40.49 & 3.33 \\
18 & 7 & 14 & 60 & 1.17 & 2.33 & 92.36 & 42.80 & 2.45 \\
19 & 6 & 13 & 42 & 1.43 & 3.10 & 85.30 & 42.14 & 3.24 \\
20 & 13 & 22 & 100 & 1.30 & 2.20 & 109.01 & 38.21 & 2.31 \\
\hline
\end{tabular}


Sample number: JR12-30

Mineral: Apatite

Irradiation code: vuw013-28

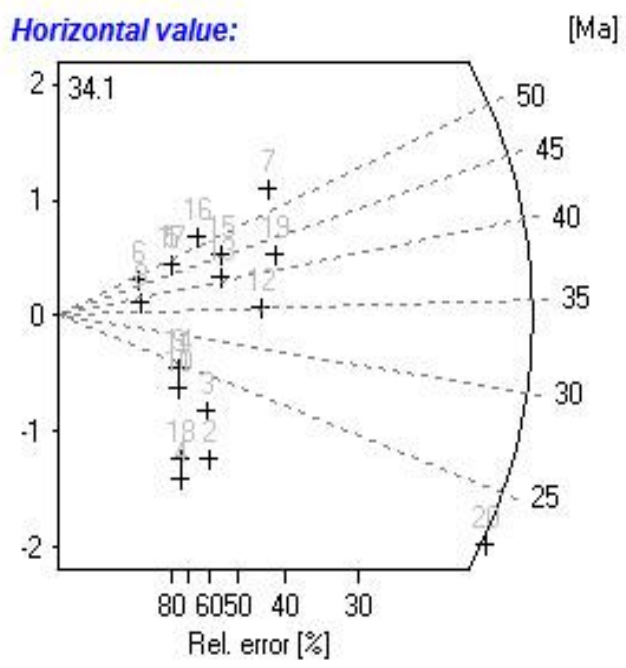

Chi-sq.: $\quad 12.87$

$\mathrm{P}(\%) \quad 84.54$

Dispersion: 0.02

RhoD: 11.49

Nd: 7438

U standard CN_5

Zeta $\pm 1 \sigma \quad 339 \pm 6.5$

counted by RJ

\begin{tabular}{ccccccccc} 
Crystal & $\mathrm{Ns}$ & $\mathrm{Ni}$ & Area & RhoS(e5) & RhoI(e5) & Age(Ma) & $+-1 \mathrm{~s}$ & $\mathrm{U}(\mathrm{ppm})$ \\
\hline 1 & 2 & 8 & 25 & 0.80 & 3.20 & 48.51 & 38.37 & 3.20 \\
2 & 3 & 36 & 16 & 1.88 & 22.50 & 16.21 & 9.75 & 22.52 \\
3 & 3 & 28 & 15 & 2.00 & 18.67 & 20.84 & 12.67 & 18.68 \\
4 & 2 & 32 & 12 & 1.67 & 26.67 & 12.16 & 8.87 & 26.69 \\
5 & 2 & 8 & 15 & 1.33 & 5.33 & 48.51 & 38.37 & 5.34 \\
6 & 1 & 4 & 18 & 0.56 & 2.22 & 48.51 & 54.25 & 2.22 \\
7 & 7 & 25 & 50 & 1.40 & 5.00 & 54.31 & 23.26 & 5.00 \\
8 & 1 & 5 & 12 & 0.83 & 4.17 & 38.84 & 42.56 & 4.17 \\
9 & 2 & 16 & 24 & 0.83 & 6.67 & 24.30 & 18.23 & 6.67 \\
10 & 2 & 18 & 30 & 0.67 & 6.00 & 21.61 & 16.11 & 6.01 \\
11 & 2 & 18 & 24 & 0.83 & 7.50 & 21.61 & 16.11 & 7.51 \\
12 & 6 & 33 & 64 & 0.94 & 5.16 & 35.32 & 15.69 & 5.16 \\
13 & 4 & 19 & 28 & 1.43 & 6.79 & 40.88 & 22.51 & 6.79 \\
14 & 2 & 16 & 30 & 0.67 & 5.33 & 24.30 & 18.23 & 5.34 \\
15 & 4 & 17 & 72 & 0.56 & 2.36 & 45.67 & 25.40 & 2.36 \\
16 & 3 & 11 & 30 & 1.00 & 3.67 & 52.91 & 34.48 & 3.67 \\
17 & 2 & 8 & 40 & 0.50 & 2.00 & 48.51 & 38.37 & 2.00 \\
18 & 2 & 28 & 40 & 0.50 & 7.00 & 13.90 & 10.18 & 7.01 \\
19 & 7 & 32 & 49 & 1.43 & 6.53 & 42.47 & 17.75 & 6.54 \\
20 & 25 & 216 & 30 & 8.33 & 72.00 & 22.51 & 4.78 & 72.06 \\
\hline
\end{tabular}


Sample number: JR11-10

Mineral: Apatite

Irradiation code: vuw014-30

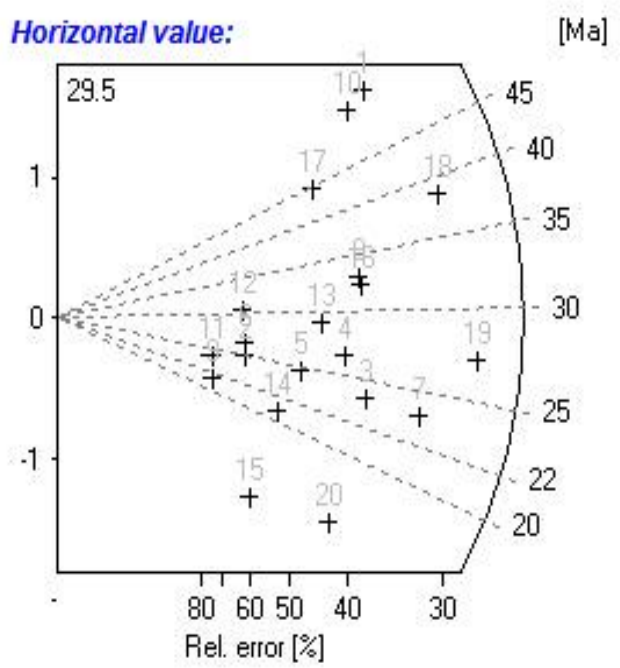

Chi-sq.: $\quad 12.73$

$\mathrm{P}(\%) \quad 85.22$

Dispersion: 0.00

RhoD: 11.43

Nd: 6387

U standard CN_5

Zeta $\pm 1 \sigma \quad 339 \pm 6.5$

counted by RJ

\begin{tabular}{ccccccccc} 
Crystal & Ns & Ni & Area & RhoS(e5) & Rhol(e5) & Age(Ma) & $+-1 \mathrm{~s}$ & U(ppm) \\
\hline 1 & 9 & 32 & 6 & 15.00 & 53.33 & 54.28 & 20.52 & 53.65 \\
2 & 3 & 23 & 15 & 2.00 & 15.333 & 25.23 & 15.50 & 15.42 \\
3 & 8 & 65 & 12 & 6.67 & 54.17 & 23.81 & 8.94 & 54.48 \\
4 & 7 & 51 & 12 & 5.83 & 42.50 & 26.55 & 10.72 & 42.75 \\
5 & 5 & 39 & 6 & 8.33 & 65.00 & 24.80 & 11.79 & 65.38 \\
6 & 3 & 22 & 9 & 3.33 & 24.44 & 26.37 & 16.24 & 24.59 \\
7 & 11 & 90 & 15 & 7.33 & 60.00 & 23.64 & 7.57 & 60.35 \\
8 & 8 & 47 & 16 & 5.00 & 29.38 & 32.90 & 12.61 & 29.55 \\
9 & 2 & 18 & 16 & 1.25 & 11.25 & 21.50 & 16.03 & 11.32 \\
10 & 8 & 29 & 8 & 10.00 & 36.25 & 53.24 & 21.30 & 36.46 \\
11 & 2 & 16 & 6 & 3.33 & 26.67 & 24.18 & 18.14 & 26.82 \\
12 & 3 & 19 & 16 & 1.88 & 11.88 & 30.53 & 18.98 & 11.94 \\
13 & 6 & 40 & 6 & 10.00 & 66.67 & 29.01 & 12.72 & 67.06 \\
14 & 4 & 37 & 12 & 3.33 & 30.83 & 20.92 & 11.02 & 31.01 \\
15 & 3 & 42 & 16 & 1.88 & 26.25 & 13.83 & 8.27 & 26.40 \\
16 & 8 & 48 & 9 & 8.89 & 53.33 & 32.22 & 12.33 & 53.65 \\
17 & 6 & 26 & 10 & 6.00 & 26.00 & 44.57 & 20.21 & 26.15 \\
18 & 13 & 65 & 12 & 10.83 & 54.17 & 38.64 & 11.77 & 54.48 \\
19 & 15 & 107 & 20 & 7.50 & 53.50 & 27.11 & 7.50 & 53.81 \\
20 & 6 & 73 & 18 & 3.33 & 40.56 & 15.91 & 6.77 & 40.79 \\
\hline
\end{tabular}


Sample number: JR11-15

Mineral: Apatite

Irradiation code: vuw014--31

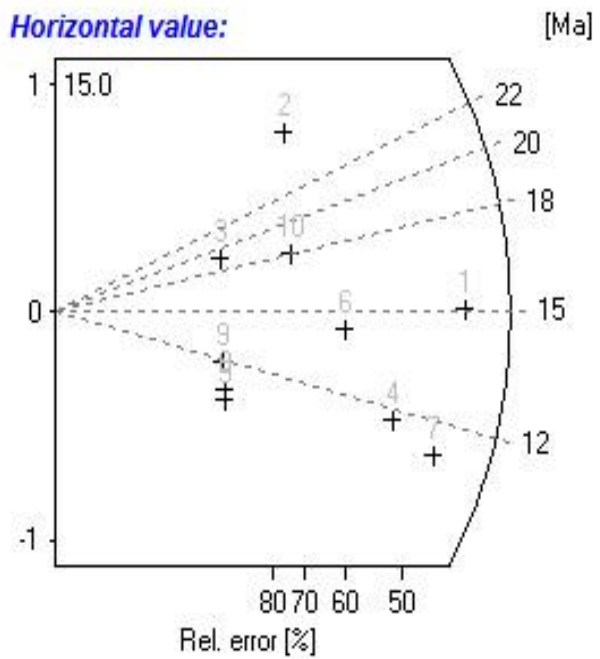

$\begin{array}{rr}\text { Pooled Age: } & 13.6 \pm 2.8 \\ \text { Mean Age: } & 15.0 \pm 1.7 \\ \text { Central Age: } & 13.6 \pm 2.8\end{array}$

Ns: 26

Ni: 364

Area: 207

RhoS: 1.256

RhoI: 17.59

Chi-sq.: $\quad 1.62$

$\mathrm{P}(\%) \quad 99.61$

Dispersion: $\quad 0.00$

RhoD: 11.29

Nd: 6387

U standard CN_5

Zeta $\pm 1 \sigma \quad 339 \pm 6.5$

counted by RJ

\begin{tabular}{ccccccccc} 
Crystal & $\mathrm{Ns}$ & $\mathrm{Ni}$ & Area & RhoS(e5) & RhoI(e5) & Age $(\mathrm{Ma})$ & $+-1 \mathrm{~s}$ & $\mathrm{U}(\mathrm{ppm})$ \\
\hline 1 & 6 & 76 & 72 & 0.83 & 10.56 & 15.08 & 6.41 & 10.76 \\
2 & 2 & 14 & 12 & 1.67 & 11.67 & 27.27 & 20.62 & 11.89 \\
3 & 1 & 10 & 25 & 0.40 & 4.00 & 19.10 & 20.04 & 4.08 \\
4 & 4 & 65 & 9 & 4.44 & 72.22 & 11.76 & 6.06 & 73.60 \\
5 & 1 & 19 & 20 & 0.50 & 9.50 & 10.06 & 10.32 & 9.68 \\
6 & 3 & 40 & 9 & 3.33 & 44.44 & 14.33 & 8.58 & 45.29 \\
7 & 5 & 85 & 20 & 2.50 & 42.50 & 11.24 & 5.18 & 43.31 \\
8 & 1 & 18 & 8 & 1.25 & 22.50 & 10.62 & 10.91 & 22.93 \\
9 & 1 & 16 & 20 & 0.50 & 8.00 & 11.94 & 12.31 & 8.15 \\
10 & 2 & 21 & 12 & 1.67 & 17.50 & 18.19 & 13.47 & 17.83 \\
\hline
\end{tabular}


Sample number: JR11-16

Mineral: Apatite

Irradiation code: vuw014-33

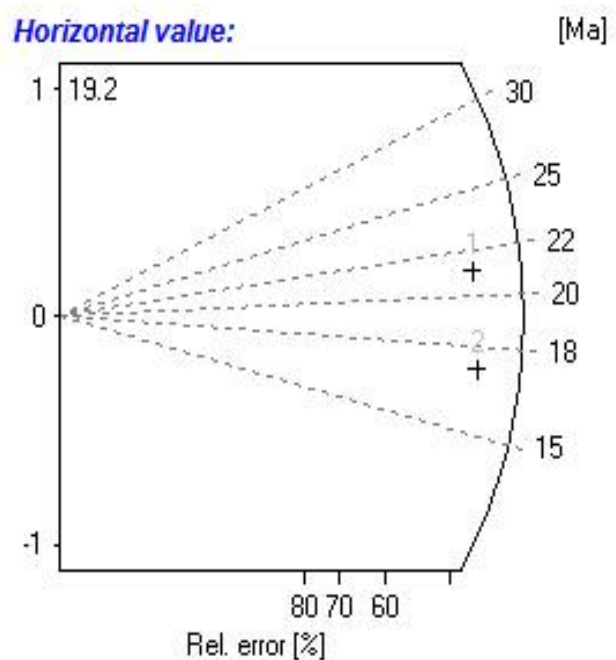

Chi-sq.: $\quad 0.1$

$\mathrm{P}(\%) \quad 75.75$

Dispersion: $\quad 0.00$

RhoD: 10.99

Nd: 6387

U standard CN_5

Zeta $\pm 1 \sigma \quad 339 \pm 6.5$

counted by RJ

\begin{tabular}{ccccccccc} 
Crystal & $\mathrm{Ns}$ & $\mathrm{Ni}$ & Area & RhoS(e5) & RhoI(e5) & Age(Ma) & $+-1 \mathrm{~s}$ & $\mathrm{U}(\mathrm{ppm})$ \\
\hline 1 & 5 & 44 & 9 & 5.56 & 48.89 & 21.13 & 9.98 & 51.17 \\
2 & 5 & 54 & 20 & 2.50 & 27.00 & 17.22 & 8.06 & 28.26 \\
\hline
\end{tabular}


Sample number: JR11-17

Mineral: Apatite

Irradiation code: vuw014-34

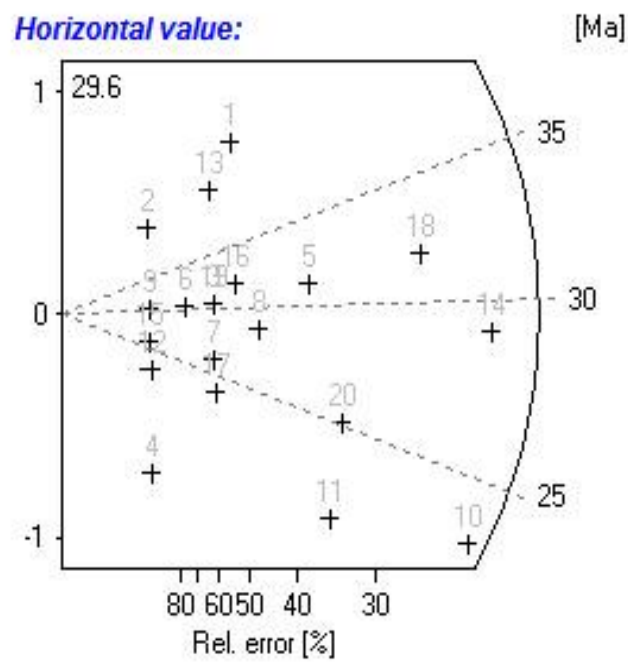

Chi-sq.: $\quad 3.77$

$\mathrm{P}(\%) \quad 99.99$

Dispersion: 0.00

RhoD: $\quad 10.84$

Nd: 6387

U standard CN_5

Zeta $\pm 1 \sigma \quad 339 \pm 6.5$

counted by RJ

\begin{tabular}{ccccccccc} 
Crystal & $\mathrm{Ns}$ & $\mathrm{Ni}$ & Area & RhoS(e5) & RhoI(e5) & Age(Ma) & $+-1 \mathrm{~s}$ & $\mathrm{U}(\mathrm{ppm})$ \\
\hline 1 & 4 & 16 & 9 & 4.44 & 17.78 & 45.76 & 25.60 & 18.86 \\
2 & 1 & 4 & 9 & 1.11 & 4.44 & 45.76 & 51.18 & 4.72 \\
3 & 3 & 18 & 16 & 1.88 & 11.25 & 30.55 & 19.06 & 11.94 \\
4 & 1 & 13 & 16 & 0.63 & 8.13 & 14.12 & 14.65 & 8.62 \\
5 & 8 & 47 & 25 & 3.20 & 18.80 & 31.19 & 11.95 & 19.95 \\
6 & 2 & 12 & 20 & 1.00 & 6.00 & 30.55 & 23.34 & 6.37 \\
7 & 3 & 21 & 16 & 1.88 & 13.13 & 26.19 & 16.18 & 13.93 \\
8 & 5 & 32 & 12 & 4.17 & 26.67 & 28.64 & 13.79 & 28.30 \\
9 & 1 & 6 & 9 & 1.11 & 6.67 & 30.55 & 33.00 & 7.07 \\
10 & 21 & 165 & 20 & 10.50 & 82.50 & 23.34 & 5.43 & 87.54 \\
11 & 9 & 77 & 20 & 4.50 & 38.50 & 21.44 & 7.57 & 40.85 \\
12 & 1 & 8 & 25 & 0.40 & 3.20 & 22.92 & 24.32 & 3.40 \\
13 & 3 & 13 & 15 & 2.00 & 8.67 & 42.26 & 27.08 & 9.20 \\
14 & 24 & 151 & 16 & 15.00 & 94.38 & 29.13 & 6.44 & 100.14 \\
15 & 1 & 7 & 16 & 0.63 & 4.38 & 26.19 & 28.01 & 4.64 \\
16 & 4 & 23 & 16 & 2.50 & 14.38 & 31.87 & 17.28 & 15.25 \\
17 & 3 & 23 & 9 & 3.33 & 25.56 & 23.92 & 14.69 & 27.12 \\
18 & 17 & 98 & 16 & 10.63 & 61.25 & 31.79 & 8.38 & 64.99 \\
19 & 3 & 18 & 20 & 1.50 & 9.00 & 30.55 & 19.06 & 9.55 \\
20 & 10 & 73 & 30 & 3.33 & 24.33 & 25.12 & 8.49 & 25.82 \\
\hline
\end{tabular}


Sample number: JR11-24

Mineral: Apatite

Irradiation code: vuw014-40

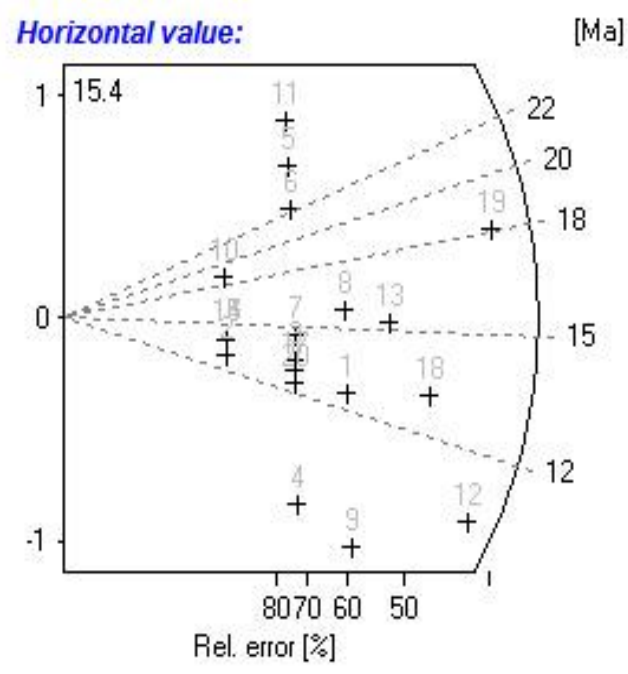

Chi-sq.: $\quad 4.62$

$\mathrm{P}(\%) \quad 99.97$

Dispersion: 0.00

RhoD: 9.94

Nd: 6387

U standard CN_5

Zeta $\pm 1 \sigma \quad 339 \pm 6.5$

counted by RJ

\begin{tabular}{ccccccccc} 
Crystal & Ns & Ni & Area & RhoS(e5) & Rhol(e5) & Age(Ma) & $+-1 \mathrm{~s}$ & U(ppm) \\
\hline 1 & 3 & 40 & 20 & 1.50 & 20.00 & 12.63 & 7.57 & 23.13 \\
2 & 1 & 13 & 20 & 0.50 & 6.50 & 12.95 & 13.45 & 7.52 \\
3 & 2 & 25 & 6 & 3.33 & 41.67 & 13.47 & 9.90 & 48.19 \\
4 & 2 & 40 & 20 & 1.00 & 20.00 & 8.42 & 6.11 & 23.13 \\
5 & 2 & 13 & 40 & 0.50 & 3.25 & 25.88 & 9.67 & 3.76 \\
6 & 2 & 15 & 48 & 0.42 & 3.13 & 22.44 & 16.90 & 3.61 \\
7 & 2 & 23 & 12 & 1.67 & 19.17 & 14.64 & 10.80 & 22.17 \\
8 & 3 & 32 & 15 & 2.00 & 21.33 & 15.78 & 9.54 & 24.67 \\
9 & 3 & 60 & 9 & 3.33 & 66.67 & 8.42 & 4.99 & 77.10 \\
10 & 1 & 9 & 16 & 0.63 & 5.63 & 18.70 & 19.72 & 6.51 \\
11 & 2 & 11 & 48 & 0.42 & 2.29 & 30.58 & 23.51 & 2.65 \\
12 & 6 & 96 & 24 & 2.50 & 40.00 & 10.53 & 4.44 & 46.26 \\
13 & 4 & 44 & 12 & 3.33 & 36.67 & 15.31 & 8.00 & 42.40 \\
14 & 1 & 12 & 25 & 0.40 & 4.80 & 14.03 & 14.61 & 5.55 \\
15 & 1 & 12 & 18 & 0.56 & 6.67 & 14.03 & 14.61 & 7.71 \\
16 & 1 & 12 & 42 & 0.24 & 2.86 & 14.03 & 14.61 & 3.30 \\
17 & 2 & 26 & 30 & 0.67 & 8.67 & 12.95 & 9.51 & 10.02 \\
18 & 5 & 64 & 15 & 3.33 & 42.67 & 13.16 & 6.12 & 49.34 \\
19 & 7 & 65 & 24 & 2.92 & 27.08 & 8.13 & 7.22 & 31.32 \\
20 & 2 & 27 & 20 & 1.00 & 13.50 & 12.47 & 9.15 & 15.61 \\
\hline
\end{tabular}


Sample number: JR12-16

Mineral: Apatite

Irradiation code: vuw014-15

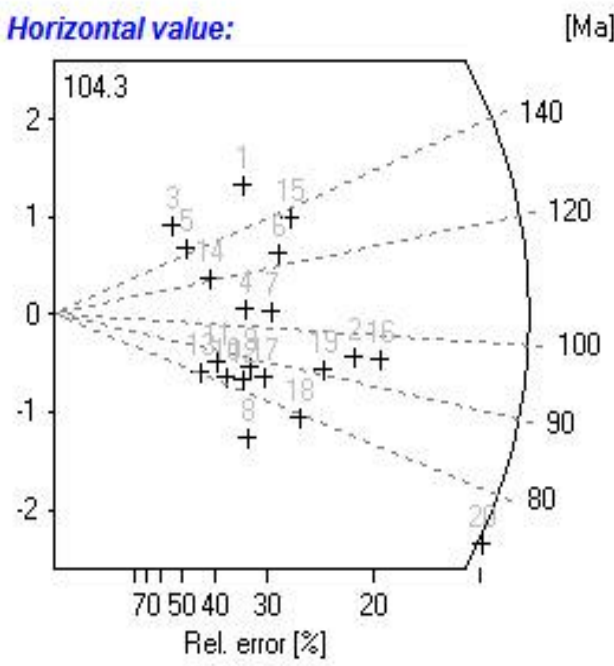

Chi-sq.: $\quad 13.31$

$\mathrm{P}(\%) \quad 82.25$

Dispersion: $\quad 0.02$

RhoD: 13.67

Nd: 6387

U standard CN_5

Zeta $\pm 1 \sigma \quad 339 \pm 6.5$

counted by RJ

\begin{tabular}{ccccccccc} 
Crystal & $\mathrm{Ns}$ & $\mathrm{Ni}$ & Area & RhoS(e5) & RhoI(e5) & Age(Ma) & $+-1 \mathrm{~s}$ & $\mathrm{U}(\mathrm{ppm})$ \\
\hline 1 & 15 & 21 & 12 & 12.50 & 17.50 & 163.39 & 55.36 & 14.73 \\
2 & 31 & 75 & 14 & 22.14 & 53.57 & 95.05 & 20.41 & 45.08 \\
3 & 6 & 8 & 12 & 5.00 & 6.67 & 171.45 & 92.67 & 5.61 \\
4 & 13 & 28 & 16 & 8.13 & 17.50 & 106.67 & 35.88 & 14.73 \\
5 & 7 & 11 & 45 & 1.56 & 2.44 & 145.76 & 70.55 & 2.06 \\
6 & 19 & 35 & 25 & 7.60 & 14.00 & 124.55 & 35.61 & 11.78 \\
7 & 17 & 37 & 18 & 9.44 & 20.56 & 105.57 & 31.03 & 17.30 \\
8 & 12 & 40 & 20 & 6.00 & 20.00 & 69.13 & 22.81 & 16.83 \\
9 & 13 & 34 & 24 & 5.42 & 14.17 & 87.97 & 28.76 & 11.92 \\
10 & 10 & 28 & 36 & 2.78 & 7.78 & 82.21 & 30.34 & 6.55 \\
11 & 9 & 24 & 16 & 5.63 & 15.00 & 86.29 & 33.79 & 12.62 \\
12 & 12 & 33 & 8 & 15.00 & 41.25 & 83.70 & 28.28 & 34.71 \\
13 & 7 & 20 & 16 & 4.38 & 12.50 & 80.58 & 35.43 & 10.52 \\
14 & 9 & 17 & 15 & 6.00 & 11.33 & 121.49 & 50.16 & 9.54 \\
15 & 22 & 37 & 15 & 14.67 & 24.67 & 136.29 & 36.83 & 20.76 \\
16 & 37 & 89 & 24 & 15.42 & 37.08 & 95.60 & 18.83 & 31.20 \\
17 & 15 & 40 & 12 & 12.50 & 33.33 & 86.29 & 26.20 & 28.05 \\
18 & 20 & 58 & 6 & 33.33 & 96.67 & 79.39 & 20.67 & 81.34 \\
19 & 25 & 63 & 20 & 12.50 & 31.50 & 91.28 & 21.68 & 26.51 \\
20 & 59 & 185 & 64 & 9.22 & 28.91 & 73.46 & 11.11 & 24.32 \\
\hline
\end{tabular}


Sample number: JR12-17

Mineral: Apatite

Irradiation code: vuw014-13

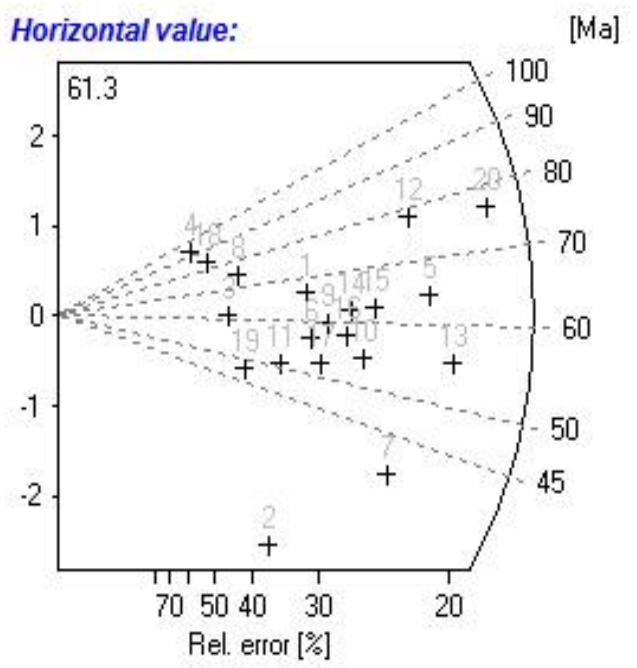

Chi-sq.: $\quad 15.35$

$\mathrm{P}(\%) \quad 70.02$

Dispersion: $\quad 0.04$

RhoD: 13.97

Nd: 6387

U standard CN_5

Zeta $\pm 1 \sigma \quad 339 \pm 6.5$

counted by RJ

\begin{tabular}{ccccccccc} 
Crystal & $\mathrm{Ns}$ & $\mathrm{Ni}$ & Area & RhoS(e5) & Rhol(e5) & Age(Ma) & $+-1 \mathrm{~s}$ & $\mathrm{U}(\mathrm{ppm})$ \\
\hline 1 & 13 & 46 & 30 & 4.33 & 15.33 & 66.55 & 20.96 & 12.63 \\
2 & 8 & 79 & 25 & 3.20 & 31.60 & 23.93 & 8.89 & 26.02 \\
3 & 6 & 23 & 20 & 3.00 & 11.50 & 61.46 & 28.21 & 9.47 \\
4 & 4 & 10 & 18 & 2.22 & 5.56 & 94.00 & 55.65 & 4.58 \\
5 & 29 & 106 & 25 & 11.60 & 42.40 & 64.44 & 13.58 & 34.92 \\
6 & 13 & 54 & 9 & 14.44 & 60.00 & 56.74 & 17.58 & 49.41 \\
7 & 21 & 122 & 35 & 6.00 & 34.86 & 40.62 & 9.64 & 28.71 \\
8 & 7 & 22 & 16 & 4.38 & 13.75 & 74.88 & 32.54 & 11.32 \\
9 & 15 & 59 & 12 & 12.50 & 49.17 & 59.90 & 17.38 & 40.49 \\
10 & 19 & 82 & 20 & 9.50 & 41.00 & 54.62 & 13.96 & 33.76 \\
11 & 10 & 46 & 20 & 5.00 & 23.00 & 51.25 & 17.92 & 18.94 \\
12 & 27 & 81 & 20 & 13.50 & 40.50 & 78.42 & 17.52 & 33.35 \\
13 & 32 & 136 & 30 & 10.67 & 45.33 & 55.46 & 10.97 & 37.33 \\
14 & 18 & 68 & 15 & 12.00 & 45.33 & 62.36 & 16.59 & 37.33 \\
15 & 21 & 79 & 9 & 23.33 & 87.78 & 62.62 & 15.44 & 72.29 \\
16 & 17 & 69 & 15 & 11.33 & 46.00 & 58.06 & 15.78 & 37.88 \\
17 & 14 & 63 & 36 & 3.89 & 17.50 & 52.39 & 15.53 & 14.41 \\
18 & 5 & 14 & 20 & 2.50 & 7.00 & 83.99 & 43.80 & 5.77 \\
19 & 7 & 34 & 12 & 5.83 & 28.33 & 48.55 & 20.18 & 23.33 \\
20 & 40 & 123 & 64 & 6.25 & 19.22 & 76.52 & 14.04 & 15.83 \\
\hline
\end{tabular}


Sample number: JR12-18

Mineral: Apatite

Irradiation code: vuw014-10

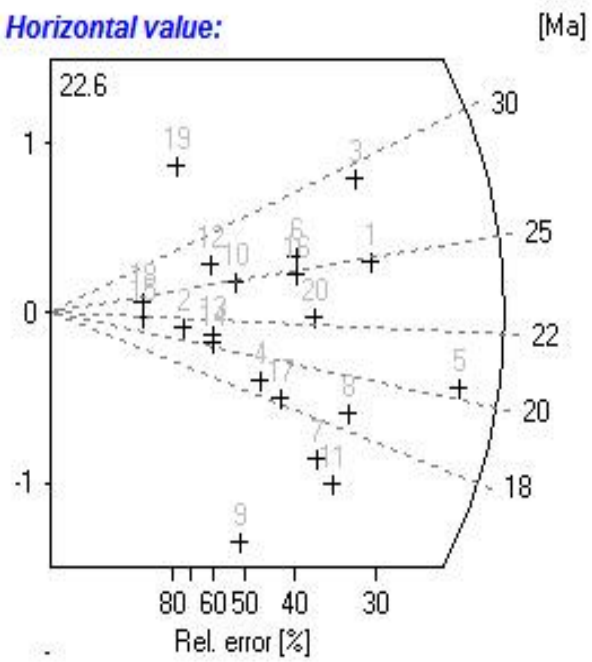

Chi-sq.: $\quad 6.07$

$\mathrm{P}(\%) \quad 99.78$

Dispersion: $\quad 0.00$

RhoD: 14.41

Nd: 6387

U standard CN_5

Zeta $\pm 1 \sigma \quad 339 \pm 6.5$

counted by RJ

\begin{tabular}{ccccccccc} 
Crystal & $\mathrm{Ns}$ & $\mathrm{Ni}$ & Area & RhoS(e5) & RhoI(e5) & Age(Ma) & $+-1 \mathrm{~s}$ & $\mathrm{U}(\mathrm{ppm})$ \\
\hline 1 & 12 & 118 & 21 & 5.71 & 56.19 & 24.79 & 7.53 & 44.84 \\
2 & 2 & 23 & 20 & 1.00 & 11.50 & 21.21 & 15.64 & 9.18 \\
3 & 11 & 92 & 25 & 4.40 & 36.80 & 29.14 & 9.32 & 29.37 \\
4 & 5 & 65 & 25 & 2.00 & 26.00 & 18.76 & 8.72 & 20.75 \\
5 & 19 & 228 & 48 & 3.96 & 47.50 & 20.32 & 4.88 & 37.91 \\
6 & 7 & 66 & 18 & 3.89 & 36.67 & 25.86 & 10.30 & 29.26 \\
7 & 8 & 118 & 100 & 0.80 & 11.80 & 16.54 & 6.05 & 9.42 \\
8 & 10 & 131 & 20 & 5.00 & 65.50 & 18.62 & 6.12 & 52.27 \\
9 & 4 & 86 & 70 & 0.57 & 12.29 & 11.35 & 5.81 & 9.80 \\
10 & 4 & 39 & 64 & 0.63 & 6.09 & 25.01 & 13.14 & 4.86 \\
11 & 9 & 137 & 35 & 2.57 & 39.14 & 16.03 & 5.53 & 31.24 \\
12 & 3 & 27 & 28 & 1.07 & 9.64 & 27.09 & 16.50 & 7.70 \\
13 & 3 & 35 & 48 & 0.63 & 7.29 & 20.90 & 12.58 & 5.82 \\
14 & 3 & 36 & 25 & 1.20 & 14.40 & 20.32 & 12.22 & 11.49 \\
15 & 1 & 11 & 64 & 0.16 & 1.72 & 22.17 & 23.16 & 1.37 \\
16 & 7 & 69 & 54 & 1.30 & 12.78 & 24.73 & 9.83 & 10.20 \\
17 & 6 & 80 & 16 & 3.75 & 50.00 & 18.30 & 7.76 & 39.90 \\
18 & 1 & 10 & 18 & 0.56 & 5.56 & 24.38 & 25.58 & 4.43 \\
19 & 2 & 11 & 35 & 0.57 & 3.14 & 44.26 & 34.04 & 2.51 \\
20 & 8 & 87 & 25 & 3.20 & 34.80 & 22.42 & 8.30 & 27.77 \\
\hline
\end{tabular}


Sample number: JR12-19

Mineral: Apatite

Irradiation code: vuw014-9

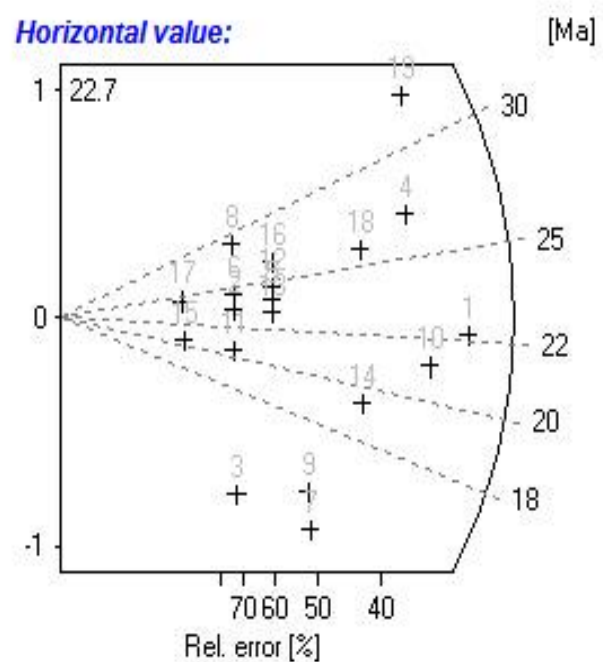

Chi-sq.: $\quad 3.81$

$\mathrm{P}(\%) \quad 99.98$

Dispersion: 0.00

RhoD: 14.56

Nd: 6387

U standard CN_5

Zeta $\pm 1 \sigma \quad 339 \pm 6.5$

counted by RJ

\begin{tabular}{ccccccccc} 
Crystal & Ns & Ni & Area & RhoS(e5) & RhoI(e5) & Age(Ma) & $+-1 \mathrm{~s}$ & $\mathrm{U}(\mathrm{ppm})$ \\
\hline 1 & 11 & 122 & 35 & 3.14 & 34.86 & 22.21 & 7.01 & 27.53 \\
2 & 2 & 21 & 20 & 1.00 & 10.50 & 23.46 & 17.37 & 8.29 \\
3 & 2 & 38 & 12 & 1.67 & 31.67 & 12.98 & 9.42 & 25.01 \\
4 & 8 & 73 & 15 & 5.33 & 48.67 & 26.99 & 10.07 & 38.44 \\
5 & 3 & 31 & 15 & 2.00 & 20.67 & 23.84 & 14.43 & 16.32 \\
6 & 2 & 20 & 12 & 1.67 & 16.67 & 24.63 & 18.28 & 13.16 \\
7 & 4 & 70 & 24 & 1.67 & 29.17 & 14.09 & 7.25 & 23.04 \\
8 & 2 & 17 & 12 & 1.67 & 14.17 & 28.97 & 21.67 & 11.19 \\
9 & 4 & 64 & 20 & 2.00 & 32.00 & 15.41 & 7.95 & 25.28 \\
10 & 9 & 105 & 24 & 3.75 & 43.75 & 21.12 & 7.35 & 34.56 \\
11 & 2 & 24 & 16 & 1.25 & 15.00 & 20.53 & 15.12 & 11.85 \\
12 & 3 & 30 & 36 & 0.83 & 8.33 & 24.63 & 14.93 & 6.58 \\
13 & 3 & 32 & 18 & 1.67 & 17.78 & 23.10 & 13.96 & 14.04 \\
14 & 6 & 76 & 9 & 6.67 & 84.44 & 19.46 & 8.26 & 66.70 \\
15 & 1 & 12 & 20 & 0.50 & 6.00 & 20.53 & 21.38 & 4.74 \\
16 & 3 & 28 & 12 & 2.50 & 23.33 & 26.39 & 16.04 & 18.43 \\
17 & 1 & 10 & 20 & 0.50 & 5.00 & 24.63 & 25.84 & 3.95 \\
18 & 6 & 57 & 6 & 10.00 & 95.00 & 25.93 & 11.14 & 75.03 \\
19 & 8 & 60 & 25 & 3.20 & 24.00 & 32.82 & 12.38 & 18.96 \\
\hline
\end{tabular}


Sample number: JR12-20

Mineral: Apatite

Irradiation code: vuw014-8

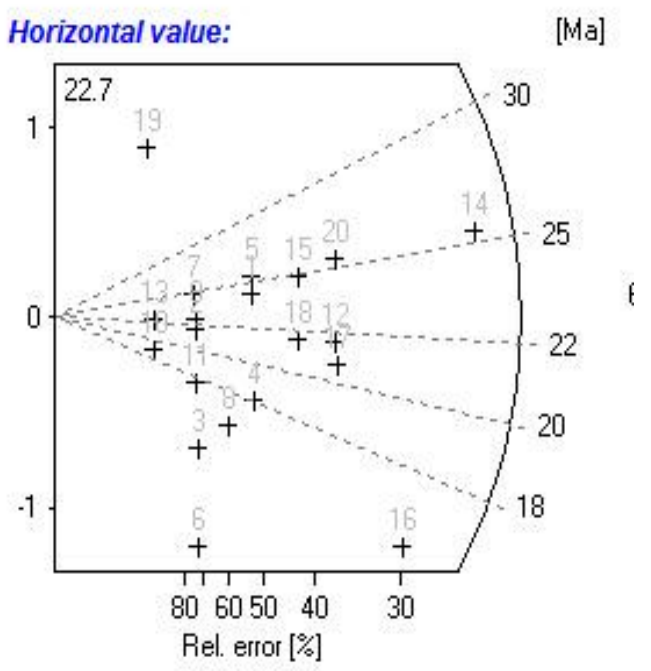

Chi-sq.: $\quad 5.22$

$\mathrm{P}(\%) \quad 99.92$

Dispersion: 0.00

RhoD: $\quad 14.70$

Nd: 6387

U standard CN_5

Zeta $\pm 1 \sigma \quad 339 \pm 6.5$

counted by RJ

\begin{tabular}{ccccccccc} 
Crystal & $\mathrm{Ns}$ & $\mathrm{Ni}$ & Area & RhoS(e5) & Rhol(e5) & Age(Ma) & $+-1 \mathrm{~s}$ & $\mathrm{U}(\mathrm{ppm})$ \\
\hline 1 & 4 & 41 & 28 & 1.43 & 14.64 & 24.28 & 12.73 & 11.45 \\
2 & 2 & 23 & 24 & 0.83 & 9.58 & 21.64 & 15.96 & 7.49 \\
3 & 2 & 36 & 16 & 1.25 & 22.50 & 13.84 & 10.06 & 17.59 \\
4 & 4 & 55 & 20 & 2.00 & 27.50 & 18.11 & 9.39 & 21.50 \\
5 & 4 & 39 & 16 & 2.50 & 24.38 & 25.52 & 13.41 & 19.06 \\
6 & 2 & 52 & 28 & 0.71 & 18.57 & 19.58 & 6.91 & 14.52 \\
7 & 2 & 20 & 24 & 0.83 & 8.33 & 24.88 & 18.46 & 6.52 \\
8 & 3 & 46 & 28 & 1.07 & 16.43 & 16.24 & 9.68 & 12.85 \\
9 & 2 & 22 & 48 & 0.42 & 4.58 & 22.63 & 16.72 & 3.58 \\
10 & 1 & 13 & 35 & 0.29 & 3.71 & 19.15 & 19.88 & 2.90 \\
11 & 2 & 28 & 24 & 0.83 & 11.67 & 17.78 & 13.02 & 9.12 \\
12 & 8 & 92 & 30 & 2.67 & 30.67 & 21.64 & 7.99 & 23.98 \\
13 & 1 & 11 & 20 & 0.50 & 5.50 & 22.63 & 23.64 & 4.30 \\
14 & 18 & 176 & 35 & 5.14 & 50.29 & 25.45 & 6.32 & 39.32 \\
15 & 6 & 60 & 40 & 1.50 & 15.00 & 24.88 & 10.67 & 11.73 \\
16 & 12 & 188 & 36 & 3.33 & 52.22 & 15.90 & 4.75 & 40.83 \\
17 & 8 & 96 & 36 & 2.22 & 26.67 & 20.74 & 7.65 & 20.85 \\
18 & 6 & 69 & 25 & 2.40 & 27.60 & 21.64 & 9.23 & 21.58 \\
19 & 1 & 4 & 16 & 0.63 & 2.50 & 62.03 & 69.37 & 1.96 \\
20 & 8 & 78 & 49 & 1.63 & 15.92 & 25.52 & 9.49 & 12.45 \\
\hline
\end{tabular}


Sample number: JR12-21

Mineral: Apatite

Irradiation code: vuw014-5

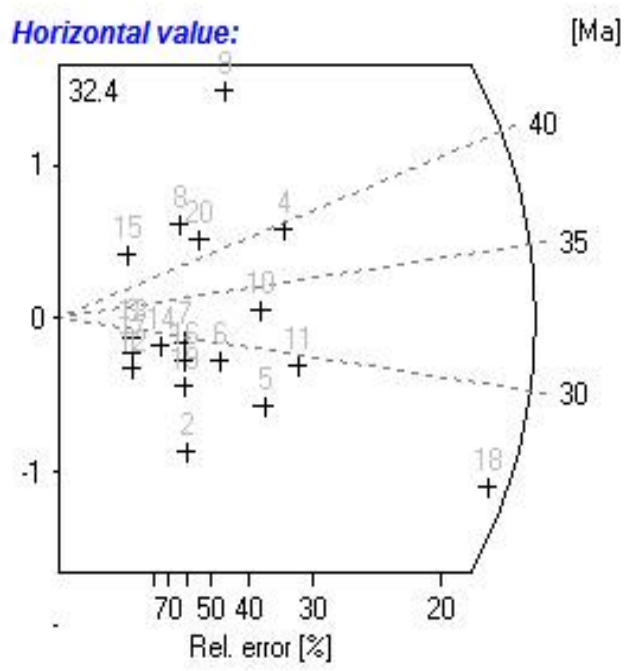

Chi-sq.: $\quad 6.32$

$\mathrm{P}(\%) \quad 99.7$

Dispersion: $\quad 0.00$

RhoD: $\quad 15.16$

Nd: 6387

U standard CN_5

Zeta $\pm 1 \sigma \quad 339 \pm 6.5$

counted by RJ

\begin{tabular}{ccccccccc} 
Crystal & $\mathrm{Ns}$ & $\mathrm{Ni}$ & Area & RhoS(e5) & Rhol(e5) & Age(Ma) & $+-1 \mathrm{~s}$ & $\mathrm{U}(\mathrm{ppm})$ \\
\hline 1 & 1 & 11 & 18 & 0.56 & 6.11 & 23.31 & 24.35 & 4.64 \\
2 & 3 & 40 & 15 & 2.00 & 26.67 & 19.24 & 11.52 & 20.24 \\
3 & 1 & 9 & 9 & 1.11 & 10.00 & 28.48 & 30.03 & 7.59 \\
4 & 10 & 65 & 12 & 8.33 & 54.17 & 39.40 & 13.41 & 41.10 \\
5 & 8 & 78 & 20 & 4.00 & 39.00 & 26.30 & 9.78 & 29.59 \\
6 & 5 & 45 & 30 & 1.67 & 15.00 & 28.48 & 13.44 & 11.38 \\
7 & 3 & 26 & 20 & 1.50 & 13.00 & 29.57 & 18.05 & 9.86 \\
8 & 3 & 16 & 16 & 1.88 & 10.00 & 47.99 & 30.21 & 7.59 \\
9 & 6 & 24 & 25 & 2.40 & 9.60 & 63.91 & 29.21 & 7.28 \\
10 & 8 & 62 & 30 & 2.67 & 20.67 & 33.06 & 12.44 & 15.68 \\
11 & 11 & 96 & 35 & 3.14 & 27.43 & 29.37 & 9.37 & 20.81 \\
12 & 1 & 11 & 20 & 0.50 & 5.50 & 23.31 & 24.35 & 4.17 \\
13 & 1 & 9 & 16 & 0.63 & 5.63 & 28.48 & 30.03 & 4.27 \\
14 & 2 & 18 & 6 & 3.33 & 30.00 & 28.48 & 21.24 & 22.76 \\
15 & 1 & 5 & 18 & 0.56 & 2.78 & 51.18 & 56.07 & 2.11 \\
16 & 3 & 28 & 15 & 2.00 & 18.67 & 27.47 & 16.70 & 14.16 \\
17 & 1 & 10 & 28 & 0.36 & 3.57 & 25.64 & 26.90 & 2.71 \\
18 & 35 & 337 & 70 & 5.00 & 48.14 & 26.63 & 4.77 & 36.53 \\
19 & 3 & 31 & 15 & 2.00 & 20.67 & 24.81 & 15.01 & 15.68 \\
20 & 4 & 24 & 42 & 0.95 & 5.71 & 42.68 & 23.07 & 4.34 \\
\hline
\end{tabular}


Sample number: JR12-22

Mineral: Apatite

Irradiation code: vuw014-4

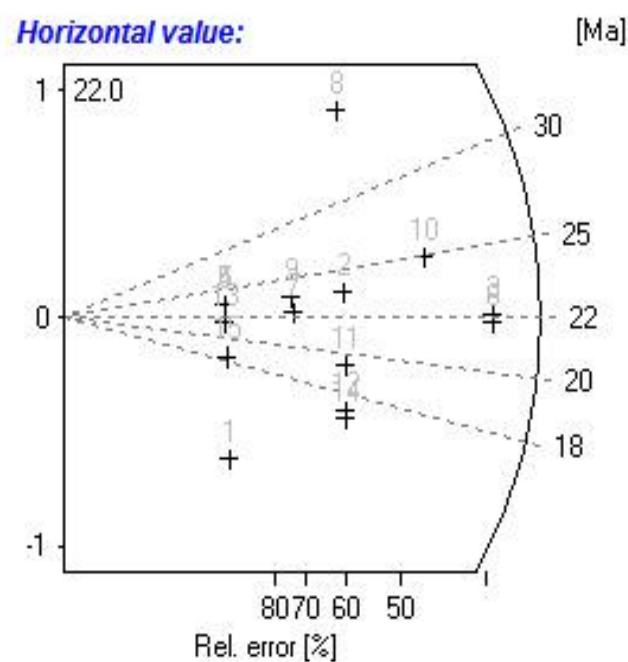

Chi-sq.: $\quad 1.8$

$\mathrm{P}(\%) \quad 100$

Dispersion: $\quad 0.00$

RhoD: 15.31

Nd: 6387

U standard CN_5

Zeta $\pm 1 \sigma \quad 339 \pm 6.5$

counted by RJ

\begin{tabular}{ccccccccc} 
Crystal & $\mathrm{Ns}$ & $\mathrm{Ni}$ & Area & RhoS(e5) & RhoI(e5) & Age(Ma) & $+-1 \mathrm{~s}$ & $\mathrm{U}(\mathrm{ppm})$ \\
\hline 1 & 1 & 22 & 12 & 0.83 & 18.33 & 11.78 & 12.05 & 13.78 \\
2 & 3 & 33 & 9 & 3.33 & 36.67 & 23.54 & 14.21 & 27.55 \\
3 & 7 & 82 & 12 & 5.83 & 68.33 & 22.11 & 8.72 & 51.35 \\
4 & 1 & 11 & 9 & 1.11 & 12.22 & 23.54 & 24.59 & 9.18 \\
5 & 1 & 11 & 8 & 1.25 & 13.75 & 23.54 & 24.59 & 10.33 \\
6 & 7 & 83 & 9 & 7.78 & 92.22 & 21.84 & 8.61 & 69.30 \\
7 & 2 & 23 & 6 & 3.33 & 38.33 & 22.52 & 16.61 & 28.80 \\
8 & 3 & 20 & 9 & 3.33 & 22.22 & 38.80 & 24.04 & 16.70 \\
9 & 2 & 22 & 12 & 1.67 & 18.33 & 23.54 & 17.39 & 13.78 \\
10 & 5 & 52 & 12 & 4.17 & 43.33 & 24.90 & 11.67 & 32.56 \\
11 & 3 & 40 & 12 & 2.50 & 33.33 & 19.43 & 11.64 & 25.05 \\
12 & 3 & 45 & 10 & 3.00 & 45.00 & 17.27 & 10.31 & 33.81 \\
13 & 1 & 12 & 4 & 2.50 & 30.00 & 21.58 & 22.47 & 22.54 \\
14 & 3 & 46 & 4 & 7.50 & 115.00 & 16.90 & 10.08 & 86.41 \\
15 & 1 & 14 & 12 & 0.83 & 11.67 & 18.50 & 19.16 & 8.77 \\
\hline
\end{tabular}


Sample number: JR12-23

Mineral: Apatite

Irradiation code: vuw014-2

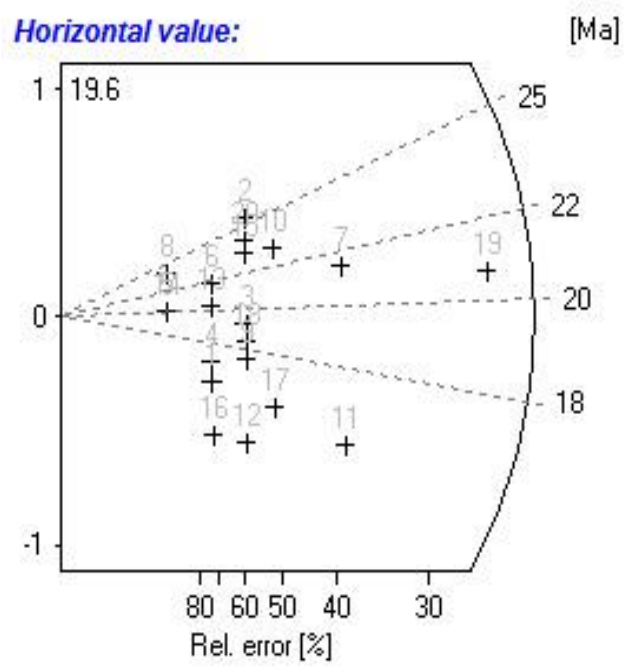

Pooled Age: $\quad 19.2 \pm 2.4$

Mean Age: $19.6 \pm 0.8$

Central Age: $19.2 \pm 2.4$

Chi-sq.: $\quad 1.84$

$\mathrm{P}(\%) \quad 100$

Dispersion: 0.00

RhoD: $\quad 15.60$

Nd: 6387

U standard CN_5

Zeta $\pm 1 \sigma \quad 339 \pm 6.5$

counted by RJ

\begin{tabular}{ccccccccc} 
Crystal & Ns & Ni & Area & RhoS(e5) & Rhol(e5) & Age(Ma) & $+-1 \mathrm{~s}$ & U(ppm) \\
\hline 1 & 2 & 33 & 12 & 1.67 & 27.50 & 16.01 & 11.66 & 20.27 \\
2 & 3 & 31 & 15 & 2.00 & 20.67 & 25.54 & 15.46 & 15.23 \\
3 & 3 & 41 & 12 & 2.50 & 34.17 & 19.32 & 11.57 & 25.18 \\
4 & 2 & 31 & 20 & 1.00 & 15.50 & 17.04 & 12.44 & 11.43 \\
5 & 1 & 13 & 20 & 0.50 & 6.50 & 20.31 & 21.08 & 4.79 \\
6 & 2 & 24 & 15 & 1.33 & 16.00 & 22.00 & 16.20 & 11.79 \\
7 & 7 & 86 & 14 & 5.00 & 61.43 & 21.49 & 8.46 & 45.28 \\
8 & 1 & 11 & 20 & 0.50 & 5.50 & 24.00 & 25.07 & 4.05 \\
9 & 3 & 45 & 20 & 1.50 & 22.50 & 17.61 & 10.51 & 16.58 \\
10 & 4 & 46 & 16 & 2.50 & 28.75 & 22.96 & 11.98 & 21.19 \\
11 & 7 & 117 & 20 & 3.50 & 58.50 & 15.80 & 6.16 & 43.12 \\
12 & 3 & 56 & 24 & 1.25 & 23.33 & 14.15 & 8.39 & 17.20 \\
13 & 2 & 26 & 16 & 1.25 & 16.25 & 20.31 & 14.91 & 11.98 \\
14 & 1 & 13 & 9 & 1.11 & 14.44 & 20.31 & 21.08 & 10.65 \\
15 & 3 & 34 & 28 & 1.07 & 12.14 & 23.29 & 14.04 & 8.95 \\
16 & 2 & 39 & 20 & 1.00 & 19.50 & 13.55 & 9.83 & 14.37 \\
17 & 4 & 66 & 25 & 1.60 & 26.40 & 16.01 & 8.25 & 19.46 \\
18 & 3 & 43 & 8 & 3.75 & 53.75 & 18.43 & 11.01 & 39.62 \\
19 & 16 & 204 & 16 & 10.00 & 127.50 & 20.71 & 5.40 & 93.98 \\
20 & 3 & 33 & 16 & 1.88 & 20.63 & 24.00 & 14.48 & 15.20 \\
\hline
\end{tabular}


Sample number: JR12-31

Mineral: Apatite

Irradiation code: vuw014-28

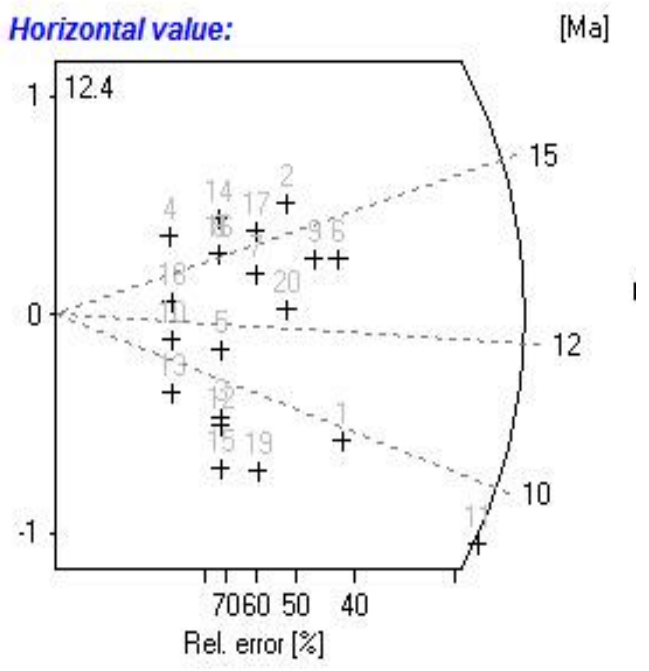

Chi-sq.: $\quad 3.92$

$\mathrm{P}(\%) \quad 99.99$

Dispersion: 0.00

RhoD: 11.73

Nd: 6387

U standard CN_5

Zeta $\pm 1 \sigma \quad 339 \pm 6.5$

counted by RJ

\begin{tabular}{ccccccccc} 
Crystal & $\mathrm{Ns}$ & $\mathrm{Ni}$ & Area & RhoS(e5) & RhoI(e5) & Age(Ma) & $+-1 \mathrm{~s}$ & $\mathrm{U}(\mathrm{ppm})$ \\
\hline 1 & 6 & 122 & 35 & 1.71 & 34.86 & 9.77 & 4.09 & 34.17 \\
2 & 4 & 49 & 36 & 1.11 & 13.61 & 16.21 & 8.44 & 13.34 \\
3 & 2 & 45 & 30 & 0.67 & 15.00 & 8.83 & 6.39 & 14.71 \\
4 & 1 & 11 & 20 & 0.50 & 5.50 & 18.05 & 18.86 & 5.39 \\
5 & 2 & 36 & 40 & 0.50 & 9.00 & 11.04 & 8.02 & 8.82 \\
6 & 6 & 86 & 60 & 1.00 & 14.33 & 13.86 & 5.86 & 14.05 \\
7 & 3 & 43 & 36 & 0.83 & 11.94 & 13.86 & 8.28 & 11.71 \\
8 & 2 & 26 & 20 & 1.00 & 13.00 & 15.28 & 11.22 & 12.74 \\
9 & 5 & 71 & 49 & 1.02 & 14.49 & 13.99 & 6.48 & 14.20 \\
10 & 1 & 18 & 20 & 0.50 & 9.00 & 11.04 & 11.34 & 8.82 \\
11 & 13 & 280 & 42 & 3.10 & 66.67 & 9.23 & 2.63 & 65.35 \\
12 & 2 & 46 & 49 & 0.41 & 9.39 & 8.64 & 6.24 & 9.20 \\
13 & 1 & 23 & 25 & 0.40 & 9.20 & 8.64 & 8.83 & 9.02 \\
14 & 2 & 23 & 18 & 1.11 & 12.78 & 17.27 & 12.74 & 12.53 \\
15 & 2 & 53 & 35 & 0.57 & 15.14 & 7.50 & 5.40 & 14.85 \\
16 & 2 & 26 & 24 & 0.83 & 10.83 & 15.28 & 11.22 & 10.62 \\
17 & 3 & 38 & 20 & 1.50 & 19.00 & 15.68 & 9.41 & 18.63 \\
18 & 1 & 15 & 15 & 0.67 & 10.00 & 13.24 & 13.68 & 9.80 \\
19 & 3 & 73 & 36 & 0.83 & 20.27 & 88.17 & 4.81 & 19.88 \\
20 & 4 & 63 & 25 & 1.60 & 25.20 & 12.61 & 6.51 & 24.70 \\
\hline
\end{tabular}


Sample number: JR12-32

Mineral: Apatite

Irradiation code: vuw014-25

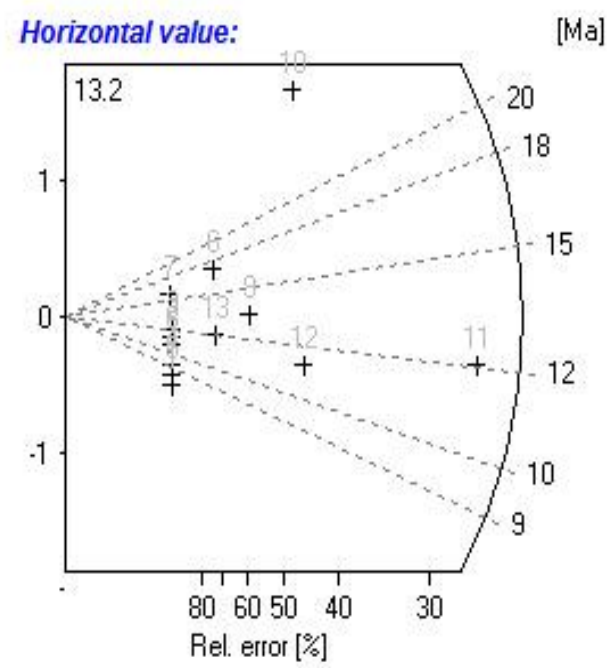

Chi-sq.: $\quad 4.05$

$\mathrm{P}(\%) \quad 98.26$

Dispersion: 0.00

RhoD: 12.18

Nd: 6387

U standard CN_5

Zeta $\pm 1 \sigma \quad 339 \pm 6.5$

counted by RJ

\begin{tabular}{ccccccccc} 
Crystal & Ns & Ni & Area & RhoS(e5) & Rhol(e5) & Age(Ma) & $+-1 \mathrm{~s}$ & $\mathrm{U}(\mathrm{ppm})$ \\
\hline 1 & 1 & 26 & 16 & 0.63 & 16.25 & 7.93 & 8.09 & 15.35 \\
2 & 1 & 18 & 8 & 1.25 & 22.50 & 11.46 & 11.77 & 21.25 \\
3 & 1 & 17 & 12 & 0.83 & 14.17 & 12.13 & 12.49 & 13.38 \\
4 & 1 & 22 & 12 & 0.83 & 18.33 & 9.38 & 9.59 & 17.31 \\
5 & 1 & 24 & 9 & 1.11 & 26.67 & 8.60 & 8.77 & 25.18 \\
6 & 2 & 24 & 20 & 1.00 & 12.00 & 17.18 & 12.65 & 11.33 \\
7 & 1 & 13 & 16 & 0.63 & 8.13 & 15.86 & 16.46 & 7.67 \\
8 & 1 & 19 & 12 & 0.83 & 15.83 & 10.86 & 11.14 & 14.95 \\
9 & 3 & 46 & 20 & 1.50 & 23.00 & 13.45 & 8.02 & 21.72 \\
10 & 5 & 35 & 12 & 4.17 & 29.17 & 29.42 & 14.08 & 27.54 \\
11 & 15 & 256 & 25 & 6.00 & 102.40 & 12.08 & 3.22 & 96.70 \\
12 & 5 & 91 & 36 & 1.39 & 25.28 & 11.33 & 5.21 & 23.87 \\
13 & 2 & 34 & 9 & 2.22 & 37.78 & 12.13 & 8.83 & 35.68 \\
\hline
\end{tabular}


Sample number: JR12-33

Mineral: Apatite

Irradiation code: vuw014-24

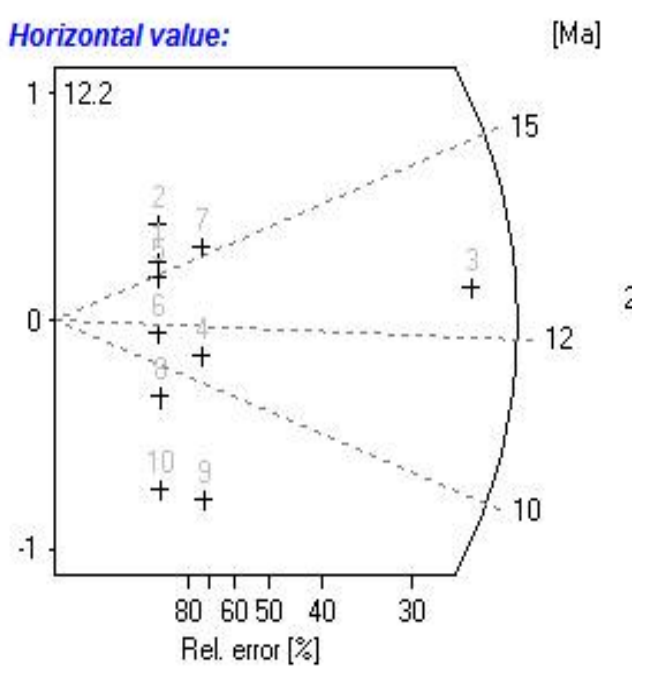

Chi-sq.: $\quad 1.75$

$\mathrm{P}(\%) \quad 99.48$

Dispersion: $\quad 0.00$

RhoD: 12.33

Nd: 6387

U standard CN_5

Zeta $\pm 1 \sigma \quad 339 \pm 6.5$

counted by RJ

\begin{tabular}{ccccccccc} 
Crystal & $\mathrm{Ns}$ & $\mathrm{Ni}$ & Area & RhoS(e5) & RhoI(e5) & Age(Ma) & $+-1 \mathrm{~s}$ & $\mathrm{U}(\mathrm{ppm})$ \\
\hline 1 & 1 & 13 & 12 & 0.83 & 10.83 & 16.05 & 16.66 & 10.11 \\
2 & 1 & 11 & 9 & 1.11 & 12.22 & 18.97 & 19.82 & 11.40 \\
3 & 16 & 263 & 36 & 4.44 & 73.06 & 12.70 & 3.28 & 68.16 \\
4 & 2 & 38 & 12 & 1.67 & 31.67 & 10.99 & 7.98 & 29.54 \\
5 & 1 & 14 & 4 & 2.50 & 35.00 & 14.91 & 15.43 & 32.65 \\
6 & 1 & 18 & 8 & 1.25 & 22.50 & 11.60 & 11.92 & 20.99 \\
7 & 2 & 27 & 6 & 3.33 & 45.00 & 15.46 & 11.33 & 41.98 \\
8 & 1 & 24 & 15 & 0.67 & 16.00 & 8.70 & 8.88 & 14.93 \\
9 & 2 & 60 & 16 & 1.25 & 37.50 & 6.96 & 5.01 & 34.99 \\
10 & 1 & 36 & 9 & 1.11 & 40.00 & 5.80 & 5.88 & 37.32 \\
\hline
\end{tabular}


Sample number: JR12-34

Mineral: Apatite

Irradiation code: vuw014-22

Ns: 37

Ni: 577

Area: 171

RhoS: 2.164

RhoI: 33.74

Pooled Age: $\quad 13.7 \pm 2.3$

Mean Age: $17.9 \pm 3.0$

Central Age: $13.7 \pm 2.3$

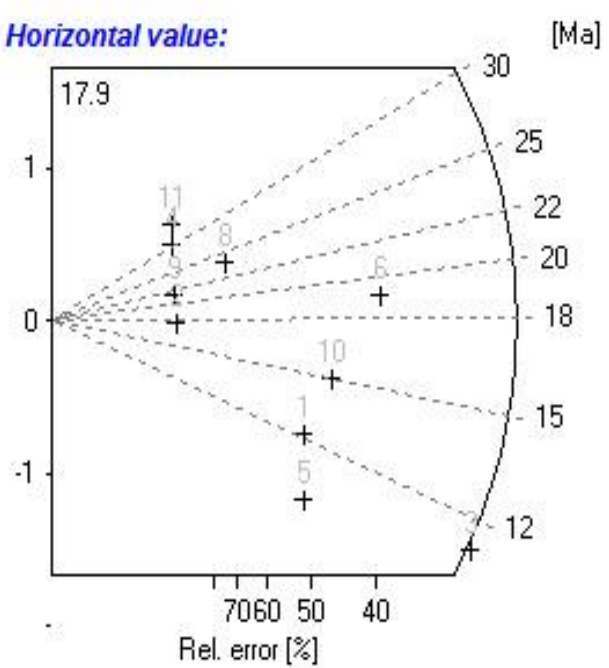

Chi-sq.: $\quad 4.48$

$\mathrm{P}(\%) \quad 92.33$

Dispersion: $\quad 0.00$

RhoD: 12.63

Nd: 6387

U standard CN_5

Zeta $\pm 1 \sigma \quad 339 \pm 6.5$

counted by RJ

\begin{tabular}{ccccccccc} 
Crystal & $\mathrm{Ns}$ & $\mathrm{Ni}$ & Area & RhoS(e5) & RhoI(e5) & Age $(\mathrm{Ma})$ & $+-1 \mathrm{~s}$ & $\mathrm{U}(\mathrm{ppm})$ \\
\hline 1 & 4 & 70 & 12 & 3.33 & 58.33 & 12.22 & 6.29 & 53.14 \\
2 & 1 & 12 & 12 & 0.83 & 10.00 & 17.81 & 18.54 & 9.11 \\
3 & 11 & 209 & 16 & 6.88 & 130.63 & 11.25 & 3.49 & 118.99 \\
4 & 1 & 7 & 16 & 0.63 & 4.38 & 30.50 & 32.61 & 3.99 \\
5 & 4 & 87 & 25 & 1.60 & 34.80 & 9.83 & 5.03 & 31.70 \\
6 & 7 & 78 & 12 & 5.83 & 65.00 & 19.18 & 7.58 & 59.21 \\
7 & 0 & 9 & 9 & 0.00 & 10.00 & 0.00 & 0.00 & 9.11 \\
8 & 2 & 18 & 9 & 2.22 & 20.00 & 23.73 & 17.70 & 18.22 \\
9 & 1 & 10 & 16 & 0.63 & 6.25 & 21.36 & 22.41 & 5.69 \\
10 & 5 & 71 & 35 & 1.43 & 20.29 & 15.05 & 6.97 & 18.48 \\
11 & 1 & 6 & 9 & 1.11 & 6.67 & 35.57 & 38.43 & 6.07 \\
\hline
\end{tabular}


Sample number: JR12-35

Mineral: Apatite

Irradiation code: vuw014-21

Ns: 94

Ni: 1425

Area: 373

RhoS: 2.52

RhoI: 38.2

Pooled Age: $\quad 14.3 \pm 1.6$

Mean Age: $13.5 \pm 0.9$

Central Age: $14.3 \pm 1.6$

Chi-sq.: $\quad 6.92$

$\mathrm{P}(\%) \quad 99.47$

Dispersion: 0.00

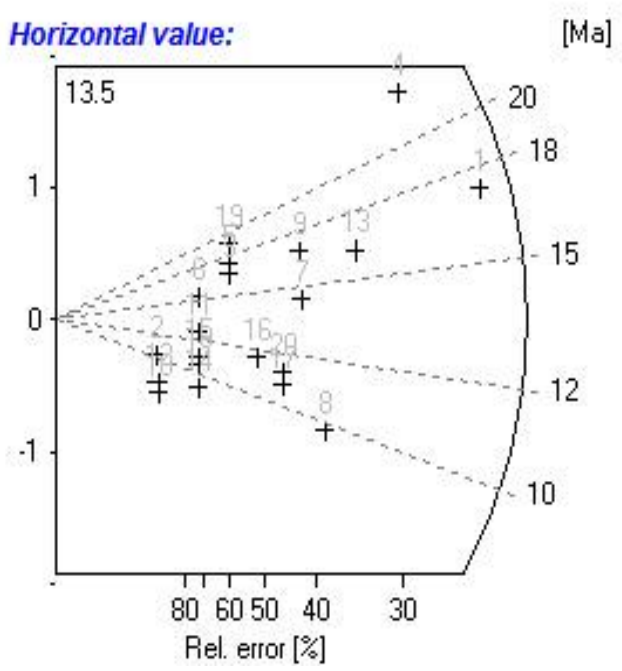

RhoD: $\quad 12.77$

Nd: 6387

U standard CN_5

Zeta $\pm 1 \sigma \quad 339 \pm 6.5$

counted by RJ

\begin{tabular}{ccccccccc} 
Crystal & $\mathrm{Ns}$ & $\mathrm{Ni}$ & Area & RhoS(e5) & RhoI(e5) & Age(Ma) & $+-1 \mathrm{~s}$ & $\mathrm{U}(\mathrm{ppm})$ \\
\hline 1 & 18 & 226 & 56 & 3.21 & 40.36 & 17.22 & 4.24 & 36.33 \\
2 & 1 & 21 & 15 & 0.67 & 14.00 & 10.30 & 10.55 & 12.60 \\
3 & 3 & 39 & 12 & 2.50 & 32.50 & 16.63 & 9.97 & 29.26 \\
4 & 12 & 114 & 24 & 5.00 & 47.50 & 22.75 & 6.92 & 42.77 \\
5 & 3 & 37 & 16 & 1.88 & 23.13 & 17.53 & 10.53 & 20.82 \\
6 & 2 & 28 & 12 & 1.67 & 23.33 & 15.45 & 11.31 & 21.01 \\
7 & 6 & 90 & 20 & 3.00 & 45.00 & 14.42 & 6.09 & 40.51 \\
8 & 7 & 155 & 25 & 2.80 & 62.00 & 9.77 & 3.78 & 55.82 \\
9 & 6 & 77 & 16 & 3.75 & 48.13 & 16.85 & 7.15 & 43.33 \\
10 & 1 & 28 & 25 & 0.40 & 11.20 & 7.73 & 7.87 & 10.08 \\
11 & 2 & 34 & 20 & 1.00 & 17.00 & 12.72 & 9.26 & 15.31 \\
12 & 1 & 26 & 15 & 0.67 & 17.33 & 8.32 & 8.48 & 15.61 \\
13 & 9 & 120 & 15 & 6.00 & 80.00 & 16.22 & 5.62 & 72.03 \\
14 & 2 & 46 & 12 & 1.67 & 38.33 & 9.41 & 6.80 & 34.51 \\
15 & 2 & 39 & 12 & 1.67 & 32.50 & 11.09 & 8.05 & 29.26 \\
16 & 4 & 74 & 18 & 2.22 & 41.11 & 11.69 & 6.01 & 37.01 \\
17 & 5 & 100 & 24 & 2.08 & 41.67 & 10.82 & 4.96 & 37.51 \\
18 & 2 & 41 & 9 & 2.22 & 45.56 & 10.55 & 7.65 & 41.01 \\
19 & 3 & 34 & 15 & 2.00 & 22.67 & 19.08 & 11.50 & 20.41 \\
20 & 5 & 96 & 12 & 4.17 & 80.00 & 11.27 & 5.17 & 72.03 \\
\hline
\end{tabular}


Sample number: JR12-36

Mineral: Apatite

Irradiation code: vuw014-19

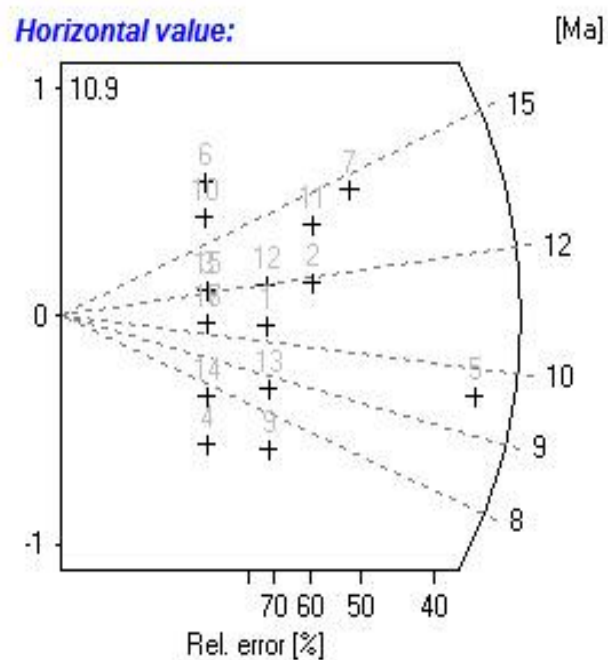

Chi-sq.: $\quad 3.51$

$\mathrm{P}(\%) \quad 99.95$

Dispersion: 0.00

RhoD: 13.07

Nd: 6387

U standard CN_5

Zeta $\pm 1 \sigma \quad 339 \pm 6.5$

counted by RJ

\begin{tabular}{ccccccccc} 
Crystal & Ns & Ni & Area & RhoS(e5) & RhoI(e5) & Age(Ma) & $+-1 \mathrm{~s}$ & U(ppm) \\
\hline 1 & 2 & 42 & 9 & 2.22 & 46.67 & 10.54 & 7.63 & 41.06 \\
2 & 3 & 56 & 25 & 1.20 & 22.40 & 11.86 & 7.03 & 19.71 \\
3 & 1 & 18 & 20 & 0.50 & 9.00 & 12.30 & 12.64 & 7.92 \\
4 & 1 & 36 & 9 & 1.11 & 40.00 & 6.15 & 6.24 & 35.19 \\
5 & 8 & 185 & 25 & 3.20 & 74.00 & 9.57 & 3.46 & 65.11 \\
6 & 1 & 11 & 25 & 0.40 & 4.40 & 20.11 & 21.01 & 3.87 \\
7 & 4 & 61 & 12 & 3.33 & 50.83 & 14.51 & 7.50 & 44.72 \\
8 & 0 & 27 & 12 & 0.00 & 22.50 & 0.00 & 0.00 & 19.80 \\
9 & 2 & 62 & 16 & 1.25 & 38.75 & 7.14 & 5.13 & 34.09 \\
10 & 1 & 13 & 9 & 1.11 & 14.44 & 17.02 & 17.67 & 12.71 \\
11 & 3 & 48 & 15 & 2.00 & 32.00 & 13.83 & 8.24 & 28.15 \\
12 & 2 & 37 & 12 & 1.67 & 30.83 & 11.97 & 8.69 & 27.13 \\
13 & 2 & 51 & 20 & 1.00 & 25.50 & 8.68 & 6.26 & 22.44 \\
14 & 1 & 29 & 28 & 0.36 & 10.36 & 7.64 & 7.77 & 9.11 \\
15 & 1 & 18 & 16 & 0.63 & 11.25 & 12.30 & 12.64 & 9.90 \\
16 & 1 & 21 & 24 & 0.42 & 8.75 & 10.54 & 10.79 & 7.70 \\
17 & 1 & 21 & 30 & 0.33 & 7.00 & 10.54 & 10.79 & 6.16 \\
\hline
\end{tabular}


Sample number: JR11-23

Mineral: Apatite

Irradiation code: vuw015-3

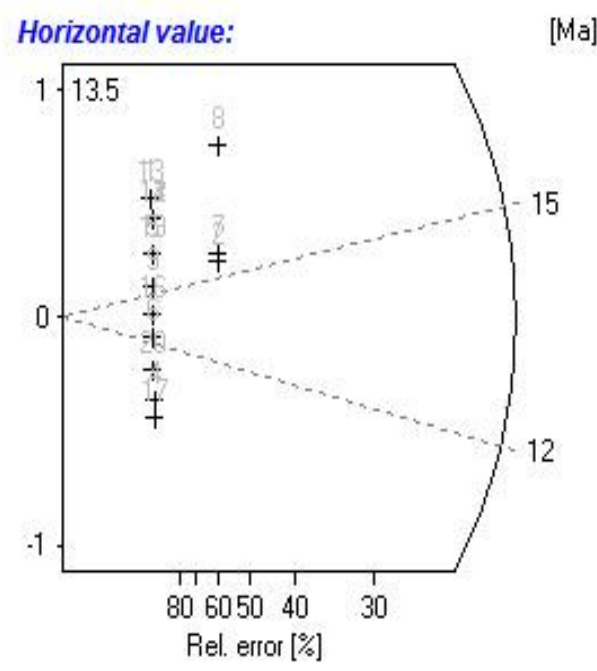

Chi-sq.: $\quad 4.38$

$\mathrm{P}(\%) \quad 99.98$

Dispersion: $\quad 0.00$

RhoD: 13.88

Nd: 5277

U standard CN_5

Zeta $\pm 1 \sigma \quad 339 \pm 6.5$

counted by RJ

\begin{tabular}{ccccccccc} 
Crystal & Ns & Ni & Area & RhoS(e5) & RhoI(e5) & Age(Ma) & $+-1 \mathrm{~s}$ & U(ppm) \\
\hline 1 & 1 & 10 & 21 & 0.48 & 4.76 & 23.48 & 24.64 & 3.95 \\
2 & 3 & 45 & 42 & 0.71 & 10.71 & 15.66 & 9.35 & 8.88 \\
3 & 0 & 9 & 42 & 0.00 & 2.14 & 0.00 & 0.00 & 1.78 \\
4 & 1 & 25 & 40 & 0.25 & 6.25 & 9.40 & 9.59 & 5.18 \\
5 & 1 & 13 & 35 & 0.29 & 3.71 & 18.07 & 18.76 & 3.08 \\
6 & 1 & 19 & 40 & 0.25 & 4.75 & 12.37 & 12.69 & 3.94 \\
7 & 3 & 44 & 21 & 1.43 & 20.95 & 16.02 & 9.57 & 17.36 \\
8 & 3 & 33 & 80 & 0.38 & 4.13 & 21.35 & 12.89 & 3.42 \\
9 & 1 & 15 & 54 & 0.19 & 2.78 & 15.66 & 16.18 & 2.30 \\
10 & 0 & 7 & 16 & 0.00 & 4.38 & 0.00 & 0.00 & 3.63 \\
11 & 1 & 11 & 49 & 0.20 & 2.25 & 21.35 & 22.31 & 1.86 \\
12 & 1 & 11 & 36 & 0.28 & 3.06 & 21.35 & 22.31 & 2.53 \\
13 & 1 & 10 & 35 & 0.29 & 2.86 & 23.48 & 24.64 & 2.37 \\
14 & 1 & 11 & 24 & 0.42 & 4.58 & 21.35 & 22.31 & 3.80 \\
15 & 0 & 13 & 60 & 0.00 & 2.17 & 0.00 & 0.00 & 1.80 \\
16 & 1 & 17 & 40 & 0.25 & 4.25 & 13.82 & 14.23 & 3.52 \\
17 & 1 & 27 & 36 & 0.28 & 7.50 & 8.71 & 8.87 & 6.22 \\
18 & 0 & 9 & 25 & 0.00 & 3.60 & 0.00 & 0.00 & 2.98 \\
19 & 1 & 13 & 27 & 0.37 & 4.82 & 18.07 & 18.76 & 3.99 \\
20 & 1 & 22 & 60 & 0.17 & 3.67 & 10.68 & 10.93 & 3.04 \\
\hline
\end{tabular}


Sample number: JR11-25

Mineral: Apatite

Irradiation code: vuw015-4

Ns: 87

Ni: 1826

Area: 485

RhoS: 1.794

RhoI: 37.65

Pooled Age: $\quad 11.1 \pm 1.2$

Mean Age: $\quad 11.5 \pm 0.8$

Central Age: $11.1 \pm 1.2$

Chi-sq.: $\quad 5.03$

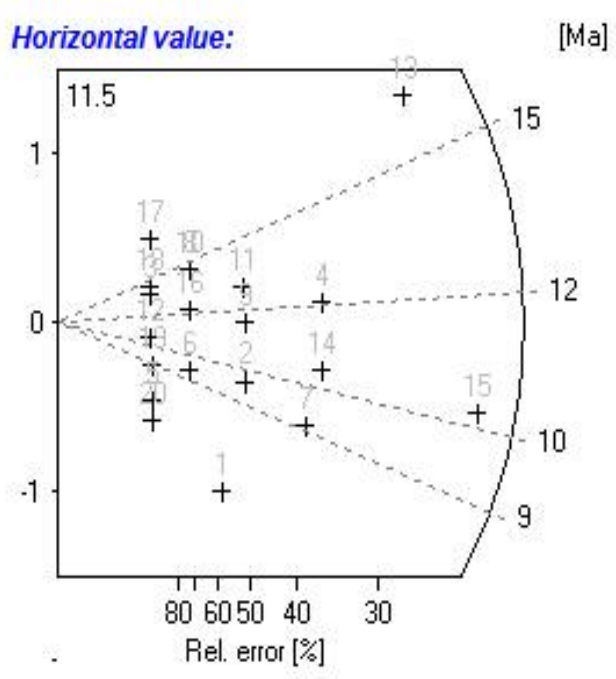

$\mathrm{P}(\%) \quad 99.94$

Dispersion: 0.00

RhoD: 13.73

Nd: 5277

U standard CN_5

Zeta $\pm 1 \sigma \quad 339 \pm 6.5$

counted by RJ

\begin{tabular}{ccccccccc} 
Crystal & $\mathrm{Ns}$ & $\mathrm{Ni}$ & Area & RhoS(e5) & Rhol(e5) & Age(Ma) & $+-1 \mathrm{~s}$ & $\mathrm{U}(\mathrm{ppm})$ \\
\hline 1 & 3 & 108 & 48 & 0.63 & 22.50 & 6.46 & 3.78 & 18.85 \\
2 & 4 & 96 & 42 & 0.95 & 22.86 & 9.69 & 4.95 & 19.15 \\
3 & 1 & 17 & 20 & 0.50 & 8.50 & 13.67 & 14.07 & 7.12 \\
4 & 8 & 154 & 25 & 3.20 & 61.60 & 12.08 & 4.39 & 51.61 \\
5 & 1 & 32 & 15 & 0.67 & 21.33 & 37.27 & 7.38 & 17.87 \\
6 & 2 & 49 & 10 & 2.00 & 49.00 & 9.49 & 6.85 & 41.05 \\
7 & 7 & 178 & 15 & 4.67 & 118.67 & 9.14 & 3.53 & 99.42 \\
8 & 2 & 32 & 42 & 0.48 & 7.62 & 14.53 & 10.59 & 6.38 \\
9 & 4 & 80 & 9 & 4.44 & 88.89 & 11.62 & 5.96 & 74.47 \\
10 & 2 & 32 & 12 & 1.67 & 26.67 & 14.53 & 10.59 & 22.34 \\
11 & 4 & 72 & 35 & 1.14 & 20.57 & 12.91 & 6.64 & 17.24 \\
12 & 1 & 22 & 9 & 1.11 & 24.44 & 10.57 & 10.81 & 20.48 \\
13 & 14 & 194 & 35 & 4.00 & 55.43 & 16.77 & 4.66 & 46.44 \\
14 & 8 & 178 & 16 & 5.00 & 111.25 & 10.45 & 3.78 & 93.21 \\
15 & 20 & 454 & 42 & 4.76 & 108.10 & 10.24 & 2.35 & 90.56 \\
16 & 2 & 38 & 20 & 1.00 & 19.00 & 12.23 & 8.88 & 15.92 \\
17 & 1 & 12 & 20 & 0.50 & 6.00 & 19.36 & 20.16 & 5.03 \\
18 & 1 & 16 & 25 & 0.40 & 6.40 & 14.53 & 14.98 & 5.36 \\
19 & 1 & 26 & 25 & 0.40 & 10.40 & 8.94 & 9.12 & 8.71 \\
20 & 1 & 36 & 20 & 0.50 & 18.00 & 6.46 & 6.55 & 15.08 \\
\hline
\end{tabular}


Sample number: JR11-35

Mineral: Zircon

Irradiation code: vuw005-20

Ns: 1628

Ni: 323

Area: 147

RhoS: 110.7

RhoI: 21.97

Pooled Age: $\quad 153 \pm 10.1$

Mean Age: $\quad 157.6 \pm 8.4$

Central Age: $\quad 153 \pm 10.1$

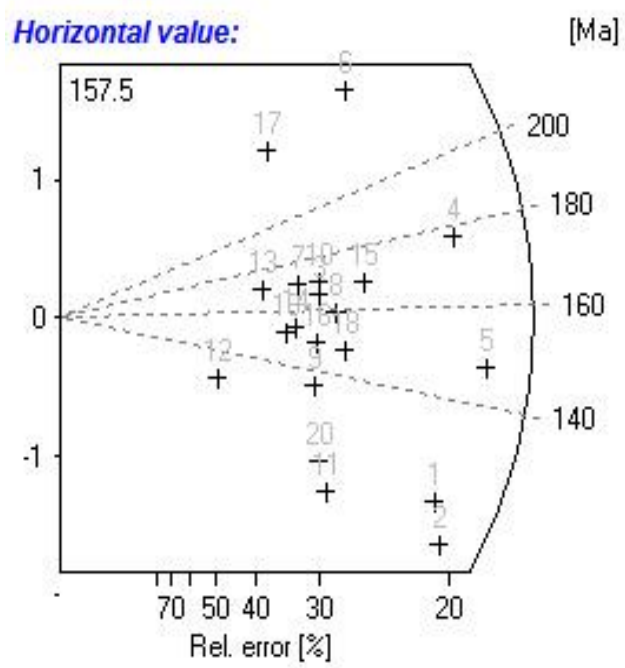

Chi-sq.: $\quad 12.43$

$\mathrm{P}(\%) \quad 86.63$

Dispersion: $\quad 0.01$

RhoD: 4.279

Nd: 2590

U standard CN_1

Zeta $\pm 1 \sigma \quad 143.6 \pm 2.4$

counted by RJ

\begin{tabular}{ccccccccc} 
Crystal & $\mathrm{Ns}$ & $\mathrm{Ni}$ & Area & RhoS(e5) & RhoI(e5) & Age(Ma) & $+-1 \mathrm{~s}$ & $\mathrm{U}(\mathrm{ppm})$ \\
\hline 1 & 114 & 29 & 16 & 71.25 & 18.13 & 119.64 & 25.07 & 134.38 \\
2 & 111 & 30 & 9 & 123.33 & 33.33 & 112.67 & 23.37 & 247.13 \\
3 & 71 & 13 & 6 & 118.33 & 21.67 & 165.63 & 50.15 & 160.63 \\
4 & 175 & 30 & 9 & 194.44 & 33.33 & 176.76 & 35.22 & 247.13 \\
5 & 175 & 36 & 18 & 97.22 & 20.00 & 147.63 & 27.28 & 148.28 \\
6 & 123 & 15 & 12 & 102.50 & 12.50 & 247.11 & 67.88 & 92.67 \\
7 & 62 & 11 & 6 & 103.33 & 18.33 & 170.87 & 56.07 & 135.92 \\
8 & 79 & 15 & 4 & 197.50 & 37.50 & 159.80 & 45.19 & 278.02 \\
9 & 58 & 13 & 8 & 72.50 & 16.25 & 135.62 & 41.76 & 120.48 \\
10 & 73 & 13 & 4 & 182.50 & 32.50 & 170.24 & 51.44 & 240.95 \\
11 & 54 & 15 & 9 & 60.00 & 16.67 & 109.65 & 32.13 & 123.56 \\
12 & 21 & 5 & 2 & 105.00 & 25.00 & 127.75 & 63.66 & 185.35 \\
13 & 45 & 8 & 4 & 112.50 & 20.00 & 170.53 & 65.58 & 148.28 \\
14 & 56 & 11 & 4 & 140.00 & 27.50 & 154.53 & 51.12 & 203.88 \\
15 & 100 & 18 & 4 & 250.00 & 45.00 & 168.45 & 43.35 & 333.62 \\
16 & 64 & 13 & 6 & 106.67 & 21.67 & 149.49 & 45.64 & 160.63 \\
17 & 66 & 8 & 6 & 110.00 & 13.33 & 248.59 & 93.28 & 98.85 \\
18 & 78 & 16 & 6 & 130.00 & 26.67 & 148.05 & 40.81 & 197.70 \\
19 & 50 & 10 & 10 & 50.00 & 10.00 & 151.80 & 52.73 & 74.14 \\
20 & 53 & 14 & 4 & 132.50 & 35.00 & 115.26 & 34.76 & 259.48 \\
\hline
\end{tabular}


Sample number: JR11-40a

Mineral: Zircon

Irradiation code: vuw005-30

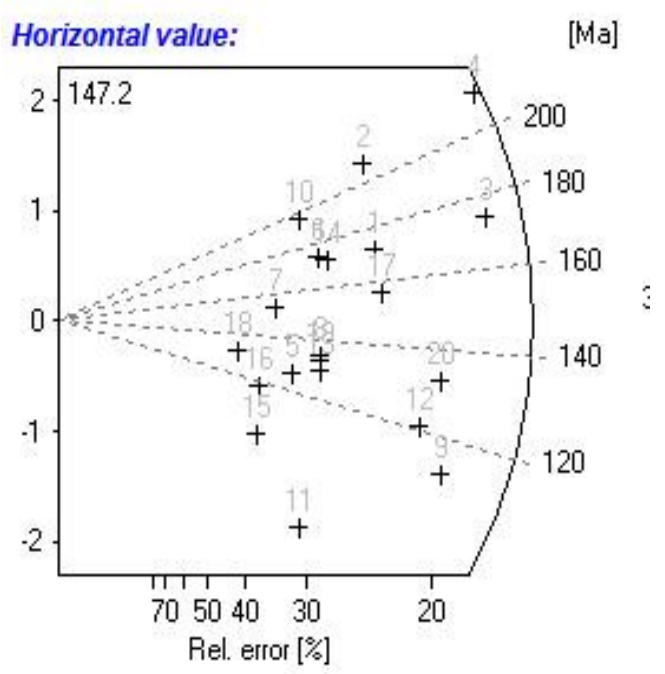

Chi-sq.: $\quad 18.68$

$\mathrm{P}(\%) \quad 47.74$

Dispersion: 0.08

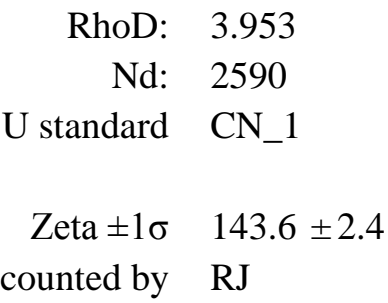

\begin{tabular}{ccccccccc} 
Crystal & $\mathrm{Ns}$ & $\mathrm{Ni}$ & Area & RhoS(e5) & RhoI(e5) & Age(Ma) & $+-1 \mathrm{~s}$ & $\mathrm{U}(\mathrm{ppm})$ \\
\hline 1 & 129 & 21 & 16 & 80.63 & 13.13 & 172.02 & 40.72 & 105.33 \\
2 & 142 & 19 & 9 & 157.78 & 21.11 & 208.69 & 51.26 & 169.42 \\
3 & 236 & 38 & 16 & 147.50 & 23.75 & 173.89 & 30.72 & 190.59 \\
4 & 268 & 35 & 15 & 178.67 & 23.33 & 213.73 & 38.81 & 187.25 \\
5 & 54 & 12 & 4 & 135.00 & 30.00 & 126.46 & 40.49 & 240.75 \\
6 & 87 & 14 & 12 & 72.50 & 11.67 & 174.00 & 50.30 & 93.63 \\
7 & 55 & 10 & 4 & 137.50 & 25.00 & 154.23 & 53.17 & 200.63 \\
8 & 72 & 15 & 9 & 80.00 & 16.67 & 134.81 & 38.42 & 133.75 \\
9 & 132 & 33 & 16 & 82.50 & 20.63 & 112.53 & 22.09 & 165.52 \\
10 & 84 & 12 & 6 & 140.00 & 20.00 & 195.66 & 60.59 & 160.50 \\
11 & 41 & 14 & 9 & 45.56 & 15.56 & 82.58 & 25.65 & 124.83 \\
12 & 125 & 29 & 9 & 138.89 & 32.22 & 121.18 & 25.17 & 258.58 \\
13 & 69 & 15 & 3 & 230.00 & 50.00 & 129.25 & 36.97 & 401.25 \\
14 & 92 & 15 & 12 & 76.67 & 12.50 & 171.76 & 48.03 & 100.31 \\
15 & 32 & 9 & 6 & 53.33 & 15.00 & 100.13 & 37.87 & 120.38 \\
16 & 38 & 9 & 6 & 63.33 & 15.00 & 118.73 & 44.12 & 120.38 \\
17 & 123 & 22 & 16 & 76.88 & 13.75 & 156.75 & 36.51 & 110.34 \\
18 & 33 & 7 & 3 & 110.00 & 23.33 & 132.42 & 55.21 & 187.25 \\
19 & 71 & 15 & 16 & 44.38 & 9.38 & 132.95 & 37.94 & 75.23 \\
20 & 151 & 32 & 12 & 125.83 & 26.67 & 132.55 & 26.02 & 214.00 \\
\hline
\end{tabular}


Sample number: JR11-40b

Mineral: Zircon

Irradiation code: vuw005-34, 35

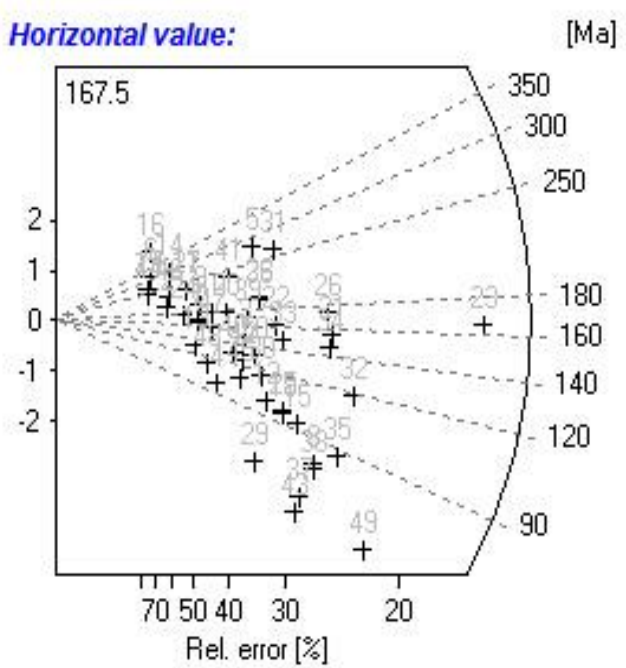

Chi-sq.: $\quad 89.19$

Ns: 2689

Ni: 537

Area: 300

RhoS: 89.63

RhoI: 17.9

Pooled Age: $\quad 137.1 \pm 7.4$

Mean Age: $168 \pm 11.1$

Central Age: $136.2 \pm 9.8$

$\mathrm{P}(\%) \quad 0.04$

Dispersion: 0.31

RhoD: 3.853

Nd: 2590

U standard CN_1

Zeta $\pm 1 \sigma \quad 143.6 \pm 2.4$

counted by RJ

\begin{tabular}{ccccccccc} 
Crystal & $\mathrm{Ns}$ & $\mathrm{Ni}$ & Area & $\mathrm{RhoS}(\mathrm{e} 5)$ & $\mathrm{RhoI}(\mathrm{e} 5)$ & Age(Ma) & $+-1 \mathrm{~s}$ & $\mathrm{U}(\mathrm{ppm})$ \\
\hline 1 & 31 & 5 & 3 & 103.33 & 16.67 & 169.29 & 81.70 & 137.20 \\
2 & 22 & 3 & 4 & 55.00 & 7.50 & 199.76 & 123.05 & 61.74 \\
3 & 49 & 9 & 4 & 122.50 & 22.50 & 148.90 & 54.13 & 185.22 \\
4 & 25 & 7 & 3 & 83.33 & 23.33 & 98.06 & 42.01 & 192.08 \\
5 & 93 & 9 & 6 & 155.00 & 15.00 & 279.73 & 97.92 & 123.48 \\
6 & 24 & 2 & 3 & 80.00 & 6.67 & 323.73 & 238.41 & 54.88 \\
7 & 30 & 5 & 4 & 75.00 & 12.50 & 163.90 & 79.28 & 102.90 \\
8 & 54 & 19 & 8 & 67.50 & 23.75 & 78.16 & 20.94 & 195.51 \\
9 & 36 & 5 & 4 & 90.00 & 12.50 & 196.18 & 93.77 & 102.90 \\
10 & 40 & 6 & 6 & 66.67 & 10.00 & 181.86 & 79.75 & 82.32 \\
11 & 34 & 4 & 2 & 170.00 & 20.00 & 230.98 & 122.24 & 164.64 \\
12 & 44 & 12 & 6 & 73.33 & 20.00 & 100.65 & 32.88 & 164.64 \\
13 & 24 & 5 & 3 & 80.00 & 16.67 & 131.45 & 64.71 & 137.20 \\
14 & 33 & 3 & 4 & 82.50 & 7.50 & 297.37 & 179.48 & 61.74 \\
15 & 55 & 16 & 6 & 91.67 & 26.67 & 94.41 & 26.93 & 219.52 \\
16 & 34 & 2 & 3 & 113.33 & 6.67 & 453.97 & 330.52 & 54.88 \\
17 & 20 & 2 & 2 & 100.00 & 10.00 & 270.89 & 201.02 & 82.32 \\
18 & 49 & 14 & 6 & 81.67 & 23.33 & 96.11 & 29.23 & 192.08 \\
19 & 20 & 2 & 4 & 50.00 & 5.00 & 270.89 & 201.02 & 41.16 \\
20 & 46 & 7 & 3 & 153.33 & 23.33 & 179.29 & 72.89 & 192.08
\end{tabular}


Appendix III

\begin{tabular}{ccccccccc}
21 & 109 & 19 & 10 & 109.00 & 19.00 & 156.80 & 39.19 & 156.41 \\
22 & 72 & 12 & 5 & 144.00 & 24.00 & 163.90 & 51.28 & 197.57 \\
23 & 273 & 45 & 16 & 170.63 & 28.13 & 165.70 & 27.00 & 231.53 \\
24 & 26 & 4 & 3 & 86.67 & 13.33 & 177.37 & 95.37 & 109.76 \\
25 & 50 & 14 & 9 & 55.56 & 15.56 & 98.06 & 29.76 & 128.05 \\
26 & 115 & 18 & 20 & 57.50 & 9.00 & 174.38 & 44.43 & 74.09 \\
27 & 34 & 4 & 4 & 85.00 & 10.00 & 230.98 & 122.24 & 82.32 \\
28 & 72 & 10 & 6 & 120.00 & 16.67 & 196.18 & 66.40 & 137.20 \\
29 & 28 & 12 & 6 & 46.67 & 20.00 & 64.23 & 22.22 & 164.64 \\
30 & 47 & 11 & 4 & 117.50 & 27.50 & 117.14 & 39.35 & 226.38 \\
31 & 107 & 11 & 15 & 71.33 & 7.33 & 263.66 & 83.76 & 60.37 \\
32 & 100 & 23 & 16 & 62.50 & 14.38 & 119.18 & 27.73 & 118.34 \\
33 & 71 & 13 & 6 & 118.33 & 21.67 & 149.36 & 45.22 & 178.36 \\
34 & 102 & 19 & 12 & 85.00 & 15.83 & 146.84 & 36.89 & 130.34 \\
35 & 70 & 22 & 9 & 77.78 & 24.44 & 87.43 & 21.49 & 201.23 \\
36 & 71 & 10 & 6 & 118.33 & 16.67 & 193.50 & 65.55 & 137.20 \\
37 & 41 & 18 & 4 & 102.50 & 45.00 & 62.71 & 17.81 & 370.44 \\
38 & 53 & 19 & 6 & 888.33 & 31.67 & 76.72 & 20.61 & 260.68 \\
39 & 57 & 9 & 4 & 142.50 & 22.50 & 172.88 & 62.17 & 185.22 \\
40 & 38 & 8 & 6 & 63.33 & 13.33 & 130.10 & 50.72 & 109.76 \\
41 & 61 & 7 & 6 & 101.67 & 11.67 & 236.70 & 94.65 & 96.04 \\
42 & 41 & 9 & 6 & 68.33 & 15.00 & 124.82 & 46.06 & 123.48 \\
43 & 37 & 18 & 4 & 92.50 & 45.00 & 56.62 & 16.34 & 370.44 \\
44 & 18 & 2 & 1 & 180.00 & 20.00 & 244.31 & 182.21 & 164.64 \\
45 & 36 & 9 & 4 & 90.00 & 22.50 & 109.73 & 40.99 & 185.22 \\
46 & 25 & 3 & 2 & 125.00 & 15.00 & 226.53 & 138.53 & 123.48 \\
47 & 35 & 6 & 4 & 87.50 & 15.00 & 159.40 & 70.55 & 123.48 \\
48 & 25 & 6 & 8 & 31.25 & 7.50 & 114.26 & 52.03 & 61.74 \\
49 & 64 & 29 & 8 & 80.00 & 36.25 & 60.77 & 13.69 & 298.41 \\
50 & 48 & 10 & 6 & 80.00 & 16.67 & 131.45 & 45.82 & 137.20 \\
\hline & & & & & & & & \\
& & & &
\end{tabular}


Sample number: JR11-40c

Mineral: Zircon

Irradiation code: vuw005-32, 33

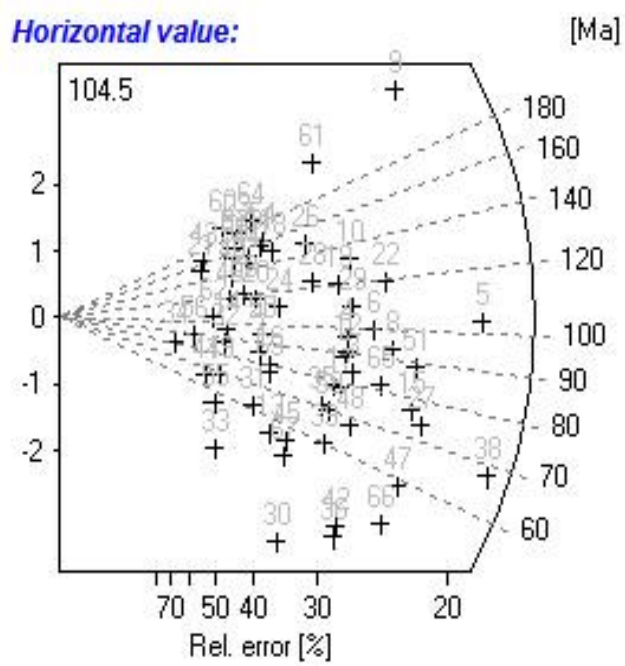

Chi-sq.: $\quad 125.2$

Ns: 3151

Ni: 917

Area: 470

RhoS: $\quad 67.04$

RhoI: 19.51

Pooled Age: $\quad 95.1 \pm 4.3$

Mean Age: $\quad 104.6 \pm 5.5$

Central Age: $\quad 93.0 \pm 5.5$

$\mathrm{P}(\%) \quad 0.0$

Dispersion: $\quad 0.28$

RhoD: 3.882

Nd: 2590

U standard CN_1

Zeta $\pm 1 \sigma \quad 143.6 \pm 2.4$

counted by RJ

\begin{tabular}{ccccccccc} 
Crystal & $\mathrm{Ns}$ & $\mathrm{Ni}$ & Area & RhoS(e5) & Rhol(e5) & Age(Ma) & $+-1 \mathrm{~s}$ & $\mathrm{U}(\mathrm{ppm})$ \\
\hline 1 & 48 & 17 & 16 & 30.00 & 10.63 & 78.22 & 22.17 & 86.83 \\
2 & 58 & 18 & 12 & 48.33 & 15.00 & 89.19 & 24.17 & 122.58 \\
3 & 58 & 19 & 12 & 48.33 & 15.83 & 84.52 & 22.45 & 129.39 \\
4 & 63 & 18 & 18 & 35.00 & 10.00 & 96.82 & 26.00 & 81.72 \\
5 & 142 & 38 & 18 & 78.89 & 21.11 & 103.32 & 19.06 & 172.52 \\
6 & 76 & 21 & 4 & 190.00 & 52.50 & 100.08 & 24.81 & 429.02 \\
7 & 28 & 9 & 4 & 70.00 & 22.50 & 86.13 & 33.08 & 183.87 \\
8 & 81 & 24 & 16 & 50.63 & 15.00 & 93.38 & 21.84 & 122.58 \\
9 & 177 & 21 & 24 & 73.75 & 8.75 & 230.73 & 53.58 & 71.50 \\
10 & 82 & 17 & 9 & 91.11 & 18.89 & 133.05 & 35.62 & 154.36 \\
11 & 46 & 8 & 6 & 76.67 & 13.33 & 158.30 & 60.78 & 108.96 \\
12 & 59 & 18 & 6 & 98.33 & 30.00 & 90.71 & 24.54 & 245.16 \\
13 & 22 & 11 & 6 & 36.67 & 18.33 & 55.50 & 20.55 & 149.82 \\
14 & 21 & 6 & 4 & 52.50 & 15.00 & 96.82 & 44.89 & 122.58 \\
15 & 78 & 28 & 9 & 86.67 & 31.11 & 77.18 & 17.12 & 254.23 \\
16 & 29 & 10 & 3 & 96.67 & 33.33 & 80.32 & 29.53 & 272.39 \\
17 & 51 & 18 & 4 & 127.50 & 45.00 & 78.49 & 21.61 & 367.73 \\
18 & 49 & 9 & 6 & 81.67 & 15.00 & 149.98 & 54.53 & 122.58 \\
19 & 70 & 16 & 12 & 58.33 & 13.33 & 120.80 & 33.62 & 108.96 \\
20 & 34 & 8 & 3 & 113.33 & 26.67 & 117.38 & 46.22 & 217.92
\end{tabular}




\begin{tabular}{|c|c|c|c|c|c|c|c|c|}
\hline 21 & 22 & 4 & 4 & 55.00 & 10.00 & 151.49 & 82.44 & 81.72 \\
\hline 22 & 95 & 22 & 15 & 63.33 & 14.67 & 119.24 & 28,38 & 119.58 \\
\hline 23 & 40 & 6 & 4 & 100.00 & 15.00 & 183.18 & 80.33 & 122.58 \\
\hline 24 & 40 & 10 & 9 & 44.44 & 11.11 & 110.53 & 39.18 & 90.80 \\
\hline 25 & 31 & 9 & 9 & 34.44 & 10.00 & 95.90 & 36.16 & 81.72 \\
\hline 26 & 65 & 12 & 9 & 72.22 & 13.33 & 149.23 & 47.04 & 108.96 \\
\hline 27 & 80 & 30 & 27 & 29.63 & 11.11 & 73.90 & 15.93 & 90.80 \\
\hline 28 & 58 & 13 & 12 & 48.33 & 10.83 & 123.16 & 37.93 & 88.53 \\
\hline 29 & 71 & 18 & 9 & 78.89 & 20.00 & 109.01 & 28.90 & 163.44 \\
\hline 30 & 17 & 15 & 9 & 18.89 & 16.67 & 31.51 & 11.19 & 136.20 \\
\hline 31 & 20 & 9 & 4 & 50.00 & 22.50 & 61.64 & 24.79 & 183.87 \\
\hline 32 & 19 & 6 & 4 & 47.50 & 15.00 & 87.66 & 41.11 & 122.58 \\
\hline 33 & 10 & 7 & 6 & 16.67 & 11.67 & 39.69 & 19.59 & 95.34 \\
\hline 34 & 9 & 3 & 1 & 90.00 & 30.00 & 83.07 & 55.42 & 245.16 \\
\hline 35 & 41 & 16 & 4 & 102.50 & 40.00 & 71.03 & 21.02 & 326.87 \\
\hline 36 & 31 & 21 & 6 & 51.67 & 35.00 & 41.01 & 11.64 & 286.01 \\
\hline 37 & 36 & 6 & 4 & 90.00 & 15.00 & 165.09 & 72.92 & 122.58 \\
\hline 38 & 105 & 43 & 12 & 87.50 & 35.83 & 67.70 & 12.38 & 292.82 \\
\hline 39 & 37 & 17 & 6 & 61.67 & 28.33 & 60.38 & 17.76 & 231.54 \\
\hline 40 & 30 & 6 & 4 & 75.00 & 15.00 & 137.87 & 61.76 & 122.58 \\
\hline 41 & 12 & 5 & 2 & 60.00 & 25.00 & 66.54 & 35.46 & 204.30 \\
\hline 42 & 33 & 21 & 6 & 55.00 & 35.00 & 43.65 & 12.24 & 286.01 \\
\hline 43 & 24 & 4 & 2 & 120.00 & 20.00 & 165.09 & 89.26 & 163.44 \\
\hline 44 & 37 & 7 & 2 & 185.00 & 35.00 & 145.66 & 60.15 & 286.01 \\
\hline 45 & 26 & 13 & 4 & 65.00 & 32.50 & 55.50 & 18.91 & 265.58 \\
\hline 46 & 26 & 6 & 3 & 86.67 & 20.00 & 119.66 & 54.28 & 163.44 \\
\hline 47 & 59 & 28 & 12 & 49.17 & 23.33 & 58.46 & 13.50 & 190.68 \\
\hline 48 & 49 & 20 & 8 & 61.25 & 25.00 & 67.92 & 18.11 & 204.30 \\
\hline 49 & 15 & 6 & 3 & 50.00 & 20.00 & 69.30 & 33.52 & 163.44 \\
\hline 50 & 31 & 9 & 4 & 77.50 & 22.50 & 95.29 & 36.16 & 183.87 \\
\hline 51 & 90 & 28 & 7 & 128.57 & 40.00 & 88.97 & 19.39 & 326.87 \\
\hline 52 & 39 & 7 & 2 & 195.00 & 35.00 & 153.44 & 63.11 & 286.01 \\
\hline 53 & 34 & 6 & 3 & 113.33 & 20.00 & 156.03 & 69.21 & 163.44 \\
\hline 54 & 47 & 8 & 4 & 117.50 & 20.00 & 161.70 & 61.98 & 163.44 \\
\hline 55 & 12 & 6 & 4 & 30.00 & 15.00 & 55.50 & 27.79 & 122.58 \\
\hline 56 & 13 & 4 & 2 & 65.00 & 20.00 & 89.95 & 51.48 & 163.44 \\
\hline 57 & 36 & 6 & 4 & 90.00 & 15.00 & 165.09 & 72.92 & 122.58 \\
\hline 58 & 31 & 7 & 3 & 103.33 & 23.33 & 122.26 & 51.26 & 190.68 \\
\hline 59 & 43 & 17 & 6 & 71.67 & 28.33 & 70.11 & 20.17 & 231.54 \\
\hline 60 & 36 & 5 & 2 & 180.00 & 25.00 & 197.61 & 94.45 & 204.30 \\
\hline 61 & 94 & 12 & 8 & 117.50 & 15.00 & 214.70 & 66.05 & 122.58 \\
\hline 62 & 19 & 5 & 2 & 95.00 & 25.00 & 105.05 & 52.87 & 204.30 \\
\hline 63 & 28 & 10 & 4 & 70.00 & 25.00 & 77.57 & 28.65 & 204.30 \\
\hline 64 & 48 & 7 & 4 & 120.00 & 17.50 & 188.33 & 76.35 & 143.01 \\
\hline 65 & 68 & 23 & 6 & 113.33 & 38.33 & 81.88 & 19.86 & 313.25 \\
\hline 66 & 48 & 27 & 9 & 53.33 & 30.00 & 49.36 & 11.94 & 245.16 \\
\hline 67 & 24 & 13 & 4 & 60.00 & 32.50 & 51.25 & 17.70 & 265.58 \\
\hline
\end{tabular}


Sample number: JR11-45

Mineral: Zircon

Irradiation code: vuw005-37

$$
\begin{aligned}
\text { Ns: } & 1464 \\
\text { Ni: } & 262 \\
\text { Area: } & 167 \\
& \\
\text { RhoS: } & 87.67 \\
\text { RhoI: } & 15.69 \\
& \\
\text { Pooled Age: } & 148.9 \pm 10.7 \\
\text { Mean Age: } & 145.5 \pm 6.4 \\
\text { Central Age: } & 148.9 \pm 10.7 \\
\text { Chi-sq.: } & 6.89 \\
\text { P(\%) } & 99.48 \\
\text { Dispersion: } & 0.00 \\
\text { RhoD: } & 3.754 \\
\text { Nd: } & 2590 \\
\text { U standard } & \text { CN_1 } \\
\text { Zeta } \pm 1 \sigma & 143.6 \pm 2.4 \\
\text { counted by } & \text { RJ }
\end{aligned}
$$

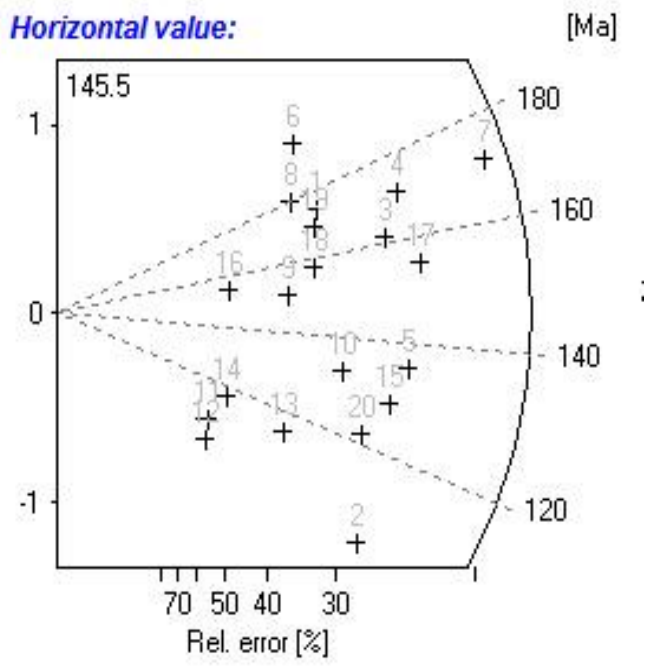

\begin{tabular}{ccccccccc} 
Crystal & Ns & Ni & Area & RhoS(e5) & Rhol(e5) & Age(Ma) & $+-1 \mathrm{~s}$ & U(ppm) \\
\hline 1 & 72 & 11 & 8 & 90.00 & 13.75 & 174.05 & 56.52 & 116.19 \\
2 & 62 & 16 & 9 & 68.89 & 17.78 & 103.60 & 29.17 & 150.22 \\
3 & 109 & 18 & 6 & 181.67 & 30.00 & 161.18 & 41.22 & 253.50 \\
4 & 122 & 19 & 8 & 152.50 & 23.75 & 170.78 & 42.35 & 200.69 \\
5 & 107 & 21 & 9 & 118.89 & 23.33 & 135.89 & 32.62 & 197.17 \\
6 & 68 & 9 & 6 & 113.33 & 15.00 & 200.49 & 71.30 & 126.75 \\
7 & 193 & 30 & 20 & 96.50 & 15.00 & 171.10 & 33.87 & 126.75 \\
8 & 61 & 9 & 6 & 101.67 & 15.00 & 180.14 & 64.49 & 126.75 \\
9 & 51 & 9 & 8 & 63.75 & 11.25 & 150.95 & 54.72 & 95.06 \\
10 & 70 & 14 & 9 & 77.78 & 15.56 & 133.37 & 39.20 & 131.45 \\
11 & 16 & 4 & 8 & 20.00 & 5.00 & 106.92 & 59.83 & 42.25 \\
12 & 15 & 4 & 3 & 50.00 & 13.33 & 100.29 & 56.49 & 112.67 \\
13 & 39 & 9 & 12 & 32.50 & 7.50 & 115.75 & 42.91 & 63.38 \\
14 & 22 & 5 & 6 & 36.67 & 8.33 & 117.51 & 58.30 & 70.42 \\
15 & 92 & 19 & 8 & 115.00 & 23.75 & 129.20 & 32.73 & 200.69 \\
16 & 29 & 5 & 3 & 96.67 & 16.67 & 154.46 & 74.90 & 140.84 \\
17 & 128 & 22 & 12 & 106.67 & 18.33 & 154.94 & 35.98 & 154.92 \\
18 & 65 & 11 & 6 & 108.33 & 18.33 & 157.33 & 51.45 & 154.92 \\
19 & 70 & 11 & 12 & 58.33 & 9.17 & 169.28 & 55.08 & 77.46 \\
20 & 73 & 16 & 8 & 91.25 & 20.00 & 121.81 & 33.77 & 169.00 \\
\hline
\end{tabular}


Sample number: 786

Mineral: Zircon

Irradiation code: vuw006-31, 32

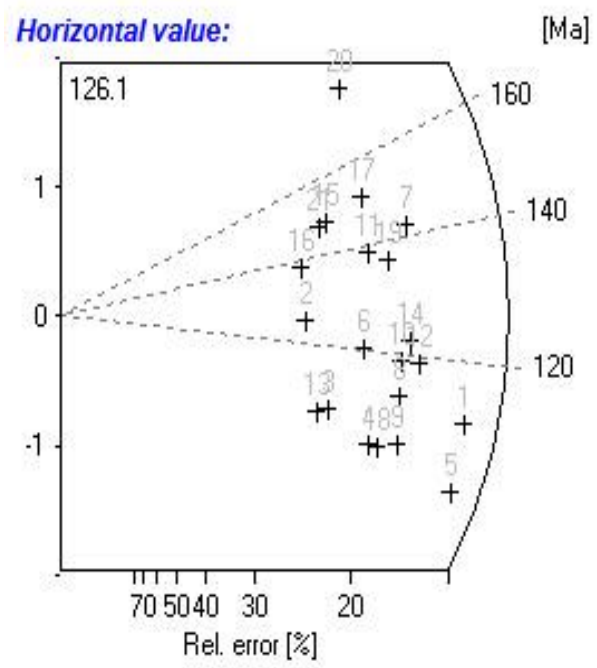

Chi-sq.: $\quad 13.14$

Ns: 3193

Ni: 768

Area: 270

RhoS: 118.3

RhoI: 28.44

Pooled Age: $123.4 \pm 5.7$

Mean Age: $\quad 126.1 \pm 4.5$

Central Age: $123.4 \pm 5.7$

$\mathrm{P}(\%) \quad 87.12$

Dispersion: $\quad 0.00$

$\begin{aligned} \text { RhoD: } & 4.175 \\ \text { Nd: } & 4415 \\ \text { U standard } & \text { CN_1 } \\ & \\ \text { Zeta } \pm 1 \sigma & 143.6 \pm 2.4 \\ \text { counted by } & \text { RJ }\end{aligned}$

\begin{tabular}{ccccccccc} 
Crystal & Ns & Ni & Area & RhoS(e5) & RhoI(e5) & Age(Ma) & $+-1 \mathrm{~s}$ & U(ppm) \\
\hline 1 & 230 & 61 & 20 & 115.00 & 30.50 & 112.04 & 16.33 & 231.74 \\
2 & 93 & 22 & 9 & 103.33 & 24.44 & 125.48 & 29.88 & 185.73 \\
3 & 98 & 27 & 10 & 98.00 & 27.00 & 107.89 & 23.58 & 205.15 \\
4 & 127 & 36 & 9 & 141.11 & 40.00 & 104.89 & 19.94 & 303.92 \\
5 & 201 & 58 & 10 & 201.00 & 58.00 & 103.05 & 15.53 & 440.69 \\
6 & 138 & 34 & 9 & 153.33 & 37.78 & 120.53 & 23.24 & 287.04 \\
7 & 206 & 43 & 9 & 228.89 & 47.78 & 142.03 & 24.03 & 363.02 \\
8 & 164 & 43 & 18 & 91.11 & 23.89 & 113.32 & 19.58 & 181.51 \\
9 & 154 & 43 & 12 & 128.33 & 35.83 & 106.47 & 18.52 & 272.26 \\
10 & 172 & 43 & 12 & 143.33 & 35.83 & 118.80 & 20.43 & 272.26 \\
11 & 159 & 34 & 15 & 106.00 & 22.67 & 138.68 & 26.39 & 172.22 \\
12 & 192 & 48 & 12 & 160.00 & 40.00 & 118.80 & 19.36 & 303.92 \\
13 & 90 & 25 & 10 & 90.00 & 25.00 & 107.02 & 24.31 & 189.95 \\
14 & 185 & 45 & 18 & 102.78 & 25.00 & 122.07 & 20.47 & 189.95 \\
15 & 125 & 25 & 12 & 104.17 & 20.83 & 148.16 & 32.63 & 158.29 \\
16 & 98 & 21 & 9 & 108.89 & 23.33 & 138.39 & 33.42 & 177.29 \\
17 & 163 & 32 & 12 & 135.83 & 26.67 & 150.91 & 29.37 & 202.62 \\
18 & 134 & 38 & 15 & 89.33 & 25.33 & 104.85 & 19.41 & 192.48 \\
19 & 179 & 39 & 25 & 71.60 & 15.60 & 136.13 & 24.25 & 118.53 \\
20 & 166 & 27 & 12 & 138.33 & 22.50 & 181.71 & 37.93 & 170.96 \\
21 & 119 & 24 & 12 & 99.17 & 20.00 & 146.94 & 33.05 & 151.96 \\
\hline
\end{tabular}


Sample number: 793

Mineral: Zircon

Irradiation code: vuw006-33

Ns: 1339

Ni: 270

Area: 150

RhoS: $\quad 89.27$

RhoI: 18

Pooled Age: $\quad 145.6 \pm 10.3$

Mean Age: $\quad 153.2 \pm 13.2$

Central Age: $145.3 \pm 11.3$

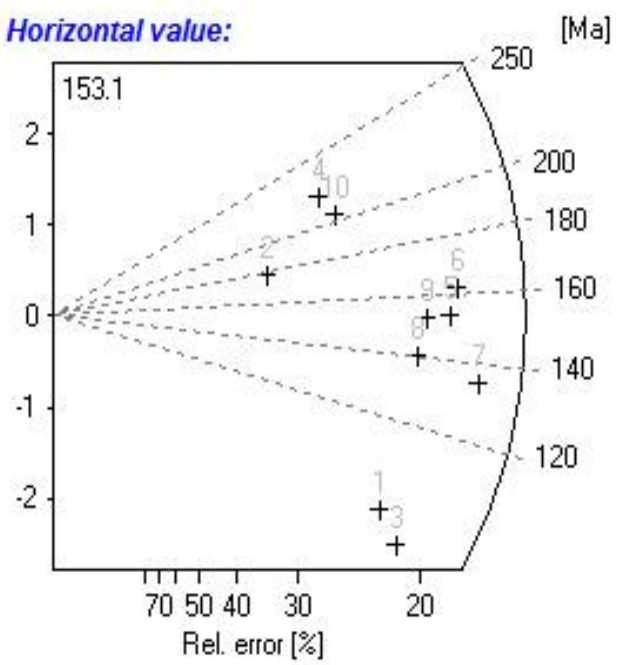

Chi-sq.: $\quad 14.32$

$\mathrm{P}(\%) \quad 11.15$

Dispersion: $\quad 0.10$

$\begin{aligned} \text { RhoD: } & 4.136 \\ \text { Nd: } & 4415 \\ \text { U standard } & \text { CN_1 }\end{aligned}$

Zeta $\pm 1 \sigma \quad 143.6 \pm 2.4$

counted by RJ

\begin{tabular}{ccccccccc} 
Crystal & Ns & Ni & Area & RhoS(e5) & RhoI(e5) & Age(Ma) & $+-1 \mathrm{~s}$ & U(ppm) \\
\hline 1 & 84 & 26 & 4 & 210.00 & 65.00 & 95.24 & 21.48 & 498.47 \\
2 & 61 & 10 & 4 & 152.50 & 25.00 & 178.66 & 61.09 & 191.72 \\
3 & 88 & 29 & 16 & 55.00 & 18.13 & 89.50 & 19.27 & 139.00 \\
4 & 113 & 15 & 9 & 125.56 & 16.67 & 219.94 & 60.64 & 127.81 \\
5 & 183 & 35 & 25 & 73.20 & 14.00 & 153.44 & 28.52 & 107.36 \\
6 & 199 & 36 & 15 & 132.67 & 24.00 & 162.11 & 29.59 & 184.05 \\
7 & 188 & 41 & 20 & 94.00 & 20.50 & 134.76 & 23.42 & 157.21 \\
8 & 143 & 30 & 16 & 89.38 & 18.75 & 140.03 & 28.30 & 143.79 \\
9 & 161 & 31 & 16 & 100.63 & 19.38 & 152.43 & 30.09 & 148.58 \\
10 & 119 & 17 & 25 & 47.60 & 6.80 & 204.61 & 53.25 & 52.15 \\
\hline
\end{tabular}


Sample number: 14210

Mineral: Zircon

Irradiation code: vuw006-39

Ns: 2245

Ni: 392

Area: 196

RhoS: 114.5

RhoI: 20

Pooled Age: $\quad 161.7 \pm 9.6$

Mean Age: $\quad 173.2 \pm 19.3$

Central Age: $\quad 158.5 \pm 13.2$

Chi-sq.: $\quad 31.03$

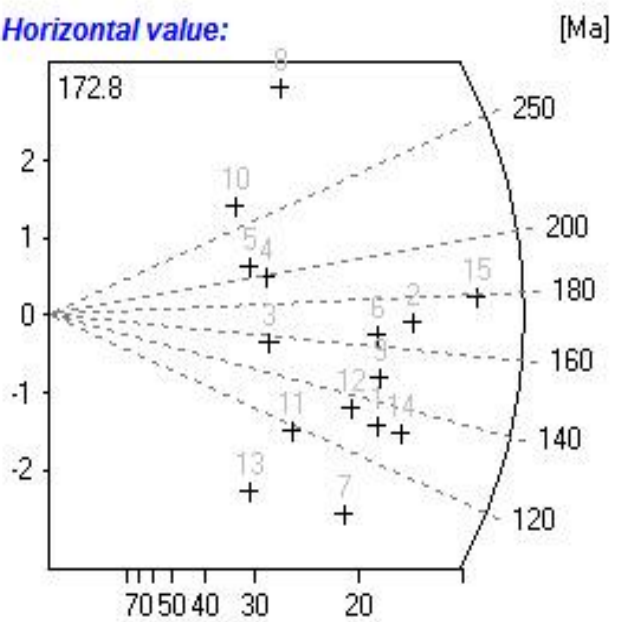

$\mathrm{P}(\%) \quad 0.55$

Riel. error [\%]

Dispersion: 0.22

RhoD: 3.982

Nd: 4415

U standard CN_1

Zeta $\pm 1 \sigma \quad 143.6 \pm 2.4$

counted by RJ

\begin{tabular}{ccccccccc} 
Crystal & $\mathrm{Ns}$ & $\mathrm{Ni}$ & Area & RhoS(e5) & RhoI(e5) & Age(Ma) & $+-1 \mathrm{~s}$ & $\mathrm{U}(\mathrm{ppm})$ \\
\hline 1 & 159 & 34 & 24 & 66.25 & 14.17 & 132.35 & 25.18 & 112.84 \\
2 & 242 & 40 & 20 & 121.00 & 20.00 & 170.71 & 29.39 & 159.31 \\
3 & 83 & 15 & 9 & 92.22 & 16.67 & 156.31 & 43.99 & 132.76 \\
4 & 99 & 14 & 4 & 247.50 & 35.00 & 199.09 & 57.02 & 278.79 \\
5 & 90 & 12 & 5 & 180.00 & 24.00 & 210.96 & 65.00 & 191.17 \\
6 & 193 & 33 & 16 & 120.63 & 20.63 & 165.09 & 31.32 & 164.29 \\
7 & 103 & 29 & 16 & 64.38 & 18.13 & 100.76 & 21.30 & 144.37 \\
8 & 206 & 15 & 10 & 206.00 & 15.00 & 381.18 & 102.30 & 119.48 \\
9 & 179 & 34 & 15 & 119.33 & 22.67 & 148.80 & 28.04 & 180.55 \\
10 & 99 & 10 & 4 & 247.50 & 25.00 & 277.03 & 92.13 & 199.13 \\
11 & 79 & 19 & 10 & 79.00 & 19.00 & 117.80 & 30.22 & 151.34 \\
12 & 139 & 29 & 9 & 154.44 & 32.22 & 135.61 & 27.85 & 256.66 \\
13 & 42 & 14 & 4 & 105.00 & 35.00 & 85.21 & 26.37 & 278.79 \\
14 & 182 & 39 & 25 & 72.80 & 15.60 & 132.07 & 23.49 & 124.26 \\
15 & 350 & 55 & 25 & 140.00 & 22.00 & 179.44 & 26.34 & 175.24 \\
\hline
\end{tabular}


Sample number: 14213

Mineral: Zircon

Irradiation code: vuw006-44

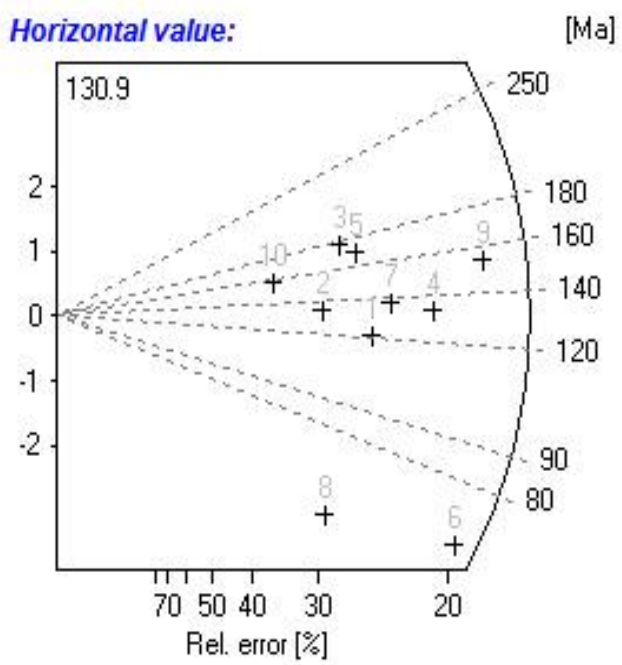

Chi-sq.: $\quad 25.91$

$\mathrm{P}(\%) \quad 0.21$

Dispersion: $\quad 0.3$

RhoD: 3.854

Nd: 4415

U standard CN_1

Zeta $\pm 1 \sigma \quad 143.6 \pm 2.4$

counted by RJ

\begin{tabular}{|c|c|c|c|c|c|c|c|c|}
\hline Crystal & Ns & $\mathrm{Ni}$ & Area & RhoS(e5) & RhoI(e5) & $\operatorname{Age}(\mathrm{Ma})$ & $+-1 \mathrm{~s}$ & $\mathrm{U}(\mathrm{ppm})$ \\
\hline 1 & 89 & 20 & 9 & 98.89 & 22.22 & 121.98 & 30.31 & 182.90 \\
\hline 2 & 69 & 14 & 9 & 76.67 & 15.56 & 134.96 & 39.68 & 128.03 \\
\hline 3 & 98 & 15 & 10 & 98.00 & 15.00 & 178.30 & 49.60 & 123.46 \\
\hline 4 & 137 & 28 & 15 & 91.33 & 18.67 & 133.99 & 27.95 & 153.64 \\
\hline 5 & 106 & 17 & 10 & 106.00 & 17.00 & 170.27 & 44.65 & 139.92 \\
\hline 6 & 88 & 37 & 9 & 97.78 & 41.11 & 65.48 & 12.91 & 338.37 \\
\hline 7 & 111 & 22 & 12 & 92.50 & 18.33 & 138.13 & 32.38 & 150.89 \\
\hline 8 & 35 & 18 & 5 & 70.00 & 36.00 & 53.58 & 15.59 & 296.30 \\
\hline 9 & 197 & 35 & 15 & 131.33 & 23.33 & 153.90 & 28.44 & 192.05 \\
\hline 10 & 52 & 9 & 8 & 65.00 & 11.25 & 157.93 & 57.13 & 92.59 \\
\hline
\end{tabular}


Sample number: DS10-01

Mineral: Zircon

Irradiation code: vuw006-10

Ns: 2517

Ni: 562

Area: 222

RhoS: $\quad 113.4$

RhoI: 25.32

Pooled Age: $\quad 154.9 \pm 8.0$

Mean Age: $\quad 161.7 \pm 9.3$

Central Age: $\quad 155.0 \pm 8.8$

Chi-sq.: $\quad 23.43$

$\mathrm{P}(\%) \quad 17.48$

Dispersion: 0.1

RhoD: 4.877

Nd: 4415

U standard CN_1

Zeta $\pm 1 \sigma \quad 143.6 \pm 2.4$

counted by RJ

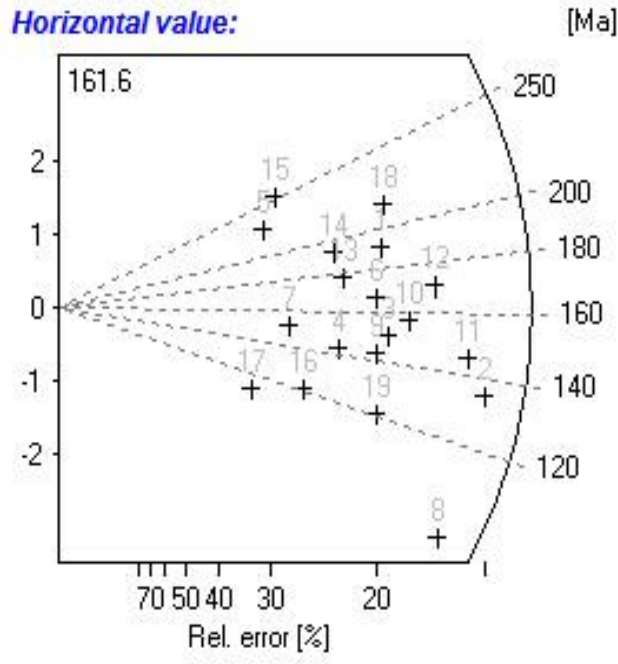

a] 
Sample number: DS10-13

Mineral: Zircon

Irradiation code: vuw006-21

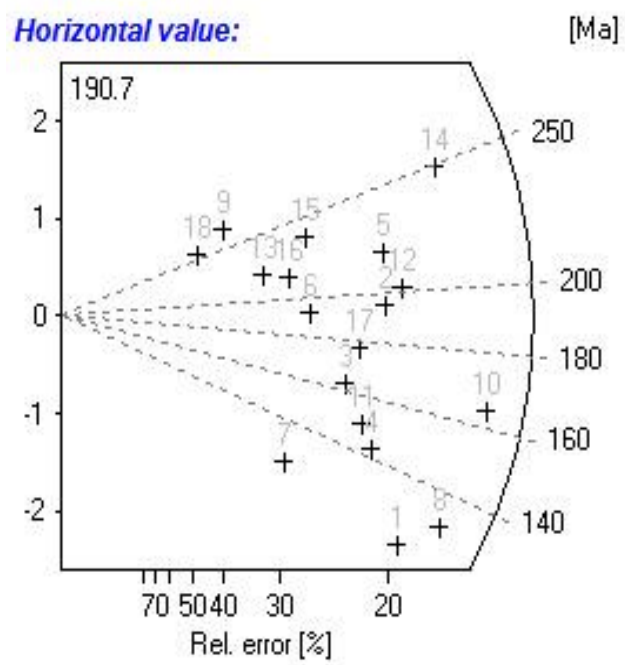

Chi-sq.: 20.68

$\mathrm{P}(\%) \quad 24.09$

Dispersion: $\quad 0.1$

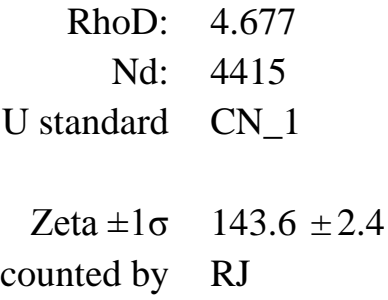

\begin{tabular}{ccccccccc} 
Crystal & $\mathrm{Ns}$ & $\mathrm{Ni}$ & Area & RhoS(e5) & RhoI(e5) & Age(Ma) & $+-1 \mathrm{~s}$ & $\mathrm{U}(\mathrm{ppm})$ \\
\hline 1 & 124 & 34 & 18 & 68.89 & 18.89 & 121.31 & 23.64 & 128.12 \\
2 & 171 & 29 & 25 & 68.40 & 11.60 & 195.02 & 39.41 & 78.68 \\
3 & 113 & 23 & 24 & 47.08 & 9.58 & 162.90 & 37.44 & 65.00 \\
4 & 121 & 28 & 18 & 67.22 & 15.56 & 143.50 & 30.27 & 105.51 \\
5 & 185 & 28 & 16 & 115.63 & 17.50 & 218.13 & 44.50 & 118.70 \\
6 & 99 & 17 & 9 & 110.00 & 18.89 & 192.64 & 50.76 & 128.12 \\
7 & 56 & 15 & 6 & 93.33 & 25.00 & 124.16 & 36.20 & 169.57 \\
8 & 166 & 42 & 9 & 184.44 & 46.67 & 131.37 & 22.88 & 316.53 \\
9 & 58 & 7 & 6 & 96.67 & 11.67 & 272.39 & 109.16 & 79.13 \\
10 & 253 & 51 & 15 & 168.67 & 34.00 & 164.46 & 25.51 & 230.61 \\
11 & 118 & 26 & 10 & 118.00 & 26.00 & 150.62 & 32.81 & 176.35 \\
12 & 195 & 32 & 12 & 162.50 & 26.67 & 201.44 & 38.69 & 180.87 \\
13 & 73 & 11 & 6 & 121.67 & 18.33 & 219.07 & 71.03 & 124.35 \\
14 & 281 & 37 & 18 & 156.11 & 20.56 & 250.10 & 44.10 & 139.42 \\
15 & 115 & 16 & 6 & 191.67 & 26.67 & 236.94 & 63.44 & 180.87 \\
16 & 91 & 14 & 10 & 91.00 & 14.00 & 214.65 & 61.81 & 94.96 \\
17 & 134 & 25 & 8 & 167.50 & 31.25 & 177.51 & 38.88 & 211.96 \\
18 & 39 & 5 & 6 & 65.00 & 8.33 & 256.73 & 122.09 & 56.52 \\
\hline
\end{tabular}


Sample number: DS10-16

Mineral: Zircon

Irradiation code: vuw006-19, 20

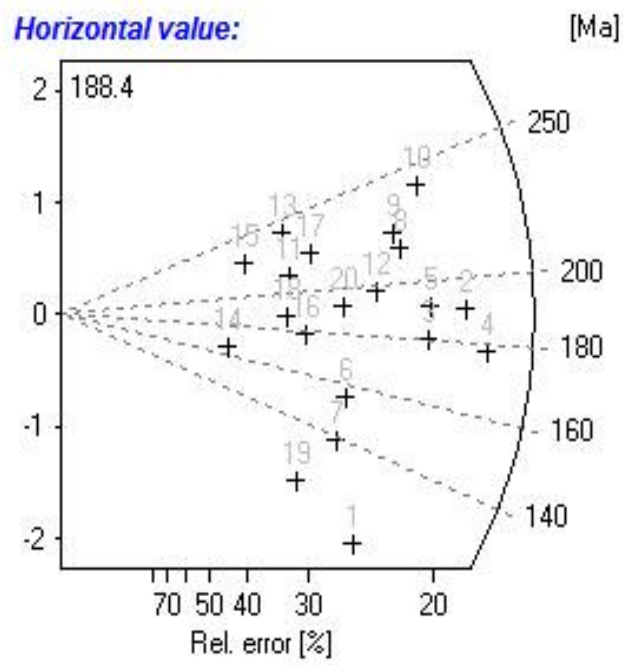

Chi-sq.: $\quad 12.32$

$\mathrm{P}(\%) \quad 87.16$

Dispersion: $\quad 0.00$

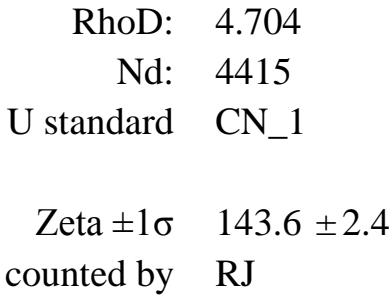

\begin{tabular}{ccccccccc} 
Crystal & $\mathrm{Ns}$ & $\mathrm{Ni}$ & Area & RhoS(e5) & RhoI(e5) & Age(Ma) & $+-1 \mathrm{~s}$ & $\mathrm{U}(\mathrm{ppm})$ \\
\hline 1 & 67 & 20 & 12 & 55.83 & 16.67 & 112.16 & 28.69 & 112.39 \\
2 & 200 & 35 & 10 & 200.00 & 35.00 & 190.16 & 35.10 & 236.02 \\
3 & 157 & 29 & 10 & 157.00 & 29.00 & 180.30 & 36.67 & 195.56 \\
4 & 208 & 39 & 16 & 130.00 & 24.38 & 177.66 & 31.26 & 164.37 \\
5 & 167 & 29 & 24 & 69.58 & 12.08 & 191.62 & 38.79 & 81.48 \\
6 & 84 & 18 & 16 & 52.50 & 11.25 & 155.72 & 40.60 & 75.86 \\
7 & 71 & 17 & 9 & 78.89 & 18.89 & 139.54 & 37.81 & 127.38 \\
8 & 155 & 24 & 9 & 172.22 & 26.67 & 214.52 & 47.30 & 179.83 \\
9 & 154 & 23 & 15 & 102.67 & 15.33 & 222.26 & 49.94 & 103.40 \\
10 & 188 & 26 & 15 & 125.33 & 17.33 & 239.70 & 50.44 & 116.89 \\
11 & 70 & 11 & 25 & 28.00 & 4.40 & 211.42 & 68.74 & 29.67 \\
12 & 125 & 21 & 18 & 69.44 & 11.67 & 197.97 & 46.90 & 78.67 \\
13 & 73 & 10 & 9 & 81.11 & 11.11 & 241.95 & 81.77 & 74.93 \\
14 & 30 & 6 & 8 & 37.50 & 7.50 & 166.70 & 74.64 & 50.58 \\
15 & 48 & 7 & 10 & 48.00 & 7.00 & 227.53 & 92.20 & 47.20 \\
16 & 70 & 13 & 12 & 58.33 & 10.83 & 179.34 & 54.31 & 73.05 \\
17 & 87 & 13 & 9 & 96.67 & 14.44 & 222.15 & 66.25 & 97.41 \\
18 & 62 & 11 & 9 & 68.89 & 12.22 & 187.61 & 61.52 & 82.42 \\
19 & 46 & 13 & 25 & 18.40 & 5.20 & 118.41 & 37.29 & 35.07 \\
20 & 98 & 17 & 25 & 39.20 & 6.80 & 191.82 & 50.58 & 45.86 \\
\hline
\end{tabular}


Sample number: DS10-18

Mineral: Zircon

Irradiation code: vuw006-23, 24

Ns: 4308

Ni: 789

Area: 384

RhoS: 112.2

RhoI: 20.55

Pooled Age: $\quad 179.1 \pm 8.0$

Mean Age: $\quad 177.9 \pm 7.8$

Central Age: $\quad 178.0 \pm 8.7$

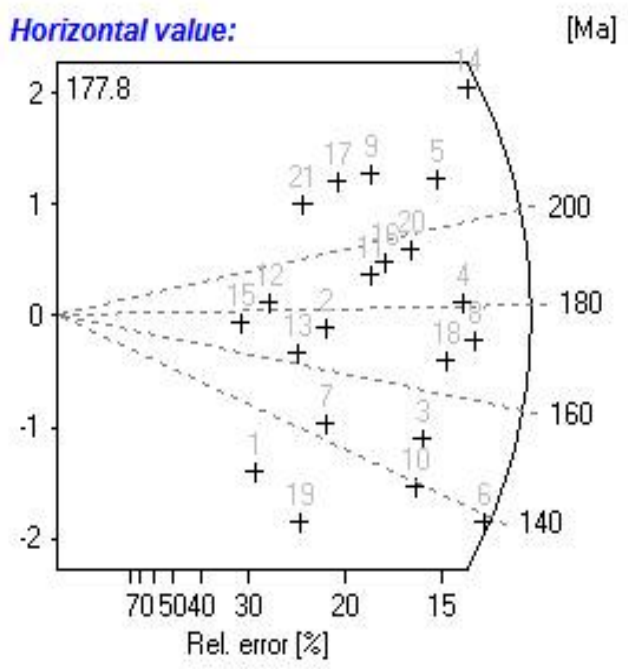

Chi-sq.: $\quad 25.22$

$\mathrm{P}(\%) \quad 19.33$

Dispersion: 0.09

RhoD: 4.631

Nd: 4415

U standard CN_1

Zeta $\pm 1 \sigma \quad 143.6 \pm 2.4$

counted by RJ

\begin{tabular}{ccccccccc} 
Crystal & Ns & Ni & Area & RhoS(e5) & RhoI(e5) & Age(Ma) & $+-1 \mathrm{~s}$ & U(ppm) \\
\hline 1 & 54 & 15 & 4 & 135.00 & 37.50 & 118.61 & 34.72 & 256.85 \\
2 & 138 & 26 & 9 & 153.33 & 28.89 & 174.12 & 37.43 & 197.87 \\
3 & 223 & 49 & 12 & 185.83 & 40.83 & 149.58 & 23.84 & 279.68 \\
4 & 326 & 59 & 16 & 203.75 & 36.88 & 181.16 & 25.95 & 252.57 \\
5 & 328 & 50 & 16 & 205.00 & 31.25 & 214.53 & 32.92 & 214.04 \\
6 & 286 & 68 & 25 & 114.40 & 27.20 & 138.36 & 18.92 & 186.30 \\
7 & 119 & 27 & 9 & 132.22 & 30.00 & 144.92 & 31.06 & 205.48 \\
8 & 331 & 63 & 18 & 183.88 & 935.00 & 172.38 & 24.01 & 239.72 \\
9 & 234 & 34 & 12 & 195.00 & 28.33 & 224.89 & 41.58 & 194.06 \\
10 & 203 & 48 & 16 & 126.87 & 530.00 & 139.12 & 22.55 & 205.48 \\
11 & 203 & 35 & 18 & 112.78 & 19.44 & 190.04 & 35.04 & 133.18 \\
12 & 90 & 16 & 12 & 75.00 & 13.33 & 184.38 & 50.20 & 91.32 \\
13 & 105 & 21 & 15 & 70.00 & 14.00 & 164.15 & 39.41 & 95.89 \\
14 & 421 & 58 & 30 & 140.33 & 19.33 & 236.96 & 33.61 & 132.42 \\
15 & 64 & 12 & 9 & 71.11 & 13.33 & 174.95 & 55.18 & 91.32 \\
16 & 225 & 38 & 25 & 90.00 & 15.20 & 193.94 & 34.29 & 104.11 \\
17 & 189 & 27 & 15 & 126.00 & 18.00 & 228.66 & 47.32 & 123.29 \\
18 & 281 & 55 & 36 & 78.06 & 15.28 & 167.69 & 25.01 & 104.64 \\
19 & 80 & 23 & 12 & 66.67 & 19.17 & 114.64 & 27.24 & 131.28 \\
20 & 263 & 44 & 50 & 52.60 & 8.80 & 195.76 & 32.19 & 60.27 \\
21 & 145 & 21 & 25 & 58.00 & 8.40 & 225.61 & 52.92 & 57.53 \\
\hline
\end{tabular}


Sample number: DS10-19

Mineral: Zircon

Irradiation code: vuw006-27, 28

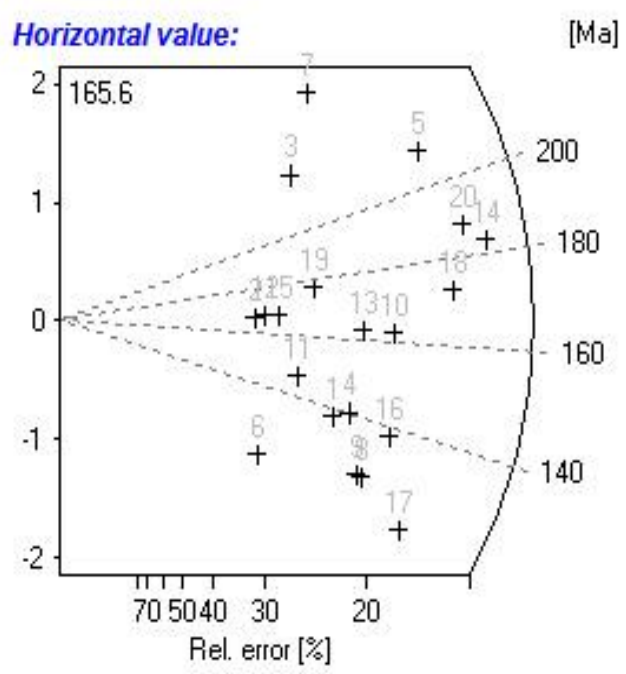

Pooled Age: $\quad 165.5 \pm 8.4$

Mean Age: $\quad 165.7 \pm 8.5$

Central Age: $\quad 165.1 \pm 8.6$

Chi-sq.: $\quad 19.42$

$\mathrm{P}(\%) \quad 43.01$

Dispersion: 0.05

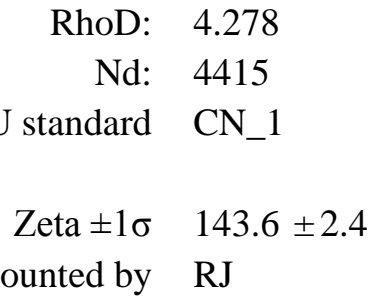

\begin{tabular}{ccccccccc} 
Crystal & Ns & Ni & Area & RhoS(e5) & RhoI(e5) & Age(Ma) & $+-1 \mathrm{~s}$ & U(ppm) \\
\hline 1 & 109 & 24 & 9 & 121.11 & 26.67 & 138.00 & 31.27 & 197.75 \\
2 & 66 & 12 & 8 & 82.50 & 15.00 & 166.74 & 52.46 & 111.24 \\
3 & 122 & 16 & 9 & 135.56 & 17.78 & 230.03 & 61.38 & 131.83 \\
4 & 125 & 27 & 12 & 104.17 & 22.50 & 140.64 & 30.01 & 166.85 \\
5 & 273 & 39 & 27 & 101.11 & 14.44 & 211.48 & 36.51 & 107.12 \\
6 & 50 & 13 & 8 & 62.50 & 16.25 & 117.06 & 36.54 & 120.51 \\
7 & 160 & 18 & 16 & 100.00 & 11.25 & 267.38 & 66.74 & 83.43 \\
8 & 125 & 30 & 25 & 50.00 & 12.00 & 126.71 & 25.92 & 88.99 \\
9 & 121 & 29 & 15 & 80.67 & 19.33 & 126.89 & 26.39 & 143.37 \\
10 & 188 & 35 & 15 & 125.33 & 23.33 & 162.89 & 30.21 & 173.03 \\
11 & 87 & 18 & 15 & 58.00 & 12.00 & 146.76 & 38.15 & 88.99 \\
12 & 72 & 13 & 15 & 48.00 & 8.67 & 167.89 & 50.74 & 64.27 \\
13 & 156 & 29 & 18 & 86.67 & 16.11 & 163.13 & 33.19 & 119.48 \\
14 & 338 & 56 & 25 & 135.20 & 22.40 & 182.76 & 26.69 & 166.11 \\
15 & 83 & 15 & 12 & 69.17 & 12.50 & 167.74 & 47.21 & 92.70 \\
16 & 159 & 35 & 16 & 99.38 & 21.88 & 138.03 & 25.96 & 162.22 \\
17 & 150 & 38 & 12 & 125.00 & 31.67 & 120.11 & 21.98 & 234.83 \\
18 & 273 & 48 & 25 & 109.20 & 19.20 & 172.35 & 27.25 & 142.38 \\
19 & 117 & 20 & 8 & 146.25 & 25.00 & 177.21 & 43.06 & 185.39 \\
20 & 310 & 50 & 25 & 124.00 & 20.00 & 187.66 & 28.91 & 148.31 \\
\hline
\end{tabular}


Sample number: DS11-03

Mineral: Zircon

Irradiation code: vuw006-4, 5

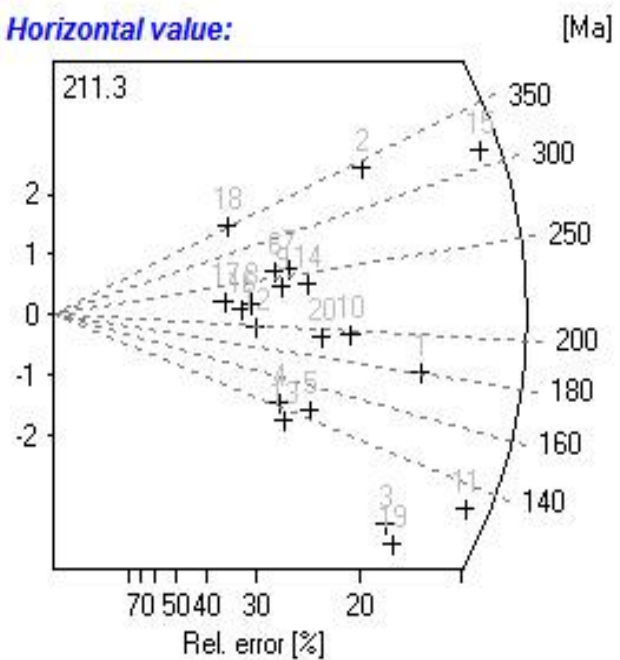

Chi-sq.: $\quad 62.01$

$\mathrm{P}(\%) \quad 0$

Dispersion: 0.29

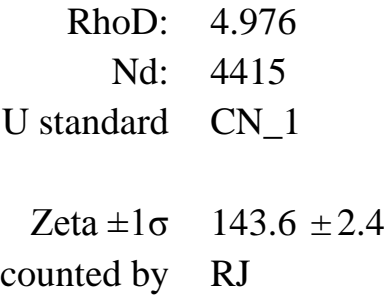

\begin{tabular}{ccccccccc} 
Crystal & Ns & Ni & Area & RhoS(e5) & RhoI(e5) & Age(Ma) & $+-1 \mathrm{~s}$ & U(ppm) \\
\hline 1 & 221 & 43 & 16 & 138.13 & 26.88 & 181.07 & 30.45 & 171.31 \\
2 & 276 & 28 & 20 & 138.00 & 14.00 & 342.92 & 68.45 & 89.24 \\
3 & 124 & 39 & 9 & 137.77 & 843.33 & 112.62 & 20.83 & 276.22 \\
4 & 69 & 17 & 10 & 69.00 & 17.00 & 143.42 & 38.97 & 108.36 \\
5 & 91 & 22 & 9 & 101.11 & 24.44 & 146.13 & 34.87 & 155.81 \\
6 & 110 & 15 & 10 & 110.00 & 15.00 & 256.84 & 70.93 & 95.61 \\
7 & 125 & 17 & 9 & 138.89 & 18.89 & 257.51 & 66.82 & 120.40 \\
8 & 77 & 12 & 6 & 128.33 & 20.00 & 225.29 & 70.10 & 127.48 \\
9 & 109 & 16 & 9 & 121.11 & 17.78 & 238.93 & 64.19 & 113.32 \\
10 & 158 & 28 & 15 & 105.33 & 18.67 & 198.53 & 40.95 & 118.99 \\
11 & 216 & 58 & 16 & 135.00 & 36.25 & 131.71 & 19.70 & 231.06 \\
12 & 74 & 13 & 9 & 82.22 & 14.44 & 200.25 & 60.39 & 92.07 \\
13 & 68 & 18 & 16 & 42.50 & 11.25 & 133.59 & 35.54 & 71.71 \\
14 & 137 & 20 & 10 & 137.00 & 20.00 & 240.22 & 57.76 & 127.48 \\
15 & 485 & 54 & 25 & 194.00 & 21.60 & 313.18 & 45.48 & 137.68 \\
16 & 68 & 11 & 6 & 113.33 & 18.33 & 217.18 & 70.75 & 116.86 \\
17 & 59 & 9 & 9 & 65.56 & 10.00 & 230.08 & 82.50 & 63.74 \\
18 & 92 & 9 & 4 & 230.00 & 22.50 & 355.27 & 124.34 & 143.42 \\
19 & 124 & 41 & 12 & 103.33 & 34.17 & 107.17 & 19.46 & 217.79 \\
20 & 127 & 23 & 9 & 141.11 & 25.56 & 194.34 & 44.26 & 162.90 \\
\hline
\end{tabular}


Sample number: JR12-26

Mineral: Zircon

Irradiation code: vuw016-23

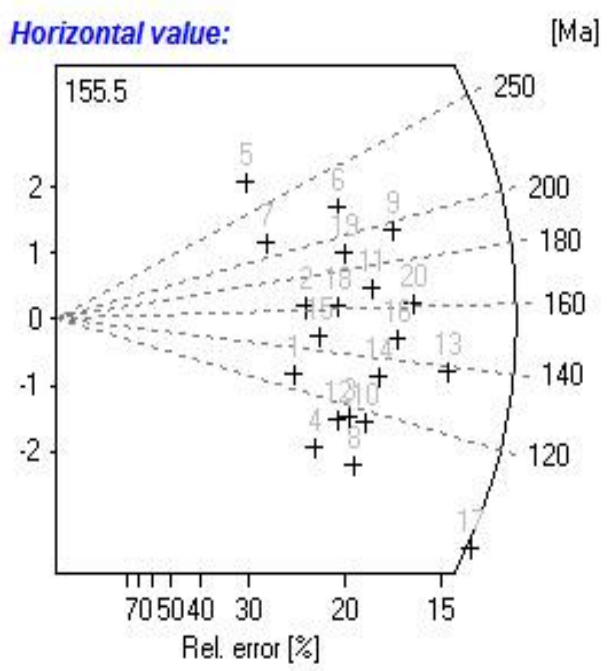

Chi-sq.: $\quad 39.47$

$\mathrm{P}(\%) \quad 0.38$

Dispersion: 0.19

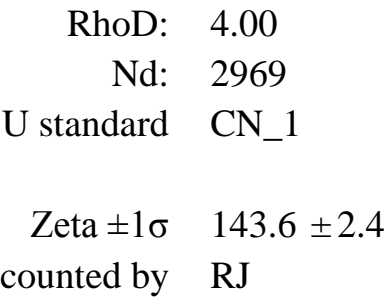

\begin{tabular}{ccccccccc} 
Crystal & $\mathrm{Ns}$ & $\mathrm{Ni}$ & Area & RhoS(e5) & RhoI(e5) & Age(Ma) & $+-1 \mathrm{~s}$ & $\mathrm{U}(\mathrm{ppm})$ \\
\hline 1 & 94 & 21 & 6 & 156.67 & 35.00 & 127.34 & 30.90 & 277.44 \\
2 & 126 & 22 & 15 & 84.00 & 14.67 & 162.49 & 37.76 & 116.26 \\
3 & 131 & 32 & 12 & 109.17 & 26.67 & 116.56 & 23.17 & 211.39 \\
4 & 92 & 26 & 5 & 184.00 & 52.00 & 100.87 & 22.54 & 412.20 \\
5 & 125 & 12 & 9 & 138.89 & 13.33 & 292.55 & 88.71 & 105.69 \\
6 & 210 & 27 & 12 & 175.00 & 22.50 & 219.68 & 45.24 & 178.36 \\
7 & 114 & 15 & 8 & 142.50 & 18.75 & 214.74 & 59.22 & 148.63 \\
8 & 121 & 34 & 9 & 134.44 & 37.78 & 101.45 & 19.85 & 299.46 \\
9 & 271 & 39 & 12 & 225.83 & 32.50 & 196.62 & 34.03 & 257.63 \\
10 & 147 & 36 & 9 & 163.33 & 40.00 & 116.27 & 21.81 & 317.08 \\
11 & 210 & 35 & 8 & 262.50 & 43.75 & 170.12 & 31.35 & 346.81 \\
12 & 120 & 30 & 9 & 133.33 & 33.33 & 113.91 & 23.42 & 264.23 \\
13 & 273 & 56 & 12 & 227.50 & 46.67 & 138.57 & 20.62 & 369.93 \\
14 & 178 & 38 & 10 & 178.00 & 38.00 & 133.20 & 24.03 & 301.23 \\
15 & 130 & 25 & 10 & 130.00 & 25.00 & 147.70 & 32.46 & 198.17 \\
16 & 219 & 42 & 15 & 146.00 & 28.00 & 148.10 & 25.22 & 221.96 \\
17 & 226 & 67 & 12 & 188.33 & 55.83 & 96.19 & 13.59 & 442.59 \\
18 & 160 & 28 & 9 & 177.78 & 31.11 & 162.12 & 33.45 & 246.62 \\
19 & 195 & 29 & 15 & 130.00 & 19.33 & 190.36 & 38.18 & 153.26 \\
20 & 256 & 45 & 12 & 213.33 & 37.50 & 161.41 & 26.40 & 297.26 \\
\hline
\end{tabular}


Sample number: JR12-33

Mineral: Zircon

Irradiation code: vuw016-33

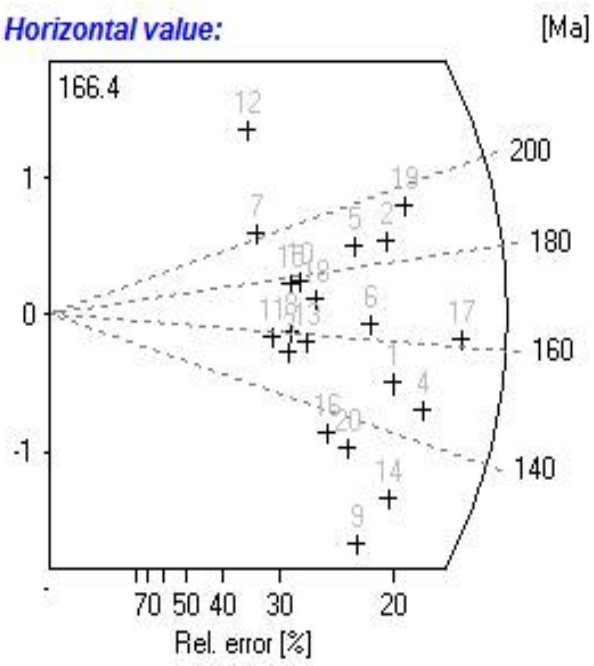

Chi-sq.: $\quad 10.46$

$\mathrm{P}(\%) \quad 94.06$

Dispersion: 0.00

RhoD: 3.27

Nd: 2969

U standard CN_1

Zeta $\pm 1 \sigma \quad 143.6 \pm 2.4$

counted by RJ

\begin{tabular}{ccccccccc} 
Crystal & Ns & Ni & Area & RhoS(e5) & Rhol(e5) & Age(Ma) & $+-1 \mathrm{~s}$ & U(ppm) \\
\hline 1 & 188 & 29 & 9 & 208.89 & 32.22 & 150.64 & 30.28 & 312.15 \\
2 & 217 & 27 & 12 & 180.83 & 22.50 & 186.24 & 38.29 & 217.97 \\
3 & 93 & 14 & 6 & 155.00 & 23.33 & 154.31 & 44.40 & 226.04 \\
4 & 214 & 34 & 9 & 237.78 & 37.78 & 146.30 & 27.25 & 365.97 \\
5 & 177 & 22 & 12 & 147.50 & 18.33 & 186.43 & 42.40 & 177.60 \\
6 & 177 & 25 & 12 & 147.50 & 20.83 & 164.34 & 35.35 & 201.82 \\
7 & 88 & 10 & 6 & 146.67 & 16.67 & 203.64 & 68.14 & 61.46 \\
8 & 97 & 14 & 8 & 121.25 & 17.50 & 160.87 & 46.16 & 69.53 \\
9 & 118 & 24 & 6 & 196.67 & 40.00 & 114.57 & 25.81 & 387.50 \\
10 & 115 & 15 & 6 & 191.67 & 25.00 & 177.77 & 49.00 & 242.19 \\
11 & 82 & 12 & 6 & 136.67 & 20.00 & 158.68 & 49.20 & 193.75 \\
12 & 104 & 9 & 6 & 173.33 & 15.00 & 266.10 & 92.70 & 145.31 \\
13 & 109 & 16 & 9 & 121.11 & 17.78 & 158.21 & 42.54 & 172.22 \\
14 & 158 & 29 & 9 & 175.56 & 32.22 & 126.83 & 25.82 & 312.15 \\
15 & 107 & 14 & 9 & 118.89 & 15.56 & 177.23 & 50.56 & 150.69 \\
16 & 110 & 19 & 6 & 183.33 & 31.67 & 134.69 & 33.63 & 6.77 \\
17 & 285 & 41 & 15 & 190.00 & 27.33 & 161.39 & 27.25 & 264.79 \\
18 & 126 & 17 & 9 & 140.00 & 18.89 & 171.94 & 44.63 & 182.99 \\
19 & 252 & 30 & 12 & 210.00 & 25.00 & 194.52 & 37.88 & 242.19 \\
20 & 126 & 22 & 9 & 140.00 & 24.44 & 133.26 & 30.97 & 236.80 \\
\hline
\end{tabular}


Sample number: JR11-06

Mineral: Zircon

Irradiation code: vuw012-41

Ns: 4337

Ni: 474

Area: 357

RhoS: 121.5

RhoI: 13.28

Pooled Age: $\quad 264.0 \pm 15.1$

Mean Age: $\quad 279.1 \pm 15.5$

Central Age: $\quad 264.0 \pm 15.1$

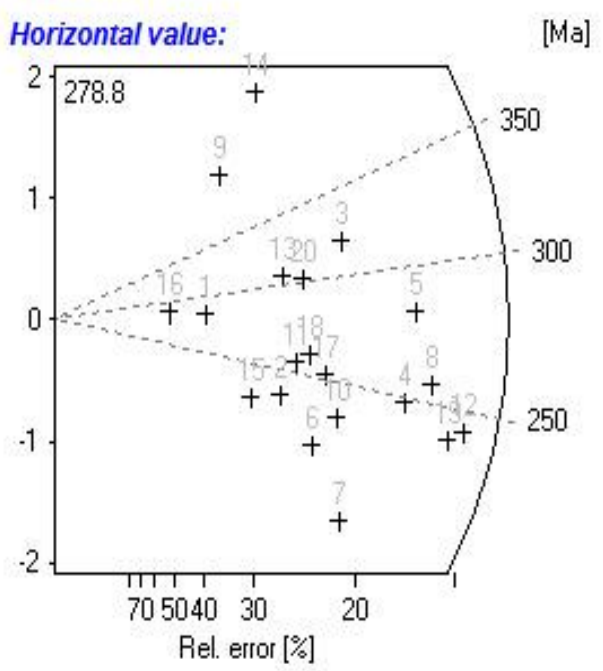

Chi-sq.: $\quad 12.72$

$\mathrm{P}(\%) \quad 85.24$

Dispersion: 0.00

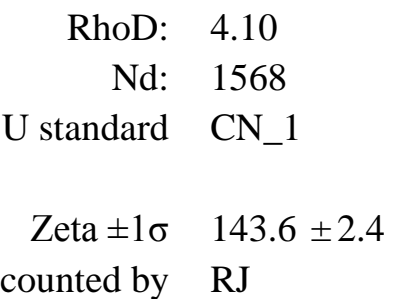

\begin{tabular}{ccccccccc} 
Crystal & $\mathrm{Ns}$ & $\mathrm{Ni}$ & Area & RhoS(e5) & RhoI(e5) & Age(Ma) & $+-1 \mathrm{~s}$ & $\mathrm{U}(\mathrm{ppm})$ \\
\hline 1 & 69 & 7 & 8 & 86.25 & 8.75 & 283.91 & 112.95 & 67.68 \\
2 & 131 & 16 & 16 & 81.88 & 10.00 & 236.69 & 63.09 & 77.35 \\
3 & 278 & 25 & 24 & 115.83 & 10.42 & 319.40 & 67.39 & 80.57 \\
4 & 327 & 38 & 30 & 109.00 & 12.67 & 248.54 & 43.26 & 97.97 \\
5 & 392 & 40 & 24 & 163.33 & 16.67 & 282.30 & 47.63 & 128.91 \\
6 & 159 & 21 & 12 & 132.50 & 17.50 & 219.18 & 51.32 & 135.35 \\
7 & 177 & 26 & 20 & 88.50 & 13.00 & 197.41 & 41.89 & 100.55 \\
8 & 390 & 44 & 21 & 185.71 & 20.95 & 255.86 & 41.42 & 162.06 \\
9 & 121 & 8 & 8 & 151.25 & 10.00 & 430.67 & 157.76 & 77.35 \\
10 & 203 & 25 & 24 & 84.58 & 10.42 & 234.78 & 50.27 & 80.57 \\
11 & 160 & 18 & 9 & 177.78 & 20.00 & 256.57 & 64.26 & 154.69 \\
12 & 438 & 52 & 24 & 182.50 & 21.67 & 243.38 & 36.45 & 167.58 \\
13 & 171 & 16 & 9 & 190.00 & 17.78 & 307.27 & 80.87 & 137.50 \\
14 & 206 & 12 & 18 & 114.44 & 6.67 & 486.66 & 145.27 & 51.56 \\
15 & 95 & 12 & 18 & 52.78 & 6.67 & 229.00 & 70.50 & 51.56 \\
16 & 40 & 4 & 9 & 44.44 & 4.44 & 287.94 & 151.25 & 34.38 \\
17 & 201 & 23 & 15 & 134.00 & 15.33 & 252.33 & 56.07 & 118.60 \\
18 & 181 & 20 & 18 & 100.56 & 11.11 & 261.13 & 62.04 & 85.94 \\
19 & 398 & 48 & 30 & 132.67 & 16.00 & 239.65 & 37.33 & 123.75 \\
20 & 200 & 19 & 20 & 100.00 & 9.50 & 302.74 & 73.25 & 73.48 \\
\hline
\end{tabular}


Sample number: JR11-07

Mineral: Zircon

Irradiation code: vuw012-43, 44

Ns: 1516

Ni: 230

Area: 175

RhoS: 86.63

RhoI: 13.14

Pooled Age: $\quad 188.6 \pm 14.5$

Mean Age: $\quad 194.3 \pm 10.4$

Central Age: $\quad 188.6 \pm 14.5$

Chi-sq.: $\quad 10.38$

$\mathrm{P}(\%) \quad 94.3$

Dispersion: 0.00

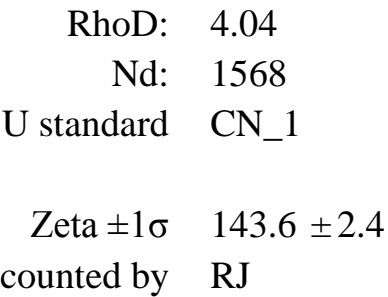

counted by RJ

\begin{tabular}{ccccccccc} 
Crystal & Ns & Ni & Area & RhoS(e5) & RhoI(e5) & Age(Ma) & $+-1 \mathrm{~s}$ & $\mathrm{U}(\mathrm{ppm})$ \\
\hline 1 & 71 & 9 & 6 & 118.33 & 15.00 & 225.12 & 79.94 & 117.64 \\
2 & 65 & 12 & 9 & 72.22 & 13.33 & 155.41 & 49.06 & 104.57 \\
3 & 65 & 16 & 12 & 54.17 & 13.33 & 116.91 & 32.82 & 104.57 \\
4 & 54 & 8 & 9 & 60.00 & 8.89 & 193.10 & 73.39 & 69.71 \\
5 & 139 & 20 & 20 & 69.50 & 10.00 & 198.73 & 47.91 & 78.43 \\
6 & 37 & 7 & 4 & 92.50 & 17.50 & 151.70 & 62.69 & 137.25 \\
7 & 65 & 12 & 12 & 54.17 & 10.00 & 155.41 & 49.06 & 78.43 \\
8 & 194 & 23 & 12 & 161.67 & 19.17 & 240.41 & 53.51 & 150.32 \\
9 & 123 & 23 & 6 & 205.00 & 38.33 & 153.46 & 35.17 & 300.64 \\
10 & 140 & 23 & 12 & 116.67 & 19.17 & 174.38 & 39.59 & 150.32 \\
11 & 42 & 7 & 6 & 70.00 & 11.67 & 171.93 & 70.38 & 91.50 \\
12 & 56 & 6 & 8 & 70.00 & 7.50 & 265.50 & 114.33 & 58.82 \\
13 & 85 & 11 & 16 & 53.12 & 56.88 & 220.58 & 71.00 & 53.92 \\
14 & 43 & 8 & 4 & 107.50 & 20.00 & 154.23 & 59.57 & 156.86 \\
15 & 55 & 7 & 6 & 91.67 & 11.67 & 224.23 & 90.24 & 91.50 \\
16 & 28 & 4 & 4 & 70.00 & 10.00 & 200.14 & 107.15 & 78.43 \\
17 & 54 & 10 & 6 & 90.00 & 16.67 & 154.94 & 53.55 & 130.71 \\
18 & 77 & 7 & 8 & 96.25 & 8.75 & 311.78 & 123.44 & 68.62 \\
19 & 61 & 9 & 6 & 101.67 & 15.00 & 193.88 & 69.48 & 117.64 \\
20 & 62 & 8 & 9 & 68.88 & 98.89 & 221.22 & 83.38 & 69.71 \\
\hline
\end{tabular}

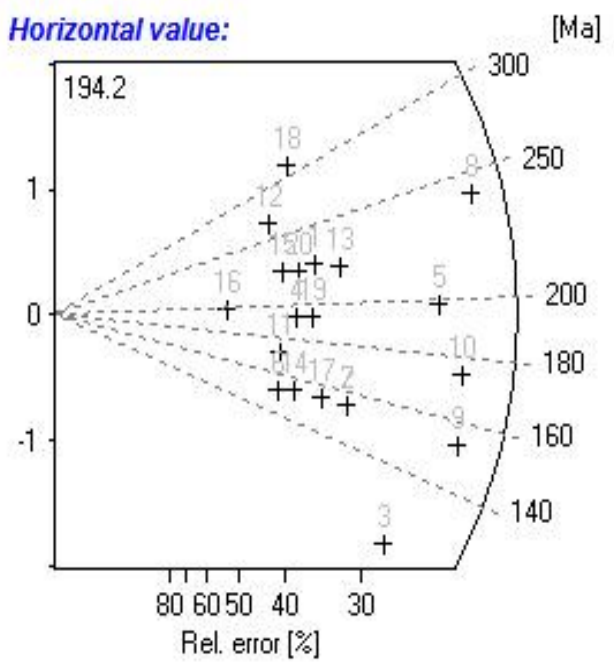


Sample number: JR11-08

Mineral: Zircon

Irradiation code: vuw012-49

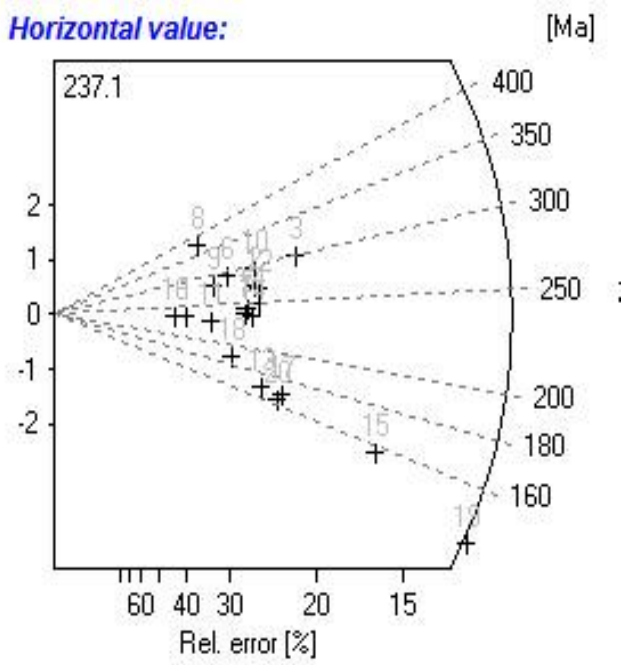

Chi-sq.: $\quad 29.81$

$\mathrm{P}(\%) \quad 5.42$

Dispersion: $\quad 0.19$

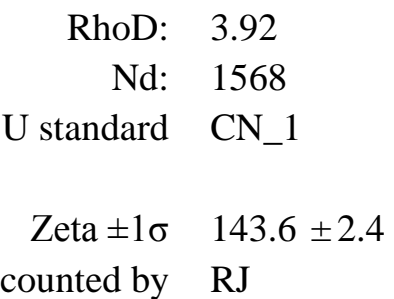

\begin{tabular}{ccccccccc} 
Crystal & $\mathrm{Ns}$ & $\mathrm{Ni}$ & Area & RhoS(e5) & RhoI(e5) & Age(Ma) & $+-1 \mathrm{~s}$ & $\mathrm{U}(\mathrm{ppm})$ \\
\hline 1 & 59 & 7 & 6 & 98.33 & 11.67 & 232.97 & 93.40 & 94.41 \\
2 & 158 & 16 & 12 & 131.67 & 13.33 & 272.11 & 71.86 & 107.89 \\
3 & 250 & 23 & 20 & 125.00 & 11.50 & 298.89 & 65.75 & 93.06 \\
4 & 153 & 17 & 18 & 85.00 & 9.44 & 248.46 & 63.96 & 76.42 \\
5 & 132 & 15 & 9 & 146.67 & 16.67 & 243.04 & 66.63 & 134.87 \\
6 & 129 & 12 & 6 & 215.00 & 20.00 & 295.68 & 89.69 & 161.84 \\
7 & 129 & 15 & 9 & 143.33 & 16.67 & 237.62 & 65.22 & 134.87 \\
8 & 111 & 8 & 6 & 185.00 & 13.33 & 379.15 & 39.27 & 107.89 \\
9 & 102 & 10 & 8 & 127.50 & 12.50 & 280.88 & 93.46 & 101.15 \\
10 & 172 & 16 & 12 & 143.33 & 13.33 & 295.68 & 77.80 & 107.89 \\
11 & 82 & 10 & 9 & 91.11 & 11.11 & 226.76 & 76.26 & 89.91 \\
12 & 166 & 17 & 12 & 138.33 & 14.17 & 269.14 & 69.02 & 14.64 \\
13 & 110 & 18 & 12 & 91.67 & 15.00 & 169.75 & 43.46 & 121.38 \\
14 & 136 & 16 & 12 & 113.33 & 13.33 & 234.91 & 62.49 & 107.89 \\
15 & 249 & 44 & 20 & 124.50 & 22.00 & 157.34 & 26.17 & 178.02 \\
16 & 51 & 6 & 6 & 85.00 & 10.00 & 234.91 & 101.63 & 80.92 \\
17 & 134 & 22 & 12 & 111.67 & 18.33 & 169.19 & 39.26 & 148.35 \\
18 & 89 & 13 & 12 & 74.17 & 10.83 & 189.87 & 56.67 & 87.66 \\
19 & 371 & 74 & 25 & 148.40 & 29.60 & 139.59 & 18.27 & 39.52 \\
20 & 125 & 21 & 9 & 138.89 & 23.33 & 165.39 & 39.33 & 188.81 \\
\hline
\end{tabular}


Sample number: JR11-10

Mineral: Zircon

Irradiation code: vuw012-52

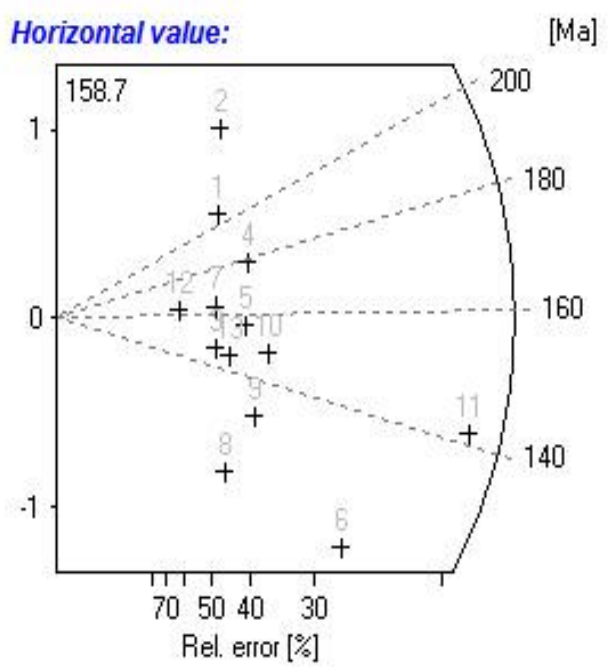

Chi-sq.: $\quad 3.8$

$\mathrm{P}(\%) \quad 98.68$

Dispersion: $\quad 0.00$

RhoD: 3.85

Nd: 1568

U standard CN_1

Zeta $\pm 1 \sigma \quad 143.6 \pm 2.4$

counted by RJ

\begin{tabular}{ccccccccc} 
Crystal & Ns & Ni & Area & RhoS(e5) & RhoI(e5) & Age(Ma) & $+-1 \mathrm{~s}$ & $\mathrm{U}(\mathrm{ppm})$ \\
\hline 1 & 38 & 5 & 6 & 63.33 & 8.33 & 206.84 & 98.60 & 68.62 \\
2 & 47 & 5 & 6 & 78.33 & 8.33 & 254.88 & 120.14 & 68.62 \\
3 & 27 & 5 & 4 & 67.50 & 12.50 & 147.65 & 72.02 & 102.93 \\
4 & 46 & 7 & 4 & 115.00 & 17.50 & 179.24 & 72.92 & 144.11 \\
5 & 40 & 7 & 4 & 100.00 & 17.50 & 156.14 & 64.14 & 144.11 \\
6 & 71 & 17 & 9 & 78.89 & 18.89 & 114.49 & 31.11 & 155.55 \\
7 & 30 & 5 & 6 & 50.00 & 8.33 & 163.85 & 79.30 & 68.62 \\
8 & 24 & 6 & 4 & 60.00 & 15.00 & 109.69 & 50.18 & 123.52 \\
9 & 38 & 8 & 6 & 63.33 & 13.33 & 130.05 & 50.74 & 109.80 \\
10 & 49 & 9 & 4 & 122.50 & 22.50 & 148.85 & 54.17 & 185.28 \\
11 & 176 & 34 & 15 & 117.33 & 22.67 & 141.60 & 26.87 & 186.65 \\
12 & 18 & 3 & 4 & 45.00 & 7.50 & 163.85 & 102.30 & 61.76 \\
13 & 32 & 6 & 4 & 80.00 & 15.00 & 145.85 & 65.03 & 123.52 \\
\hline
\end{tabular}


Sample number: JR11-13

Mineral: Zircon

Irradiation code: vuw012-37

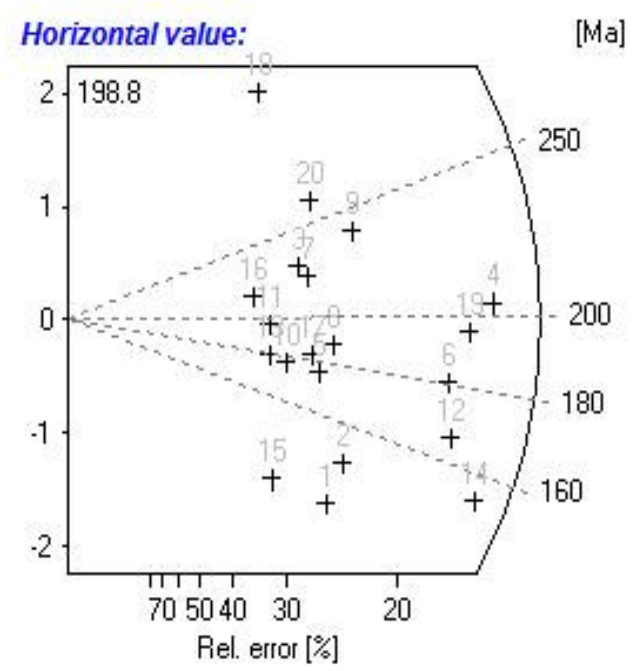

Chi-sq.: $\quad 16.37$

$\mathrm{P}(\%) \quad 63.25$

Dispersion: 0.01

$$
\begin{aligned}
\text { RhoD: } & 4.19 \\
\text { Nd: } & 1568 \\
\text { U standard } & \text { CN_1 } \\
& \\
\text { Zeta } \pm 1 \sigma & 143.6 \pm 2.4 \\
\text { counted by } & \text { RJ }
\end{aligned}
$$

\begin{tabular}{ccccccccc} 
Crystal & Ns & Ni & Area & RhoS(e5) & RhoI(e5) & Age(Ma) & $+-1 \mathrm{~s}$ & U(ppm) \\
\hline 1 & 84 & 19 & 8 & 105.00 & 23.75 & 131.71 & 33.70 & 179.73 \\
2 & 104 & 21 & 8 & 130.00 & 26.25 & 147.35 & 35.53 & 198.64 \\
3 & 108 & 14 & 6 & 180.00 & 23.33 & 228.09 & 65.16 & 176.57 \\
4 & 330 & 48 & 15 & 220.00 & 32.00 & 203.66 & 32.06 & 242.16 \\
5 & 101 & 17 & 8 & 126.25 & 21.25 & 176.38 & 46.55 & 160.81 \\
6 & 238 & 39 & 15 & 158.67 & 26.00 & 181.10 & 31.76 & 196.75 \\
7 & 112 & 15 & 6 & 186.67 & 25.00 & 220.90 & 61.10 & 189.18 \\
8 & 121 & 19 & 9 & 134.44 & 21.11 & 188.88 & 46.96 & 159.76 \\
9 & 170 & 21 & 12 & 141.67 & 17.50 & 239.15 & 55.79 & 132.43 \\
10 & 78 & 13 & 8 & 97.50 & 16.25 & 178.10 & 53.63 & 122.97 \\
11 & 73 & 11 & 6 & 121.67 & 18.33 & 196.70 & 63.90 & 138.74 \\
12 & 224 & 40 & 20 & 112.00 & 20.00 & 166.38 & 29.00 & 151.35 \\
13 & 67 & 11 & 8 & 83.75 & 13.75 & 180.76 & 59.06 & 104.05 \\
14 & 238 & 46 & 10 & 238.00 & 46.00 & 153.87 & 25.22 & 348.10 \\
15 & 51 & 12 & 8 & 63.75 & 15.00 & 126.66 & 40.82 & 113.51 \\
16 & 65 & 9 & 6 & 108.33 & 15.00 & 213.78 & 76.31 & 113.51 \\
17 & 99 & 16 & 10 & 99.00 & 16.00 & 183.59 & 49.78 & 121.08 \\
18 & 123 & 9 & 9 & 136.67 & 10.00 & 398.73 & 138.22 & 75.67 \\
19 & 284 & 43 & 16 & 177.50 & 26.88 & 195.78 & 32.58 & 203.37 \\
20 & 135 & 15 & 10 & 135.00 & 15.00 & 265.34 & 72.66 & 113.51 \\
\hline
\end{tabular}


Sample number: JR11-47

Mineral: Zircon

Irradiation code: vuw012-55

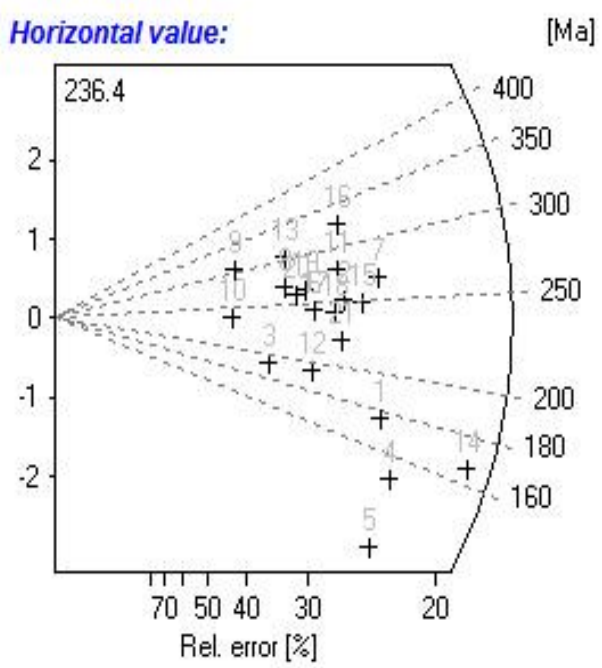

Chi-sq.: $\quad 21.54$

$\mathrm{P}(\%) \quad 36.62$

Dispersion: 0.08

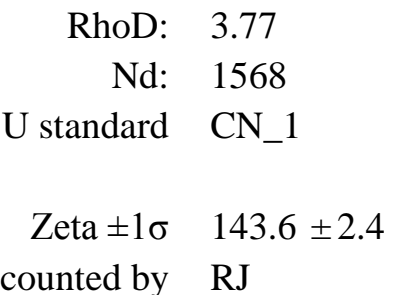

\begin{tabular}{ccccccccc} 
Crystal & Ns & Ni & Area & RhoS(e5) & RhoI(e5) & Age(Ma) & $+-1 \mathrm{~s}$ & U(ppm) \\
\hline 1 & 138 & 21 & 12 & 115.00 & 17.50 & 175.60 & 41.47 & 147.14 \\
2 & 151 & 16 & 6 & 251.67 & 26.67 & 250.71 & 66.35 & 224.21 \\
3 & 65 & 9 & 12 & 54.17 & 7.50 & 192.73 & 68.79 & 63.06 \\
4 & 128 & 23 & 12 & 106.67 & 19.17 & 149.02 & 34.05 & 161.15 \\
5 & 92 & 21 & 12 & 76.67 & 17.50 & 117.60 & 28.66 & 147.14 \\
6 & 119 & 13 & 9 & 132.22 & 14.44 & 243.32 & 71.45 & 121.45 \\
7 & 202 & 20 & 20 & 101.00 & 10.00 & 267.95 & 63.33 & 84.08 \\
8 & 102 & 10 & 9 & 113.33 & 11.11 & 270.55 & 90.02 & 93.42 \\
9 & 70 & 6 & 6 & 116.67 & 10.00 & 308.53 & 131.58 & 84.08 \\
10 & 54 & 6 & 6 & 90.00 & 10.00 & 239.30 & 103.23 & 84.08 \\
11 & 158 & 15 & 8 & 197.50 & 18.75 & 279.20 & 75.91 & 57.65 \\
12 & 95 & 13 & 6 & 158.33 & 21.67 & 194.98 & 57.96 & 182.17 \\
13 & 116 & 10 & 8 & 145.00 & 12.50 & 306.81 & 101.54 & 105.10 \\
14 & 212 & 34 & 16 & 132.50 & 21.25 & 166.73 & 31.21 & 178.66 \\
15 & 168 & 18 & 10 & 168.00 & 18.00 & 248.00 & 61.96 & 151.34 \\
16 & 185 & 15 & 8 & 231.25 & 18.75 & 325.72 & 88.00 & 157.65 \\
17 & 119 & 13 & 12 & 99.17 & 10.83 & 243.32 & 71.45 & 91.08 \\
18 & 136 & 15 & 9 & 151.11 & 16.67 & 241.04 & 65.98 & 140.13 \\
19 & 119 & 12 & 12 & 99.17 & 10.00 & 263.18 & 80.11 & 84.08 \\
20 & 108 & 11 & 8 & 135.00 & 13.75 & 260.62 & 82.86 & 115.61 \\
21 & 132 & 16 & 12 & 110.00 & 13.33 & 219.69 & 58.54 & 112.10 \\
\hline
\end{tabular}


Sample number: JR11-48

Mineral: Zircon

Irradiation code: vuw012-57

Ns: 2545

Ni: 302

Area: 198

RhoS: 128.5

RhoI: $\quad 15.25$

Pooled Age: $\quad 222.3 \pm 15.1$

Mean Age: $\quad 238.0 \pm 12.7$

Central Age: $\quad 222.3 \pm 15.7$

Chi-sq.: $\quad 15.48$

$\mathrm{P}(\%) \quad 69.18$

Dispersion: 0.07

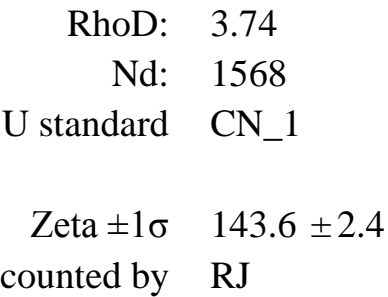

\begin{tabular}{ccccccccc} 
Crystal & $\mathrm{Ns}$ & $\mathrm{Ni}$ & Area & RhoS(e5) & RhoI(e5) & Age(Ma) & $+-1 \mathrm{~s}$ & $\mathrm{U}(\mathrm{ppm})$ \\
\hline 1 & 112 & 11 & 6 & 186.67 & 18.33 & 267.69 & 84.97 & 155.54 \\
2 & 165 & 16 & 10 & 165.00 & 16.00 & 271.06 & 71.45 & 135.75 \\
3 & 48 & 5 & 9 & 53.33 & 5.56 & 252.69 & 18.99 & 47.13 \\
4 & 123 & 17 & 10 & 123.00 & 17.00 & 191.36 & 49.85 & 144.23 \\
5 & 127 & 13 & 9 & 141.11 & 14.44 & 257.06 & 75.26 & 122.55 \\
6 & 79 & 11 & 9 & 87.78 & 12.22 & 189.97 & 61.41 & 103.70 \\
7 & 144 & 18 & 12 & 120.00 & 15.00 & 211.26 & 53.20 & 127.26 \\
8 & 85 & 7 & 6 & 141.67 & 11.67 & 318.00 & 125.41 & 98.98 \\
9 & 105 & 15 & 9 & 116.67 & 16.67 & 185.23 & 51.43 & 141.40 \\
10 & 121 & 17 & 6 & 201.67 & 28.33 & 188.29 & 49.10 & 240.38 \\
11 & 170 & 12 & 9 & 188.89 & 13.33 & 369.51 & 110.93 & 113.12 \\
12 & 58 & 7 & 6 & 96.67 & 11.67 & 218.68 & 87.75 & 98.98 \\
13 & 139 & 18 & 12 & 115.83 & 15.00 & 204.04 & 51.48 & 127.26 \\
14 & 50 & 6 & 6 & 83.33 & 10.00 & 219.91 & 95.25 & 84.84 \\
15 & 69 & 6 & 6 & 115.00 & 10.00 & 301.55 & 128.67 & 84.84 \\
16 & 143 & 14 & 12 & 119.17 & 11.67 & 268.53 & 75.64 & 98.98 \\
17 & 335 & 53 & 28 & 119.64 & 18.93 & 167.48 & 25.27 & 160.59 \\
18 & 102 & 17 & 9 & 113.33 & 18.89 & 159.09 & 41.95 & 160.26 \\
19 & 168 & 22 & 9 & 186.66 & 724.44 & 201.80 & 46.16 & 207.39 \\
20 & 202 & 17 & 15 & 134.67 & 11.33 & 311.34 & 79.19 & 96.15 \\
\hline
\end{tabular}

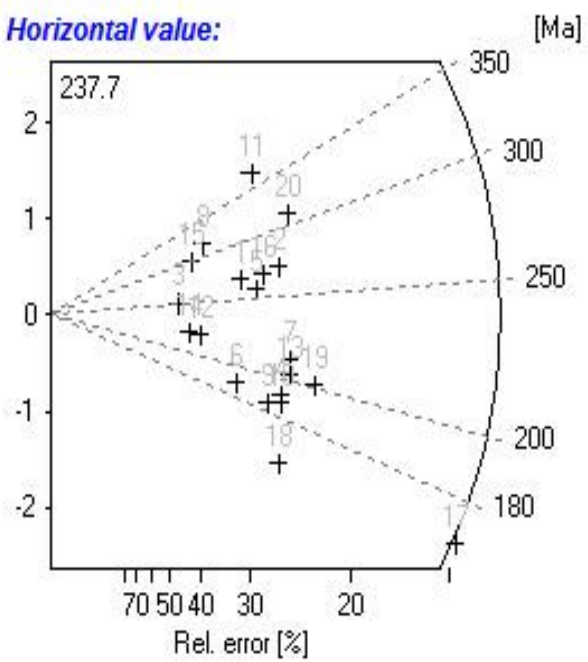


Sample number: JR11-50

Mineral: Zircon

Irradiation code: vuw012-60

Ns: 2847

Ni: 386

Area: 238

RhoS: $\quad 119.6$

RhoI: $\quad 16.22$

Pooled Age: $\quad 191.5 \pm 11.9$

Mean Age: $\quad 195.6 \pm 11.0$

Central Age: $\quad 190.4 \pm 12.9$

Chi-sq.: $\quad 20.78$

$\mathrm{P}(\%) \quad 34.89$

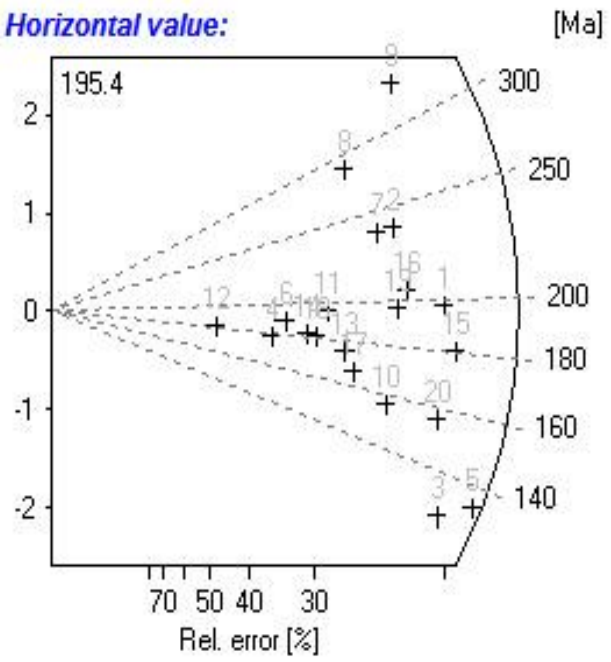

Dispersion: $\quad 0.12$

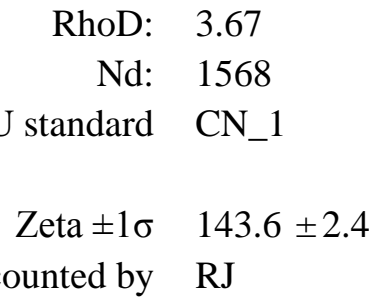

\begin{tabular}{ccccccccc} 
Crystal & $\mathrm{Ns}$ & $\mathrm{Ni}$ & Area & RhoS(e5) & RhoI(e5) & Age(Ma) & $+-1 \mathrm{~s}$ & $\mathrm{U}(\mathrm{ppm})$ \\
\hline 1 & 213 & 28 & 12 & 177.50 & 23.33 & 197.45 & 40.14 & 201.63 \\
2 & 193 & 21 & 12 & 160.83 & 17.50 & 237.79 & 55.11 & 151.22 \\
3 & 142 & 29 & 15 & 94.67 & 19.33 & 127.78 & 26.33 & 167.06 \\
4 & 62 & 9 & 6 & 103.33 & 15.00 & 179.06 & 64.10 & 129.62 \\
5 & 175 & 34 & 10 & 175.00 & 34.00 & 134.25 & 25.49 & 293.80 \\
6 & 73 & 10 & 8 & 91.25 & 12.50 & 189.59 & 64.19 & 108.01 \\
7 & 175 & 19 & 8 & 218.75 & 23.75 & 238.30 & 58.01 & 205.23 \\
8 & 168 & 15 & 12 & 140.00 & 12.50 & 288.64 & 78.27 & 108.01 \\
9 & 261 & 20 & 15 & 174.00 & 13.33 & 335.10 & 78.41 & 115.22 \\
10 & 126 & 21 & 18 & 70.00 & 11.67 & 156.23 & 37.13 & 100.81 \\
11 & 106 & 14 & 9 & 117.78 & 15.56 & 196.53 & 56.20 & 134.42 \\
12 & 35 & 5 & 6 & 58.33 & 8.33 & 181.91 & 87.14 & 72.01 \\
13 & 108 & 16 & 8 & 135.00 & 20.00 & 175.50 & 47.31 & 172.82 \\
14 & 84 & 12 & 12 & 70.00 & 10.00 & 181.91 & 56.41 & 86.41 \\
15 & 209 & 30 & 16 & 130.63 & 18.75 & 181.05 & 35.77 & 162.02 \\
16 & 182 & 23 & 14 & 130.00 & 16.43 & 205.26 & 45.85 & 141.96 \\
17 & 109 & 17 & 15 & 72.67 & 11.33 & 166.82 & 43.79 & 97.93 \\
18 & 91 & 13 & 6 & 151.67 & 21.67 & 181.91 & 54.22 & 187.23 \\
19 & 167 & 22 & 12 & 139.17 & 18.33 & 197.03 & 45.09 & 158.42 \\
20 & 168 & 28 & 24 & 70.00 & 11.67 & 156.23 & 32.24 & 100.81 \\
\hline
\end{tabular}


Sample number: JR12-01

Mineral: Zircon

Irradiation code: vuw012-34

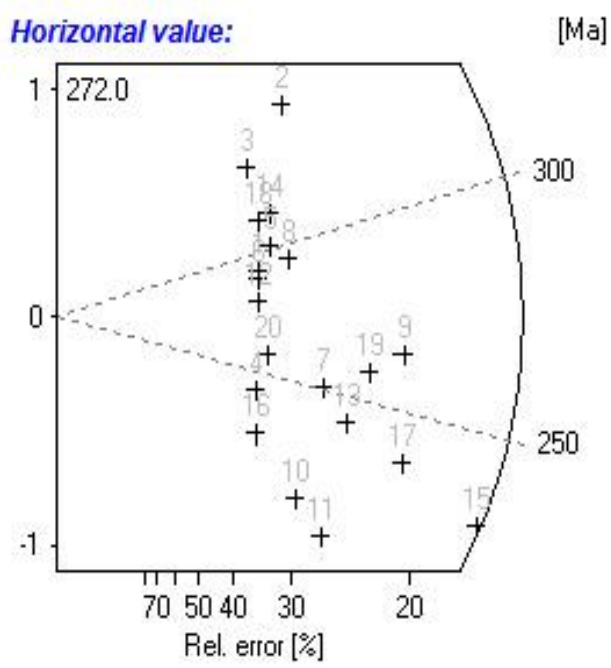

Chi-sq.: $\quad 5.18$

$\mathrm{P}(\%) \quad 99.93$

Dispersion: 0.00

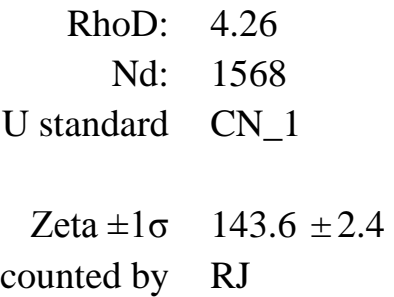

\begin{tabular}{ccccccccc} 
Crystal & $\mathrm{Ns}$ & $\mathrm{Ni}$ & Area & RhoS(e5) & RhoI(e5) & Age(Ma) & $+-1 \mathrm{~s}$ & $\mathrm{U}(\mathrm{ppm})$ \\
\hline 1 & 88 & 9 & 4 & 220.00 & 22.50 & 292.32 & 102.68 & 167.55 \\
2 & 135 & 11 & 6 & 225.00 & 18.33 & 364.84 & 114.93 & 136.52 \\
3 & 93 & 8 & 4 & 232.50 & 20.00 & 346.09 & 127.94 & 148.93 \\
4 & 73 & 9 & 4 & 182.50 & 22.50 & 243.42 & 86.31 & 167.55 \\
5 & 101 & 10 & 6 & 168.33 & 16.67 & 301.73 & 100.44 & 124.11 \\
6 & 87 & 9 & 9 & 96.67 & 10.00 & 289.07 & 101.60 & 74.47 \\
7 & 134 & 16 & 9 & 148.89 & 17.78 & 251.19 & 66.87 & 132.39 \\
8 & 118 & 12 & 12 & 98.33 & 10.00 & 293.94 & 89.51 & 74.47 \\
9 & 237 & 27 & 16 & 148.13 & 16.88 & 263.03 & 54.02 & 125.66 \\
10 & 93 & 13 & 9 & 103.33 & 14.44 & 215.17 & 64.04 & 107.56 \\
11 & 112 & 16 & 12 & 93.33 & 13.33 & 210.61 & 56.65 & 99.29 \\
12 & 84 & 9 & 6 & 140.00 & 15.00 & 279.32 & 98.33 & 111.70 \\
13 & 154 & 19 & 15 & 102.67 & 12.67 & 243.25 & 59.60 & 94.32 \\
14 & 106 & 10 & 6 & 176.67 & 16.67 & 316.31 & 105.08 & 124.11 \\
15 & 311 & 40 & 25 & 124.40 & 16.00 & 233.51 & 39.86 & 119.15 \\
16 & 68 & 9 & 4 & 170.00 & 22.50 & 227.04 & 80.83 & 167.55 \\
17 & 215 & 27 & 21 & 102.38 & 12.86 & 239.06 & 49.34 & 95.74 \\
18 & 95 & 9 & 6 & 158.33 & 15.00 & 315.01 & 110.28 & 111.70 \\
19 & 189 & 22 & 12 & 157.50 & 18.33 & 257.54 & 58.54 & 136.52 \\
20 & 86 & 10 & 9 & 95.56 & 11.11 & 257.80 & 86.49 & 82.74 \\
\hline
\end{tabular}


Sample number: DS10-15

Mineral: Zircon

Irradiation code: vuw012-62

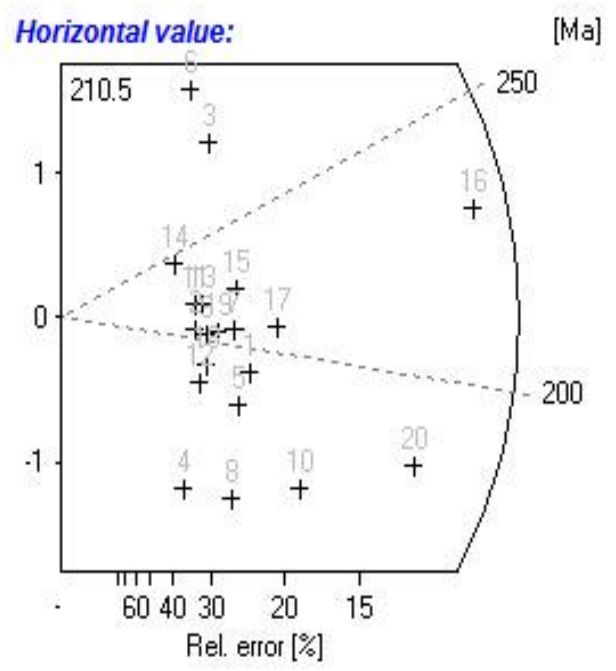

Chi-sq.: $\quad 11.14$

$\mathrm{P}(\%) \quad 91.92$

Dispersion: $\quad 0.00$

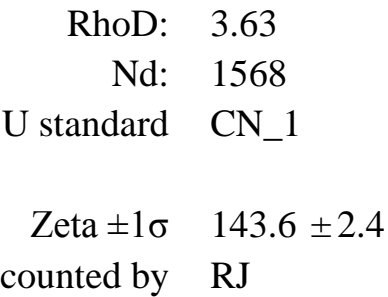

\begin{tabular}{ccccccccc} 
Crystal & $\mathrm{Ns}$ & $\mathrm{Ni}$ & Area & RhoS(e5) & RhoI(e5) & Age(Ma) & $+-1 \mathrm{~s}$ & $\mathrm{U}(\mathrm{ppm})$ \\
\hline 1 & 150 & 20 & 14 & 107.14 & 14.29 & 192.34 & 46.15 & 124.99 \\
2 & 80 & 10 & 10 & 80.00 & 10.00 & 204.96 & 69.03 & 87.49 \\
3 & 143 & 12 & 12 & 119.17 & 10.00 & 302.98 & 91.52 & 87.49 \\
4 & 48 & 9 & 4 & 120.00 & 22.50 & 137.36 & 50.07 & 196.86 \\
5 & 127 & 18 & 12 & 105.83 & 15.00 & 181.10 & 45.94 & 131.24 \\
6 & 129 & 9 & 16 & 80.63 & 5.63 & 362.72 & 125.54 & 49.21 \\
7 & 137 & 17 & 12 & 114.17 & 14.17 & 206.44 & 53.45 & 123.95 \\
8 & 100 & 17 & 10 & 100.00 & 17.00 & 151.34 & 39.97 & 148.74 \\
9 & 95 & 12 & 9 & 105.56 & 13.33 & 202.86 & 62.45 & 116.66 \\
10 & 217 & 33 & 40 & 54.25 & 8.25 & 168.94 & 31.98 & 72.18 \\
11 & 85 & 10 & 12 & 70.83 & 38.33 & 217.56 & 73.03 & 72.91 \\
12 & 78 & 11 & 6 & 130.00 & 18.33 & 181.99 & 58.87 & 160.40 \\
13 & 93 & 11 & 12 & 77.50 & 9.17 & 216.41 & 69.31 & 80.20 \\
14 & 67 & 7 & 12 & 55.83 & 5.83 & 244.47 & 97.39 & 51.04 \\
15 & 147 & 17 & 12 & 122.50 & 14.17 & 221.26 & 57.08 & 123.95 \\
16 & 841 & 94 & 36 & 233.61 & 26.11 & 228.79 & 25.83 & 228.45 \\
17 & 211 & 26 & 24 & 87.92 & 10.83 & 207.87 & 43.66 & 94.78 \\
18 & 89 & 12 & 9 & 98.89 & 13.33 & 190.23 & 58.78 & 116.66 \\
19 & 112 & 14 & 12 & 93.33 & 11.67 & 204.96 & 58.43 & 102.07 \\
20 & 512 & 71 & 40 & 128.00 & 17.75 & 185.04 & 24.09 & 155.30 \\
\hline
\end{tabular}

